\title{
Inovatīvi risinājumi ceḷā uz ilgtspēju: sabiedrība, ekonomika, vide
}
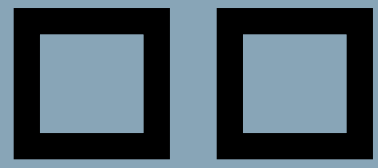

- $0 \bullet$

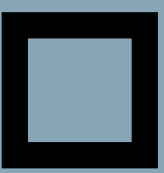

000

- 000

○ 00

0000

0000

- 000

000

- 000
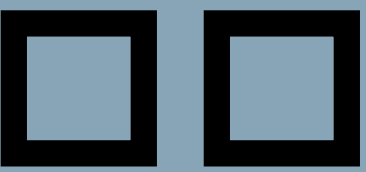

0000

- 000

0000

000

000

- 000

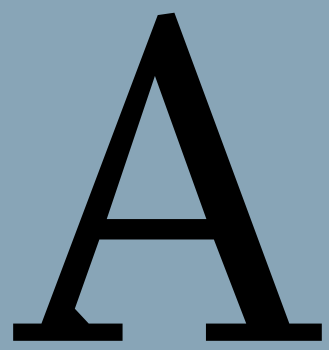

Zinātniskā redaktore

Dr. sc. soc. Aija Zobena 


\section{Inovatīvi risinājumi ceḷā uz ilgtspēju: sabiedrība, ekonomika, vide}


1 ILGTSPĒJIIGAS ATTİSTİBAS IZAICINĀJUM I PĒCKRĪZES LATVIJĀ: SABIEDRĪBA, EKONOMIKA, VIDE

RECENZENTI:

Dr. phil. soc. darbā Signe Dobelniece, Latvijas Lauksaimniecības universitāte Dr. sc. soc. Līga Paula, Latvijas Lauksaimniecības universitāte

Kolektīvā monogrāfija ir apstiprināta publicēšanai ar Latvijas Universitātes Sociālo zinātnu fakultātes Sociālo un politisko pētījumu institūta zinātnes padomes sēdes lēmumu 09.04.2018. (protokola Nr. SZF-V15.5/4).

LITERĀRĀ REDAKTORE Ieva Zarāne

Kolektīvā monogrāfija izstrādāta LU Sociālo zinātnu fakultātes Sociālo un politisko pētijumu institūtā ar Valsts pētijumu programmas «Inovācija un ilgtspējiga attīstība: Latvijas pēckrīzes procesi globālā kontekstā» (SUSTINNO) finansiālu atbalstu.

\section{SUSTINNO}

ISBN 978-9934-18-309-6

(c) Baiba Bela, Jānis Brizga, Raimonds Ernšteins, Renārs Felcis,

Baiba Holma, Jānis Kauliṇš, Anita Kovalevska, Marija Krūmiṇa,

Ligita Melece, Mareks Niklass, Jurijs N̦ikišins, Jānis Pleps,

Liga Rasnača, Iveta Reinholde, Vineta Silkāne, Guna Spurava,

Marta Tripāne, Visvaldis Valtenbergs, Anete Vingre, Aija Zobena, 2018

1.1 Baiba bela, Baiba holma, ANIta kovaleVska, JāNis pleps, LİGA RASNAČA, IVETA REINHOLDE, VINETA SILKĀNE, MARTA TRIPĀNE, ANETE VINGRE Ilgtspējiggas attīstības sociālie izaicinājumi

1.2 VISVALDIS VALTENBERGS Kolektīvā rīcība interneta politiskās komunikācijas un sabiedrības vērtīborientācijas izmainu kontekstā

1.3 MARIJA KRŪmıña Uzṇēmējdarbỉba, eksports, nodokḷi, ènu ekonomika un konkurētspēja: turpmākas analīzes ietvars

1.4 LIGITA MELECE Ilgtspējigas lauku attīstïbas ekonomiskie, vides un sociālie aspekti

1.5 JĀNIS BRIZGA, RAIMONDS ERNŠTEINS Ilgtspējigss patēriṇš un vides pārvaldỉba

\section{INOVATĪVI RISINĀJUMI CELĀ UZ ILGTSPĒJU}

2.1 BaIba beLA, ANITA KoVAL̨EVSKA, MAREKS NIKLASS, JURIJS N̦IKIŠINS, LĪCA RASNAČA, IVETA REINHOLDE, MARTA TRIPĀNE, ANETE VINGRE, VINETA SILKĀNE, GUNA SPURAVA Ilgtspējīgas attīstības sociālā dimensija - kā virzāmies pretī cieṇpilnai dzivei sociāli atbildīgā valstî

2.2 AIJA ZOBENA, RENĀrs felCIS Ceḷā no anomijas uz pašorganizāciju un kolektīvu rīcību

2.3 mariJa krūmıña Uzṇēmējdarbiba, eksports, nodokḷi, ēnu ekonomika un konkurētspēja: analizzes rezultāti

2.4 LIGITA MELECE Inovativi risinājumi ilǵtspējīgai lauku attīstībai

2.5 RAIMONDS ERNŠTEINS, JĀNIS KAULIŇš, JĀNIS BRIZGA Sabiedrỉbas vērtības-rīcības-slodzes un municipālā vides pārvaldība

\section{IZMANTOTIE AVOTI}

AUTORI

ENGLISH SUMMARY

AUTHORS 
Latvijas Universitātes Sociālo zinātnu fakultātes Sociālo un politisko pētijumu institūta vadībā laikā no 2014. lỉdz 2018. gadam tika ìstenota valsts pētijumu programma «Inovācija un ilgtspējiğa attīstība: Latvijas pēckrizes procesi globālā kontekstā» (SUSTINNO), kuras mērḳis bija analizēt ilgtspējigas attisstibas veidošanu un to ietekmējošos faktorus Latvijā, īpašu uzmanību veltot inovācijas vietai un lomai šai procesā kā ekonomikā, tā sociālajā sfērā un atsedzot ilgtspējigas attīstỉbas procesu cēloṇsakarības. Valsts un sabiedrïbas ilgtspējīgas attīstības izpētes procesā tika izveidotas jaunas starpdisciplināras zinātniskās grupas, kuras strādāja, lai radītu akadēmiski nozīmīgas zināšanas par ilgtspējigas attīstības likumsakarībām, kas būtu izmantojamas arī sabiedrības pārvaldībā, lai veicinātu Latvijas globālo konkurētspēju.

SUSTINNO ietvaros tika īstenoti četri pētnieciskie projekti. Projektā «Ekonomiskā konkurētspēja un inovācija tautsaimniecībā» tika analizēti uznēmuma līmena faktori, kuri ietekmē Latvijas uznēmumu konkurētspēju ārējos tirgos, lai iegūtu jaunas zināšanas par ilgtspējas ekonomisko komponentu un inovācijām tautsaimniecībā. Projektā «Ilgtspējas sociālā dimensija un sociālā inovācija» tika turpināta inovācijas analīze, pievēršoties sociālajai inovācijai un tās spējām risināt sociālās un reǵ̛ionālās attīstības problēmas, vienlaikus vērtējot sociālās nevienlīdzības mazināšanas pasākumus un politikas plānošanas sistēmas funkcionēšanu šai jomā. Ilğtspējas sociālā komponenta analīze turpinājās projektā «Sabiedrības vērtīborientācijas un sabiedrības atjaunošanās», kas aplūkoja noteiktu vērtīborientāciju ğenēzi un izplatību Latvijas multikulturālajā sabiedrībā, padziḷinot izpratni par indivīdu sociālo izturēšanos, tai skaitā līdzdalību sabiedriskajās aktivitātēs. Šìs uzvedības ietekme uz vidi tika analizēta projektā «Vides daudzveidība un ilgtspējiğa izmantošana», kas līdztekus patēriṇa ieradumu analīzei aplūkoja gan resursu dinamikas atbilstibu telpiskās plānošanas nostādnēm, gan ar dabas kapitāla komponentus un faktorus, kas tos apdraud.

Programmu istenoja Latvijas Universitāte (LU) - viena no lielākajām zinātniskajām institūcijām valstī, kurai ir būtiska kompetence inovācijas, ilgtspējigas attīstỉbas, vides un politikas pētijumos. Projektos piedalījās LU Sociālo zinātnu fakultātes Sociālo un politisko pētijumu institūts (SPPI) un tā pētnieku grupas vadošo pētnieku - profesora Jāṇa Ikstena, Dr. sc. pol., (2014-2017), profesores Aijas Zobenas, Dr. sc. soc., (2017-2018), un asociētās profesores Baibas Belas, Dr. sc. soc.,- - vadībā, kā arì pētnieki no LU Geogrāfijas un Zemes zinātnu fakultātes Vides zinātnes nodaḷas vadošā pētnieka profesora Raimonda Ernšteina, Dr. habil. paed., vadỉbā. Nozimīgu ieguldījumu SUSTINNO izpildē deva Agroresursu un ekonomikas institūta (AREI) pētnieku komanda vadošās pētnieces Ligitas Meleces, $D r$. oec., vadībā; šis institūt ir vadošā pētnieciskā institūcija lauku teritoriju ekonomiskajā attīstībā. Latvijas ekonomiskās ilgtspējas un inovācijas jomas izpēti profesora Alfa Vanaga, MSc. (Econ.) (1942-2016) (2014-2016) un Marijas Krūminas, Mg. oec. (2016-2018) 
vadībā veica Baltijas Starptautiskais ekonomikas politikas studiju centrs (BICEPS), kas ir uzkrājis lielu pieredzi tautsaimniecības pētỉjumu veikšanā.

Kolektīvā monogrāifija «INOVATİvI RISINĀJUMI CEḶ̂̄ UZ ILGTSPĒJU: SABIEDRİBA, EKONOMIKA, VIDE» (zinātniskā redaktore AIJA ZoBENA), kas iznāk sērijā «Inovācijas un ilgtspējiga attīstība Latvijā», apkopo SUSTINNo izpildes gaitā iegūtas nozimīigākās teorētiskās atziṇas, praktiskos ieteikumus un iezīmē turpmākās izpētes virzienus.

Kolektīvās monogrāfijas pirmā dala «Ilgtspējìgas attīstības izaicinājumi pēckrīzes Latvijā: sabiedrība, ekonomika, vide» pievēršas SUSTıNNo projektos identificēto problēmu konceptualizācijai un to nacionālā, reğionālā un globālā konteksta raksturojumam. Pirmajā nodalā «ILGTSPĒjĪGAS ATTĪSTĪBAS SOCIĀLIE IZAICINĀJUMI» autoru kolektîvs (BAIBA BELA, BAIBA HoLma, ANita Koval̨evska, JĀNis Pleps, Līga Rasnača, IVeta Reinholde, Vineta SilkāNe, MARTA Tripāne, ANEte Vingre) iezimē valsts pētijumu programmas SUSTINNO 2. projekta «Ilgtspējas sociālā dimensija un sociālā inovācija» tematisko loku, kas aptver Latvijas pēckrīzes sociālo problēmu analīzi saistỉbā ar ilgtspējịgu sociālo un reǵionālo attīstību, tiesiskā ietvara noteiktos pienākumus ilgtspējigigas attīstības nodrošināšanai un pārvaldes sistēmas spēju efektîvi risināt sociālās problēmas, kā arì sociālo inovāciju analīzi saistībā ar to ieguldỉjumu kopienu drošumspējā.

Otrajā nodalā «KOLEKTİVĀ RİCİBA INTERNETA POLITISKĀS KOMUNIKĀCIJAS UN SABIEDRİBAS VĒRTİBORIENTĀCIJAS IZMAIN̦U KONTEKSTĀ» VISVALDIS VALTENBERGS pēta interaktivitātes un informācijas pieejamības jaunās iespējas, interneta un sociālo mediju ietekmi uz iedzīvotāju iesaisti sabiedriskajās aktivitātēs un politikā. ASv prezidenta vēlēšanu, Brexit un Krievijas stratēǵiskās informativāās kampaṇas pieredze ir mazinājusi sākotnējo optimismu par interneta pozitivo iespaidu uz politisko komunikāciju un demokrātiskajiem procesiem sabiedrībā. Vai kolektīvo organizāciju uzticības krīze, augošã anomija apvienojumā ar manipulatīvu komunikatīvo ietekmi kḷūs par bumbu ar laika degli liberālajām demokrātijām?

Trešajā nodalā «UZNĒMĒJDARBİBA，EKSPORTS，NODOKḶI， ĒNU EKONOMIKA UN KONKURĒTSPËJA: PĒCKRİZES PROCESU ANALİZES KONCEPTUĀLAIS IETVARS» MARIJA KRŪMIN̦A iezīmē konceptuālo ietvaru pēckrizes Latvijas ekonomisko procesu analīzē, ipaši pievēršoties Latvijas eksporta konkurētspējas izpētei. Apkopojot empïrisko pētijumu rezultātus par eksportējošiem un neeksportējošiem Eiropas valstu un ASv uzṇēmumiem, var secināt, ka eksportējošie uzṇēmumi vidēji ir produktīvāki nekā citādā ziṇā lïdzịgie uzṇēmumi, kas nenodarbojas ar eksportu. Noda!̣aa apkopotas teorētiskās atziņas arì par ènu ekonomikas un valsts nodokḷu struktūras ietekmi uz valsts ilgtermiṇa ekonomisko izaugsmi.

Ceturtajā nodalā «ILGTSPẼIIGAS LAUKU ATTİSTİBAS EKONOMISKIE, VIDES UN SOCIĀLIE ASPEKTI» LIGITA MELECE sniedz ieskatu par
ES stratēǵiju un politiku programmatiskajiem izaicinājumiem lauku ilgtspējigas (ekonomiskās, vides un sociālās) attīstỉbas jomā. Autore skaidro lauksaimniecības un vides mijiedarbỉbas daudzfunkcionalitāti, tās ietekmi uz bioloğiskās daudzveidības saglabāšanu un ekosistēmu pakalpojumu piedāvājumu, akcentējot mazo lauku saimniecību nozīmi. Aplūkojot lauku saimniecību diversifikācijas nozīmi lauku turpmākā attīstībā, uzsvērt potenciālie ieguvumi-daudzveidīgu preču un pakalpojumu piedāvājums un papildu ienākumi.

Kolektīvās monogrāfijas pirmo dạu noslēdz nodaḷ «ILGTSPĒ JīGS PATẼRIN̦Š UN VIDES PĀRVALDİBA», kurā JĀNIS BRIZGA Un RAIMONDS ERNŠTEINS apkopo projekta «Vides daudzveidỉba un ilgtspējiga izmantošana» realizācijas gaitā gūtās atzinas. Šì projekta mērḳis bija pētìt kompleksu socioekoloğisko sistēmu, vides un ilgtspējigas attīstības pārvaldību Latvijā, novērtējot sabiedrības vērtỉbu-rīcību-slodžu izmainu parametrus un faktorus vides saglabāšanas un ilgtspējịgas izmantošanas, un sabiedrības daudzdimensionālās tematiskās un vispārīgās attīstỉbas pārvaldības satura un procesu ietekmju ietvarā, sākot no vietējās pārvaldības.

Otrajā kolektīvās monogrāfijas daḷā «Inovatîvi risinājumi ceḷā uz ilgtspēju» ir apkopotas nozīmīgākās praktiskās atziṇas, kas gūtas SUSTINNO realizācijas gaitā.

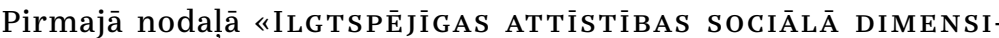
JA: VIRZİBA PRETĩ CIENPILNAI DZİVEI SOCIĀLI ATBILDİGĀ VALSTİ̀ BAI-

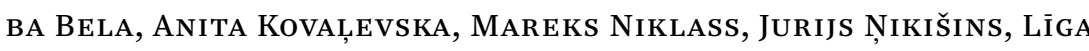
Rasnača, IVeta Reinholde, Marta Tripāne, Anete Vingre, Vineta SILKĀNE Un GUNA SPURAVA pauž viedokli, ka sociālo inovāciju analīze ir nozìmīgs, bet līdz šim salīdzinoši maz izmantots (un maz pētîts) resurss sociālo problēmu risināšanā, iekḷaujošas ekonomikas veidošanā un sabiedrības kopigā labuma sekmēšanā. SUSTINNO ietvaros veiktā pētījuma ierobežotie resursi ḷāva padziḷināti novērtēt tikai valsts nozīmi sociālo inovāciju sekmēšanā un analizēt vien atsevišķus gadijumus. Autori atzīmēè, ka valsts maz izprot sociālo inovāciju lomu un nozīmi pārvaldē, par ko liecina sociālo inovāciju kā resursa un instrumenta neietveršana NAP 2020 prioritārajā virzienā «Cilvēka drošumspēja», kā arī ilgais un grūtais ceḷš sociālās uzṇēmējdarbības likuma tapšanā. Pētỉjumā veikto gadỉjumu analizze rosina domāt par sociālajām inovācijām ievērojami plašāk, nevis tikai sociālās uzṇēmējdarbības ietvaros, un uzsver sociālo inovāciju būtisku nepieciešamỉbu, lai varētu pilnvērtigi izmantot visas priekšrocibas, ko dod dzive 21. gadsimtā.

Otrajā nodalāā «CEḶĀ NO ANOMIJAS UZ PAŠORGANIZĀCIJU UN KOLEKTİVU RİCİBU» autori AIJA ZoBENA un RENĀRS FELCIS, apkopojot secinājumus par daudzveidīgajām anomijas izpausmēm un tās ietekmi uz iedzīvotāju vērtīborientācijām pēckrīzes Latvijas sabiedrībā, atzīst - lai 
gan anomijas izpausmes ir daudzveidīgas un plašas, Latvijas sabiedrībā ir vērojamai procesi, kas ḷauj nākotnē raudzīties ar zināmu optimismu. Visai piesardzīgus secinājumus par to ḷauj izdarīt tirgus un sociālo pētījumu centra «Latvijas Fakti» laikā no 2017. gada 2. decembra lìdz 20. decembrim veiktā Latvijas Republikas pastāvīgo iedzìvotāju $(N=1003)$ vecumā no 18 lïdz 74 gadiem aptauja (SUSTINNO 2017). Aptaujas dati liecina-lai gan savstarpējās uzticēšanās līmenis ir visai zems, gandrīz desmitā daḷa Latvijas iedzīvotāju jau ir iesaistījušies un gandrīz ceturtā dala ir gatavi iesaistīties kolektīvās darbỉbās lēmumu pieṇemšanas iniciatīvu izvirzīšanai. Aptaujā SUSTINNO 2017 iegūtie dati rosina turpināt Latvijas iedzivotāju attieksmes un vērtỉbu izpēti no anomijas perspektīvas, meklējot iespējamos nosacijjumus tās pārvarēšanai.

Trešajā nodaḷā «UZñĒMĒJDARBĪBA, EKSPORTS, NODOKL,I, ĒNU EKONOMIKA UN KONKURĒTSPẼJA PĒCKRİZES LATVIJĀ» MARIJA KRŪMINA apkopo galvenos secinājumus, kas iegūti SUSTINNo projekta «Ekonomiskā konkurētspēja un inovācija tautsaimniecībā» ietvaros. Šī projekta mērḳis bija empiriski analizēt Latvijas uzṇēmumu konkurētspēju ārējos tirgos, îpašu uzmanību pievēršot uznēmuma limena faktoriem. Izmantojot jaunākās pētnieciskās metodes, tika veikti vairāki pētỉjumi par uzṇēmumu konkurētspēju ietekmējošiem faktoriem - sākumposma uznēmējdarbïbu, eksportu un ES struktūrfondu ietekmi uz uznēmumu eksportspēju, ēnu ekonomikas un nodokḷu sistēmas ietekmi uz Latvijas uzṇēmumu konkurētspēju.

Ceturtajā nodal̦ā «INOVATİVI RISINĀJUMI ILGTSPĒJIİGAI LAUKU ATTİSTİBAI» LigitA MELECE apkopo projektos «Ekonomiskā konkurētspēja un inovācija tautsaimniecībā» un «Ilghtspējas sociālā dimensija un sociālā inovācija» iegūtos secinājumus un izvērtē sociālo inovāciju potenciālu ilgtspējigai lauksaimniecības un lauku attistìbai. Autore raksturo sociālo un vides inovāciju saistību un mijiedarbību un sniedz dažu Latvijā isstenotu inovatīvu risinājumu (agrovides pasākumu, bioenerǵijas ražošanas un lokālo pārtikas sistēmu) vērtējumu.

Monogrāfiju noslēdz nodala «SABIEDRĪBAS VĒRTİBAS-RĪCĪBAS-SLODZES UN MUNICIPĀLĀ VIDES PĀRVALDĪBA», kurā RAIMONDS ERNŠTEINS, JĀNIS KAULIN̦š un JĀNIS BRIZGA aplūko izaicinājumus, kas rodas videi draudzīgas rīcības pārvaldības praksē vietējā pārvaldes līmenī un mājsaimniecībās, lai atrastu optimālāko veidu, kā veicināt pozitīvas izmaiṇas indivìdu un mājsaimniecību ikdienas rīcībā, laujot cilvēkiem pārvarēt videi draudzīgas rīcibas barjeras un padarot cilvēku ikdienu videi draudzigāku un ilgtspējigàku. Lai analizētu vides pārvaldỉbu un videi draudzìgu rīcỉbu mājsaimniecībās, pēc SUSTINNO pasūtijuma 2016. gada martā socioloğisko pētijumu firma TNS veica reprezentativu Latvijas iedzivotāju aptauju $(N=1009)$, kurā iegūtie dati aplūkoti šajā nodalā.

\section{Pateicības}

Kolektivās monogrāfijas autori izsaka pateicību visiem, kuri veicināja šì darba tapšanu. İpaši pateicamies profesoram Jānim Ikstenam, valsts pētỉjumu programmas «Inovācija un ilgtspējiga attīstība: Latvijas pēckrīzes procesi globālā kontekstā» (SUSTINNO) un projekta «Sabiedrības vērtīborientācijas un sabiedrỉbas atjaunošanās» vadītājam laika posmā no 2014. līdz 2017. gadam, un profesoram Alfam Vanagam † (1942-2016), projekta «Ekonomiskā konkurētspēja un inovācija tautsaimniecībā» vadītājam laika posmā no 2014. līdz 2016. gadam, par programmas ideju un būtisku ieguldijumu tās realizēšanā. Par palīdzỉbu tulkošanas darbā pateicamies Zanei Vārpiṇai.

Dr. sc. soc. Aija Zobena

zinātniskā redaktore 


\section{llgtspējīgas attīstības} izaicinājumi pēckrīzes Latvijā: sabiedrība, ekonomika, vide 


\section{Ilgtspējīgas attīstības sociālie izaicinājumi}

Valsts pētijumu programmas SUSTINNO 2. projekta «Ilgitspējiggas attīstības sociālā dimensija un sociālās inovācijas» tematiskais loks aptver Latvijas pēckrīzes sociālo problēmu analīzi saistībā ar ilgtspējigu sociālo un reǵionālo attîstỉbu, tiesiskā ietvara noteiktos pienākumus ilgtspējīgas attīstības nodrošināšanai un pārvaldes sistēmas spēju efektīvi risināt sociālās problēmas, kā arī sociālo inovāciju analīzi saistībā ar to ieguldỉjumu kopienu drošumspējā. Šajā rakstā aplūkots konceptuālais ietvars, kas veido teorētisko pamatu minēto tēmu izpētē.

\section{Ilgtspējīgas attīstības sociālā dimensija starp- tautiskajā darbakārtībā}

Divdesmit pirmajā gadsimtā jēdziens «ilgtspējiga attīstība» ir kḷuvis gan par modes vārdu, ideālistisku politisku mērki, gan dziḷ zinātnisku diskusiju tēmu un plašu pētījumu virzienu. Ilgtspējigas attīstỉbas idejas centrā ir vizija par labāku pasauli tagad un arī nākamajām paaudzēm, un tā sākotnēji ietver priekšstatus par pamatvajadzību apmierināšanu un iespēju uzlabot dzīves standartus visiem, vienlaikus aizsargājot dabas ekosistēmas, lídzsvarojot un integrējot vides un attistîbas jautājumus (WCED, 1987; United Nations Conference .., 1992).

Mūsdienās politiskās diskusijas priekšplānā izvirzās iekḷaujošas un uz cilvēka brīvību paplašināšanu vērstas attīstības idejas, kas nostiprinātas 2015. gada 25. septembrī Apvienoto Nāciju Organizācijas pieņemtajā rezolūcijā «Mūsu pasaules pārveidošana: Ilğtspējīgas attīstības programma 2030. gadam» un dokumentā «llgtspējīgas attīstìbas mērḳi», ko parakstīja 193 valstu pārstāvji. Šo dokumentu pamata ideja ir samazināt nabadzību, aizsargāt planētu un nodrošināt labklājību visiem. Būtiski mērḳi ir veidot tādu pasauli, kas sniedz iespēju ikvienam dzivot ar cienu un realizēt cilvēktiesību pamatvērtības (United Nations General Assambley, 2015). Tiek uzsvērta nepieciešamība radīt vienlīdzīgas iespējas, kas ḷautu katram isstenot savu potenciālu un piedalìties kopèjās labklājības celšanā. Nabadzības mazināšana, bada un nepilnvērtỉga uztura problēmas risināšana, veselības aprūpes pieejamība, dzimumu vienlīdzība, labas izglìiības pieejamïba, tīra dzeramā ūdens un tīras enerğijas pieejamība, nevienlīdzības mazināšana ir būtiskie ilǵtspējas sociālās dimensijas jautājumi (United Nations General Assambley, 2015). Jāatzīst, ka tie nav risināmi bez ilgtspējas ekonomiskās dimensijas, kas ietver iekḷaujošu ekonomisko izaugsmi, un arī bez koordinētas rīcíbas un sadarbỉbas visos limeṇos - starptautiskā, nacionālā un lokālā.

Ilgtspējīgas attīstības principi un sasniedzamie mērḳi, kas iepriekš definēti gan Riodežaneiro 1992. gadā, gan Johannesburgā 2002. gadā pienemtajā deklarācijā par ilgtspējigigu attīstību, tālāk tika attīstīti ANo 
Ilgtspējigas attīstības programmā 2030. gadam. Būtiskās atšķirības no ANO iepriekš pieṇemtajām deklarācijām un rīcības programmām ir tajā, ka ANO principos ir noteikti konkrētāki mērḳi un rādītāji mērḳu sasniegšanas mērīšanai (atbildot uz iepriekš izteikto kritiku par vēlmju domāšanu un konkrētības trūkumu); 2) ir būtiska konceptuāla pārvirze ilgtspējīgas attīstības definēšanā no vajadzību apmierināšanas (1987.gadā postulētais princips) uz cilvēka brīivibu paplašināšanos un sava potenciāla realizāciju. Sākotnēji šĩs idejas zinātnē attīstijja Amartija Sens (Amartya Sen), formulējot attīstỉbu kā labklājibu visiem un tieši brīivibu paplašināšanos kā attīstības mērḳi (Sen, 1999). SUSTıNNo pētijuma konceptuālais ietvars sabalsojas ar jaunākajiem ANO izvirzitajiem principiem.

Atgriežoties pie ilgtspējīgas attīstības jautājumiem starptautiskajā darbakārtībā, ir būtiski aplūkot arī Eiropas Savienības Ilgtspējigas attīstības stratêgijā nostiprinātos principus (Eiropas Savienības Padome, 2006) un attīstības stratēǵijā «Eiropa 2020» (Eiropas Komisija, 2010) noteiktās prioritātes gudrai, integrējošai un ilghtspējiggai izaugsmei. Tieši pēdējā dokumentā pirmo reizi ES vēsturē attīstības plānošanā sociālie mērķi tiek uzlūkoti kā vienlīdz svarīgi salïdzinājumā ar ekonomiskajiem mērḳiem, turklāt nabadzības mazināšanai ierādìta ne tikai deklaratīva loma, bet arī izvirzìti konkrēti mērḳi - līdz 2020. gadam par 20 miljoniem samazināt to cilvēku skaitu, kuri ir pakḷauti nabadzības un sociālās atstumtības riskam. Nozīmīgs kvantitatîvs mērḳis iekḷaujošas izaugsmes vecināšanā ir arī princips līdz 2020. gadam panākt, lai būtu nodarbināti $75 \%$ vīriešu un sieviešu vecuma grupā no 20 līdz 64 gadiem. Savukārt konkurētspējīgākas un produktīvākas ekonomikas stimulēšanai vajadzētu panākt, lai 40\% iedzivvotāju vecuma grupā no 30 līdz 34 gadiem būtu ar augstāko izglîtỉbu un izdevumi pētniecībai un attīstībai sasniegtu $3 \%$ no IKP.

ES ilghtspējiǵas attīstības stratēóijijā kā nākotnes mērkis uzsvērta labklājīgāka un taisnīgāka sabiedrība, kura dzīvo tīrākā, drošākā un veselīgākā vidē. Salīdzinājumā ar ANo Ilgtspējīgas attīstības stratēégiju vairāk ir akcentēti ekonomiskie jautājumi. Stratēǵijā «Eiropa 2020» dominē vēl lietiškāāks, uz ekonomisko attīstību vērsts skatījums, uzsverot nepieciešamỉbu atkopties no 2008. gada globālās finanšu krīzes radītajiem satricinājumiem. Vienlaikus abi dokumenti atzīst nabadzību kā būtisku risināmu problēmu. Stratēǵija «Eiropa 2020» nosaka rīcības solus nabadzỉbas mazināšanai, piemēram, sekmēt kolektīvo un individuālo atbildību nabadzības novēršanā; attīstìt sociālās inovācijas, kas būtu vērstas uz ievainojamāko sabiedrības dalībnieku izglìtošanu, apmācību un nodarbinātỉbu; pārvērtēt sociālās drošîbas un pensiju sistēmas, lai tās adekvāti atbalstìtu ienākumu gūšanu un pieeju veselības pakalpojumiem (Eiropas Komisija, 2010). SUSTINNO pētijums tika konceptuāli veidots tā, lai ṇemtu vērā arī ES mērķus un uzdevumus ilgtspējigai attīstïbai.
Ilgtspējīga attīstība un sociālie jautājumi zinātniskajās diskusijās

Mūsdienu sociālās zinātnes meklē atbildes un risinājumus aktuāliem izaicinājumiem - nozīmīgām ekonomiskās attīstības un sociālās drošỉbas atškirī-

bām starp valstīm un šo atškirību radītājām sekām, kā arì iespējām sabalansēt nepārtrauktas ekonomiskās izaugsmes nepieciešamību ar planētas resursu izsmelšanu. Kaut arī radikālākās idejas joprojām nav iekḷuvušas politiskajā darbakārtībā (piemēram, ideja par attīstību, kas nav vērsta uz izaugsmi), tomēr ilgtspējigas attīstỉbas izpēte ir kḷuvusi par jaunu un strauji augošu starpdisciplināru pētījumu lauku. Piemēram, nozīmīgajā zinātnisko publikāciju datubāzē Web of Science ilgtspējīgas attīstības tēmai laikā no 1990. līdz 1999. gadam veltîti 1668 raksti zinātniskos žurnālos un apmēram tikpat publikāciju konferenču rakstu krājumos; laikā no 2000 lìdz 2009. gadam ir jau 6278 raksti zinātniskos žurnālos un nedaudz mazāk publikāciju konferenču rakstu krājumos. Savukārt nākamajos piecos gados (2010-2015) par ilgtspējiggas attīstības jautājumiem publicēti 10858 raksti zinātniskos žurnālos un 9349 raksti konferenču rakstu krājumos. Jāatzīmē, ka vienīgajā sociālo zinātnu jomā, kurā pieškir Nobela prēmijas,-ekonomikā-kopš 199o. gada ir piešḳirtas divas prēmijas zinātniekiem tieši par iekḷaujošas ekonomikas ideju attīstišanu. 1998. gadā Nobela prēmija pieškirta Amartijam Senam par labklājỉbas ekonomikas tēmas attīstī̌anu un 2015. gadā - Angusam Dìtonam (Angus Deaton) par patērina, nabadzības un labklājīibas analīzi. Arī 2001. gada laureāts Džozefs Stiglics (Jozef Stiglitz) ir pētijis nevienlīdzību un tās negatīvo ietekmi uz attīstìbu, pamatojot, ka sabiedrībās ar aug̣stiem nevienlīdzības rādītājiem ekonomiskā izaugsme notiek lēnāk (Stiglitz, 2012).

Sociālajās zinātnēs ilgtspējiggas attīstības tēma ietver arī plašākas diskusijas par individuāāā un sabiedriskā attiecībām, par kapitālisma un politiskās sistēmas attiecībām, par centra un perifērijas (attīstīto un attīstības valstu) attiecībām, kā arī par kultūras un politikas faktoriem, kas ir pamatā nozīmīgām ekonomiskās nenodrošinātības atškiiībām, kādas pastāv starp turīgākajām valstīm. Tiek diskutēts arī par nabadzības un nevienlïdzības strukturālajiem cēloṇiem, nabadzỉbas definēšanu un mērīšanas metodēm.

Raksta ierobežotā apjoma dēl īsi raksturotas vienīgi tās idejas, kuras palīdz kritiskāk domāt par kapitālismu kā sistēmu un sociālās politikas nozīmīgumu, jo Latvijā ilgstošās padomju okupācijas iespaida dẹḷ joprojām kapitālisma kritiku ḷoti vienkāršoti saista tikai ar marksistu un sociālistu idejām (kas liek izvēlēties starp kapitālismu un sociālismu), savukārt anglosakšu un kontinentālās Eiropas zinātnieki attīsta daudz niansētākas diskusijas par dažādiem kapitālisma veidiem, valsts un kultūras vērtību nozīmi.

Tā kā nabadzỉba un nevienlïdzība tiek uzlūkoti kā nopietnākie ierobežojumi tādas sabiedrības veidošanā, kurā ekonomiskā attīstība paaugstina 
labklājību visiem tās dalībniekiem, tad zinātnieku uzmanības centrā ir nevienlīdzības un nabadzības cēloṇu analīze un diskusijas par to novēršanas iespējām. Pētnieki uzsver, ka kapitālisms kā sistēma darbojas visur līdzīgi, tomēr dažās valstīs nevienlīdzības rādītāji ir ievērojami augstāki nekā citās. Tiek uzskatīts, ka to lielā mērā ietekmē valsts, pienemot lēmumus, kuri nosaka, tieši kādā veidā šì sistēma darbosies konkrētajā valstī (tiesiskais regulējums, nodokḷu politika, sociālās drošỉbas sistēma u. c.). Piemēram, Subsahāras Āfrikas valstīs un Kīnā vēl nesen galējas nabadzības rādītāji bija samērā lìdzịgi. Pēdējos desmit gados Subsahāras Āfrikas valstis nav sekmīgi mazinājušas galējo nabadzību, lai gan tām ir sniegta ievērojama starptautiskā palīdzība, savukārt Kỉna galējo nabadzību ir ḷoti sekmīgi samazinājusi arī bez starptautiskās palīizības (Deaton, 2015, citēts pēc Galbraith, 2016).

Klasisks piemērs valsts nozīmei nevienlïdzības mazināšanā ir ASV un Eiropas salīdzinājums (uz šìm atšķiiỉbām atsaucas daudzi autori, piemēram, Stiglitz, 2015): neoliberālajās valstīs - ASV un Lielbritānijā - nevienlīdzības rādītāji ir ḷoti augsti, savukārt egalitārajās Skandināvijas valstīs tie ir zemi (Eppard, Chomsky, Rank \& Brady, 2017). Arī amerikāṇu ekonomists Džeims Galbreits norāda uz saistỉbu starp valsts politisko sistēmu un nevienlīdzỉbas rādītājiem - egalitārās valstīs nevienlīdzības rādītāii ir zemāki. Savukārt salīdzinot attīstitās un attīstỉbas valstis, pētnieks uzsver tieši vidusslāṇa nozīmi attīstītajās valstīs - jo lielāks un spēcīgāks ir vidusslānis, jo kopumā labklājīgāka ir sabiedrība (Galbraith, 2011, 2016). Ekonomists arī pierāda, ka nevienlīdzība, bezdarbs un migrācija ir ḷoti cieši saistīti negatìvi sociāli fenomeni. Savukārt vienlīdzīgāka darba samaksa rada zemāku bezdarba līmeni un neveicina migrāciju. Vinš kā piemēru min Zviedrijas un Spānijas darba tirgus salīdzinājumu -Zviedrijā ir lielāka algu vienlīdzība un mazāks bezdarbs nekā Spānijā. Lielas atšḳirības algās stimulē sliktāk atalgota darba pamešanu un labāka darba meklēšanu, bet labāki darbi parasti ir pieejami ierobežotā daudzumā, tiem vajag augstāku kvalifikāciju, tāpēc cilvēki vai nu izvēlas nestrādāt, vai dodas tur, kur ir pieejams labāk atalgots darbs (tas varētu būt no laukiem uz pilsētu vai no vienas valsts uz citu) (Galbraith, 2016).

Arì Lorens Epards (Lawrence Eppard), Noems Čomskis (Noem Chomsky), Marks Ranks (Mark Rank) un Deivids Bredijs (David Brady) uzsver valsts izvēlētās sociālās politikas lielo nozīmi, jo, vinuuprāt, tikai tā var izskaidrot ievērojamās ienākumu atškirības, kādas kapitālisma sistēma rada salīdzinoši līdzīgi attīstîtās valstīs. Viṇi norāda, ka var izvēlēties minimālisma pieeju attiecībā pret brīvā tirgus neizbēgamajiem ierobežojumiem, pieḷaujot augstu nabadzības un nevienlïdzibas līmeni, bet var arī izvēlēties nopietni ierobežot nabadzỉbu, līdz pat $80 \%$, kā tas notiek uz labklājỉbas valsts modeli orientētās valstīs. D. Bredijs apgalvo, ka dāsna sociālā politika sabiedrībai ir tikai ieguvums un nāk par labu visiem - bagātos caur nodokḷ politiku tuvina vidusškirirai; caur resursu pārdali tiek panākts vienlïdzīgāks resursu sadalījums sabiedrībā-arī cilvēki ar zemiem ienākumiem var atlauties dzivot labklājigi un ar cieņu (Eppard et al., 2017). Pētnieki uzsver, ka mūsdienu situācija, kurā dažas sociālas grupas (piemēram, cilvēki ar zemu izglīìibu, viena vecāka ğimenes, gados vecākas sievietes, kuras dzīvo vienas) ir vairāk pakḷautas nabadzỉbai, liecina par to, ka sabiedrībai nav izdevies izveidot tādu sociālo struktūru, kas dotu vienlīdzịgas iespējas un atbalstu visiem. Autori atsaucas uz A. Sena ideju, ka attīstības centrā jābūt cilvēka brīivibai un iespējai īstenot tādu dzivi, kādu cilvēks uzskata par vērtīgu, neskatoties uz savas dzīves sākuma punktu. A. Sena skatījumā attīstība ir iespējama tikai kā cilvēka brīvas darbības rezultāts, savukārt brīìibas pamata aspekti ir labklājības brīviba (kas ietver cilvēka funkcionēšanu un rīcībspēju) un rīcības brīvība (kas ietver izvēli un autonomiju). Pētnieks nabadzìbu ir definējis kā brīvības neesamību, kas neḷauj cilvēkiem ìstenot savu potenciālu, tāpēc attīstỉbai ir jāsniedz brīviba no nabadzības, brīiiba no sistemātiskas sociālas deprivācijas, kā arī brīvïba no citiem ierobežojumiem (Sen, 1999).

Noslēdzot šo diskusiju, gribētos uzsvērt Noema Čomska argumentu par kultūras vērtībām un priekšstatu spēku - tie veido ietvaru mūsu domas telpai (the frame for thinkable thought) un tātad arī robežas tam, kā mēs veidojam savu dzīvi, tostarp - kā valstu valdības veido normatīvo ietvaru (nodokḷu politiku, sociālo politiku u.c.) mūsu ikdienas dzīvei. Mūsu pasaule varētu būt pavisam citāda, ja mēs par to domātu citādi (Eppard et al., 2017).

\section{Nabadzība kā sociāla problēma un tās negatīvo seku daudzveidība}

Nabadzība kā nopietna problēma mūsdienās tiek uzlūkota tādēl, ka tā nelauj cilvēkam pilnvērtīgi piedalīties sabiedrības dzivē un dzīvot atbilstoši tam dzives līmenim, kuru par normu uzlūko konkrētā sabiedrỉba. Nabadzỉba nav tika materiālo un finanšu resursu trūkums, tā ietver arī prasmju, fizisko spēju, rīcībspējas un pašcieṇas deprivāciju, kas kopumā traucē iekḷauties sabiedrībā (Lāce, 2012). Nabadzība ietekmē cilvēka ikdienas dzīvi dažādos negatīvos veidos - tā var nozìmēt bezdarbu vai darbu par loti zemu atalgojumu; nepietiekamu pārtiku; sliktu veselību un neatbilstošu veselības aprūpi; ierobežotu pieeju vai pieejas trūkumu izglìtỉbai un citiem pamata pakalpojumiem; neatbilstošus mājokla apstāklus un bezpajumtniecību; dzivi nedrošā un degradētā apkaimē; diskrimināciju un atstumtību. Nabadzību raksturo līdzdalības trūkums lēmumu pieņemšanā, kā arì nepietiekama līdzdalība pilsoniskajā, sociālajā un kultūras dzìvē (United Nations, 1995; Council of the European Union, 2004).

Kompleksa pieeja nabadzības dimensiju izpētē ietver tādu jautājumu aplūkošanu kā ienākumu nepietiekamība, materiālā deprivācija, un jaunākajos pētijumos tiek aplūkota arī psiholoğiskā labbūtība, jo tiek uzskatīts, 
ka nabadzības rosinātās kauna jūtas rada depresiju, apātiju, neticību sev un citus rīcībspēju bloḳējošus psiholoğiskus stāvokḷus (Walker, 2014). Gan nabadzība, gan sociālā atstumtība ir saistītas ar zemu dzives standartu (resursu, tiesibu, labumu un pakalpojumu nepietiekamïbu), kas nopietni ierobežo cilvēka iespējas darboties ekonomikas, sociālajā, kultūras un politikas laukā (Levitas, 2007, citēts pēc Bak \& Larsen, 2015). SUSTINNo pētijumā analizējām nabadzību kā kompleksu problēmu, pievēršot uzmanību tās daudzveidīgajām negatīvajām sekām gan Latvijas sabiedrībā kopumā, gan dzilāk aplūkojot vienu sevišḳi ievainojamu sociālu grupu - sievietes ar zemu izglìīibu, kuras bērnus audzina vienas vai ar problemātiskiem partneriem.

Atseviškła uzmaniba tika pievērsta veselības nevienlïdzïbas un mājokl̦a pieejamības jautājumiem, jo tie skar būtiskas cilvēka pamata vajadzības un tiesības. Kaut arī veselības stāvokli ietekmē daudzi faktori-vecums, dzimums, iedzimtie faktori, dzivesveida jeb individuālās uzvedības faktori, sociālie un kopienas tīklu, strukturālie faktori, sociāli ekonomiskie, kultūras un vides apstākḷi (Eyal et al., 2013) -, pētījumi parāda pārliecinošu saistību starp sociālekonomiskajiem rādītājiem un veselības stāvokli raksturojošo statistiku (European Commission, 2013).

Veselības stāvokḷa saistība ar sociālajiem apstākḷiem un ekonomisko stāvokli (būtiskas atšḳirības dzìves ilgumā, mirstības rādītājos, kā arì veselības stāvokḷa pašnovērtējumā) ir konstatēta lielākajā dạ̣ā pasaules reğionu, lai gan ir panākti uzlabojumi veselības aprūpē un dzives standartos (OECD, 2008), un tādēḷ pētnieki arvien lielāku uzmanību pievērš veselības stāvokḷa nevienlïdzības jautājumiem. Lietojot jēdzienu «veselïbas stāvokḷa nevienlïdzība», tiek skatīta sociālā un ekonomiskā nevienlïdzība, ar kuru šis veselïbas stāvokḷa atšķirīibas ir saistītas (Graham, 2009). Izpētē parasti iekḷauj arī ietekmējošo faktoru analīzi. Visbiežāk veselības stāvokḷa pētỉjumos un veselības stāvokla ietekmējošo faktoru identificēšanai tiek izmantots Jorena Dālgrena (Göran Dahlgren) un Margaretas Vaithedas (Margaret Whitehead) veselības stāvokḷa ietekmējošo faktoru modelis (Dahlgren \& Whitehead, 1991), ko izmantojusi arī SUSTINNO pētniece savā doktora disertācijā. Šie pētījumi ir sevišķi nozīmīgi, izstrādājot rekomendācijas politikas veidotājiem. Pētijumi rāda, ka veselỉbas stāvokḷa nevienlīdzỉbai nereti ir cieša saikne ar tādiem faktoriem kā labklājība, izglìtỉba, ienākumi, vide, kuri nevar tikt novērsti vienkāršā veidā, isstenojot noteiktas rīcībpolitikas veselības aprūpes sistēmā (Killoran \& Kelly, 2010). Taču rīcībpolitikām var būt liela nozīme nevienlīdzìbas iemeslu, kā arī potenciālo un radīto seku novēršanā (Eurostat, 2015).

Kā nopietna problēma mūsdienu sabiedrības attīstībai, jo ìpaši mazaizsargātām grupām, tiek uzlūkota mājokḷa pieejamība. Mājokḷa pamatfunkcija ir sniegt patvērumu, un mājokla kvalitāte ir nozīmīgs labklājỉbas rādītājs. Bezpajumtniecība un mājoklu trūkums, neapšaubāmi, ir visnopietnākie nabadzības un sociālās atstumtības piemēri Eiropas Savienībā. Sociālā nevienlīdzība mājokḷa nodrošinājumā izraisa nevienlīdzību arī citu sociālo pakalpojumu pieejamībā un sociālajā kapitālā, tādēl ilgstoša nevienlīdzība var pastiprināt dažu sociālo grupu neaizsargātību (Carter \& Polevychok, 2004).

Slikti dzives apstākḷi, pamata ērtību trūkums, pārapdzivotỉba, paaug stināts troksnis, piesārṇojums un vardarbība var pastiprināt veselības problēmas, ierobežot sasniegumus izglītỉbā, darba iespējas un integrāciju sabiedrībā. Ilgstošas grūtības segt hipotēkas vai îres maksu var radìt nepieciešamību mainīt dzīvesvietu, var veicināt augstāku pieprasijumu pēc sociālajiem mājokliem un ārkārtējās situācijās - arī veicināt bezpajumtniecību. ES ir izplatīta prakse, ka valdība vai vietējās pašvaldības var iejaukties un nodrošināt mājokḷus neaizsargātām grupām. Valsts intervence (vai tās trūkums) mājoklu tirgū rada atškirīgas priekšrocības (vai to trūkumu) dažādām sociālajām un teritoriālajām grupām (Fahey \& Norris, 2004). Starp ieguvumiem var būt sociālās nevienlīdzības samazināšana, ja valsts palīdzỉba mājokḷu jomā tiek sniegta pienācīgi.

Kopsavelkot, nabadzības un nevienlīdzïbas mazināšana, no vienas puses, un vidusslāṇa nostiprināšana, no otras, ir nozīmīgi attīstības mērḳi gan starptautiskajā darbakārtībā, gan Latvijas politikā. Sociālo zinātṇu pētījumi sniedz nozīmīgus pierādỉjumus šo mērku pamatotìbai. Tādēl nākamais būtiskais jautājums ir par attīstības mērku iedzivināšanu - kādu atbalstu sniedz valsts tiesiskais ietvars un cik efektiva ir pārvaldība, lai tos sasniegtu. Turklāt ilgtspējīgas attīstības kontekstā valstij jāspēj sabalansēt vides un sabiedrības vajadzības, neuzlūkojot dabu kā neizsmelamu resursu sabiedrības labklājibas celšanai.

\section{Tiesiskais ietvars un vieda pārvaldība}

Ilstspējịga attīstība ir salīdzinoši jaun jēdziens, tādēl konstitucionālajām tiesībām pēdējie gadu desmiti ir bijis būtisks izaicinājums. Konstitucionālo tiesību teorijā atzìts, ka konstitucionālo tiesību jēdzienu, normu un principu pabeigtība pat mūsdienu apstākḷos vēl joprojām ir nosacìta (Klepfers, 2003). Ilgtspējigas attīstības ideja ir bijis liels izaicinājums arī Latvijas konstitucionālajai iekārtai, jo no valsts tiek prasīta noteikta rīcība, lai lēmumu pieṇemšanā tiktu ievērotas ne vien esošās paaudzes, bet arī nākamo paaudžu intereses, kā arì lai tiktu isstenota politika, kas vērsta uz sabiedrïbas labklājibas, apkārtējās vides un ekonomikas sabalansētu attīstibu. Ilgtspèjigas attīstības ideja noteic juridisku valsts rīcibas ietvaru vides, sociālās un ekonomiskās politikas jomās, kurās līdz šim valstij bijus plaša rīcības brīvība. Savukārt tas nozīmē, ka jautājumos, kas skar šīs politikas īstenošanu, minimālos apjomos ir iespējams noteikt valsts pienākumu 
pret sabiedrību un atsevišku personu un prasīt šo pienākumu izpildi tiesas ceḷā. Lìdz ar to šajās jomās samazinās valsts brīva izšḳiršanās; Satversme un vispārējie tiesību principi (vispirms jau ilğtspējigas attīstības princips) pieprasa noteiktas valsts politikas îstenošanu.

Kopumā ilgtspējigas attīstības tiesiskais ietvars ir jauna joma, sociālās dimensijas tiesiskais nodrošinājums balstās uz sociāli atbildīgas valsts principu, un tā vēsture aizsākusies jau 19. gadsimtā. Mūsdienās sociāli atbildīgas valsts princips konstitūcijās tiek nostiprināts divos veidos: 1) ir tieši noteikts, ka valsts ir sociāli atbildīga; 2) šis princips nav tieši noteikts, tomēr šāds secinājums izriet no cita konstitūcijā ietverta regulējuma. Mūsdienās tiek pieñemts, ka sociāli atbildīgas valsts pienākums ir rūpēties par taisnigu sociālo kārtību, izlīdzinot sociālās atškiinības un aizsargājot sociāli vājākos (Maunz \& Dürig, 2014; Muckel, 2009). Sociāli atbildīgai valstij ir jāveicina tādi apstākḷi, kas sekmē individu un sabiedrības grupu vienlīdzỉbu, kā arī nodrošina to, ka individs ne tikai teorētiski, bet arì praktiski var istenot savas brivibas (Roca, 2012-2013; Maunz \& Dürig, 2014).

Sociāli atbildīgas valsts idejā ietvertas tādas vērtỉbas kā cilvēka cieṇa, taisnïgums, vienlïdzỉba un solidaritāte. Ilgtspējigas attīstības mērku kontekstā sevišķi jāuzsver cilvēka cieņas un brīvỉbas aspekts, kuru garantēšana prasa rūpēties, lai tiktu nodrošināti cilvēka cienīgas dzīves minimālie priekšnoteikumi. No taisnīguma izriet prasība, lai cilvēkiem ne tikai formāli tiktu nodrošināta vienlīdzība, bet arì lai faktiski tiem būtu vienlīdzīgas iespējas realizēt savas tiesības. Savukārt solidaritāte nozīmē, ka cilvēkiem ir pienākums cits citam palïdzēt (Saaremäel-Stoilov, 2007; Maunz \& Dürig, 2014; Muckel, 2009). Kopumā var teikt, ka ilgtspējiggas attīstības sociālo mērḳu sasniegšana neuzliek valstij kādas jaunas atbildỉbas, ja tajā jau ir nostiprināti sociāli atbildīgas valsts principi. Tiek prasīta konsekventāka rīcība sociālo mērḳu sasniegšanā un publiskajā diskursā biežāk atgādināta to nozīme.

Sociāli atbildīgas valsts tiesiskais ietvars, uz labklājibu visiem orientētas rīcībpolitikas mērḳi un pārvaldības prasme tos îstenot dzīvē ir būtiski instrumenti taisniggākas un labklājigāakas sabiedrības veidošanā, un tiem tika pievērsta uzmanība arī SUSTINNO pētijumā.

Tā kā pārvaldībai ir būtiska nozìme tiesiskā ietvara noteikto principu iedzīvināšanā un politiski nosprausto attīstības mērku sasniegšanā, pētijjumā pievērsta uzmanība arī pārvaldības principiem un efektivitātei. Pārvaldība bieži vien saistās ar nepamatotiem mītiem. Iestādes likuma normām neatbilstoša rīcỉba tiek nosaukta par labas pārvaldỉbas trūkumu. Savukārt laba pārvaldība tiek uztverta drīzāk kāēteriska un netverama parādība, nevis kā institucionāla realitāte. Sākotnēji Eiropas Komisija bija galvenā virzìtāja pārvaldības ideju iedzīvināšanai, un «Baltajā grāmatā Eiropas pārvaldībai» tika uzsvērtas piecas labas pārvaldỉbas pazimes - atvērtïba, lïdzdalïba, atbildỉgums, lietderīgums un saskanotỉba - kā 21. gadsimta sākuma dominējošās
Šeit un turpmāk angḷu Sermins «wicked problems tiks tulkots kā «launās problêmas», lai uzsvềrtu šajāā jēdzienā ietverto problēm dabas kompleksumu, nenoteiktibu, neprognozējamib to dinamikā un nepieciešamỉbu pēc daudzu institūciju esaistes. Tieši dažādu dalïbnieku iesaiste un to atšḳirigăs intereses bieži vien sâdu problēmu risināšanu apgrūtina un palēnina. vērtības (European Commission, 2001). «Baltā grāmata Eiropas pārvaldībai» uzsvēra sabiedrības iesaisti un līdzdalību rīcibpolitiku izstrādes procesā, uzskatot, ka tā būs iespējam padarìt rīcībpolitikas labākas, racionālākas un arī saprotamākas iedzīvotājiem. Tajā pašā laikā starpinstitucionālā un pārnozaru sadarbiba tika uzskatita par veiksmes atslēgu «ḷauno» problēmu (wicked $\left.{ }^{1}\right)$ risināšanai.

Šobrīd gan labas pārvaldības jēdzienu un izpratni ir nomainījusi viedā vai lietpratīgā (smart) pārvaldỉba, kas par būtisku vienlaikus atzīst gan pārvaldības procesu, gan arì rezultātu (World Health Organization..., 2011). Tajā ir svarīga gan atklāta un pārskatāma rīcībpolitika, gan sabiedrībā diskutēts un akceptēts rezultāts. Tomēr lietpratīgās pārvaldības uzmanïbas centrā ir tieši «launās» problēmas, kuru risināšanai ir jāmeklē jaunas sadarbības formas un jāveido sadarbības tỉkli. Tādēl lietpratīgā pārvaldỉba tiek saistīta ar informācijas tehnolog̣ijas attīstību un publiskās pārvaldes modernizāciju, piemērām, ES stratēóijā «Eiropa 2020» lietpratīga pārvaldỉba izriet no publiskās pārvaldes modernizācijas, kur jauni institucionāli modelị, IT lietojums, inovācijas un e-koordinācija ir mūsdienu realitāte.

Lietpratīga pārvaldība mudina publisko pārvaldi, izmantojot iekšējos un ārējos resursus, pienemt racionālus un izsvērtus lēmumus, kas balstīti starpinstitucionālā (vai tìklu) pārvaldības ieviešanā (Scholl, H.J. \& Scholl, M.C., 2014). Tas izskaidro, kādēḷ pēdējos gados jēdziens «lietpratīgā pārvaldỉba» tiek lietots kā sinonīms terminam «sadarbïbas pārvaldība« (collaborative governance) vai «tìklu pārvaldība» (network governance). Šādu lēcienu ir izraisijusi faktoru kopa: mainīga ārējā vide; «ḷaunās» problēmas; publiskās pārvaldes apzināšanās, ka tā viena nespēs atrast «ḷaunās» problēmas; sabiedrības spiediens.

Kaut arī tālāk pētījumā «launo» problēmu tēma netiek izvērsta, tā varētu būt nozīmìga turpmākajā izpētē, jo raksturo jaunāko konceptuālo skatījumu uz nozīmīgākajām problēmām, ar kurām jāsastopas pārvaldībai mūsdienās. Tieši «launās» problēmas ar savu daudzškautnaino raksturu ir mainījušas organizāciju skatijjumu uz pārvaldību un ietekmējušas iestāžu darbu. «Launajām» problēmām piemìt stratēǵiska nenoteiktība, jo dažādām institūcijām var būt atškirīgi viedokli par problēmas risināšanas nepieciešamỉbu, instrumentiem un pieejām (Emerson, Nabatchi, \& Balogh, 2012). Šìm problēmām piemīt arī institucionāla nenoteiktība - institucionālo atbildỉbu fragmentācija un kompetenču robežu novilkšana veicina nevis problēmas risināšanu, bet tās pārvirzī̌̌anu uz citu institūciju. Visbeidzot, «ḷaunajām» problēmām piemīt arī kognitīva nenoteiktība, jo indivīdiem ir atškirīga izpratne par cēloniem un iespējamām sekām (Bueren, Klijn, \& Koppenjan, 2003). Tieši «launo» problēmu eksistēšana izskaidro, 
kāpēc lietpratīgā pārvaldỉba balstās uz pierādỉjumu un datu izmantošanu lēmumu pieṇemšanai (Reinholde, 2013).

Sociālās inovācijas kopienu drošumspējas stiprināšanai

góionālā attīstība, kas ir valsts pētījumu sināšanā cita starpā potenciāli liela nozīme var būt sociālajām inovācijām. Tāpēc pētijjumā vispirms tika analizēta ši jēdziena daudzveidīgā izpratne. Latvijā «sociālā uzṇēmējdarbỉba» un «sociālā inovācija» ir salīdzinoši jauni jēdzieni, tāpēc ir būtiski konceptuāli izprast to lietojumu.

Starptautiskajā akadēmiskajā diskusijā par sociālajām inovācijām atzìts - neskatoties uz jomu, kurā sociālā inovācija notiek (piemēram, vides problēmas, demogrāfiskie izaicinājumi, sociālās problēmas, reǵionālā attīstība, pilsoniskā līdzdalība vai citas), būtiska ir labvēlīga vide, kurā inovācijai rasties, attīstìties un darboties ilgtermiṇā (Mulgan et al., 2007). Savukārt labvēlīgas (vai tieši pretēji-traucējošas) vides izveidē būtiska nozīme var būt valstij. Tādēl šì pētỉjuma ietvaros tika konceptuāli analizēta arì valsts nozīme sociālo inovāciju attīstībā.

Gan akadēmiskajā diskusijā, gan praksē sociālo inovāciju jēdziena izpratne ir samērā izplūdusi. Viens no skatījumiem uz sociālo inovāciju ir plašs, piemēram: «Sociālā inovācija ir jauna sociālā prakse ar sociāliem mērkiem un sociāliem līdzekliem to sasniegšanai» (Franz, Hochgerner, \& Howaldt, 2012). Citi sociālo inovāciju izpratni ierobežo, norādot, ka tās notiek ārpus valsts organizācijām un organizācijām, kuru mērḳis ir gūt peḷnu. Sociālās inovācijas drīzāk raksturīgas sabiedriskajā un nevalstiskajā, labdarības, brīvprātīgajā, kopienu sektorā (Haugh \& Kitson, 2007). Lai arī pastāv jau minētā diskusija par to, kas var būt sociālo inovāciju radītājs, ir vienota izpratne par to, ka sociālo inovāciju mērḳis ir risināt kādu sociālu problēmu bez peḷnas gūšanas mērka, un tam ir jānotiek jaunā vai uzlabotā veidā, radot pozitìvas pārmainas. Tas ir konceptuālais princips, kas būtu izmantojams sociālo inovāciju atpazišanai un padziḷinātai analīzei.

N̦emot vērā sociālo inovāciju potenciālu sabiedrībai aktuālu problēmu risināšanā un to, ka indivìdu vai indivīdu grupu līmenī var pietrūkt motivācijas un resursu jaunu ideju attīstī̌šnai, tiek pien,emts, ka šajos procesos būtu vēlams valsts atbalsts. Starptautiskos pētijumos ir secināts, ka tas ir atkarīgs no sociālās inovācijas attīstības posma, proti, vai sociālā inovācija ir tikai idejas stadijā, tiek ieviesta/testēta, vai arī tiek izvērsta jaunās jomās, teritorijās vai apjomā. Sākuma posmā valsts institūcijām var būt motivējoša loma, radot iniciatīvu nākt klajā ar sociālām inovācijām - konkursu, nelielu grantu un tamlīdzīgās formās. Ideju testēšanas fāzē tas var būt atbalsta finansējums, kompetenču piesaiste, bet paplašināšanās fāzē tas var būt valsts pasūtijums vai pat jaunu standartu ieviešana (Mulgan et al., 2007).

Sociālo inovāciju jēdziena un valsts nozīmes konceptuālās analīzes galvenais secinājums ir - sociālo problēmu risināšanai un reğionālajai attīstībai sociālās inovācijas var dot būtisku ieguldỉjumu, taču ir būtiski, lai to rašanās un attīstỉba lielākā vai mazākā mērā tiktu atbalstìta arī valsts politikas līmenì. Latvijā pienememtais Sociālās uznēēējjarbības likums un plānotie atbalsta pasākumi ir pirmais solis šajā virzienā (Latvijas Republikas Saeima, 2016).

Sociālo inovāciju izpausmes ir ḷoti dažādas, un pētījuma ierobežoto resursu dēl bija jāizvēlas, kam pievērst uzmanību. Straujajā sabiedrības pārmainu laikā aktuāls uzdevums ir savlaikus apgūt jaunās zināšanas un dzìves prasmes, lai spētu izmantot tos resursus, kas ir pieejami un kas ḷauj labāk risināt dzives uzdevumus. Pētnieki nolēma pievērst uzmanību diviem sociālo inovāciju piemēriem: 1) sociālajām inovācijām publiskajās bibliotēkās, jo tās ir vietas, kur cilvēki iegūst jaunas zināšanas un prasmes, kas ir nosacijums, lai veidotos sociālās inovācijas un drošumspēja; 2) pavirzišanai kā sociālai inovācijai veselības aprūpes laukā. Abi inovāciju piemēri ir saistìti ar kopienas un cilvēku drošumspējas stiprināšanu, ar to saprotot spēju nenonākt nedrošā situācijā un nezaudēt drošības izjūtu, bet, ja tas noticis, spēju drošību un drošības izjūtu atgūt. Cilvēkdrošības jēdziens ir saistìts gan ar valsts iesaisti dažādās ar cilvēka drošỉbu saistîtās jomās, gan ar cilvēku drošỉbas izjūtu, savukārt cilvēka drošumspējas jēdziens priekšplānā izvirza cilvēka paša spēju saglabāt drošỉbu un tikt galā ar apdraudējumiem.

Prasmēm ir būtiska ietekme uz katra individa dzives iespējām. Ekonomiskās sadarbības un attīstỉbas organizācijas (OECD) pētījumā ir atzīmēts ja cilvēkam ir nepieciešamās prasmes, tās var pozitivi pārveidot viṇa dzīivi, savukārt, ja prasmju nav, tas cilvēkam var likt justies atstumtam no sabiedrības, bet attiecībā uz valsti kopumā nepieciešamo prasmju trūkums var negatīvi ietekmēt ekonomisko attīstību, kā arī vājināt tās pozīijas citu valstu starpā (OECD, 2013). Mūsdienās arvien svarīgākas kḷūst prasmes rīkoties ar informācijas un komunikācijas tehnoloğijām, tās nodrošina dažādu informācijas resursu pieejamību bieži vien neierobežoti laikā un telpā. Tehnoloǵiju lietošanas prasmju trūkums var būtiski traucēt piekḷuvi informācijai, kā arī apmainai ar to, tā radot digitālo plaisu sabiedrībā. Savukārt prasmju trūkums novērtēt informācijas kvalitāti var radīt pat negatìvas sekas cilvēka rīcibai (piemēram, kḷūdainas informācijas izmantošana personas ārstēěanās nolūkā) un dzīves kvalitātei.

Pētỉjumi Latvijā rāda, ka iedzīvotāji samērā pozitīvi vērtē savas informācijas ieguves, novērtēšanas un lietošanas prasmes, taču vinu reālā rīcība daudzos gadỉjumos liecina par pretējo, un tas ir nopietns signāls par draudu drošumspējai. Pètot dzives meistarību un informācijpratību, varēja secināt, ka dzīves jomās, kurās informācijpratības novērtējums ir zemāks, 
iedzīvotājiem biežāk nav veicies arī ar dzìves plānu īstenošanu (piemēram, finanšu pārvaldišanā, veselības uzturēšanā un saglabāšanā). Latvijas iedzīvotāju dzīves meistarība nav pietiekama veselības, finanšu, ğimenes attiecību un bērnu audzināšanas, politikas, darba karjeras plānošanas un izglitīibas jomā (Holma, 2017). Arvien skaidrāk redzams, ka tieši dažādu informācijas un komunikācijas tehnoloğiju izmantošanas prasmes (digitālā pratība) ir nepieciešamas, lai piekḷūtu informācijai un to izmantotu. Piemēram, daudz efektīvāk ir lietot speciālas lietotnes saziṇai ar dažādām institūcijām, nekā tās fiziski apmeklēt vai zvanìt pa tālruni.

Publiskās bibliotēkas ir vienas no sabiedriskajām institūcijām, kuras neformālās izglìtības ceḷa var palīdzēt vietējās kopienas iedzivotājiem apgūt dažādas prasmes un zināšanas, to skaitā arī digitālo pratību. Vietējās kopienas izglītošana nav jauns uzdevums, taču digitālās pratības apguve un tās mācišana citiem ir inovācija bibliotekāru darbỉbā. Jaunās tehnoloğijas būtiski mainijjušas arī bibliotēku statusu - no pasīvām, uz pieprasijumiem reaĝejošām institūcijām tām jākḷūst par arvien aktīvākām un radošākām institūcijām. Tas uzskatāmi redzams jaunajā publisko bibliotēku konceptuālajā modelī, kuru izstrādājuši dāṇu informācijas zinātnieki (Jochumsen, Rasmussen, \& Skot-Hansen, 2012).

Publisko bibliotēku veido četras telpas, kas pārklājas: 1) iedvesmas telpa, kurā lietotājs gūst pieredzi, kas pārveido uztveri; 2) mācību telpa, kurā lietotājs var atklāt un pētît pasauli, tādējādi pilnveidojot savas zināšanas un prasmes; 3) satikšanās telpa, kurā cilvēki var satikties, lai apmainītos ar domām un pieredzi; 4) radošo izpausmju telpa, kurā bibliotēkas apmeklētāji var izpaust savas idejas un ieceres. Šo telpu un tajās notiekošo aktivitāšu uzdevums ir attīstìt un/vai paplašināt cilvēku pieredzi (meklēt jaunas nozīmes, identitātes), iedrošināt (attīstīt stipras un neatkarīgas personības) un iesaistìt (attīstìt vēlmi līdzdarboties) tos, kā arì veicināt radošu un inovatìvu domāšanu (meklēt jaunas atbildes praktiski risināmām problēmām u.tml.). Tādējādi publiskā bibliotēka kā visiem brīvi pieejama sabiedrības institūcija var sekmēt arī iedzivotāju un kopienas drošumspēju, un tajās notiekošās sociālās inovācijas ir būtisks pētỉjumu lauks.

Tā kā viens no SUSTıNNO uzdevumiem bija veidot starpdisciplināru skatijjumu uz izpētes problēmu, sociālās inovācijas kopienas drošumspējas stiprināšanas aspektā tika pētìtas arī caur cilvēku uzvedības ekonomikas analīzi veselības jomā. Sociālo problēmu cēloṇi nav tikai sabiedrības kā sistēmas radīti (piemēram, zems algu līmenis noteiktos nodarbinātības sektoros vai zemas pensijas), tie balstās arī uz cilvēka uzvedības psiholoğiju. Tāpat arī problēmu risināšanā politiski lēmumi dažkārt nevar mainìt situāciju, kamēr cilvēki nemaina attieksmi un domāšanu, kas ir pamats noteikta veida rīcībai.

Tradicionāli ekonomikā un arī rīcibpolitikas veidošanā tiek uzskatîts, ka indivìds pieṇems racionālu lēmumu vai rỉkosies lietderīgi, un tā rezultātā palielināsies viṇa ieguvums (subjektīvi sagaidāmā lietderība), t. sk. apmierinātība, laimes izjūta u.c. personiskie ieguvumi. Tomēr cilvēki ne vienmēr rìkojas racionāli un ne vienmēr cenšas palielināt savu ieguvumu un labumu. Cilvēki bieži vien ir ieraduma subjekti, kam raksturīga vēlēšanās sasniegt maksimālus rezultātus ar minimālas piepūles palīdzību (Prager, 2012), kā arī tiem raksturīga koncentrēšanās uz istermiṇa, ne ilgtermiṇa ieguvumiem (Kollmuss \& Agyeman, 2002). Cilvēki bieži pieņem lēmumus, kas nav viņu interesēs, un tas notiek vājas paškontroles vai arī pārāk sarežg̀itas informācijas dēḷ (Mont, Lehner, \& Heiskanen, 2014). Tiek uzskatīts, ka pietiek ar zināšanām un pārliecību, lai indivīda izvēle būtu racionāla un saprātīga. Iespējams, tieši tāpēc visbiežāk kādas noteiktas uzvedỉbas veicināšanai tiek izmantota cilvēku informēšana. Tādējādi netiek ṇemta vērā atškiirība starp nodomiem un rīcību. Tomēr informācija un aicinājumi ir viens no vismazāk efektīviem uzvedības ietekmēšanas veidiem, pat ja cilvēki ir informēti par riskiem (Bandura, 1977). Tāpat jānnem vērā, ka cilvēki bieži vien nereağêe uz ieteikumiem, kā labāk rīkoties (Branson et al., 2012).

Lai veicinātu visas sabiedrības labklājību un ierobežotu indivīdiem kaitējošu uzvedību, rīcibpolitikas veidošanā jānem vērā un jāizmanto uzvedības zinātṇu, t. sk. uzvedības ekonomikas (behavioral economics), sniegtās atziṇas un pētijumu rezultāti. Ekonomiskās un psiholoğiskās pieejas papildina cita citu, un tiek ṇemti vērā faktori, kas var konfliktēt ar racionalitāti, piemēram, altruisms, nepatika pret risku u.c.

Lai mainītu indivīdu uzvedību un palīdzētu veikt labākas izvēles, nereti tiek izmantota pavirzišana (nudğing $)$. Tã ir «jebkurš mēǵinājums prognozējamā veidā ietekmēt cilvēku spriedumus, izvēles vai uzvedību, ko iespējamu padara domāšanas neobjektivitātes un kḷūdas, kas rada barjeras lēmumu pieṇemšanā un traucē cilvēkiem rỉkoties racionāli vinuu pašu interesēs» (Hansen, 2014, p. 2). Tie ir netieši ieteikumi, lai mēǵinàtu bez piespiešanas ietekmēt grupu un individu motivvus, stimulus un lēmumu pieṇemšanu un palīdzētu veikt labākas izvēles, lai indivĩdu dzive būtu veselīgāka, labklājigāāka un laimiggāka. Pavirzīšana daudzviet tiek izmantota kā inovatīvs politikas instruments, un arī Latvijā ir iespēja pavirzišanu izmantot rīcībpolitiku veidošanā.

Pastāv dažādi modeḷi un teorijas, kas skaidro indivīda uzvedỉbu. Uzvedības modeli palīdz izprast rīcību un identificē to ietekmējošos faktorus. Savukārt uzvedības maiṇas teorijas parāda, kā uzvedỉba var tikt mainīta un kā tā mainās laika gaitā. Pētijumos trīs biežāà izmantotie modeḷi un teorijas (Davis et al., 2015) ir sociāli kognitīvā teorija (Bandura, 1986), plānotās uzvedības teorija (Ajzen, 1985) un transteorētiskais jeb pārmaiṇu posmu modelis (Prochaska \& DiClemente, 1982).

Sociāli kognitivajā teorijā tiek uzskatîts, ka individa uzvedības mainas iespējamību ietekmē pašefektivitāte, uzvedības mērkis un rezultāta gaidas 
(Bandura, 2004). Saskanā ar plānotās uzvedības teoriju (Ajzen, 1985) indivīds istenos vēlamo uzvedību tad, ja ticēs, ka tai būs pozitīvas sekas (attieksme), ja indivìdam nozīmīgie cilvēki uzskatīs, ka konkrētā uzvedība ir vēlama (sociālā norma), kā arī ja būs pieejami nepieciešamie resursi un indivìds jutīsies pārliecināts par savām spējām (pašefektivitāte) isstenot iecerēto (Conner, 2002).

Transteorētiskās jeb pārmainu posmu teorijas pamatideja ir, ka uzvedïbas maiņa ir process. Uzvedibas modeḷi un uzvedỉbas maiņas teorijas visbiežāk izmantotas pētījumos par 1) videi draudzīgu uzvedību, piemēram, atkritumu šḳirošanu un otrreizējo pārstrādi; 2) iepirkšanos un patērētāju uzvedību; 3) veselīga dzivvesveida veicināšanu, piemēram, smēķēšanas pārtraukšanu; 4) transporta izmantošanu, piemēram, drošu braukšanu, sabiedriskā transporta lietošanu; 5) finanšu uzvedību, piemēram, uzkrājumu veikšanu (Darnton, 2008; Davis et al., 2015). Tomēr ir svarīgi saprast, ka modeḷi ir veidoti konceptuālā līmenī un nav uzvedības reprezentācija. Uzvedība ir daudz komplicētāka, nekā to paredz teorētiskie modeli. Šie modeli nav lietojami visās jomās un situācijās, kā arī ne vienmēr skaidro atsevišḳu indivīdu uzvedỉbu, bet ir orientēti uz vidējo statistisko cilvēku (Darnton, 2008). Šis konceptuālais ietvars SUSTINNO pētijumā tika ievērots, pētot pavirzišanas iespējas, lai veicinātu dalību vēža savlaicīgas atklāšanas programmā.

Noslēgums

SUSTINNO 2.projekta ambiciozie mērķi paredzēja aptvert Latvijas sabiedrības attīstỉbas virzỉbu pēc krīzes un padzilināti analizēt kompleksās sociālās problēmas, kā nabadzību un nevienlīdzību, un to pārvarēšanas iespējas. Ilgtspējigas attīstỉbas integrēta izpēte ir jauns izaicinājums arī pētniekiem, kuri tradicionāli strādā tikai savā disciplīnā. Pētijuma mērḳu sasniegšanai dažādu sociālo zinātṇu disciplīnu (sociolog̣ijas, politikas zinātnes, psiholoğijas, tiesību zinātnes, informācijas pārvaldības un bibliotēkzinātnes) pētnieki sadarbojās trīs gadus, integrējot katras disciplīnas teorētiskās zināšanas, jaunāko pētijumu atzinas, pētijumu metodes. Ilǵtspējigas attistības pieeja sniedza auglīgu konceptuālu ietvaru sadarbỉbai, un starpdisciplinārā pieeja lâva vispusīgi aplūkot plašo pētỉjuma tēmu, skarot daudzveidīgu jautājumu oku - no ilgtspējigas attīstîbas tiesiskā ietvara un politiskā pamatojuma, kas alstîts uz labklājības ideālu un tādām vērtībām kā cilvēka cienna, taisnìgums, vienlīdzība un solidaritāte, lìdz cilvēka uzvedības psiholoğijai, kas parāda atšķirìbu starp nodomiem un rīcību un pēta, kā pavirzìt cilvēku pretī saprātīgākām izvēlēm 


\section{Kolektivā rīcība interneta politiskās \\ komunikācijas un sabiedrības vērtīborientācijas izmaiṇu kontekstā}

Komunikācijas tehnolog̣iju attīstība un sabiedrības kolektīvās organizācijas mehānismi nav analizējami atrauti. Lai gan tradicionālajiem plašsaziṇas lỉdzekḷiem - televīzijai, radio un interneta portāliem - uz kopējo sabiedrības viedokli ietekme joprojām ir ievērojama, tomēr komunikācijas tehnoloğiju attīstỉba radijjusi būtiskas izmainas auditorijas plašsaziṇas līdzekḷu patēriṇa struktūrā - pēdējo gadu laikā vērojama drukātâs preses patēriṇa samazināšanās, samazinājies arì vidējais televizijas skatīšanās laiks, savukārt interneta lietojuma laiks ir palielinājies (Eurobarometer, 2016). Dati liecina, ka 2013. gadā sociālo mediju platformas Eiropā reizi nedēlāā lietoja $44 \%$ iedzīvotāju, savukārt 2016. gadā-jau teju puse Eiropas iedzìvotāju, bet 38\% iedzivotāju tās lietoja gandrīz katru dienu (Eurobarometer, 2013, 2016). Latvijā saskaṇā ar valsts pētijumu programmas projektā SUSTINNO veikto aptauju 2015. gadā sociālos tỉklus regulāri izmantoja 66\% iedzīvotāju, kas ir tikai par vienu procentpunktu mazāk nekā to iedzivotāju ipatsvars, kas lasa drukāto presi latviešu valodā (67\%) (SUSTINNO, 2015).

Sociālie mediji stratēǵgiskajā politiskajā komunikācijā

Jēdziens «sociālie mediji» ietver dažādas informācijas un komunikācijas tehnoloǵijas, kuras veicina dalǐšanos ar informāciju pēc sociālo tīklu funkcionēšanas principa, kur pamatā ir attiecību tìklojums. Šìs tehnoloğijas var būt interaktīvas mājaslapas, kas izmanto t. s. Web 2.o tehnoloğiju, - emuāri, sīkziṇu rakstī̌̌anas vietnes ātrai ziṇu nodošanai (piemēram, Twitter), foto un video dalīšanās pakalpojumi, kā arī sociālo tìklu platformas (piemēram, Facebook) un profesionālo sociālo tìklu platforma LinkedIn. Akadēmiskajā literatūrā sastopams arī jēdziens «jaunie mediji», ar kuru plašākā nozīmē apzimē komunikāciju tehnoloğijas, kas veicina interaktivitāti starp lietotāiiem un starp lietotāijiem un informāciju (Marvin, 1988). Mūsdienu komunikācijas telpām raksturīga iezīme, ka blakus tradicionālajiem plašsaziṇas līdzekḷiem - laikrakstiem, televizijai, radio - pastāv ar «jaunie mediji», ko veido interneta portāli, emuāri, sociālo tīklu platformas, sīkzinu rakstišanas platformas, dažādas interaktīva rakstura platformas (van Dijck \& Poell, 2013). Tādējādi ir iespējams runāt par konceptuāli jaunu hibrī dās mediju sistēmas modeli (Chadwick, 2013). Šajā modelī sabiedriskās darba kārtības veidošanos nevar viegli paredzēt, jo to ietekmē kā jauno, tā arī tradicionālo plašsazinas līdzekḷu apakšsistēmas. Abas mediju apakšsistēmas atrodas mijiedarbē. Tie pētnieki, kuri centušies izprast šis mijiedarbes dabu, lieto jēdzienu «starpmediju darba kārtỉbas veidošanās» (intermedia ag̉enda setting). Starpmediju darba kārtỉba ir jauns veids, kādā aplūkot to, kā plašsaziṇas līdzekḷu darba kārtību ietekmē jaunie mediji un kā plašsaziṇas lỉdzekḷu vēstījumi ieplūst jaunajos medijos (Broersma \& Graham, 2012; Oates \& Moe, 2016; Wallsten, 2015; Wells et al., 2016). 
Arī politiskajā komunikācijā iesaistītās puses jeb aktori (actors) cenšas pielāgoties mediju sistēmas attīstībai. Šì nodaḷa pievēršas divām politiskās komunikācijas perspektīvām. Vispirms politiskā komunikācija aplūkota no politisko organizāciju un kandidātu stratēǵiskās komunikācijas viedoklạ, kas ietver sociālo mediju izmantošanu kampaņās (vairums pētijumu veikti tieši par politiskajām kampaṇām). Šo perspektīvu var dēvēt arī par t. s. lejupvērsto (top-down) perspektīvu. N̦emot vērā jauno mediju interaktivitātes potenciālu, uz komunikatīvajiem procesiem var paraudzities arī no indivìda un dažādu formālu un neformālu sabiedrības grupu viedokḷa. Šo perspektīvu var dēvēt par augšupvērsto (bottom-up) perspektīvu, un tajā svarīga ir ne tikai informācijas pārvadišana, bet arī savstarpējas sadarbïbas un koordinācijas veicināšana.

Sabiedriski aktīvie iedzīvotāji augstu novērtē sociālos medijus, jo tajos var viegli un efektīvi veidot un izplatīt dažāda veida saturu. Sociālo tỉklu platformas paver iespējas klūt neatkarīgākiem no politiskās komunikācijas tradicionālajiem «vārtu sargātājiem». Plašāku sociālo mediju ietekmi uz vēlēšanu politisko komunikāciju varēja novērot jau 2012. gadā notikušajās ASV prezidenta vēlēšanās, kurās aptuveni $5-10 \%$ no vēlēšanu kampanas budžeta tika atvēlēti tieši interneta medijiem (Römmele, 2012, pp.116-118). Jau drìz pēc tam sociālie mediji ar dažādām sekmēm tika izmantoti arī vēlēšanu politiskajā komunikācijā İrijā, Vācijā, Austrijā, Zviedrijā, Somijā, Dānijā, Polijā, Lielbritānijā un Eiroparlamenta vēlēšanās.

No politiḳa, kandidāta vai sabiedriskā aktīvista skatpunkta ir viegli pamanit sociālo mediju platformu priekšrocibas. Sociālo mediju platformas lauj mazāk zināmiem kandidātiem un partijām «izspraukties cauri plašsaziṇas līdzekḷu filtram» (Skovsgaard \& van Dalen, 2013). Lai arī kandidāti vai organizācijas, kas izvērš kampaņas sociālajos tïklos, ne vienmēr ir sabiedriski atpazistamas, to sabiedrisko «redzamïbu» pastiprina virtuālo sociālo tỉklu vidē aktīvi žurnālisti, mediju personības vai slavenības, kuriem sociālajos medijos ir liels sekotāju skaits (Lodge, 2009, p. 21). Skandināvijas valstu vēlēšanu pētỉjumi apliecina, ka vēlēšanu komunikācija sociālo mediju platformās patiešām var būt efektīva taktika kandidātiem, kuri nav iepriekš ievēlēti, vai arī tiem kandidātiem, kuri neatrodas vēlēšanu saraksta galvgalì (Moe \& Larsson, 2012; Carlson \& Strandberg, 2013).

Vēl viena specifiska sociālo mediju politiskā komunikācijas joma ir lietotāju radītā satura (user-generated content) izmantošana kampaṇās. N̦emot vērā interneta politisko kampaṇu specifiku, ierindas lietotāju radītie videokomentāri, ar kampanu saistītie vizuālie materiāli u. c. elementi nereti sanem vairāk skatijjumu un simpātiju nekā par pašu kandidātu radītais materiāls (Gasser \& Gerlach, 2011). Lietotāju radìtais saturs piešķ̧ir kampaṇai dzīvīgumu un palielina kopējo intrigu. Tomēr kampaṇu regulācijas kontekstā diezgan problemātiski ir objektīvo informāciju par kandidātu nošḳirt no kandidāta apmaksātas reklāmas vai no materiāla, kas īpaši kampanai veidots sabiedrisko attiecību uzlabošanai. Arī nekontrolēta sociālo mediju lietotāja satura ieplūdināšana kampaṇas vēstijumos var traucēt kampaṇai un pat diskreditēt kandidātu (Gasser \& Gerlach, 2011).

Nemot vērā salīdzinoši vājo interneta vides regulāciju, sociālo mediju izmantošana politiskajās kampaṇās kḷūst aizvien plašāk izplatīta. Sociālo tîklu platformas lauj apiet vēlēšanu aǵitācijas ierobežojumus, jo uzraugošajām iestādēm ir faktiski neiespējami izsekot līdzi aǵitācijas materiālam vai pierādìt to saistību ar kandidātu, ja materiālus savos profilos ir ievietojušas citas personas.

Aizvien biežāk vērojama sociālo plašsazinas līdzeklu satura migrācija uz masu informācijas līdzekḷiem-interneta portāliem, žurnāliem, laikrakstiem -, kuri bieži ir saistiti ar rezonansi ieguvušiem Twitter vai Facebook ierakstiem (Small, 2011). Tādējādi «izkaisīto» sociālo tỉklu saturu iespējams fokusēt, lai sasniegtu daudz plašāku auditoriju. Sociālie mediji lauj kandidātiem un aktīvistiem nepārtraukti sekot līdzi norisēm (monitorēt) publiskajā sfērā vēlēšanu kampaṇas laikā, un tas veicina pieprasījumu pēc dažādām sociālo tīklu monitoringa metodēm un rỉkiem (Stieglitz \& Dang-Xuan, 2012). Būtu pārsteidzīgi apgalvot, ka sociālo tīklu noskaņojums (sentiments) vienmēr atspoguḷojas arī sabiedriskajā domā, lai gan atsevišḳos jautājumos iespējams novērot līdzības (Römmele, 2012, p.121). Pēc dažu pētnieku domām, atbilstoša sociālo tỉklu komunikācijas taktika ḷauj identificēties nevis ar kaut kādu kopigu noskaṇojumu, bet gan ar konkrētu ietekmīgu sociālo mediju lietotāju - personibu (influentials) - noskaņojumu (Dang-Xuan et al., 2013).

\section{Stratēǵiskās}

komunikācijas pieejas

Interneta izmantošanā politisko kampanu laikā var novērot četras pieejas. Biežāk izmantotā pieeja ir vērsta uz jauniešu auditorijas aktivizēšanu. Tā balstās pieṇēmumā, ka jauniešu elektorāts ir grūtāk aizsniedzams ar citiem plašsazinnas līdzekḷiem - presi, radio, televīziju. Par jauniešu auditorijas uzmanību konkurē tie kandidāti un organizācijas, kuri vēlas iegūt sev elektorāta dalı, kas vai nu nezina, par ko balsot, vai ar ir svārstīgi izvēlē. Tā kā internets sabiedrībā joprojām tiek lietots nevienmērīgi un dažādās vecuma grupās atškiras interneta izmantošanas mērki, uzrunāt jauniešu grupu, izmantojot sociālos medijus, ir pamatota stratēóija. Saskaņā ar Eurostat datiem par interneta lietošanas veidiem Eiropā gados jauni cilvēki vecumā no 16 lïdz 24 gadiem joprojām ir ievērojami aktivāki sociālajos tīklos $(85 \%)$ un skatās internetā arī video ( $81 \%)$, savukārt gados vecāki iedzìvotāji internetā dod priekšroku saziṇai (e-pasta lasīšanai) un dažādu pakalpojumu izmantošanai (informācijas meklēšana par precēm un pakalpojumiem) (Eurostat, 2017). Vērtējot zinu lasišanu internetā, atšḳirības 
starp vecuma grupām pamazām izzūd. Ziṇas internetā lasa gan jaunieši, gan pieaugušie. Tomēr jauniešu auditorijas sasniegšana vēl nenozīmē tās «iešūpošanu» noteiktai rīcibai, t. sk. arī balsošanai vēlēšanās.

Otra sociālo tīklu mobilizācijas pieeja saistīta ar t. s. mikromērkēěšanas jeb mikrotargēšanas (micro-targeting) izmantošanu. Politiskajā komunikācijā šì pieeja pirmo reizi izmēǵināta ASV prezidenta Baraka Obamas ASV prezidenta kampaṇas laikā 2012. gadā. Kampaṇas «motors» bija elektroniska vēlētāju datubāze ar vairākiem miljoniem ierakstu, kuros tika fiksēta arī potenciālo vēlētāja dzìvesvieta. Īpaši rūpīgi tika apkopota informācija par tiem vēlētājiem, kuri dzīvoja štatos, kur uzvara noteiktos vēlēšanu apgabalos garantētu uzvaru arī visās vēlēšanās (swing states). Iepretī katra respondenta identifikatoram datubāzē tika ievadìta informācija arì par to, vai respondents jau ir izlēmis balsot par kādu no kandidātiem. Tika fiksēta ari gatavỉba iesaistîties noteiktās ar vēlēšanām saistītās aktivitātēs, piemēram, ziedošanā, e-pasta uzaicinājumu un vēlēšanu reklāmas izsūtišanā potenciālajiem atbalstîtājiem u.c. ar vēlēšanu aktīvismu saistītās darbībās. Datubāze ietvēra informāciju par potenciālā vēlētāja vecumu, dzimumu un sociālo kontaktu, respektivi, draugu loku. Izanalizējot datus, tika identificètas respondentu grupas, kuras vēl nebija pārliecinātas par savu piedalī̌̌anos vēlēšanās, kā arī grupas, kas vēl nebija izvēlējušās konkrētu kandidātu. Komunikācijas platforma lāva nosūtìt mērkētus aicinājumus vēlètāiem, kas dzīvoja noteiktos vēlēšanu apgabalos. Tomēr kampaṇas plānotāji deva priekšroku personalizētai aicinājumu nosūtî̌šanai, l̦aujot aicinājumus izsūtît nevis centralizēti, bet gan caur vēèteāju draugiem un paziṇām. Šì pieeja izrādijjās rezultatìva. Pēc dažu novērotāju aplēsēm, vidēji viens no pieciem uzrunātajiem «draugiem» nobalsoja par Baraku Obamu (Pilkington \& Michel, 2012).

2016. gada ASV senāta vēlēšanās mikromērḳēšanas pieeja izpaudās jaunā kvalitātē. Teksasas štata senatora Teda Krūza kampanas laikā informācijas apjomu par vēl ne līdz galam izlēmušajiem papildināja dati no vinuu sociālo tīklu platformām (t. sk. arī laika joslas (timeline) saturs un tajā ievietotie attēli un video), kā arì informācija no citiem datu reǵistriem (par tiem visa informācija netiek izpausta). N̦emot vērā milzīgo informācijas apjomu, kas pieejams par katru vēlētāju, mikromērķēšana radija nopietnas bažas gan par sociālo tỉklu lietotāja privātuma nodrošināšanu, gan arī par manipulāciju ar vēlētāiiem, tāpat radās bažas par ārvalstu specdienestu iespējamo iesaisti prezidenta vēlēšanu rezultātu iespaidošanā (Issenberg, 2016; Brannelly, 2016). Lỉdz šim mikromērḳeššanas izmantošana Eiropas vēlēšanu kontekstā nav bijusi aktuāla. Partijas Eiropā neveido visaptverošas datubāzes par esošajiem un potenciālajiem vēlētājiem. Dažās valstīs, piemēram, Nìderlandē, partijām ir atḷauts veidot datubāzes tikai par saviem biedriem, bet Lielbritānijā mikromērkēěšanas izmantošanu ierobežo datu privātuma likumdošana (EPRS, 2014).
Mikromērkēěšanas būtība slēpjas precīzā mērkłauditorijas segmentēšanā, balstoties uz lietotāju sociālo tīklu profilu datiem, kas tiek analizēti ar kompleksu algoritmu palïdzību, lai konstatētu sakarības starp personas sociālo tìklu profilu un dažādiem psiholoğiskiem, sociāliem un demogrāfiskiem rādītājiem. Datu algoritmi palīdz identificēt sociālo tỉklu platformas lietotāja sociālpsiholoğisko profilu un atbilstoši šim profilam pieskaṇo vēstijjumu, kuru lietotājs saṇem. Nozimmīgu ieguldījumu mikromērḳēšanas metožu pilnveidošanā ir sniedzis Mihals Kosinskis (Michal Kosinski). Vinš pētija sakarības starp Facebook lietotāju profilu saturu, t. sk. lietotāju profilu attēliem un viṇu personības iezimēm, kuras noteica, balstoties uz ìsu katra lietotāja Facebook platformā personiski aizpildītu tiešsaistes psiholoğisko testu (Kosinski et al., 2015).

Uzaicinājumi uz klātienes pasākumiem uzskatāmi par vienu no plašāk izmantotajām sociālo mediju politiskās komunikācijas pieejām. Uzaicinājumus uz mìtiniem, piketiem, demonstrācijām, diskusijām, semināriem izmanto gan neformālas domubiedru grupas, gan politiskās organizācijas. Populārākā platforma uzaicinājumu nosūtīšanai ir Facebook (Facebook events). Pie ievērỉbas cienigiem gadijjumiem var pieskaitìt tos, kuros sākotnēji neformāla tikšanās un pasākums ar laiku pārtop sociālā vai politiskā kustībā (Bartlett et al., 2013). Pieminēšanas vērta ir Itālijas populārā komiķ̧a, bet vēlāk par politiki tapušā Bepes Grillo sociālo mediju komunikācijas taktika. Vina veidotā piecu zvaigžnu kustība Movimento 5 Stelle-M5S aizsākās kā politiķa privātais emuārs - beppegrillo.it - un tiešsaistē pieteikti pasākumi domubiedriem. 2013. gadā $M 5 S$ kandidāti ieguva $25 \%$ vēlētāju balsu, 108 vietas parlamentā un 54 vietas senātā (Bartlett et al., 2013).

Tomēr visplašāk izplatītais sociālo mediju komunikācijas virziens ir kampañas personalizācija. Aktīvistu personības, idejas vai jautājuma «humanizācija» un personalizētu attiecību veidošana ar sekotājiem Facebook, Twitter un Instagram platformās kḷuvusi par izplatītu praksi pat sistēmās ar politisko partiju dominanci (party-centred systems), kurās varētu sagaidīt ciešāku partijas kontroli pār kandidātu komunikāciju (Enli \& Skogerbo, 2013). Novērojumi liecina, ka personalizēta «mājas stila» saziṇa sociālajos tìklos palielina kandidāta pievilcību, lai gan tikai neliela dą̣a no politiķu Twitter satura parast uzskatāma par atğriezeniskās saites sniegšanu vēlētājiem (Graham et al., 2013). Kandidātu reag̊ēšana uz komentāriem un izteikumiem sociālo tỉklu platformās mēdz būt laikietilpịga, turklāt pastāv risks iesaistīties sarunās ar naidīgi un kritiski noskaņotiem interneta komentētājiem.

Interneta anonimitāte piedāvā aizsegu individuāliem komentētājiem, tomēr nereti aiz tā var slēpties arī vairāki algoti komentētāji - t. s. troḷıi. N̦emot vērā minētos faktorus, kandidāti un politiḳi kopumā ir visai piesardzịgi interaktīvo formātu izmantošanā un vairumā gadījumu sociālo tīklu platformās izvēlas vienvirziena komunikāciju (Bruns \& Burgesss, 2012; Graham 
et al., 2013; Kalsnes, Larsson, \& Enli, 2017; Kreiss, 2014; Stromer-Galley, 2014). Toties neizmantoto interaktivitātes potenciālu var bagātīgi atsvērt tā saturs. Šajā gadỉjumā īpaši izceḷama būtu ASv prezidenta Donalda Trampa aktīvā «čivināšana» Twitter platformā, tā pārsteidz ar tvītu spontanitāti un pompozitāti (Enli, 2017; Ott, 2017). D. Trampa un citu politiķu personalizētā komunikācija sociālajos tỉklos var radīt tūlìtējas konsekvences politiskajā darba kārtībā, taču ilgtermin̄ā politiku individuālā komunikācija sociālajos tīklos var palielināt ideoloğisko fragmentāciju, kā arī veicināt polarizētu, vienkāršotu un emocionālu realitātes atainojumu atbilstoši populistiskajai retorikai (Engesser et al., 2016).

\section{Sociālo mediju} potenciāls sociālajā un

politiskajā aktīvismā

Sociālo mediju potenciāls plašāka mēroga sociālo pārmainu veicināšanai ir pētìts salīdzinoši daudz kopš t. s. Arābu pavasara norisēm Tuvajos Austrumos, lai gan pētỉjumu ğeogrāfiskais tvērums ar laiku kḷuvis plašāks. Gadỉjumi, kuros aktīvisti izmantojoši sociālos medijus politiskajā aktīvismā, novēroti Spānijā, Grieķijā, Turcijā, Azerbaidžānā, Singapūrā, Dienvidāfrikā un ASV (Bocsh, 2017; Bruns et al., 2016; Gerbaudo, 2017; Karpf, 2012; Penney \& Dadas, 2013). Pētnieki norāda, ka interneta aktīvisms sekmēe «pagrīdes aktivitātes» autoritāros režìmos, piemēram, Ķin̄ā (Wallis, 2011; Yang, 2014). Pastāv dažādas versijas par sociālo mediju ietekmi uz sociālo aktīvismu. Visbiežāk tiek uzsvērts sociālo mediju potenciāls jauna tipa mobilizācijas mehānismu jeb t. s. tîkloto mobilizāciju (networked mobilization) un jauna veida lïdzdalïbas formu veicināšanā, uzsverot, ka sociālo mediju kampaṇu mērḳis ir nevis tieši veicināt pārmaiņas, bet gan pievērst plašākas sabiedrības uzmanību noteiktam jautājumam, sekmējot redzamību vai plašākā nozīmē sekmējot arī t. s. redzamības politiku (politics of visibility). Būtiskie ierobežojumi sociālo mediju izmantošanai aktīismā ir saistīti ar digitālo plaisu un nespēju uzturēt ilgsstošu kontaktu vai ciešas attiecības aktīvistu vidū (van Laer \& van Aelst, 2010).

Iesaistišanās sociālo mediju kampaṇās demokrātiskās sabiedrībās ir saistāma ar minimālu risku un piepūli, un tā neprasa ievērojamu personisku ieguldijjumu. Var teikt, ka šādi aktīvisma uzplaiksnijumi sociālajos tìklos iedibinājuši jauna veida līdzdalības «žanru»-klikšku aktīvismu (clickactivism). Savās izpausmēs klikšḳu aktivisms robežojas ar simbolisku līdzdalību un izklaides aktivitātēm, tādēl sabiedrisko procesu komentētāji un komunikācijas speciālisti aicina nepārvērtēt tā ietekmi uz politiskajiem procesiem (Morozov, 2011). Turklāt daudzos gadijjumos klikšḳu aktīvisms un citas sociālos tîklos izplatītas lỉdzdalības un sadarbỉbas prakses tiek rosinātas labi nomaskētu komerciālu interešu vārdā. Vērojot tradicionālo līdzdalības formu norietu, daži pētnieki saglabā piesardzīgu optimismu par interneta aktīvismu, norādot uz interneta potenciālu iesaistīt līdz šim neaktīvos interneta lietotājus un rosināt jaunas līdzdalības formas, kas ir piemērotākas informācijas sabiedrības apstākḷiem (Halupka, 2014; Rotman et al., 2011).

\section{Kolektīvās rīcības} mehānismi

Sociālo mediju mobilizācijas potenciāla izvērtējamam nevajadzētu aprobežoties ar vispusīgu vērtējumu, kuru visbiežāk nosaka novērotāja normatīvās pozīcijas un zināšanas. Padzilinātu ieskatu mobilizācijas gadījumos var sniegt kolektīvās rīcibas (collective action) teorētiskās pieejas. Šo pieeju attīstībā liela nozìme ir bijusi sociālo kustību un protesta akciju pētijumiem. Pētnieki nākuši klajā ar iespaidīgu uzskaitijumu to faktoru, kas iespaido kolektīvo rīcỉbu (sk. McAdam, McCarthy, Zald, 1996), tomēr kopumā iespējams nodalīt divas faktoru grupas. Pirmā grupa faktoru saistīta ar organizāciju lomu dažādu mobilizācijas procesu nodrošināšanā pretstatā vāji koordinētām individuālām darbībām. Otra grupa faktoru ietver kolektīvā rīcībā iesaistìto aktoru komunikācijas saturu un t. s. rāmējumu (framing $)$. Šajā kontekstā rāmējums apzīmē organizētas ideju vai stāstu tēmas, kas atklāj mobilizācijas jēgu, kā arī veido noteiktu subjektīvu realitāti, kurā norisinās kolektīvās rīcības darbības. Rāmējumi var būt gan kolektîvi ievirzìti, gan arī kolektīvi veidoti. Dažos gadỉjumos rāmējumi ir kolektīivi veidoti, bet viegli personalizējami, piemēram, protesta kustības sauklis «mēs esam 99\%» (Snow et al., 1986; Snow \& Benford, 1988; Hunt, Benford, \& Snow, 1994; Benford \& Snow, 2000).

20. gadsimta otrajā pusē par vienu no vadošajām sociālās mobilizācijas pieejām kḷuva resursu mobilizēšanas teorija, kurā vadošā loma tika ierādīta organizācijām (McCarthy \& Zald, 1977). Organizācijas nodrošināja savu biedru vai dalībnieku selektīvu stimulēšanu, un tas lāva tām labāk novērtēt ar līdzdalību saistìto izmaksu un ieguvumu attiecību dažādu kolektīvo mērku îstenošanā. Selektīvie stimuli mazināja līdzdalības un mobilizācijas materiālās un kognitīvās izmaksas. Organizācijas ienēma centrālo vietu arì kolektīvo pasākumu loğistikā, sadarbības veicināšanā ar citām orğanizācijām. Tāpat organizācijas nodrošināja arī kopīgu rīcības ietvaru (action frames), kas veidoja aktivistu rīcibas idejisko pamatojumu un noteica kampanas galvenos vēstijumus (McAdam, Tarrow, \& Tilly, 2001).

Internetam kḷūstot par kolektīvās rīcības veicinošo infrastruktūru, organizāciju loma mazinājās. Viens no mūsdienu interneta kolektīvās darbỉbas vēstnešiem bija t.s. virtuālās kopienas (virtual communities), kurās apvienojās indivĩdi no dažādām sociālajām grupām, sociālajiem slāniem vai organizācijām (Rheingold, 2002). Virtuālā kopiena bija jauna tipa sociālā formācija, jo tā paplašināja indivìdu iespēju sasniegt citus līdzịgi domājošus indivìdus neatkarīgi no sociālajām grupām, organizācijām, pie kurām tie 
pieder, vai neatkarīgi no šo organizāciju, grupu līderiem, kuri tās pārstāv. Iedzivotāji varēja pulcēties elektroniskajos forumos un ziṇu grupās atbilstoši savām interesēm. Tiem vairs nebija vajadzīgs starpnieks (indivīds vai organizācija), kas sankcionētu pieeju citu indivìdu un organizāciju resursiem. Formālā starpnieka loma bija mazinājusies, un indivīdi nu lika lietā savu personīgo sociālo tīklojumu (kontaktus, pazišanās, intereses), lai dibinātu attiecības ar citiem līdzịgi domājošiem indivìdiem un organizācijām un gūtu pieeju to resursiem un zināšanām (Bennett, 2003). Virtuālo kopienu aktivitāte agrīnajās interneta kolektīvajās platformās daudziem vēstija par jaunu kolektīvās darbības ēras sākumu. Lai arī pārsvarā iedzìvotāji apmierināja savu kolektivo ziṇkāri, sekojot lídzi sadziviskiem, ar izklaidi un personiskām interesēm saistītiem jautājumiem, dažos gadỉjumos virtuāāās kopienas bija vērstas arī uz politisko un sociālo aktīismu.

Lìdz ar otrās paaudzes tīmekḷa tehnoloğiju (Web 2.0) attīstību 21. gadsimta sākumā notika kvalitatìvs lēciens - t. s. personālo sociālo tehnologíiju attīstība (personal social technologies). Šo tehnolog̣iju savdabỉgu «svēto trīsvienïbu» veidoja sociālo tìklu platformas YouTube, Facebook un Twitter. Iedzivotāji bez ìpašām pūlēm varēja tām sekot lïdzi un pievienoties dažādām kampaṇām vienlaicīgi. Personālo sociālo tehnolog̣iju dažādība pavēra iespējas kombinēt dažādus komunikācijas slānuus (layer), piemēram, mājaslapa + emuārs + Facebook + Twitter, un komunikatìvos rïkus, piemēram, tēmturus (hashtag). Personālo sociālo tehnolog̣iju kampaṇām bija zemi līdzdalības ierobežojumi un līdz ar to arī niecīgas individuālo saistību izmaksas (van Aelst \& Walgrave, 2011). Aktīvistu rīkotās kampanas kḷva ìslaicīgākas un neformālākas. Tradicionālās kampanu organizatoriskās funkcijas nu bija zaudējušas savu nozīmi un tika aizstātas ar jaunu asociāciju dinamiku, kurā izšķirošā nozime bija tīklveida komunikācijai (networked communication).

Lai labāk saprastu un analizētu tīklveida komunikācijas radītos mobilizācijas fenomenus pretstatā tradicionālajai kolektīvās darbības tradīcijai (collective action), kuru vēl 1965. gadā bija formulējis slavenais ekonomists un sociālais teorētikis Mankūrs Olsons (Mancur Olson), 2012. gadā Lencs Bennets (Lance Bennett) un Aleksandra Segerberga (Alexander Segerberg) piedāvāja īpašu jēdzienu - «savienojošā darbỉba» (connective action). Saskaṇā ar L. Beneta un A. Segerbergas piedāvāto ietvaru, savienojošajai darbībai piemita divas būtiskas iezīmes. Pirmkārt, personālās komunikāciju tehnoloğijas ḷauj iedzīvotājiem dalīties uzziṇu resursos un izplatīt tos uzticamos sociālajos tîklos bez oficiālām saiknēm vai saistībām ar organizācijām vai citām kolektīvās dalības formām; pretstatā tradicionālajai resursu mobilizācijas teorijai individi organizējas paši bez centrālo vai vadošo organizatorisko dalībnieku palīdzỉbas (Bennett \& Segerberg, 2012). Otrkārt, politisko informāciju ir viegli personalizēt un var norādìt uz dažādiem problēmas iemesliem un sabiedriski aktuāliem jautājumiem.

1. tabula. Trīs kolektīvās rīcības tipi

\begin{tabular}{|c|c|c|}
\hline $\begin{array}{l}\text { Savienojošā darbība } \\
\text { tikklos, ko veido paši } \\
\text { lietotāji }\end{array}$ & $\begin{array}{l}\text { Savienojošā darbība } \\
\text { tîklos, ko veido } \\
\text { organizācija }\end{array}$ & $\begin{array}{l}\text { Kolektīivā darbība } \\
\text { tīklos, kuros organizācija } \\
\text { ir galvenā noteicēja }\end{array}$ \\
\hline $\begin{array}{l}\text { Organizācijai ir maza } \\
\text { koordinējošā nozīme } \\
\text { vai arī tās nav vispār }\end{array}$ & $\begin{array}{l}\text { Organizācijai ir ne- } \\
\text { liela koordinējošā } \\
\text { nozīme }\end{array}$ & $\begin{array}{l}\text { Organizācija koordi- } \\
\text { nē visu darbibu }\end{array}$ \\
\hline $\begin{array}{l}\text { Sociālās tehnoloğijas } \\
\text { tiek lietotas dau- } \\
\text { dzos slāņos, plaši un } \\
\text { individuāli }\end{array}$ & $\begin{array}{l}\text { Organizācija nodroši- } \\
\text { na sociālo tehnoloği- } \\
\text { ju pamata slāṇus }\end{array}$ & $\begin{array}{l}\text { Sociālās tehnoloğijas } \\
\text { izmanto pašas orga- } \\
\text { nizācijas, kas vada } \\
\text { iesaistīto personu } \\
\text { līdzdalību un koordi- } \\
\text { nē mērḳus }\end{array}$ \\
\hline $\begin{array}{l}\text { Komunikācijas } \\
\text { saturs centrēts uz } \\
\text { iekḷaujošiem per- } \\
\text { soniskās darbības } \\
\text { rāmējumiem }\end{array}$ & $\begin{array}{l}\text { Komunikācijas saturs } \\
\text { centrēts uz organi- } \\
\text { zācijas veidotiem } \\
\text { iekḷaujošiem per- } \\
\text { soniskās darbibas } \\
\text { rāmējumiem }\end{array}$ & $\begin{array}{l}\text { Komunikācijas } \\
\text { saturs centrēts uz } \\
\text { kolektīvās darbības } \\
\text { rāmējumiem }\end{array}$ \\
\hline $\begin{array}{l}\text { Sociālajos tîklos lie- } \\
\text { totāji dalās ar perso- } \\
\text { niskajām izpausmēm }\end{array}$ & $\begin{array}{l}\text { Organizācija sociā- } \\
\text { lajos tīklos zināmā } \\
\text { mērāir tīkla lietotāju } \\
\text { personisko izpaus- } \\
\text { mju moderators }\end{array}$ & $\begin{array}{l}\text { Sociālo tīklu pārval- } \\
\text { dīšnā organizācijā } \\
\text { lielāks uzsvars likts } \\
\text { uz starppersonu } \\
\text { attiecību veidošanu, } \\
\text { kas sekmē kolektīvo } \\
\text { rīcību }\end{array}$ \\
\hline $\begin{array}{l}\text { Neformālie kolek- } \\
\text { tivi bieži nonicina } \\
\text { formālo organizāciju } \\
\text { iesaistišanos }\end{array}$ & $\begin{array}{l}\text { Organizācija darbojas } \\
\text { vāji savienotu tikklu } \\
\text { fonā }\end{array}$ & $\begin{array}{l}\text { Organizācija ir koalī- } \\
\text { cijas noteicēja, un tā } \\
\text { darbojas kā efektīvs } \\
\text { starpnieks }\end{array}$ \\
\hline
\end{tabular}

(Pēc Bennett \& Segerberg, 2012) 
Balstoties uz vairāku protesta kampaṇu pētijumiem, L. Bennets un A. Segerbergá secina, ka viṇu piedāvātā mobilizācijas tipoloğija tomēr neaptver visus gadijjumus, jo kolektīvās darbības mehānismi nav skaidri nodalāmi. Starp tradicionālo resursus mobilizējošo organizāciju (galvenā ir organizācija) un savienojošās darbības tỉklu (galvenie mobilizācijas dalïbnieki ir paši indivīdi) pastāv vēl arī citas mobilizācijas formas, kur organizācijai var būt noteikta nozīme mobilizācijas procesu koordinēšanā (piemēram, organizācija izveido vienotu kampanas vizuālo identitāti un nodrošina protesta pasākumu loğistisko atbalstu), savukārt indivìdi var aktīvi izmantot personālās komunikācijas tehnoloğijas kampaṇas individuālo vēstijumu izstrādē un izplatî̌anā. Tādējādi daudzas mobilizācijas formas patiesībā ir hibrīdas. Autori izdala trīs mobilizējošo tikklu tipus -1) savienojošās darbības tìkli, kuri atbilst savienojošās darbības mobilizācijas pieejai; 2) savienojošās darbības tìkli, kurus veido organizācija; 3) kolektīvās darbïbas tīkli, kuros organizācija ienem galveno - brokera lomu. Atškirīibas starp šiem mobilizācijas tỉklu tipiem atspoguḷotas 1. tabulā.

Situācijā, kad organizācijas un to līderi zaudē savas pozịcijas kā galvenie kolektīvās rīcības veicinātāii, ir svarīgi turpināt apzināt alternatīvus sociālās mobilizācijas kampaṇu mehānismus un to dinamiku. Lai arī Latvijā nevar runāt par plaša mēroga sociālo kustību un protesta akciju popularitāti, pēdējā laika novērojumi liecina, ka šim apgalvojumam rodas aizvien jauni iznēmumi.

\section{Vai Latvija uzkarst?}

2016. un 2017. gadā publiskajā telpā un internetā varēja novērot vairākas akcijas, kas piesaistijja plašu sabiedrības uzmanību. «Pilsēta cilvēkiem», «Sieviešu maršs», «Par sievietes tiesībām lemt par savu kermeni», «100 kailcirtes Latvijas simtgadei», «Par kokiem Rīgā», «Par cirku bez dzīnniekiem», «Par Āgenskalna tirgus glābšanu», «Kapu tramvajs» ir dažas no tām. Šajās akcijās aktivisti centās pievērst sabiedrỉbas uzmanỉbu problēmām, par kurām līdz šim pilsoniskās sabiedrības kontekstā tika diskutēts diezgan maz. Latvijā kopumā konvencionālā politiskā līdzdalība ir vāji izteikta, bet ir vērojamas dažas spilgtas nekonvencionālās politiskās līdzdalības formas, taču tās lielākoties bijušas īslaicīgas vai pievērsušas samērā mazu sabiedrības uzmanību.

Lai arī Latvijā nav vērojamas plašas sociālās kustības, par savdabīgu alternatīvu tādai kustỉbai ir kḷuvusi ikgadējā akcija «Lielā talka», kurā ik gadu piedalās vairāki tūkstoši iedzīvotāju. Akcijai sākotnēji bija manāmi daži politiskā aktīvisma rāmējuma elementi, tomēr šobrīd tā vairāk ieguvusi saimniecisku raksturu. 2009. gada ekonomiskās recesijas iespaidā pieauga individuāli radītā satura îpatsvars un izveidojās vairāki interneta sociālās mobilizācijas portāli. Plašāko sabiedrisko rezonansi Latvijā radīja Latvijas Universitātes Matemātikas un informātikas institūta Mākslìgā intelekta laboratorijas pētnieka Ilmāra Poikāna jeb Neo aktivitātes. Izmantojot sīkziṇu platformu Twitter, I. Poikāns internetā publicēja no Valsts ienēmuma dienesta Elektroniskās deklarēšanas sistēmas noplūdinātos datus par atsevišḳu valsts iestāžu un to amatpersonu nesamērīg augsto atalgojumu, kas tika maksāts valsts budžeta taupības apstākḷıs. Neo darbība radijja plašu sabiedrisko rezonansi, un to varētu klasificēt par t. s. haktīvisma gadījumu, kurā ielaušanās informācijas sistēmās tiek attaisnota sabiedriski nozīmīgu mērḳu vārdā.

2017. gadā istenotos protestus pret Rīgas pašvaldỉbas ielu remontdarbu organizēšanu, apkaimju un dabas aizsardzỉbu var uzskatît par jau zināmām tēmām Latvijas sabiedriskajos protestos, taču globāla mēroga rāmējumu izmantošana kampaṇās ir samērā jauna tendence Latvijas pilsoniskās pašorganizācijas kontekstā. Dzivnnieku biedrības aktīvistu kampanāa pret dējējvistu turēšanu šauros sprostos izmantotie saukli «Tuvāk mājām, tālāk no sirdsapziṇas», «Tas nav mans Rimi», «Lielām ciešanām-mazas cenas» izcel kontrastu starp sociāli atbildīga korporativa uzṇēmuma tēlu un šì uzṇēmuma reālo praksi, iepērkot produkciju no industriālām fermām ar apšaubāmu praksi dzīvnieku labturībā.

Lieluzṇēmumu korporatīvā tēla diskreditēšana, konfrontējot tos ar realitātē istenoto praksi ražošanā vai izejvielu ieguvē, ir plaši izmantots rāmējums globālā mērogā. Dzivnnieku biedrība par šo jautājumu ir organizējusi 12 piketus, prasot ar 2025. gadu no tirdzniecības izṇemt sprostos dētas olas (Puke, 2017). Akciju rezultātā devini Latvijas restorāni publiski atteicās no olām, kas dētas sprostos. Cīnoties par aizliegumu izmantot cirkā savvalas dzīvniekus, Dzīvnieku biedrībai vajadzēja rīkot vairāk protestu un piketu. Pēc tam, kad tika savākti vairāk nekā 10 ooo iedzīvotāju paraksti iniciatīvā ManaBalss.lv, kad tika sarīkotas regulāras pulcēšanās pie Saeimas u.c. aktivitātes, šai organizācijai tomēr izdevās sasniegt savu mērḳi. Savvalas dzivnieku izmantošana cirkā tika aizliegta. Lìdzīgi Dzìvnieku biedrības darbỉbai, arī apvienības «Pilsēta cilvēkiem» aktivitātēs sociālie mediji tika izmantoti, lai mobilizētu iedzīvotājus reālās dzives aktivitātēm. Apvienība «Pilsēta cilvēkiem» organizēja velojoslas svētkus, sociālajos tîklos aicināja riteņbraucējus palīgā tās sargāt (Puḳe, 2017).

İstenotajās protesta akcijās uzmanību piesaista izteiktais cilvēktiesību diskurss (aborti, sievietes tiesỉbas lemt par savu k̦ermeni) un postmateriālo, identitātes politikas tēmu aktualitāte (vide, mājdzīvnieku labturība).

Labvēlīgu infrastruktūru protesta iniciativvu pieteikšanai, popularizēšanai un virzišanai politiskajā darba kārtībā piedāvā politisko iniciatīvu platforma ManaBalss. Vērojams, ka gandrīz visas plašāku redzamỉbu ieguvušās protesta iniciativvas ir izmantojušas ManaBalss piedāvāto infrastruktūru iedzìvotāju parakstu vākšanā. 
Saskaṇā ar 2017. gada beigās (23.11.2017.) apkopoto portāla statistiku tajā kopš tā darbỉbas uzsākšanas 2011. gadā bija ievietotas 1224 pilsoṇu iniciatīvas, par kurām kopā, izmantojot identitātes autentifikāciju caur interneta banku, bija savākti 876340 paraksti. Saeima bija atbalstījusi risinājumus 17 iniciatīvām, bet noraidijjusi 12 iniciatìvas. Tikpat daudz iniciatìvu vēl bija iesniegtas Saeimā, bet pašvaldībās bija iesniegtas 3 pilsoṇu iniciatīvas. Vislielāko parakstu skaitu bija savākusi iniciatīva «Atcelt nekustamā īpašuma nodokli vienīgajam īpašumam» (26087 paraksti, pagaidām noraidīta), «Marihuānas dekriminalizācija» (10 617 paraksti, noraidīta), «Lai vēzis būtu ārstējama slimība» (11 459 paraksti, daḷēji pozitivss rezultāts), «Par atklātu balsojumu prezidenta vēlēšanās» (11 429 paraksti, pagaidām noraidìta) (ManaBalss.lv, 2018).

Pēc 2015. gadā veiktā ManaBalss iniciatìvu apsekojuma ievērojamu dalu portālā veidoja kreisi un mēreni orientētas iniciatīvas. Jāpiebilst, ka tas atbilst vadošajai vērtību orientācijai Latvijas sabiedrībā kopumā, kas arī tiek raksturota kā kreisi konservativa (Populares Latvija, SKDS, 2012). Par novirzi no sabiedrībā dominējošā vērtību portreta liecināja tas, ka portāla iniciatīvu vidū bija salīdzinoši maz konservatīvu iniciatīvu, toties daudz vairāk bija tādu iniciatīvu, kuras varētu atbilst t. s. jaunajai politikai (new politics). Jaunā politika ietver jautājumus par dabas piesārṇojumu, sieviešu vienlīdzỉbu, cilvēktiesībām, nepieciešamību pēc mierīgas starptautiskās līdzāspastāvēšanas un pēc palīdzēšanas trešãs pasaules valstīm. Jaunā politika uzsver, cik svarīga ir atvērta pieeja politiskajiem līdzdalības līdzekḷiem un resursiem, tā atbalsta minoritāšsu vārda brīvibu, pieeju valsts lēmumu pieṇemšanas procesiem un kopumā atbalsta iespēju piedalīties politikā (Brooks \& Manza, 1994). Tātad zināmā mērā ManaBalss patiešām palielina pilsoniskajā sabiedrībā aktīvo balsu dažādību.

Mēǵinot saskatît Latvijas pilsonisko iniciatīvu un sabiedrisko protestu kaleidoskopā dažāà kolektīvās rīcības tipu pazīmes, jāuzsver, ka neinstitucionalizētās vai dạ̣ejii institucionalizētās līdzdalības aktivitātes ir prasijušas salīdzinoši ilgu laiku no aktīvāko iedzīvotāju puses un nebūt neliecina par klikšķu aktīvisma mānīgo vieglumu. ManaBalss iniciatīvu pieteicēju vidū ir iespējams sazīmēt visus trīs kolektīvās rīcības tipus. Dažos gadỉjumos pieteiktās iniciatīvas virza noteikta organizācija (piemēram, «Dzīve bez hepatīta C»), savukārt vairākumā gadījumu tomēr iespējams identificēt neformālu iniciatīvas grupu vai atsevišku aktīvistu tīklotas aktivitātes, kur organizatorisks atbalsta trūkums nav traucējis sasniegt iecerēto rezultātu. To apliecina, piemēram, iniciatīva «Par nekustamā īpašuma nodokḷa atcelšanu vienīgajam ippašumam», kas savākusi visvairāk iedzivvotāju parakstu.

Sociālās mobilizācijas mehānismu izpētei ManaBalss iniciatīvās un sabiedriskā protesta akcijās būtu nepieciešama dziḷāka analīze turpmākajos pētījumos. Tomēr situācijas attīstỉbu palīdz noskaidrot arī ar iedzìvotāju līdzdalību un tehnoloğiju attīstību saistīti faktori.
PALIELINĀS SOCIĀLO MEDIJU LIETOJUMS Pirmkārt, protams, palielinās interneta loma informācijas iegūšanā par sabiedriskiem un politiskiem notikumiem. 2015. gadā ziņas par sabiedriski politiskiem notikumiem no interneta portāliem latviešu valodā katru dienu vai gandrīz katru dienu ieguva aptuveni $40 \%$ iedzivotāju un krievu valodā $-18 \%$ iedzivotāju. Nedaudz mazāk nekā trešā daḷa iedzīvotāju (27\%) sociālajos tìklos ieguva informāciju par sociāli politiskiem notikumiem. Turklāt interneta kā ziṇu avota nozìmìba Latvijā ir salīdzinoši augsta. 66 \% iedzīvotāju izmanto internetu gandrīz katru dienu, un informāciju par sabiedriski politiskiem notikumiem latviešu valodā iegūst $81 \%$ interneta lietotāju, bet krievu valodā- $52 \%$ lietotāju.

2017. gada pavasarī Latvijā populārākā interneta vietne bija Google.lv. Otrajā vietā ar 43,8\% (706 tūkstoši liela auditorija) ierindojās video koplietošanas interneta vietne YouTube (kopš 2016. gada pavasara tā ir pakāpusies par vienu vietu auggstāk). Trešo vietu popularitātes zinā ieṇem sociālais portāls Facebook, to vidēji dienā izmanto 43,1\% interneta lietotāju (694 tūkstoši cilvēku). Ievērojamu kāpumu savā pozīcijā pēdējo divu gadu laikā piedzivojis arì attēlu sociālais tìkls Instagram (TNS, 2018). Interesanti, ka tipiskais sociālo tỉklu neizmantotājs ir bijis vecāka gadagājuma iedzivotājs vecumā no 55 lỉdz 74 gadiem, vīrietis, kas dzìvo Rīgā vai Pierīgā (SUSTINNO, 2017). 24 \% iedzìvotāju ir izmantojuši Facebook, lai pieteiktos vai reǵistrētos uz dažādiem pasākumiem vai notikumiem. Interneta lietotāju vidū šo iespēju bija izmantojuši $43 \%$ respondentu (SUSTINNO, 2017).

Tieša mijiedarbe ar politiķiem un institūcijām sociālajos tīklos ir mazāk izplatīta. Sīkziṇu rakstīšanas vietnē Twitter politikiiem seko līdzi samērā neliela sabiedrības dala - orientējoši 4,4\% interneta lietotāju (SUS TINNO, 2015). Tomēr, ṇemot vērā to, ka sociālo tīklu platformās liela nozīme ir sociālo tīklu centrālajiem dalībniekiem, politiķu un amatpersonu rakstītais nereti aizsniedz daudz lielāku sabiedrības dalu.

SABIEDRISKĀS INICIATĨVAS IR REDZAMAS, TAČU PIEDALī̌̌ANĀS PROTESTOS NAV POPULĀRA Saskanā ar 2014. gada pētījuma «Cik demokrātiska ir Latvija? Demokrātijas audits, 2005-2014» ietvaros veiktajām aptaujām protesta akcijās Latvijā iesaistijās salīdzinoši maz iedzivotāju $-6 \%$. Krievu tautības respondentu vidū ipatsvars bija vēl mazāks $-4 \%$. Aptuveni tikpat daudz respondentu bija parakstījuši petīiju, bet nedaudz populārāka bija noteiktās valstīs ražotu produktu boikotēšana vai pirkšana $-6 \%$. Lai gan rādītāji ir zemi, iedzīvotāju īpatsvars, kas 2017. gadā bija dzirdējuši kaut ko par sabiedriskajām iniciatīvām «Par cirku bez dzīvniekiem», «Gribu palīdzēt bēgliem», «Tiešās pirkšanas kustība», bija ievērojami lielāks (2. tabula). Par sabiedrisko iniciativvu «Par cirku bez dzînniekiem» bija dzirdējuši pat 74 \% aptaujāto. Kā jau varēja gaidìt, interneta lietotāju vidū par sabiedriskajām iniciativām dzirdējušo īpatsvars bija salīdzinoši lielāks. 
2. tabula. ledzīvotāju īpatsvars, kas dzirdējuši kaut ko par sabiedriskajām iniciatīvām (2017.gada decembris, \%)

\begin{tabular}{lcrr}
\hline Sabiedriskā iniciativa & Kopā & $\begin{array}{r}\text { No tiem, kas } \\
\text { izmantojuši } \\
\text { internetu* }\end{array}$ & $\begin{array}{r}\text { No tiem, kas nav } \\
\text { izmantojuši } \\
\text { internetu* }\end{array}$ \\
\hline $\begin{array}{l}\text { Dzivnieku briviba-«Par cirku } \\
\text { bez dzivnniekiem» }\end{array}$ & 74 & 27 & 16 \\
\hline Gribu palìdzēt bēgliem & 37 & 38 & 28 \\
\hline Tiešãs pirkšanas kustiba & 25 & 75 & 67 \\
\hline
\end{tabular}

* Interneta izmantošana pēdējā mēneša laikā. (suStinNo, 2017)

SAGLABĀJAS UZTICĪBA MEDIJIEM, BET UZTICC̄BA INSTITŪCIJĀM JOPROJĀM IR ZEMA Lìdzịi kāi ikviena medija, arī sociālo mediju informācijas kanālu popularitāte ir saistīta arī ar to, cik lielā mērā sabiedrība tiem uzticas. Latvijā tradicionāli vērojama loti zema sabiedrības uzticība institūcijām. Uz šāda fona sabiedrības uzticība medijiem var šḳist augsta. Saskaṇā ar Eirobarometra standarta aptaujām uzticība medijiem Latvijā ir nedaudz augtāka nekā vidēji ES, lai gan atšḳirībā no tradicionālajiem plašsazinnas lïdzekliem sociālajiem tīkliem iedzivotāji uzticas ievērojami mazāk. 2017. gadā sociālajiem tīkliem uzticējās $27 \%$ Latvijas iedzīvotāju. Lielāku iedzīvotāju uzticību joprojām bauda televizija (65\%), radio $(63 \%)$, prese $(50 \%)$ (Eurobarometer, 2017). Jaunāki iedzīvotāji vairāk uzticas interneta portāliem, bet vecāka gadagājuma respondenti par uzticamākām atzīst televizijas un radio programmas (SUSTINNO, 2015). 82 \% Latvijas iedzīvotāju mēelz lasīt komentārus interneta portālos (Eurobarometer, 2017). Diezgan bieži un ḷti bieži komentārus lasa aptuveni $27 \%$ interneta lietotāju, savukārt aptuveni 73 \% tos lasa diezgan reti, ḷoti reti vai nekad (SUSTINNO, 2015). Tomēr vienlaikus lielākā dạ̦a $(89 \%)$ respondentu tomēr uzskata, ka interneta komentāriem kopumā nevar uzticēties (SUSTINNO, 2015).

PALIELINĀS DRAUDI INFORMATĪVĀS TELPAS DROŠĪBAI Latvijas sabiedrỉbai kopumā raksturigga zema uzticỉba institūcijām, taču samērā augsta ir uzticība cilvēkiem personisko attiecību lokā. Šis faktoru kopums var sekmēt viltus ziṇu izplatī̌šanos sociālajos tîklos. Latvijas informatīvajā telpā klātesoši ir t. s. klikšķu portāli, kas nav reǵistrēti kā plašsazinas lïdzekli, tomēr tie, publicējot provokatīvu materiālu, piesaista sabiedrïbas uzmanību. Šajos portālos publicētā informācija bieži vien ir sagrozita, nepatiesa un manipulatīva, un tos vairāk iecienījuši tieši jaunieši. Pēdējos gados interneta vietnēs citu valstu vēstījumu izplatī̌̌anā aktīvi darbojas t. s. hibrīdtroḷli. Pētījuma laikā analizējot komentārus interneta portālos apollo.lv, delfi.lv un tvnet.lv, tika noskaidrots, ka nedaudz mazāk nekā 2 \% no kopējā (vairāk nekā 200 ००o) reğistrēto komentāru skaita varētu būt uzskatāmi par hibrīdtroḷıu saturu. Visvairāk t. s. troḷli komentējuši rakstus par konfliktu Ukrainā un sankcijām pret Krieviju (Spruds et al., 2016).

Neraugoties uz interneta popularitāti, tā saturs šobrīd ir daudz vājāk regulēts nekā audiovizuālo plašsaziṇas lỉdzekḷu saturs. Tāpēc vairākas valstis, t. sk. Lielbritānija, Polija, Nīderlande, Vācija un Francija, ir intensificējušas ciṇu pret dezinformāciju sociālo tìklu platformās. Arī Eiropas Komisija ir uzsākusi sabiedriskās konsultācijas un izveidojusi darba grupu, kas sagatavos ziṇojumu par viltus ziṇām un dezinformāciju (European Commission, 2017).

PIEAUG MEDIJPRATības NOzīme Kritiski spriestspējīgāka sabiedrība ir uznēmīgāka pret manipulatīvu un dezinformējošu saturu medijos. Plašsaziṇas lïdzekḷu lietotprasme ietver spēju izvēlēties un saprast medijos publicēto materiālu, kā arī ietver spēju satura, formas/stila, ietekmes, nozares un ražojuma kontekstā apšaubìt, novērtēt to un uzmanigi reaĝèt uz medijos publicēto (National Telemedia Council, 1992). Eksperti apgalvo, ka Latvijas iedzìvotāju plašsaziṇas līdzekḷu lietojumam pārsvarā ir vienvirziena raksturs, dominē pasīvs informācijas sanemšanas paradums. Dalai sabiedrības piemit konservativi mediju lietošanas paradumi, tostarp nekritiska pieeja ikdienā izmantotajiem medijiem. Iedzivvotāji nemeklē alternatīvus informācijas avotus, bet aprobežojas ar viena plašsaziṇas līdzekḷa piedāvāto informāciju un arī vienas valodas informatìvo telpu. Tādējādi pastāv priekšnoteikumi mediju izmantošanai propagandas nolūkā un manipulācijai ar iedzivotāju uzskatiem un vērtībām (Holma, 2017). Paralēli sabiedrības medijpratības stiprināšanai būtu jāsekmē arī pētnieciskajā žurnālistikā balstìtas iniciatìvas. Apsverama būtu specializētas platformas radīšana informācijas ticamības un korektuma pārbaudei.

\section{Nākotnes scenārij}

Rezumējot galvenās tendences, var teikt, ka, no vienas puses, sociālo mediju izmantošana stratēğiskajā politiskajā komunikācijā nodrošina sava veida piedāvājumu iedzīvotājiem vairāk iesaistīties sabiedriskajos un politiskajos procesos. No otras puses, sociālo mediju izmantošana sabiedriskajās un politiskajās aktivitātēs liecina par sabiedrības pieprasijumu pēc izmainām. Pamatojoties uz elektroniskās demokrātijas attīstības scenārijiem, 


\section{1. attēls. Elektroniskās demokrātijas attīstības scenāriji}

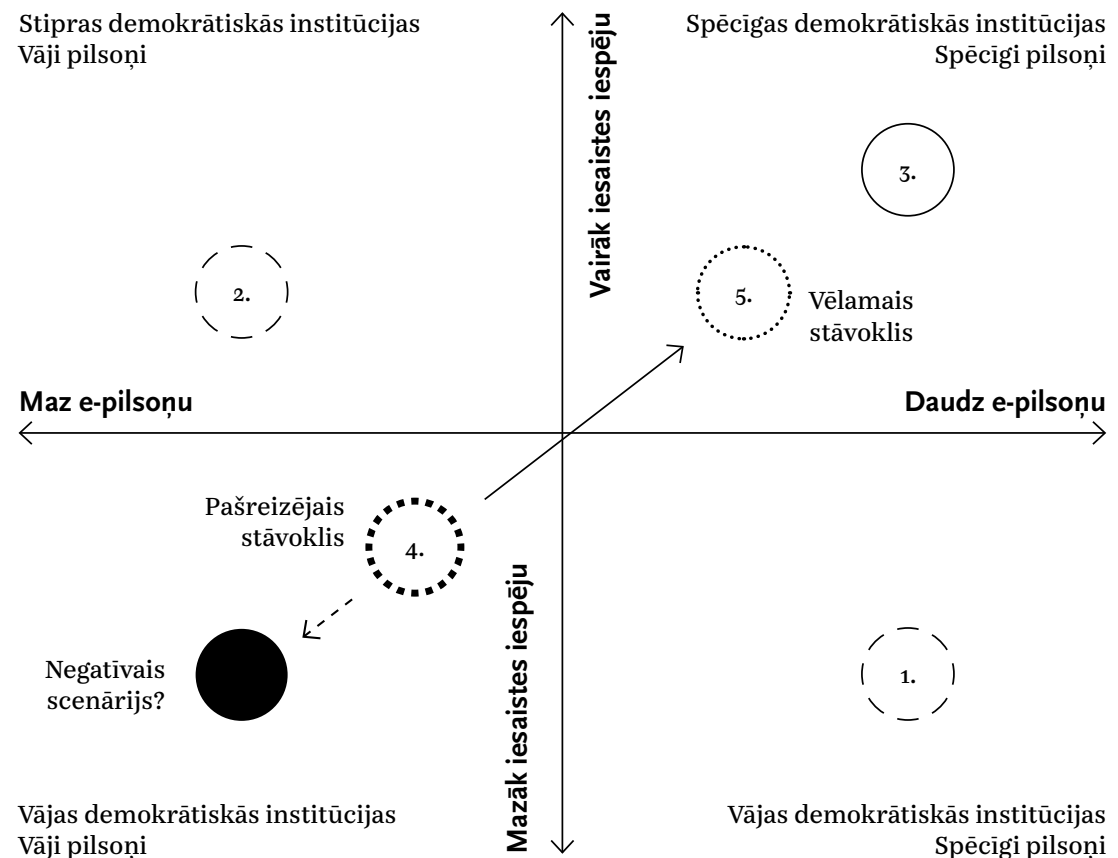

Vāji pilsoṇi

Spēcigigi pilsoṇi uzsvars tiek likts tikai uz vienvirziena komunikāciju, piepildīsies otrais scenārijs-spēcīgas demokrātiskās institūcijas, bet vāji pilsoṇi. Iedzīvotāju ỉpatsvars, kas iesaistities sociālajā un politiskajā aktīvismā, būs zems.

3. Spēcīgas demokrātiskās institūcijas un spēcìgi pilsoni. Trešais scenārijs iezīmē vēlamo demokrātijas un pilsoniskās sabiedrības «atdzīvināšanas» virzienu. Palielinās interneta un sociālo mediju izmantošana stratēĝiskajā politiskajā komunikācijā un valsts pārvaldē, bet arī sabiedrība aizvien vairāk mobilizējas un pašorganizējas.

4. Vāji pilsoni un vājas demokrātiskās institūcijas. Ceturtais scenārijs istenosies, ja netiks veiktas ievērojamas izmaiņas pašreizējā situācijā. Pēc S. Klifta domām, internets patlaban ir efektīvākais medijs politiskās intereses un līdzdalības veicināšanai, tādēl demokrātijām informācijas laikmetā būtu jāizveido asociācija ar efektīviem informācijas un komunikācijas tehnoloğiju lietojumiem. Ja iedzīvotāji, institūcijas un nevalstiskās organizācijas nespēs saskatìt un praktiski izmantot šo «savienību,» viṇu līdzdalība, visticamāk, turpinās mazināties.

5. Nedaudz spēcìgàki pilsoni un demokrātiskās institūcijas. Scenārijs iezīmē reālistisko optimistisko scenāriju, kurā interneta un sociālo mediju iespējas izmanto neliela dạ̣a valsts iedzīvotāju. Tādā gadijjumā komunikācijas tehnolog̣iju lietojums palīdzēs uzlabot demokrātiskos procesus un stimulēs vēl intensīvāku komunikācijas tehnoloğiju iespēju izmantošanu. Sabiedrības un pārvaldes attiecibas tuvināsies trešajam scenārijam - spēcīgas demokrātiskās institūcijas un spēcīgi pilsoṇi (Valtenbergs, 2010).

Pētnieku un komentētāju vidē nav vienprātības saistībā ar sociālo mediju ietekmi uz politiskajiem procesiem. Izlïdzinošais scenārijs paredz, ka sociālie mediji paplašina mazāk ietekmīgo organizāciju un indivīdu potenciālu, palielina komunikācijas aizsniedzamību un kontroli pār savu vēstỉjumu. Rezultātā rodas jaunas formālas un neformālas iniciatīvas, kas palielina pilsoniskās un politiskās mobilizācijas plurālismu.

Normalizācijas scenārijā sociālie mediji paplašina jau aktīvo iedzīvotāju politiskās līdzdalības iespējas, tādējādi pastiprinot pastāvošās tendences politiskajā līdzdalībā. Normalizācijas scenārija kritiḳi norāda, ka sociālie mediji veicina t. s. atbalss efektu (echo-chamber effect), kurā līdzịgs mediju saturs cirkulē starp līdzịgi domājošajiem (Trent, 2011; Boutyline \& Willer, 2016). Atbalss efektu veicina katram sociālo tīklu platformas lietotājam ar 
ipašu algoritmu palīdzību piemeklēts saturs. Visbiežāk šāds saturs atbilst lietotāja un vina sekotāju jau iepriekš aplūkotai informācijai. Tādējādi sociālo tīklu lietotāja iespēja saṇemt viṇa interesēm vai uzskatiem neatbilstošu informāciju ievērojami samazinās. Citi pētnieki uzskata, ka sociālie tîkli politisko uzskatu zināa ir vēl pietiekami heterogēni (Römmele, 2012).

Minētie scenāriji ir diskutabli, jo tos gan apstiprina, gan noliedz vairāki empiriski pētijumi. Piemēram, izlīdzinošo scenāriju pastiprina iedzìvotāju dažādu individualizētu elektroniskās līdzdalības formu popularitātes palielināšanās, t. sk. dažādu elektronisku petīciju parakstī̌šana, savukārt pētījums par Facebook pastiprinošo ietekmi uz vēlēšanu lïdzdalïbu Zviedrijā apstiprina normalizācijas scenāriju (Gustafsson, 2012). Arī Latvijā būtu nepieciešami tālāki pētỉjumi par sociālo mediju veicinātām aktīvisma formām un konkrētiem sociālās mobilizācijas mehānismiem. 


\section{Uzṇēmējdarbība, eksports, nodokḷi, ènu ekonomika un konkurētspēja: turpmākas analizes ietvars}

Uznēmējdarbība ir uzskatāma par svarīgu ekonomiskās izaugsmes dzinējspēku, kas nodrošina produktivitātes uzlabojumus, jaunāko tehnolog̣iju ieviešanu, nodarbinātības veicināšanu un kopējas iedzivotāju labklājības celšanos (Schumpeter, 1934; Acs \& Audretsch, 1988; Wennekers \& Thurik, 1999; Baumol, 2002; Acs \& Storey, 2004). Pēdējo divu gadu desmitu laikā jauno tehnolog̣iju attīstîba, zinātniskie atklājumi, kā arī jaunu uzṇēmējdarbỉbas modeḷu parādišanās radikāli mainijusi uzṇēmējdarbỉbas vidi - salīdzinājumā ar lielajām korporācijām palielinājusies mazo un vidējo uzṇēmumu (MVU) nozime. Saskaṇā ar Eiropas Savienības MVU 2016/2017 gada pārskatu MVU sektors ir viens no svarīgākajiem Eiropas ekonomikas elementiem, mazie un vidējie uznēmumi veido $99 \%$ no visiem uznēmumiem, tie nodrošina $67 \%$ no visām darbvietām un rada $57 \%$ no ES IKP.

Apzinoties uzn̄ēmējdarbības ietekmi uz valsts ekonomikas izaugsmi, vairāki valsts politikas galvenie uzdevumi ir vērsti uz to, lai veicinātu valsts konkurētspēju, kāpinātu inovativitāti un sekmīgi mazinātu bezdarbu, un tas ir saistits ar valsts uzṇēmējdarbibas kapacitātes un uzṇēmējdarbibas aktivitātes līmeṇa paaugstināšanu, uzṇēmējdarbïbas vides kvalitātes un kultūras uzlabošanu un sakārtošanu.

Eiropas Komisijas pieṇemtais «Rīcības plāns uzṇēmējdarbības jomā 2020. gadam» par galvenajām prioritātēm nosaka uzṇēmējdarbības gara atdzīvināšanu ES valstīs, uznēmējdarbības kvalitātes aspektu ievērošanu, būtisko šḳēršḷ (tādu, kas kavē uzṇēmumu attīstību gan valsts, gan Eiropas līmenī) likvidēšanu, uzṇēmējdarbības izglìīibas un mācību attīstību, pareizas uznēmējdarbības vides izveidošanu, kā arī konkrētu iedzīvotāju grupu sasniegšanu. Pasākumi, kas vērsti uz noteiktu grupu pārstāvju (sievietes, vecāka gadagājuma cilvēki, migranti, bezdarbnieki un jaunieši) iesaistišanos uzṇēmējdarbībā, ne tikai var veicināt šo grupu ekonomisko un sociālo aktivitāti, stimulēt valsts attīstību kopumā, bet tie var arī mazināt šo grupu sociālo atstumtību.

Biznesa cikla ietekme uz uzṇēmējdarbïbas līmeni valstī

posma uznēēējdarbiba atškiririgi ietekmē valsts konkurētspējas attīstību. Iespējas motivētā sākumposma uzṇēmējdarbỉba, kad cilvēki iesaistās uzṇēmējdarbibas aktivitātēs, jo saredz labas biznesa iespējas, dos lielāku ieguldījumu nācijas konkurētspējas ilgtermina attīstībā nekā nepieciešamỉbas spiestā uzṇēmējdarbība, kad cilvēki ir spiesti iesaistities uzṇēmējdarbībā, jo nav citu iespēju nopelnīt (Acs \& Varga, 2005). Īpaša nozīme valsts konkurētspējas stiprināšanā ir novatoriskai sākumposma uznēmējdarbỉbai, jo tā 
veicina kopējo valsts inovāciju līmeni, un tāpat nozīmīga ir arī uz eksportu orientētā uzṇēmējdarbỉba (Suddle \& Hessels, 2007).

Līdzīgi kā monetārā un fiskālā politika, arī uzṇēmējdarbības atbalsta politika ir svarīgs ekonomikas izaugsmes priekšnosacijums, un, iespējams, uzṇēmējdarbības politika ir vissvarīgākais instruments globālā un uz zināšanām balstītā ekonomikā (Gilbert, Audretsch, \& McDougall, 2004). Piemēram, vairāki pētnieki (McMillan \& Woodruff, 2002) norāda, ka pārejas posma ekonomikas panākumu vai neveiksmes pamatā galvenokārt ir attiecịgās ekonomikas uzṇēmēju darbības rezultāti, jo pārejas posma ekonomikā pašiem uzṇēmējiem ir jāmeklē jauni saimniekošanas veidi, un tā viṇi kḷūst par reformatoriem.

Saikne starp uzn̄ēmējdarbību, nodarbinātỉbu un ekonomikas izaugsmi nebūt nav vienkārša. Kā minēts vairāku pētnieku darbā (Llopis et al., 2015), šis faktors piesaista îpašu interesi 2007.-2010. gada globālās finanšu krìzes un tālākās ekonomikas atlabšanas kontekstā.

\section{Eksports kā uznēmējdarbību} veicinošs faktors Kopš ekonomikas lejupslīdes Latvijas konkurētspēju raksturo spēcīga izaugsme gan attiecībā uz eksportējamo produktu, gan eksporta tirgu skaitu (Beṇkovskis, 2012). Lai noteiktu Latvijas eksporta konkurētspēju, ir lietderïgi izmantot makroekonomisko pieeju, kuras pamatā ir faktiskais valūtas kurss vai darbaspēka vienības izmaksas, un to palīdz noteikt pētỉjumi, kas balstīti uz salīdzināmo priekšrocību ideju. K. Beṇkovskis (2012) ir norādījis, ka tāpat nozimīgi ir līdz šim nepietiekami novērtētie faktori-tie, kas ietekmē konkurētspēju un nav saistīti ar cenu.

Ir daudz empirisku pētījumu par eksportējošiem un neeksportējošiem Eiropas valstu un ASV uzṇēmumiem. Šajos pētijumos pierādīts, ka eksportējošie uznēmumi vidēji ir produktîvāki salīdzinājumā ar līdzịiem uzṇēmumiem, kas nenodarbojas ar eksportu. Vai eksports veicina produktivitāti? J.Vāgners (Wagner, 2007) norāda, ka eksportējošie uzṇēmumi ir produktīvāki ne tik daudz to ieguvumu dēl, ko rada eksportēšana, bet gan tādēl, ka to sākotnējā produktivitāte lauj tiem pārvarēt fiksētās izmaksas, kas saistītas ar ienākšanu ārvalstu tirgos (tā dēvētā pašatlases hipotēze). Eksportējošie uznēmumi salīdzinājumā ar tiem, kas neeksportē, biežāk maksā darbiniekiem lielākas algas, jo eksporta tirgū pēc pašatlases principa nonāk produktīvākie uzṇēmumi; tādēl augstāku algu cēlonis nav eksports (Schank, Schnabe, \& Wagner, 2010).

Un pretēji, eksports var uzlabot uznēmuma produktivitāti, piemēram, tas ḷauj saglabāt konkurētspēju sīvas konkurences apstāklos, jo uznēmums mācās eksportējot un atg̣ūst līdzeklus, kas ieguldīti lielākos pārdošanas apjomos (Love \& Roper, 2015).

J. Maso un P.Vahters (Masso \&Vahter, 2015) parāda, ka starp produktivitāti un eksportu pastāv pozitîva saikne. Lai arī galvenais viṇu pètijjuma mērḳis ir pierādìt «mācǐšanos eksportējot», proti, ka uzṇēmumi pēc pievienošanās starptautiskajiem tirgiem kḷūst produktîvāki, pētijuma rezultāti arī liecina par spēcīgu atlases ietekmi, tādējādi norādot, ka augsta produktivitāte varētu būt priekšnoteikums, lai sāktu eksportēt un segtu attieciggās neatgūstamās izmaksas.

ES Statistikas biroja pētijumā (Eurostat, 2015) ir salīdzināti eksportējošie un neeksportējošie uznēmumi no astonām Eiropas valstīm, to skaitā no Latvijas, un tas sniedz pārskatu par ekonomisko veiktspēju un eksportētāju raksturojumu 2008. un 2012. gadā, analizējot ekonomisko attīstību kopš ekonomiskās krīzes sākuma. Autori secina, ka salīdzinājumā ar eksportētājiem neeksportētāji izjuta finanšu krīzi daudz dzilāk. Vairumā valstu neeksportētāji laikposmā no 2008. līdz 2012. gadam zaudēja vairāk darbinieku nekā eksportētāji. Turklāt eksportētāji lielākajā dạ̣ā valstu ir palielinājuši produktivitāti vairāk nekā neeksportētāji. Jānem vērā arī, ka ārvalstu kontrolētajiem tirgotājiem ir relatīvi lielāka eksporta dạla nekā pašmāju kontrolētajiem tirgotājiem. T. Putniņa pētijums (2013) pirmoreiz aprakstija Latvijas eksportējošos uznēmumus atkarībā no to lieluma, ražiguma un īpašuma formas (Putniņš, 2013). Vinš norāda, ka eksporta uznēmumi ir lielāki, jaunāki un ātrāk augoši nekā neeksportējošie. Tajos tiek maksātas lielākas algas, un tas apliecina pieñēmumu par augstāku darbaspēka ražìumu.

Secinājumi par saikni, kas pastāv starp finansiālajiem faktoriem un uzṇēmuma vēlmi eksportēt, ir pretrunīgi. Daḷa pētnieku (Bellone et al., 2009) parāda, ka uzṇēmumiem ar labāku finansiālo situāciju ir augstāka varbūtība klūt par eksportētājiem un ka finansiāli ierobežojumi ir škērslis sākt eksportu. Citā empīriskajā literatūrā (piemēram, Greenaway, Guariglia, Kneller, 2007) ir minēti pierādỉjumi tam, ka iesaistī̌sanās eksportā uzlabo uzṇēmuma finansiālo stāvokli, taču tas neliecina, ka uznēmumiem, kas pievienojas eksporta tirgum, būtu kādas provizoriskas finansiālas priekšrocības.

Citā pètījumā parādīts, ka neatgūstamās izmaksas (sunk costs) spēcīgi ietekmē uznēmuma iespējas kḷūt par eksportētāju (Das, Roberts, Tybout, 2007); šì pētijuma autori uzskata - lai sāktu eksportēt, uznēmumam nepieciešams veikt ievērojamus ieguldījumus kā laika, tā arì naudas izteiksmē. Viṇu modelī uzṇēmums izvēlēsies kḷūt par eksportētāju, ja to prognozējamā peḷna no eksporta pārsniegss ar to saistîtās neatgūstamās izmaksas. Iegūtie rezultāti noved pie trīs svarīgiem secinājumiem. Pirmkārt, neatgūstamās izmaksas ir liels šḳērslis eksportēšanas uzsākšanai; eksportu vairāk veicina vienību subsīdijas, nevis vienreizēji granti. Otrkārt, lielie uznēmumi var vieglāk ieiet starptautiskajos tirgos nekā mazie uznēmumi. 
Treškārt, pastāv saistība starp ārvalstu îpašniekiem un augstāku eksporta varbūtību, un to, iespējams, nosaka mazākas izmaksas informācijas kanālu veidošanai, kas arì ir būtisks faktors, pieṇemot lēmumu par eksportu (Das, Roberts, Tybout, 2007).

Turpinot pētìt finansiālo faktoru ietekmi Latvijas kontekstā, ir vērts aplūkot Eiropas Strukturālo un investīiju fondu (ESIF) ietekmi uz uzṇēmuma lēmumu eksportēt. Viens no ESIF mērḳiem ir veicināt konkurētspēju un produktivitāti. Lai arī ESIF normativijos noteikumos nav skaidru norāžu, ka to finansējums ir paredzēts eksporta veicināšanai, var uzskatit, ka fondi to dara netieši. Pirmkārt, saṇēmēji var finansējumu izmantot, lai segtu neatgūstamās izmaksas saistībā ar eksporta izveidošanu. Otrkārt, sanemot ESIF finansējumu, var rasties informācijas kanāli, kas l̦auj vieglāk piekḷūt ārzemju tirgiem (vairāk attiecībā uz Eiropas iekšējo tirgu).

\section{Ēnu ekonomikas nozīme} uzñēmumu konkurētspējas noteikšanā

Starp Baltijas valstīm tieši Latvijas uzṇēmumi ir visvairāk neapmierināti ar nodokḷu sistēmu un valdību (Sauka, Putniņš, 2011). Iespējams, tāpēc ēnu ekonomika Latvijā ir ievērojami lielāka (21,3\%) nekā Igaunijā (14,9\%) un Lietuvā (15\%) (Putniņ̌̌, Sauka, 2016). Ekonomisti savos pētījumos pievērš lielu uzmanību ietekmei, kādu tirdzniecība atstāj uz kopējo ekonomikas izaugsmi apstākḷıs, kad novērojama uzṇēmumu neviendabība. M. Melica (Melitz, 2003) pētījumā ir konstatēts, ka nozares iekšèjās produktivitātes izaugsmes mikroekonomiskais pamats ir resursu pārdale. Piemēram, darbaspēka pāriešana no mazāk produktīviem uzṇēmumiem uz produktīvākiem uzṇēmumiem, jo notiek ieiešana eksporta tirgū un uzṇēmumi paplašinās arī lieluma ziṇā. Tirdzniecība ietekmē kopējo ražìgumu galvenokārt tādējādi, ka ražìgākie uznēmumi izvēlas kḷūt par eksportējošiem uzṇēmumiem, jo eksports tiem nodrošina lielāku peḷnu. Sīvāka konkurence par resursiem liek mazāk produktīviem uznēēmumiem pamest šo tirgu. Šāds pārdales radìtais nozares ražìguma kopējais pieaugums veicina arì labklājību un valsts ilgtspējigu attīstību.

Vēl viena šādas sakarības izpausme ir eksportējošu uzṇēmumu spēja absorbēt augstākas ražošanas izmaksas, vienlaikus saglabājot spēju gūt pelnu. Juridisko noteikumu un nodoklu likumdošanas ievērošana no uznēmuma peḷnas saglabāšanas viedokḷa rada mazāk problēmu, ja uzṇēmums ir ražīgāks par konkurentiem. Tādējādi eksportējoši uznēemumi, kas spēj izturēt gan iekšēju, gan ārēju konkurenci, var būt potenciāli mazāk tendēti izvairīties no nodoklu maksāšanas un kukuḷt nekā uzṇēmumi, kas nav eksportētāji. Ir arī saprotams, ka šai saiknei var būt pretēja ietekme - uzṇēmumi, kas dod kukuḷus un izvairās no nodokḷu maksāšanas vairāk nekā konkurenti, iespējams, sanem ìpašu attieksmi no iestādēm, un tāpēc tiem ir zemākas izmaksas un lielākas izredzes gūt panākumus eksportā. Lỉdz ar to, jo vairāk uznēmums eksportē, jo vairāk tas varētu censties izvairīties no nodokḷiem un nodarbināt cilvēkus neoficiāli. N̦emot vērā visu iepriekšminēto, sakarība starp ēnu ekonomiku un eksportu ir empirisks jautājums.

Viena no galvenajām grūtībām ir noteikt cēlonssakarību virzienu, kas ir svarīgs politikas veidošanas procesā. Ja pastāv pozitīvas attiecības starp eksportu un likumu ievērošanu, ir iespējams, ka uzn̄ēmumi, kas maksā nodoklus un nepārkāpj citus likumā noteiktos ierobežojumus, varētu sākt eksportēt, jo eksportētāiiem parasti ir jāiziet relatīvi daudz administratīvo pārbaužu (uz robežas un ārvalstīs). Tādēl, no politikas skatpunkta, striktāks likumu regulējums un to ievērošanas nodrošināšana varētu vēl vairāk veicināt eksportu. Tāpat jāatzīmē, ka spēcīgākā konkurencē starp ārvalstu un pašmāju uzṇēmumiem izdzìvo produktīvākie uzṇēmumi, kam ir mazāk problēmu darboties atbilstoši likumam un maksāt nodokḷus. Šādas cēlonsakarību attiecības nozimēe ka eksportu veicinoša politika samazina uznēēmumu nelikumīgās darbības.

Lēmums piedalīties ēnu ekonomikā pamatā ir uzṇēmuma iekšējs lēmums, un tas ir atkarīgs no dažãdiem politiskiem, ekonomiskiem, sociāliem un institucionāliem faktoriem. Turklāt V.Tanzi (Tanzi, 1982) norāda, ka būtiska ir arī uzṇēmuma vadītāja attieksme.

Ēnu ekonomika visciešāk ir saistìta ar cilvēku rīcību, un to nosaka stimuli un škēršli. Vairums iepriekšējos gados veikto pētījumu pievērsušies valsts politikas aspektiem saistībā ar ēnu ekonomiku. Taču neformālo uzṇēmumu loma ekonomikas attīstībā ir joma, kuru nepieciešams pētīt dziḷāk. No vienas puses, daži pētỉjumi aplūko oficiālo un neoficiālo uznēmumu lỉdzìbas, taču, no otras puses, tiek izvirzīti argumenti, ka abi uzṇēmumu veidi ir loti atšķirīgi. Lìdz šim neviens pētnieks nav nonācis pie vienojoša slēdziena par ènu ekonomikas ietekmi uz uznēmuma veiktspēju.

Dažos avotos minēts (de Soto, 1989, 2000), ka nelegālajiem un legālajiem uzṇēmumiem ir līdzịgas iezīmes. F. Šneiders (Schneider, 1998) parāda, ka vairāk nekā $50 \%$ no ēnu ekonomikas peḷnas tiek sadalìta likumīgajos sektoros, atbalstot ekonomisko izaugsmi. Pastāv arī pretējs uzskats, ka nelegālie uznēmumi grauj ekonomiku. Nelikumīgie uzṇēmumi iegūst vairāk, izvairoties no nodokḷiem un likumu normām, un tas kompensē to, ka tie nav lieli un tiem ir zemāka produktivitāte (Farrell, 2004). Ja nelikumīgajiem uznēmumiem ir izdevīgāka pozīcija nekā likumīgajiem, likumīgie uzṇēmumi tiek izstumti no tirgus. Tāpēc nelikumīgie uzṇēmumi kaitē valsts attīstībai divos veidos. Pirmkārt, tie ir mazi un neproduktīvi, un, otrkārt, tie konkurē ar produktīvajiem likumigajiem uzṇēmumiem un atṇem to tirgus dalı (Gomory, 1994). Turklāt valstìs ar spēcīgu ēnu ekonomiku ir pārmērīgi smaga nodokḷu nasta (Muller et al., 2013). Šāds nodokḷu slogs traucē ienākt investīcijām, un tāpēc tas ir galvenais ekonomiskās izaugsmes škēèrslis. 
Pretēji šiem abiem uzskatiem duālais skatījums vērš uzmanību uz ievērojamām atšḳirībām starp oficiālajiem un neoficiālajiem uzṇēmumiem. Šis skatijjums turpina Dž. Rauča (Rauch, 1991) sākotnējo teoriju par neoficiālo (ēnu) ekonomiku, kurā secināts, ka mazāk produktīvi darbinieki strādā neoficiālajos uzṇēmumos un attiecīgi saṇem arī zemākas algas. Izmantojot attīstīto valstu datus, R. La Porta un A. Šleifers (La Porta \& Shleifer, 2008) analizējuši oficiālo un neoficiālo uznēèmumu lielumu un produktivitāti. Viṇi secināja, ka neoficiālie uznēemumi ir daudz mazāki, kā arī mazāk produktīvi nekā oficiālie.

Neoficiālo uzṇēmumu zemāku efektivitāti nenosaka ārēji faktori. Pirmkārt, oficiālo uznēmumu produktivitāte palielinās proporcionāli uzṇēmuma lielumam (Hsieh, Olken, 2014). Lielums nav vienīgais iemesls, kādēl oficiālie uzṇēmumi ir produktīvāki par neoficiālajiem. R. La Porta un A. Šleifers (2014) parāda, ka pastāv krasa produktivitātes atšḳirība starp vienāda lieluma neoficiālajiem un oficiālajiem uznēmumiem. Vēl viens zemas produktivitātes rādītājs neoficiālajā sektorā ir zemas algas. Izmantojot starptautiskos datus, R. La Porta un A. Šleifers (2008) nonāca pie secinājuma, ka algas nelielajos neformālajos uznēmumos ir uz pusi mazākas par tām, ko maksā mazi oficiālie uzṇēmumi. Algu atšķiirības palielinās proporcionāli uzṇēmuma lielumam.

\section{Latvijas nodokḷu un} pabalstu sistēma

\section{raugoties no stimulējošu}

pasākumu skatupunkta
Veidojot nodokḷu un pabalstu politiku, valdības saskaras ar fundamentālu konfliktu. No vienas puses, valdibas uzdevums ir pasargāt mazāk aizsargātās grupas (piemēram, bezdarbniekus, trūcīgos, mazu bērnu vecākus), lai samazinātu nabadzību un nevienlīdzību. No otras puses, slikti veidota aizsardzības shēma var radìt šķēršlıu darbam un ienākumu gūšanai, un tas ilgtermiṇā noved pie sociālo slānu veidošanās un atstumšanas. Turklāt, ja sociālos izdevumus finansē lielāki nodokḷi, tas var kaitēt stabilai konkurētspējai un kavēt likumu ievērošanu.

Lai sasniegtu ilgtspējigu ekonomikas izaugsmi, ir svarīgi nogludināt šo konfliktu: ir jānodrošina saprātīgs atbalsts mazāk aizsargātajām grupām un ir arī jārada pareizie atbalsta pasākumi cilvēkiem un uznēmumiem. No teorētiskās literatūras par nodokḷiem ir zināms, ka nodokḷ struktūra ietekmē ilgtermiṇa ekonomisko izaugsmi. Nodokḷs var novērtēt pēc to ietekmes uz izaugsmi. Piemēram, samazinot nodoklu slogu uz darbaspēku, pieaugs nodarbinātība un aizvien vairāk darbinieku pāries no ēnu ekonomikas uz legālu nodarbošanos, ỉpaši tajās valstīs, kur izvairīšanās no nodokḷiem ir ḷti izplatîta. No budžeta viedokḷa, neitrālas nodoklu izmainas, nonemot slogu no darbaspēka ienākumiem, var ìstenot, ja nodokḷu slogs valstī ir relatīvi neliels vismaz vienā no trim jomām: patēriṇa nodokḷi, atkārtoti maksājami ipašuma nodokli vai vides nodokḷi. Tiek uzskatits, ka visas šis nodokḷ kategorijas vismazāk kaitē izaugsmei (OECD, 2010; Prammer, 2011; Arnold et al., 2011).

Politikas veidotāji attīstītajās un vidēju ienākumu valstīs saskaras ar milzigiem izaicinājumiem, cenšoties apkarot dažādus nodoklu apiešanas veidus. Teorētiskajā literatūrā ir aprakstīts, ka izvairišanās no nodokḷiem var kaitēt izaugsmei un tā ir îpaši izteikta mazo uzṇēmumu vidū.

Formulējot nodoklu un pabalstu politikas noteikumus, ir svarīgi saprast darbaspēka pieejamības aspektus, jo īpaši to, kā nodokḷu un pabalstu sistēmas izmainas ietekmē cilvēka lēmumu ieiet darba tirgū. Pasivitātes un bezdarba rādītāiji Latvijā saglabājas nemainīgi augsti, proti, 2016. gadā reǵistrētie bezdarbnieki bija 7,6\% un 23,7\% bija ekonomiski neaktīvi iedzīvotāji vecumā no 15 lìdz 64 gadiem. Bezdarba līmenis vīriešiem ir 11,2\%, un tas ir augstāks nekā sievietēm, jo to bezdarba rādītājs ir 8,6\%. Savukārt ekonomiski neaktīvo iedzìvotāju vidū ir vērojama pretēja tendence: ekonomiski neaktīi ir $21,2 \%$ viriešu, bet $26 \%$ ir ekonomiski neaktīvas sievietes vecumā no 15 lïdz 64 gadiem (Central Statistical Bureau of Latvia, 2017). Bezdarba līmenis Latvijā loti paaugstinājās finanšu un politiskās krīzes laikā 2008.-2010. gadā: no 8\% 2008. gadā līdz augstākajam rādītājam 19,8\% 2010. gadā. Lai gan ir vērojama tendence, ka vispārējais bezdarba līmenis un neaktîvo iedzìvotāju daḷa sarūk, Latvijai ir nepieciešama efektiva politika, lai veicinātu nodarbinātỉbu.

Ir veikts daudz pētijumu, kas parāda, ka darba iespējas ir atkarīgas no sagaidāmā neto algas līmeṇa tirgū un sagaidāmajām neto izmaiṇām, ja tiek mainīts nodarbinātỉbas statuss, uzsākot strādāt (piemēram, Benczur et al., 2012; Bicakova, Slacalek \& Slavik, 2011; Siebertová et al., 2013). Nodarbinātības līmenis ietekmē produkcijas līmeni un nodrošina sociālās drošǐbas sistēmas ilgtspēju. Relatīvi augsts nodokḷu slogs kavē nodarbinātību: tas samazina pelnitāju rīcỉbā esošos ienākumus, savukārt darba devējiem palielina darbaspēka izmaksas.

Ṇemot vērā visu iepriekšminēto, izkristalizējas vairāki virzieni iespējamai analīzei, kura arī tika îstenota, veicot zinātniskus pētijumus par šãdiem uznēmumu konkurētspēju ietekmējošiem faktoriem:

1) sākumposma uzṇēmējdarbỉba un biznesa cikls

2) eksports kā uznēēmējdarbību veicinošs faktors;

3) ES struktūrfondu ietekmes novērtējums uz uznēmumu eksportspēju;

4) ènu ekonomika un Latvijas uzṇēmumu konkurētspēja;

5odoklu un pabalstu sistēma un Latvijas uzn̄ēmumu konkurētspēja. 


\section{Ilgtspējịgas lauku attīstības \\ ekonomiskie, vides un sociālie aspekti}

Ilgtspējigas attīstības pamatideja aicina apmierināt esošās paaudzes vajadzības, līdzsvarojot sabiedrības labklājības, vides un ekonomiskās attīstības intereses, vienlaikus nodrošinot vides prasību ievērošanu un dabas daudzveidības saglabāšanos, lai nemazinātu nākamo paaudžu vajadzību apmierināšanas iespējas (Latvijas Republikas Saeima, 2010). Lauku ilgtspējigga attīstỉba ir daudzdimensionāla koncepcija, kas ietver un integrē lauku teritoriju vides, ekonomiskās un sociālās dimensijas (Kitchen \& Marsden, 2009; Govindan et al., 2016). Eiropas Savienibas lauku teritorijas veido lielāko ES daḷ - apmēram $86 \%$. Turklāt ievērojams īpatsvars iedzīvotāju apdzīvo šĩs lıti atškiriīgās teritorijas, veicot dažādas ekonomiskās aktivitātes un radot un saglabājot unikālas un senas kultūras un sociālās tradīcijas (Boggia et al., 2014).

Lauksaimniecības un lauku teritoriju ilgtspējīga attīstība

Viens no ilgtspèjīgas un lïdzsvarotas attīstibas priekšnoteikumiem ir resursu un iespēju apzināšanās un pilnvērtīga, nenoplicinoša izmantošana, it ipaši lauku teritorijās. Politikas plānošana dokumentos lauku teritorija tiek definēta kā viena no nacionālo interešu telpām ar izcilu vērtību un nozīmi valsts ilgtspējigai attīstībai, identitātes saglabāšanai, un lauku teritorija ietver valsts attīstībai nozimīgus stratēgiskos resursus (Latvijas Republikas Saeima, 2010). Tomēr pēdējos gados raksturīga telpiskās attīstības tendence gan Eiropā, gan Latvijā ir lauku depopulācija un zems apdzivvotības blīvums, kas mazina lauku iedzivotāju socializēšanās iespējas, kā arī klūst par iemeslu ierobežotai pakalpojumu pieejamỉbai-pakalpojumu sniegšanas vietas attālinās, samazinās valsts finansējums veselïbas aprūpes, transporta un izglitiibas infrastruktūrai, un lauku teritorija tiek paklautas nelïdzsvarotai, nevienmērïgai attīstîbai. Darba vietu pieejamìba un iespēja gūt ienākumus tuvu dzives vietai ir viens no nozīmīgākajiem teritorijas apdzivotības priekšnoteikumiem.

Lauksaimniecības un lauku teritoriju ilgtspējiga attīstība ir ES visaptverošais ilgtermina mērkis. Lauksaimniecības zemju izmantošanā Eiropā ir novērojami divi dominējošie procesi: 1) lauksaimniecības intensifikācija un specializācija; 2) marginalizācija un zemes pamešana. Abi šie procesi ir saistīti ar lauku saimniecibu struktūras izmainām, kad novēro mazo un vidējo saimniecību nozìmes samazināšanos (van der Sluis et al., 2017). Dominējošo tradicionālo produktivitātes paradigmu raksturo lauksaimniecības lielais ražošanas apjoms, cilvēka un dabas kapitāla aizstāšana ar finanšu kapitālu, monokultūru ieviešana, augsti specializētu saimniecību dominēšana un vertikāli integrētais rūpnieciskais ražošanas veids (Henke \& Vanni, 2017). Lauksaimniecības intensifikācija un specializācija dalēji ir tehnoloğiskā progresa rezultāts, ko stimulē ekonomiskie, politiskie 
un sociālie mērki. Ar intensifikācijas un specializācijas procesiem saistītās norises ir daudzveidīgas: agroḳimikāliju izmantošanas palielināšana, saimniecību specializācija un mehanizācija, efektīva zemes pārdališ̌na, kā arī mazo lauksaimnieku zemju izpirkšana un lauku platību palielināšana. Tā rezultātā negatīvi tiek ietekmēta vides kvalitāte un bioloğiskā daudzveidỉba. Turklāt ir novērojama ienākumu nevienlīdzība ne tikai starp lauku mājsaimniecībām, bet arī starp pilsētu un lauku kopienām un atsevišķām lauku pašvaldībām (Brown \& Schucksmith, 2016). Eurostat dati liecina, ka vidēji ES iedzīvotāji lauku teritorijās ir vairāk pakḷauti nabadzības vai sociālās atstumtības riskam nekā pilsētās, turklāt Latvijas lauku teritorijās 2016. gadā to iedzīvotāju îpatsvars, kas paklauti nabadzības riskam, ir par 9,6 procentpunktiem augstāks nekā pilsētās un par 3,6 procentpunktiem augstāks nekā mazpilsētās (Eurostat, 2018).

Lauku ilgtspējīgas attīstības mērḳi ir: lauksaimniecības produkcijas diversifikācija; lauksaimniecības daudzfunkcionalitāte, kur papildus produktivajai funkcijai (piemēram, nodrošināšanai ar pārtiku), tiek vairotas šādas ar lauksaimniecisko darbību saistītas sociālās, vides un kultūras funkcijas: nodarbinātība un ienākumu paaugstināšana; dabas resursu apsaimniekošana un vides aizsardzība, kā arī sociālo un kultūras tradīiju saglabāšana (European Commission, 2013b; EEB, 2017).

Ilgtspējigai lauku attīstībai ir nepieciešama vispusīga pārnozaru un starpnozaru politikas pieeja, lai panāktu, ka ekonomiskās, sociālās un vides problēmas tiek risinātas kopā. Turklāt kopējās lauksaimniecības politikas ietekmes novērtējumos ir jāaplūko vides, sociālā un ekonomiskā ietekme, lai pārliecinātos, ka ilgtspējỉbas apsvērumi ir pārdomāti un nemti vērā (European Commission, 2016). Turpmākai ilgtspējigai lauku attīstỉbai līdztekus tiek uzsvērtas pārvaldības izmainas, kur nepieciešami inovatīvi risinājumi, kas balstās uz plašāku visdažādāko institūciju, organizāciju un sabiedrības pārstāvniecības iesaisti pārvaldības procesos.

Kaut gan Eiropas Komisija (European Commission, 2016) uzsver vides, ekonomiskās un sociālās dimensijas, tomēr pētnieki tās papildina ar kultūras dimensiju un ieklauj pārvaldību kā vienojošo elementu (1. attēls).

\section{Ekosistēmu pakalpojum}

Ir izstrādātas vairākas ekosistēmu pakalpojumu klasifikācijas sistēmas. Tomēr līdz šim nav akceptēta vienota ekosistēmu pakalpojumu terminu, definīciju un klasifikācijas sistēma. Pašlaik apritē ir vairākas, kuras tiek pilnveidotas un papildinātas, ṇemot vērā izmantošanas mērḳi.

Šajā nodaḷā ekosistēmu pakalpojumu definēšanai izmantota projektā «Ekosistēmu un bioloğiskās daudzveidības ekonomika» (The Economics of Ecosystems and Biodiversity-TEEB) sniegtā definīcija: «Ekosistēmu
1. attēls. Lauku attīstības koncepcijas dimensijas

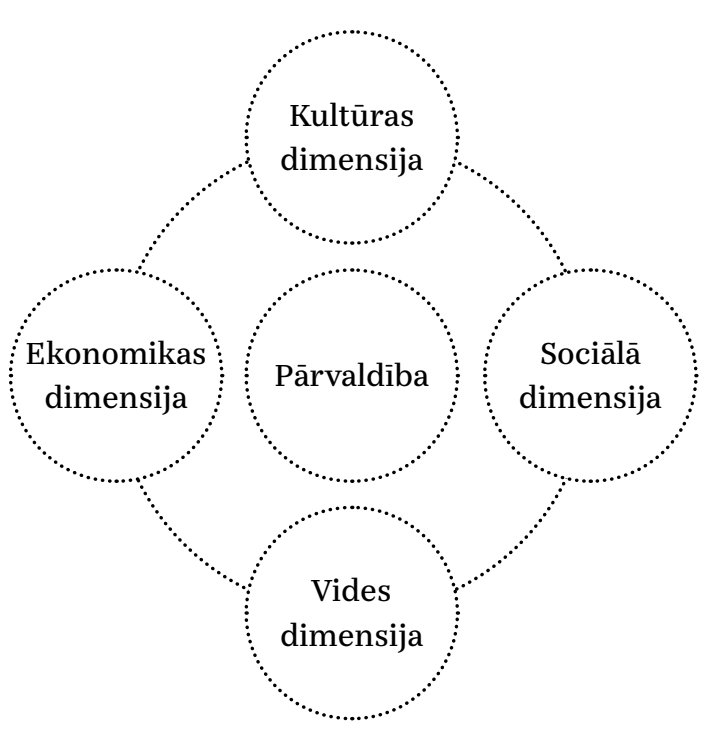

(Pēc Papageorgiou, 2007)

pakalpojumi ir tiešais un netiešais ekosistēmu ieguldỉjums cilvēku labklājībā. Termins «ekosistēmas preces un pakalpojumi» ir sinonīms ekosistēmu pakalpojumiem.» (TEEB, 2010, p.3).

Pirmā izstrādātā ekosistēmu pakalpojumu klasifikācija tika ieklauta ANo dokumentā «Tūkstošgades ekosistēmu novērtējums» (Millennium Ecosystem Assessment-MEA), kur visi ekosistēmu pakalpojumi iedalīti četrās grupās (MEA, 2005):

1. Apgādes jeb nodrošināšanas pakalpojumi (provisioning services) ir produkti, kas iegūti no ekosistēmām, tostarp: pārtikas produkti (kultūraugu, lauksaimniecības dzīvnieku, akvakultūras, savvalas augu un dzīvnieku izcelsmes produkti), škiedra (kokmateriāli, kokvilna, kaṇepes, zìds, koksnes kurināmais un citi bioloğiski materiāli, kas tiek izmantoti kā enerğijas avots), gonētiskie resursi, biokīmiskie līdzekli, dabīgie medikamenti un farmaceitiskie preparāti, dekoratīvie resursi un svaigs ūdens.

2. Regulējošie pakalpojumi (regulating services) ir ieguvumi no ekosistēmas procesu regulēšanas, tostarp gaisa kvalitātes regulēšana, klimata regulēšana, ūdens regulēšana, erozijas regulěšana, ūdens attīiřšna un atkritumu apstrāde, slimību regulēšana, kaitēkḷ regulēšana, apputeksnēšana un dabas apdraudējuma regulēšana. 
3. Kultūras pakalpojumi (cultural services) ir nemateriālie ieguvumi, ko cilvēki gūst no ekosistēmām ar garìgo bagātināšanos, kognitīvo attīstību, atveseḷošanos, atpūtu un estētisko pieredzi, tostarp kultūras daudzveidība, zināšanu sistēmas (tradicionālās un formālās), izglìtības vērtỉbas, iedvesma, estētiskās vērtības, sociālās attiecỉbas, vietas sajūta, kultūras mantojuma vērtība, atpūta un ekotūrisms.

4. Atbalsta pakalpojumi (supporting services) ir pakalpojumi, kas nepieciešami, lai nodrošinātu visu citu ekosistēmu funkcionēšanu un pakalpojumu piegādi, tostarp: augssnes veidošanās, fotosintēze, barības vielu aprite un ūdens cirkulācija.

Lai ekosistēmu pakalpojumus varētu novērtēt, Kopējās starptautiskās ekosistēmu pakalpojumu klasifikācijas (Common International Classification of Ecosystem Services - CICES) ietvaros tika apvienoti regulācijas un atbalsta pakalpojumi, jo atbalsta pakalpojumiem nebija iespējams noteikt to vērtību. CICES (Haines-Young \& Potschin, 2017) ekosistēmu pakalpojumus iedala trīs grupās:

1. Apgādes jeb nodrošinājuma pakalpojumi sniedz cilvēkiem tiešus ieguvumus. Tos parasti vērtē naudas izteiksmē.

2. Regulācijas un atbalsta pakalpojumi ir procesi, kas uztur ekosistēmu, tie ir bez noteiktas tirgus vērtības, bet ar lielu nozīmi cilvēces labklājībā un ekosistēmu pastāvēšanā.

3. Kultūras jeb nemateriālie pakalpojumi saistīti ar sabiedrības vajadzību pēc nemateriālām vērtībām. Tie vairo zināšanas, nodrošina estētisku baudijjumu un atpūtas iespējas.

Ekosistēmu pakalpojumu pieeja palīdz pieṇemt tālredzīgus lēmumus, kā arī sekmēt līdzsvarotu ekonomisko attístìbu un dabas resursu izmantošanu. Veselas ekosistēmas nodrošina daudzus ekosistēmu pakalpojumus cilvēkiem, piemēram, tīru gaisu, ūdeni un pārtiku. Tādējādi ekosistēmu piesārṇojums, degradācija un iznīcināšana apdraud pakalpojumu piegādes iespēju un tā rezultātā-cilvēku labklājỉbu (European Commission, 2016; Englund, Berndes \& Cederberg, 2017).

Nosakot vērtību dažādiem dabas objektiem, jāṇem vērā, ka nākas vērtēt to daudzveidigās funkcijas. Viena no pieejām vides kompleksajā ekonomiskajā novērtēšanā ir ekosistēmu kopējās ekonomiskās vērtỉbas koncepcija. Atbilstoši tai ekosistēmu kopējo ekonomisko vērtību veido dažādu izmantošanas vērtību un ar izmantošanu nesaistìtu vērtību summa. Kopējās ekonomiskās vērtības sastāvdalas parāda vērtību, ko sabiedrība pieškir dažādām dabas objektu īpašībām. Kopējās ekosistēmu pakalpojumu ekonomiskās

2. attēls. Daudzfunkcionālas lauksaimniecības un ekosistēmu pakalpojumu mijiedarbība

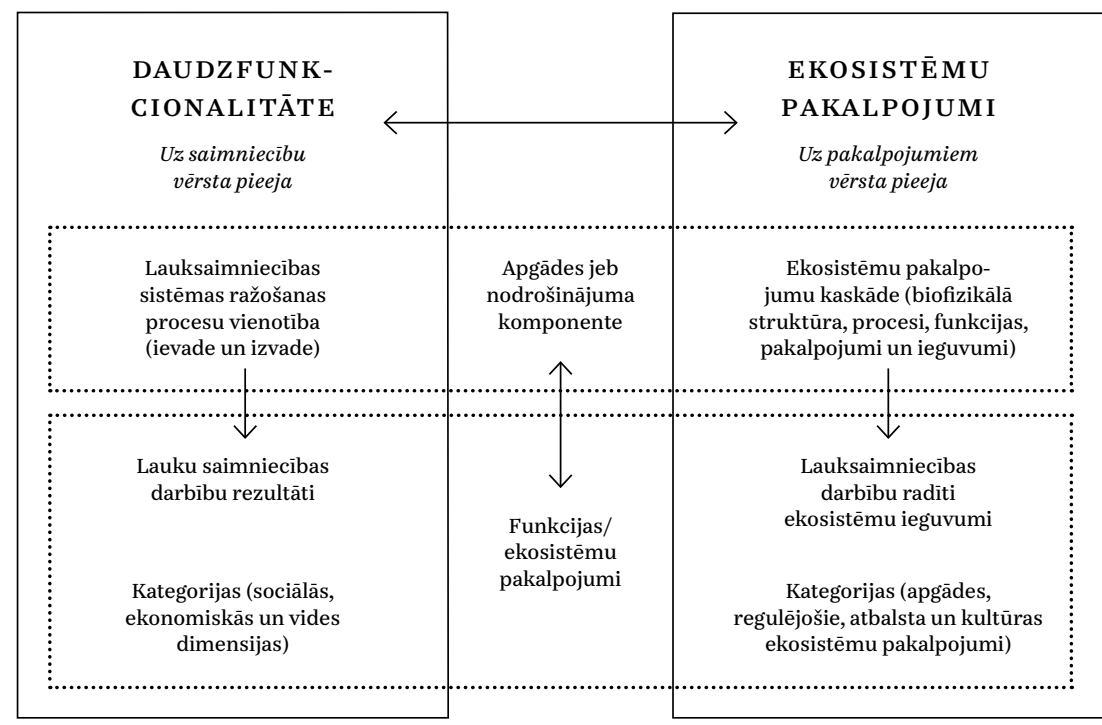

(Pēc van der Ploeg \& Roep, 2003; Renting et al., 2009)

vērtības galvenās sastāvdaląas ir: izmantošanas vērtība, kuru veido pakalpojuma tiešās un netiešās izmantošanas vērtỉbu summa; ar izmantošanu nesaistìtā vērtība, kuru veido pakalpojuma iespējamās izmantošanas, pastāvēšanas un saglabāšanas vērtību summa. Izmantojot šādu pieeju, var novērtēt dažādus ekosistēmu pakalpojumu sniegtos ieguvumus jeb labuma veidus, to skaitā tos, kurus nevar vienkārši izteikt naudas izteiksmē.

Ekosistēmu pakalpojumu novērtēšanā pašlaik dominē monetārā vērtība jeb vērtības noteikšana naudas izteiksmē, mazāka vērība veltìta citām sociālajām perspektīvām un to nozīmei cilvēku labklājības nodrošināšanā (Scholte, van Teeffelen, \& Verbug, 2015). Vairāki pētnieki uzsver, ka monetārās vērtības noteikšana nav universāla metode, it ippaši, vērtējot atbalsta un kultūras ekosistēmu pakalpojumus (Brickhill, 2015; Scholte, van Teeffelen, \& Verbug, 2015; Allen \& Moore, 2016). ES monetārā vērtēšana koncentrējas uz ekosistēmu pakalpojumiem, kurus var novērtēt ar tirgus metodēm, savukārt mazāk materiāli pakalpojumi, piemēram, estētiski vai iedvesmojoši pakalpojumi, bieži tiek pat ignorēti. Esošo ekosistēmu savstarpējā mijiedarbība un ieguldijums cilvēku labklājīibā ir sarežğìts, tāpēc arvien vairāk autoru iesaka vērtējumā izmantot plurālistisku pieeju (Brickhill, 2015; Scholte, van Teeffelen, \& Verbug, 2015). 
Dažas ekosistēmas funkcijas konceptuāli tiek uztvertas kā ekosistēmas pakalpojumi, tāpēc to monetārā vērtēšana vispār nav iespējama (Gomez-Baggethun \& Ruiz-Perez, 2011). Netirgojamo ekosistēmu pakalpojumu novērtēšanai tiek izmantotas dažādas metodes, un dažas no tām ir aptauju veikšana, fokusgrupu un ekspertu viedokḷu uzklausišsana (Allen \& Moore, 2016).

Daudzas vērtīgas dzivotnes un to veicinātā bioloğiskā daudzveidība ir atkarīga no lauksaimniecības sistēmām. Tomēr tirgus neatzist centienus saglabāt šo bioloğisko daudzveidỉbu, tāpēc tas neatspoguḷojas lauksaimnieku produkcijas lauksaimnieciba» ir saistits un darbibu, kuras pamatā ir savstarpēji saistitit, papildinoši cikli pēc iespējas tuvāk saimniecỉbai un kura daudzveidigu darbvietu pašvaldibu un reğionu, un kura tiek istenota atbildigi pret dabu, dzivniekiem un nākamajām paaudzēm.
1 Termins «tradicionāla ar lauksaimnieka domāšan ir vērsta uz kvalificētu un saglabāšanu, saistita ar rīga no pienācigas apsaimniekošanas prakses, šajās praksēes, ko veicina konkurences spiediens, notikušas izmainas - dažās platībās palielinājusies ražošanas specializācija un intensifikācija, bet citās platībās zemes apsaimniekošana tikusi pārtraukta. Tas rada spiedienu uz bioloǵisko daudzveidību, negatīi iespaido augsni, ūdeni un klimatu, kā arī pakḷauj riskam lauksaimniecības sektora ilgtermiṇa ražošanas potenciālu.

Eiropas Ekonomikas un sociālo lietu komiteja (EESK) norāda, ka notiek pakāpeniska, bet apjomīga un nemitīga bioloğiskās daudzveidības samazināšanās, lai arī lauksaimnieki lielākoties ievēro spēkā esošos tiesību aktus, isstenojot labo lauksaimniecības praksi. EESK pauž viedokli, ka situāciju nevar mainīt, grozot tiesību aktus dabas aizsardzības jomā, bet tikai vienlaikus mainot zemes izmantošanas praksi un lauksaimniecibas atbalsta politiku (EESC, 2016). ES lauksaimniecības politika joprojām bieži ir pretrunā ar bioloğiskās daudzveidỉbas politiku (Papadopoulos, 2015), pat ja dažas kopējās lauksaimniecibas politikas daḷas, jo ippaši 2.pīlāra agrovides programmas jeb pasākumi, iezīmē šo pretrunu risinājuma iespējas (E ESC, 2016). Turklāt sistemātiski būtu jānovērtē agrovides programmu ietvaros ìstenoto pasākumu daudzfunkcionāāā ietekme uz vidi, kur pasākumu ieviešanas pievienotā vērtība jānosaka gan kvantitatīvi, gan telpiski (Galler, von Haaren, \& Albert, 2015).

Lai pārtikas preču ražošanas apjomi arī turpmāk būtu pietiekami, lai preces būtu kvalitativi augstvērtīgas un reğionāli atšḳirīgas, lai ražošana notiktu visā ES teritorijā un nenodarìtu kaitējumu videi, lai vienlaikus tiktu sargāta un kopta Eiropas telpa, saglabāta pārtikas daudzveidība un atškirīgās iezīmes, kā arī Eiropas daudzveidīgās un ar dažādām sugām bagātās kultūrainavas un lauku teritorijas, Eiropas Savienībā jāsaglabā un jāturpina pilnveidot Eiropas lauksaimniecības modelis, proti, tradicionāla ${ }^{1}$ un daudzfunkcionāla lauksaimniecība, kur lauksaimnieku ienākumi ir pielīdzināmi attiecīgās valsts vai reğiona vidējiem ienākumiem (EESC, 2016).

Eiropas Ekonomikas un sociālo lietu komiteja uzskata, ka tikai politiskās gribas trūkums Eiropas Komisijai liedza īstenot Es bioloğiskās daudzveidības politiku, kaut gan esošās problēmas bija apzinātas un nepieciešamie instrumenti izveidoti, un tā norāda, ka nepieciešamais finansējums dalībvalstìm būtu jāpiešḳir (E ESC, 2016).

Lauku attīstība ir kopējās lauksaimniecības politikas otrais pilārs, un ir pieejami finanšu līdzekḷi ES lauku reǵ̛ionu un kopienu attīstìbai. Turklāt ES lauksaimniecības politika pēdējo desmit gadu laikā ir pievērsusi lielāku vērību vides problēmu risinājumiem, kur cilvēku darbïbas ilgtspēja ir viena no svarīgākajām problēmām.

Pārtikas un lauksaimniecības organizācijas (Food and Agriculture Orga nisation of the United Nations - FAO) padome 1988. gadā definēja ilgtspējigu attīstību kā «dabas resursu apsaimniekošanu un saglabāšanu, kā arī tehnoloğisko un institucionālo izmainu virzību tādā veidā, lai nodrošinātu cilvēku vajadzību sasniegšanu un nepārtrauktu apmierināšanu pašreizējai un nākamajām paaudzēm. Šāda ilgtspējìga attīstība lauksaimniecības, mežsaimniecības un zivsaimniecības nozarēs saglabā zemes, ūdens, augu un dzīvnieku genenētiskos resursus, ir videi nekaitīga, tehniski piemērota, ekonomiski dzìvotspējiğa un sociāli pieṇemama» (Boggia et al., 2014).

Kopịga kritika saistībā ar ekosistēmu pakalpojumu jēdziena skaidrojumu ir, ka tās antropocentriskais fokuss izslēdz ideju par ekosistēmām un par biolog̣isko daudzveidību kā būtisku vērtỉbu, kas nav saistìta ar cilvēka vajadzībām. Tiek arī paustas bažas par jēdziena utilitāro raksturu, kas balstìts tikai uz cilvēka ieguvumiem. Vairāki argumenti ir pret šo kritiku. Pētnieki atzīmē, ka ekosistēmu pakalpojumu struktūras ieviešana-ekosistēmu pakalpojumu pieeja - var tikt izmantota līdzās idejai par patieso vērtìbu vai pat zināmā mērā to ieklaut, ietverot kultūras pakalpojumus, piemēram, garīgo vai ainavas estētisko vērtību (Brickhill, 2015).

Ekosistēmu atsevišḳu pakalpojumu novērtējums ìstermiṇā nevarētu būt politikas mērkis. MAES darba grupas tehniskajā zinojumā (Maes et al., 2014) norādīts, ka pētỉjumos būtu jānoskaidro «ekosistēmu daudzfunkcionalitāte, lai saglabātu ilgtermiṇa cilvēku labklājību». Ilgtermiṇa un stabils ekosistēmu pakalpojumu nodrošinājums ir jāizvirza par galīgo mērkị. Tādēl, novērtējot saikni starp bioloğisko daudzveidỉbu un ekosistēmu pakalpojumiem, ir jāpārbauda biolog̣iskās daudzveidības samazināšanās ietekme uz ekosistēmu stabilitāti un noturību.

Lauku teritorijās ir jāpanāk tāda attīstība, kas, uzlabojot sociālos un ekonomiskos apstākḷus, saskaṇā ar ES Ilgtspējigigas attīstības stratēǵijas pamatnostādnēm ḷautu šìm teritorijām kḷūt par ilgtspējigām. Kopējās lauksaimniecības politikas ietvaros lauku attīstības programma Eiropā tiek pastāvigi izvērtēta un pārskatìta, un pēdējos gados tajā tiek iekḷauti vides, ekonomisko un sociālo aspektu risinājumi. Veiksmịgākai lauku attīstības programmu un plānu îstenošanai loti svarïga ir vietējo iespēju un teritoriālo ipatnïbu analīze un izpratne (EESC, 2010). 
Lai veicinātu klimatam un videi labvēlīgu lauksaimniecības praksi kopējā lauksaimniecības politikā 2014.-2020. gadā, tika ieviests zaḷināšanas pasākums, kas sasaistīts ar vienoto platības maksājumu. Lai zaḷināšanas maksājumu saṇemtu, lauku saimniecībām jāievēro zaḷināšanas prasības, kuras iespējams izpildīt, veicot šādus pasākumus: 1) kultūraugu dažādošana; 2) ekoloǵiski nozimīgu platību izveidošana un/vai uzturēšana; 3) esošo ilggadīgo zālāju saglabāšana (European Commission, 2013b). Ekoloğiski nozīmīgu platību izveidošanas un uzturēšanas mērkis ir bioloğiskās daudzveidības aizsargāšana un uzlabošana saimniecībā. Tādēl par ekoloğiski nozīmīgām platībām būtu jāuzskata platības, kas tieši vai netieši ietekmē bioloğisko daudzveidību. Tieši daudzveidỉbu ietekmē, piemēram, papuve un ainavu elementi, bet netieši-, piemēram, slāpekli piesaistoši kultūraugi, jo šādā saimniecībā mazāk tiek izmantoti lỉdzekḷi ražỉbas palielināšanai. Lai gan zalināšanas pasākums ES dalībvalstīs ir ieviests tikai ar 2014. vai 2015. gadu, tam pamatotu kritiku izteikusi gan Eiropas Komisija (European Commission, 2017a), gan pētnieki (Pe'er et al., 2017; Underwood \& Tucker), jo lielākā dạ̦a ES lauksaimnieku ir izvēlējušies tieši šo netiešo zalināšanas pasākumu - slāpekli piesaistošu kultūraugu audzēšanu, kas biolog̣isko daudzveidību praktiski neietekmē. Vairāki pētnieki (Pe’er et al., 2017) pauž viedokli, ka visiem trim zaḷināšanas pasākumiem ir zema efektivitāte, jo lauksaimniekiem plaši tiek piemēroti iznēmumi un tādas prasības, kas praksē neprasa nekādas izmainas vai tikai nelielas izmaiñas.

Salīdzinot pētnieku (Pe'er et al., 2017) apkopotos ES veiktos maksājumus par dažādo zalināšanas pasākumu îstenošanu, redzams, ka slāpekli saistošo kultūraugu audzēšanai atbalsta maksājums par vienu hektāru ir gandrīz desmit reizes augstāks nekā «Natura 2000» teritorijās - Eiropas Savienības nozìmes aizsargājamās teritorijās - un trīs reizes augstāks nekā bioloğiskās lauksaimniecības platībās (1.tabula).

Lauku saimniecību izškiršanos pāriet uz daudzfunkcionālu lauksaimniecību un diversificēt saimniecisko darbību nosaka dažādi apstākḷi un apsvērumi, kurus nosaciti var apkopot divos variantos: 1) sabiedribas pieprasijums pēc ekosistēmu pakalpojumiem un lauksaimnieka ētiskieapsvērumi par videi draudzịgu lauksaimniecības metožu izvēli; 2) lauku saimniecības stratēǵijas maiņa, kas pamatota ar tirgus situācijas un riska izvērtējumu (3. attēls). 1. varianta diversifikāciju parasti izvēlas bioloğiskās lauksaimniecības un mazās saimniecības, kuras vēlas izmantot videi draudzīgas metodes un sniegt labumu sabiedrībai - tie ir «zaḷā» dzīvesveida pārstāvji. 2. varianta diversifikāciju ìsteno specializētās saimniecības, kuras saskata problēmas noieta tirgos vai citus riskus, kas varētu būtiski apdraudēt vai samazināt saimniecības ienākumus, kā arī lielās saimniecības, kuras var atḷauties veikt ieguldỉjumus un tādējādi paplašināt darbỉbu.

1.tabula. ES agrovides pasākumu platības un vidējie maksājumi 2017.gadā

\begin{tabular}{llcr}
\hline Pasākums & Pasākuma raksturojums & $\begin{array}{r}\text { Lauksaimniecībā } \\
\text { izmantojamās zemes } \\
\text { platība, milj. ha }\end{array}$ & $\begin{array}{r}\text { Maksājumi, } \\
\text { EUR/ha }\end{array}$ \\
\hline Zaḷināšana & Ekoloğiski nozīmīgas platības & 8,00 & 789,89 \\
\hline $\begin{array}{l}\text { Agrovide } \\
\text { un klimats }\end{array}$ & $\begin{array}{l}\text { Ietver platības un maksājumus } \\
\text { bioloğiskajai lauksaimniecībai, bet } \\
\text { neietver maksājumus teritorijās } \\
\text { ar dabas ierobežojumiem }\end{array}$ & 13,15 & 247,17 \\
\hline «Natura 2000» & ES nozīmes zālāju platības & & \\
\hline
\end{tabular}

(Pēc Pe’er et al., 2017)

3. attēls. Lauku saimniecību diversifikācijas varianti

1. VARIANTS

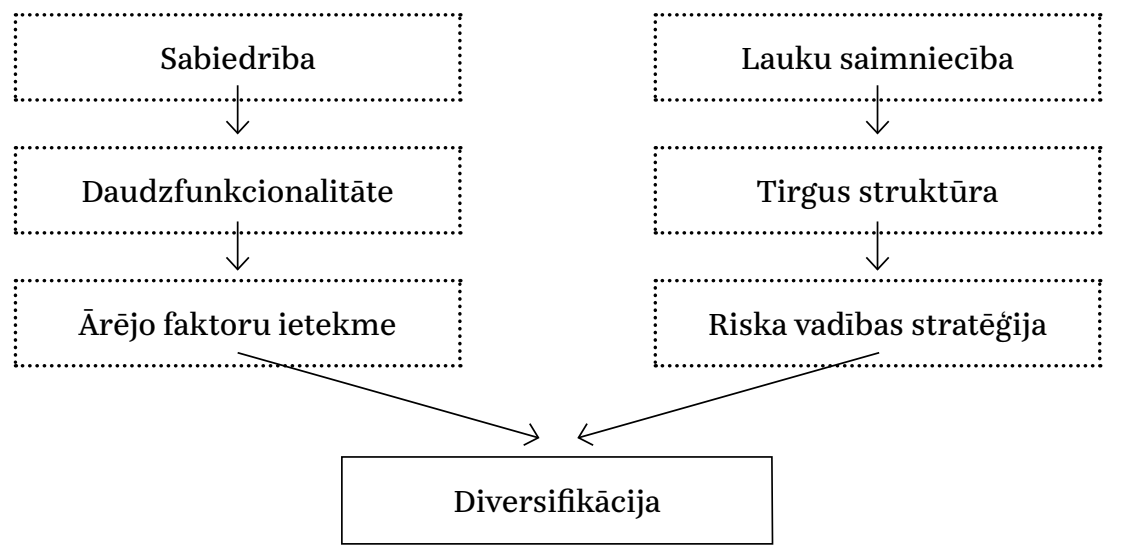

(Pēc Meraner et al., 2015)

Pēdējos gados ir veikti vairāki pētījumi, lai noskaidrotu lauku saimniecību diversifikāciju veicinošos un ierobežojošos faktorus. Kaut gan dažādās valstis un reĝ́ionos veikto pētijumu metodes un rezultāti atškiras, tomēr daži diversifikāciju veicinošie faktori ir līdzīgi, piemēram, 
lauksaimnieka vecums (jaunāki lauksaimnieki ir aktīvāki), izglītības un informētības līmenis, līdzšinējā saimniekošanas pieredze, kā arī pieprasījums un patērētāju sasniedzamība. Lauku saimniecību diversifikāciju veicinošie faktori apkopoti 2.tabulā.

Lauksaimniecības ġenētisko resursu saglabāšana un ilgtspējiga izmantošana veicina sabiedriskā labuma radīšanu un ekosistēmu pakalpojumu nodrošināšanu. Turklāt tai ir izšķiroša nozīme ilgtspējiggā lauksaimnieciskajā ražošanā, tostarp apputeksnēšanā, uzlabotā kaitēklu apkarošanā, elastīgāku agroekosistēmu izveidē un augsnes stabilitātes saglabāšanā (European Commission, 2015). Attiecīgi lauksaimniecỉbas biolog̣iskā daudzveidība veicina nodrošinātību ar pārtiku, mazinot riskus, kas saistìti ar intensīvām un ḷoti specializētām ražošanas sistēmām (European Commission, 2013a). Mūsdienu konvencionālajā lauksaimniecībā ir tendence izmantot tipiskās škirnes un varietātes. Tādējādi lauksaimniecības ainavās lielākoties dominē monokultūras un viendabīgas škirnes. Lauksaimniecības šḳirṇu un varietāšu ǵenētisko resursu daudzveidỉbas saglabāšana un attīstỉba ir kā drošỉbas tìkls, kas sniegs ekonomiskas iespējas daudzveidīgas kvalitātes shēmām atbilstošas pārtikas piegādei.

Lauksaimniecībai ir liela nozīme 2030. gada ilgtspējigas attīstïbas programmā un ilgtspējịgā nākotnē kopumā, jo tā ir cieši saistita ar tādiem jautājumiem kā nodarbinātība, pārtika, gaiss, klimata pārmaiṇas, ūdens resursi, augssne un bioloğiskā daudzveidỉba (United Nations, 2015).

ES ilgtspējiga stratēógija «Eiropa 2O2O» izvirza trīs savstarpēji papildinošas turpmākās izaugssmes prioritātes: 1) gudra attīstība - zināšanās un inovācijās balstìtas ekonomikas attīstība; 2) ilgtspējīga attīstība - resursefektīvākas, videi nekaitīgākas un konkurētspējiḡākas ekonomikas veicināšana; 3) iekḷaujoša attīstỉba - augsta nodarbinātỉbas līmeṇa ekonomikas veicināšana, nodrošinot ekonomisko, sociālo un teritoriālo kohēziju (European Commission, 2010). Kopējā lauksaimniecības politika un lauku attistỉbas programma ir saistīta ar Eiropas ilgtspējiggas stratēǵijas mērḳu îstenošanu (4. attēls).

Reformētajā kopējā lauksaimniecības politikā (2014-2020) ir trīs mērkii, kuri joprojām ir aktuāli un ar augstu prioritāti: 1) ekonomiski dzivotspējiga pārtikas ražošana; 2) ilgtspējigga dabas resursu apsaimniekošana un klimata politika; 3) līdzsvarota teritoriālā attīstìba (Papadopoulos, 2015). Lïdzịgi arī reformētās kopējās zivsaimniecības politikas mērkis ir veicināt ilgtspējīgu pārtikas ražošanu, nosakot ilgtspējigas zvejas un akvakultūras darbỉbas.

Pēdējo gadu desmitu laikā panāktie uzlabojumi Eiropā vides jomā ir bijuši iespējami, jo ir izstrādāti ES tiesību akti, ar kuriem tiek noteikta augsta aizsardzības pakāpe tādās jomās kā ūdens kvalitāte un dabas saglabāšana. Putnu direktīva un Biotopu direktīva aizsargā ekosistēmas, tāpat nozīmīgs sasniegums ir aizsargājamo teritoriju tỉkla «Natura 2000» platības palielināšana līdz 18 \% no ES. Tomēr ir nepieciešami papildu centieni, lai

2. tabula. Lauku saimniecības diversifikāciju veicinošie faktorì

Faktori

lespēja (pull) Nepieciešamība (push)

\begin{tabular}{|c|c|c|c|}
\hline \multirow{4}{*}{$\begin{array}{l}\text { Nosacījumi } \\
\text { jeb apstākḷi }\end{array}$} & Zemes pieejamība & - & + \\
\hline & Infrastruktūra un loğistika & + & + \\
\hline & Vietējo tīklu klātbūtne & + & - \\
\hline & Patērētāju sasniedzamība & + & - \\
\hline \multirow[t]{3}{*}{ Politika } & Teritoriālā politika un plānošana & + & + \\
\hline & Vietējo iestāžu atbalsts & + & - \\
\hline & ES politika & + & + \\
\hline \multirow[t]{3}{*}{ Tirgus } & Īsās piegādes k̦ēdes & + & - \\
\hline & Risks & + & + \\
\hline & Jauno aktivitāšu rentabilitāte & + & - \\
\hline \multirow{3}{*}{$\begin{array}{l}\text { Lauku } \\
\text { saimniecība }\end{array}$} & Sociālās un vides vērtības & + & - \\
\hline & Darbaspēks & + & + \\
\hline & Ienākumu cikliskums & - & + \\
\hline
\end{tabular}

(Pēc Renting et al., 2009; Henke \& Vanni, 2017)

sasniegtu ES mērķus apturēt bioloğiskās daudzveidības samazināšanos līdz 2020. gadam un atjaunot vismaz 15\% no degradētajām ekosistēmām (European Parliament, 2016).

N̦emot vērā, ka joprojām pastāv daudz būtisku problēmu dabas jomā, ES arvien vairāk lïdztekus likumdošanai attīsta arī cita veida politikas, kuru mērķis ir «nodrošināt ilgtspējīgus patēriņa un ražošanas modeḷus» (12. ilgtspējīgas attīstības mērḳis). Saistībā ar šo mērḳi rīcība attiecībā uz resursu izmantošanas efektivitāti un aprites ekonomiku ir vērsta uz to, lai noškirtu ekonomikas izaugsmi no resursu izmantošanas un vides degradēšanas. 
4. attēls. ES ilgtspējīgas stratēgijas sasaiste ar kopējās

lauksaimniecības politikas (KLP) un lauku attīstības

programmas (LAP) stratēgiskajiem un politiskajiem mērḳiem

«EIROPA 2O2O»

Kopējā lauksaimniecības politika (KLP):

gudra ilgtspējiga iekḷaujoša

KLP GALVENIE

MẼRKY

\begin{tabular}{|c|c|c|c|c|}
\hline \multicolumn{2}{|c|}{$\begin{array}{l}\text { Dzivotspējiga pārtikas } \\
\text { ražosasana }\end{array}$} & $\begin{array}{c}\begin{array}{c}\text { Ilgtspējiga dabas resursu } \\
\text { apsaimniekososana un riciba } \\
\text { klimata părmainu jomāa }\end{array} \\
\uparrow\end{array}$ & \multicolumn{2}{|c|}{$\begin{array}{l}\text { Lidzsvarota teritoriāalā } \\
\text { attistiba }\end{array}$} \\
\hline $\begin{array}{c}\text { 2. Lauku } \\
\text { saimniecibu } \\
\text { dzivotspeja un } \\
\text { konkuretspejaja }\end{array}$ & $\begin{array}{c}\text { 3. Pārtikas } \\
\text { kēedes } \\
\text { organizācija } \\
\text { un riska } \\
\text { pārvaldiba }\end{array}$ & $\begin{array}{l}\text { 4. Ekosistêmu } \\
\text { atjaunošana, } \\
\text { sagglabašana un } \\
\text { uzlabošana }\end{array}$ & $\begin{array}{l}\text { 5. Resursu ziñā } \\
\text { efektiva un kli- } \\
\text { mata pārmainām } \\
\text { pielāgotaa } \\
\text { ekonomika }\end{array}$ & $\begin{array}{c}\text { 6. Sociālā } \\
\text { integrācija, } \\
\text { nabaddzibas } \\
\text { mazināšana un } \\
\text { ekonomiskā } \\
\text { attistiba }\end{array}$ \\
\hline$\uparrow$ & $\uparrow$ & $\uparrow$ & $\uparrow$ & $\uparrow$ \\
\hline
\end{tabular}

(Pēc European Commission, 2010; European Commission, 2013b)

Ilgstspējiga patēriṇa uzturēšanai būs nepieciešama arī patērētāju politika, kas sekmē informētỉbu un ḷauj patērētājiem pieṇemt apzinātus lēmumus, kuri veicina ilgtspējỉbu (European Commission, 2016).

ES vides jomas tiesību aktu kopuma (6., 14. un 15. ilgtspējigas attīstibas mērḳis) ìstenošana joprojām ir ḷoti nozimìga ilgtspējibai ilgtermiņā un nav nodalāma no plašākām ekonomikas un sociālām problēmām. 7.vides rīcības programmā ir uzsvērts, ka dabas resursu bāzes uzturēšana un uzlabošana ir svarīga arī tāpēc, lai tautsaimniecības nozares spētu sniegt savus pakalpojumus, piemēram, lauksaimniecība, zivsaimniecība vai enerğētika.

2011. gadā EK (European Commission, 2011) pienēma jaunu stratēǵiju, lai apturētu bioloğiskās daudzveidības samazināšanos un uzlabotu Eiropas sugu, dzīvotṇu, ekosistēmu un to sniegto pakalpojumu stāvokli nākamajos desmit gados, vienlaikus palielinot ES ieguldijumu globālās bioloğiskās daudzveidības samazināšanās novēršanai. Tajā noteikti seši galvenie mērkị, lai samazinātu apdraudējumu dabai un ekosistēmu pakalpojumiem gan ES, gan ārpus tās, kā ari noteikta stratēgíija un rīcibas programmatiskais ietvars turpmākajiem desmit gadiem.
5. attēls. ES stratēgisko mērku sasaiste ar

ES strukturālajiem un investīciju fondiem

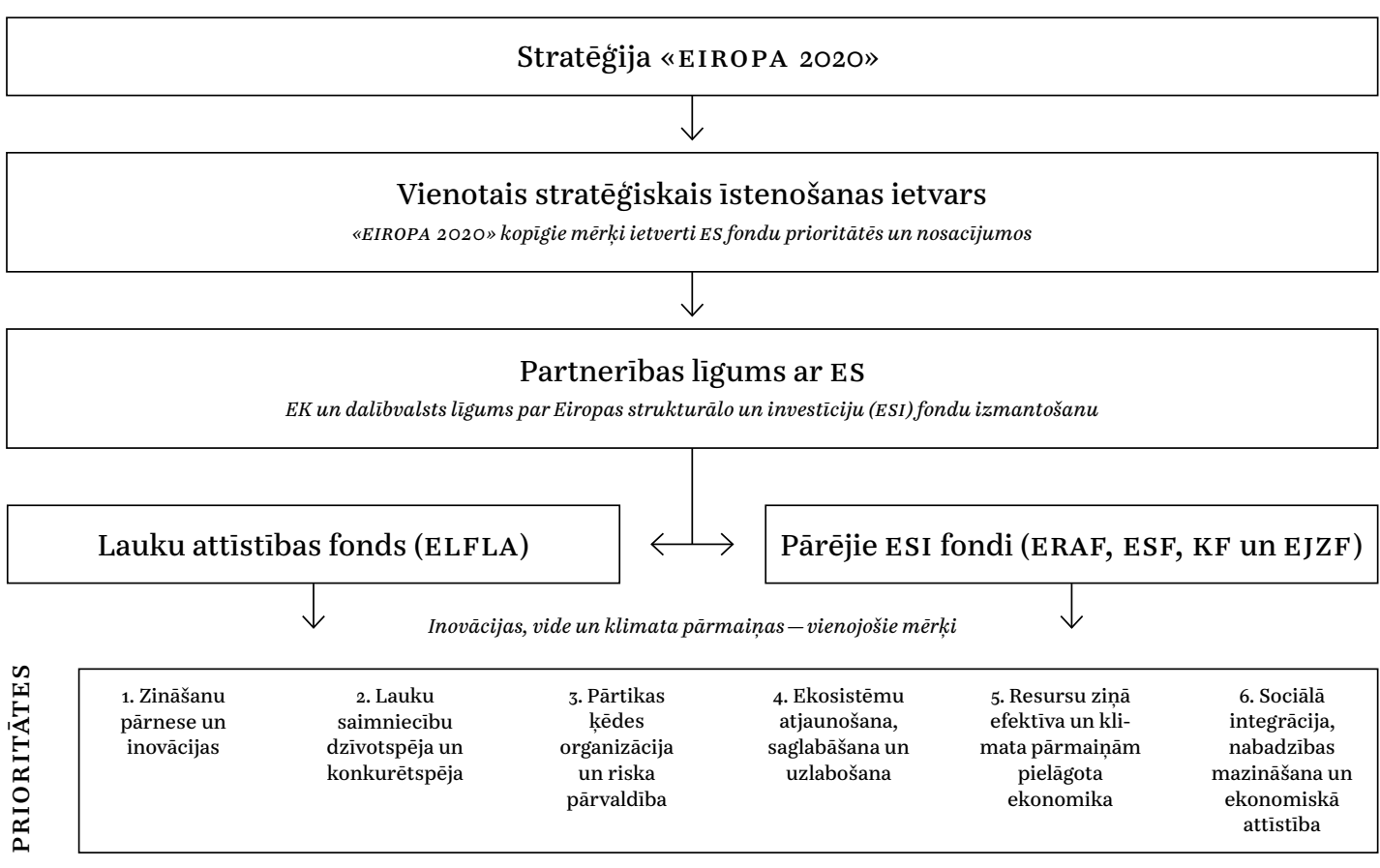

Lauku attistibas programma

Stratēóija balstīta uz 2010. gadā pienemtajiem dokumentiem: ES 27 valstu vaditāju 2010. gadā pienemto vienošanos un politisko uzdevumu - noteikt ilgtermiṇa mērḳus un dubultot centienus, lai saglabātu Eiropāa arvien vairāk apdraudēto bioloğisko daudzveidību; Nagojā (Japāna) 193 valstu augstākā līmena lìderu pienemto Protokolu par genētisko resursu pieejamỉbu un to izmantošanā iegūto labumu taisnīgu un vienlïdzịgu sadali, kurš papildina Konvenciju par bioloğisko daudzveidibu.

Bioloğiskās daudzveidības politikas nostādnes ir jāintegrē nozaru politikās, un tās jāṇem vērā, pievēršoties plašākām politikas problēmām. Tādēl panākumu atslēga būs zivsaimniecības, lauksaimniecības un mežsaimniecības politikas ieguldījumu palielināšana bioloğiskās daudzveidỉbas aizsardzībā. Šajā virzienā jau ir pieliktas pūles, padarot bioloğiskās daudzveidības stratēǵiju par neatṇemamu dalıu no Eiropas 2020. gada gudras, integrējošas un ilgtspējigas izaugsmes stratêgíijas. Jaunā stratēóiija pilnỉbā apzinās ekosistēmu pakalpojumu ekonomisko vērtỉbu un to atjaunošanu ekonomikas labā. 
3. tabula. Dabisko ekosistēmu un agroekosistēmu

\section{radītās īpašibas un to raksturojums}

\begin{tabular}{|c|c|c|c|}
\hline \multirow[t]{2}{*}{ Ekosistēmu radītās īpašǐbas } & \multirow{2}{*}{$\begin{array}{l}\text { Dabiskās } \\
\text { ekosistēmas }\end{array}$} & \multicolumn{2}{|c|}{ Agroekosistēmas veids } \\
\hline & & Konvencionāla* & Ilgtspējiga \\
\hline Produktivitāte & Vidēja & Augsta & $\begin{array}{l}\text { Vidēja (iespējams } \\
\text { augsta) }\end{array}$ \\
\hline Sugu daudzveidība & Augsta & Zema & Vidēja \\
\hline Strukturālā daudzveidība & Augsta & Zema & Vidēja \\
\hline Funkcionālā daudzveidība & Augsta & Zema & Vidēja līdz augsta \\
\hline Ražotspējas stabilitāte & Vidēja & Zema līdz vidēja & Augsta \\
\hline Biomasas uzkrāšanās & Augsta & Zema & Vidēja līdz augsta \\
\hline Augu barïbas vielu aprite & Slēgta & Atvērta & Daḷēji slēgta \\
\hline Trofiskās attiecības (ḳēde) & Kompleksas & Vienkāršas & Starpposma \\
\hline Dabisko populāciju līdzsvars & Augsts & Zems & Vidēja līdz augsta \\
\hline Noturība & Augsta & Zema & Vidēja \\
\hline Dzīvotspēja & Augsta & Zema & Vidēja \\
\hline $\begin{array}{l}\text { Atkarība no ārējās ievades } \\
\text { (izejmateriāli) }\end{array}$ & Zema & Augsta & Vidēja \\
\hline Autonomija & Augsta & Zema & Augsta \\
\hline $\begin{array}{l}\text { Cilvēka ietekme uz } \\
\text { ekoloğiskajiem procesiem }\end{array}$ & Zema & Augsta & Zema līdz vidēja \\
\hline Ilgtspēja & Augsta & Zema & Augsta \\
\hline
\end{tabular}

*Attisstito valstu agroekosistēmas. (Pēc Gliessman, 2005; Pretty \& Bharucha, 2014)
4. tabula. Ekosistēmu funkciju un

pakalpojumu (aktīva) vērtība

\begin{tabular}{|c|c|}
\hline Vērtïba & Raksturojums \\
\hline Tirgus vērtība & Apmaiṇas vērtība vai cena atvērtā tirgū \\
\hline Patiesā vērtība & $\begin{array}{l}\text { Vērtība, kurai ir maza tirgus vērtība vai tās nav vispār, } \\
\text { bet piemìt izmantošanas vērtìba }\end{array}$ \\
\hline $\begin{array}{l}\text { Iekšējā } \\
\text { neizmantotā } \\
\text { vērtība }\end{array}$ & $\begin{array}{l}\text { Vērtìba, kas pievienota videi un dzīvỉbas formām viṇu } \\
\text { pašu labā }\end{array}$ \\
\hline $\begin{array}{l}\text { Eksistences } \\
\text { vērtība }\end{array}$ & $\begin{array}{l}\text { Vērtība, kas saistīta ar zināšanām, ka sugas, dabiskā } \\
\text { vide un citi ekosistēmu pakalpojumi pastāv, pat ja } \\
\text { indivīds neplāno tos aktîvi izmantot }\end{array}$ \\
\hline $\begin{array}{l}\text { Empātiskā } \\
\text { vērtïbas }\end{array}$ & $\begin{array}{l}\text { Vēlme maksāt par vides saglabāšanu savas paaudzes } \\
\text { vai turpmāko paaudžu cilvēku labumam }\end{array}$ \\
\hline Pašreizējā vērtība & Nākotnes aktīva vērtība, kas ir diskontēta līdz tagadnei \\
\hline Iespējamā vērtība & Vēlme maksāt šodien par aktīva izmantošanu nākotnē \\
\hline $\begin{array}{l}\text { Škietami } \\
\text { iespējamā vērtība }\end{array}$ & $\begin{array}{l}\text { Saglabāšanas vērtība iespējamai izmantošanai } \\
\text { nākotnē, pieņemot, ka pieaugs zināšanas par dabiskās } \\
\text { vides procesiem }\end{array}$ \\
\hline
\end{tabular}

(Pēc Spangenberg \& Settele, 2010; Davidson, 2013)

Lai gan bioloğiskās daudzveidības zuduma apturēšanas pasākumi prasa naudu, paredzams, ka bezdarbïbas izmaksas būs vēl lielākas. Bioloğiskās daudzveidības samazināšanās sabiedrībai ir loti dārga, jo īpaši nozarēs, kas lielā mērā atkarīgas no ekosistēmu pakalpojumiem. Piemēram, daudzi lauksaimnieki ir atkarīgi no kukainu apputeksnēšanas, jo tā ir nepieciešama 75\% pārtikā izmantojamo kultūru (Maes et al., 2013). Ir svarīga arī apputeksnētāju sugu daudzveidība (piemēram, savvalas bites veic lielu daḷ no apputeksnēšanas pakalpojumiem), turklāt kukaiṇu veikta apputeksnēšana piešḳir lielāku tirgus vērtību (augstāka kvalitāte, ilgāks uzglabāšanas laiks) daudzām entomofilajām kultūrām, piemēram, zemenēm un āboliem (Nieto et al., 2014). 
5. tabula. Lauksaimniecības attīstības modeli

\begin{tabular}{|c|c|c|c|c|}
\hline Attīstības modeli & 1. & 2. & 3. & 4. \\
\hline $\begin{array}{l}\text { Politikas } \\
\text { paradigma }\end{array}$ & Konkurētspējiga & Daudzfunkcionāla & & \\
\hline $\begin{array}{l}\text { Plānošanas } \\
\text { diskurss }\end{array}$ & Ražošanas telpa & Darbibu tīklojums & Teritoriju tiklojums & Ekosistēma \\
\hline $\begin{array}{l}\text { Galvenais } \\
\text { lauksaimniecibas } \\
\text { modelis }\end{array}$ & $\begin{array}{l}\text { Rūpnieciski } \\
\text { attistita, liela } \\
\text { mēroga preču } \\
\text { ražošanas } \\
\text { lauksaimniecība }\end{array}$ & $\begin{array}{l}\text { Agrobiznesa } \\
\text { komplekss, kas } \\
\text { izmanto vietējās } \\
\text { salìdzinošās } \\
\text { priekšrocības }\end{array}$ & $\begin{array}{l}\text { Diversificētas } \\
\text { vietējās pārtikas } \\
\text { sistēmas }\end{array}$ & $\begin{array}{l}\text { Ekologóiskās } \\
\text { lauksaimniecibas } \\
\text { sistēmas }\end{array}$ \\
\hline $\begin{array}{l}\text { Galvenais } \\
\text { produktu tirgus }\end{array}$ & $\begin{array}{l}\text { Pasaules preču } \\
\text { tirgus }\end{array}$ & $\begin{array}{l}\text { Identificēti vērtïbu } \\
\text { kēdes pasaules tirgi }\end{array}$ & $\begin{array}{l}\text { Vietējais pārtikas } \\
\text { tirgus }\end{array}$ & $\begin{array}{l}\text { Speciālie integrētās } \\
\text { un bioloğiskās lauk- } \\
\text { saimniecības tirgi }\end{array}$ \\
\hline Reğionālā pieeja & $\begin{array}{l}\text { Tādas nav, } \\
\text { atseviškie ražotāji } \\
\text { organizēti pa } \\
\text { nozarêm }\end{array}$ & $\begin{array}{l}\text { Reğionālais } \\
\text { agrobiznesa } \\
\text { komplekss ar } \\
\text { ligumattiecibām }\end{array}$ & $\begin{array}{l}\text { Reğionāāā identitāte } \\
\text { ar reğionālo } \\
\text { markējumu jeb } \\
\text { preču zimi }\end{array}$ & $\begin{array}{l}\text { Vietèjāa } \\
\text { agroekoloớiskā } \\
\text { sistēma }\end{array}$ \\
\hline $\begin{array}{l}\text { Iespējamie } \\
\text { ierobežojumi }\end{array}$ & $\begin{array}{l}\text { Konkurētspēja } \\
\text { pasaules tirgū } \\
\text { (konkurence ar } \\
\text { zemuizmaksu } \\
\text { ražotāiem) }\end{array}$ & $\begin{array}{l}\text { Vērtibu kēèdes } \\
\text { konkurètspēja } \\
\text { pasaules tirgūü } \\
\text { (rūpniecibas } \\
\text { părvietošana) }\end{array}$ & $\begin{array}{l}\text { Teritoriālā } \\
\text { konkurētspēja } \\
\text { (piesātināti tirgi) }\end{array}$ & $\begin{array}{l}\text { Konkurētspēja } \\
\text { nišas tirgos } \\
\text { (mazie tirgi) }\end{array}$ \\
\hline Ilgtspējas robežas & $\begin{array}{l}\text { Ekonomika } \\
\text { (nodarbinātīiba) }\end{array}$ & $\begin{array}{l}\text { Ekonomika } \\
\text { (nodarbinātiba un } \\
\text { pakalpojumi) }\end{array}$ & Sociālas & Ekoloğiskas \\
\hline $\begin{array}{l}\text { Ilgtspējības un } \\
\text { daudzfunkciona- } \\
\text { litātes palielinā- } \\
\text { šanas politika }\end{array}$ & $\begin{array}{l}\text { Vietējā tïklojuma } \\
\text { stiprināšana } \\
\text { un augstākas } \\
\text { vērtības radiššnas } \\
\text { veicināšana }\end{array}$ & $\begin{array}{l}\text { Konkurētspējas } \\
\text { stiprināšana, } \\
\text { pamatojoties uz } \\
\text { teritoriālajiem } \\
\text { resursiem (uz } \\
\text { produktiem, } \\
\text { nevis uz mērogu } \\
\text { orientêta) }\end{array}$ & $\begin{array}{l}\text { Reğionālās } \\
\text { identitātes } \\
\text { stiprināašana un } \\
\text { vertikaāo tirgu } \\
\text { izveide }\end{array}$ & $\begin{array}{l}\text { Vietējo pārtikas } \\
\text { tikklu un } \\
\text { netirgojamo preču } \\
\text { un pakalpojumu } \\
\text { tirgus izveide }\end{array}$ \\
\hline
\end{tabular}

(Pēc van Huylenbroeck et al., 2007)

Visā Eiropas Savienībā kopējā kukainu veiktā apputeksnēšanas pakalpojuma ekonomiskā vērtỉba tiek lēsta no 15 līdz 22 miljardiem eiro gadā (Maes et al., 2013; Nieto et al., 2014).

ES tikai $17 \%$ dzivotṇu un sugu un $11 \%$ galveno ekosistēmu, kas ir aizsargātas saskaṇā ar ES tiesību aktiem, ir labā stāvoklī, lai gan centieni samazināt bioloğiskās daudzveidỉbas samazināšanos ir pieauguši, īpaši kopš 2001. gada, kad tika izvirzîts ES 2010. gada mērḳis bioloğiskās daudzveidỉbas saglabāšanas jomā (European Commission, 2011). Neraugoties uz veiktajiem pasākumiem, turpinās ilgstoša un pieaugoša lauksaimniecības intensifikācijas radīta slodze, kas kaitē Eiropas bioloğiskajai daudzveidỉbai un izraisa izmainas zemes izmantojumā, turpinās bioloğiskās daudzveidības un tās komponentu pārmērīga izmantošana, invazivvu svešzemju sugu izplatišanās. Tādējādi piesārnojums un klimata pārmainas nav mazinājušās vai ir pat palielinājušās (European Commission, 2015). Turklāt bioloğisko daudzveidỉbu ietekmē arī netiešie faktori, piemēram, vāja izpratne par bioloğisko daudzveidību un fakts, ka bioloğiskās daudzveidības vērtība, tai skaitā ekonomiskā, netiek nemta vērā lēmumu pienemšanā.

Lauksaimniecības sistēmu jeb agroekosistēmu izmainu rezultātā mainās ekosistēmu dažādās ippašỉbas (3.tabula). Konvencionālā agroekosistēma, kuras galvenais mērḳis ir produktivitātes paaugstināšana, ir attīstîto valstu pašreizējā lauksaimniecības sistēma. Ilgtspējīgas agroekosistēmas izveide ir saistìta ar tāda produktivitātes līmeṇa uzturēšanu, kas balstās uz dabiskiem procesiem, neraugoties uz biomasas ieguvi ilgākā laikā. (Gliessman, 2005; Pretty \& Bharucha, 2014). N̦emot vērā agroekosistēmas radītās ietekmes, ir nepieciešams pārstrukturēt pašreizējo - konvencionālo lauksaimniecības sistēmu, lai tā radītu nepieciešamos resursus (pārtiku, škiedras, enerğiju), vienlaikus saglabājot vides un dabas daudzveidības resursus (Pretty, 2008).

Lauksaimniecības sistēmas veicina atšķiirịgas ekonomiskās, dabas, kultūras un teritoriālās apakšsistēmas, un tām ir liels potenciāls, lai, izmantojot daudzfunkcionālas darbības, pakāpeniski nodrošinātu pāreju uz ekoloğisku saimniekošanu, izveidojot vietējo pārtikas sistēmu jeb k̦ēdi un netirgojamo preču un pakalpojumu tirgu jeb publisko piedāvājumu. 5. tabulā apkopoti lauksaimnieciibas attīstības modeli, sniedzot to raksturojumu.

Mazās lauku saimniecības veic ne vien lauksaimniecisko ražošanu, bet arì citas būtiskas funkcijas, kas ir saistītas ar sabiedriskā labuma preču un pakalpojumu nodrošināšanu. Saimniecības, izmantojot videi draudzīgas lauksaimnieciskās ražošanas metodes, piemēram, bioloğiskās, audzējot tradicionālās lauksaimniecības dzīvnieku un kultūraugu sugas un šķirnes, kā arī diversificējot savu darbību, ir uzskatāmas par multifunkcionālām. To aktivitātes aptver:

— ar vides saudzēšanu un ainavu uzturēšanu saistītas darbỉbas, kas palīdz saglabāt gan raksturīgās lauku ainavas, gan bioloğisko daudzveidību, tai skaitā lauksaimniecības bioloğisko jeb genētisko daudzveidību;

- sociālas darbïbas, kas nodrošina iztiku, novērš nabadzibu un klūst par darbaspēka avotu rūpniecībai un citām ekonomikas nozarēm, piemēram, tūrismam; 
— kultūras darbỉbas, kas saglabā tradīcijas, tautas ieražas un citas nemateriālās, kultūrvēsturiskās vērtības, kā arī ražo reğionālos un tradicionālos produktus.

Eiropas Parlaments (European Parliament, 2014) norāda, ka Eiropā mazās lauku saimniecības nepārtraukti izjūt demogrāfisko, komerciālo un tehnoloğisko spiedienu, kas izraisa pakāpenisku deagrarizāciju un depopulāciju tajās lauku teritorijās, kurās šãdas saimniecības ir vairākumā, tostarp izraisa masveida atteikšanos audzēt nelielus mājlopu ganāmpulkus un īpašas vietējās kultūras. Eiropas Ekonomikas un sociālo lietu komiteja uzskata, ka zemes piesavināšanās (land grabbing) un lauksaimniecības zemju koncentrācija (land concentration) apdraud mazās ǵimenes lauku saimniecības. Turklāt zemes platību koncentrācija ir pretrunā ilgtspējigam un daudzfunkcionālam Eiropas lauksaimniecības modelim, kas galvenokārt balstîts uz ǵimenes lauku saimniecībām. Tās veic sabiedrībai svarīgas un videi noderīgas funkcijas, kuras nevar piedāvāt rūpnieciskie lauksaimnieki lielražotāji. Lai ǵimenes lauku saimniecības būtu dzìvotspējīga alternatīva rūpnieciskai lauksaimniecībai un ar to saistìtai zemes piesavināšanai, dalībvalstīm ir jāîsteno aktīvi ğimenes lauku saimniecību aizsardzības pasākumi (EESC, 2015).

Lauku saimniecību skaita un lauksaimniecībā nodarbināto skaita samazināšanās ir savstarpēji saistīta. Piemēram, no 2005. līdz 2010. gadam Austrumeiropas valstīs, īpaši Baltijas valstīs (Igaunijā, Latvijā un Lietuvā), krasi samazinājās lauku saimniecību skaits un krasi samazinājās arī darbaspēka pieprasijjums (Bulgārijā un Rumānijā par 8,9 \% gadā un Baltijas valstîs par 8,3 \% gadā) (EESC, 2015).

Ilgtspējigu izredžu radī̌anai, jo īpaši jauniešiem, lauku teritorijās ir izšķiiroša nozìme mazo lauku saimniecību nākotnes nodrošināšanā; to esība un izdzìvošana garantē ienākumus un ierobežo iedzivotāju izbraukšanu. Iedzivotāju izceḷošana un lauku pamešana vēl vairāk būtiski pasliktina lauku kopienu dzives apstākḷus un lauksaimnieku dzìves un darba kvalitāti. Šiem faktoriem bieži ir izšķiroša nozime lēmumā par lauku saimniecības saglabāšanu vai likvidēšanu.

Mazo lauku saimniecību intereses nav pietiekami ņemtas vērā ES kopējās lauksaimniecības politikas izveidē un îstenošanā, kur atbalsta pasākumu un subsīdiju struktūra galvenokārt ir balstìta uz zemes platībām un iepriekšējiem ražošanas apjomiem.

A.Papadopuls (Papadopoulos, 2015) uzsver, ka Es kopējā lauksaimniecības politika ir zaudējusi uzticibu un kluvusi bezjēdzìga, jo tã ir pārveidojusies no lauksaimniecibas politikas uz lauksaimnieku atbalsta politiku. Turklāt tā 1) joprojām absorbē lielu daḷu no ES budžeta; 2) nevienmērīgi sadala atbalstu starp nozarēm un sanēēējiem; 3) joprojām ir orientēta uz ražošanu un tāpēc ir radījusi ievērojamu kaitējumu videi. Kopējās lauksaimniecības politikas ietvaros ir novērojama liela atbalsta maksājumu nevienlīdzība gan starp ES dalïbvalstīm, gan to iekšienē (Papadopoulos, 2015). 2007. gadā $25 \%$ ES 27 dalībvalstu lielākās saimniecības saṇēmušas $75 \%$ no abu pillāru atbalsta maksājumiem. Turklāt $25 \%$ ES tā saukto veco 15 dalībvalstu saimniecības ir saṇēmušas trīs reizes lielāku atbalstu nekā vidēji visi saṇēmēji. Tas liecina, ka maksājumi, kas paredzēti, lai nodrošinātu lauksaimniekiem garantētus ienākumus, nav efektīvs instruments trūcīgāko lauksaimnieku atbalstam (Papadopoulos, 2015)

2016. gadā $80 \%$ no tiešmaksājumiem ir sanēemuši $20 \%$ lauksaimnieku (European Commission, 2017b). Latvijā situācija ỉr lỉdzịga, jo vairāk nekā 70\% Latvijas lauku saimniecību ir sanēmušas 1250 eiro vai mazāku atbalstu uz saimniecību, un tas ir 5-15\% no kopējā tiešmaksājumos izmaksātā finansējuma; lỉdz 0,5\% saimniecību saṇēmušas 50 ooo-100 ooo eiro (10-15\% no kopējā finansējuma), bet 0,25-0,50\% saimniecībām, kas tiešmaksājumos sanēmušas vairāk par 100000 eiro, izlietoti 15-30\% no kopējā finansējuma apjoma (European Commission, 2017b).

Mazo saimniecību turpmākā darbība ir apdraudēta, ṇemot vērā faktu, ka kopējā lauksaimniecības politika un lauku attīstỉbas programma nespēj atbilstìgi reaǵēt uz mazo lauku saimniecību situāciju un ka atsevišķas dalībvalstis lauku attīstības programmas otrajā pilārā nosaka minimālās finansēšanas robežvērtības vai arī vispār nav noteikušas atbalsta pasākumus, kas atbilst šādu saimniecību vajadzībām. Eiropas Parlaments aicina dalībvalstis un Eiropas Komisiju veikt atbilstošus pasākumus kopējās lauksaimniecības politikas 2014-2020 ietvaros, kā arī sagatavot pamatnostādnes periodam pēc 2020. gada, vairāk nnemot vērā īpašas mazo un ǵimeṇu saimniecỉbu vajadzibas. Šîs saimniecỉbas ir nozìmīgs Eiropas lauksaimniecības modeḷa elements, kā arī pamats lauku teritorijas daudzfunkcionālai attīstỉbai un reğionu ilgtspējīgai attīstỉbai kopumā (European Parliament, 2014).

Eiropas Parlaments norāda, ka mazo lauku saimniecibu skaita ierobežošanai nav jākḷūst par galveno restrukturizācijas pasākumu mērḳi, jo tas nepalielinās lielāku saimniecību konkurētspēju. Lai palielinātu mazo lauku saimniecību konkurētspēju, dzīvotspēju un ienesīgumu, lai attīstītu uzṇēmējdarbỉbu, radītu darbvietas un apturētu iedzivotāju skaita mazināšanos lauku teritorijās, EP aicina dalībvalstis izstrādāt mazajām lauku saimniecībām piemērotus risinājumus un attīstības modelus, nemot vērā attiecīgās valsts lauksaimniecības ippatnības un reğionālās atšḳirības. Mazajām lauku saimniecībām jāapvienojas organizācijās, ražotāju grupās vai kooperatīvos un jāveido kopējas mārketinga kampanas. Turklāt visu veidu mazo lauku saimniecību sadarbỉbas formām (kooperatīviem un ražotāju organizācijām) vai resursu (piemēram, iekārtu, tehnikas) apvienošanai un koplietošanai (pooling resources) ir jāsaṇem ippašs ES un valsts atbalsts (European Parliament, 2014). 
2010. gadā pieṇemtajā ES ilgtspējigas attīstības stratēǵijā «Eiropa 2020. Stratēǵija gudrai, ilgtspējigai un integrējošai izaugsmei» tika uzsvērts, ka ilğtspējigiga izaugsme ir resursu ziṇā efektîvākas, videi nekaitīgākas un konkurētspējigas ekonomikas veidošana (European Commission, 2010). Šādas pieejas îstenošana veicinās ES samazināt oglekḷa dioksīda emisijas, vienlaikus novēršot vides degradāciju, bioloğiskās daudzveidỉbas samazināšanos un resursu nesaimniecisku izmantošanu. Tas sekmēs ekonomisko, sociālo un teritoriālo kohēziju.

2015. gadā ANO G̣enerālajā asamblejā tika pieņemta rezolūcija «Mūsu pasaules pārveidošana: ilgtspējigas attīstỉbas programma 2030. gadam» (United Nations, 2015). Tā nosaka 17 ilgtspējīgas attīstības mērḳus un 169 apakšmērķus, kas sasniedzami, lai pasaulē mazinātos nabadzỉba un pasaules attīstìba būtu ilgtspējiga. Ilğtspējigas attīstỉbas mērḳos var izšķirt ekonomiskos, sociālos un vides aspektus.

Pamatojoties uz šo rezolūciju EK (EC, 2016) 2016. gada ziṇojumā «Turpmākie pasākumi ilgtspējīgai Eiropas nākotnei. Eiropas rīcība ilgtspējỉbas jomā» prezentēja ES Ilğtspējigas attīstïbas programmu 2030. gadam un ilgtspējiggas attīstības mērkus, no rezolūcijas mērkiem izvēloties 10 prioritāros mērḳus. Viens no mērḳiem - 15. ilgtspējigas attīstỉbas mērḳis - nosaka, ka sauszemes ekosistēmas ir jāaizsargā un jāatjauno, jāveicina to ilgtspējīga izmantošana, ir ilgtspējigi jāapsaimnieko meži, jāaptur pārtuksnešošanās un augsnes degradācija, veicot tās uzlabošanu, un jāaptur bioloğiskās daudzveidības izzušana. Vēl šajā programmā ir uzsvērts, ka nepieciešami papildu centieni, lai sasniegtu jau izvirzìtos ES mērkus un apturētu bioloğiskās daudzveidības samazināšanos līdz 2020. gadam, atjaunojot vismaz 15\% no degradētajām ekosistēmām. EK norāda, ka lauksaimniecībai (2. ilgtspējighas attīstibas mērḳis) ir liela nozime 2030. gada programmā un ilgtspējigā nākotnē kopumā, jo tā ir cieši saistīta ar tãdiem jautājumiem kā nodarbinātība, pārtika, gaiss, klimata pārmaiṇas, ūdens resursi, augsne un biolog̣iskā daudzveidība (8., 12., 6., 13. un 15.ilgtspējigas attīstỉbas mērḳis). Tāpēc EK paredz turpināt kopējās lauksaimniecības politikas vienkāršošanu un modernizāciju, lai maksimāli palielinātu tās ieguldỉjumu ilgtspējigas attīstības mērḳu ìstenošanā (European Commission, 2016).

Lauksaimniecības un lauku daudzfunkcionalitāti, šo jēdzienu visplašākajā pienemtajā nozīmē, var attiecināt uz vairāku ekosistēmu funkciju ìstenošanu lauku teritorijās, piemēram, ainavu un bioloğiskās daudzveidības pārvaldība, ūdens resursu apsaimniekošana, lauku teritoriju dzīvotspējas, kā arì vēsturiskā un kultūras mantojuma uzturēšana, g̊enētisko resursu saglabāšana u. tml. (van Huylenbroeck et al., 2007; Aguglia et al., 2009). Lauksaimniecỉbas daudzfunkcionalitāte attiecas arī uz ieguvumiem resursu saglabāšanā, turklāt visā vērtību k̦ēdē (Fagioli et al., 2007). Daudzfunkcionālās darbỉbas rezultātā tiek radīti ekosistēmu pakalpojumi, kuri lauku saimniecībām sniedz iespēju diversificēt savu darbību un gūt ienākumus, piedāvājot dažāādus pakalpojumus gan sabiedrībai kopumā (piemēram, lauku ainava), gan patērētājiem (piemēram, rekreācijas, tūrisma, veselības, izglītošanas pakalpojumi), kā arī piedāvājot preces (piemēram, pārtikas preces, amatniecības izstrādājumus) (Sutherland et al., 2016). Lauku saimniecība diversifikāciju var ìstenot divējādi: 1) padzilinot (deepening) darbỉbu, radot produktam vai pakalpojumam pievienoto vērtibu; 2) paplašinot (broadening) darbỉbu, radot dažādu jaunu preču un pakalpojumu piedāvājumu (Knickel, Renting, \& van der Ploeg, 2004). Vēl viens lauku saimniecību darbības diversifikācijas veids ir, izmantojot lauku saimniecības resursus, gūt ienākumus ārpus lauksaimniecības, piemēram, ar saimniecības tehniku izpildìt citu uznēmumu, valsts vai pašvaldību ligumdarbus. Lauku saimniecību darbïbas diversifikācija kḷūst par nepieciešamību, bet mazajām lauku saimniecībām - par izdzìvošanas stratēgiju (Weltin et al., 2017).

Ienākumu ieguves diversifikāciju, kas nav saistìta ar lauku saimniecības resursiem, bet gan ar lauksaimnieka mājsaimniecības darbaspēka resursiem, dēvē arī par ienākumus nesošo darbību dažādošanu (pluriactivity), tādējādi to nodalot no lauku saimniecības diversifikācijas (European Commission, 2008; Auguglia et al., 2009; Melece \& Krievina, 2015). Ienākumus nesošo darbību dažādošana ir saistīta ar mazajām ğimenes saimniecībām, kur lauku saimniecības īpašnieks vienlaikus strādā gan savā lauku saimniecībā, un tas bieži ir nepilna laika darbs, gan arī algotā darbā, kas var būt ar lauksaimniecību nesaistīts, vai citā lauku saimniecībā (European Commission, 2008). Vairāki pētnieki uzskata, ka ğimenes saimniecības (mājsaimniecības) locekḷu algotais darbs ārpus saimniecības ir jāuzskata par papildu ienākumu (van Huylenbroeck et al., 2007; Auguglia et al., 2009). 


\section{Ilgtspējīgs patēriṇš un vides pārvaldỉba}

Šìs nodaḷas mērkis ir sniegt ieskatu ilgtspējiga patēriṇa pārvaldības un vides pārvaldības teorētiskajā starpdisciplinaritātē, konceptuālajās pieejās un rīcībpolitiku prakses attīstībā, kas ḷoti lielā mērā nosaka ilgtspējigu patēriṇa paradumu iespējas un ierobežojumus. Vienlaikus nodąlas mērķis nav plaši un detāli raksturot ne ilgtspējigas attīstības, nedz vides pārvaldỉbas un citas teorijas un to attīstību (šāda analize atrodama citās publikācijās un materiālos); te norādìti tikai attiecīgo konceptu galvenie elementi, ciktāl tas nepieciešams raksta pamattēmas izpratnei un valsts pētijumu programmas SUSTINNO projekta «Vides daudzveidība un ilgtspējigga izmantošana» konceptuālā ietvara galveno aspektu izveidei.

\section{Ilgtspējīga patērina pieeja}

Diskusija par resursu izmantošanas jautājumiem nav nekas jauns. Jau 19.gadsim-

ta ekonomisti rakstijja par resursu efektīvu izmantošanu un cilvēku pārāk lielo patēriṇu, kā arī par bagāto un nabadzīgo iedzīvotāju patēriṇa apjoma lielajām atšķirībām (Jevons, 2001; Malthus, 1798). Mūsdienās diskusija par ilgtspējīgu patērinu aktualizējās 1972. gadā pēc grāmatas «Robežas izaugsmei» (Meadows et al., 1972) izdošanas un īpaši-pēc pirmās ANo konferences par vidi un attīstîbu (1992). Pats termins «ilgtspējīgi patēriņa paradumi» pirmo reizi tika izmantots rīcības programmā 21.gadsimtam - «Agenda 21», kas tika pieṇemta minētajā ANO konferencē «Vide un attīstība» 1992. gadā Riodežaneiro. «Agenda 21» (United Nations, 1992) ceturtajā nodaḷā «Mainot patēriṇa paradumus» ir uzsvērts, ka galvenais pastāvigais globālās vides pasliktināšanās iemesls ir neilğtspējigigie patērina un ražošanas paradumi, īpaši industrializētajās valstīs. Dokumentā «Agenda 21» valstīm izteikts aicinājums

— veicināt ilgtspējīga patērina un ražošanas paradumus, kas samazina vides slodzi un nodrošina cilvēces pamatvajadzibas;

— veicināt labāku izpratni par patēriņa saistību ar vides kvalitāti

un to, kā veicināt ilğtspējigus patēriṇa paradumus.

«Agenda 21» runā par neilgtspējigo patērina un ražošanas paradumu ierobežošanu. Lìdz ar to radās pašsaprotams jautājums, kāda ir alternatīva? Kā definēt ilgtspējīgu patēriņu? Tā 1994. gadā Norvēǵijas valdība ANO Ilgtspējigas attīstības komisijas darba ietvaros rỉkoja Ilgtspējiga patēriņa simpoziju, kas pirmo reizi definēja, ka ilgtspējiggs patēriņš ir «preču un pakalpojumu lietošana, lai apmierinātu pamatvajadzības un celtu dzives kvalitāti, tajā pašā laikā mazinot dabas resursu izmantošanu un piesārnojumu preču un pakalpojumu dzivescikla laikā tā, lai neapdraudētu nākamo paaudžu vajadzības» (Ofsted, 1994).

Ar ilgtspējīga patērina un ražošanas politiku starptautiskā līmenī strādā ANO Vides programma (UNEP), kas issteno nozīmīgas aktivitātes un 
rīcības attiecībā uz tīrāku ražošanu, atkritumu pārvaldību un vides pārvaldỉbas instrumentiem, lai sasniegtu ilgtspējiga patēriṇa un ražošanas mērḳus. Sākot no 1998. gada, UNEP Ilgtspējiga patēriṇa un ražošanas nodaḷa ir devusi būtisku ieguldījumu, lai attīstītu nacionālās ilgtspējiga patērina un ražošanas programmas vai rīcības plānus. Atbilstoši Johannesburgas Ilgtspējīgas attīstības konferencē pieṇemtajai rīcības programmai 2003. gadā Marrākešā ANO organizēja ekspertu konferenci par ilgtspējīga patēriņa un ražošanas 10 gadu programmas (saukta par Marrākešas procesu) plānošanu un ieviešanu. To tālāk îsteno UNEP, un šì procesa mērḳis ir palīdzēt pasaules valstīm veidot «zaḷāku» ekonomiku, bet iedzinotājiem orientēties uz ilgtspējigu dzivesveidu.

Marrākešas procesa ietvaros ir izstrādātas 10 gadu ietvarprogrammas (vairāk sk. Clark, 2007; Vergragt, 2017), un to mērḳis ir atbalstīt reğionālās un nacionālās ilgtspējigga patērina iniciatìvas, stiprināt spējas tās īstenot un sniegt tehnisko atbalstu, nodrošināt «zalās» darbavietas un mazināt nabadzību, kā arī kḷūt par informācijas un zināšanu apmaiṇas platformu. Kḷūstot par 10 gadu ietvarprogrammas partneri (tās pamatā ir valstis), ir iespējams kombinēt dažāda veida rīcības, attīstot inovatīvus projektus, kuros var piesaistīt dažādus finansējuma avotus. No programmas partneriem netiek prasīts finansiāls vai cilvēkresursu ieguldījums, bet gan apṇemšanās būt aktīvam ieviešanas procesā atbilstīgās programmas kontekstā, tādējādi sniedzot ieguldijjumu kopējiem centieniem, lai virzìtos uz ilgtspējiga patērina un ražošanas modeliem un praksēm. Programmu istenošanu valstīs nodrošina nacionālie kontaktpunkti, kas Latvijas gadijumā ir Vides aizsardzības un reg̣ionālās attīstības ministrija (VARAM). Latvija šo programmu ietvaros pamatā iesaistās ar zaḷo publisko iepirkumu saistitās aktivitātēs.

Papildus 10 gadu darba programmām ilgtspējīgs patēriņš un ražošana ir ieklauti arī Ilgtspējigas attīstības mērkos. 2015. gada 25. septembrī ANO G̣enerālā asambleja apstiprināja 17 ilgtspējigigas attīstỉbas mērḳus, no kuriem 12. mērḳis ir tieši veltîts ilgtspējīgam patēriṇam un ražošanai. Tādējādi ANo apliecināja, ka ilgtspējīgs patēriňš ir Darba kārtības 2030. gadam integrāla sastāvdala. Tiek izstrādāti indikatori, lai uzraudzītu politiku ietekmi un iniciatīvas un arī institucionālās spējas izvirzìto mērḳu un apakšmērḳu efektīvai sasniegšanai. Nozīmīgs izaicinājums valstīm ir noteikt, kuri tematiskie jautājumi ir svarīgi, identificējot stipros un vājos punktus statistiskajā sistēmā un procedūru izveidē, lai varētu «ražot», analizēt, ziṇot un komunicēt statistisko informāciju.

Arī Ekonomiskās sadarbības un attīstības organizācija (OECD) ir paveikusi nozīmīgu darbu, lai identificētu mājsaimniecības patēriṇa ietekmi uz vidi un izveidotu uz mājsaimniecībām vērstu vides politiku. Nepieciešams uzsvērt, viens no pašreizējiem OECD projektiem ir tieši fokusēts uz vides politikas ietekmes uz mājsaimniecību uzvedības mainu izvērtējumu attiecībā uz enerğijas izmantošanu, atkritumiem, transportu un ūdens patērinuu. OECD ir uzsācis darbu, lai identificētu pasākumus ilgtspējigai ražošanai, liekot akcentu uz Austrumu partneribas valstīm. Lai nodrošinātu zinātnisko izpēti, zināšanu un pieredzes pārnesi ilgtspējiga patērina un ražošanas jomā, UNEP un Vupertāles Klimata, vides un energóijas institūts izveidoja Ilgtspējìga patēriņa un ražošanas sadarbỉbas centru. Tas dod ieguldijumu Johannesburgas samita (2002) izstrādātās rīcības programmas izpildē, atbalsta jaunu ekonomiskās attīstības modeli, veidojot partnerību, kas nodrošina labāku pieeju ilgtspējigiem vides pakalpojumiem.

Eiropas Komisija 2008. gadā apstiprināja Ilgtspējiga patēriņa un ražošanas un ilgtspējigas rūpniecības politikas rīcības plānu (COM(2008)0397), kura mērḳi ir uzlabot ražojumu ekoloğiskos raksturlielumus visā to aprites ciklā, palielināt patērētāju izpratni un pieprasījumu pēc ilgtspējigām precēm un ražošanas tehnoloğijām, veicināt Eiropas Savienības rūpniecības inovāciju un pievērsties starptautiskiem aspektiem. Šie priekšlikumi izriet un papildina tādas ES politikas nostādnes kā Ekoinovāciju rīcības plānu un Integrētu ražojumu politiku (COM(2001)68), ar ko ES politikas nostādnēs pirmoreiz oficiāli ieviesa aprites cikla koncepciju.

ES ilgtspējiga patēriņa un ražošanas politika ir nozimīga ES Ilgtspējigas attīstības stratēǵijas sastāvdaḷa, kas apliecina ES centienus īstenot Marrākešas procesu, balstoties uz 10 gadu ietvarprogrammu. Rīcibas plāns integrē un papildina vairākas ES un tās dalïbvalstu rīcibas, lai veicinātu resursu efektîvu izmantošanu un videi draudzigu izstrādājumu izmantošanu. 2014. gada decembrī Eiropas Komisija izlēma atsaukt atkritumu direktīvas priekšlikumu un uznēmās saistỉbas, lai sagatavotu jaunu tiesisko ietvaru, kas aptvertu visu aprites ciklu, ne tikai atkritumu samazināšanas mērḳus. 2015. gada 2. decembrī Eiropas Komisija apstiprināja ES rīcības plānu «Noslēgt aprites loku - ES rīcības plāns pārejai uz aprites ekonomiku» (COM(2015)614/2), kas paredz reformēt ar atkritumu apsaimniekošanu saistītās direktīvas. Vienlaikus šis plāns aptver arī citus aprites cikla posmus, t.sk. ražošanu un patērinu. 2017. gada janvārī EK publicēja pirmo pārskatu par istenotajām aktivitātēm aprites ekonomikas veicināšanai (COM(2017)33).

Pēc iepriekš minēto ilgtspējīgas attīstības mērḳu apstiprināšanas Eiropas Komisija, Padome un dalībvalstis strādā pie rīcībām, kas virzìtas uz šo mērku sasniegšanu, progresa uzraudzību un rādītājiem. 2016. gada ANO Vides asamblejas (UNEA) 2. sesijā tika pieņemta ES iesniegtā rezolūciju par ilgtspējigu patēriņu un ražošanu (United Nations, 2016), tā akcentē valstu un iesaistìto partneru sadarbību un paātrinātu pāreju uz ilgtspējīgu patērinu un ražošanu, pamatojoties uz dzives cikla pieeju, ilgtspējigu dabas resursu nodrošināšanu, izglītỉbu un apmācību. Sekojot «Agenda 21» aicinājumam un izmantojot dažādas pieejas, daudzas valstis ir izstrādājušas nacionālos ilgtspējīga patērina un ražošanas plānus un programmas. 


\section{llgtspējīga patēriṇa} pārvaldība Latvijā

Latvijas Ilgtspējigas attīstības stratēǵijā lìdz 2030. gadam (Latvijas Republikas Saeima, 2010) tiek atzits, ka Latvijas dabas resursu vērtība un dabiskās vides pieejamība sniedz unikālu iespēju attīstīt «zalọ» ekonomiku un ilgtspējigu patērinu, veidot un saglabāt Latvijas kā «zaḷas» valsts tēlu - valsts starptautiskās atpazistamības būtisku sastāvdaḷu. Tas ir cieši saistits ar stratēǵijas izvirzito mērḳi: «203o. gadā Latvija būs plaukstoša aktīvu un atbildīgu pilsoṇu valsts. Ikviens varēs justies drošs un piederïgs Latvijai, šeit katrs varēs isstenot savus mērḳus. Nācijas stiprums sakṇosies mantotajās, iepazîtajās un jaunradìtajās kultūras un garīgajās vērtībās, latviešu valodas bagātībā un citu valodu zināšanās. Tas vienos sabiedrību jaunu, daudzveidīgu un neatkārtojamu vērtību radīšanai ekonomikā, zinātnē un kultūrā, kuras novērtēs, pazīs un cienīs arī ārpus Latvijas».

Diemžēl Latvijā nav vienotas ilgtspējiga patērina un ražošanas pārvaldības stratēgijijas, politikas vai plānu un trūkst plānveidīgas un koordinētas pieejas šo jautājumu risināšanā, proti, nepastāv ilgtspējigga patēriṇa un ražošanas pārvaldības nozares/pārnozares plānojums un tā ieviešanas cikls. Tātad dominē integratīvā pieeja - šiem jautājumiem jābūt integrētiem visās tautsaimniecības nozarēs-, un tas teorētiski ir pareizi, taču integrācijas prakse, lai kādā jomā to skatītu (arī vides izglìtỉbā vai vides pārvaldības pārnozaru attīstības kontekstā u.c.) Latvijā un citviet, izrādās sistēmiski grūti realizējama (gan metodoloğiski, gan nozaru un interešu grupu pretmetos u.c.). Tāpēc ilgtspējiga patēriņa un ražošanas pārvaldỉbas dažādo un daudzveidīgo instrumentu grupu iespējami komplementāra attīstība un integratīva izmantošanas prakse klūst par būtisku priekšnosacijumu (Ernšteins, 1999; 2016b).

Ar ilgtspējigiga patēriṇa un ražošanas jautājumiem galvenokārt nodarbojas VARAM, taču nepieciešams uzsvērt, ka atbildība par ilgtspējigga patērina pārvaldības dažādiem elementiem Latvijā ir sadalīta starp vairākām institūcijām:

— nodokḷu politika, publiskā iepirkuma regulējums, investīcijas par to atbild Finanšu ministrija;

— mājokḷa, enerḡètikas politika-Ekonomikas ministrija;

- pārtikas jautājumi-Zemkopibas ministrija;

- transporta sektors-Satiksmes ministrija.

Līdz ar to VARAM, īstenojot ilgtspējīga patēriṇa un ražošanas iniciatīvas, ir aktīvi jāstrādā ar nozaru ministrijām, ilgtspējas jautājumus integrējot to stratēǵijās, pamatnostādnēs un plānos. Atsevišķas ministrijas izstrādā arī alternatīvas ekonomiskās attīstības stratēǵijas. Tā Zemkopības ministrija ir apstiprinājusi Bioekonomikas stratēǵiju, bet VARAM izstrādā Ogleḳ̣a mazietilpigas attīstibas stratêgiju un Aprites ekonomikas stratēǵiju. Latvijā ilgtspējigga patērina pārvaldībā lielākā uzmanība pašlaik ir pievērsta energoefektivitātes palielināšanai, zaḷajam publiskajam iepirkumam un atkritumu apsaimniekošanas jautājumiem.

Ilgtspējigiga patēriṇa un ražošanas procesu pārvaldībā (gan formāli, gan neformāli) iesaistās arī citas mērḳgrupas (nevalstiskās organizācijas, uznēmumi, pašvaldības, izglìtības iestādes, plašsazinas līdzekli un zinātnes institūcijas), kuru intereses daudzos gadijjumos ir pretējas. Situāciju sarežğ apstāklis, ka dažādi ilgtspējīga patēriṇa un ražošanas pārvaldỉbas element ir sastopami atškirīgos politikas plānošanas dokumentos un normativvajos aktos. Iepriekš jau tika citēta Latvijas ilgtspējīgas attīstības stratēǵijā līdz 2030. gadam formulētā stratēǵiskā pieeja. Diemžēel vidējā termiṇa plānošanas dokuments - Nacionālais attīstības plāns 2014.-2020. gadam - zalāas ekonomikas attīstībai pievērš maz uzmanības, tas vairāk koncentrējas uz ekonomisko izaugsmi.

Pēdējā laikā Latvijā tiek īstenotas vairākas iniciatīvas, kas vērstas uz produktu un pakalpojumu dzives cikla koncepta ieklaušanu Latvijas normativajā regulējumā. Šis iniciatīvas veicinās pieprasijuma un piedāvājuma veidošanos zaḷajam iepirkumam un zaḷajam publiskajam iepirkumam, kā arì laus dzives cikla analīzi (life cycle assessment) piemērot citās politikas jomās. VARAM ir izstrādājusi Zạāa iepirkuma un zaḷā publiskā iepirkuma veicināšanas plānu 2015.-2017. gadam (Ministru kabinets, 2015), tajā izvirzîti sasniedzamie mērki zalā publiskā iepirkuma îpatsvara palielināšanai Latvijā. Atbilstoši šim plānam 2017. gadā valsts un pašvaldỉbu veiktajos iepirkumos zaḷo publisko iepirkumu bija paredzēts îstenot 30\% apmērā. 2017. gadā tika pienemti jauni Ministru kabineta noteikumi Nr. 353 «Prasibas zalajam publiskajam iepirkumam un to piemērošanas kārtība». Tiek attīstìts un pilnveidots energoefektivitātes normativais regulējums, kura jumta likums ir 2016. gada martā pieṇemtais Energoefektivitātes likums.

\section{llgtspējīga patērina teorētiskās perspektīvas vides pārvaldības attīstībai}

Ilgtspējīga patēriņa pētniecība ir attīstījusies dažādās disciplīnās, bet līdz šim dominējošais ir bijis ekonomiskais un sociālpsiholoğiskais diskurss, kas ilgtspējīgu patērinu galvenokārt apskata no individuālās, nevis sociālās puse (Spaargaren, 2011). Mazāk novērtēta, tomēr svarīga ir bijusi arī sistēmiskā jeb institucionālā ilgtspējiğa patēriṇa pieeja, kas balstās uz jaunākajiem tehnoloǵiskajiem sasniegumiem. Diskusija par šīm dažādajām perspektīvām ir ietekmējusi un joprojām turpina ietekmēt vides pārvaldības teorētisko attīstību. Tālāk nedaudz detalizētāk apskatîtas šis dažādās pieejas.

EKONOMISKĀ PERSPEKTīva Lai izprastu patērētāju uzvedību, dažādos pētniecības līmenos plaši tiek izmantotas ekonomiskās pieejas, tostarp 
mikroekonomikas lēmumu pieņemšanas izpēte (Deaton, 1992). Ekonomikas teorijas vadošajā neoklasicisma tradīijāā ir pieṇemts, ka indivīds rỉkojas, meklējot maksimālu lietderỉbu (van den Bergh \& Ferrer-i-Carbonell, 1999). Tomēr šì pieeja tiek kritizēta, jo tā ignorē neracionālus vai iracionālus uzvedỉbas faktorus (Scitovsky, 1976). Pakāpeniski arvien lielāku atbalstu ekonomistu vidū gūst tādas patērētāju uzvedības perspektīvas, kas izriet no jēdziena «ierobežotā racionalitāte» (Thaler, 1980), tās skaidro patērētāju izvēli, nevis izcel lietderību. Piemēram, ierobežotās racionalitātes teorijā (Simon, 1972) un zemo izmaksu hipotēzē (Diekmann \& Preisendörfer, 2003) tiek ṇemta vērā informācijas asimetrija, kognitivāà disonanse un augstākas darijumu izmaksas.

SOCIĀLPSIHOLOG̣ISKĀS TEORIJAS To mērḳis ir saprast, kā cilvēka domas, jūtas un uzvedību ietekmē citu cilvēku faktiskā, iedomātā vai netiešā klātbūtne (Allport, 1985). Šis teorijas izskaidro cilvēka uzvedību kā cilvēka psihiskā stāvokḷa mijiedarbību ar sociālo kontekstu, un tās tiek plaši izmantotas, pētot un analizējot ilgtspējiggu patērinu. Būtībā individuāla izvērtēěana ir galvenais faktors lēmuma pienemšanā (Renningss et al., 2012). Tomēr sociālpsiholoğiskās pieejas, kas paskaidro patēriṇa veidu, kura pamatā ir indivìda nodomi un sociālo normu uztvere, joprojām tiek testētas, jo nespēj izskaidrot attieksmes un uzvedibas neatbilstïbas (McEachern et al., 2005; Shove, Trentmann, \& Wilk, 2009).

Sistēmiskas Un (INFra)Strukturālas perspektīvas Dal̨ejii pretstatā uz indivìdu orientētām pieejām tika izstrādāta vēl viena pieeja, kas aplūko videi draudzīgas rīcības no citas perspektīvas. Šajās sistēmiskajās vai strukturālajās perspektīvās uzsvars tiek likts uz kontekstuālajiem faktoriem, it ipaši tehnoloğisko un infrastrukturālo sistēmu dinamiku, kas ietekmē vai pat nosaka (palīdz noteikt) indivīdu videi draudzīgās rīcības. Šajā paradigmā tiek uzskatîts, ka cilvēku uzvedību nosaka dažādu līmeṇu sociāli tehniskās sistēmas un struktūras (Graham \& Marvin, 2001).

sociālās prakses perspektīvas Pēdējo desmit gadu laikā gan strukturālistu, gan individuālistu (ekonomiskie vai sociālpsiholoğiskie faktori) pieejas ir kritizētas patērina veida skaidrojuma ierobežotības dēl. Meklējot pieeju, kas aptvertu šos dažāasos aspektus, vides sociālo pētnieku vidū plaši pieṇemta ir sociālās prakses pieeja (Shove, 2003b, 2010; Shove, Pantzar, \& Watson, 2012; Spaargaren, 2003; Warde, 2005). Tā ir kluvusi arvien populārāka ikdienas patēriṇa veidu empīiskajos pētijumos, piemēram, pētot patēēēāju praksi mājokḷu, pārtikas patēriṇa, mobilitātes un apg̉ērba izvēlē, kā arī mājsaimniecību enerğijas, ūdens un atkritumu apsaimniekošanas jomā.
Ilgtspé̄jíga patērina pārvaldības pieejas Bez jau iepriekš raksturotajām patērētāju uzvedību skaidrojošajām teorijām pastāv arī vairākas pieejas ilgtspējīga patēriṇa pārvaldībā. Veiksmīga ilgtspèjīga patēriṇa pārvaldība, tāpat kā veiksmìga pārvaldības attīstība, atkarīga no valdības (nacionālajā pārvaldības līmenī) izdarītajām izvēlēm un uzṇemtās atbildības. Pakāpeniska neilgtspējīgu patēriņa prakšu izskaušana (Church \& Lorek, 2007) un izvēḷu precizēšana ir valstu valdību atbildība (Maniates, 2010). Diemžēl pašreizējā patērina pārvaldỉbas pieeja galvenokārt balstās uz informācijas instrumentiem, kuri bieži vien ir neefektīvi, jo pastāv informācijas pārpilnība un cilvēki nespēj izraudzìties nepieciešamos un uzticamos informācijas avotus, kā arī informācija bieži vien ir pretrunīga un slikti sagatavota. Ir pietiekami daudz pierādījumu, ka normatīvie un ekonomiskie instrumenti ir visefektīvākie ilgtspējiga patēriṇa pārvaldībā (ASCEE Team, 2008; Lorek, Giljum, \& Bruckner, 2008; Rehfeld, Rennings, \& Ziegler, 2007).

Kopumā var izdalīt trīs ilgtspējiga patēriṇa pārvaldības pieejas: ekoefektivitātes, pārslēgšanās un pietiekamības pieeju. Dažādi autori šīm pieejām ir devuši atškirīgus nosaukumus, piemēram, Dž. Seifanga (Seyfang, 2004) runā par hierarhisko (piegādes sistēmu), tirgus (ekoloğiskās modernizācijas) un egalitāro (sociālā mārketinga) pieeju, E. Šova (Shove, 2003a) savukārt min piedāvājuma restrukturizāciju, efektivitātes veicināšanu un pieprasijuma restrukturizāciju, E. Paredis (Paredis et al., 2009) runā par dekomercializācijas, ekoefektivitātes un pietiekamības pieeju, bet UNEP min dematerializācijas, ekoefektivitātes un optimizācijas pieeju. Katra no šīm pieejām izmanto atškirīgus pārvaldỉbas instrumentus un ietekmē atškirīgus faktorus, kas nosaka patēriņa vides slodzi. Ekoefektivitātes pieeja, kas balstās neoklasiskajā brīvā tirgus paradigmā, ir vērsta uz ekoefektivitātes uzlabošanu un nav pretrunā ar ekonomisko izaugsmi. Savukārt pietiekamības pieeja ir vērsta uz patēriṇa apjoma samazināšanu un līdz ar to atbalsta bezizaugsmes ekonomiku (Daly, 1973) un pat ekonomiskās izaugsmes samazināšanu attīstītajās valstīs, tã atbalsta labklāijību un apmierinātību ar dzìvi, kuras pamatā ir sociālā kapitāla attīstỉba un nemateriālistisks dzivesveids. Savukārt pārslēgšanās pieeja cenšas mainīt kolektivvās rīcības, koncentrējoties uz piegādes sistēmām, lai mainītu patēriṇa struktūru.

exoefeKtivitātes Pieeja Tā balstās pieņēmumā, ka daba ir pārpilnības sistēma, kas, reaǵêjot uz cilvēku iejaukšanos, atgūst līdzsvaru, bet patērētāji izdara racionālas, efektivas izvēles un, pamatojoties uz pieejamo informāciju, samazina savu ietekmi uz vidi. Šì pieeja balstās vairākās savstarpēji saistītās un arī konkurējošās pieejās, tās ir: ekoloğiskā modernizācija (Bonds \& Downey, 2015; Buttel, 2000; Spaargaren \& Mol, 1992), industriālā ekoloǵija (Huber, 200o; Newell \& Cousins, 2014; Socolow, 1997), ekoefektivitāte 
(Schmidheiny, 1992; von Weizsacker et al., 2009), tïrākas tehnoloğijas (Almeida et al., 2015; Jackson, 1993; Kemp \& Soete, 1992) kā arī citas pieejas (Ayres, 2000).

PĀRSLĒGŠANĀS PIEEJA Tā tiek dēvēta arī par dekomercializāciju) nekoncentrējas uz resursu plūsmas samazināšanu, palielinot efektivitāti vai samazinot patēriņu, be aplūko iespējas mainìt izmantoto resursu plūsmu (Huber, 1995), mainot gan piegādes sistēmas, gan preču un pakalpojumu pieejamību un lietošanas veidus (Spaargaren \& van Vliet, 2000). Tās mērḳis ir ilgtspējīga resursu pārdale pārdomātos, slēgtos ekonomiskos ciklos, un tā meklē jaunus tehnoloğiskus un sociālus risinājumus. Visos patēriṇa attīstîbas līmeṇos sākot no tirgus ekonomikas un beidzot ar góimenes attiecîbām - var notikt preču un pakalpojumu radīšana un apmaiṇa. Taču tikai daži no tiem iekḷaujas formālajā ekonomiskaja apritē (Harvey et al., 2001).

Dekomercializācija lielā mērā koncentrējas uz sociālajām (sistēmiskajām) inovācijām - jaunām programmām, produktiem, idejām vai iniciatīvām, kas maina sociālajāa sistēmās dominējošos paradumus, resursu plūsmas, vara attiecỉbas un uzskatus. Šìs pieejas īstenošanai tiek izmantoti pakalpojumu, infrastruktūras, komunikācijas un difūzijas instrumenti - vietējie apmainas tîkli, kopienas dārzi u.tml. (Mauch, North, \& Pulli, 2001). Šo pieeju bieži vien izmanto pašpalīdzibas grupas vai kooperatīvi, lìdz ar to tā bieži vien tiek istenota ārpus monetārās sistēmas (Stahel, 1999). Intensīvāka un kopēja resursu lietošana var samazināt atkritumu (t. sk piesārnojuma) apjomu, un sistēmas dalībnieki tā var panākt ekonomisku ieguvumu.

Dekomercializācijas pieeja lielā mērā balstās savstarpē-

E. Rodžera (Rogers, 1995) novāciju difüzijas teorija izšķir piecus difüzijas posmus: inovatori, agrinie adaptori, agrinnais vairākums, vêlākais vairākum un atpalicēji. Tiklìdz kādā no grupām inovāciju pienem pietiekams individu skaits (kritiskā masa), inovācijas izplatās patstāvigi.

Atsitiena efekts (rebound efect) (Khazzoom, 1980, Hering, 1998; Hertwich, 2005; Holm \& Englund, 2009) resursu patēriņa absolūtais pieaugums, kas rodas efektivitates pieauguma un patēriña izmaksu samazināsanās rezultăta (Herring 1998). Atsitiena efekts ir cieši saistis ar ekonomikas pieprasijuma un piedāvājuma likumu, kas nosaka, ka, cenām samazinoties, pieprasijums un attiecigi Tas noved pie pi pieaug. Tas noved pie paradoksa, ka nacionalajai programma vai tehnologijai, kas vèrsta samazināšanu, ir tendence palielināt pieprasijumu un lijz ar to - ari patērinu. Taču atsitiena efektu var etekmēt ne tikai finanšu izmaksas. Tas var būt saistits arī ar laika patērin vai risku samazināšanonos va komforta pieaugumu.

PIETIEKamības PIEeja Tā balstās apsvērumā, ka resursi uz Zemes ir ierobežotā apjomā, un tas nosaka robežas arī ekonomiskajai izaugsmei (Meadows et al., 1972; Sachs, 2000). Minēto pieeju atbalsta daudzi dažādu nozaru zinātnieki: psihologi (piemēram, T. Kasser), sociologi (piemēram, A. Etzioni, F. Hirsch), ekonomisti (piemēram, T. Scitovski, R. Frank, R. E. Lane, R. Layard) un filozofi (piemēram, K. Soper). P. M. Bulanžēe (Boulanger, 2010) bez pietiekamỉbas pieejas izšķir arī kultūras dematerializācijas pieeju, kas ir vērsta uz materiālo vērtỉbu nozīmes samazināšanu labklājības nodrošināšanā. Šì pieeja lielā mērā saskan ar diskusiju par cilvēku vēlmēm un vajadzībām.

Ilgtspējīga patērina pārvaldības attīstības ietvars
Sociālās inovācijas ir vienas no galvenām stipra ilgtspējīga patēriṇa virzītājām (Jaeger-Erben et al., 2015; Lorek \& Fuchs, 2013), kas atbalsta pietiekamības stratēóijas istenošanu praksē. Šì iniciatīvas var būt saistìtas ar mājokḷa, mobilitātes, pārtikas un enerğijas patēriņu un ietver dažādu ilgtspējigu pakalpojumu sniegšanu, piemēram, ekociematu izveidošanu un vietējo valūtu nodrošināšanu (Hargreaves, Longhurst, \& Seyfang, 2013; Seyfang \& Haxeltine, 2012). Sociālās inovācijas var stimulēt arī ar tiesiski normatīvo aktu palīdzību, piemēram, nodrošinot stratēğisko tirgus nišu vadību (Schot \& Geels, 2008) vai veicinot jaunu, ilgtspējiḡāku sociālo praksi (Shove \& Walker, 2010). Taču jānem vērā, ka sociālo inovāciju pārvaldība ir lielā mērā atkarīga no sadarbības dažādos pārvaldības līmenos, lai izvairìtos no potenciālas negatīvas ietekmes uz atseviškām sociālajām grupām. Dažādu līmenu pasākumi ir jākoordinē tā, lai vietējāes, ambiciozās iniciatīvas atbalstìtu gan valsts (nacionālā līmeṇa) pārvalde, gan starptautiskās institūcijas, pēc tam nacionālos un starptautiskos procesos ir jādalās ar rezultātiem un pieredzi (Lorek, 2005) Tādējādi savlaicīga informācija par politiskajiem procesiem ir nepieciešama jau vietējā līmenī, jo ir nepieciešams vietējo iniciatīvu kopums, lai ilgtspējīga patērina pārvaldỉbu stimulētu nacionālā un starptautiskā līmenì.

M. Jēgers-Erbens ar kolēǵiem (Jaeger-Erben et al., 2015) ir aprakstijuši pamata situācijas, kas noved pie neilgtspējīgo patēriņa paradumu izmaiņām sociālo inovāciju dēḷ. Minētie autori ir identificējuši vairāku alternatīvu patêrina veidu situācijas, kas balstās uz diviem atškirīgiem principiem, uz esošās prakses izmaiṇām un uz trīs dažādiem faktoriem, kas nosaka rīcību.

Kombinējot uzsvaru uz sociālai praksei piemītošām problemātiskām nozimēm un uzsvaru uz pakalpojumu, infrastruktūru un produktu patērin iespēju trūkumu, autori (Jaeger-Erben et al., 2015) ir identificējuši produktu patēriņa veidu piecus dažādus alternatīvos modeḷus:

1. Patēriňš, kas spēcina kopienu (piemēram, pilsētas

dārzkopibas vai sabiedribas atbalstìtas lauksaimniecības pieejas nav vērstas uz tām mērkơrupām, kuras dažādu iemeslu dēl nevēlas praktizēt ilgtspējigu dzìvesveidu (Seyfang \& Paavola, 2007). 
produktu patēriņ̌̌). Pastāv uzskats, ka šis patērinš ne tikai rada atškirīigu patērinu, bet arī jaunu vērtỉbu. Tas rodas kā atbilde uz sabiedrības sadarbỉbas, kohēzijas, līdzdalības un solidaritātes trūkumu.

2. Patēriṇš, kas paplašina kompetenci (patēriñǔ saistīts ar cilvēka paša darbỉbu); to var uzskatit par risinājumu patērētājos valdošajai nekompetencei. Patērētājos tiek attīstìtas nepieciešamās prasmes, lai radìtu un remontētu savas plaša patēriṇa preces.

3. Patērinšš, kas samazina resursu un atkritumu apjomu (piemēram, pārstrāde un atkārtota izmantošana), ir saistìts ar tām patēriṇa precēm, kas tiek izšksēerdētas un netiek pietiekami novērtētas konvencionālā ražošanā un patērina praksē. Risinājums ir dažādas piegādes sistēmas, kas var, piemēram, atkritumus pārvērst resursos un tālāk-produktos.

4. Kopienas patēriṇš (koplietošana, mainīšanās un cita veida sadarbỉbas patēriña formas) arī balstās kopienas attīstībā, bet istermiṇā, un tas galvenokārt ir orientēts uz patēriṇa vajadzỉbu apmierināšanu. Šì rīcība bieži vien tiek pamatota ar nepieciešamỉbu pēc efektivaākiem produktiem (piemēram, dalǐšanās ar tiem).

5. Uz vajadzību un lietderību orientēts patēriṇš. Tã pamatā ir iespēju trūkums efektivi izmantot produktus, un risinājumi ir saistīti ar individuālu rīcību (piemēram, îri). Tie ietver alternativvus ražošanas un pakalpojumu piegādes veidus, kas mēg̣ina tieši reağèt uz faktiskām patēētāju vajadzībām un izvairìties no neefektiviem darijumiem, piemēram, neiegādāties reti izmantotus produktus.

Pieci aprakstītie sociālo inovāciju veidi ataino jomas, kurās notiek sociālās prakses izmainnas. Tie parāda dažādus veidus, kā izskaust neilgtspējīgas prakses, kā arī dažādas ilgtspējigu alternatīvu formas. Tomēr atsevišḳos gadijumos, kad tiek attīstîts kopienas patēriňš, nozime ir arī patērina infrastruktūras mainai. Tāpat dažos gadijjumos patērinš, kas stiprina kopienu, spēj nodrošināt arī patērētāju vajadzības.

Patērina rīcībpolitikas

instrumenti un

sadarbības tīkli
Ilgtspējiga patērina un ražošanas rīcībpolitikas istenošanai ir nepieciešama sistēmiska pieeja un komplementāra dažādu instrumentu izmantošana, kurus lieto gan valsts un pašvaldību pārvaldes iestādes, gan sabiedriskās organizācijas, uzṇēmumi un citas mērkgrupas (Rubik et al., 2009). Ilgtspējiga patērina un ražošanas instrumenti ir lïdzekḷi, kurus var izmantot pārejai uz ilgtspējigu patērinu un ražošanu. Tos var iedalït 6 instrumentu pamata grupās (Ernšteins, 1999):

1) plānošanas instrumenti-ietver nacionālos, nozaru un teritoriālos plānus un stratēóijias, kas ietekmē ilgtspējīgu patēriņu un ražošanu;

2) normatīvie instrumenti-ietver normatīvos/likumdošanas aktus, kas nosaka tiesības, pienākumus un aizliegumus ilgtspējig̀a patēriņa un ražošanas jomās;

3) institucionālie instrumenti - aptver institucionālo sistēmu, cilvēkresursus, kas viss nepieciešams ilgtspējiga patērina un ražošanas plānošanā, ieviešanā un kontrolē;

4) infrastruktūras instrumenti - vērsti uz ilğtspējīga patērina un ražošanas nodrošināšanai nepieciešamās infrastruktūras (piemēram, veloceliṇu, atkritumu apsaimniekošanas sistēmas) izveidi;

5) finanšu un ekonomiskie instrumenti-ietver, piemēram, subsīdijas, nodokḷus un tarifus, tirdzniecības atvieglojumus, kā arī finanšu atbalsta mehānismus un emisiju tirdzniecības sistēmas;

6) komunikācijas instrumenti-ietver komplementāri

informatīvos pasākumus, apmācības, publikācijas, iesaisti un līdzdalību, kā arī obligātās un brīvprātīgās sertifikācijas sistēmas (piemēram, ekomarķējumus), tātad visa veida labās prakses

demonstrējumu, ilgtspējīgam patērinam draudzịgu rīcību.

Pāreja no hierarhiskas pārvaldības uz tirgus un tìklveida pārvaldību (Bähr \& Treib, 2007) nodrošina plašāku interešu grupu iesaisti ilgtspējigga patērina pārvaldībā. Līdz ar to valsts pārvalde vairs nav vienigais ilgtspējīga patēriṇa pārvaldības ağents un citu interešu grupu nozīme nepārtraukt pieaug. Visas interešu grupas ir atbildīgas par pašreizējo vides stāvokli, tām ir jāklūst par pārmainu ağentiem ilgtspējiggākas nākotnes veidošanā, nodrošinot izmainas makrovides faktoros. Taču vēl joprojām ilgtspējiga patēriṇa pārvaldības instrumentu veiksmiggs lietojums lielā mērā atkarīgs no aktìvas valsts pārvaldes institūciju iesaistǐ̌anās.

Lìdz šim ir zināmi tikai daži veiksmiggi ilgtspējiga patēriṇa instrumenti ar ierobežotu valsts pārvaldes lomu, piemēram, dažādas kopienas iniciatìvas un brivpprātigie instrumenti. Brivprātỉgos instrumentus arvien vairāk izmanto arī valsts pārvalde, iesaistoties partnerībā ar privāto sektoru, kā arī izmantojot komunikācijas instrumentus. Taču vēl joprojām valsts pārvalde visplašāk praksē izmanto tieši normativos un ekonomiskos instrumentus, piemēram, standartus, nodoklus un subsīdijas. Valsts pārvaldes uzdevums 
ir novērst tirgus nepilnības, ieviešot zaḷā budžeta reformu, kā arī nodrošināt taisnigu resursu pārdali sabiedrībā, veidot tehnisko infrastruktūru, telpisko un tiesisko ietvaru, atbalstīt sociāāās (sistēmiskās) inovācijas un sociālo uzṇēmējdarbību, stimulēt un veicināt sabiedrības lỉdzdalību, dialogu, eksperimentus, mācišanos un labo piemēru izplatību plašākā sabiedrībā, lai veicinātu ilgtspējigāâkus patēriṇa paradumus. Šìs funkcijas ìstenojamas sadarbỉbā ar citām interešu grupām.

Biznesa stratēǵijas ilgtspējiğa patērina attīstībā ierobežo peḷnas un izaugssmes efekts (izṇemot sociālo uzṇēmējdarbỉbu), jo uzṇēmumi darbojas akcionāru interesēs, kuri iegulda uzṇēmumos, lai gūtu peḷnu. Tāpēc uznēmumu pieeja ilgtspējigga patērina jomā parasti aprobežojas ar ekoefektivitātes pieeju - resursu efektivitātes uzlabojumiem piegādes ķēdē, produktu ekodizainu, zaḷā iepirkuma principu ieviešanu un zaḷo mārketingu. Biznesa pieeja ilgtspējīga patērina pārvaldībā atbilst pašlaik istenotajai tirgus pārvaldības pieejai, kas nerisina apjoma un atsitiena efekta radìto vides slodžu pieaugumu.

Šo problēmu ir tikai dạ̣ēji iespējams risināt pašreizējāe ekonomiskā modela ietvaros. Parādās arvien jaunas biznesa iniciativas, piemēram, uznēmumi, kuri veicina produktu koplietošanu, un sociālie uznēemumi, kuru galvenais uzdevums nav peḷnas gūšana, bet iedzivotāju vajadzību apmierināšana un kādu sabiedrībai būtisku funkciju veikšana. Latvijā šāda veida bizness sāk tikai attīstīties. Taču pastāv daudz nišu biznesam bioloğiskās lauksaimniecỉbas, ekokosmētikas un otrreizēji pārstrādātu produktu jomās.

Iedzīvotāju videi draudzīgas rīcības prakse saistīta ar jomām, kas sniedz ekonomisku ieguvumu, nodrošina statusu vai tiek plaši apspriestas. Patērētāji labprāt iesaistās atkritumu šḳirošanā, ja tas neprasa daudz pūḷu un līdzekḷu, vai, ja ir pietiekami turīgi, izvēlas videi draudzīgus produktus un pakalpojumus, taču ir atturigi pret patērina samazināšanu un būtiskām izmain̄ām ikdienas dzīves organizācijā. Sabiedrībā ierastās prakses ir grūti laužamas, un patērētāju uzvedības paradumus nosaka komplekss ārējo un iekšējo faktoru kopums. Patērētāji nevar būt galvenie atbildīgie par ilgtspējigu patēriņu, jo to uzvedỉbas paradumu maiņu ierobežo daudzi ārējie faktori, piemēram, infrastruktūra un piegādes sistēmas. Liela dalı patērētāju Latvijā nav gatavi mainìt savu rīcỉbu un resursu noplicināšanā un vides piesārṇojumā vaino uznēmumus, bet uz tiem neizdara spiedienu, pieprasot augstāku korporatīvo vides atbildību. Savukārt uzṇēmumi nevirzās ilgtspējiğga patēriṇa virzienā, jo nav attiecīgs stingrāks valsts normatīvais regulējums, patērētāju un nevalstisko organizāciju spiediens.

Nevalstiskās organizācijas (NVo) ir galvenie pietiekamības pieejas atbalstîtāji. Taču šìm organizācijām Latvijā trūkst stratēĝiskas, koordinētas rīcỉbas šo jautājumu risināšanā, to spējas ietekmēt lēmumus ir ierobežotas. Latvijā nav sabiedriskā diskursa par ilgtspējigiga patērina tēmu. Veiksmiggākas ilgtspējīga patērina pārvaldỉbas nodrošināšanai būtu jāveicina plašāka zinātnieku un Nvo, kā arī zinātnieku un valsts pārvaldes sadarbỉba, lai pārnestu zinātnes atziṇas un teorijas ilgtspējiga patēriṇa jomā uz plašāku sabiedrību un valsts pārvaldi. Zināšanu pārneses nodrošināšanai būtiska ir NVo sadarbỉba ar patēēētājiem. NVo un zinātnes nozīme pārmainu piramìdā loti svarīga, jo šìm interešu grupām ir visaugstākā sabiedrības uzticiba.

Izpratne par dzives kvalitāti atspoguḷojas interešu grupu ilgtspējigga patērina pārvaldības rīcībās. Dažādas interešu grupas regulējošo, ekonomisko un komunikācijas instrumentu izmantošanu tādās jomās kā energoefektivitāte uzskata par pieṇemamu un atbalstāmu rīcību, bet, piemēram, priekšlikums samazināt autotransporta un elektropreču izmantošanu vai mainit cilvēka ēšanas paradumus tiek uztverts par indivïda izvēles brīvïbas ierobežošanu, un tāpēc šajās jomās trūkst saskaṇotas, mērḳtiecīgas rīcības vides slodžu mazināšanā.

Interešu grupu novērtējums veiktajos pētījumos parāda, ka Latvijā nav izveidojies funkcionāls interešu grupu sadarbỉbas tikls ilgtspējiga patērina pārvaldībā un ka interešu grupu îstenotajām iniciatīvām ir gadijjuma raksturs, kas neveido kopigu sistēmu. Interešu grupu sadarbïbas tìkliem ir jāveicina sadarbỉba, informācijas apmaiṇa, sniedzot metodoloğisku atbalstu interešu grupu īstenotajām iniciativām ilgtspējigga patēriṇa pārvaldībā. Šādas pārvaldības pieejas attīstība prasa kopējas intereses un visu iesaistīto pušu kopīgus centienus. Šādu daudzveidīgu tỉklu pārvaldība ir būtiska, bet paralēli pastāvošo konfliktējošo interešu dēḷ-komplekss process. Pašreizējā rīcībpolitika akcentē uznēmēju nozimi pārvaldības procesā, bet nespēj saskano patērētāju un uznēmumu intereses ilg̣tspējiggā patērinā. Tāpēc lielāka uzmanība jāpievērš valsts pārvaldes un patērētāju attiecību stiprināšanai.

Ciešu, saskannotu sadarbibas tîklu attīstības priekšnosacijums ir interešu grupu horizontālā un vertikālā sadarbỉba. Latvijā vājā starpsektoru biznesa sadarbība un sadarbība piegādes k̦ēdē, kā arī vājā sadarbība starp valsti un citām interešu grupām, ir faktors, kas ierobežo ilgtspējiga patēriṇa pārvaldỉbu. Sadarbïbu ierobežo zemais uzticības lïmenis, kas ir vērojams starp dažādām interešu grupām un šo grupu iekšienē. Uzticības trūkums noved pie nevēlēšanās dalīties problēmās, idejās un meklēt kopīgus risinājumus.

Uzticība veidojas pamazām, un tā ir atkarìga no lēmumu pieñemšana caurskatāmības un lïdzdalības iespējām. Viens no celiem šìs krīzes pārvarēšanai ir vietējo viedokḷu līeru un mediatoru, kuriem uzticētos sabiedrība, identificēšana un iesaistišana ilgtspējiga patēriṇa diskursā. Uzticības krīzi sabiedrïbā veicina arī sabiedrỉbas nevienlīdzïba. Džini koeficients, kas parāda ienākumu atškiriības sabiedrībā, Latvijā palielinās, un tas liecina par ienākumu nevienlīdzības pieaugumu. Nevienlïdzīgas sabiedrības nespēj radīt funkcionējošus sadarbibas tìklus, un to galvenais attīstibas dzinulis ir materiālā labklāīiba, kas ir pretstatā ilgtspējigam patērinam. 


\section{Integrēta ilgtspējīga} patēriṇa pārvaldība

Pašlaik ilğtspējīga patērina pārvaldību Latvijā un arì citur pasaulē nosaka neoklasiskās ekonomikas paradigma, kas balstās ticībā par bezgalīgu eksponenciālu ekonomisko izaugsmi un tirgus spējām efektīvi pārvaldīt resursus. Kā jau iepriekš raksturots, šì pieeja balstās tirgus pārvaldības pieejā, ir vērsta uz piedāvājuma puses pārvaldību un ekoefektivitāti, taču tā nav pietiekama absolūto vides slodžu samazināšanai, un tā sabiedrībā nostiprina materiālistisku pasaules uzskatu. Tai ir raksturīga centralizēta, institucionalizēta lēmumu pieṇemšana (vertikālā integrācija) un ierobežota interešu grupu līdzdalība, kā arī tirgus pārvaldỉbas instrumentu izmantošana un tehniski risinājumi (Brizga, 2012, 142.lpp.)

Lai arī kopienas iniciatīvas Latvijā līdz šim ir bijušas marginalizētas, pakāpeniski attīstās alternatīvs hedonisms (Soper, 2008), kas atbalsta integrētas pārvaldības pieeju. Tomēr lïdz šim postmateriālistiskais pasaules uzskats Latvijā nav ìstenojies plašas sabiedrïbas pienemtos patērina paradumos, un sabiedrībā valda attieksmju un rīcibu plaisa, kad cilvēki augstu vērtē tīru vidi un nosoda vides piesārṇojumu un degradāciju, bet vides problēmas nesaista ar saviem ikdienas uzvedỉbas un patērina paradumiem, nav gatavi istenot ilgtspējigu patērinu un videi draudzīgu rỉcību.

Lai nodrošinātu integrētu ilgtspējīga patēriņa pārvaldību, ir nepieciešamas izmainas tajos makrovides faktoros, kas nosaka patērinu, kā arì jābūt normatīvajai bāzei, organizatoriskajām struktūrām un novērtējuma sistēmai, kas veicina un uztur šādu integrētu pārvaldību, jābūt visu pārvaldības instrumentu grupu piemērošanas atbalstam. Normativajai bāzei jāveicina vertikālā un horizontālā integrācija -ilgtspējìga patērina rīcībpolitiku principu, mērḳu un uzdevumu saskaņotība starp dažādiem pārvaldības limeṇiem (starptautisko, reǵionālo, nacionālo un vietējo) un rīcībpolitikas jomām (piemēram, klimata, transporta un enerǵētikas rīcibpolitiku savstarpējā integrācija), kā arī vajadzịgs politiskais un sabiedrỉbas atbalsts šìs rīcibpolitikas îstenošanai. Rīcībpolitikas izstrādei, ieviešanai un uzraudzībai ir nepieciešama 1) progresiva resursu patērina atsaistī̌ana no ekonomiskās izaugsmes tempiem; 2) sociālo jautājumu integrācija ilgtspèjīga patēriṇa rīcībpolitikā; 3) apjoma un atsitiena efekta novēršana; 4) sistēmiskas, savstarpēji saskaṇotas izmainas makrovides faktoros.

\section{Vides pārvaldības rīcībpolitika: videi} draudzīga rīcība

Ilgtspējigas attīstības mērķu sasniegšanas pamata priekšnosacijums ir sabiedrības kopuma, visu mērkgrupu, visa veida organizāciju un individu vides apziņa un videi draudzīgas rīcības prakse ikdienā. Ar vidi tās plašākajā konceptā saprotama dabas vides un sociāli ekonomiskās vides mijsakarību sistēma,
1. attēls. Ilgtspējīgas attīstības pamatmodeḷa trīs dimensiju paplašināšanas struktūrshēma: mājsaimniecību vides pārvaldības segmenta attīstības iekšējais jeb tematiskā satura konteksts

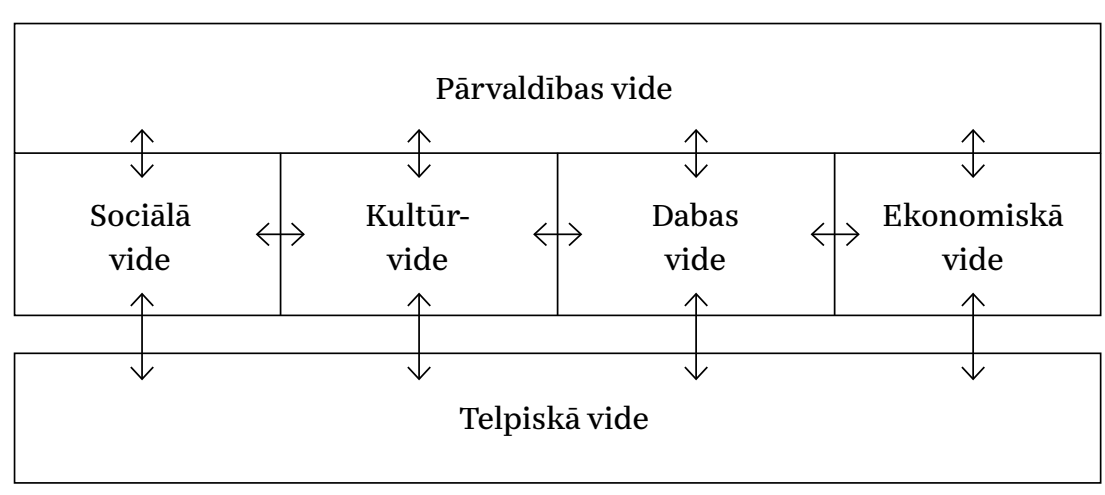

(Ernšteins, 2016

2. attēls. Vides pārvaldības segmentu kopējā struktūrshēma: mājsaimniecību vides pārvaldības segmenta attīstības ārējais jeb galveno mērkgrupu sadarbïbas konteksts

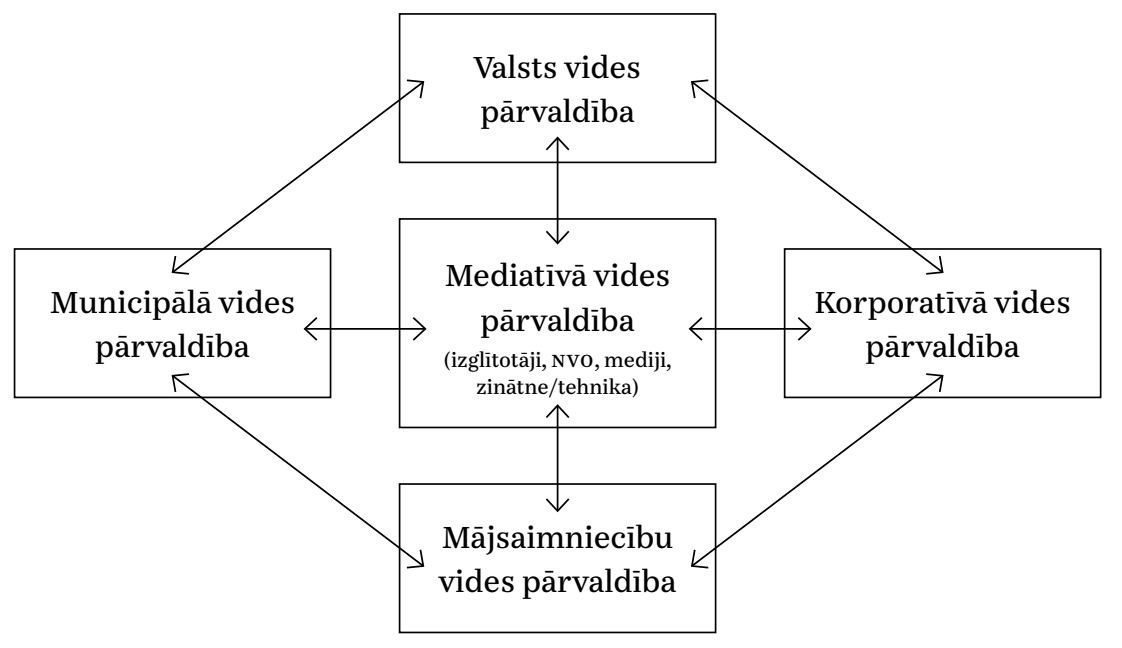

(Adaptēts no Ernšteins, 1999)

tātad ilgtspējības princips ir arī vides pārvaldības pamatprincips neatkarīgi no tā, vai to skatām globālajā vai vietējā un arì mājsaimniecību līmenī,videi draudzịgas rīcības šajā kontekstā ir arī ilgtspējīgas attīstības rīcỉbas. 
Mājsaimniecību patērinš Eiropā, t. sk. Latvijā, turpina augt, un tas ir jau vairāk nekā $60 \%$ no antropogēnajām vides slodzēm (Tukker et al., 2006). Te minami galvenie patēriņa sektori, saukti arī par klasteriem, kuri rada lielāko ietekmi uz vidi, vērtējot kā pēc ekoloğiskās pēdas nospieduma, tā arī pēc mājsaimniecību radīto siltumnīcefekta gāzu izmešu daudzuma. Šie klasteri ir pārtika, mājoklis, mobilitāte. Atbilstoši tam ir nepieciešams gan lēmumu pieņemšanas līmeņos panākt lïdzsvaru starp ilgtspējigas attīstības dimensijām, proti, starp ekonomisko izaugsmi, sociālo nodrošinājumu un vides saglabāšanas, vides pārvaldības mērḳiem, gan arī panākt iedzīvotāju attieksmes un rīcības attīstỉbu vietējā mērogà un konkrēti-mājsaimniecībās, respektīi, panākt attīstību mājsaimniecību vides pārvaldībā-nepietiekami novērtêtā un mērḳtiecīgi aktualizētā iedzīvotājiem vistuvākajā vides pārvaldes lïmenì (sk. Ernšteins, 1999). Tāpēc videi draudzīgas rīcības aspektā ir svarïgi atpazìt/novērtēt visas ilgtspējigas attīstības dimensijas tieši mājsaimniecību vides pārvaldības praksē (tātad-îstenot horizontālo integrāciju) un izprast to mijiedarbību mājsaimniecību vides pārvaldības iekšêjā kontekstā (1. attēls), kā arì komplementāri iepazìt un veicināt sadarbỉbu starp visiem vides pārvaldības segmentiem (tātad arī panākt vertikālo integrāciju), t. sk. tieši mājsaimniecību vides pārvaldỉbā ārējā konteksta mijiedarbību sekmīgā attīstībā (2. attēls).

Atbilstoši 2. attēlā redzamajai vides pārvaldības segmentu pamatshēmai, kura vienlaikus atspoguḷo arī galvenos vides pārvaldỉbas aktorus jeb interešu grupas, ir iespējams konstruēt arì videi draudzịgas rīcības pārvaldības segmentu kopsistēmas shēmu (3. attēls), tā akcentējot vides pārvaldības (politikas) patieso prakses mērkorientāciju, ievērojot šo pārvaldības segmentu savstarpējo atkarỉbu un ietekmes gan pētijumos, gan rīcỉbpolitiku attīstībā/ieviešanā. Tā ietver galvenos vides pārvaldības aktorus (interešu grupas), vides pārvaldības pamatdimensijas un to savstarpējo atkaribu un ietekmes.

Definēt ilgtspējīgu dzivesveidu nav tik vienkārši, jo skaidrojumā būtu jāiekḷauj arī katra indivìda un visas sabiedrības dažādās izpratnes par to, kas ir vide un tai draudzịgas rīcības un uzvedỉba kopumā (Ernšteins, 2016c). ANO Ilgtspējigas attīstības komisijas piedāvātā definīcija nosaka, ka ilgtspējigss dzìvesveids ir tāda patērina un rīcību paraugs, kas apmierina cilvēka pamatvajadzības; nodrošina labāku dzīves kvalitāti; samazina dabas resursu izmantošanu; atkritumu un citu piesārnotāju emisiju visā produkta dzives ciklā un neapdraud nākamo paaudžu vajadzības. Savukārt Latvijas Ilgtspējigas attīstìbas stratēóijā (LIAS 2030) tas tiek definēts kā veselīgs un videi draudzịgs dzivesveids, kas ietver: saudzigu attieksmi pret vidi un dabu, atceroties par nākamo paaudžu vajadzībām; pārdomātus lēmumus un saprātỉgu rīcību, veidojot pēc iespējas labāku dzìvi sev un saviem bērniem. Videi draudzīga rīcība saistāma ar literatūrā atrodamo jēdzienu «videi nozīmīga uzvedība», kuras

3. attēls. Videi draudzīgas rīcības (VDR) kopdimensionālā shēma kā vides pārvaldības praktiskās mērḳorientācijas reprezentācija

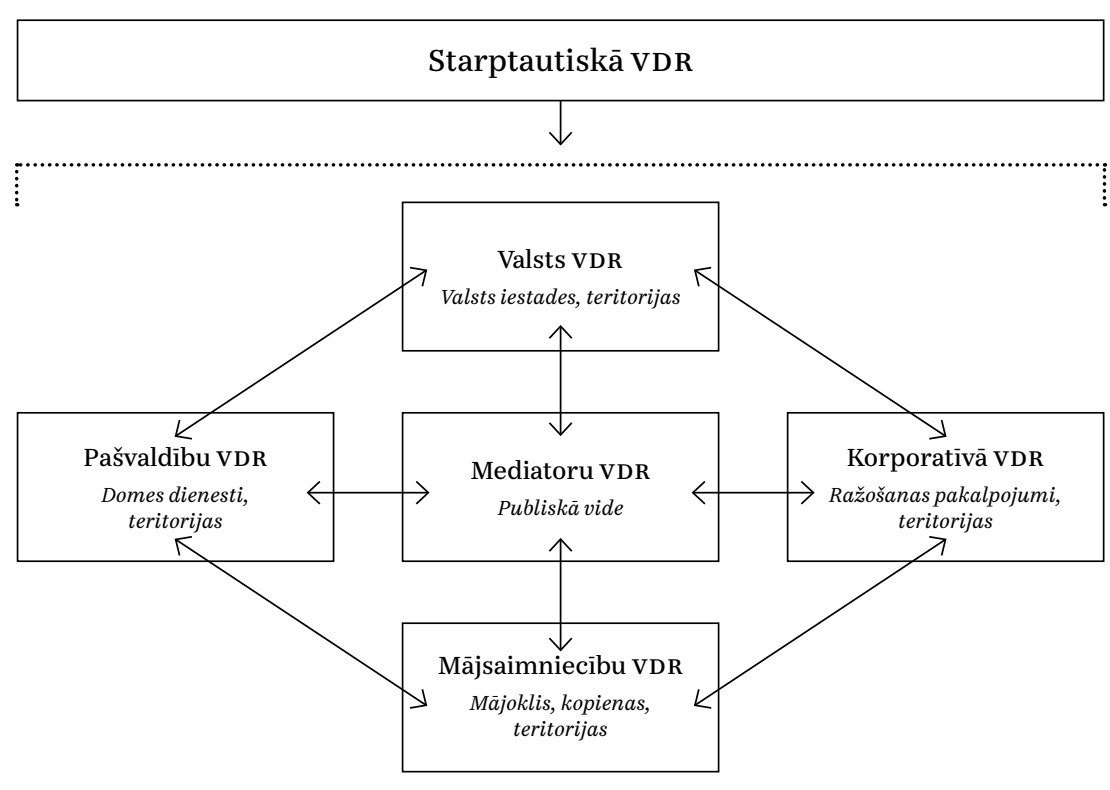

(Ernšteins, 2016a)

pamatā ir ietekme uz vidi, kas rodas konkrētas uzvedības rezultātā (Stern, 2000). P. Stērns savos darbos videi draudzīgas rīcības izpausmes klasificē divās pamatgrupās: 1) rīîibas, kas orientētas uz nodomiem (rīcība, kuru persona, kas rỉkojas, uzskata par videi draudzīgu); 2) rīcỉbas, kas orientētas uz ietekmēm. Viņš izstrādājis arī vērtību-pārliecību-normu-uzvedības modeli, izdalot trīs indivìdu vērtību un tām pakārtotu videi draudzīgas uzvedības grupas: 1) egoistiskās vērtības un tām pakārtotā uz sevi vērstā videi draudzịgā uzvedība; 2) altruistiskās vērtības un tām pakārtotā uz kopienu vērstā videi draudzīgā uzvedỉba; z) biosfēriskās vērtības un tām pakārtotā uz vidi vērstā videi draudzigāā uzvedība (Stern et al., 1999).

Videi draudzịgas rīcības var definēt arī vides pārvaldības procesa kontekstā kā sabiedrības un indivìda vides apziṇā motivētas rīcības, kuras izpaužas profesionālajā un ikdienas darbībā un kuru mērḳis ir vides problēmu identificēšana un risināšana (Ernšteins, 1999). Videi draudzigas rīīibas ietekmē gan iekšèjie faktori (vides apziņa u. c.), gan ārējie faktori visu ilgtspējigas attīstības dimensiju kontekstā. Videi draudzịgas rīcības var izpausties tieši, piemēram, atkritumu šķirošana, talkas, un netieši, arī kā nodokḷu izmaiṇas, vides izglìtības pasākumi, sabiedrības līdzdalība u.tml. 
Ilgtspējigam dzìvesveidam jāatspoguḷo katras sabiedrī- 3 Ministru kabineta noteibas īpašais kultūras, dabas, ekonomikas, sociālais mantojums. Tajā noteikti ietverams sabiedrības pārvaldỉbas un telpiskais mantojums (1. attēls) to savstarpējā mijiedarbỉbā, kā arī šodienas/nākotnes vides pārvaldības un ilgtspējịgas attīstības principi (Ernšteins, 2016c), lìdz ar to ilgtspējiga dzīvesveida virzība ir saistìta ne tikai ar evolucionāriem, bet arī ar revolucionāriem sabiedrisko inovāciju izaicinājumiem: 1) pārskatīt esošă dzivesveida izpausmes, piemēram, kā iepērkamies, organizējam ikdienas dzivi; 2) mainìt to, kā veidojam attiecības ar lìdzcilvēkiem, t.i., mainām, atklājam, audzinām, veidojam savu identitāti; 3) pārvērtēt sabiedrību un dzivesveidu dabas vides kontekstā; 4) darìt to mājās un darba vietā, visu līmenu valsts pārvaldības institūcijās, uznēmējdarbībā. Bieži vien tiek uzskatīts, ka tieši cilvēka vērtības un vides apzina nosa-

ka cilvēka rīcību. Respektīvi, cilvēkiem ar augstu vides apziṇu būtu jāīsteno videi draudzīgas rīcības, kas izpaustos arì zemās vides slodzēs, tomēr starptautiskie pētijumi to neapliecina.

\section{Vides pārvaldības}

konceptuālais un prakses attīstības ietvars

Vides pārvaldības vēsturisko attīstību un mūsdienas, skatot vides pārvaldỉbu saistībā ar rīcībpolitikas praksi, var konspektīivi raksturot kā pārvaldì-

bas satura, procesa un pārvaldes segrmentu attīstību - no dabas vides aizsardzības un pārvaldes līdz ilgtspējigas attīstỉbas pārvaldībai (Ernšteins, 2016b). Pašlaik, pēc Riodežaneiro 1992. gada ANO paradigmatiskā samita, pasaulē vides konceptu būtu akadēmiski un lietiški skatìt kā dabas vides un sociālās (sociālekonomiskās) vides mijsakarību sistēmu (4.attēls), turklāt ar ḷoti ievērojamu sociālekonomiskās jeb antropogēnās slodzes/ ietekmju nozìmi. Tāpēc konkrētās vides sistēmas mijsakarỉbas ir nepieciešams izzināt vispirms multidisciplināri, vēlams - maksimāli interdisciplināri, un tad atklātās mijsakarības būtu adekvāti jāpārveido atbilstoši lïdzsvarotas ilgtspējigas attīstības uzdevumiem - interaktīvi pārvaldìt, ievērojot visus pārvaldības cikla posmus (5P pārvaldības cikla modelis: problēmanalīze-politika-plānošana-pārvalde-pārbaude).

Pašlaik vides pārvaldībā Latvijā no akadēmiskā interdisciplinārā viedokḷa vides zinātnes, lỉdzīgi kā daudzviet pasaulē (Clark, 2007), tiek skatìtas kā atsevišḳas zinātṇu nozares/apakšnozares un vides pārvaldība tiek ieklauta vienā no apakšnozarēm³ ${ }^{3}$, kaut kopš 1998. gada Latvijas Zinātnes padomes atzinuma, vides zinātne bija vienota zinātnes nozare (interdisciplināra starpnozare) ar savām apakšnozarēm, t. sk. vides pārvaldību. Savukārt lietiškajā
4. attēls. Ilgtspējīgas attīstības tradicionālās pamatdimensijas to mijsakarībā un vides pārvaldības satura izpratnes un prakses attīstība

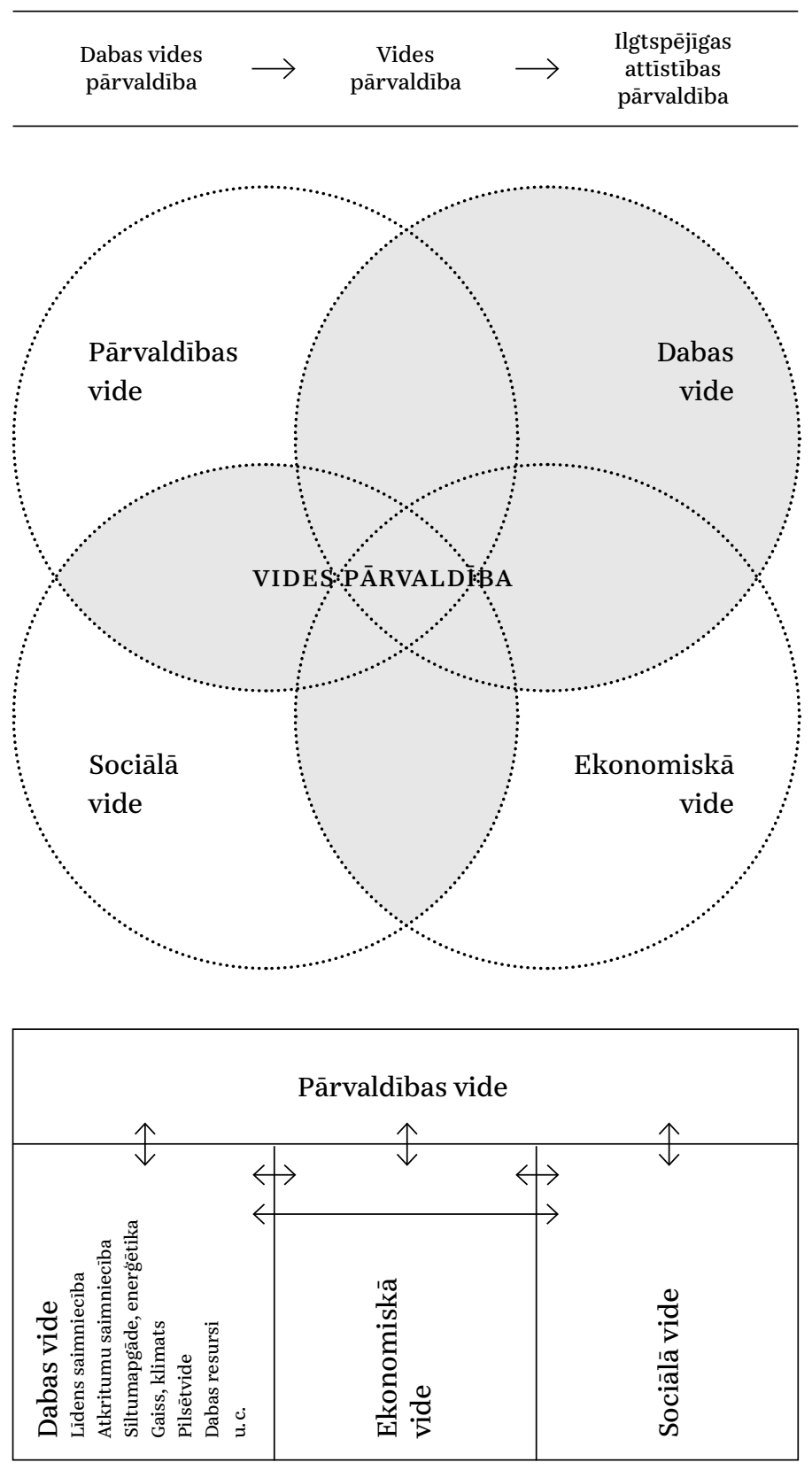

(Ernšteins, 2016b) 
publiskās pārvaldes laukā vides pārvaldība saistîta ar vides nozares ministrijas (Vides aizsardzības un reğionālas attīstības ministrijas) darbỉbu, un tiek îstenota visu nozares un ārpusnozares aktoru (interešu grupu) sadarbỉba, tā nodrošinot ne tikai disciplināro jeb nozarisko/sektoriālo vides pārvaldību, bet arī integratīvo vides pārvaldību, jo vides nozares jautājumi, procesi un mērkģrupu intereses tiek integrētas visās valsts pārvaldes nozarēs.

Vides pārvaldības vēsturiskajā attīstībā iekḷaujams arī pārvaldības procesuālo pieeju skatijjums - vispirms lejupvērstā vides pārvaldỉbas pieeja (top-down government); uz tirgus instrumentiem balstītā pieeja (marketbased governance); augšupvērstā, uz vietējo kopienu/sabiedrības pārstāvniecības līdzdalību balstītā vides pārvaldỉbas pieeja (bottom-up community based participatory governance) un vides pārvaldības pamatprincipiem atbilstošā labas pārvaldības prakses pieeja (good governance).

Šìs visas pieejas nozīmīgi atbalsta un papildina sadarbības pārvaldības pieeja (Ernšteins, 2008) un citas saistītās pieejas, t. sk. adaptīvā (adaptive), daudzlīmeṇu (multi-level), mērḳgrupu lïdzdalïbas (multi-stakeholder governance) u.c. pārvaldības pieejas. Tās ir îpaši nozīmīgas videi draudzīgas rīiibas attīstïbai un vides pārvaldības apzinas veicināšanai. Sadarbības pārvaldības pieejas attīstības kontekstā ir iespējams izvirzìt trīs komplementārus vides pārvaldības pamatprincipus. Tie ir: 1) ilgtspējigas attīstības un sabiedrības līdzdalības princips; 2) integrācijas un disciplinarizācijas komplementaritātes princips (universālais paradigmatiskais princips); 3) sadarbības pārvaldības princips (Ernšteins, 1999).

Lai sekmētu ilgtspējīgu vides pārvaldỉbas attīstību pašvaldībās, nepieciešams nodrošināt vienoti komplementāru dabas, sociālo un ekonomisko jautājumu risināšanu, kā arī visu interešu grupu savstarpēju sadarbību, panākot sistēmiskas un integratìvas pieejas realizāciju, īpaši izstrādājot pašvaldības t. s. pārvaldības vides saturisko un procesuālo kontekstu. Pašvaldību vides pārvaldības attīstība tiek veidota gan tieši no valsts puses, respektīvi, nosakot dažādus normatìvos aktus (lejupvērstā pieeja), gan no reğionālā vides pārvaldỉbas lìmenna, veicot vietējā līmeṇa vides pārvaldības uzraudzību, kā arī pašai pašvaldībai atbildot par savām autonomajām funkcijām vides jeb, precīzāk, komunālajā sektorā, kā tas nosaukts likumā «Par pašvaldībām». Atsevišḳu labās prakses piemēru analìze parāda, cik būtiski iespējams veicināt pašvaldību un tās mērkğgrupu pašiniciatìvu savu vides un ar to saistīto attīstības jautājumu ieinteresētā sakārtošanā un nepastarpinātā izmantošanā savas teritorijas un sabiedrības attīstībā.

Pastāv trīs galvenās municipālās vides pārvaldības ietvara problēmjomas (Lontone-Ieviṇa, Ernšteins, Zilniece, 2016):

- Sistēmiskas pieejas nepietiekamība (nacionālais-reǵionālaisvietējais līmenis). Latvijas Republikas normativie akti un dokumenti nenosaka nozarisku/sektoriālu jeb disciplināru vides pārvaldības plānošanu (kā tas bija līdz 2006. gadam) un attīstību vietējo pašvaldību līmenī, savukārt vides pārvaldības (kā nozares) integrācija tiek noteikta katras pašvaldības obligātajos attīstības plānošanas dokumentos - ilgtspējīgas attīstības stratēĝijā, attīstības programmā un teritorijas plānojumā. Vides pārvaldības attīstības nepieciešamība pašvaldībās (plašākajā skatījumā vērtējot vidējo situāciju, īpaši mazajās/lauku pašvaldībās) nav pietiekami atzìta/novērtēta kā vietējai attīstība pozitìva, netiek mērḳtiecīgi sistēmiski veicināta, nepietiekam izstrādātas lokālās prioritātes un mērki, turklāt procesuālā struktūra un metodoloğija nacionālā-reǵionālā-vietējā līmenī neveicina ne pašvaldību motivāciju aktivizēt vides pārvaldību, ne pilnveidot tās kapacitāti un meklēt resursus vietējā pašvaldỉbas līmenì.

- Metodoloğiskā izpratne un resursi (vietējais pašvaldību līmenis). Likums «Par pašvaldībām» (15. pants) centralizēti nosaka to autonomās funkcijas, t. sk. arī vides/komunālajā sektorā (ūdens, siltums, atkritumi), tomēr jūtams kopēja daudzveidīga metodoloğiskā nodrošinājuma un pat metodoloğiskās izpratnes trūkums, skatot vides pārvaldỉbas sektoru ne tikai disciplināri, bet arī integrēti citos pārvaldības sektoros. To novēršot, uzlabotos konsekvence un saskaņotỉba starp pašvaldibas kopējiem attīstības sektoriem.

- Horizontālā vides pārvaldības attīstība-mērkgrupu iesaiste un sadarbība. Interešu grupu lỉdzdalība attīstības plānošanas jautājumos un lēmumu pieṇemšanā, kā arī sabiedrības izpratne par labvēlīgas vides nozimi un vides uzlabošanas nepieciešamỉbu ir nepietiekama. İstenojot vides pārvaldỉbas un attīstỉbas plānošanas procesu visos pārvaldības līmeṇos, mērḳgrupu iesaiste nereti notiek formāli, un iesaistittās mērkgrupas un īpaš iedzīvotāji (mājsaimniecības) nav sagatavoti, līdz ar to tie netiek aktîvi iesaistīti līdzdalības procesā, un formāla informācijas apmaiṇa neveicina sadarbỉbu interešu grupu un pašvaldỉbu starpā. Lai attīstītu vides pārvaldību, ir nepieciešams apzināt, attīstīt un aprobēt praksēe, kā arī izplatīt jaunas modeḷpieejas, izstrādājot konkrētus municipālās vides pārvaldības attistỉbas priekšnosacijumus, pamatnostādnes un to ieviešanas instrumentus un izveidojot vienotu vides pārvaldības metodiku, kas balstîta gan uz pragmatiski lietišķo municipālās labās prakses pieeju, gan arī uz akadēmiskām pieejām (sistēmpieeja, integrācijas pieeja u.c.) un sadarbības pārvaldības modeliem. Tā 
tiktu nodrošināta gan vertikālā un horizontālā sadarbība starp interešu grupām, gan vienotas izpratnes veidošana par kopigām vides pārvaldības un attīstības problēmjomām un arī tiktu noteiktas rīcības, kā vides pārvaldỉbu isstenot.

Vides un sabiedrības mijiedarbības izaicinājums: videi draudzīgas rīcības pārvaldība pārvaldības procesā ir jārēkinās ar ilǵtspējigigas attīstības, tai skaitā ilgtspējiga patēriṇa, elementu nevienādību, nenoteiktỉbu, attistibas neatgriezeniskumu, kontekstu un daudzveidibu. Patērina paradumus ietekmē komplekss savstarpēji saistītu iekšējo un ārējo faktoru kopums, kuri ir atkarīgi no dabas vides un plašākas sociālekonomiskās vides - no pieejamajām tehnoloğijām un infrastruktūras, ekonomiskās, demogrāfiskās, institucionālās un sociālās vides. Kopumā var secināt, Latvijā ilgtspējigga patēriṇa un ražošanas pārvaldỉbas lielākā uzmanỉba ir vērsta uz piedāvājumu (t.i., ražošanu) - uz ekoefektivitātes palielināšanu un videi draudzìgu tehnolog̣iju izmantošanu, bet paša patēriṇa pārvaldības izzināšanai un attīstībai atstāts daudz mazāk ievērības.

Līdz šim patēriṇa pārvaldības diskurss ir pārāk koncentrējies uz tehnoloğiskajām inovācijām un brīvā tirgus risinājumiem, kuru mērḳis ir moderno neoliberālo sabiedrību ievirziššna videi draudzīgāku rīcību gultnē. Taču šĩ pieeja nespēj nodrošināt resursu patērina un piesārnojuma samazināšanu. To kritizē pietiekamības pieejas atbalstītāji, kas uzsver, ka ikdienas dzīvē cilvēkam ir grūti mainīt savus ieradumus, pat ja viņš ir labi informēts un motivēts. Lìdz ar to ir nepieciešams ar sociālām (sistēmiskām) inovācijām, ņemot vērā pieprasījumu, mainìt videi draudzịgas rīcības pašreizējo praksi un, protams, ne tikai individuālās, bet arī kolektīvās rīcības, tādējādi mainot patērina struktūru un apjomu. Izzinot un attistot videi draudzigas rīcības pārvaldību, būtu jāaptver sociālekoloğiskās sistēmas mijsakarību kopums - gan visi vides pārvaldības un arī patēriṇa (īpaši mājokḷa, pārtikas un mobilitātes) sektori visos pārvaldes līmenonos, gan pats pārvaldỉbas procesa cikls un visi pārvaldỉbas instrumenti to komplementaritātē (īpaši-vides/ patēriṇa komunikācijas instrumentu kopums), kā arī jāaptver visas galvenās mērḳgrupas, īpaši tās, kas veicina un nodrošina starpgrupu komunikācijumediji, NVo, izglìtotāji un zinātne.

Kopumā jāskata arī viss vērtību-rīcību-slodžu cikls videi draudzīgas rīcības pārvaldības attīstībā, bet, lai panāktu vides slodžu samazinājumu, ir būtiski saprast faktorus, kas ietekmē izmaiṇas tieši mājsaimniecības, korporatīvās vides un pašvaldību līmenī. Slodžu samazināšanas pasākumi prasa noturīgas izmainas mājsaimniecību, iestāžu un uzṇēmumu rīcībā. Taču indivìdiem un grupām, kam jāievieš šĩs izmainas, joprojām ir nepietiekams vides apziṇas un motivācijas lìmenis, bet instrumenti un tehnoloğijas, kas atvieglotu šādu rīcību, nav brivi pieejami. Lìdz ar to slodžu samazināšanas nolūkā ir jāatgriežas pie vērtībām un jācenšas panākt attieksmes mainu, jārada videi draudzīgas rīcības motivācija, kā arī jāmeklē jaunas partnerības un jārada inovācijas un pārvaldības instrumenti, lai izvērtētu un nodrošinātu nepieciešamās izmainas. Šajā kontekstā ir būtiski tālāk attīstīt (un jo ipaši-izmantot) vides komunikācijas modeḷu pieejas, kas vērstas uz rīcỉbu (piemēram, attīstît vides informācijas un vides izglìtibas/apmācības pieeju), kā arī izmantot vides lïdzdalības un videi draudzīgas rīcības komunikācijas komplementāros instrumentus, kas lauj pēctecīgi un pakāpeniski pilnveidoties indivìdu un grupu vai kopienu vides un ilgtspējiga patēriṇa zināšanām, prasmēm, attieksmēm, paradumiem, pašpieredzei un uzvedībai (Ernšteins, 2016a). Šo vides komunikācijas attīstības praksi Latvijā ir iespējams transformēt tā, lai veidotos mērḳtiecīga un atbilstoši mērḳgrupām selektivi orientēta ilgtspējigga patēriņa komunikācija.

Tieši pašvaldībām, proti, rīcībām vietējā pārvaldes līmenī, šajā zinā ir lielas priekšrocības, jo tās ir tieši saistìtas ar mājsaimniecībām un vietējiem uzṇēmumiem, turklāt šìs pašvaldības iestādes savā darbā var attīstīt un izplatìt videi draudzīgu rīcỉbu labo praksi, būt par piemēru šãdai rīcībai, un tādu piemēru Latvijā nav maz. Tāpat vietējās pašvaldỉbas var identificēt un atbalstīt aktīvas interešu grupas, organizācijas, radošu projektu pieejas, la aktivizētu inovatīvas pārmainas, kas veicina, piemēram, zema oglekḷa dioksìda emisiju līmena pieejas attīstību pašvaldībā, tādējādi nostiprinot videi draudzīgu rīcību. Šãdi daudzveidīgi soḷi savukārt stiprina vietējo identitāti un pat lepnumu par sasniegto labklājības veicināšanā un vides slodžu mazināšanā un mudina veikt nākamos videi draudzīgas rīcības solus.

Daudzas no jomām, kurām ir būtiska ietekme, piemēram, uz siltumnīcefekta gāzu emisijām, ir saistitas ar tiešajām pašvaldỉbas funkcijām va ieklaujas plašākā atbildības sfērā. Mājokḷu sektors ir viena no šīm jomām, kur pašvaldība videi draudzīgas rīcības attīstībā var panākt būtisku siltumnīcefekta gāzu emisiju samazinājumu, kā tas daudzviet arī notiek, piemēram, siltinot savā īpašumā esošās ēkas, veicinot privātmāju energoefektivitātes uzlabojumus un nodrošinot labāku būvniecības praksi. Tāpat ir būtiski iepirkumu procedūrās aktīvāk izmantot vides kritērijus un visus videi draudziğas rīcības pasākumus, integrēt tos vietējā attīstìbas un telpiskajā plānošanā, jo tas nodrošinātu ilgtermiṇa stratēǵisku pieeju zema oglekḷa dioksīda emisiju līmena pieejas attīstībai un dotu attiecīgus signālus investoriem. Savukārt plānošanas dokumentu un to ieviešanas prakses sociālekoloğisko sistēmu un videi draudzịgas rīcības strukturēts municipālais monitorings nodrošinātu atgriezenisko saiti. Kopumā, skatot vērtību-rīcību-slodžu ciklu 
municipālajā videi draudzīgas rīcības pārvaldībā, vispirms būtu akcentējami pētijjumi un pārvaldības inovācijas plānošanas-praktiskās rīcības-monitoringa pēctecīgo mijiedarbības pārvaldības cikla soḷu attīstībā.

Videi draudzīgas rīcības un ilgtspèjīga patērina pārvaldībā nevar koncentrēties tikai uz vienu no ilgtspējigiga patērina pārvaldības pieejām. Jālieto visas šis pieejas selektivi komplementāri, taču to nozimīgums var atšķirties atkarībā no patēriṇa sektora (pārtika, mobilitāte, mājoklis u.c.), mērķgrupas un sociālekonomiskā konteksta (makrovides faktoriem). Lai attīstìtos ilgtspējīgs patēriṇš, pārmaiņām jānotiek tajos makrovides sociālekonomiskajos u. c. faktoros, kas cilvēkus ieslēdz neilgtspējigās izvēlēs, proti, visās ilgtspējības dimensijās (sk. sešu dimensiju modeli 1. attēlā):

— ekonomiskajā vidē-jāattīsta tādi tirgus mehānismi un instrumenti, kas veicina videi draudzīgu ražošanu un patēriņu un ierobežo neilgtspējīgus patērina paradumus, bet produktiem un pakalpojumiem ar mazāku ekoloğisko pēdu ir jāklūst pieejamākiem un dominējošiem tirgū;

— sociālajā vidē-mainot patēriṇa simbolisko nozīmi un attīstot mazāk materiālistisku, altruistiskāku dzìves stilu un vērtības, piemēram, cilvēktiesības, jāveicina vienlīdzība un rūpes par vidi;

— kultūras vidē - jāakcentē dabas un kultūras mantojums, tradīcijas un prasmes, piemēram, ekotūrisma koncepta prakse u.c.;

— dabas vidē-jāakcentē ekoloğisko pakalpojumu un sociālekoloğisko sistēmu līdzsvara saglabāšanas un attīstības pieejas un instrumenti;

- telpiskajā vidē - jāattīsta atbilstoša nepieciešamā infrastruktūra, lai atvieglotu ilgtspējigu patēriṇu un izskaustu neilgtspējigus patērina paradumus,

— pārvaldības vidē - jāveicina ne tikai tirgus, bet arī ārpus tirgus ekonomikas esošu modeḷu attīstỉba cilvēku vajadzỉbu apmierināšanai (piemēram, sociālā kapitāla stiprināšana);

- iekšêjā (psiholoớiskajā) vidē - jāattīsta patērētāju zināšanas un vides apzina, informējot patērētājus par vinu patērina paradumu saistību ar konkrētām vides slodzēm un palielinot patērētāju zināšanas par produktu un pakalpojumu vides marḳejumiem un alternativu.

Apkopojot minēto, ir jāveicina tāda sabiedrības pārvaldības izpratne (jo ippaši videi draudzīgas rīcības pārvaldība), kas lielāko uzsvaru liek uz integrētu tìklveida pārvaldību, kurā pārvaldība vairs nav tikai valsts pārvaldes monopols, bet sabiedrības procesus būtiski virza arī pašvaldības un citas interešu grupas. Turklāt īpaši jāakcentē tādas sabiedrības pārstāvības formas kā kopienas, arī nevalstiskās un privātās struktūras un tādas formas,

kuru pamatā ir sadarbība, ilg̣termina domāšana un resursu pārdale, ko stimulē dažādas sociālās inovācijas. Šĩ pieeja saskan ar ilgtspējigas attīstības mērḳiem un principiem, kas atbalsta nehierarhisku un uz līdzdalību vērst vides pārvaldību, sadarbības pārvaldību. Būtiski šeit akcentējama sadarbības komunikācija. Pāreja no valdīšanas uz pārvaldību paver jaunas iespējas ilgtspējīgam patēriṇam. 


\section{Inovatīvi risinājumi} ceḷā uz ilgtspēju

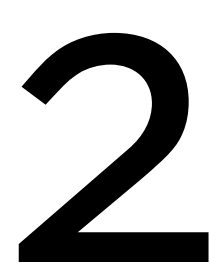




\section{Ilgtspējīgas attīstības sociālā \\ dimensija - kā virzāmies \\ pretî cienpilnai dzivei \\ sociāli atbildīgā valstī}

Attīstības plānošanā Latvija iet kopsolī ar globālajām tendencēm un starptautiskajām saistībām, ko valsts ir uzṇēmusies, - ilgtspējīgas attīstības vīzija tiek veidota saistībā ar globālo skatijumu uz ilgtspējīgu attīstību, kas prasa līdzsvarot sabiedrỉbas labklājības, vides un ekonomiskās attīstības intereses. Latvijas ilgtspējigas attīstības stratēǵijā līdz 2030. gadam (turpmāk tekstā-LIAS 2030) kā nozīmīgi sociāli mērḳi izvirzìti iedzīvotāju dzìves kvalitātes paaugstināšana, drošỉbas izjūta, piederība un iespēja ìstenot sev svarīgus mērkus (Latvijas Republikas Saeima, 2010).

Latvijas ilgtspējìgas attīstības vìzija kā vienu no septiṇām prioritātēm ietver attīstības virzienu «Iespēju vienlīdzỉba un vidusslāņa veidošanās», kurā izvirzîts mērkis: «Pieaugot IKP, samazināt sociālo un ienākumu nevienlīdzību - veicināt sociālo iekḷuušanos, mazināt nabadzības riskus, sekmēt sociāli un ekonomiski stabila vidusslāṇa veidošanos sabiedrībā» (Latvijas Republikas Saeima, 2010, 24.lpp.). Arī vidēja termina attīstības redzējumāLatvijas Nacionālās attīstības plānā 2014.-2020. gadam (turpmāk tekstāNAP 2020) - labklājības pieaugumam pievērsta galvenā uzmanība, sociālo mērḳu priekšplānā izvirzot cilvēka drošumspējas stiprināšanu un atbilstoš ilgtermina redzējumam - arī vidusslāna nostiprināšanu (Pārresoru koordinācijas centrs, 2012). Turklāt Latvijai kā Eiropas Savienības dalībvalstij un Ekonomiskās sadarbības un attīstības organizācijas dalībvalstij ir saistoši arī šo organizāciju izvirzìtie mērḳi un attīstības izpratne.

ES attīstības stratēǵijā «Eiropa 2O2O» noteiktas prioritātes gudrai, integrējošai un ilgtspējigai izaugsmei, kas cita starpā pirmo reizi ES vēsturē attīstības plānošanā ietver arī konkrētus sasniedzamos mērkus nabadzības mazināšanai-lìdz 2020 gadam par 20 miljoniem samazināt to cilvēku skaitu, kuri ir pakḷauti nabadzības un sociālās atstumtības riskam (European Commission, 2010). Latvijai ir saistoša arī OECD misija - veidot labāku rīcībpolitiku (policies) iedzivotāju ekonomiskās un sociālās labklājības veicināšanai (OECD, 2018).

Tomēr joprojām kā starptautiskajāa arēnā, tā arì Latvijas publiskajā telpā nav vienprātības par celiem šo mērḳu sasniegšanā. Gan no attīstỉbas plānošanas, gan sociālo zinātṇu perspektīvas raugoties, sociālā un ienākumu nevienlīdzība, kā arī nabadzība un sociālā atstumtība (kā pretmets iekḷaušanai), tiek uzlūkoti kā liecības, ka izaugsme neskar visus līdzịgā mērā, dažas sociālās grupas atrodas daudz nelabvēlīgākā situācijā nekā citas. Zinātnieku vidū nostiprinās uzskats, ka augsti nevienlīdzības rādītāji ir ekonomisko izaugsmi kavējošs faktors (Wilkinson \& Pickett, 2010; Galbraith, 2011; Stiglitz 2012; Walker, 2014). Gan politikas veidotāji, gan zinātnieki dažādās valstîs uzdod līdzīgus jautājumus. Piemēram, vai, kāpjot IKP, automātiski samazināsies ienākumu un sociālā nevienlīdzība? Vai ekonomiskā izaugsme automātiski nozimē dzives līmena paaugstināšanos visiem iedzivotāiiem? Vai nabadzību rada strukturāli faktori globālā un nacionālā mērogā, vai tomēr

Baiba Bela, Anita Kovalevska, Mareks Niklass, Jurijs N̦ikišins, Līga Rasnača, Iveta Reinholde, 
nabadzīgie paši ir vainīgi? Vai sociālais atbalsts veicina iekḷaujošas sabiedrības veidošanos, vai arī pabalsti un palīdzìba tikai veicina nevēlēšanos strādāt un iemāca bezpalīdzību? Šie ir tikai daži no jautājumiem, kuri ir globālu diskusiju lokā gan zinātnē, gan pilsoniskās kustībās, gan starptautisku organizāciju darbakārtībā.

2008. gada globālās finanšu krīzes iespaidā atbildes uz šiem jautājumiem tiek pārskatìtas no jauna, izvērtējot gan globālās finanšu sistēmas nozīmi, gan nacionālo rīcỉbpolitiku ietekmi nabadzỉbas un nevienlīdzỉbas mazināšanā (piemēram, Galbraith, 2011; Deaton 2013). Eiropas Savienībā Latviju ekonomiskā krīze skāra vissmagāk, jo 2009. gadā tā pārklājās arī ar nacionālās ekonomikas pārkaršanu. Vēl 2012.gadā dalijāās domas par to, vai esam sekmīgi no krizzes atkopušies (Oslunds, Dombrovskis, 2012), vai tā ir tikai makroekonomisko rādītāju kāpuma ilūzija, kas faktiski nenodrošina jūtamu dzīves kvalitātes kāpumu un labklājības pieaugumu Latvijas iedzīvotājiem (Hazans, 2012). Kā norāda ekonomisti, tikai 2016. gadā eirozonas ekonomika kopumā bija pārsniegusi pirmskrīzes līmeni, tomēr ne Latvijā (Zorgenfreija, 2016).

N̦emot vērā ilgstoši augstos nabadzîbas riskam pakḷauto iedzivotāju îpatsvara rādītājus un tāpat ilgsstoši augstos ienākumu nevienlïdzības rādītājus Latvijā, kā arī 2008.-2009. gada ekonomiskās krīzes dziḷumu, valsts pētỉjumu programmu periodā no 2014. līdz 2017. gadam valdỉba ir atbalstījusi šo jautājumu padzilinātu izpēti. Valsts pētỉjumu programmas «Inovācija un ilgtspējīga attīstība: Latvijas pēckrizes procesi globālā kontekstā» (SUSTINNO) projekta «Ilgtspējigas attīstības sociālā dimensija un sociālās inovācijas» pētnieku komanda pētỉja tieši ilgtspējīgas attīstības sociālos jautājumus pēckrīzes attīstības kontekstā (nemot vērā atzinu, ka sociālajos jautājumos krīžu sekas ir jūtamas ilgāk nekā ekonomiskajos (Brigsa et al., 2014)). Pētījumā tika analizēts, kādas ir Latvijas pēckrizes sociāāās problēmas un to ietekme uz ilgtspējīgu sociālo un reǵionālo attīstỉbu, vērtētas sociālo problēmu pārvarēšanas iespējas, kā arì analizēti tiesiskā ietvara noteiktie pienākumi ilgtspējigigas attīstības nodrošināšanai un pārvaldes sistēmas spēja efektīivi risināt sociālās problēmas.

Šajā rakstā aplūkoti galvenie pētijuma rezultāti, to izklāstu veidojot ap trim centrālajiem pētijuma jautājumiem: kāds ir juridiskais ietvars un pārvaldes efektivitāte ilgtspējiggas attīstỉbas nodrošināšanai, kā veicas ar ilgtspējīgas sociālās attīstības galveno bremzētāju - nabadzỉbas un nevienlīdzības - mazināšanu, un kādas ir sociālo inovāciju iespējas sociālu problēmu risināšanā un kopienu drošumspējas paaugstināšanā. Noslēgumā apkopoti svarīgākie ieteikumi sociālās politikas veidošanā, lai sekmīgāk virzìtos pretī iekḷaujošas un labklājigigas sabiedrības veidošanai Latvijā.

Pētijumā izmantotas vairākas sociālo zinātṇu pētijumu metodes. Padzilinātai nabadzības un sociālās atstumtības analīzei 2015. gadā tika veikta reprezentatīva Latvijas iedzīvotāju aptauja $(N=2007)$. Nemot vērā dzivo nabadzībā ja vinu ienākumi un resursi nav atbilstoši, lai varêtu atlauties tāidu dzives standartu, kāess tầu dzives standartu, kāds sabiedribā, kurā viṇi dzivo. Savas nabadzibas dẹẹ cilvēk var piedzivot dažādas grūtibas (disatvantages), kā bezdarbs, zemi ienākumi, slikta mājokḷa kvalitāte, neatbilstoša veselibas aprūpe un ierobežota pieeja müžizglitibai, kulturai, sportam un atpūtai. Viņi ir izstumti no lidzdalibas ekonomiskajās, sociālajās un kultūras aktivitātềs, kuras citi cilvēh uzlūko kā normu, kā arì vinu tiesibu istenošana va būt ierobežota (Council of the European Union, 2004, p. 8). Skatîts arī ANO ziño(United Nations, 1995). nabadzỉbas un sociālās atstumtības mērišanas standarta pieejas ierobežoto skatījumu (pamatā fokuss uz materiālajiem resursiem), aptaujas instrumentārija izveidē pētnieki balstijās ANO un ES izmantotajās nabadzības definīcijās ${ }^{1}$, zstrādāja un pievērsa uzmanību tam, vai ar savā rīcībā esošajiem ienākumiem cilvēki var nodrošināt pieņemama dzīves līmeņa minimumu, kas ietver arī sociālās, pilsoniskās un kultūras aktivitātes. Tika ierakstītas arī 25 dzivesstāsta intervijas ar cilvēkiem, kuri pārstāv dažādas ievainojamas sociālas grupas un atšḳirīgas grūtību uzkrāšanās pieredzes (pensijas un pirmspensijas vecuma cilvēki, invalīdi, bezdarbnieki, strādājošo nabadzībai paklauti cilvēki, viena vecāka ğimenes, daudzbērnu ğimenes, jaunieši ar zemu izglìtības līmeni). Biogrāisiskā metode lāva padzilināti aplū-

kot grūtībās nonākušo cilvēku ikdienas dzives pieredzi, personiskās izvēles dzives gaitā, ğimenes un plašāka sociālā konteksta mijietekmes. Pētnieki veikuši arī statistikas datu analīzi, sekundāro datu analīzi, dokumentu analīzi, kā arī veikuši intervijas un aptaujas atbilstiggi savai tēmai-par veselības stāvokḷa pašnovērtējumu (tēmās par nevienlīdzìbu un rīcibpolitiku) un par publisko bibliotēku bibliotekāru gatavību pildīt jaunas sociālās lomas attiecībā uz bērnu un jauniešu digitālās pratības pilnveidošanu (tēmā par sociālo inovāciju). Sociālo inovāciju izpētē tika arī eksperimentāli pārbaudīta pavirzī̌anas iespēju izmantošana iedzīvotāju dalības veicināšanai vēža savlaicīgas atklāšanas programmā.

\section{Juridiskais ietvars un pārvaldes efektivitāte ilgtspējīgas attīstības nodrošināšanai}

Projektā ilgtspējīgas attīstības sociālās dimensijas kontekstā tika analizēts, va no tiesību normām izriet kādi konkrēt valsts pienākumi labklājības sekmēšanas, sociālās nevienlīdzības un nabadzìbas mazināšanas jomā. Jāsecina, ka Latvijas Republikas Satversmē ir noteikt valsts pienākums sekmēt un aizsargāt labklājību plašā nozīmē-garīgo labklājỉbu, sociālo labklājību, kultūras labklājību un materiālo labklājỉbu (Kovalevska, 2018). Daudz konkrētāki valsts pienākumi labklājības sekmēšanā un aizsardzībā izriet no citām Latvijas Republikas Satversmes normām, it ịpaš no Latvijas Republikas Satversmes VIII nodạ̦ā ietvertajām cilvēka pamattiesībām, kuras rada ne tikai vispārīgu pienākumu valstij veikt noteiktas darbības, bet arī subjektīvas (tiesā aizstāvamas) tiesības atsevišḳai personai prasī valstij konkrētu darbību veikšanu vai atturēšanos no konkrētam darbībām. 
Īpaši nozīmīgs šādā kontekstā ir arī sociāli atbildīgas valsts princips, kas minēts Latvijas Republikas Satversmes ievada 4. rindkopā un kas ir viens no Latvijas Republikas demokrātisko valsts iekārtu raksturojošiem principiem. Sociāli atbildīgas valsts princips ietver četrus elementus: 1) valsts pienākumu nodrošināt cilvēka cienīgas eksistences minimālos priekšnoteikumus; 2) valsts pienākumu nodrošināt aizsardzỉbu sociāla riska gadījumā; 3) valsts pienākumu rūpēties par sociālo taisnīgumu un 4) cilvēka saistību ar sabiedrību, kas ietver arī cilvēka pienākumus pret citiem cilvēkiem (Kovaḷevska, 2008). Tas uzliek pienākumus visiem trīs valsts varas atzariem rūpēties gan par šì principa nostiprināšanu tiesību aktos, gan arī par tā istenošanu (Satversmes tiesa, 2006).

Lìdz ar to Latvijas Republikā pastāv tāds tiesiskais ietvars, kas liek valstij rūpēties par sociālās nevienlīdzības un nabadzỉbas mazināšanu. Lielākā problēma ir saistīta ar to, ka līdz šim nav izstrādāta viena pasaulē vispāratzìta metode, kā noteikt, vai valsts šos pienākumus ir izpildỉjusi vismaz minimālā līmenī. Pastāv dažādas metodes, ko lieto starptautiskās organizācijas. Satversmes tiesa ir atzinusi, ka Latvijas situācijai vispiemērotākās metodes argumentēta izvēle ir likumdevēja politiskās izškiršanās jautājums (Satversmes tiesa, 2009). Lìdz ar to rodas jautājums, vai likumdevējam šajā ziṇā ir neierobežota rīcības brīiviba un vai likumdevēja veikto politisko izvēli var paklaut pārbaudei tiesā.

Lìdz šim Latvijā Satversmes tiesa un arī pārējās tiesas nav atzinušas, ka tās varētu pārbaudīt, vai likumdevējs ir tiesību normās noteicis, piemēram, tādu sociālo pabalstu un pensiju apmēru, kas nodrošina vismaz cilvēka cienīgas eksistences minimālos priekšnoteikumus. Taču, piemēram, Vācijas Federālā Konstitucionālā tiesa ir atzinusi-lai gan tā ir likumdevēja prerogatīva noteikt minimālo pabalstu un pensiju apmēru un likumdevējam ir rīcības brīviba šajā zinā, tomēr tiesa var pārbaudìt, kādi apsvērumi ir bijuši konkrētās likumdevēja izvēles pamatā. Proti, tiesa var pārbaudīt, vai izvēelētā metode ir piemērota cilvēka cienīgas dzīves nodrošināšanai, vai ir iegūti visi metodes piemērošanai nepieciešamie fakti, vai likumdevējs ir rỉkojies konsekventi un visās aprēḳina stadijās ir izmantojis izvēlēto metodi un strukturālos principus (Vācijas Federālā Konstitucionālā tiesa, 2010). Arī Latvijā gan Satversmes tiesai, gan pārējām tiesām būtu nepieciešams atzìt, ka tiesā ir pārbaudāms, kā likumdevējs ir izmantojis savu rīcības brīvību šajā jomā. Tikai tādā veidā būs iespējams nodrošināt Latvijas Republikas Satversmē noteiktā tiesiskā ietvara pilnvērtīgu funkcionēšanu.

Sociāli atbildỉgas valsts principu funkcionēšanu var nodrošināt ar atbilstošu sociālo politiku, kuru plašā skatījumā var definēt kā lēmumu, rīcību un programmu kopumu un kura ir vērsta uz visu iedzivotāju labklājỉbas un dzìves kvalitātes palielināšanu. Šādā skatījumā katra atseviškā rīcībpolitika ir vērsta uz minēto mērku sasniegšanu (piemēram, Walsh, Stephens,
\& Moore, 2000). Šaurā skatījumā sociālā politika ir saistìta ar sociālo pakalpojumu sniegšanu, savukārt plašā skatijumā persona var arī nebūt sociālo pakalpojumu klients, bet vienlaikus tā var būt sociālās politikas subjekts (piemēram, caur nodokḷu politiku, kas vērsta uz ienākumu nevienlīdzības samazināšanu).

Latvijai ir saistoša Eiropas Parlamenta nostāja, kas drīzāk atbalsta plašu skatijjumu, uzsverot, ka jebkuriem vispārējās nozìmes pakalpojumiem ir jāveicina sociālā un teritoriālā kohēzija, lai panāktu labklājības līmeṇa pieaugumu un sociālās nevienlīdzības mazināšanu. Sociālā kohēzija ir nevis izolēta rīcībpolitika, bet gan sabiedrības un publiskās pārvaldes kopējā spēja un prasme nodrošināt labklājību visiem tās locekḷiem (European Parliament, 2010).

Pētījumā tika pievērsta uzmanība tam, vai sociālajos jautājumos Latvijas publiskās pārvaldes darbība tuvojas viedas pārvaldības principiem, saskanā ar kuriem rīcībpolitiku veidošanā ir jānodrošina starpinstitucionāla perspektiva un sadarbiba, lai galapatērētājs iegūtu tādu pakalpojumu, kas nodrošina kompleksu problēmu risinājumu (World Health Organization, 2011; European Commission, 2012). Labklājības jomā ekonomiskā krīze 2008. gadā iezīmēja būtiskas izmainas, jo ekonomiskās lejupslīdes rezultātā valdībai nācās samazināt valsts budžeta izdevumus. 2009. gada vidū valdỉba bija samazinājusi neapliekamo minimumu (no 90 lïdz 35 latiem), uzsākusi reformas izglìtibas un veselības aprūpes jomā, kā arī samazinājusi sociālos izdevumus (piemēram, pensijas, maternitātes pabalstus) (Finanšu ministrija, 2009). Vienlaikus tika piedāvāts arī sociālās drošības tīkls, kam bija jāakumulē ekonomiskās lejupslīdes trieciens iedzivotājiem ar zemiem ienākumiem (piemēram, tika samazināts bezdarba pabalsta saṇemšanas laiks, lai ierobežoto lỉdzekḷu apstākḷos pabalstu varētu saṇem visi, kam tas bija nepieciešams). 2010. gada vidū valdỉba bija gatava palielināt sociālās drošỉbas tìkla nodrošināšanai paredzētos izdevumus, vienlaikus iezīmējot atsevišķu pabalstu samazināšanu (piemēram, pabalstu bezdarba vai slimības gadijjumā) (Finanšu ministrija, 2010). Tiek uzskatîts, ka valdība reağēja ātri un pārkārtojumi būtiski palīdzēja iedzivotājiem tikt galā ar grūtībām (World Bank, 2013). Tomēr divreiz palielinājās emigrējušo skaits - no 17019 cilvēkiem 2006. gadā un 15463 cilvēkiem 2007. gadā līdz 38208 cilvēkiem 2009. gadā un 39651 cilvēkam 2010. gadā (Koroleva, Mierina, 2015). Tas liecina, ka cilvēki paši risināja savas grūtības, valdības palīdzỉbu uzlūkojot kā nepietiekamu.

Aplūkojot virzību pretī viedai pārvaldībai, vispirms jāuzsver pozitīvais. Nacionālais attīstības plāns 2007.-2013. gadam (Reğionālās attīstības un pašvaldỉbu lietu ministrija, 2006) paredzēja pārvaldības mehānismus, ar kuru palīdzību varētu sasniegt tajā noteiktos mērkus, nodrošinot publisko pakalpojumu pieejamību un kvalitāti. Tāpat tika definētas arì citas labas 
pārvaldības pazīmes - komunikācija ar sabiedrību, ilgtermiṇa plānošana un resursu kontrole. «Latvijas Nacionālais attīstības plāns 2014.-2O2O. gadam» iezīmē nepieciešamību samazināt ienākumu plaisu starp dažādām sociālām grupām un aktualizē jautājumu par ienākumu pietiekamību, kas ir gan būtiski subjektīvai drošỉbai, gan arī objektīvs pamats dzīvei bez sociālās palīdzības. Tādēl attīstības plānā prioritātē «Cilvēka drošumspēja» iezīmētie rīcības virzieni-«Cienigss darbs», «Stabili pamati tautas ataudzei», «Kompetenču attīstïba», «Vesels un darbspējigiss cilvēks» un «Cilvēku sadarbỉba, kultūra un pilsoniskā līdzdalība kā piederỉbas Latvija pamats» (Pārresoru koordinācijas centrs, 2012) - ieskicē to, ka labklājības politika ir kompleksa un tā būtu jāuzskata par horizontālo prioritāti.

Kritiskāk jāvērtē, kā tālāk tiek veidoti pārvaldības

mehānismi, lai sasniegtu izvirzìtos mērḳus. Labklājības jomā ir politikas plānošanas dokumenti, kas nosaka rīcību sociālās politikas, sociālās apdrošināšanas un sociālo pakalpojumu sfērā. Tomēr fragmentētās pieejas dēl ir diezgan grūti saprast nākotnes labklājỉbas politikas modeli un tā pārvaldỉbas shēmu. Rīcībpolitiku sadalījumu atsevišķās jomās un rīcībpolitikas plānošanas dokumentu savstarpējo saistību un hierarhiju skaidri definē Ministru kabineta noteikumi Nr. 300 «Ministru kabineta kārtības rullis» (Ministru kabinets, 2009), kas labklājības jautājumus skata kā «nodarbinātỉbas un sociālo politiku» ar vairākām rīcībpolitikas nozarēm - darba politiku, sociālo aizsardzību, dzimumu līdztiesību, sociālo ieklaušanu, bērnu un ǵimenes politiku. Saskaṇā ar Ministru kabineta noteikumiem ir paredzētas vienpadsmit rīcībpolitikas apakšnozares. Pētijumā tika analizētas piecas spēkā esošas pamatnostādnes ${ }^{2}$ un secināts, ka labas un efektīvas pārvaldības jomā ir vērojami uzlabojumi, tomēr joprojām pastāv būtiska fragmentācija (arī rezultatīvo rādītāju fragmentācija); skatījums veidots jau pierastā jomas ietvarā, un trūkst starpsektoriālas koordinācijas, kaut arī atsevišķos dokumentos tā ir paredzēta (Reinholde, 2018).

Aplūkojot konkrētus instrumentus nabadzības un ienākumu nevienlīdzības mazināšanai, kā sasniegumi jāuzsver: 1) ǵimenes valsts pabalsta palielināšana (par otro, trešo, ceturto un nākamajiem bērniem) saskanā ar Valsts sociālo pabalstu likuma 6. pantu un 2009. gada 22. decembra Ministru kabineta noteikumiem Nr. 1517; 2) Ministru kabineta rikojums Nr. 245 «Par Valsts nodokḷu politikas pamatnostādnēm 2018.-2021. gadam»; 3) Saeimas 28. jūlijā apstiprinātā nodokḷu reformas likumu pakete, saskaṇā ar kuru tiek būtiski celta minimālā alga (430 eiro no 2018. gada 1. janvāra), tiek ieviesta progresīvā IIN likme, paaugstināts neapliekamais minimums (turklāt ar diferencētu pieeju, pilnā apmērā to piemērojot mazajām algām), kā arī paaugstināti atvieglojumi par apgādībā esošu personu (Finanšu ministrija, 2017). Ieguvumi no šĩs reformas gan būs redzami tikai tuvākajos gados.

Būtiska iecere efektīvas nabadzības mazināšanas virzienā ir «Koncepcija par minimālā ienākumu līmena noteikšanu» (Labklājības ministrija, 2014a). Koncepcijā ietvertie priekšlikumi būtu nozimīgs solis pretī Eiropas Parlamenta 2010. gada rezolūcijā izteiktajam aicinājumam dalībvalstīm ieviest atbilstošas minimālā ienākuma shēmas un noteikt ienākumu minimālo slieksni, kas atbilstu vismaz $60 \%$ no attiecīgās valsts mājsaimniecību rīcībā esošo ienākumu mediānas vērtỉbas, kas tiek aprēḳināta, ṇemot vērā ekvivalento patērētāju skaitu mājsaimniecībā (statistikā tas zināms kā nabadzības riska slieksnis). Latvijā lïdz šim minimālo ienākumu līmenis nav ticis saistīts ne ar nabadzības riska slieksni, ne ar kādiem zinātniski pamatotiem aprēḳiniem par minimālo patēriṇa grozu dzīves pamatvajadzību segšanai: «Nacionālā līmenī normatīvajos aktos definētie minimālie ienākumu līmeni/ nabadzïbas riska sliekšṇi netiek noteikti, pamatojoties uz konkrētu aprēkin metodolog̣iju. Tie tiek noteikti atkarībā no valsts un pašvaldību finansiālās iespējas konkrētajā brīdī.» (Labklājības ministrija, 2014a, 9.lpp). Diemžēl valdỉba šajā dokumentā ietverto solu istenošanu atliek gadu no gada, jo tas gan prasītu ievērojamus budžeta izdevumus sociālās palīdzības palielināšanai, gan liktu vēl straujāk celt minimālo algu (kas tomēr palīdzētu sekmīgāk risināt strādājošo iedzīvotāju nabadzības jautājumu).

Garantētais minimālais ienākums (53 eiro 2009. gadā un atkārtoti 2018. gadā, pa vidu svārstoties no 57 eiro ekonomiskās krīzes gados līdz 49,80 eiro pēdējos piecus gadus) un trūcīgas personas ienākumu līmenis (128,09 eiro kopš 2009. gada) ilgsstoši nav pārskatīti, kaut gan tiek atzīts, ka tie nespēj nodrošināt pamatvajadzības pat minimālā apmērā (sk. Ministru kabinets, 2014). Maznodrošinātas personas statusa piešḳiršana raisa vēl lielāku kritiku, jo ienākumus, kas atbilst šim statusam, pašvaldỉbas noteikušas intervālā no 142 līdz 360 eiro, un tas dažādu pašvaldību iedzivotājiem ar līdzigām problēmām rada ḷoti atšḳirìgas palīdzības saṇemšanas iespējas. Labklājibas ministrija gan plāno būtiskus uzlabojumus - trūcīgas personas ienākumu līmeni no 2019. gada ir paredzēts noteikt 188 eiro apmērā, garantēto minimālo ienākumu līmeni noteikt 94 eiro apmērā (kā pusi no trūcīgas personas līmeña), bet, sākot ar 2020. gadu, paredzēts noteikt visās pašvaldībās vienotu maznodrošinātās personas ienākumu līmeni (Labklājibas ministrija, 2017, 9. marts).

Var teikt, ka sociālās drošības tỉkla ziṇā valsts joprojām nav sekmīgi atkopusies no krīzes, jo nespēj sniegt pietiekami efektīvu atbalstu vismazāk aizsargāto cilvēku pamatvajadzỉbu nodrošināšanai un sociālajai iekḷaušanai. Lai ilustrētu problēmu nopietnību, ar kurām saskaras zemo ienākumu saṇēmēji, tālāk aplūkoti ienākumu nevienlīdzības, nabadzības un sociālās atstumtỉbas jautājumi no iedzīvotāju skatpunkta. 
Pēckrīzes sociālo problēmu analīze

Pēckrīzes attīstības virzība tika analizēta kontekstā ar izvirzìto valsts ilgtermiņa attīstības prioritāti-mazināt ienākumu nevienlīdzību un nabadzības riskus, kā arī sekmēt sociālo ieklaušanos un vidusslāna veidošanos (Latvijas Republikas Saeima, 2010). Lai to izpētītu, tika veikta mājsaimniecību materiālās nenodrošinātības padziḷināta analìze, konkrētu sociālu grupu grūtību pieredzes mikroanalīze, tika analizēta strādājošo nabadzība, veselības nevienlīdzība un mājokḷu pieejamības nevienlīdzība. N̦emot vērā vidēja termiṇa attīstības plānošanā izvirzìto mērķi attīstìt izaugsmi atbalstošas teritorijas, kurās pieejamie pakalpojumi nodrošinātu lïdzvērtīgas darba iespējas un dzives apstāklus Latvijas iedzìvotājiem (Pārresoru koordinācijas centrs, 2012), kā arī ilgstošās grūtỉbas izlīdzināt reǵ̛ionu nevienmērīgo attīstību, uzmanība pievērsta arī reǵ̛ionālo atšksirìbu aplūkojumam.

Sākumā ieskicēsim kopējo situāciju pētỉjuma veikšanas laikā. 2015.gadā vairums Latvijas iedzīvotāju varēja aț̣auties nodrošināt pamatvajadzỉbas pēc ēdiena ( 81 \% var atḷauties ēst galıu, zivis vai atbilstošu veǵetāru maltìti katru otro dienu), pēc pajumtes ( 83 \% cilvēku nav bijuši parādi par îri, komunālajiem maksājumiem vai hipotekārā kredīta maksājumiem) un pēc apgeērba (64\% var atḷauties novalkātās drēbes nomainīt pret jaunām, nevis no lietoto preču veikala). Vairumam mājsaimniecību ir pieejamas sadzives ilglietošanas preces - telefons (98\%), televizors (97\%), veḷas mazgājamā mašina $(88 \%)$ un dators $(68 \%)$, pusei mājsaimniecỉbu ir pieejama arī mašīna. Nedaudz vairāk nekā puse mājsaimniecību (58\%) pat var atlauties vienu nedēlu doties brīvdienās ārpus mājām (Centrālā statistiskas pārvalde, 2016a). Skatoties rādītāju dinamiku kopš ekonomiskās krīzes smagi skartajiem gadiem-2009. un 2010. gada -, bezdarba rādītāji normalizējas: 2010. gada pirmajā ceturksnì bezdarbs sasniedza pat $20 \%$, savukārt 2017. gada pirmajā ceturksnī-9,4\% (Hazans, 2012; Centrālā statistikas pārvalde, 2017, 22. maijs). Arī ilgstošo bezdarbnieku îpatsvars samazinās - 2012. gadā ilgstošie bezdarbnieki bija $52 \%$ no visiem bezdarbniekiem, bet 2016. gadā to bija $41 \%$ (Labklājības ministrija, b. g.). Vidējā darba samaksa valstī lēnām atkopjas no ekonomiskās krīzes2010. gada 1. ceturksnī vidējā darba samaksa bija 614 eiro, savukārt 2017.gada 1. ceturksnī-879 eiro (Centrālā statistikas pārvalde, 2017a). Arī banku eksperti Latvijā turpina zinot par strauju IKP kāpumu un paredz, ka iedzivotājiem maciṇos naudas būs vairāk gan algas kāpuma, gan nodokḷu reformas dēl (Kazāks, 2017).

Uz kopējo pozitivo tendenču fona tomēr jānorāda, ka joprojām bruto alga virs 1000 eiro mēnesī ir tikai $27 \%$ no visiem algas saṇēmējiem un bruto alga virs 4000 eiro - tikai o,5\% no visiem algas saṇēmējiem (Kazāks, 2017). Salīdzinājumam - Luksemburgā minimālā alga tuvojas 2000 eiro, sešās ES valstīs tā ir ap 1500 eiro (Eurostat, 2017a). Nemot vērā, ka vidējā alga valstì
1. attēls. Nabadzības riskam paklauto iedzīvotāju īpatsvars dažādās sociālekonomiskajās grupās 2004.-2016. gadā (\%)

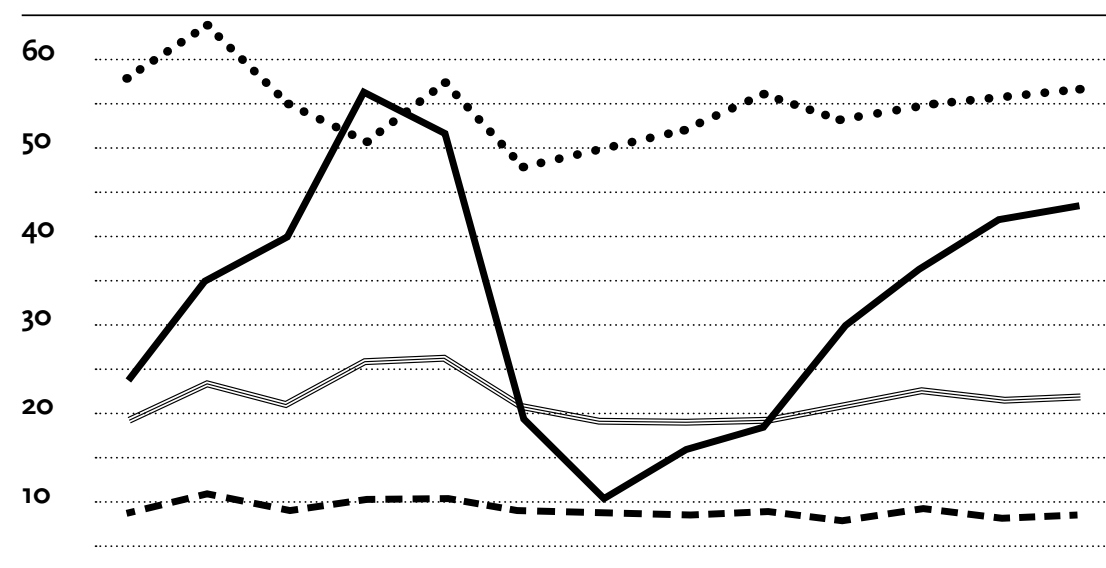

$\begin{array}{lllllllllllll}2004 & 2005 & 2006 & 2007 & 2008 & 2009 & 2010 & 2011 & 2012 & 2013 & 2014 & 2015 & 2016\end{array}$

... Visi iedzivotāij

- Strādājošie

$=$ Bezdarbniek

-- Pensionā

(Centrālā statistikas pārvalde, 2018, 18.janv.)

tuvojas 1000 eiro robežai-2017. gada 3. ceturksnī tā bija jau 925 eiro (Centrālās statistikas pārvalde, 2017a) - šie skaitli liek uzdot jautājumus ne tikai par pēckrīzes attīstỉbas virzỉbu, bet arī par ienākumu nevienlïdzību un to, ka pēdējo gadu ekonomikas izaugsme skar dažādas Latvijas iedzīvotāju sociālās grupas atškirīgā mērā un kādas vajadzības mazāk turīgie iedzivvotāji var apmierināt ar tiem ienākumiem, kas ir vinu rīcībā.

Starptautiskos salīdzinošos rādītājos par lielo nevienlīdzību Latvijā liecina joprojām augistais Džini koeficients - 2016. gadā tas bija 34,5, bet ES vidējais rādīiājs ir 30,7 (zemākie rāditāji ir Slovēnijai un Slovākijai (24,4 un 24,3) un augstākie - Bulgārijai un Lietuvai (38,3 un 37,0)) (Eurostat, 2017b). Arī nabadzības rādītāju ilgtermina dinamika liek domāt, ka krīze vissmagāk skāra vidusslāni un turīgākos iedzivotājus, kuru ienākumi pamazām atjaunojas iepriekšêjā līmenī. Bet nabadzīgākie kā bija, tā joprojām ir relatîvi turpat, izṇemot seniorus, kuru ienākumu dinamika ir minimāla. Senioru ienākumu rādītājs drīzāk parāda pensiju stagnāciju pret kāpumiem (pirmskrīzes, pēckrīzes laikā) un kritumiem (krīzes laikā) vidējos ienākumos (2016. gadā nabadzības riskam pakḷauto iedzīvotāju īpatsvars vecuma grupā virs 65 gadiem bija 39,9\%, un, ja persona vecumā virs 65 gadiem dzivo viena pati, šis rādītājs ir 72,8\% no visiem senioriem) (Centrālā statistikas pārvalde, 2018, 18. janv.). 
1. tabula. Strādājošo mēneša vidējā darba samaksa

Latvijas regionos 2010.-2016. gadā (bruto, EUR)

\begin{tabular}{lccccccc} 
Reǵgions & 2010 & 2011 & 2012 & 2013 & 2014 & 2015 & 2016 \\
\hline Pavisam & 633 & 660 & 685 & 716 & 765 & 818 & 859 \\
\hline Riga & 724 & 757 & 778 & 815 & 869 & 925 & 971 \\
\hline Pieriga & 603 & 622 & 649 & 677 & 721 & 770 & 806 \\
\hline Vidzeme & 485 & 518 & 528 & 560 & 598 & 643 & 675 \\
\hline Kurzeme & 544 & 559 & 598 & 608 & 651 & 693 & 716 \\
\hline Zemgale & 508 & 547 & 571 & 597 & 645 & 683 & 725 \\
\hline Latgale & 440 & 468 & 475 & 490 & 522 & 564 & 592 \\
\hline
\end{tabular}

(Centrālā statistikas pārvalde, 2017f)

2. tabula. Nabadzības riska indekss Latvijas reğionos 2010.-2015. gadā

\begin{tabular}{lcccccc} 
Reǵions & 2010 & 2011 & 2012 & 2013 & 2014 & 2015 \\
\hline Pavisam & 19,0 & 19,2 & 19,4 & 21,2 & 22,5 & 21,8 \\
\hline Riga & 11,9 & 12,9 & 10,7 & 13,7 & 13,8 & 13,5 \\
\hline Pieriga & 15,3 & 15,5 & 17,3 & 19,6 & 17,5 & 18,6 \\
\hline Vidzeme & 23,5 & 27,8 & 30,7 & 26,8 & 28,2 & 29,2 \\
\hline Kurzeme & 20,4 & 19,8 & 19,6 & 21,2 & 22,9 & 21,7 \\
\hline Zemgale & 23,9 & 22,2 & 22,3 & 24,6 & 27,1 & 23,0 \\
\hline Latgale & 30,2 & 28,6 & 30,5 & 33,0 & 40,4 & 39,2 \\
\hline
\end{tabular}

(Centrālā statistikas pārvalde, 2016, 2017g)
Vispirms pievērsīsimies ienākumu, nabadzības riska un ekonomiskās spriedzes atšķirībām reğionālā griezumā. Tās ḷauj spriest par to, kā virzāmies pretī vienlīdzīgām dzīves iespējām visā Latvijā un stabilam vidusslānim. Iespējas nodrošināt pienācīgu dzìves līmeni un sociālā drošỉba sākas ar drošību darba tirgū un iespēju sanemt taisnigu atalgojumu. Lai gan vērojams strādājošo mēneša vidējās darba samaksas kāpums (kopš darba algu limeṇa krituma ekonomiskās krīzes laikā 2008. un 2009. gadā), saglabājas nozīmīgu reğionālo atškirību tendence. Rỉgā atalgojums ir ievērojami augistāks nekā citos reǵiionos, turklāt Latgalē vidējā darba samaksa pat sešus gadus pēc krīzes ir zemāka nekā vidējā darba samaksa Rīgā krīzes laikā (1. tabula). Atšḳirības vidējās darba samaksas rādītājos starp turīgākajām un trūcīgākajām pašvaldībām ir vēl izteiktākas (sevišḳi novadu griezumā).

Kā nākamais svarīgākais rādītājs aplūkots nabadzības riska indekss. Saskanā ar to pienem, ka nabadzïbas riska slieksnis ir «60\% no rīcibā esošo ienākumu mediānas, pārrēkinātas uz ekvivalento patērētāju skaitu mājsaimniecībā» (Centrālā statistikas pārvalde, 2016, 30. maijs). Tā kā nabadzības riska indekss ir saistīts ar vidējiem ienākumiem valstī, pēckrīzes rādītāja virzība liecina - augot vidējiem ienākumiem, šo kāpumu neizjūt visi vienādā mērā. Trūcīgāko iedzīvotāju ienākumu kāpums atpaliek no labāk nodrošināto iedzīvotāju ienākumu kāpuma, tāpēc arī nabadzības riskam pakḷauto iedzīvotāju īpatsvars visumā saglabājas vai pat nedaudz pieaug. Rādìtājs, kam patiešām jāpievērš uzmanība, ir nozīmīgās atšķirības nabadzības riskam pakḷauto iedzīvotāju īpatsvarā reĝ́ionu griezumā (9. tabula). Vienỉgi Rīgã nabadzības rādītāji ir zem vidējiem Eiropas Savienībā, tie 2015. gadā bija 17,3\% (Eurostat, 2016a).

Tomēr tiešāk dzīves līmeni, kādu iedzīvotāji var aț̣auties ar tiem ienākumiem, kas ir vinu rỉcībā, raksturo mājsaimniecību ekonomiskās spriedzes indekss. Šo indeksu rēkina ar vairāku jautājumu palīdzību, kuros respondentiem jānovērtē mājsaimniecības spēja segt izmaksas piecās jomās: 1) samaksāt komunālos maksājumus, iri un kredītu (t. sk. līzinga maksājumus par pirkumiem uz kredìta); 2) uzturēt mājokli siltu; 3) ațauties segt neparedzētus izdevumus no pašu lídzekliem; 4) ēst galu, putnu galu vai zivis, vai līdzvērtīgu veǵetāro maltìti katru otro dienu; 5) katru gadu vienu nedēḷu doties brīvdienās ārpus mājām. Mājsaimniecības, kuras vismaz uz diviem jautājumiem sniedz noraidošu atbildi, tiek uzskatītas par paklautām ekonomiskai spriedzei (Centrālā statistikas pārvalde, 2015, 9. apr.). Minētos ikdienas izdevumus var uzlūkot arì kā Eiropā pieṇemta dzìves standarta minimumu, jo lïdzās pamatvajadzībām tiek mērìtas iespējas segt neparedzētus izdevumus (parasti neto minimālās mēnešalgas apmērā) un apceḷot kaut vai dzimto zemi (aptaujā ir norādīts - neskaitot apmešanos vasarnīcā vai pie radiem).

Kaut arī pēc ekonomiskās krìzes ar katru gadu spriedzes rādītāiji ievērojami uzlabojas, tomēr tie labi parāda, ka iedzivotāju ienākumi attiecībā 
3. tabula. Ekonomiskā spriedze mājsaimniecībās 2010.-2015.gadā (\%)

\begin{tabular}{lcccccc}
\hline Regions & 2010 & 2011 & 2012 & 2013 & 2014 & 2015 \\
\hline Pavisam & 66,3 & 68,9 & 65,7 & 58,3 & 53,0 & 47,1 \\
\hline Rìga & 61,6 & 59,7 & 57,9 & 51,5 & 45,6 & 38,9 \\
\hline Pieriga & 69,6 & 74,7 & 67,9 & 56,3 & 56,3 & 49,6 \\
\hline Vidzeme & 70,6 & 78,3 & 70,0 & 69,3 & 61,5 & 54,1 \\
\hline Kurzeme & 65,5 & 70,4 & 67,3 & 63,6 & 51,1 & 46,4 \\
\hline Zemgale & 68,0 & 67,5 & 68,0 & 63,1 & 57,5 & 52,7 \\
\hline Latgale & 70,0 & 76,8 & 74,8 & 61,0 & 58,5 & 54,5 \\
\hline
\end{tabular}

(Centrālā statistikas pārvalde, 2017f)

pret dzìves standarta minimumu joprojām ir pieticīgi, kaut arī Rỉgas mājsaimniecību ekonomiskās spriedzes rādītāji ir ievērojami labāki nekā citos reğionos (3. tabula).

Tomēr mūsdienās vairāki ārvalstu autori pauž kritiku, ka standarta pieeja neietver būtiskus labklājību un sociālo iekḷautību raksturojošus rādìtājus (piemēram, mājokḷa apstākḷus, kultūras līdzdalību, iespējas uzturēt sociālās attiecības, pieeju veselības un izglìtibas pakalpojumiem u.c.). Nemot vērā augstos nabadzības un mājsaimniecību ekonomiskās spriedzes rādītājus Latvijā, var pieṇemt, ka kompleksāka pieeja iedzìvotāju dzìves līmeṇa izpētē precĩzāk atsegtu tās daudzveidīgās grūtības, ar ko sastopas Latvijas iedzīvotāji, un ienākumu sliekšņus, pie kuriem šìs grūtības kḷūst arvien smagākas. Šāda izpēte ir sevišḳi būtiska, pirmkārt, tādēl, ka ienākumu līmeṇi sociālas palīdzības un pakalpojumu sanemšanai un arì minimālo ienākumu sliekšni Latvijas sociālajā politikā nav saistìti ne ar kādiem objektīviem un zinātniskiem kritērijiem. Kaut arī Labklājības ministrija šo jautājumu ir aktualizējusi jau gadiem (Labklājības ministrija, 2014a, 2014b; Celmiṇa, 2017), tas joprojām paliek nesadzirdēts lēmumu pieneēmēju vidū. Otrkārt, kamēr lēmumu pieņēmēji redz tikai ienākumu rādìtājus un neizprot, cik daudzveidīgus ierobežojumus un smagas grūtỉbas zemi ienākumi rada cilvēku dzivē, tikmēr tie nav ieinteresēti problēmas risināt kompleksi un stimulēt starpinstitucionālu sadarbību.
3 1) Katru gadu vienu nedẹlu doties brivdienās ārpus mājāim (neieskaitot palikšanu citā mājokl (dārza mājāi, vasarnicāā) vai pie draugiem/radiniekiem); 2) èst galu, putnu galu vai zivis (vai lìdzvērtīgu dienu; 3) uzturēt mājokli pietiekami siltu; 4) nomain nolietotās mēbeles; 5) veikt dzivokla remontu, kad tas ir nepieciešams; 6) iegadāties jaunas drēbes (ne no lietotu preču veikala), 7) reizi mênesiu uzaicināt radus vai draugus uz pusdienām; 8) lietot interneta pieslēgumu
SUSTINNO pētijuma laikā tika veikta padzilināta materiālās nenodrošinātības izpēte, lietojot kompleksu skatijumu uz nabadzību kā dažādu resursu nepietiekamību, kas neḷauj dzivot atbilstoši vairākuma pieṇemtajam dzives standartam un nelauj pilnvērtīgi ieklauties sabiedrības ekonomiskajā, sociālajā, politiskajā, kultūras dzīvē (plašāk sk. Bela, N̦ikišins, 2018; Niklass, Rasnača, 2018). Par pamatrādìtāju pārticībai un nabadzībai tika aplūkotas respondentu atbildes uz vairākiem dihotomiskiem ( «jā» vai «nē» formāta) jautājumiem par to, vai respondenti var aț̣auties izdevumus noteiktās jomās, kas aptver atpūtu, uzturu, mājokḷa komunālos maksājumus, mājokḷa iekārtu un stāvokli, apǵērbu, sociālos kontaktus un komunikācijas tehniskās iespējas ${ }^{3}$ (4. tabula). Lai padzị̣ināti noskaidrotu respondentu iespējas apmierināt konkrētas vajadzības, SUSTINNo pētijumā tika uzdoti arī jautājumi par to, vai pēdējo 12 mēnešu laikā no aptaujas veikšanas briža respondenta mājsaimniecībā (ǵimenē) ir bijušas situācijas, kas saistìtas ar nespēju seǵt izdevumus par noteiktām vajadzībām. Jautājumi aptvēra cilvēka cienīgai dzivei svarīgus pakalpojumus un aktivitātes, kas skar iztiku, mājokḷa uzturēšanu, veselības aprūpi, kontaktus ar radiem un draugiem, bērnu izglītību, kā arī atpūtas un kultūras vajadzības. Jautājums paredzēja četrus atbilžu variantus, kas parāda, vai respondents vienmēr varēja segt šos izdevumus; 1-2 reizes vai 3 un vairāk reizes nevarēja segt šos izdevumus (analīzē ērtỉbas labad šìs atbildes tika apvienotas); vai arī vinam nebija nepieciešamïba risinăt attiecīgu problēmu (piemēram, ja mājsaimniecībā nav bērnu, tad nebija arī vajadzības pirkt mācībām nepieciešamo inventāru) (11. tabula).

Respondentu mājsaimniecību materiālās nenodrošinātỉbas analīzē pirmā būtiskā atzina ir tā, ka deprivācijas rādītāji atškiras ne tikai starp respondentu grupām, bet arī dažādās jomās. Gandrīz visi respondenti (95\%) norāda, ka var atḷauties uzturēt mājokli pietiekami siltu, tai pašā laikā remonta veikšanu, kad tas ir nepieciešams, var atlauties mazāk nekā puse. Arī nolietoto mēbeḷ nomainišana ir problemātiska vairāk nekā pusei mājsaimniecību - to var aț̣auties vien $45 \%$ respondentu. Runājot par izmaksām sociālo kontaktu uzturēšanai, $23 \%$ jeb nedaudz mazāk nekā viena ceturtdala mājsaimniecību nevar atlauties kaut reizi mēnesī uzaicināt radus vai draugus uz pusdienām.

Kopumā aptaujas datu analize liek domāt, ka cilvēki loti rūpigi apsver izdevumu prioritātes. Komunālie maksājumi ir jāsedz, jo var atslēgt pakalpojumu, bet vecās mēbeles var arī nenomainīt un dzīvokli var neremontēt, ja līdzekḷu visu vajadzību apmierināšanai nepietiek; pārtika ir jāiegādājas, jo neēst nav iespējams, bet ārsta izrakstitas zāles var nepirkt vai analizzes var neveikt; bērnu izglítībā nepieciešamie izdevumi ir jāsedz, lai bērns ieklautos 
4. tabula. Mājsaimniecību īpatsvars, kas var aț̣auties

\section{segt izmaksas noteiktās jomās}

\section{Indikatori}

\section{Īpatsvars}

1. Katru gadu vienu nedēḷu doties brīvdienās | ||||||||||||||||||||||||||||| ārpus mājām

\begin{tabular}{|c|c|c|}
\hline 2. & $\begin{array}{l}\text { Ẽst galu, putnu galu, zivis vai līdzvērtīgu } \\
\text { vegogetāro ēdienu katru otro dienu }\end{array}$ & ||||||||||||||||||||||||||||||||||||||||||||||||||||||||||| \\
\hline 3. & Uzturēt mājokli pietiekami siltu & |||||||||||||||||||||||||||||||||||||||||||||||||||||||||||||||||||||| $\mid$ \\
\hline 4. & Nomainìt nolietotās mēbeles & |||||||||||||||||||||||||||||||| \\
\hline 5. & $\begin{array}{l}\text { Veikt dzīvokḷa remontu, kad tas } \\
\text { ir nepieciešams }\end{array}$ & ||||||||||||||||||||||||||||||| \\
\hline 6. & Iegādāties jaunas drēbes & |||||||||||||||||||||||||||||||||||||||||||||||||| \\
\hline 7. & $\begin{array}{l}\text { Reizi mēnesī uzaicināt radus vai draugus } \\
\text { uz pusdienām }\end{array}$ & |||||||||||||||||||||||||||||||||||||||||||||||||||| \\
\hline
\end{tabular}

(Aptauja par nabadzỉbas un sociāāās atstumtibas riskiem, SUSTINNO, 2015)

izglìtības sistēmā un klases kolektīvā, bet personiskās vajadzības, kā tālāk dzivojošu radu un draugu apciemošana, var arī atlikt; pie friziera ir jāiet, jo uz darbu jādodas sakoptā izskatā, savukārt pie zobārsta vai zobu higiēnista var arī neaiziet, ja vien nav patiešām liela nepieciešamība, utt. Gandrīz katrā izdevumu kategorijā apmēram 10-30\% respondentu vismaz vienu vai vairākas reizes pēdējā gada laikā nav varējuši seǵt vajadzigos tērinus (5. tabula).

Pētijuma rezultāti uzskatāmi parāda, ka nabadzỉbai un materiālai nenodrošinātībai piemīt multidimensionāla ietekme, kas pasliktina nevis vienu vai divas jomas, bet pasliktina cilvēka dzīves kvalitāti vienlaikus vairākos veidos un virzienos. Analizējot iepriekš minētās iespējas atḷauties izdevumus noteiktās jomās, kas aptver atpūtu, uzturu, mājokḷ komunālos maksājumus, mājokḷa iekārtu un stāvokli, apgoèrbu, sociālos kontaktus un interneta pieslēgumu, pētijuma dati sniedz interesantu ieskatu sakarībās starp ienākumiem un lietu skaitu, ko cilvēki var vai nevar atlauties.
5. tabula. Respondentu iespējas segt izmaksas

dažādu vajadzību apmierināšanai (\%)

\begin{tabular}{|c|c|c|c|c|}
\hline Situācija, kas prasijja noteiktu izdevumu segšanu & $\begin{array}{l}\text { Vareja samak- } \\
\text { săt vienmert }\end{array}$ & $\begin{array}{c}\text { Nevarēia sa- } \\
\text { maksatu vienu } \\
\text { vai vairkakas } \\
\text { reizes }\end{array}$ & $\begin{array}{c}\text { Nav bijusi } \\
\text { nepiecie- } \\
\text { samiba }\end{array}$ & $\begin{array}{r}\text { Izmakssas bija } \\
\text { iāsedz, bet } \\
\text { dažei to } \\
\text { nevarếja }\end{array}$ \\
\hline Jāsamaksā par mājokḷa īri & 61,1 & 13,9 & 25 & 18,5 \\
\hline $\begin{array}{l}\text { Jāsamaksā par komunālajiem pakalpojumiem } \\
\text { (siltumu, ūdeni, elektrību) }\end{array}$ & 78,7 & 18,8 & 2,5 & 19,3 \\
\hline $\begin{array}{l}\text { Jāiegādājas mājsaimniecībā nepieciešamās } \\
\text { mēbeles (galds, gulta, krēsls u.tml.) }\end{array}$ & 49,4 & 23,9 & 26,7 & 32,6 \\
\hline $\begin{array}{l}\text { Jānomaksā parādi, lai tiktu atjaunota komunālo } \\
\text { pakalpojumu sniegšana (elektrïbas, siltā ūdens } \\
\text { padeve) }\end{array}$ & 93,7 & 3,2 & 3,1 & 3,3 \\
\hline Jāiegādājas ārsta izrakstītās zāles & 70 & 16,5 & 13,5 & 19,1 \\
\hline $\begin{array}{l}\text { Jāsamaksā par ārsta noteiktajiem } \\
\text { izmeklējumiem (analīzēm, pārbaudēm) }\end{array}$ & 71,4 & 14,4 & 14,2 & 16,8 \\
\hline $\begin{array}{l}\text { Jāizmanto dārgi pakalpojumi-jāapmeklē } \\
\text { zobārsts vai zobu higiēnists }\end{array}$ & 57,8 & 27,4 & 14,8 & 32,2 \\
\hline $\begin{array}{l}\text { Jānopērk ikdienā nepieciešamie pārtikas } \\
\text { produkti }\end{array}$ & 87,8 & 10,5 & 1,7 & 10,7 \\
\hline $\begin{array}{l}\text { Jānopērk mājsaimniecībā nepieciešamās lietas } \\
\text { (mazgāšanas līdzekḷi, sīkais inventārs) }\end{array}$ & 85,9 & 12,3 & 1,8 & 12,5 \\
\hline Jāapmeklē frizieris & 77,2 & 15,9 & 6,9 & 17,1 \\
\hline $\begin{array}{l}\text { Jānopērk bērnam pedagogu prasītais inventārs } \\
\text { vai mācību līdzekḷi (bērnudārzā un/vai skolā) }\end{array}$ & 39,7 & 2,6 & 57,7 & 6,1 \\
\hline $\begin{array}{l}\text { Jāsamaksā par izglitīibas iestāžu } \\
\text { organizētajām ekskursijām, koncertu un } \\
\text { izrāžu apmeklējumiem }\end{array}$ & 40,0 & 4,1 & 55,9 & 9,3 \\
\hline
\end{tabular}




\begin{tabular}{|c|c|c|c|c|}
\hline Situācija, kas prasijja noteiktu izdevumu segšanu & $\begin{array}{l}\text { Varēja samak- } \\
\text { săt vienmēer, \% }\end{array}$ & $\begin{array}{r}\text { Nevarēia sa- } \\
\text { maksāt vienu } \\
\text { vai vairākas } \\
\text { reizes, \% }\end{array}$ & $\begin{array}{l}\text { Nav bijusi } \\
\text { nepiecie- } \\
\text { samiba, } \%\end{array}$ & $\begin{array}{r}\text { Izmakssas bija } \\
\text { jāsedz, bet } \\
\text { dažrezz to } \\
\text { nevarêja, \% }\end{array}$ \\
\hline $\begin{array}{l}\text { Jāapciemo radinieki citā pašvaldībā Latvijā un } \\
\text { jāsedz transporta pakalpojumi (biḷetes, degviela) }\end{array}$ & 61,3 & 24,3 & 14,4 & 28,4 \\
\hline $\begin{array}{l}\text { Jāapciemo tuvi draugi citā pašvaldībā Latvijā un } \\
\text { jāsedz transporta pakalpojumi (biletes, degviela) }\end{array}$ & 60,7 & 24,8 & 14,5 & 29,0 \\
\hline $\begin{array}{l}\text { Jāsvin dzimšanas diena vai vārda diena sev vai } \\
\text { kādam ǵimenes loceklim }\end{array}$ & 74,5 & 20,0 & 5,5 & 21,2 \\
\hline Jāapmeklē kino, teātra izrāde vai koncerts & 57,1 & 32,4 & 10,5 & 36,2 \\
\hline
\end{tabular}

7. tabula. Respondentu materiālās nodrošinātības kategoriju īpatsvars pēc reǵiona

\begin{tabular}{lcc} 
Kategorijas & $\begin{array}{r}\text { İpatsvars } \\
\text { Rīgā̈* }\end{array}$ & $\begin{array}{r}\text { İpatsvars } \\
\text { pārējā } \\
\text { Latvijā }\end{array}$ \\
\hline $\begin{array}{l}\text { Pirmā (mājsaimniecība nevar aț̣auties } \\
\text { 6-8 lietas no saraksta) }\end{array}$ & 4,3 & 15,7 \\
\hline Otrā (nevar aț̣auties 4-5 lietas no saraksta) & 18,8 & 22,3 \\
\hline Trešã (nevar aț̣auties 3 lietas no saraksta) & 16,8 & 12,5 \\
\hline Ceturtā (nevar atḷauties 1-2 lietas no saraksta) & 33,3 & 22,7 \\
\hline Piektā (var atḷauties visu no saraksta) & 26,8 & 27 \\
\hline
\end{tabular}

Izkliedes analīzes rezultāti sniedz priekšstatu par katram deprivācijas līmenim atbilstošās grupas vidējiem ienākumiem (6.tabula). Jāṇem vērā, ka no 2007 aptaujas respondentiem saturiskās atbildes par savu ienākumu limeni sniedza 1414 jeb $70 \%$ respondentu.

Datu analīze, balstoties uz sociāldemogrāfiskiem rādītājiem, atklāja nedaudz negaidìtus rezultātus. Tika konstatēts, ka būtisku atškirību starp vỉriešu un sieviešu materiālo nenodrošinātỉbu nav, kā arī bērnu skaits ǵimenē nav nozīmīgs faktors. Nabadzības riskam pakḷauto iedzivotāju īpatsvara rādītāji dažādās sociāldemogrāfiskās grupās un mājsaimniecībās lika domāt

\section{6. tabula. Vidējie ienākumi dažāâdos deprivācijas līmeṇos}

\begin{tabular}{llcccccccccc}
$\begin{array}{l}\text { Lietu skaits, ko mājsaimniecība } \\
\text { var ațauties }\end{array}$ & & 0 & 1 & 2 & 3 & 4 & 5 & 6 & 7 & 8 \\
\hline $\begin{array}{l}\text { Grupai piederīgo } \\
\text { respondentu skaits }\end{array}$ & Kopā: & 1414 & 32 & 72 & 100 & 146 & 155 & 169 & 154 & 217 & 369 \\
\hline $\begin{array}{l}\text { Vidējie ienākumi uz 1 mājsaim- } \\
\text { niecības locekli grupā, EUR* }\end{array}$ & Vid.: & 329 & 193 & 182 & 211 & 263 & 279 & 318 & 360 & 373 & 415
\end{tabular}

* Ērtibas labad noapalıots lídz veseliem eiro.

(Aptauja par nabadzibas un sociāāss atstumtibas riskiem, sustinNo, 2015)

* Īpatsvars Rigai un pārējai Latvijai noapaḷots lỉdz desmitdạ̄ām.

(Aptauja par nabadzibas un sociālās atstumtỉbas riskiem, susTiNNo, 2015)

par citiem sagaidāmiem rezultātiem, tāpēc saistība starp ienākumiem, mājsaimniecību vajadzībām un izdevumu struktūru prasa papildu izpēti. Savukārt tādi faktori kā nodarbinātība un izglìtība rada nozīmīgas atškirìibas materiālajā nodrošinājumā (un šāda sakarība parādās arì citos pētỉjumos, kā iedzivotāju ienākumu un dzīves apstākḷu apsekojums (Centrālā statistikas pārvalde, 2016a; 2017e)). Piemēram, pie nabadzīgākās kategorijas pieder ap $7 \%$ strādājošo un $20 \%$ nestrādājošo, savukārt aț̣auties tēriṇus visās astoṇās jomās var 32,2 \% visu strādājošo un mazāk nekā $20 \%$ visu nestrādājošo respondentu. Individi ar salïdzinoši augstāku izglìtïbas līmeni ir labāk nodrošināti - vidējie nodrošinātības rādītāji personām ar augstāko izglìiibu ir labvēlīgi (var seğt izmaksas vidēji 6 no 8 definētajām jomām), savukārt indivīdi ar pamatizglìtibu un arodizglìtību ir visvairāk paklauti nabadzības riskam (var segt izmaksas vidēji 4 no 8 jomām).

Latvijas pilsētu un novadu izteikti nevienmērīgais attīstības līmenis nosaka nepieciešamību salīdzināt dzìves līmeni raksturojošos rādìtājus arī reǵ̛ionālā griezumā. Materiālas nenodrošinātības zinā reǵ̛ionu atškirību vidējie rādītāji nav sevišķi izteikti, taču ir vērā ṇemamas atziṇas. Pirmkārt, pretēji vispāratzìtajam pieṇēmumam, ka Latgale sociālekonomiskās situācijas ziṇā ir problemātiskākais Latvijas reğions, vidējais labumu skaits, kuru var atḷauties Latgali pārstāvošie respondenti, ir 5,4; tas ir vienā līmenī 
ar Pierīgu un augsstāk nekā vidējie rādītāji Vidzemē $(5,0)$ un Kurzemē $(5,1)$. Otra svarīga atziṇa ir - vienīgā statistiski nozīmīgā atšḳirība, izmantojot iepriekš izklāstìto astoṇu labumu skalu, ir starp Rỉgu (vidēji var atḷauties 5,9 labumus no astoniem) un pārējiem pieciem regóioniem. Tomēr, salīdzinot dažādos deprivācijas līmeņos esošo mājsaimniecỉbu îpatsvaru Rīgā un pārējos Latvijas reğionos, parādās būtiskas atšḳirības (sk. 7.tabulu, kur mājsaimniecības ir sagrupētas piecās grupās, ņemot vērā statistiski nozīmịgas atškirības ienākumos (eiro) katrai mājsaimniecību grupai salīdzinājumā ar visām pārējām).

Viskrasāk atšķirības izpaužas, salīdzinot visnelabvēlīgāk situēto mājsaimniecību îpatsvaru Rīgã (4,3\%) pret pārējo Latviju (15,7\%). Otrajā vietā ierindojas atšķirības ceturtajā, salīdzinoši pārtikušajā, kategorijā, šie respondenti var aț̣auties lielāko dạı no astoṇiem labumiem - Rỉgā viṇu ịpatsvars ir viena trešā dala,a, un tas pusotru reizi pārsniedz īpatsvaru pārējā Latvijā. Vislabāk situēto respondentu kategorija ir vienlīdz pārstāvēta Rỉgā un pārējā Latvijā (26,8\% un $27 \%)$.

SUSTINNO datu deskriptīvā analīze liecina, ka kopumā 47,1\% jeb gandrīz puse mājsaimniecību nevar atlauties trīs vai vairāk no astonām mūsdienu dzives līmeni raksturojošām lietām (kas dạ̣ēji pārklājas ar materiālās nodrošinātības standarta rādītājiem). Savukārt 33,9\% mājsaimniecību nevar atlauties četras vai vairāk lietas no ši saraksta. Balstoties uz šiem rādìtājiem, aptuveni viena trešā dạ̣a Latvijas mājsaimniecību atzīstamas par nabadzìgām un vēl 13,2 \% atrodas riska zonā.

Jānorāda, ka grūtībās nonākušās sociālās grupas ir ārkārtīgi dažādas. Lielākās no tām ir jaunieši ar zemu izglìtỉbu, viena vecāka ǵimenes, pirmspensijas vecuma cilvēki ar hroniskām slimībām vai neatbilstošu kvalifikāciju, vientuḷie pensionāri. Katras grupas iemesli nokḷūšanai nabadzībā ir dažādi, un atškirīgai vajadzētu būt arī atbalsta pieejai. İsi apkopojot galvenos kvalitatīvās analizzes rezultātus, teju ikviens intervētais cilvēks norāda, ka vismaz reizi ir sastapies ar pazemojošu sociālo dienestu darbinieku attieksmi, kā arī zina nosaukt kādu, kuram palīdzỉba būtu nepieciešama, bet pēc tās nevēršas, jo nevēlas tikt stigmatizēts.

Dažkārt pastāv neatbilstība starp palīdzības faktisko nepieciešamību un loti stingriem noteikumiem, lai kvalificētos palīdzības sanemšanai (šajā jomā ir notikuši nozīmīgi uzlabojumi, tomēr joprojām pieeja ir ḷti formālapiemēram, ja sieviete ar bērniem ir laulībā vai reǵ̛istrēta vienā dzivesvietā ar partneri vai radinieku, kam ir pietiekami ienākumi, bet kurš par sievieti un bērniem materiāli nerūpējas, vina nevar sanemt palīdzību situācijās, kad tā ir neieciešama). Daudzos gadijumos ir nepieciešams nozimīgs un ilgstošs sociālā darbinieka vai jurista atbalsts formālo jautājumu sakārtošanā. Ilgsstošās grūtībās esošie cilvēki bieži neizprot trūcīgā un maznodrošinātā statusa atškirības, nav informēti par savām tiesībām un pienākumiem, ir maz informēti par dažādiem valsts pakalpojumiem savas situācijas uzlabošanai un rīcībspējas paaugstināšanai. Sevišḳi grūtā situācijā ir cilvēki, kuru ienākumi nedaudz pārsniedz noteiktos sliekšṇus - viņiem bieži būtu nepieciešams neliels atbalsts dzives sakārtošanai, lai situācija nepasliktinātos. Diemžēl sociālās palīdzības un sociālo pakalpojumu sistēma ir neelastīga un nekāda palīdzība riska zonā esošiem cilvēkiem nav paredzēta. Jāatzimēe, ka ḷoti ierobežotā sociālā budžeta dēḷ liela dạa formāli pastāvošo pakalpojumu faktiski nav pieejami pat tiem, kuriem tie pienākas un būtu nepieciešami, lai efektīvāk pārvarētu radušās grūtỉbas (piemēram, ǵimenes asistenta pakalpojums trūcīgām sociālā riska g̛̣imenēm).

\section{Strādājošo nabadzība}

Kaut arī dati rāda, ka darbspējas vecuma iedzīvotāju vidū nabadzības riskam vai-

rāk ir paklauti bezdarbnieki, piemēram, 2016. gadā-56,5\% (Centrālās statistikas pārvalde, 2018, 18. janv.), iesaiste darba tirgū nepalìdz pārvarēt nabadzỉbu arī daḷai strādājošo. Salīdzinot dažādas ES dalībvalstis, redzams, ka strādājošo nabadzïbas riska indekss (in-work at-risk-of-poverty rate) Latvijā ir pat zemāks nekā vidēji ES. 2016. gadā strādājošo nabadzības riska indekss Latvijā bija 8,3\%, savukārt ES-28 - 9,6\% (Eurostat, 2016b). Tomēr strādājošo nabadzībai būtu jāpievērš nopietna uzmanība kaut vai tādēl, ka tas ir relatìvs rādìtājs un drīzāk raksturo kopējo ienākumu līmeni valstī, nevis to, kādu mājsaimniecību dzīves līmeni var nodrošināt ar nopelnīto algu. Piemēram, strādājošo nabadzības riskam pakḷauto cilvēku ịpatsvars Vācijā un Lielbritānijā ir lielāks nekā Latvijā, tomēr vidējais atalgojuma un ienākumu līmenis šajās valstīs ir daudz augstāks. 2015. gadā vidējais neto gada ienākums strādājošajam (bez apgādājamiem) rūpniecībā Latvijā bija 9588 eiro, savukārt Vācijā un Lielbritānijā - attiecīgi 46800 eiro un 49620 eiro (Eurostat, 2017d). Rādītāji liek domāt, ka pat vidējās algas saṇēmējs Latvijā sastopas ar lielākām grūtībām nekā zemas algas saṇēmējs Lielbritānijā vai Vācijā.

Vairākums iedzìvotāju Latvijā ienākumus gūst no darba algas vai sociālajiem pabalstiem (pensijas, dažādu veidu pabalsti). Piemēram, 2016. gadā Latvijā ienākumi no algota darba veidoja 71,2 \% no visiem mājsaimniecību rīcībā esošajiem ienākumiem, savukārt sociālie pabalsti - 24,7\% (Centrālā statistikas pārvalde, 2017e). Tātad strādājošo nabadzības riska indekss faktiski ir atkarīgs no atalgojuma un dažādiem sociālajiem transfertiem. Ja vidējais atalgojums ir neliels, tad arī mediāna ir maza un attiecīgais nabadzỉbas riska slieksnis ir zems. Šis indikators maz raksturo reālo materiālo nenodrošinātỉbu (material deprivation), t.i., personas vai mājsaimniecības iespējas iegādāties pirmās nepieciešamības preces vai pakalpojumus.

Eurostat un Centrālā statistikas pārvalde nepiedāvā statistisko datu apkopojumu un aprēkinus par strādājošo materiālo nenodrošinātību. Dati ir 
pieejami tikai par visu iedzìvotāju materiālo nenodrošinātības indeksu ${ }^{4}$. 2015. gadā materiālās nenodrošinātības indekss Latvijā bija 26,4\%, bet ES vidēji-15,7\% (Eurostat, 2017c). Jāuzsve ka šis indekss neieklauj tādu pakalpojumu grupu kā veselības aprūpe. Tomēr Latvijā ir îpaši svarīgi pievērst uzmanību veselības aprūpes pakalpojumu pieejamībai, jo valsts izceḷa ar vienu no mazākajiem asignējumiem veselïbas aprūpei ES un ievērojamu pacientu līdzmaksājumu dalu. 2014. gadā Latvija veselības aprūpei tērēja 5,88 \% no IKP, savukārt ES vidēji-10,04\%. Lỉdzmaksājumu dą̧a pacientiem Latvijā ir 35,13\% no visiem izdevumiem veselības aprūpei, savukārt ES dalībvalstīs-vidēji 13,94\% (World Bank, 2017). Rezumējot, veselïbas aprūpei Latvijā atvēl ḷoti maz naudas, turklāt pašiem pacientiem jāsedz ievērojama dala no pakalpojumu izmaksām. Tas ippaši sāpīgi skar noteiktas sociālās grupas, piemēram, nabadzības riskam pakḷautos. Tāpat veselības aprūpes izdevumu neiekḷaušana materiālās nenodrošinātības indeksa aprēkinos var nesniegt patiesu priekšstatu par materiālās nenodrošinātības riskam pakḷauto ipatsvaru un nabadzibas daudzdimensionālo raksturu.

Lai kompleksāk aplūkotu nabadzības riskus un novēr-

4 Materiāāās nenodrošinātibas indekss raksturo to personu ipatsvaru (\%) kuras nespēj seğt/atlauties vismaz trìs no tālāk minētajām preču vai pakalpojumu grupām komunālos maksājumus, iri vai atmaksāt kreditu; 2) finansiāli ațauties uzturêt mājokli siltu; 3) pēkšṇus, neparedzētus izdevumus no pašu lïdzeklịem; 4) èst galu, putnu galu vai zivis katru tro dienu; 5) katru gadu vienu nedēlu doties brivdienăs arpus majām; lietot savām vajadzibām 6) vieglo auto; 7) velas mazgājamo mašinu; 8) krâsu televizoru; 9) telefonu (Centrāāā statistikas pärvalde, 2017, 15. dec.). 5 Veselibas aprūpes pakalpojumu pieejamib atsevišk̦i aplükota nākama apakšnodaḷ îpatsvaru, pētijjumā tikai aptaujāti 2007 respondenti 15-74 gadu vecumā. Lai padzilināti novērtētu materiālās nenodrošinātības risku strādājošo grupā, tālākā analīzē tika ieklauti 1246 respondenti, kuri aptaujas brīdī bija nodarbināti un kuri bija darbspējas vecumā (15-64 gadi).

SUSTINNO aptaujas datu analīzes rezultāti liecina, ka 25,7\% aptaujāto strādājošo Latvijā ir paklauti materiālās nenodrošinātības riskam, ja tiek ṇemta vērā arī veselības aprūpes pakalpojumu pieejamỉba. Kontekstam jāatceras, ka nabadzības riskam Latvijā 2015. gadā bija pakḷauti $21,8 \%$ no visiem iedzīvotājiem un materiālajai nenodrošinātỉbai - 26,4 \% no visiem iedzīvotājiem. Tā kā strādājošo nabadzībai pakḷauti 8,9\% respondentu, tas vedina domāt, ka attiecīgi arī strādājošo materiālās nenodrošinātības rādìtājiem jābūt zemākiem nekā vidēji valstī. Tomēr atškirīibā no Eurostat nenodrošinātības mērīšanas aprēkinos SUSTINNo pētijumā ir ieklauta veselības aprūpes pakalpojumu grupa, kas būtiski maina rezultātu. Daudzi aptaujātie strādājošie nevarēja atḷauties ārsta izrakstītās zāles vai nozīmētos izmeklējumus.

Log̣istiskās regresijas analīze identificē, ka strādājošo materiālās nenodrošinātības riskam visbiežāk pakḷautas ir personas pirmspensijas vecumā, vīrieši, personas ar zemu izglìīibas līmeni, kā arì indivīdi, kas ir ilgsstoši slimi vai invalīdi. Tāpat jāpiemin tas, ka lielāks materiālās nenodrošinātības risks ir personām, kuras ir nodarbinātas nepilnu laiku. Šie secinājumi lielā mērā

sakrìt ar citos pētijumos un statistisko datu apsekojumos konstatēto. Taču ir arī satraucošas indikācijas, ka sociālajiem transfertiem (to esamībai mājsaimniecībā) nav statistiski nozīmīga ietekme uz materiālās nenodrošinātības risku strādājošo grupā. Dažāda veida transferti ir pārāk mazi, lai samazinātu strādājošo materiālās nenodrošinātības risku.

Domājot par attīstības scenārijiem nākotnē, minētā aptauja liecina, ka materiālās nenodrošinātības risks dažās sabiedrības grupās, visticamāk, nemazināsies, ja nem vērā faktorus, kas ir saistīti ar darba devēja un pašu cilvēku ieguldījumu zināšanās un prasmēs. Piemēram, strādājošajiem ar pamatizglìtību ir deviṇas reizes mazāk izredžu (odd ratio) būt iesaistītiem kādā apmācībā darbavietā nekā strādājošajiem ar augstāko izglìtỉbu. Mazākas izredzes būt iesaistītiem apmācībā ir arī nelatviešiem un tiem darbiniekiem, kuriem ir terminēti darba lïgumi. No tā var secināt, ka prasmju plaisa (skills gap) iepriekš identificētajām nodarbināto grupām nākotnē varētu pat palielināties. Citiem vārdiem, personām ar zemu izglìtību varētu būt ievērojami grūtāk paaugstināt kvalifikāciju un tādējādi iegūt labāk atalgotu darbu.

No jau minētā izriet, ka sociālajiem zinātniekiem un politisko lēmumu pienēmējiem būtu jāpārvērtē, kādi indikatori līdz šim ir izmantoti strādājošo nabadzības mērījumos. Nabadzības mērījumos būtu jāiekḷauj tās pakalpojumu vai preču grupas, kuras ir vitāli svarīgas nabadzības riskam pakḷautajās grupās, piemēram, veselības aprūpes pakalpojumi. Šis pētījums arì parāda, ka Latvijā būtu nepieciešamas lielākas investīcijas veselības aprūpē un dažādos aktīvajos nodarbinātības pasākumos, lai paaugstinātu konkurētspēju personām ar zemu izglìtību. Tāpat jāuzsver, ka sociālie transfert ir bijuši pārāk mazi, lai ievērojami samazinātu materiālās nenodrošinātības risku strādājošajiem. Tas nenozīmē, ka jāpalielina dažādi pabalsti (kaut arī elastīgāka pieeja to piešḳiršanā ir jāapsver), bet politisko lēmumu pieṇēmējiem būtu jādomā, kā palielināt strādājošo rīcībā esošos ienākumus. Latvijas gadijumā tas nozīmētu vienlaicīgi algas palielināšanu un nodokḷa sloga samazināšanu zemāk atalgotajām strādājošo grupām. 2017. gada vasarā pieṇemtā nodokḷu reforma bija vērsta tieši šajā virzienā, un jau 2018. gada noslēgumā būs redzams, vai reforma ir bijusi pietiekami efektīva strādājošo nabadzības un ienākumu nevienlīdzības mazināšanai

Veselības aprūpes pieejamība un veselības stāvokḷa nevienlīdzïba
SUSTINNo veiktās aptaujas rezultāti parāda, ka ievērojamai daḷai Latvijas iedzīvotāju veselības problēmas un nepieciešamības tās risināt pārvēršas par finansiālu izaicinājumu. Kopumā ṇemot, iegādāties ārsta izrakstîtās zāles kaut vienu reizi pēdējos 12 mēnešos nevarēja 16,5\% respondentu, kuriem bija radusies šāda vajadzība. Samaksāt par ārsta noteiktajiem izmeklējumiem 
8. tabula. Deprivācija veselības aprūpes jomā regionālā griezumā (\%)

\begin{tabular}{|c|c|c|c|c|c|c|c|c|}
\hline & 点 & 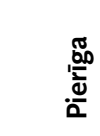 & $\begin{array}{l}\stackrel{0}{E} \\
\stackrel{N}{N} \\
\stackrel{N}{>}\end{array}$ & $\begin{array}{l}\stackrel{\ddot{E}}{E} \\
\underline{\underline{N}}\end{array}$ & 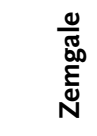 & $\begin{array}{l}\frac{0}{\pi} \\
\frac{\pi}{5} \\
\text { J }\end{array}$ & 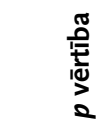 & 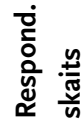 \\
\hline $\begin{array}{l}\text { Nevarēja iegādāties } \\
\text { ārsta izrakstītās zāles }\end{array}$ & 20,96 & 15,28 & 14,74 & 20,27 & 16,17 & 24,16 & 0,025 & 1736 \\
\hline $\begin{array}{l}\text { Nevarēja samaksāt par } \\
\text { ārsta nozīmētājiem } \\
\text { izmeklējumiem } \\
\text { (analīzēm, pārbaudēm) }\end{array}$ & 18,32 & 16,82 & 12,85 & 19,37 & 14,66 & 17,13 & 0,361 & 1722 \\
\hline $\begin{array}{l}\text { Nevarēja ațlauties } \\
\text { zobārsta/higiēnista } \\
\text { pakalpojumus }\end{array}$ & 29,27 & 35,62 & 23,11 & 38,34 & 34,51 & 36,59 & 0,002 & 1710 \\
\hline
\end{tabular}

(Aptauja par nabadzibas un sociālās atstumtibas riskiem, SUSTINNO, 2015)

9. tabula. Ilgstošas saslimšanas/invaliditātes izplatība Latvijā reǵionālā griezumā (\%)

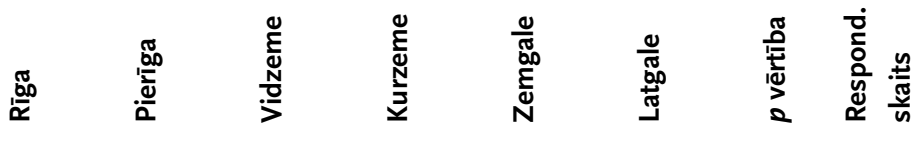

Vai Jums ir kāda

$12,28 \quad 15$,

25,65

20,08

$26,44 \quad 24,62$

O 2007

gstoša saslimšana

vai invaliditāte? «Jā

atbilžu ipatsvars

(Aptauja par nabadzibas un sociāāās atstumtibas riskiem, suSTINNO, 2015)

(analīzēm, pārbaudēm) nevarēja 14,4\% respondentu, kuriem šãda vajadzī-

ba bija. Dārgākus, bet visiem nepieciešamus ārstniecibas pakalpojumus, kā

zobārsta vai zobu higiēnista apmeklējums, nevarēja aț̣auties $27,4 \%$ respon-

dentu. Uz dažu citu deprivācijas rādìtāju fona var izskatīties, ka šie rādītāii

nav tik augsti, tomēr jānem vērā, ka veselïbas aprūpe un slimìbu novēršana vistiešākajā veidā nosaka cilvēku dzives kvalitāti, ilgumu un arī veiktspēju (darba tirgū, ǵimenē utt.), līdz ar to situācija, kurā septìtā dala vai pat ceturtāa dą̣a Latvijas iedzīvotāju nevar ațlauties noteiktus veselïbas aprūpes pakalpojumus, ir atzistama par satraucošu.

Nemot vērā izteiktu reǵionālo nevienlīdzỉbu Latvijā, deprivācijas līmenis veselības aprūpē jāanalizē arī reǵionālā griezumā. Analīzes uzskatāmỉbai aplūkots to respondentu ipatsvars, kuri kaut vienu reizi pēdējos 12 mēnešos nevarēja seğt izmaksas par ārsta izrakstītām zālēm, ārsta nozīmētiem izmeklējumiem un zobārsta vai zobu higiēnista pakalpojumiem. Respondentu îpatsvars salīdzināts sešu plānošanas reǵionu starpā (Rỉga, Pierīga, Vidzeme, Kurzeme, Zemgale, Latgale) (8.tabula).

No šīs tabulas redzama visai neviendabīgā situācija ar veselības aprūpes pakalpojumu finansiālo pieejamību dažādos Latvijas reğionos. Pirm kārt, nav novērotas statistiski nozīmīgas atškirības $(p=0,361)$ ārsta nozīmēto izmeklējumu pieejamībā, šis rādìtājs svārstās 17-19 procentpunktu robežās, turklāt vislielākais deprivēto cilvēku ippatsvars ir nevis Latgalē, bet Kurzemē. Otrkārt, reĝ́ionālās atškirības izteiktāk izpaužas jautājumā par ārsta izrakstīto zālu iegādāšanos, taču šajā jautājumā vislabvēlīgākā situācija ir nevis Rīgā (kas ir vienīgais reĝ́ions Latvijā, kurā nabadzības rādītāji ir zem vidējiem Eiropā), bet Vidzemē (14,7\%), savukārt Latgalē šis rādītājs ir gandrīz par 10 procentpunktiem augstāks un viena ceturtā dala a $(24,2 \%)$ iedzivotāju nevar iegādāties ārsta izrakstītas zāles. Šīs atškirības arī ir statistiski nozīmīgas $(p=0,025)$. Treškārt, vislielākās atšḳirīibas parādās zobārsta un higiēnista sniegto pakalpojumu jomā $(p=0,002)$, un šoreiz - starp Vidzemi (nevar atlauties $23,1 \%$ respondentu) un Kurzemi (38,3\% respondentu). Zimigi ir tas, ka visās trijās dimensijās Rīga uzrāda viduvējus rādìtājus, kas, ṇemot vērā augstāku vidējo darba atalgojumu Rỉgā, var liecināt par izteiktu sabiedrības noslānošanos. Zināmā mērā pārsteidzoši ir tas, ka Pierīga, kas asociējas ar tuvibu galvaspilsētai un bieži tiek uzskatìta par vietu, uz kuru no Rỉgas pārceḷas pārtikušāki iedzìvotāii, uzrāda nelabvēlīgu rādītāju zobārstu pakalpojumu finansiālās pieejamības zinā (35,6\% Pierīgas iedzivotāju un 36,6 \% Latgales iedzivotāju norāda, ka pēdējā gada laikā nevarēja atlauties zobārsta vai higiēnista pakalpojumus, kad tie bija nepieciešami).

Šì aina aktualizē jautājumu par Latvijas iedzìvotāju veselības stāvokli, jo šie rādītāji būtiski raksturo dzīves līmeni un dzīves kvalitāti. Turpinoties sabiedrības novecošanās procesiem un padziḷinoties t. s. demogrāfiskajai bedrei, paredzamā nākotnē šis jautājums kḷūs arvien asāks un aizvien vairāk ietekmēs Latvijas sociālekonomisko situāciju.

Saskanā ar SUSTINNO aptaujas datiem (2015) 19,3\% jeb viena piektā dala Latvijas iedzīvotāju sniedza apstiprinošu atbildi uz jautājumu, vai viniiem ir kāda ilgsstoša saslimšana vai invaliditāte. Turklāt divas trešdalas (67,53\%) no tiem, kas atzina šādas saslimšanas esamību, norādijja, ka tā ierobežo tādas 
vinu ikdienas aktivitātes kā darbs, mājsaimniecības darbi, bērnu aprūpe. Aplūkojot šos datus, redzamas lielas atšķirības šĩ viena veselības stāvokḷa rādìtājā Latvijas reǵionos. Vismazāk par ilgstošu slimību vai invaliditāti sūdzas Rỉgas iedzīvotāji (12\%), visvairāk - respondenti Vidzemēe, Zemgalē un Latgalē, kur attiecīgie procenti ir līdzīgi (viena ceturtā dạ̦a reĝ́iona iedzìvotāju). Tā iemesli meklējami gan sabiedrības vecuma struktūras īpatnībās (līdz ar vecuma palielināšanos veselība kopumā kḷūst sliktāka), gan arī medicīnisko pakalpojumu finansiālā un īpaši góeogrāiskā pieejamỉbā (mazpilsētās un lauku novados varētu būt izteiktāks ǵimenes ārstu un jo īpaši ārstu speciālistu trūkums, noslogotība utt.).

Veselības jautājumiem ir jāpievērš pastiprināta uzmanība, jo Latvijas veselības aprūpes sistēma ir novērtēta kā viena no sliktākajām Eiropā, vidējais iedzivotāju paredzamais mūža ilgums ir 72,2 gadi (otrs zemākais rādītājs ES), Latvijā pastāv saskarsme ar nopietnām sabiedrības veselības problēmām - augsta HIV saslimstỉba, liels alkohola patērinš un viens no augstākajiem pašnāvību rādītājiem pasaulē, vairāk nekā 10\% iedzīvotāju savu veselību vērtē kā sliktu vai l,oti sliktu (European Commission, 2013; EuroHealthNet, n.d.). Tādēl pētījumā tika pievērsta uzmanība arī veselības stāvokḷa pašnovērtējumam saistībā ar veselības stāvokḷa nevienlīdzības padziḷinātu analīzi. Veselības stāvokḷa pašnovērtējumā tika konstatēti faktori, kam bija vislielākā ietekme. Tie ir: vecums (jo vecāks ir cilvēks, jo sliktāks ir vina veselības stāvokḷa pašnovērtējums); nodarbinātības statuss (bezdarbnieki un ekonomiski neaktīvie iedzivotāji novērtē savu pašreizējo veselības stāvokli kā sliktāku); izglìtības līmenis un ienākumi (jo zemāks ir cilvēka izglitiibas līmenis un ienākumi, jo sliktāk viṇš novērtē savu pašreizējo veselības stāvokli). Tika identificēta arì saistỉba ar medikamentu patēriņu, veselības aprūpes pakalpojumu pieejamību un kvalitāti (cilvēki, kuri raksturoja savu veselības stāvokli kā sliktāku, bija kritiskāki par veselības aprūpes pakalpojumu kvalitāti un pieejamību, kā arī patērēja vairāk medikamentu), dzìves un darba apstākḷiem. Daudzi minētie faktori ir ietekmējami ilgtermināa un pakāpeniski, atsevišḳos gadỉjumos pat paaudžu nomainas kontekstā. Lielāka uzmanība būtu jāpievērš individuālās uzvedības, materiālā nodrošinājuma un veselības aprūpes pakalpojumu pieejamỉbas un kvalitātes aspektiem (Tripāne, 2018).

\section{Mājokḷa nedrošība}

Mājokḷa situācija Latvijā analizēta, lai noskaidrotu tos aspektus, kuri var ietekmēt iedzivotāju nedrošību par savu mājokli pēckrīzes periodā (2010-2016). Pētỉjumā pievērsta uzmanība mājokḷa kvalitātes, īpaši-labiekārtojuma jautājumiem un finansiālajai drošībai, kā arì tā subjektīvajam novērtējumam un mājokḷa politikai. Mājokḷa politikas analīzē tiek aplūkoti sociālās mājokḷa politikas rezultāti un iespējamie trūkumi, tos saistot ar nevienlīdzības dimensiju un grūtību uzkrāšanos (cumulative disadvantage).

Analizējot mājokḷa kvalitātes rādītājus, izmantoti Latvijas Centrālās statistikas pārvaldes dati (t. sk. Mājsaimniecību budžeta apsekojums), EUSILC (apsekojums «Eiropas Savienibas statistika par ienākumiem un dzives apstākḷiem»), citi Eiropas Statistikas biroja (Eurostat) dati. Latvijas iedzivotāju mājokḷ apstākḷu novērtējums veikts, salīdzinot to dinamiku pēckrīzes periodā un atseviškos rāditājos pievēršot uzmanību Eiropas Savienības datu kontekstam. Mājokḷa kvalitāte tiek vērtēta pēc objektīviem rādītājiem (piemēram, labiekārtojuma līmenis, maksājumu īpatsvars mājsaimniecību budžetā u. c.) vai pēc subjektīvā viedokḷa, kas iegūts statistikas apsekojumos vai socioloğiskajās aptaujās.

Apkopojot datus par mājokḷa labiekārtojuma rādītājiem un platību uz vienu iedzīvotāju, jāsecina, ka Latvijā mājokla kvalitātes rādītāii un vienas personas apdzīvotā dzīvojamā platība kvadrātmetros uzlabojas gan laika griezumā, gan salīdzinājumāa ar citām ES valstīm. Tomēr dati liecina arī par iespējamu neizdevigā situācijā nonākušu iedzìvotāju «iestigšanu nedrošíbā», proti, neizdevigie apstākḷi mēdz uzkrāties un savstarpēji pastiprināt cits citu. Par mājokḷa kvalitātes nodrošinājuma uzlabošanos var secināt, analizējot datus par tām mājsaimniecībām, kuru mājokḷi ir apgādāti ar karsto un auksto ūdeni, kanalizāciju, nav pārapdzīvoti un kam nav pārāk smagas finansiālās nastas. Tomēr Latvijā vēl arvien nozìmīga dala mājsaimniecību ikdienā iztiek bez šīm ērtībām un uzskata mājokḷa uzturēšanas maksājumus par-«lıoti apgrūtinošiem».

Ja mājoklī nav kanalizācijas, siltā un aukstā ūdens, tad 21. gadsimtā Eiropā tās tiek uzlūkotas kā mājokḷa deprivācijas pazimes. Ja vismaz trīs pazimes konstatējamas vienlaicīgi, tad jau to var saukt par dziḷu deprivāciju (Eurostat, 2014). Pēckrīzes periodā to mājsaimniecību îpatsvars, kurās vērojamas deprivācijas pazīmes, ir samazinājies, taču novērojamas būtiskas atškirīibas dažādām sociāldemogrāfiskajām grupām un teritoriālajām vienībām. 2016.gadā 91,4\% Latvijas mājsaimniecību bija nodrošinātas ar auksto ūdeni (ir ūdensvads), 83,8\% - ar karsto ūdeni, 84,3 \% mājsaimniecību mājoklos bija vanna vai duša un $85,7 \%$-tualete ar ūdens novadu (Centrālā statistikas pārvalde, 2016b). Mājokla labiekārtotība ar aukstā un karstā ūdens nodrošinājumu un kanalizāciju vēl arvien statistiski nozīmīgi atškiras laukos un pilsētās. Pilsētās ar šīm ērtībām ir nodrošināti vairāk nekā 95\% mājokḷu, savukārt laukos arī 2016.gadā aukstā ūdens nebija katrā piektajā (22,4\%) mājoklī; kanalizācijas nebija katrā ceturtajā (26,4\%), bet karstā ūdens - katrā trešajā mājoklī (35,4\%).

Analizējot EU-SILC datus, tika salīdzināti mājokḷa labiekārtojuma pazimju vidējie rādītāji Latvijas un ES iedzivotājiem: I - tekošs jumts, mitras sienas vai trupe logu rāmjos vai grīdās; II - nav vannas vai dušas; III - trūkst tualetes ar ūdens novadu; IV - pārāk tumšs, maz dienasgaismas. Tekošs 
jumts, mitras sienas vai trupe logu rāmjos vai grīdās ir pazīme, kuras novērtējumā ir tikai nelielas atšḳirīibas starp Latvijas un ES iedzivotāju vidējiem rādītājiem (attiecīgi 15,9 un 15,4\%). Vislielākās atšķirības ir vannas, dušas un tualetes ar ūdens novadu esamībā. Piemēram, Latvijā 2016. gadā tualetes ar ūdens novadu trūka 5,4\% iedzīvotāju, bet ES tādu bija tikai o,6\%. Vannas vai dušas trūkumu 2016. gadā norādỉja 8,3\% Latvijas iedzivotāju un 3,6\% respondentu ES (Eurostat, 2017e).

Iedzīvotājiem, kas mīt îrētos sliktas kvalitātes mājokḷos, var būt lielāks risks saskarties ar izlikšanu no mājokḷa, jo jaunajiem ipašniekiem ir objektìvs pamats namu nojaukt, veikt tajā kapitālo remontu, kas ir likumā «Par dzīvojamo telpu ïri» 28. panta 4. dalāa paredzēts attaisnots izlikšanas iemesls (28.2. pants - izlikšana, ja ir trīs mēnešu îres un komunālo pakalpojumu apmaksas parāds; 28.4. pants - izlikšana sakarā ar kapitālo remontu) (Augstākā padome, 1993). Arī denacionalizēta nama īpašnieks var izlikt îrnieku bez citas dzīvojamās telpas ierādīšanas. Šajos gadijumos var runāt par grūtību uzkrāšanos, kas apgrūtina situācijas risinājuma iespējas un prasa papildu resursu piesaisti.

Mājokla platības vidējie rādītāji pēckrīzes gados uzlabojas, kaut saglabājas nozīmīgs pārapdzìvotu mājokḷu īpatsvars (viena istaba katrai pieaugušai personai, pārim un dažādu dzimumu bērniem no 12 gadu vecuma + viena kopēja istaba mājsaimniecībai). Vidējais istabu skaits uz vienu mājsaimniecības locekli palielinājās līdz 2012. gadam pilsētās un līdz 2013. gadam laukos. Pēc tam, 2014.-2016. gadā, tas palika gandrīz nemainīgs. Šis rādītājs raisa pētniecisku interesi, jo iedzīvotāju skaits Latvijā turpina samazināties. Iespējams, to var skaidrot tā, ka ir pietiekami daudz neapdzivotu mājoklu, kuri neietekmē kopējos statistikas datus un netiek apdzivoti neatbilstošas kvalitātes, augsto izmaksu vai citu faktoru (piemēram, sarežg̀itu administratîvo risinājumu) dēl. Pilsētās vidējais istabu skaits uz vienu mājsaimniecības locekli ir 1,1, bet laukos -1,3 istabas. 2016. gadā apdzivotā mājokḷa platiiba uz vienu mājsaimniecību bija vidēji 69,6 kvadrātmetri, mājsaimniecībā tika lietotas vidēji 2,8 istabas un uz katru mājsaimniecības locekli-vidēji 1,2 istabas (Centrālā statistikas pārvalde, 2016b).

Mājokḷa uzturēšanas finansiālais slogis nozīmīgi atšḳiras dažādiem mājsaimniecību tipiem. 2016. gadā pāri ar bērniem mājokḷa uzturēšanai vidēji tērēja 216 eiro mēnesī, un šie izdevumi veidoja 14,4 \% no vinu mājsaimniecības rīcībā esošajiem ienākumiem. Savukārt mājsaimniecības ar vienu pieaugušo un bērniem mājokḷa izdevumiem vidēji tērēja 162 eiro mēnesî, un šie izdevumi veidoja 23 \% no to rīcībā esošajiem ienākumiem. Ievērojami mazāku summu mājokḷa uzturēšanai tērēja vienas personas mājsaimniecības. Vienas (lìdz 64 gadiem) personas mājsaimniecỉbas mājokḷa uzturēšanai vidēji tika tērēts 121 eiro mēnesī, un šie izdevumi veidoja 20,6 \% no personas rīcībā esošajiem ienākumiem. Savukārt vientuḷo

vecākā gadagājuma personu (no 65 gadu vecuma) mājsaimniecībā mājoklim tika tērēti 89 eiro mēnesī, un šie izdevumi veidoja ievērojami lielāku daḷu no šo personu rīcībā esošiem ienākumiem - 27,6\% (Centrālā statistikas pārvalde, 2016b).

Mazaizsargāto grupu situāciju var raksturot kā neizdevīgā stāvokla uzkrāšanos (cumulative disadvantage), kas veidojas, summējoties nelabvēlīgiem faktoriem. Piemēram, zemi mājokḷa labiekārtojuma rādītāji nozīmē zemāku ši īpašuma vērtỉbu mājoklu tirgū, neiespējamỉbu to izmantot kā kỉlu hipotekārā kredīta ṇemšanai un dzives apstākḷu uzlabošanai. Mazaizsargātās grupas mājokḷa jomā ir mājsaimniecības, kurās saimnieko viens pieaugušais ar bērnu vai bērniem, ārpus Rīgas reǵiona dzīvojošie, bezdarbnieki, atseviškì dzīvojošie pensionāri, zemu ienākumu iedzīvotāju grupas.

Radikāls mājokḷa trūkums rezultējas ekstrēmā mājokḷa deprivāci jā-bezpajumtniecībā. Latvijā ir sarežğiti noteikt bezpajumtnieku skaitu, jo statistika pieejama tikai par bezpajumtniekiem, kuri izmantojuši nakts patversmi. Nakts patversme ir sociālais pakalpojums cilvēkiem, kuriem Latvijā trūkst jebkāda mājokḷa vai patvēruma un kuru nakšṇošanas alternativva ir kāpnu telpa, grausti, dārza būdinas un citas dzivošanai nepiemērotas vietas. Lai arī kopumā mājokḷa labiekārtojuma un finansiālās drošības rādītāji uzlabojas, nakts patversmju klientu skaita dinamika neuzrāda bezpajumtniecības gadījumu skaita samazināšanos. Piemēram, 2011.gadā nakts patversmes pakalpojumus izmantoja 5,1 tūkstotis klientu, bet 2016. gadā pat vairāk $-6,7$ tūkstoši. Tas liecina par grūtību uzkrāšanās tendenci mājokḷa nodrošinājumā.

Valsts mājokḷa politika aptver gan regulācijas, gan atbalsta politiku. Centrālās valdības atbalsta politikas galvenie virzieni ir atbalsts energoefektivitātes pasākumiem un garantija bankas aizdevumam mājokḷa iegādei ğimenēm, kurām ir pastāvigi ienākumi, bet nav pietiekamu uzkrājumu pirmās iemaksas veikšanai. Abos minētajos atbalsta veidos iedzīvotājiem pašiem jābūt spējīgiem segt lielāko daḷu maksājumu, un tas nozìmē, ka trūcīgākā iedzīvotāju daḷa šo atbalstu nevar izmantot.

Tiešu atbalstu trūcīgajiem un maznodrošinātajiem iedzīvotājiem mājokḷa jomā sniedz pašvaldības. 2010.-2015. gadā mājokḷa pabalstus îres un komunālo maksājumu segšanai pašvaldības katru gadu izmaksājušas vismaz 80000 cilvēkiem. Tikai 2016. gadā personu skaits, kurām izmaksāts mājokla pabalsts, ir samazinājies līdz 68 101, tomēr viena gada situācija neḷauj spriest par noturïu tendenci (Niklass, Rasnača, 2018).

Sociālās inovācijas kopienu drošumspējas stiprināšana
Pētījumā tika pievērsta uzmanība valsts lomai sociālo inovāciju sekmēšanā un atsevišku sociālo inovāciju piemēriem. 
Latvijā inovāciju jēdziens galvenokārt tiek izprasts tikai šaurajā tehnoloğisko inovāciju nozīmē un izpratne par to, kas ir sociālās inovācijas, vēl veidojas. Normatīvajā regulējumā sociālais aspekts vismaz formāli ir atzìts inovācijas definīcijā Zinātniskās darbības likumā-«inovācija - jaunu zinātniskās, tehniskās, sociālās, kultūras vai citas jomas ideju, izstrādṇu un tehnolog̣iju îstenošana produktā vai pakalpojumā» (Latvijas Republikas Saeima, 2005). Lìdz šim Latvijā trūkst tiesiskā regulējuma sociālajām inovācijām, tomēr 2017. gada oktobrī Saeima pienēma Sociālās uznēmējdarbỉbas likumu (Latvijas Republikas Saeima, 2017). Tas ḷaus atbalstīt sociālās inovācijas, kuras tiks radītas caur sociālajiem uzṇēmumiem, šim nolūkam izmantojot Eiropas Komisijas atbalstu, kohēzijas politikas ietvaros izmantojot struktūrfondu atbalsta programmas. Jāatzīmē, ka starptautisko organizāciju līmenī lielu uzmanību sociālajām inovācijām pievērsis Pasaules Ekonomikas forums, kas ir izstrādājis vadlīnijas valdībām sociālo inovāciju atbalstam. Foruma zinojumā ir atzìta valsts būtiskā nozīme tādu biznesa modelu atbalstišanā, kuri sniedz labumu sabiedrībai. Tajā piedāvāti seši būtiski valstu rīcības virzieni, proti: atbalsts sociālo inovāciju tìkliem un galvenajām ieinteresētajām pusēm, valsts spēju attīstǐšana sociālo inovāciju atbalstam, infrastruktūras attīstī̌ana un sociālo inovāciju starpnieku atbalsts, atbalsts uzṇēmumu izaugsmei, privātā kapitāla papildināšana un rīcībpolitikas izvērtēěsana un uzlabošana (World Economic Forum, 2013).

Novērtējot, kā valsts attīstības plānošanas dokumentos tiek aplūkotas sociālās inovācijas kā sociālās saliedētỉbas veicināšanas instruments un sabiedrïbas labumu veidojošs elements, tika analizēta «Latvijas ilgtspējiggas attīstỉbas stratēǵija līdz 2030. gadam» (LIAS 2030) un «Nacionālais attīstības plāns 2014.-2O2O. gadam» (NAP 2O2O). Ilgtermiṇa plānošanas dokumentā LIAS 2030 (Latvijas Republikas Saeima, 2010) ir lietots sabiedriskās inovācijas jēdziens, un tā nozīme dokumentā sakrìt ar šai rakstā apskatìto. Savukārt nacionālā līmeṇa vidējā termiṇa plānošanas dokumentā «Nacionālais attīstības plāns 2014.-2020. gadam» sociālajai uzṇēmējdarbībai vai sociālajām inovācijām uzmanība nav veltita, inovāciju jēdziens lietots tikai šaurā izpratnē. Arī citos plāna rīcības virzienos nav aprakstīta iespēja problēmu risināšanā iesaistît sabiedrību, kas varētu nākt klajā ar jaunām idejām un panēmieniem. Tas lauj piennemt, ka ilgtermina mērḳus attiecībā uz sociālajām inovācijām būs grūti sasniegt, ja vidēja termina plānošanā sociālās inovācijas netiek uzlūkots kā resurss, ko valsts atbalstîtu sabiedriskā labuma veidošanai. Tomēr Labklājības ministrija strādā pie sociāās uzṇēmējdarbības atbalsta sistēmas izveides, kura tiks testēta pilotprojekta laikā (Labklājības ministrija, 2017).

Neskatoties uz līdz šim formalizēta valsts atbalsta trūkumu, Latvijā identificējamie sociālo inovāciju piemēri aptver dažādas jomas - jauniešu aktivitātes, vides aizsardzību, politisko līdzdalību, invalīdu problēmas un citas. Vides jomā viens no spilgtākajiem piemēriem ir ikgadējā Lielā talka. Kaut arī tas ir kampanveidìgs projekts, tam ir potenciāls veidot ilgstošu sociālo praksi - kolektīvi atgādināt, ka apkārtējo vidi nevajag piesārṇot un ka ikkatrs var sniegt savu ieguldijjumu tās tīīibas nodrošināšanā. Šis piemērs parāda, ka sociālās inovācijas var radīt sociālas pārmainas. Loti nozìmīga sociālā inovācija, kas vērsta uz sabiedrības līdzdalības palielināšanu, ir līdzdalības platforma/portāls ManaBalss.lv, kas dod iespēju vākt parakstus, lai Saeimai nodotu sabiedrības rosinātas likumdošanas iniciativas. Cita elektroniski bāzēta sociālā inovācija ir portāls ziedot.lv, kas palīdz grūtībās nonākušiem cilvēkiem. Latvijā ir sastopamas sociālās inovācijas ne vien pakalpojumu jomā, tiek radīti arī produkti. Viens no piemēriem ir velosipēdi cilvēkiem ar îpašām vajadzībām «HOPP», kuru izveidei atbalstu ir sniegusi starptautiskā kompānija «Narvesen». Velosipēdi tiek pārdoti par pašizmaksu, un šis sociālais uzṇēmums ir arì piegādājis velosipēdus bērniem bez maksas labdarības kampanu laikā (Vingre, 2018)

Jaunu un pietiekami veiksmīgu sociālo uzṇēmumu aplūkojumu varētu turpināt, tomēr tālāk uzmanība tiks pievērsta arì diviem visai atšķirīgiem sociālo inovāciju veidiem. Vienā gadijjumā inovācijas ir vērstas uz pārmainām cilvēku ierastajā uzvedībā, bet otrā - uz jaunu profesionālo un sociālo lomu uzṇemšanos saistỉbā ar jaunām tehnolog̣iskām pārmaiṇām un ar tām saistītām nepieciešamām kompetencēm un prasmēm.

Piemēram, veselības stāvokḷa pašnovērtējuma analīzē tika pievērsta uzmanība negatīvajām tendencēm ar veselību saistītu paradumu kontekstā. Šìs tendences ir, piemēram, neveselīgas pārtikas lietošana, regulārs alkohola patērinš, biežs medikamentu patērinš un zems fiziskās aktivitātes līmenis. Ar veselību saistîtu paradumu ietekmēšanai rīcībpolitikās visbiežāa izmantota informēšana un akcizes nodokḷa paaugstināšana, un šos panēmienus var uzskatīt par rīcības virzìtājiem. Ir pierādīts, ka cilvēki, kas ir informēti par riskiem un ir gatavi rỉkoties saskaṇā ar tiem, visbiežāk nav tie, kuriem tiek identificēta augstākā riska pakāpe (House of Commons. Health Committee, 2009). Savukārt kaitīgo vielu cenas kāpums akcīzes nodokḷa dẹl var radīt pretēju efektu - augstākās riska pakāpes sabiedrības dą̣a visbiežāk nevis samazina tabakas vai alkohola patēriṇu, bet samazina citas izmaksas, piemēram, sāk taupît uz veselīgas pārtikas rēkinina. Cilvēki norāda, ka viniem ir svarīgi ievērot tādu dzivesveidu, kas pozitīvi ietekmē veselības stāvokli, taču pārsvarā to neīsteno. Tādēḷ rīcībpolitikās jāpievērš uzmanỉba gan pozitivu ar veselību saistitu paradumu veicināšanai, gan pārdomātiem ierobežojumiem.

Ar veselību saistītu paradumu ietekmēšana vēlamās rīcības virzienā ir ḷoti nozīmīga, ṇemot vērā ḷoti augstos rādītājus saslimstỉbai ar vēzi (onkoloğiskās slimības ir otrs biežākais mirstỉbas cēlonis Latvijā), tāpēc pētijumā tika izstrādāti priekšlikumi par piemērotākajām pavirzī̌anas metodēm 
ar vēža skrīningu saistītu veselības pārbaužu apmeklējuma uzlabošanai. Kā iespējamie risinājumi tika ieteikti (Silkāne, 2018):

1) atgādinājumu nosūtišana (tie var būt atkārtots atgādinājums pa pastu, atgādinājums pa telefonu, arī atgādinājums ğimenes ārsta vizìtes laikā, iespējami arī mūsdienīgāki risinājumi, piemēram, lietotnes izveide);

2) sociālo normu mainī̌ana (piemēram, plašsaziṇas līdzeklọ aktīvāk informējot par citu sieviešu pieredzi un regulāru pārbaudīšanos veidojot kā normu);

3) pēc noklusējuma principa veidotu uzaicinājumu nosūtišana (uzaicinājuma vēstulē ieklaujot konkrētu vietu un apmeklējuma laiku, kad var ierasties uz pārbaudi; lai to atceltu, ir jāveic papildu darbỉba, zvanot un atsakot apmeklējumu, bet nav nekas jādara, lai pieteiktos);

4) ğimenes ārsta izteikts pamudinājums (ārstam būtu jāmotivē savi pacienti veikt profilaktiskās veselības pārbaudes);

5) iedzīvotāju emocionāla ietekmēšana (lai mazinātu bailes no ārsta apmeklējuma, jāveicina lepnuma izjūta, rūpējoties par savu veselību);

6) nākotnes ieguvumu diskontēšana (uzsvērt ieguvumus - ja cilvēks pārbaudīsies, viňš jutīsies mierīgāks par savu veselību vai arī agrīni atklāto vēzi būs iespējams novērst).

Mūsdienās arvien lielāku nozīmi iegūst digitālā pratība jeb prasmes izmantot dažādas informācijas un komunikācijas tehnoloơijas, lai pieklūtu informācijai un to izmantotu. Attīstoties informācijas un komunikācijas tehnoloğijām, rodas jaunas iespējas un arī riski informācijas pārraidē un informācijas izmantošanā. Bērni un jaunieši ir minami starp aktîvākajām sabiedrỉbas grupām tehnoloğiju un interneta lietošanā. Tajā pašā laikā «EU Kids Online» pētijjuma rezultāti liecina: kaut arī bērni un jaunieši brīvi lieto dažādas ierīces (datorus, planšetdatorus, viedtālrunus u. c.), vinu prasmes novērtēt informācijas resursu kvalitāti nereti nav augstas, kā arī bieži vien bērni neapzinās, kādi riski pastāv vinu darbībai interneta vietnēs un kādas var būt šìs darbïbas sekas (Brikse \& Spurava, 2014). Tāpēc pētijumā īpaša uzmanība tika pievērsta publiskajām bibliotēkām kā sabiedriskām institūcijām, kuras neformālās izglìtības ceḷā var palīdzēt vietējās kopienas iedzìvotāiiem apgūt dažādas prasmes un zināšanas, to skaitā arī digitālo pratību, tādā veidā sekmējot iedzivotāju un kopienas drošumspēju. Padzilināti tika veikta izpēte par bibliotekāru atbilstību digitālās pratības mediatoru lomai un gatavỉbu uzṇemties ar to saistîtos pienākumus informācijpratības, un īpaši digitālās pratības, pilnveidošanā bērnu un jauniešu vecumgrupā. N̦emot vērā, ka bieži vien vecāku spēja veicināt bērnu un pusaudžu digitālo pratību ir zema, citu pieaugušo - skolotāju un bibliotekāru - potenciālā loma digitālās pratības mediācijā kḷūst jo nozīmīgāka

Analīzes rezultāti liecina, ka bibliotekāru pašvērtējums par savām digitālajām prasmēm ir atškirīgs - augstāks pašvērtējums vērojams bibliotekāriem, kas strādā pilsētās, savukārt lauku reǵ̛ionos bibliotekāri (ar dažiem izṇēmumiem) ir kritiskāki. Kopumā bibliotekāri apzinās informācijas un komunikācijas ierī̌u lietošanas prasmju nepieciešamību, kā arī spēj novērtēt savu prasmju vājās vietas, tehnoloğisko prasmju trūkumus, kā arī zināšanu nepilnības informācijas izmantošanas tiesību jautājumos.

Bibliotēku nozares pārstāvju diskusijās tika uzsvērts, ka savu pienākumu profesionālas pildīšanas nolūkā bibliotekāram ir nepieciešams sekot lỉdz jaunākajām tendencēm tehnoloğiju attīstỉbā, norādot, ka bibliotekāram tas būtu jāuzliek par pienākumu, kaut arī nepārtraukta sekošana līdzi izmaiṇām tehnoloǵiju attīstībā prasa laiku un piepūli. Izvērtējot savu potenciālo lomu bērnu digitālās kompetences kontekstā, bibliotekāri un arī nozares pārstāvji atzīst, ka bibliotekāru būtiskais uzdevums ir iemācīt strādāt ar informāciju: bibliotekāram būtu jāprot bērniem iemācīt to, ka internetu ir iespējams izmantot ne tikai izklaidei, spēlēm un sazinai sociālajos tīklos, bet tam būtu jāsaskata bērnu intereses un jāparāda, kā meklēt to, kas viniem šḳiet interesants un ir nepieciešams arī mācībām. Reizē parādās arī jauni izaicinājum saistībā ar bērnu interneta lietojuma uzraudzību un kontroli-bibliotekāri ne vienmēr ir pārliecināti par savu lomu un tiesībām uzraudzìt un kontrolēt to, ko un cik ilgi bērns skatās vai spēlē bibliotēkas datorā.

Kopumā būtiskās izmainas tehnolog̣iju lietojumā ir radījušas nepieciešamību pēc pilnīgi jaunām pieejām bibliotekāru darbā ar bērniem un jauniešiem (Holma, Spurava, 2018). Jāatzìmē, ka šì pētijuma tēma ir veiksmīgi attīstîta gan tālākā starptautiskā sadarbỉbā ar UNESCO, gan sadarbỉbā ar Kultūras ministriju.

\section{Noslēgums}

Globāli raugoties, Latvija ir augstāk attīstìto valstu piecdesmitniekā. Esam iestājušies gan Eiropas Savienībā, gan OECD. Atbilstoši Eiropas pamatvērtībāmcilvēktiesībām, demokrātijai un tiesiskumam - ikvienam ir tiesỉbas dzivvot cienas pilnu un drošu dzivi atvērtā un demokrātiskā sabiedrībā. Vidēja un ilğa termiṇa plānošana Latvijā iet kopsolī ar globālajām tendencēm attīstības plānošanā, centrā izvirzot cilvēku labklājibas kāpumu un sabiedrības, vides un ekonomikas vajadzību līdzsvarošanu. Tomēr, padzilināti analizējot 2008.gada ekonomiskās krīzes sekas un sociālo jautājumu attīstību Latvijā pēdējo gadu laikā, ir pamats uzskatît, ka daudzām sociālajām problēmām ir iespējams at rast labāku risinājumu un Latvija var konsekventāk veidot tādu politiku, ka ìsteno Satversmē nostiprināto Latvijas kā sociāli atbildīgas valsts principu. 
Kaut arī ekonomiskie rādītāij lēnām atgriežas pirmskrīzes līmenī, bezdarbs sarūk un vidējais darba atalgojums kāpj, tomēr nabadzības un sociālās atstumtības riskam pakḷauto iedzīvotāju i ipatsvars būtiski nemainās un materiālās deprivācijas rādītājos joprojām netiekam tuvāk Eiropas vidējiem rādītājiem. Arī reğionu būtiskās sociālekonomiskās atšķirības nemazinās, un daudzos jautājumos nostiprinās nošḳīums starp Rīgu (un Rỉgas ietekmes areālu) un pārējo Latviju. Turklāt statistikā pieņemtie nabadzības mērišanas rādītāji ir relatīvi, un SUSTINNO pētỉjums parāda, ka tie būtu daudz sliktāki, ja nabadzību un materiālo nenodrošinātību mērītu kā daudzdimensionālu fenomenu un sevišḳi-ja par vienu no pamata kritērijiem iekḷautu veselības aprūpes pakalpojumu pieejamibu.

Būtiskie ieteikumi ir veidot starpsektoriālu sociālo politiku, kura vērsta uz starpinstitucionālu sadarbību un kurā dažādu jomu mērḳi ir plānoti savstarpēji saistîti. Gan SUSTINNO, gan citi pētỉjumi rāda ciešu saistỉbu starp zemu izglìtibu, sliktu veselību un zemiem ienākumiem un bezdarbu. Lìdz ar to izglìitibas, veselības, nodarbinātības un sociālās labklājỉbas jautājumi jārisina kompleksi. Jāstiprina arī attīstỉbas plānošanas un rīcībpolitikas veidošanas kapacitāte-rīcībpolitikai ir jābūt pierādījumos (evidencēs) balstìtai, nosprausto mērḳu sasniegšanas monitorēšanai ir jābalstās precizi un atbilstoši formulētos rezultatìvajos rādītājos.

Seviški steidzami uzlabojumi nepieciešami minimālā ienākumu līmeṇa sakārtošanā, strādājošo nabadzības mazināšanā, veselības aprūpes pieejamības stiprināšanā un mājokḷa deprivācijas novēršanā.

Sociālo pabalstu un pensiju apmēram ir jānodrošina vismaz cilvēka cienīgas eksistences minimālie priekšnoteikumi. Tāpēc minimālajiem ienākumu līmeņiem ir jābūt balstīitiem vai nu starptautiskos standartos par nabadzỉbas riska līmeṇa noteikšanu, vai kādos citos pamatotos aprēḳinos. Attiecībā uz strādājošo nabadzību jācer, ka 2017. gadā pienemtā nodoklu reforma sniegss būtiskus uzlabojumus zemo algu saṇēmējiem un mazinās ienākumu nevienlīdzību. Tomēr pārliecīgam optimismam nav vietas tik ilgi, cik ilgi Latvija būs starp ES valstīm ar zemāko minimālo algu. Noteikti jāatvēl vairāk līdzekḷu aktīvās nodarbinātības pasākumiem un pieaugušo izglìtībai, lai palielinātu mazāk izglìtoto darbinieku konkurētspēju un samazinātu prasmju plaisu starp dažādām nodarbināto grupām. Vienlaikus jādomā par šo pasākumu efektivitāti un pieejamību.

Veselības joma nav tradicionāla sociālās politikas joma, tomēr tā ir cieši saistīta ar citām jomām, un labs veselības stāvoklis ir izšķirošs cilvēka darbspējām un spējai veidot savu dzivi atbilstoši paša mērkiem un iecerēm. Veselības jomā ir jādomā ne tikai par reformām. Pirmkārt, ir jāatvēl vairāk līdzekḷu veselības aprūpei un precīzāk jāmērḳē atbalsts zemo algu saṇēmējiem un citām ievainojamām sociālajām grupām, lai uzlabotu pakalpojumu pieejamību un kvalitāti nabadzības riska pakḷautajiem iedzīvotājiem. Otrkārt, rīcībpolitikas veidošanā ir vērts nemt vērā arī subjektīvos veselības pašnovērtējuma rādītājus, jo tie lauj uztvert tendences, kuras tā sauktajos objektīvajos rādītājos neparādās (piemēram, nopietnas slimības, kas nerada letālas sekas), kā arī lauj identificēt sakarības starp veselības stāvokḷa pašnovērtējumu un sociālekonomiskajiem rādītājiem, kas rezultātā lauj veidot efektîvāku, situācijai atbilstošāku rīcībpolitiku. Treškārt, jādomā par efektīvākiem paṇēmieniem nepareizu ar veselību saistitu paradumu ietekmēšanai riska grupām (informatīvas kampanas mūsdienās tiek atzìtas par nepietiekami efektīvām), tāpat arī par pareizu ar veselỉbu saistītu paradumu veidošanu.

N̦emot vērā, ka liels īpatsvars Latvijas iedzīvotāju uzskata ar mājokli saistītos izdevumus par apgrūtinošiem un ka laukos salïdzinājumā ar ES vidējiem rādītājiem ir augsti mājokḷa deprivācijas rādītāji, kā arī pieaug reĝ́istrēto bezpajumtnieku skaits, ir jāapsver īpašas sociālās mājokḷu politikas veidošana. Kaut arī pašvaldỉbas katru gadu izmaksā ievērojamas summas mājokḷu pabalstos, problēmas ir daudz kompleksākas, ar tālejošu ietekmi uz cilvēku dzīves kvalitāti. Slikta mājokḷa kvalitāte var negatīvi ietekmēt kā cilvēka veselību, tā darbspējas, rezultātā sekmējot grūtỉbu uzkrāšanos un dzìves kvalitātes pazemināšanos.

Sociālo inovāciju analīze pētỉjumā parādījās kā nozīmīgs, bet salīdzinoši maz izmantots (un maz pētîts) resurss sociālo problēmu risināšanā, ieklaujošas ekonomikas veidošanā un sabiedrības kopigā labuma sekmēšanā. Pētijjuma ierobežotie resursi lāva padziḷināti novērtēt tikai valsts nozīm sociālo inovāciju sekmēšanā un detalizētāk analizēt vien atsevišḳus gadỉjumus. Jāatzīmē, ka valsts maz izprot sociālo inovāciju nozīmi, par ko liecina gan sociālo inovāciju kā resursa un instrumenta neietveršana NAP 2020 prioritārajā virzienā «Cilvēka drošumspēja», gan arī ilgais un grūtais ceḷš sociālās uzṇēmējdarbỉbas likuma tapšanā. Pētijumā veikto gadỉjumu analizze arì rosina domāt par sociālajām inovācijām ievērojami plašāk, ne tikai skatot tās sociālās uzṇēmējdarbības ietvaros. Tas ḷautu pilnvērtīgi izmantot visas priekšrocības, ko dod dzive 21. gadsimtā. 


\section{Ceḷā no anomijas uz pašorganizāciju un kolektivvu rīcību}

Kopš Latvija atguva neatkarību 1991. gadā, sabiedrības dzivēe ir notikušas būtiskas pārmainas, kas sociālo sistēmu skāra ne tikai makrolimenī, izveidojot jaunu politisko iekārtu, pārstrukturējot sabiedrības ekonomisko dzivi un sociālo struktūru, bet arī mikrolīmenī-tika izmanīta ikviena sabiedrības locekḷa ikdienas dzīve un paradumi, katram vajadzēja pārvērtēt savu attieksmi pret ḷoti daudzām vērtībām. Privatizācijas procesa lïkloči, pieredze tirgus ekonomikas attiecībās, Latvijas iestāšanās Eiropas Savienībā, brīvā darbaspēka kustība un vēl daudzi citi nozīmīgi notikumi pēdējo gadu desmitu vēsturē daudziem cilvēkiem gan pavēra jaunas iespējas, gan arī, gluži pretēji, izgrūda tos no ierastās rutīnas, sadragāja iecerētos dzives plānus. Dzilāa ekonomiskā krīze un atkopšanās pēc tās atstāja neizdzēšamu iespaidu uz Latvijas sabiedrību. Lìdztekus anomijai, kas izpaužas kä atšḳirìgu un savstarpēji konfliktējošu priekšstatu, atmiṇu un normu pastāvēšana sabiedrībā un kas rada haosu un apdraudējuma sajūtu, var konstatēt dažādas pilsoniskas lỉdzdalỉbas un sabiedrỉbas pašorganizācijas formas. Tās iezīmē cerīgas attīstỉbas tendences, kuru izpēte būtu jāturpina arī pēc valsts pētijumu programmas SUSTINNO pabeigšanas.

\section{Anomija un pēckrīzes}

sociālie procesi Latvijā

Anomijas jēdziena izmantošana ir inovativa pieeja Latvijas sabiedrisko procesu interpretācijai. Valsts pētijumu programmas «Inovācija un ilgtspējiga attīstiba: Latvijas pēckrizes proces globālā kontekstā» (SUSTINNO) projekta «Sabiedrības vērtīborientācijas un sabiedrības atjaunošanās» pētnieku komandas pētỉjumu rezultātā tikta padzilināta un paplašināta izpratne par Latvijas sabiedrībā izplatīto vērtīborientāciju genenēzi un ietekmi uz sociālo izturēšanos, t. sk. uz patēriṇa ieradumiem, ǵimenes modeliem un reproduktivo uzvedỉbu, kas loti nozimigi ietekmē ilgtermina demogrāfiskās prognozes. Projekta îstenošanas gaitā iegūtās atziṇas iezīmē nākamo pētijjumu aprises, palìdz formulēt jaunus pētnieciskos jautājumus par sabiedrïbas pašorganizācijas potenciālu, politisko līdzdalību un sabiedrisko labumu. Nozīmīgākie projekta gaitā veiktajos pētijumos iegūtie secinājumi apkopoti kolektīvajā monogrāfijā «Apmaldỉjušies brīvibā: anomija mūsdienu Latvijā», kas Latvijas Universitātes Akadēmiskajā apgādā izdota 2018. gadā. Šeit piedāvājam îsu projekta galveno atzinu apkopojumu, kas raksturo anomijas izpausmes Latvijas sabiedrībā, anomijas ietekmi uz politisko lỉdzdalību (îpaši jauniešiem), demogrāfisko uzvedību. Nozimings anomiju raksturojošs fenomens ir atmiņas par padomju laiku, tas skar lielu dalu Latvijas iedzivotāju.

Pēdējos gadu desmitos pārdzīvoto križu pieredze un ekonomiskās nenoteiktibas sajūta nav veicinājusi Latvijas iedzivotāju domāšanu un plānošanu ilgterminā, kas būtu nepieciešama, lai notiktu ilǵtspējiga valsts attīstỉba. 
Latvijā, tāpat kā Austrumeiropā kopumā, līdz šim iedzīvotāju attieksme pret ieguldijjumu kopējā labumā bijusi problemātiska, par ko liecina gan augstais ēnu ekonomikas īpatsvars, gan zemā sabiedriskā aktivitāte. Padomju mantojuma ietekmē sabiedrībai raksturīgs zems uzticēšanās līmenis līdzcilvēkiem un varai, kā arī vispārēja sabiedrības atomizācija. Lai gan šis problēmas ir labi zināmas, lìdz šim trūka zinātniski pamatotas informācijas par to, kas ietekmē Latvijas iedzìvotāju attieksmi pret līdzcilvēkiem, pilsonisko aktivitāti, sociālo atbildīgumu, sabiedrisko labumu un valsti. Citu postsociālisma valstu pieredze vedina domāt, ka šie procesi varētu būt noveduši pie situācijas, ko sociālajās zinātnēs apzīmē ar jēdzienu «anomija» (Mieriṇa, 2016).

Anomija ir atškirīgu un savstarpēji konfliktējošu priekšstatu, atminu un normu pastāvēšana sabiedrībā, tā rada haosu un apdraudējuma sajūtu, veicinot sabiedrības atomizāciju, indivīdu dezorientācijas, bezpalīdzīguma un dzìves bezjēdzìguma sajūtas izplatību, kā arī sociāli deviantu uzvedību un sabiedrības apgrūtinātu funkcionēšanu. Projekta realizācijas gaitā tapušajās publikācijās (piemēram, Misāne, 2016b) izsekots anomijas jēdziena lietojumam dažādu teorētiḳu darbos no E. Dirkema līdz P. L. Bergeram, kā arī starptautiski zināmos lietiškajos socioloğiskajos pētỉjumos (L. Sroles darbos u.c.). Iezīmētas trīs atšķirịgas anomijas jēdziena pamatinterpretācijas - kolektîvā sociālā anomija (anomie), individuālā anomija (anomia) un sociāli konstruētā anomija (anomy).

Konstatēts, ka individuālās anomijas izpētei piemērotākas ir kvantitatīvas pētnieciskās metodes, taču ir nepieciešama biežāk lietoto anomijas skalu (Leo Srole's anomia scale un tās modifikāciju) precizēšana un paplašināšana. Citu anomijas veidu izpētei piemērotāka ir jaukta metodolog̣ija, kurā kombinētas kvalitatīvās socioloǵijas, likumdošanas/dokumentu analīzes u.c. metodes (Misāne, 2016a). Jebkurā gadijumā anomija ir ārkārtējs, nenormāls stāvoklis, kas rodas, vājinoties indivìda un plašākas kopienas sociālajām saitēm un tādējādi identifikācijai ar kopienas vērtībām. Var secināt, ka anomijas risks pārejas sabiedrībās, arī Latvijā, vienmēr ir objektīvi augstāks. Daḷa veco sociālo institūciju ir likvidēta, to vietā radušās jaunas, kas vēl nav paspējušas iegūt pietiekami spēcīgu autoritāti. Sabiedrības locekḷiem nākas konstruēt jaunas identitātes. Daḷa sociālo normu vairs nedarbojas. Pie klasiskiem izaicinājumiem var minēt arī pilsonības statusa mainuu, piemērošanos citai valsts valodai un ekonomiskai sistēmai, naudas, ipašumu struktūras, izglitīibas vai pensiju sistēmas reformas.

Pētijuma dati ḷauj secināt, ka pat daudzus gadus pēc neatkarības atgūšanas un zināmā mērā saistībā ar pārmainu procesiem sabiedrībā Latvijā ir vērojams augsts sabiedrības atsvešinātības līmenis, kā arī ārkārtīgi izteikta politiskā atsvešinātība. Anomiju Latvijā veido vairākas dimensijas, kas nedaudz atšǩiras un tomēr ir cieši saistittas ar klasiskajām K. Marksa un E. Dirkema šì jēdziena interpretācijām: bezspēcība, atsvešinātỉba no sevis, normu trūkums, kultūras atsvešinātība un izolētība, skaidras pārliecības trūkums, ilgtermiṇa mērḳu un vīzijas trūkums, atsvešinātība no ǵimenes, izvairīšanās uzṇemties atbildību.

Apkopojot iepriekšējo pētijjumu un aptauju rezultātus par iedzīvotāju vērtỉborientāciju, darba gaitā tika izveidota projekta mērkiem atbilstošākā pētijuma struktūra, tika izstrādāts instrumentārijs reprezentativas Latvijas iedzīvotāju aptaujas veikšanai (2015.gadā; $N=1000$ ), lai iegūtu empīriskus datus par vērtīborientāciju, anomiju, mediju izmantošanu un sociālo izturēšanos. Izmantojot starptautisko salïdzinošo pētijjumu datus, tika analizēta Latvijas iedzivotāju attieksme pret dalību sabiedriskajā dzivēe, īpaši akcentējot paaudžu aspektu un diagnosticējot anomijas esamỉbu. Latvijas iedzivotāju attieksme tika salīdzināta ar citu Centrāleiropas un Austrumeiropas valstu iedzivotāju attieksmi, lai labāk izprastu faktorus, kas to ietekmē. Izmantojot aptaujas datus, tika analizēta saikne starp individa sociālo uzvedību, anomijas izpausmēm un informācijas patērina ieradumiem.

Aptaujas rezultāti kopumā apstiprina, ka Latvijā bezspēcība un atsvešinātība no sevis ir izteiktākās anomijas dimensijas, kam seko normu un skaidras pārliecības trūkums. Tieši normu, skaidras pārliecỉbas, kā arì ilgtermiṇa mērḳu un vīzijas trūkumu var uzskatīt par visvairāk problemātiskiem Latvijas sabiedrību raksturojošiem aspektiem. Tie ir ìpaši raksturīgi trūcīgākajiem sabiedrības slāniem. Lỉdztekus nelatviešiem trūcīgākie iedzīvotāji biežāk izjūt arī bezspēcību un atsvešinātỉbu no sevis. Politiskā un sociālā atsvešinātîba, lai gan tās ir saistītas ar anomiju, īpaši-ar skaidras pārliecības trūkumu, veido atškiirīgus kognitivos konceptus (tātad politisko neiesaistišanos un sociālo saišu vājumu, sabiedrības sociālo fragmentāciju nevar uzskatìt par tiešu anomijas pazimi). Interesanti, ka jaunieši jūtas sociāli un kulturāli atsvešinātāki, turpretī vecāki cilvēki - politiski atsvešinātāki.

Reliğijas ietekme Baltijas valstīs izrādījās mazāk nozīmīga, nekā gaidits, - vienigi katoḷu konfesijai (abu dzimumu respondentiem) bija statistiski nozīmīga ietekme uz partnerattiecỉbu veidošanu salīdzinājumā ar sekulārajiem indivīdiem. Sociālā vērtỉbu sistēma (vērtỉborientācija) ievērojami un statistiski nozīmīgi ietekmē partnerattiecību veidošanu, bet ietekmes lielums Baltijas valstīs atškiriras.

Analizējot vērtīborientācijas saikni ar konfesionālo piederību, secināts, ka vērojamas nelielas, maznozīmīgas atškirỉbas lielāko reliǵisko denomināciju (katoḷi, luterāṇi, pareizticīgie) un reliğ́ijām nepiederīgo iedzìvotāju starpā, bet savstarpēju atšķirību praktiski nav lielajām denominācijām piederīgo vidū. Tas tek skaidrots ar reliǵiskās dažādỉbas raksturu un denomināciju strukturālajām un varas attiecībām Latvijā, respektīvi, «dažādība apēd dažādību» - gadijjumos, kad lielākas reliğiskās grupas atrodas skaitliskā lïdzsvarā, atškirības samazinās. Tas konstatējams arī vērtību sfērā. Tas arī lauj izskaidrot labo ekumēnisko sadarbību lielāko reliǵisko kopienu starpā. 
Analizējot musulmanu kopienu, secināts, ka Latvijā ir izveidojušās divas musulmaṇu apakškopienas, kuru starpā valda atturīgas, dažkārt pat neuzticēšanās pilnas attiecỉbas. Šāda situācija pastāv arī citās Baltijas valstīs. Vienu grupējumu veido galvenokārt tā dēvētie etniskie jeb kultūras musulmaņi, kādreizējie emigranti no bijušajām PSRS republikām un viṇu pēcteči, kā arī personas, kas Latvijā uzturas īstermiṇā (studenti, patvēruma meklētāji). Šo grupu raksturo mazāk intensīva religóiozitāte; islāms ir vinu identitātes sastāvdala. Otru grupu veido nesenie konvertīti, kas galvenokārt nāk no latviešu vai vietējo krievvalodīgo vides un kas pieņēmuši islāmu relatīvi nesen un nopietni to praktizē. Vērtỉborientācija ir viens no galvenajiem viṇu konvertācijas motīviem (Misāne, 2016c).

Jauniešu attieksmju, līdzdalības un pilsoniskās aktivitātes izpētei tika izmantoti gan jaunu, gan agrāk veiktu pētỉjumu dati (piemēram, MYPLACE), tika apkopota informācija par jauniešu vidū izplatītajām iesaistes sabiedriskās aktivitātēs formām, vinu attieksmi pret līdzdalību, kā arī faktoriem, kas kavē jauniešus būt sabiedriski un politiski aktīvākiem (Valtenbergs, Irbīte, Ebele, 2016). Uz pētijuma bāzes tika formulēti ieteikumi jauniešu līdzdalības palielināšanai. Tāpat tika analizēta studējošo mobilitātes nozīme eiropeiskās identitātes veidošanā.

Projekta gaitā tika analizētas portālā ManaBalss.lv reǵ̛istrētās iniciatīvas un to iesniedzēju motivācija. Teorētiskais pamats bija tēze par politiskās līdzdalības individualizēšanos, kā arī divi demokrātijas modeḷu kontrasti (protektīvais un tiešais). Lai gan šis portāls sabiedrībā ir salīdzinoši labi zināms, aizvadītajā gadā elektronisko petīciju parakstišanā iesaistijāās tikai 4,7\% iedzīvotāju. Visbiežāk par ManaBalss.lv iniciatīvām parakstās jauni cilvēki ar augstāko izglìīibu un augstiem ienākumiem. Tas sasaucas arī ar iepriekš veiktajos pētijumos konstatēto tendenci, ka šìs sabiedrības grupas biežāk izmanto individualizētās līdzdalības iespējas. Sakrustojot politisko vērtību «konservativva/liberāla» un «kreisa/labēja/ jaunā politika» skalas, var redzēt, ka visbiežāk portālā tika konstatētas iniciativas, kuru raksturs vienlaikus ir kreiss un ne konservativvs, ne liberāls. Otrs biežākais iniciatĩvas raksturs ir jaunās politikas iniciatīva, kas nav ne konservatīva, ne liberāla. Lai gan iniciatīvu virzîtāji ir veikuši dažādas aktivitātes gan pirms iniciatīvas iesniegšanas, gan parakstu vākšanas laikā, bažas un nezinu rada fakts, ka trūkst informācijas par procesa norisi un rīkošanos pēc parakstu savākšanas. Apgalvojums, ka neinstitucionalizētās politiskās līdzdalības formas prasa mazāku laika, riska vai enerğijas ieguldījumu, pētijumā neapstiprinās, jo pētijjuma dalībnieki min daudzas un dažādas veiktās un plānotās aktivitātes, kuras prasa gan visus iepriekš minētos resursus, gan arī finanses.

Balstoties uz statistikas datiem (laulātība, nereǵistrēta kopdzive, škiršanās, sieviešu nodarbinātība u.c. indikatori) un aptauju rezultātiem (postmateriālisms un citas vērtīborientācijas), tika analizētas ğimenes modeḷu izmainas Latvijā kopš 1980. gada salīdzinājumā ar attīstīto valstu tendencēm. Balstoties uz pētijumu par izmaiṇām g̛̣imenes modeḷos Latvijā, tika analizēta vērtīborientācijas ietekme uz iedzivotāju reproduktīvo uzvedību un ilgtermina demogrāifiskajām prognozēm, kā arī uz izglìtošanās lēmumiem.

Pievēršoties ǵimenes pētijumiem, ir secināts, ka tādi faktori kā nodarbinātỉba un augstākā izglìiība rada spēcīgu pozitīvu ietekmi uz varbūtỉbu uzsākt kopdzīvi, efekts turklāt ir statistiski nozimīgs gan sievietēm, gan vīiešiem, un tas pierāda, ka iedzìvotāji Baltijas valstīs atbalsta līdzvērtỉgas dzimumu lomas. Interesants ir secinājums, ka viriešiem ir tendence atlikt laulību karjeras iespēju labā, tajā pašā laikā nodarbinātība iedrošina sievietes legalizēt attiecības (stāties laulībā). Pārsteidzoši, ka individa izglìīibas līmenis neietekmē varbūtību juridiski noformēt partnerattiecības, bet indivīdus piesaista augstāks partnera izglììibas līmenis, tas palielina laulïbu varbūtỉbu pretēji nereǵistrētām attiecībām.

Likumsakarīgi, ka tas, vai mājsaimniecībā ir bērni, ir pozitīvā sakarībā ar varbūtību atrasties kopdzivē. Savukārt laulïbas škiršanas iepriekšēja pieredze samazina varbūtỉbu stāties laulībā atkārtoti (salīdzinājumā ar indivīdiem, kam nav bijušas iepriekšejas laulïbas), vienlaikus palielinot varbūtỉbu nereğistrētai kopdzìvei. Slikts veselības stāvoklis arī negatīvi ietekmē iespēju stāties laulībā, bet šis efekts nav statistiski nozīmīgs nereğistrētai kopdzivei.

Cits pētỉjums izmanto kvantitatīvu mikrolimeņa pieeju un atbild uz jautājumu, kā Latvijas iedzivotāiji uztver ǵimenes jēdzienu un kā tas salīdzināms ar mājsaimniecības definīciju. Pirmie rezultāti liecina, ka ğimenēm ir daudz vairāk sastāva variāciju nekā mājsaimniecībām. Ievērojama dạa iedzīvotāju, kas dzīvo vieni, (21\%) uzskata, ka viṇu ğimene ir tikai viṇi paši, un tikpat liels skaits $(20 \%)$ ir góimenu, kas sastāv no laulātajiem bez bērniem. Tika 13 \% iedzīvotāju dzīvo klasiskās nukleārās ğimenēs, kas sastāv no laulātajiem un viṇu bērniem. Viena vecāka ğimenes ar nepilngadīgiem vai pilngadīgiem bērniem ir $9 \%$, un lïdzịgs skaits iedzivotāju par savu ǵimeni uzskata partneri (nelaulātu) ar vai bez bērniem.

Gan padomju režìma mantojums sociālajā atmiṇā, gan arī pretrunīgā pieredze, kas gūta pēdējos gadu desmitos, ievērojami kavē lielas dalas cilvēku līdzdalību sabiedrības dzivē, iespaido attieksmi pret sabiedrisko labumu, kā arī ietekmē priekšstatus par ğimenes modeliiem un to, kā tie iespaido individu reproduktīvo uzvedību un sabiedrỉbas ilgtermiṇa demogrāfiskās prognozes. Šis zināšanas veido plašāku informatīvo bāzi demogrāfiskās politikas veidošanai, kā arī ḷauj izstrādāt ieteikumus iedzīvotāju lỉdzdalỉbas veicināšanai, kas ir svarīgs sabiedrības ilgtspējiggas attīstības elements. Padziḷināta izpratne par sabiedrības vērtỉborientāciju ne tikai atklāj cēlonsakarības, kas pastāv starp cilvēka attieksmēm un rīcỉbu, bet arī lauj precīzāk formulēt 
valsts ekonomiskās, sociālās un demogrāfiskās politikas mērḳus, izvēlēties to sasniegšanai piemērotākos līdzekḷus.

Projekta realizācijas gaitā tika veikts arī savdabịgs padomju nostalğijas monitorings. Izmantojot aptauju datus un padziḷināto interviju analīzi, tika identificētas ilglaicīgākās sovjetiskās vērtības atsevišḳu sociālo grupu vērtībsistēmā, noskaidrota to cēlonība un dinamika. Šie dati l̦āva analizēt nostalğiju pēc Padomju Savienības, tās dzìves kārtības un sociālajiem labumiem, kā arī tās ietekmi uz Latvijas iedzīvotāju lēmumiem un rīcībspēju, kā arī valsts drošỉbu. Aplūkojot 2015. gadā veiktās aptaujas rezultātus, redzams, ka lielas daḷas iedzīvotāju viedoklis par vairākiem dzīves aspektiem padomju periodā ir pozitīvs. Vēl viena iezīme ir tā, ka lielai dalai nav viedokla par šo laiku. Pozitīva attieksme par padomju periodu ir konstatēta, mūsdienu Latvijas ekonomisko un sociālo situāciju salīdzinot ar dzīvi padomju Latvijā. Socioloğiskie dati vēsta, ka, pēc aptaujāto Latvijas iedzivotāju domām, padomju periodā salīdzinājumā ar mūsdienām cilvēki nebija nabadzīgi, bija optimistiski, vairāk strādāja, bija godīgāki, attiecības starp dažādu tautību cilvēkiem bija labākas, medicinnas pakalpojumi un ārstēšana bija labāka, korupcija bija mazāka. Vairākums respondentu, no vienas puses, atzīst, ka padomju valsts svētki bija skaisti un patika tos svinēt, bet, no otras puses, - ka šie svētki bija varas uzspiesti un sveši.

Lielākajai dalai aptaujāto ir negatīva attieksme pret varu padomju periodā, informācijas pieejamības un ceḷošanas ierobežojumiem. Šos datus nav iespējams skaidrot, kā sākotnēji bija iecerēts, tikai ar nostalğiju pēc padomju perioda. Būtiska loma ir populārajai kultūrai, patērniecībai, pagātnes, tagadnes un nākotnes cēlonsakarību domāšanas modela aizstāšanai ar konkrētajā laikā nesakṇotām vēstures «ainavām» (timescape), kas rada labvèlīgu augsni populisma uzplaukumam.

Ekonomisko sistēmu sociālā lesaknotība un pašorganizācija kopējo resursu pārvaldībā

No sabiedriskā labuma, kopīgo resursu (to skaitā vides resursu) apsaimniekošanas, pašorganizētas sociālās telpas attīstỉbas perspektivias skatoties uz anomijas izraisīto bezspēcỉbu, atsvešinātību no sevis, normu trūkumu, kultūras atsvešinātibu un izolētỉbu, skaidras pārliecības trūkumu, ilgtermina mērku un vīzijas trūkumu, atsvešinātību no ǵimenes, iezimējas iespējamās ekonomisko un sociālo procesu attīstỉbas iespējas pēckrīzes Latvijā. Tomēr, lai gan anomijas izpausmes ir daudzveidīgas un plašas, Latvijas sabiedrībā ir vērojamai procesi, kas ḷauj nākotnē raudzìties ar zināmu optimismu.

Līdztekus politiskajai līdzdalībai aktivitātēm kopienās ievērojams pašorganizācijas potenciāls ir arī tādām ekonomiskajām darbībām kā kooperācija un kopīgo resursu apsaimniekošana. Sociālajās zinātnēs ekonomisko un sociālo institūciju mijiedarbības izpētei ir senas tradīcijas. Sociālekonomisko sistēmu kā cilvēku radìtu sistēmu analīzē sociālajās zinātnēs tiek izmantots jēdziens «iesakṇotība». Pirmais šo jēdzienu sociālajās zinātnēs ieviesa ungāru cilmes amerikānu ekonomists Karls Polani (Karl Polanyi), kurš 1944. gadā, raksturojot valsts un tirgus attiecības kapitālismā, izvirzijja tēzi, ka saimnieciskā darbība ir iesakṇota sociālā un ekonomiskā kontekstā (Polanyi, 2001). Skaidrojot iesaknotības (embeddedness) jēdzienu, K. Polani uzsver, ka tirgus sabiedrība nerodas pati no sevis, tā ir sociāli un politiski konstruēta. Vinš uzskata, ka arì tirgus ir sociāla institūcija. Tirgus kontrolē ekonomisko sistēmu tik lielā mērā tieši tāpēc, ka tirgus ir sabiedrỉbas organizēšanās sekas. Attīstot tēzi par tirgus ekonomikas pastāvēšanas atkarību no atbilstošas sociālo institūciju organizēšanās, K. Polani raksta: «tirgus ekonomika var funkcionēt tikai tirgus sabiedrībā» (Polanyi, 2001, p. 60).

K. Polani izejas punkts, analizējot ekonomikas iesaknotību sabiedrībā, ir ekonomikas kā pašpietiekamas sistēmas funkcionēšanas iztēlošanās (Polanyi, 1977, p. 47, 48). Viṇš secina, ka iedomātās atšķirības starp «mežonīgajām» un «mūsdienu» institūcijām nav tik būtiskas, kā varētu domāt. Arī kopienas îpašuma pamatā bija individuālo tiesību tìkls, bet saskanā ar to cilvēks piederēja zemei, nevis zeme cilvēkam. Proti, cilvēks kā individs bija apnēemies apsaimniekot zemi, nevis viṇam bija piešḳirtas tiesības to apsaimniekot. Tātad, «materiālo labumu ražošana un pārdale ir iesaknotas neekonomiska rakstura sociālajās attiecībās», apkopojot antropologu atzinas, secina K. Polaṇi. Saimnieciskās darbïbas procesus nenosaka tikai ekonomiskie motīvi (individa «ieguvums ieguvuma dēḷ vai bailes būt izsalkušam), ekonomiskā uzvedība nekad nav bijusi neinstitucionāla (Polanyi, 1977, p. 51, 52). Tātad uzvedība, rīcība, rīkošanās pat tā sauktajās ekonomiskajās sistēmās ir sociāla. Priekšstats, ka ir iespējama kāda atsvešināta, individuāli kalkulējoša un racionālu ekonomisko likumu vadìta rīcība, ir maldīgs.

Sociologs Marks Granoveters (Mark Granovetter) turpina un attīsta tālāk K. Polaṇi tradīciju. M. Granoveters runā par to, ka ekonomiskās institūcijas ir sociāli konstruētas. Savā 1985. gadā pirmo reizi publicētajā darbā «Ekonomiskā darbỉba un sociālā struktūra: iesaknotỉbas problēma» (Economic Action and Social Structure: The Problem of Embeddedness), M. Granoveters, raksturojot tirgus sabiedrības, lieto iesakṇotības jēdzienu, norādot, ka pat tajās (tirgus sabiedrībās) «racionālo» ekonomisko apmainu ietekmē iepriekš pastāvējušās sociālās saites (Granovetter, 1992), to nozīme un izpausmes parasti netiek izvērtētas.

Socioloğiskajā literatūrā bieži tiek kritizēta šauri ekonomiskā pieeja, kas mākslīgi nošķiir «ekonomiskos» un «kultūras» aspektus, ippaši vietējās attīstības, resursu geoogrāfijas problēmu (Bowen, 2011, p. 325; Bakker \& Bridge, 2006, p.14) un vides resursus (Schnaiberg, 1980; Schnaiberg \& Gould, 2000) apsaimniekošanas un pārvaldības analīzes kontekstā. Cilvēku radītās 
sistēmās ārējas organizēšanas vietā varam runāt par pašorganizēšanos. Tā nebūt nenozīmē palıaušanos uz tirgus regulēšanu vai tirgus pašregulēšanos, proti, paḷaušanos uz to, ka tirgus «sakārtos» procesus. Šāda paḷaušanās uz tirgu kā ārēju regulējošu faktoru pašos pamatos izslēdz mazo grupu iespējas kontrolēt procesus. Kontroles spēju savukārt var nodrošināt izpratne par sociālekonomisko sistēmu funkcionēšanu.

Kopīgi mērḳi ir būtisks kolektīvās rīcības priekšnosacījums. Kā norāda R.Edmondsone (Ricca Edmondson) — «kolektīvā rīcībā cilvēku grupa kopīgi darbojas, lai sasniegtu kopīgus mērḳus, kurus nevar tik efektīvi sasniegt vieni paši vai kopāa ar dažiem citiem indivìdiem» (Edmondson, 1997). Kolektīiās rīcības teorija piedāvā dažādus indikatorus lietošanai situācijās, kurās cilvēki gatavi strādāt kopā, lai, piemēram, pārvaldìtu kopīgos resursus (Ostrom, 1990, 2007). Arī indivīdi var sasniegt labākus rezultātus - nevis «racionāli» rìkojoties, bet veidojot tādus apstākḷus, kur savstarpējība, reputācija un uzticēšanās var palīdzēt pārvarēt spēcīgu vēlmi vadīties pēc ìstermina personīgajām interesēm (Ostrom, 1998).

Kalifornijas Universitātes Bērkli starptautiskās vides politikas pētniece K. O’Nïla (Kate O’Neill) norāda, ka vienīgais piemērs globālajā vides pārvaldībā, kad pilsoniskā sabiedrība un rūpniecības nozares apvieno spēkus vides aizsardzībā un ilgtspējā nevis lai darbotos likumdošanas vai atbalsta, vai noliedzēju lobija grupu mērku dēl, bet lai kḷūtu par pārvaldības ağentiem pašu interesēs, ir mežu sertifikācija (O’Neill, 2009, p.167). Mežu sertifikācija ir viens no pārvaldes režìmiem pasaules mežu aizsardzībai, un šis sertifikāts apliecina, ka meža apsaimniekošana atbilst ilgtspèjīgas apsaimniekošanas prasībām (Rozentāls u.c., 2017, 260.lpp.). Senākā mežu sertifikācijas sistēma, kurai var pievienoties Latvijas mežu ipašnieki, ir F SC (Forest Stewardship Council). FSC ir apliecinājums mežu sertifikācijai atbilstoši šādiem ilgtspējiggas apsaimniekošanas principiem: tiek aizsargātas un uzturētas dabiskās dzīvotnes un augstvērtīgs mežs, tiek ievērotas strādnieku un kopienu tiesības, tiek attīstīts tirgus, tiek iegūta visaugstākā pievienotā vērtība un visiem iesaistītajiem ir vienlīdzīga pieeja ieguvumiem no šādas organizācijas. Lìdzdalïbnieki vienojās par 10 ilgtspējigiem meža menedžmenta principiem, iekḷaujot arī ciršanas kontroli, lai iegūtās koksnes apjoma dēl netiktu nodarits kaitējums trauslajai ekosistēmai, kā arì būtu ievērotas vietējo iedzivotāju tiesības (O’Neill, 2009). Tātad mežu sertifikācija ir gan iespēja, gan atbildỉba, jo mežu sertifikācijas sistēmas ir neatkarīgas no valsts pārvaldes, piemēram, FSC nav valdības pārstāvji, bet tā ir NVo, meža īpašnieku un kokrūpniecības uzṇēmumu koalīija.

Protams, šìs pašorganizācijas formas iekḷaujas arī plašāka mēroga darbībā, kur vienlaikus pastāv gan horizontālas, gan vertikālas attiecības atbilstoši neoendogēnās perspektîvas principiem. Šo pašorganizācijas formu pastāvēšanas un darbības analīze ir nozīmìgs izpētes objekts, jo iesaistītie ağenti ir jaunu zināšanu radītāji un pārnesēji. Dažādās pašorganizācijas

formās iesaistītie nav tikai pētnieku zināšanu un nozares attīstības sasniegumu patērētāji. Šo zināšanu pārnese notiek izglìtojošu un atbalsta pakalpojumu formā (sk., piemēram, Moschitz et al., 2015). Šādos gadijumos darbības iniciatīva nāk no augšupvērstas ağentu aktivitātes, un šie ağenti nav pasîvi objekti, kuri ir jāmāca, jāizglìto un citādi jāietekmē, lai panāktu vēlamās izmaiņas konkrētajās nozarēs, šajā gadỉjumā-lauksaimniecībā un mežsaimniecībā. Viens no piemēriem, kur izpaužas šādas pašorganizācijas formas, ir meža ipašnieku kooperativi. Šie kooperatīvi raksturo alternatīvu meža apsaimniekošanas veidu, kuros meža îpašnieki, no vienas puses, deleg̊ē resursu lietošanas tiesības pašu veidotai organizācijai un, no otras puses, saglabā îpašumtiesības uz šiem resursiem.

Kolektīiā rīcība un sabiedriskais labums Latvijas iedzīvotāju skatījumā
Lai iegūtu informāciju par iedzīvotāju attieksmi un vērtībām, tirgus un sociālo pētijumu centrs «Latvijas Fakti» veica Latvijas Republikas pastāvìgo iedzìvotāju ( $N=1003)$ vecumā no $18 \mathrm{līdz} 74$ gadiem aptauju (SUSTINNO 2017). Tiešās datorizētās intervijas notika respondentu dzīvesvietā latviešu vai krievu valodā. Aptauja tika veikta laikā no 2017. gada 2. decembra līdz 20. decembrim. Aptaujas izlase tika aprēkināta un stratificēta, balstoties uz Centrālās statistikas pārvaldes (CSP) publicēto informāciju par Latvijas iedzìvotāju skaitu Latvijas pilsētās un pagastos 2017. gada 1.janvārī. Aptaujā bija iekḷauti vairāki jautājumu bloki, kas noderēja padzilinātai SUSTINNO projektos aplūkoto problēmu analīzei. Respondentiem tika uzdoti jautājumi par politiskajām un pilsoniskajām attieksmēm un līdzdalību, par attieksmi pret nodokḷu maksāšanu vai nemaksāšanu, uzskatiem par valsts un individu lomu sabiedrisko labumu nodrošināšanā, par sabiedriskā labuma, sociālā kapitāla un kopienas dažādiem aspektiem, kā arī par attieksmi un rīcību vides un ekolog̣ijas jomā.

Aptaujā iegūtais plašais datu kopums tiks izmantots turpmākai izpētei un analīzei, bet jau pirmie analīzes rezultāti lauj plašākā kontekstā paraudzīties uz valsts pētỉjumu programmas projektos iegūtajiem secinājumiem, atklāt jaunas sakarības starp vērtīborientācijām un cilvēku rīcību ekonomikas, sociālās drošỉbas un vides resursu pārvaldības jomās.

Pētỉjuma izlases raksturojums liecina, ka aptaujā iegūtos datus var uzskatit par reprezentativiem (1.tabula).

Anomijai raksturīgā sajūta - neapmierinātība ar dzīvi, nespēja to ietekmēt - Latvijas iedzivotājiem nav spilgti izteikta. Aptaujas dati liecina, ka lielākā daḷa iedzivotāju kopumā tomēr ir apmierināti ar savu dzivi; lielākā dạ̣a respondentu pēc desmit ballu skalas to vērtē ar 5-9 ballēm. Respondentu atbilžu sadalïjums pēc dzivesvietas «Cik apmierināts vai neapmierināts Jūs esat ar savu pašreizējo dzīvi kopumā?» liecina, ka Pierīgā ir visvairāk gan 
1. tabula. Plānotās un realizētās izlases raksturojums (\%)

\begin{tabular}{|c|c|c|c|c|}
\hline & & $\begin{array}{r}\text { Respondentu } \\
\text { skaits izlasē } \\
\text { pirms svēršanas }\end{array}$ & $\begin{array}{r}\text { Respondentu } \\
\text { skaits izlasēe } \\
\text { pēc svēršanas }\end{array}$ & $\begin{array}{r}\text { Statistika } \\
\text { (CSP, 2017): }\end{array}$ \\
\hline \multirow[t]{2}{*}{ Dzimums } & Virieši & 42,1 & 46,8 & 45,9 \\
\hline & Sievietes & 57,9 & 53,2 & 54,1 \\
\hline \multirow[t]{6}{*}{ Vecums } & $18-24$ gadi & 11,6 & 9,8 & 9,7 \\
\hline & $25-34$ gadi & 17,5 & 19,6 & 19,7 \\
\hline & $35-44$ gadi & 20,2 & 18,1 & 18,3 \\
\hline & $45-54$ gadi & 18,5 & 19,1 & 19,2 \\
\hline & $55-64$ gadi & 17,5 & 19,3 & 19,1 \\
\hline & $65-74$ gadi & 14,7 & 14,1 & $14, \mathrm{O}$ \\
\hline \multirow[t]{2}{*}{ Tautība } & Latvieši & 69,3 & 62,1 & 62,0 \\
\hline & Cits & 30,7 & 37,9 & 38,0 \\
\hline \multirow[t]{7}{*}{ Reǵions } & Rỉga & 32,5 & 33,0 & 32,9 \\
\hline & Pierīga & 17,6 & 18,7 & 18,7 \\
\hline & Vidzeme & 9,6 & 9,2 & 9,8 \\
\hline & Kurzeme & 12,5 & 11,7 & 12,6 \\
\hline & Zemgale & 12,4 & 12,4 & 12,1 \\
\hline & Latgale & 15,4 & 15,0 & 13,9 \\
\hline & Kopā & 100,0 & 100,0 & 100,0 \\
\hline
\end{tabular}

* CSP dati uz 2017.gada 1.janvāri.
2. tabula. Respondentu sadalījums pēc dzīvesvietas atbildēs

uz jautājumu «Cik apmierināts vai neapmierināts jūs esat

ar savu pašreizējo dzīvi kopumā?» $(\%, N=1003)$

\begin{tabular}{lcccc}
\hline & Riga & Pierīga & Citi reǵioni & $\begin{array}{c}\text { Visi respon- } \\
\text { denti kopāa }\end{array}$ \\
\hline $\begin{array}{l}\text { (Pilnīgi } \\
\text { neapmierināts/a) }\end{array}$ & 1,9 & 8,2 & 1,5 & 2,8 \\
\hline 2 & 0,6 & 1,6 & 1,2 & 1,1 \\
\hline 3 & 2,5 & 5,5 & 1,9 & 2,7 \\
\hline 4 & 3,4 & 8,2 & 4,6 & 4,9 \\
\hline 5 & 15,1 & 13,1 & 15,0 & 14,7 \\
\hline 6 & 14,5 & 12,6 & 13,3 & 13,6 \\
\hline 7 & 19,4 & 17,5 & 20,2 & 19,4 \\
\hline 8 & 24,1 & 13,1 & 21,4 & 11,1 \\
\hline 9 & 10,5 & 7,7 & 12,9 & 8,9 \\
\hline 10 (Pilnīgi & 8,0 & 12,6 & 100,0 & \\
\hline apmierināts/a) & 100,0 & & & 100,0 \\
\hline Kopā & 100,0 & & \\
\hline
\end{tabular}

(SUSTINNO 2017)

to iedzīvotāju, kas ir pilnīgi neapmierināti ar savu dzivi kopumā, gan arī to, kas ir pilnīgi apmierināti. Rỉgā un citos reğionos ar savu dzīvi kopumā pilnīgi neapmierināti ir attiecīgi 1,9\% un 1,5\%, savukārt Pierīgā nepamierināti ir $8,2 \%$ respondentu (2.tabula). Iespējams, tas ir tāpēc, ka iedzivotāju nevienlīdzība Pierīgā ir vairāk izteikta nekā Rīgā un citos reǵionos, jo arī to respondentu, kas apmierinātību ar dzīvi vērtē ar 10 ballēm, visvairāk (12,6\%) ir Pierīgà. Citās respondentu atbildēs būtiskas atšķiiribas pēc dzìvesvietas reğionā nav konstatējamas (2.tabula). 
3. tabula. Respondentu sadalījums pēc nodarbošanās stāvokḷa atbildēs

uz jautājumu «Cik apmierināts vai neapmierināts Jūs esat ar savu

pašreizējo dzīvi kopumā?» $(\%, N=1003)$

\begin{tabular}{|c|c|c|c|c|}
\hline & $\begin{array}{r}\text { Vadītāijs, } \\
\text { uzṇēmējs } \\
\text { (lēmumu } \\
\text { pieṇēmējs) }\end{array}$ & $\begin{array}{r}\text { Algots darbinieks } \\
\text { (speciālists, } \\
\text { strādnieks, arī } \\
\text { bezdarbnieks) }\end{array}$ & $\begin{array}{r}\text { Ārpus darba tirgus } \\
\text { (pensionārs, } \\
\text { skolēns, students, } \\
\text { mājsaimnieks) }\end{array}$ & $\begin{array}{l}\text { Visi respon- } \\
\text { denti kopā }\end{array}$ \\
\hline $\begin{array}{l}\text { (Pilnīgi } \\
\text { neapmierināts/a) }\end{array}$ & & 3,2 & 3,4 & 2,8 \\
\hline 2 & o,8 & 1,3 & 1,1 & 1,2 \\
\hline 3 & 1,7 & 3,0 & 3,0 & 2,8 \\
\hline 4 & o,8 & 5,5 & 5,3 & 4,9 \\
\hline 5 & 12,4 & 13,5 & $18, \mathrm{o}$ & 14,6 \\
\hline 6 & 9,1 & 14,7 & 12,8 & 13,5 \\
\hline 7 & 20,7 & 19,8 & 17,7 & 19,4 \\
\hline 8 & 28,1 & 20,8 & 17,7 & 20,9 \\
\hline 9 & 17,4 & 11,0 & 8,6 & 11,1 \\
\hline $\begin{array}{l}10 \text { (Pilnīgi } \\
\text { apmierināts/a) }\end{array}$ & 9,1 & 7,2 & 12,4 & 8,8 \\
\hline Кора̄ & 100,0 & 100,0 & 100,0 & 100,0 \\
\hline
\end{tabular}

(SUSTINNO 2017)

Respondentu sadalījums pēc nodarbošanās atbildēs uz jautājumu «Cik apmierināts vai neapmierināts Jūs esat ar savu pašreizējo dzivi kopumā?» neliecina par būtiskām respondentu atšķirībām nodarbošanās ziņā. Starp vadītājiem ar savu pašreizējo dzīvi kopumā apmierināto ir vairāk: ievērojami vairāk par vidējo rādītāju (ar 7 un 8 ballēm no 10) savu pašreizējo dzivi vērtē attiecīgi 20,9\% un 28,1\% respondentu vadītāja amatā. Tomēr samērā daudz ar
4. tabula. Respondentu sadalījums pēc izglìtības līmena atbildēs uz jautājumu «Lūdzu, novērtējiet, cik lielā mērā Jūs esat savas dzīves noteicējs/a?» $(\%, N=1003)$

\begin{tabular}{|c|c|c|c|c|}
\hline & $\begin{array}{r}\text { Pamata } \\
\text { vai zemāka }\end{array}$ & $\begin{array}{r}\text { Vidējā (vidèjā/ } \\
\text { speciālā/ } \\
\text { nepabeigta } \\
\text { augstākā) }\end{array}$ & Augstākā & $\begin{array}{r}\text { Visi respon- } \\
\text { denti kopā }\end{array}$ \\
\hline $\begin{array}{l}\text { I (Nemaz neesmu } \\
\text { noteicējs) }\end{array}$ & 6,0 & 1,1 & 1,3 & 1,8 \\
\hline 2 & 1,5 & 1,5 & 0,3 & 1,1 \\
\hline 3 & 4,5 & 4,6 & 3,2 & 4,2 \\
\hline 4 & 9,0 & 3,5 & 1,9 & 3,8 \\
\hline 5 & 8,2 & 11,7 & 7,1 & 9,8 \\
\hline 6 & 11,9 & 11,1 & 10,7 & 11,1 \\
\hline 7 & 17,9 & 16,9 & 15,5 & 16,6 \\
\hline 8 & 11,2 & 21,1 & 22,7 & 20,2 \\
\hline 9 & 8,2 & 12,8 & 19,4 & 14,2 \\
\hline $\begin{array}{l}10 \text { (Pilnā mērā } \\
\text { esmu noteicējs) }\end{array}$ & 21,6 & 15,7 & 17,8 & 17,2 \\
\hline Kopā & 100,0 & 100,0 & 100,0 & 100,0 \\
\hline
\end{tabular}

(SUSTINNO 2017)

savu dzivi kopumā apmierināto ir arī starp tiem respondentiem, kas ir ārpus darba tirgus - pensionāri, studenti, mājsaimnieces un skolēni - 12,4\% vērtē savu dzivi kopumā ar 10 ballēm (3.tabula).

Izglìtības līmenis anomijas sajūtu ietekmē daudz būtiskāk, jo starp respondentiem ar pamata vai zemāku par pamata izglitíbas limeni relativi vairāk ir to, kas uzskata, ka nemaz nav noteicēji par savu dzivii: $6 \%$ šajā respondentu 
5. tabula. Respondentu sadalījums pēc vinu vecuma atbildēs

uz jautājumu «Sakiet, lūdzu, cik lielā mērā jūs jūtaties piederīgs/a

draugiem?» $(\%, N=1003)$

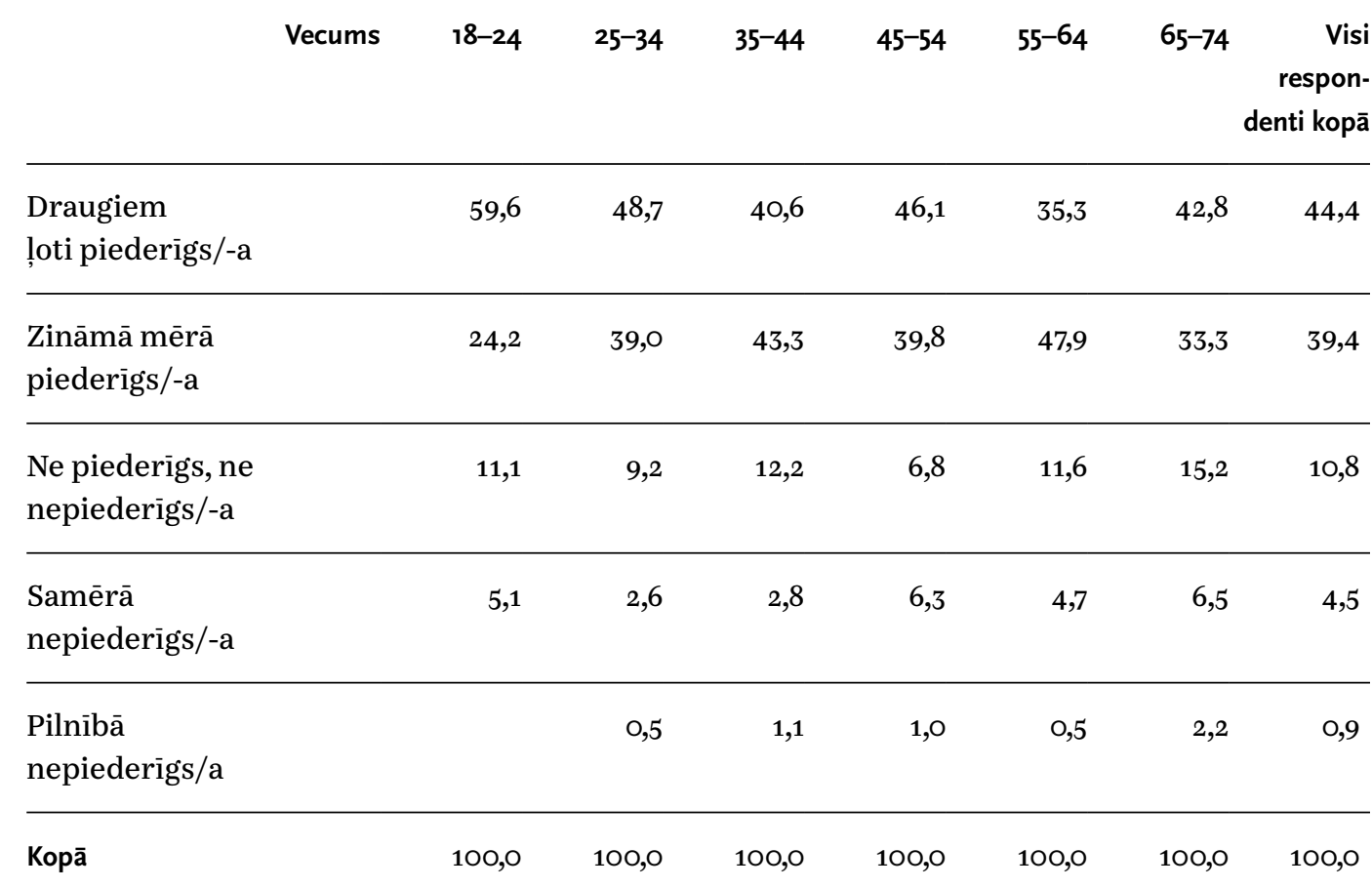

(SUSTINNO 2017)

grupā pret 1,8\% visiem respondentiem. Tomēr arì to, kas uzskata, ka ir savas dzives noteicēji, šajā respondentu grupa ir visvairāk (4.tabula).

Nozīmigs anomijas situācijas raksturojums ir piederības sajūta dažāadām sociālajām grupām - ǵimenei, draugiem, darba un studiju biedriem, arī novadam, reǵiionam, Latvijas iedzīvotājiem utt. Lai to noskaidrotu, respondentus lūdza novērtēt, cik lielā mērā vini jūtas piederīgi dažādām grupām vai vietām. Gimenei loti piederīgi jūtas 84,9 \% no visiem respondentiem, l,oti piederīgi draugiem jūtas $44,4 \%$ respondentu. Vislielākais respondentu īpatsvars, kas jūtas loti piederīgi draugiem, ir vecumā no 18 lỉdz 24 gadiem - 59,6\%, citās vecuma grupās piederības sajūta draugiem samazinās, bet tā pieaug respondentiem vecumā no 65 lỉdz 74 gadiem $-42,8 \%$ (5.tabula).

Rādītājs, kas raksturo piederību mazajām sociālajām grupām, ir samērā augssts, jo ar šìm grupām cilvēkus saista personiskas attiecības,
6. tabula. Respondentu sadalījums pēc respondenta tautības atbildēs uz jautājumu «Sakiet, lūdzu, cik lielā mērā Jūs jūtaties piederīgs/a visiem Latvijas iedzīvotājiem?» $(\%, N=1003)$

\begin{tabular}{lccr}
\hline & Latvietis & $\begin{array}{r}\text { Cita } \\
\text { tautība }\end{array}$ & $\begin{array}{r}\text { Visi respon- } \\
\text { denti kopāa }\end{array}$ \\
\hline Ḷoti piederīgs/-a & 21,7 & 6,6 & 16,0 \\
\hline Zināmā mērā piederīgs/-a & 49,3 & 39,7 & 45,7 \\
\hline Ne piederīgs, ne nepiederīgs/-a & 19,5 & 29,8 & 23,3 \\
\hline Samērā nepiederīgs/-a & 6,1 & 14,6 & 9,3 \\
\hline Pilnībā nepiederīgs/a & 3,5 & 9,4 & 5,7 \\
\hline Kopā & 100,0 & 100,0 & 100,0 \\
\hline
\end{tabular}

(SUSTINNO 2017)

7. tabula. Respondentu sadalijums pēc valodas gimenē atbildēs uz jautājumu «Sakiet, lūdzu, cik lielā mērā Jūs jūtaties piederīgs/a visiem Latvijas iedzīvotājiem?» $(\%, N=1003)$

\begin{tabular}{lccr}
\hline & $\begin{array}{r}\text { Latviešu } \\
\text { valoda }\end{array}$ & $\begin{array}{r}\text { Cita } \\
\text { valoda }\end{array}$ & $\begin{array}{r}\text { Visi respon- } \\
\text { denti kopā }\end{array}$ \\
\hline L̦oti piederīgs/-a & 21,1 & 6,0 & 15,9 \\
\hline Zināmā mērā piederīgs/-a & 49,2 & 38,9 & 45,7 \\
\hline Ne piederīgs, ne nepiederīgs/-a & 19,6 & 30,5 & 23,3 \\
\hline Samērā nepiederīgs/-a & 6,3 & 15,0 & 9,3 \\
\hline Pilnībā nepiederīgs/a & 3,8 & 9,6 & 5,8 \\
\hline Kopā & 100,0 & 100,0 & 100,0 \\
\hline
\end{tabular}

(SUSTINNO 2017) 
8. tabula. Respondentu sadalījums pēc valodas ǵimenē atbildēs uz jautājumu «Sakiet, lūdzu, cik lielā mērā jūs jūtaties piederīgs/a savas tautības cilvēkiem?» $(\%, N=1003)$

\begin{tabular}{lccr}
\hline & Latvietis & Cita tautiba & $\begin{array}{r}\text { Visi respon- } \\
\text { denti kopā }\end{array}$ \\
\hline L̦oti piederīgs/-a & 39,1 & 19,4 & 31,7 \\
\hline Zināmā mērā piederīgs/-a & 41,6 & 38,3 & 40,3 \\
\hline Ne piederīgs, ne nepiederīgs/-a & 14,2 & 29,0 & 19,8 \\
\hline Samērā nepiederīgs/-a & 2,8 & 7,9 & 4,7 \\
\hline Pilnībā nepiederīgs/a & 2,3 & 5,5 & 3,5 \\
\hline Kopā & 100,0 & 100,0 & 100,0 \\
\hline
\end{tabular}

(SUSTINNO 2017)

vairāk vai mazāk intensīva saskarsme ikdienā. Savukārt piederības sajūta Latvijas iedzīvotājiem, savas tautības iedzīvotājiem ir daudz abstraktāka. Aptaujas dati liecina, ka latviešu tautỉbas respondentu piederïbas sajūta visiem Latvijas iedzīvotājiem ir augstāka (6. tabula). Latviešu tautības respondenti jūtas ḷoti piederīgi visiem Latvijas iedzīvotājiem ievērojami vairāk nekā cittautieši-attiecīgi 21,7\% un 6,6\%, savukārt cittautiešu, kas nejūtas ne piederīgi, ne nepiederīgi, ir ievērojami vairāk nekā latviešu attiecīgi $29,8 \%$ un $19,5 \%$ (6.tabula).

Arī pēc ǵimenē lietotās valodas respondentu piederības sajūtu visiem Latvijas iedzīvotājiem var raksturot līdzịgi (7.tabula).

Latviešiem piederība savas tautỉbas cilvēkiem ir vairāk izteikta. Atbildot uz jautājumu «Sakiet, lūdzu, cik lielā mērā Jūs jūtaties piederīgs/a savas tautības iedzìvotājiem?», savas tautības iedzīvotājiem vairāk jūtas piederīgi latvieši nekā cittautieši-attiecigi 39,1\% un 19,4\%. (8. tabula).

Kopumā var secināt, ka cittautiešiem anomijas sajūta ir vairāk izteikta, jo vinu piederība visiem Latvijas iedzīvotājiem un arì savas tautības piederīgajiem ir vājāk izteikta, savukārt dažādu tautību respondentu piederības sajūta mazajām sociālajām grupām būtiski neatšķiras.

Kolektīva rīcība, pašorganizācija un darbošanās sabiedrības labā veicina anomijas pārvarēšanu, jaunu zināšanu un prasmju apgūšanu, kolektivvo
9. tabula. Respondentu sadalījums pēc dzīvesvietas atbildēs uz jautājumu «Vai Jūs esat darbojies grupā, kas nāca klajā ar kāda lēmumu pien,emšanas iniciatīvu šajā gadā, esat to darīijs agrāk, nekad neesat to darīijs, bet varētu izdarīt, vai arī Jūs nekad neesat to darīijis un arī nedarītu?» $(\%, N=1003)$

\begin{tabular}{lcccr}
\hline & Rīga & Pierīga & Citi regioni $\begin{array}{r}\text { Visi respon- } \\
\text { denti kopāa }\end{array}$ \\
\hline Esmu to darïjis šajā gadā & 1,8 & 3,4 & 3,6 & 3,0 \\
\hline Esmu to darījis agrāk & 6,4 & 8,4 & 6,1 & 6,6 \\
\hline Nekad neesmu to darījis, bet varētu izdarìt & 26,1 & 15,2 & 27,1 & 24,6 \\
\hline Nekad neesmu to darījis un nekad nedarìtu & 65,7 & 73,0 & 63,2 & 65,8 \\
\hline Kopā & 100,0 & 100,0 & 100,0 & 100,0 \\
\hline
\end{tabular}

(SUSTINNO 2017)

10. tabula. Respondentu sadalījums pēc tautības atbildēs uz jautājumu «Vai Jūs esat darbojies grupā, kas nāca klajā ar kāda lēmumu pieṇemšanas iniciatīvu šajā gadā, esat to darīijis agrāk, nekad neesat to darīijs, bet varētu izdarīt, vai arī Jūs nekad neesat to darījis un arī nedarītu?» $(\%, N=1003)$

\begin{tabular}{lccr}
\hline & Latvietis & Cita tautība & $\begin{array}{r}\text { Visi respon- } \\
\text { denti kopāa }\end{array}$ \\
\hline Esmu to darījis šajā gadā & 4,0 & 1,3 & 3,0 \\
\hline Esmu to darījis agrāk & 7,1 & 5,8 & 6,6 \\
\hline Nekad neesmu to darījis, bet varētu izdarìt & 27,2 & 20,4 & 24,6 \\
\hline Nekad neesmu to darījis un nekad nedarītu & 61,7 & 72,5 & 65,9 \\
\hline Kopā & 100,0 & 100,0 & 100,0 \\
\hline
\end{tabular}

(SUSTINNO 2017) 
11. tabula. Respondentu sadalījums pēc pilsonības atbildēs uz jautājumu «Vai Jūs esat darbojies grupā, kas nāca klajā ar kāda lēmumu pieṇemšanas iniciatīvu šajā gadā, esat to darīijis agrāk, nekad neesat to darīijs, bet varētu izdarīt, vai arī Jūs nekad neesat to darīisis un arī nedarītu?» (\%, $N=1003)$

\begin{tabular}{lccr}
\hline & $\begin{array}{c}\text { Latvijas } \\
\text { pilsonis }\end{array}$ & Cits & $\begin{array}{r}\text { Visi respon- } \\
\text { denti kopāa }\end{array}$ \\
\hline Esmu to darījis šajā gadā & 3,3 & 0,8 & 3,0 \\
\hline Esmu to darījis agrāk & 7,4 & 0,8 & 6,6 \\
\hline Nekad neesmu to darījis, bet varētu izdarìt & 26,8 & 8,4 & 24,6 \\
\hline Nekad neesmu to darīijis un nekad nedarìtu & 62,5 & 89,9 & 65,8 \\
\hline Kopā & 100,0 & 100,0 & 100,0 \\
\hline
\end{tabular}

(SUSTINNO 2017)

mācišanos un zināšanu pārnesi. Aptaujas anketā tika iekḷauts īpašs jautājumu bloks, lai noskaidrotu iedzīvotāju gatavỉbu iesaistīties šādās darbībās. To Latvijas iedzīvotāju, kuri ir iesaistījušies grupās, kas nākušas klajā ar kāda lēmuma pienemšanas iniciatīvu, nav daudz. Ārpus Rīgas ir nedaudz vairāk to iedzivvotāju, kas piedalījušies šādās grupās: Rīgā - 1,8\%, Pierīga - 3,4\% un citos reǵionos $-3,6 \%$. Iespēju iesaistīties šādās darbībās pieḷauj apmēram vienāds daudzums iedzīvotāju gan Rīgā, gan reğionos - attiecīgi $26,1 \%$ Rīgā, 15,2 \% Pierīgā un $27,1 \%$ reğionos.

Respondentu sadalījums pēc tautības atbildēs uz šo jautājumu liecina, ka latviešu, kas ir piedalijušies iniciatìvas grupās un kas varētu to izdarìt nākotnē, ir nedaudz vairāk nekā cittautiešu (10. tabula).

Vēl lielākas atšķirības ir starp Latvijas pilsoṇiem un tiem respondentiem, kas nav Latvijas pilsoni. To Latvijas pilsonu, kuri lïdz šim nav darbojušies grupās, kas nāk klajā ar lēmumu pienemšanas iniciatīvām, bet kuri pieḷauj, ka varētu to darìt nākotnē, ir ievērojami vairāk nekā to respondentu, kuri nav Latvijas pilsoṇi,-attiecīgi $26,8 \%$ un $8,4 \%$ (11. tabula).

Nozīmīgs nosacijums sekmīgai kolektīvai rīcỉbai jebkurā jomā-kopienu pašorganizācijā vai kopigā īpašuma apsaimniekošanā - ir savstarpēja uzticēšanās. Lai to novērtētu, aptaujas anketā bija ietverts jautājums «Kopumā nemot, vai Jūs uzskatāt, ka lielākajai dalai cilvēku var uzticēties vai arì piesardzības nekad nevar būt par daudz?». Respondentus lūdza novērtēt
12. tabula. Respondentu sadalījums pēc izglìtības līmeña atbildēs uz jautājumu «Kopumā nemot, vai Jūs uzskatāt, ka lielākajai dą̣ai cilvēku var uzticēties vai arī piesardzības nekad nevar būt par daudz» $(\%, N=1003)$

\begin{tabular}{|c|c|c|c|c|}
\hline & $\begin{array}{r}\text { Pamata } \\
\text { vai zemāka }\end{array}$ & $\begin{array}{r}\text { Vidējā (vidējāā/ } \\
\text { speciālā/ } \\
\text { nepabeigta } \\
\text { augstākā) }\end{array}$ & Augstākā & $\begin{array}{l}\text { Visi respon } \\
\text { denti kopāa }\end{array}$ \\
\hline $\begin{array}{l}\text { O (Piesardzības nekad } \\
\text { nevar būt par daudz) }\end{array}$ & 17,4 & 9,3 & 10,5 & 10,8 \\
\hline 1 & 3,0 & 3,3 & 2,6 & 3,1 \\
\hline 2 & 6,8 & 5,9 & 3,3 & 5,2 \\
\hline 3 & 6,8 & 7,4 & 8,9 & 7,8 \\
\hline 4 & 12,1 & 11,2 & 4,9 & 9,3 \\
\hline 5 & 20,5 & 24,2 & 18,7 & 21,9 \\
\hline 6 & 13,6 & 13,8 & 15,1 & 14,2 \\
\hline 7 & 8,3 & 10,8 & 18,0 & 12,7 \\
\hline 8 & 6,1 & 9,3 & 12,5 & 9,8 \\
\hline 9 & 3,0 & 2,6 & 2,6 & 2,7 \\
\hline $\begin{array}{l}10 \text { (Lielākajai daląai } \\
\text { cilvēku var uzticēties) }\end{array}$ & 2,3 & 2,2 & 3,0 & 2,5 \\
\hline Кора̄ & 100,0 & 100,0 & 100,0 & 100,0 \\
\hline
\end{tabular}

(SUSTINNO 2017)

uzticēšanos citiem cilvēkiem skalā, kur o nozīmē, ka piesardzības nekad nevar būt par daudz, un 10 nozīmē, ka lielākajai daḷai cilvēku var uzticēties. Aplūkojot respondentu atbilžu sadalijumu pēc izglìīibas līmenna, var secināt, ka vispiesardzīgākie attiecībās ar citiem cilvēkiem ir respondenti ar pamata 
13. tabula. Respondentu sadalījums pēc dzīvesvietas atbildēs uz jautājumu «Kopumā ṇemot, vai Jūs uzskatāt, ka lielākajai daḷai cilvēku var uzticēties vai arī piesardzības nekad nevar būt par daudz» $(\%, N=1003)$

\begin{tabular}{|c|c|c|c|c|}
\hline & Rīga & Pierīga & Citi reǵioni & $\begin{array}{r}\text { Visi respon- } \\
\text { denti kopāa }\end{array}$ \\
\hline $\begin{array}{l}\text { O (Piesardzības nekad } \\
\text { nevar būt par daudz) }\end{array}$ & 7,7 & 19,3 & 9,6 & 10,8 \\
\hline 1 & 2,8 & 4,4 & 2,8 & 3,1 \\
\hline 2 & 4,6 & 7,2 & 5,1 & 5,3 \\
\hline 3 & 6,8 & 11,6 & 7,0 & 7,8 \\
\hline 4 & 11,8 & 8,3 & 8,1 & 9,3 \\
\hline 5 & 23,8 & 13,8 & 23,6 & 21,8 \\
\hline 6 & 15,2 & 13,3 & 14,0 & 14,3 \\
\hline 7 & 15,8 & 8,3 & 12,3 & 12,7 \\
\hline 8 & 9,0 & 7,2 & 11,3 & 9,7 \\
\hline 9 & 0,9 & 2,8 & 3,8 & 2,7 \\
\hline $\begin{array}{l}10 \text { (Lielākajai daḷai } \\
\text { cilvēku var uzticēties) }\end{array}$ & 1,5 & 3,9 & 2,5 & 2,5 \\
\hline Kора̄ & 100,0 & 100,0 & 100,0 & 100,0 \\
\hline
\end{tabular}

(SUSTINNo 2017)

vai zemāku izglìtību. Respondenti ar augstāko izglìīibu visumā vairāk uzticas citiem cilvēkiem, bet lielākās daḷas respondentu uzticēšanās citiem pakāpe ir viduvēja -5 no 10 ballēm (12. tabula).

Arī pēc dzìvesvietas respondentu atbilžu sadalījums liecina, ka lielākā dala uzticēšanos citiem cilvēkiem vērtē kā viduvēju -5 balles pēc 10 ballu skalas. Vispiesardzīgākie attiecībās ar citiem cilvēkiem ir Pierīgas iedzīvotāji:
14. tabula. Respondentu sadalījums pēc tautības atbildēs uz jautājumu «Kopumā nemot, vai Jūs uzskatāt, ka lielākajai dalai cilvēku var uzticēties vai arī piesardzības nekad nevar būt par daudz» $(\%, N=1003)$

\begin{tabular}{lccc}
\hline & Latvietis & Cita tautiba & $\begin{array}{r}\text { Visi respon- } \\
\text { denti kopāa }\end{array}$ \\
\hline $\begin{array}{l}\text { O (Piesardzības nekad } \\
\text { nevar būt par daudz) }\end{array}$ & 13,3 & 6,6 & 10,8 \\
\hline 1 & 3,3 & 2,8 & 3,1 \\
\hline 2 & 4,7 & 6,1 & 5,2 \\
\hline 3 & 8,7 & 6,3 & 7,8 \\
\hline 4 & 8,8 & 10,2 & 9,3 \\
\hline 5 & 22,7 & 20,7 & 22,0 \\
\hline 6 & 11,8 & 18,5 & 14,3 \\
\hline 7 & 13,7 & 10,7 & 12,6 \\
\hline 8 & 9,3 & 10,5 & 9,8 \\
\hline 9 & 2,0 & 3,9 & 2,7 \\
\hline 10 (Lielākajai daḷai & 1,6 & 3,9 & 2,5 \\
\hline Kilvēku var uzticêties) & & & 100,0 \\
\hline Kopā & 100,0 & & \\
\hline
\end{tabular}

(SUSTINNO 2017)

tieši vini visbiežāk uzticēšanos citiem cilvēkiem vērtē viszemāk - ar o«piesardzibas nekad nevar būt par daudz» (13.tabula). Arĩ ši jautājuma respondentu sadalījums pēc tautības liecina, ka lielākā dala respondentu uzticēšanos citiem cilvēkiem vērtē kā viduvēju, tomēr ievērojami zemāks uzticēšanās līmenis ir latviešiem - atbildi «Piesardzības nekad nevar būt par daudz» izvēlējušies 13,3\% latviešu un 6,6\% (uz pusi mazāk) cittautiešu. 
Valsts pētijumu programmas SUSTINNO projekta «Sabiedrïbas vērtïborientācijas un sabiedrības atjaunošanās» realizācijas gaitā ir iegūta padziḷināta izpratne par sabiedrības vērtīborientācijām un to ietekmi uz sociālo izturēšanos. Aptaujā SUSTINNO 2017 iegūtie dati rosina turpināt Latvijas iedzīvotāju attieksmes un vērtību izpēti no anomijas perspektīvas, meklējot iespējamos nosacijjumus tās pārvarēšanai. 


\section{Uzṇēmējdarbība, eksports, nodokli, ènu ekonomika un konkurētspēja: analizes rezultāti}

1 Agrinās stadijas (sākumposma) uznēemējdarbibas fãze aptver uzṇēmējdarbìbu, sākot no pirmā aktivā̄ sola, kas tiek sperts, lai dibinātu uznēmumu, lìdz brìdim, kad uznēmums 42 mēnešus ( 3,5 gadus) ir nodrošinājis algas saviem ipašniekiem. Agrinnās stadijas uzṇēmēji ir indivīi, kas ir vai nu topošie uzṇēmēji, vai arī jaunu uzṇēmumu ipašnieki.

2 Procenti no TEA iesaistitajiem, kuri săkusi uzṇemejejdarbibu, jo viniem nav bijusi cita darba alternativa.
Šajā nodalā ir apkopoti galvenie rezultāti no vairākiem zinātniskiem pētījumiem, kas tika īstenoti valsts pētijumu programmas SUSTINNO 1. projekta «Ekonomiskā konkurētspēja un inovācija tautsaimniecībā» laikā no 2014. gada līdz 2017. gadam. Šì projekta mērkis bija empiriski analizēt Latvijas uzṇēmumu konkurētspēju ārējos tirgos, ipašu uzmanību pievēršot uzṇēmuma līmeṇa faktoriem. Projektam ir virkne savstarpēji saistìtu uzdevumu - izmantojot jaunākās pētnieciskās metodes, veikt vairākus zinātniskos pētijumus par faktoriem, kas ietekmē uzṇēmumu konkurētspēju. Šie pētījumi ir: 1) «Sākumposma uzṇēmējdarbỉba un biznesa cikls»; 2) «Eksports kā uzṇēmējdarbỉbu veicinošs faktors»; 3) «ES struktūrfondu ietekmes novērtējums uz uzṇēmumu eksportspēju»; 4) «Ēnu ekonomika un Latvijas uz nēmumu konkurētspēja»; 5) «Nodokḷ sistēma un Latvijas uzṇēmumu konkurētspēja».

Sākumposma uzṇēmēj-

darbība un biznesa cikls

Uzṇēmējdarbības globālā monitoringa (Global Entrepreneurship Monitor-GEM) ietvarā uznēmējdarbības aktivitātes galvenais rādītājs ir kopējā agrīnās stadijas (sākumposma) uzṇēmējdarbỉbas aktivitāte (Total Early-Stage Entrepreneurial Activity-TEA) ${ }^{1}$, kas kopā ar datiem par nepieciešamỉbas spiesto uzṇēmējdarbỉbu ${ }^{2}$ ir atspoguḷota 1. attēlā. Biznesa cikla ilustrēšanai un kā atsauces punkti 1. attēlā ir ieklauti arī dati par reālā IKP izaugsmi un bezdarba lìmeni.

Pirmajā fāzē, kas sekoja pēc Latvijas iestāšanās ES 2004. gada maijā, bija redzama nepieredzēta ekonomiskā izaugsme, ko nomainīja krīze 2008. gadā, savukārt 2011. gadā sākās ekonomikas pakāpeniskas atlabšanas fāze. Viens tūlītējs novērojums ir tas, ka Latvijas uzṇēmējdarbības aktivitāte ir bijusi izteikti mainiga. Pirmie pieci dramatiskie gadi, 2005.-2009.gads, kad Latvijas ekonomika no reālā IKP ikgadējā pieauguma rādītāja virs 10\% nokritās par gandrīz $18 \%$ 2009. gadā, atspoguḷojas agrīnās stadijas uzṇēmēju izplatī bas rādītājā. 2005.-2006. gadā izplatības rādītājs bija aptuveni 6,6\%, 2007.gadā tas nokritās līdz 4,4\%. (Kā norādīts literatūrā (Dombrovsky, Paalzow, Rastrigina, 2011), Latvijas uzṇēmējdarbības dinamikas paneḷpētijuma dati liecina, ka galvenās nozares, kurās 2006.-2007.gadā bija aktīvi Latvijas topošie uznēemēji, bija celtnieciba un privātie pakalpojumi. Aptuveni $20 \%$ aptaujāto topošo uzṇēmēju bija saistīti ar šīm divām nozarēm. Salīdzinājumā ar kopējo Latvijas ekonomiku tās topošo uzṇēmēju vidū dominēja ḷoti neproporcionāli.) Pēc tam šis agrīnās stadijas uznēmēju izplatības rādītājs strauji pieauga līdz 10\% 2009. gadā. Tāpat ir arī diezgan skaidrs, ka kopējo agrīnās stadijas 
uzṇēmējdarbỉbas aktivitāti galvenokārt izraisīja nepiecieša- 3 Sākot ar 2011.gadu, mības spiestas uzṇēmējdarbības pieaugums.

Turklāt 2005.-2010. gada dati ${ }^{3}$ skaidri parāda agrīnās stadijas uznēēējdarbỉbas aktivitātes pretcikliskumu. Pirmapretcikliskais raksturs vairs nepastāv. Tas varētu būt saistits ar mikrouznēmum nodokḷu režima ietekmi.

1. attēls. Uzñēmējdarbïbas aktivitātes dinamika Latvijā 2005.-2016. gadā

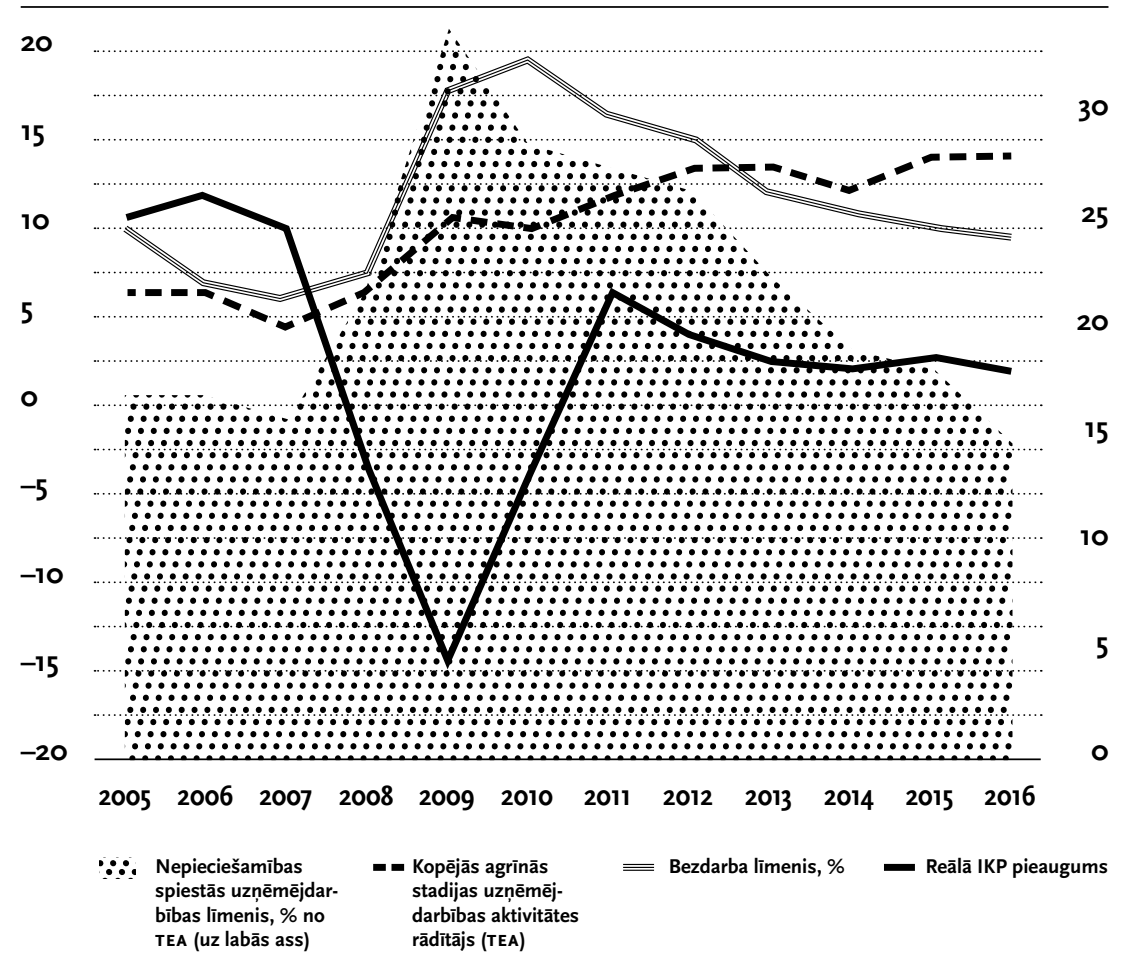

Latvijā būs ilgstoša ietekme uz kopējo Latvijas ekonomikas attīstību. Tā kā liela uzṇēmējdarbības aktivitātes dạ̣a, ko joprojām novērojam, radās kā reakcija uz ekonomikas krīzi, ir pamats domāt, ka daudzi uznēmumi, jo īpaši TEA fāzē, būs îslaicīgi vai neveiksmīgi. Vienlaikus nevar aizmirst, ka nepieciešamìbas spiestā uzṇēmējdarbība var veidot svarīgu pagaidu ienākumu avotu cilvēkiem, kurus skārusi krīze un tās sekas. (Krumina, Paalzow, 2017)

Eksports kā uznēemējdarbību veicinošs faktors: atškirības starp eksportējošiem un neeksportējošiem uzṇēmumiem
Papildus pētijumiem par sākumposma uznēmējdarbỉbu un biznesa ciklu pētījumu programmas ietvaros tika izvirzìti mērḳi noteikt eksporta šḳēršlı un atšḳirïbas starp eksportējošiem un neeksportējošiem uzṇēmumiem Latvijā. Analīze tika balstìta uz Tirgus un sabiedriskās domas pētỉjumu centra SKDS aptaujas datiem par nejauši atlasìtiem 800 vidēja lieluma Latvijas uzṇēmumiem un to ekonomisko darbību 2015. gadā. Atškirības tika pētītas no vairākiem 
aspektiem - eksporta iespējas, produktivitāte, līdzekḷu piesaistišana un inovācijas.

Rezultāti liecina, ka uzṇēmumi, kas nodarbojas ar tiešo eksportu, atškiras no neeksportējošiem uzṇēmumiem: tiešajiem eksportētājiem vidēji ir lielāks apgrozījums; tajos tiek nodarbināts lielāks darbinieku skaits; tie maksā augstākas algas, un tiem ir raksturīga augstāka produktivitāte; tiek novērots arī lielāks darbinieku skaita un algas līmeņa pieaugums. Turklāt eksportējošos uznēmumus pārvalda vadītāji ar augstāko izglìïibas lìmeni.

Pētijumā tika konstatēts, ka uzṇēmumi, kas apsekojuma laikā savu produkciju neeksportēja, nevēlèjās to darìt galvenokārt tāpēc, ka to piedāvātās preces vai pakalpojumi nav piemēroti eksportēšanai. Eksportējošie uzṇēmumi kā lielāko šḳērsli eksportam minēja spēcīgo cenu konkurenci ārvalstu tirgos. Uznēmumi, kas vēlētos eksportēt, kā lielākos škēršlı eksportēšanas uzsākšanai minēja spēcīgo cenu konkurenci ārvalstu tirgos, ar eksportu saistītas sākotnējās izmaksas un grūtỉbas atrast nepieciešamo informāciju par ārvalstu tirgiem. Tie uzṇēmumi, kas ir pārtraukuši eksportēt, šãdi rīkojušies galvenokārt konkurences spiediena, kā arī juridisku vai muitas problēmu dēḷ.

Apsekojuma dati liecina, ka eksportētāji strādā ar lielāku produktivitāti (produktivitāte mērīta kā apgrozijums uz vienu darbinieku). Pētỉjums sniedz pierādỉjumus, ka lielākā daḷa eksportētāju

1) iegulda ievērojamus līdzekḷus jauno darbinieku un esošo darbinieku apmācībā, lai uzlabotu vinu spējas pildìt savus darba uzdevumus;

2) plaši izmanto finanšu prēmijas un atalgojuma paaugstināšanu, lai atzimētu darbinieku labo sniegumu, kā arī plaši izmanto nemateriālus stimulus, lai motivētu darbiniekus;

3) iegulda līdzekḷus jaunākajās iekārtās un ievieš tās ražošanas procesā, aktīvi gadā par iekārtu un aprīkojuma uzstādīšanu, lai samazinātu ražošanas izmaksas.

Konkurences palielināšanās mudina eksportētājus meklēt iespējas, kā samazināt ražošanas izmaksas. Eksportētāji parasti ir inovatīvāki nekā neeksportētāiji. $29 \%$ jeb katrs trešais eksportētājs iegulda ievērojamus resursus jaunu produktu izpētē un izstrādē, bet no neeksportētājiem - tikai $14 \%$. Rentablāku esošo preču un pakalpojumu ražošanas veidu atrašana motivē ieguldìt pētniecībā un attīstībā 30\% eksportētāju un 14\% neeksportētāju. Visizplatîtākais jauninājumu veids ir pārstāvētajā tirgū nebijušu (jaunu vai ievērojami uzlabotu) preču vai pakalpojumu izstrāde.

Saskanā ar aptaujas rezultātiem pēdējo 3 gadu laikā 43 \% eksportētāju un $20 \%$ neeksportētāju ir piesaistijuši papildu līdzekḷus, lai attīstitu savu

uzṇēmumu. Vidēji vairāk nekā puse no piesaistìtajiem līdzekḷiem tika iegūti, izmantojot kādu no banku sniegtajiem pakalpojumiem, piemēram, bankas pārtēriṇa kredītu vai aizdevumu. Otro lielāko ieguldỉjumu kopējā finansēējuma apjomā nodrošināja ES programmas. Eksportējošiem uznēmumiem ir tendence piesaistīt lielāku finansējumu no avotiem, kas nav uznēmuma peḷna. (Pluta, 2017a)

ES struktūrfondu ietekmes novērtējums uz uzṇēmumu eksportspēju Analīzes rezultātā konstatēta pozitīva sakarība starp ES finansējuma sanemšanu un lēmumu eksportēt. Tika parādīts, ka viens ESIF programmas investēts eiro pētîtās datu kopas mediānas (median) uznēmuma gadijumā 5 gadu periodā radīs 17,9 eiro eksporta apgrozijuma.

Ši ietekme tika analizēta sadalījumā starp maziem un lieliem uznềmumiem, pieredzējušu un nepieredzējušu vadību un starp dažādiem ESIF fondiem (Eiropas Reĝionālās attīstības fondu (ERAF) un Eiropas Lauksaimniecības fondu lauku attīstibai (ELFLA)). Ir secināts, ka mazi uzṇēmumi no šìs kapitāla ieplūdes jutīs lielāku efektu; vadība ar lielāku pieredzi efektīvāk izmantos naudu; lauksaimniecības investīciju fonda finansējums izteiktāk ietekmē lēmumu eksportēt nekā Reğionālā attīstības fonda finansējums. ESIF finansējumam patiešām ir būtiska nozìme Latvijas ekonomikas un tâs konkurētspējas veicināšanā. (Viksna \& Bekeris, 2017)

\section{Ēnu ekonomika un Latvijas} uzṇēmumu konkurētspēja

Nino Kokašvili (Nino Kokashvili), Ketevani Kapanadze (Ketevani Kapanadz) un Iraklijs Barbakadze (Irakli Barbakadze) pētot sakarību starp Latvijas uznēmumu izaugssmi un to iesaisti ēnu ekonomikā 2015. gadā, parāda, ka uznēmumi, kuru iesaiste ēnu ekonomikā ir līdz $10 \%$ no uzṇēmuma kopējās ekonomiskās aktivitātes, uzrāda lielāku izaug smi (Barbakadze, Kapanadze, Kokashvili, 2017). Pētỉjumā secināts, ka pastāv pozitiva saistība starp korupcijas uztveri un darbỉbas lïmeni ēnu ekonomikā, un tas parāda, ka darbība ēnu ekonomikā paaugstina izaugsmi tikai tiem uzṇēmumiem, kam ir negatīva izaugsme. Šie uzṇēmumi križu gadījumā ir elastīgāki. Vienlaikus 10\% līmenis darbỉbai ēnu ekonomikā neizslēdz tos no finanšu tirgus. Turklāt šādi uznēmumi gūūst labumu arī no sabiedriskajām precēm un pakalpojumiem. Šāds rezultāts atbalsta pieṇēmumu, ka uzṇēmumiem ar sliktiem darbibas rezultātiem ēnu ekonomika dod iespēju izdzivot, bet nedod stimulu augt. 
Nodokḷu sistēma un Latvijas uzṇēmumu konkurētspēja

Projekta ietvaros tika analizētas Latvijas nodoklu un pabalstu sistēmas atsevišķas dimensijas. Pirmkārt, tika analizēta Latvijas nodoklu un pabalstu sistēma taisnīguma un efektivitātes bilances kontekstā. Lai gan nepastāv universālas receptes attiecībā uz to, cik daudz ienākumu valstij ir jāpārdala, šĩs bilances eksistence liecina, ka vienu un to pašu ienākuma pārdales pakāpi var panākt par dažādu cenu, izteiktu kā efektivitātes samazināšanās. Šajā projektā tika apskatìta ienākuma pārdales pakāpe, ko nodrošina Latvijas nodokḷu un pabalstu sistēma, kā arī stimuli strādāt Latvijā salīdzinājumā ar citām ES valstīm, izmantojot Eiropas mikrosimulācijas nodoklu un pabalstu modeli EUROMOD (Sutherland \& Figari, 2013), EU-SILC datus un H. K. Hara un A. Tumino (Jara \& Tumino, 2013) izstrādāto analìtisko pieeju.

Otrkārt, tika analizētas nesen īstenotās iedzivotāju ienākuma nodokla (IIN) reformas Latvijā, skatot tās ienākuma pārdales kontekstā. Kopš 1994. gada, kad tika ieviests IIN, Latvijā tika piemērota vienota likme, un neliela progresivitātes pakāpe tika panākta tikai ar neapliekamo minimumu. Šajā projektā tika novērtēta 2016. un 2018. gadā îstenoto reformu sagaidāmā ietekme uz sistēmas ienākumu pārdales i patnībām.

Treškārt, no ekonomiskās literatūras ir labi zināms, ka nodokḷu struktūra ietekmē ekonomikas izaugsmi ilgterminạā. Nodokḷi var būt ranžēti pēc to ietekmes uz izaugsmi. Piemēram, sagaidāms, ka darbaspēka nodokḷu sloga samazināšana stimulēs nodarbinātības pieaugumu un nodarbināto pāreju no ēnu sektora uz oficiālo sektoru, īpaši valstīs, kur ir izplatìta izvairīšanās no nodoklu maksāšanas. Budžetam neitrāla nodoklu sloga pārnešana no darbaspēka uz citām nodokḷ u bāzēm ir iespējama, ja nodokḷu slogs ir zems vismaz vienā no šìm sfērām: patēriṇa nodokḷi, nekustamā îpašuma nodokḷi vai vides nodokḷi. Šis nodokḷ kategorijas saskanā ar pieejamo pētijumu rezultātiem mazāk traucē ekonomikas izaugsmi (OECD, 2010; Prammer, 2011; Arnold et al., 2011). Šajā projektā tika novērtētas iespējas Latvijā pārnest nodokḷu slogu no darbaspēka uz nekustamo īpašumu, kā arì tika piedāvātas reformas, kas 1) samazinātu nodokḷu slogu uz algām; 2) dạ̣ēji kompensētu budžeta ieṇēmumu samazināšanos ar augstākiem ieṇēmumiem no nekustamā īpašuma nodokḷa; 3) uzlabotu stimulus strādāt zemu algu sanēmējiem.

Visbeidzot tika analizēti nodoklu maksāšanas stimuli, ko rada Latvijas nodokḷu un pabalstu sistēma. Izvairī̌̌anās no nodokḷu maksāšanas ir nopietna problēma attīstības valstīs un valstīs ar vidējiem ienākumiem. Ekonomiskajā literatūrā ir parādīts, ka izvairǐšanās no nodokḷu maksāšanas ir kaitīga izaugsmei, ỉpaši mazo uznēemumu attīstībai. Šajā projektā tika analizēti bērna kopšanas un vecāku pabalsti (bērna kopšanas pabalsts laikā no 2005. līdz 2008. gadam), kas Latvijā ir atkarīgi no vecāku deklarētajiem ienākumiem periodā pirms bērna piedzimšanas. Tas ḷāva novērtēt,
2. attēls. Džini koeficients sākotnējiem ekvivalentiem rīcībā esošajiem ienākumiem un ienākumu pārdale, ko nodrošina nodokḷ un pabalstu sistēma ES valstīs 2013. gadā

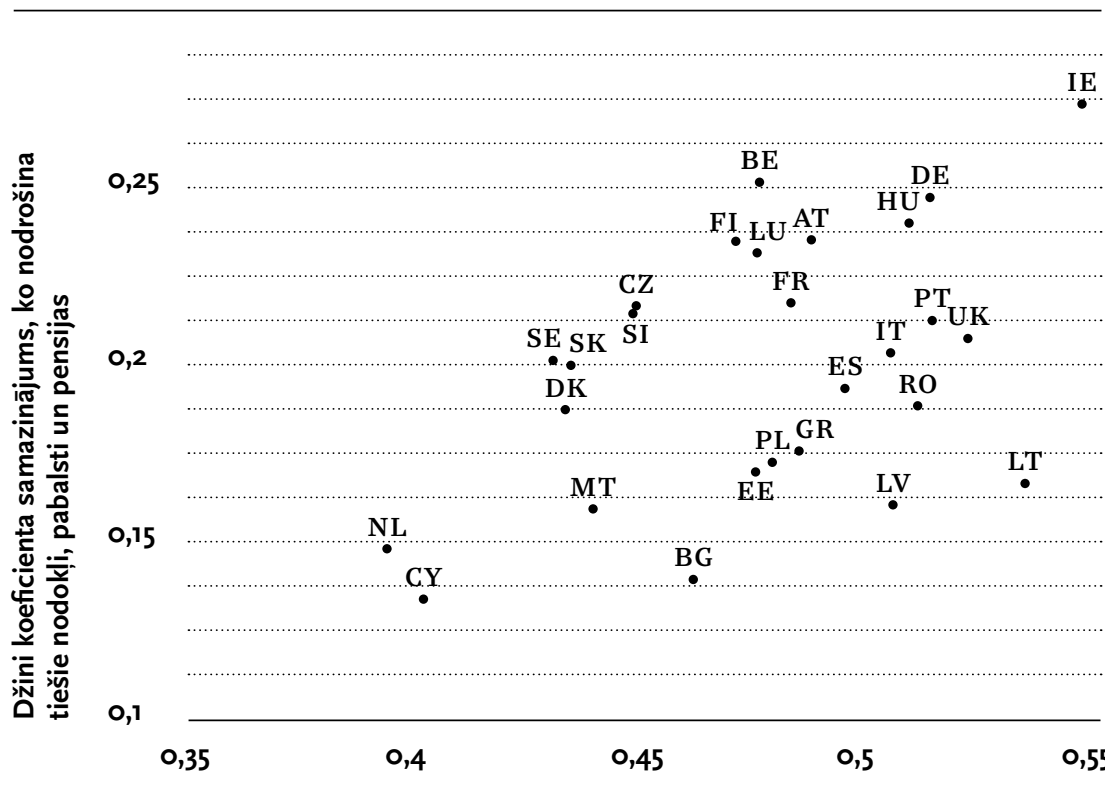

Džini koeficients sākotnējiem ekvivalentiem rīcībā esošajiem ienākumiem

(EUROMOD statistics, n.d.; autoru aprēḳini)

kā pabalstu piesaiste ienākumiem ietekmē izvairīšanos no darbaspēka nodokḷu maksāšanas (Jascisens \& Zasova, 2017).

NODOKLUU UN PABALSTU SISTĒMAS TAISNİGUMS UN ŠİS SISTĒMAS EFEKTIVITĀTE Pirmkārt, rezultāti liecina, ka taisniguma un efektivitātes bilances kontekstā Latvijā salīdzinājumā ar citām ES dalībvalstīm nodokḷu sistēma ir raksturojama gan ar salīdzinoši zemu ienākumu pārdales pakāpi, gan ar zemu efektivitāti, kas mērāma ar efektīvo nodokḷ robežlikmi (METR - marginal effective tax rate), kura nosaka stimulus strādāt. Sākotnējo ienākumu (original income) nevienlīdzība Latvijā nav daudz augstāka par ES vidējo rādītāju, bet nevienlīdzības samazinājums, ko nodrošina nodokḷu un pabalstu sistēma, ir viens no zemākajiem ES (2. attēls).

Tà kā starp ienākumu pārdali un stimuliem strādāt ir savstarpēja saikne, nodoklu un pabalstu sistēmas, kas pārdala mazāk, nodrošina labākus 
stimulus strādāt. H.K. Hara un A. Tumino (2013) ir pierādījuši šìs savstarpējās saiknes eksistenci ES valstīs 2007.-2010. gadā, identificējot negativu un statistiski nozīmīgu korelāciju starp Džini koeficientu un METR. Latvijā vidējāā MET R vērtība 2013. gadā bija 32,2 \%, tikai nedaudz zemāka par ES vidējo rādītāju (34,5\%) un daudz augstāka nekā Igaunijā (22,8\%) un Lietuvā (27,4\%), lai gan Latvijā ir zemāka ienākumu pārdales pakāpe (EUROMOD statistics .., n. d.). Cita Latvijas nodokḷu un pabalstu sistēmas ipašiba ir - tā nodrošina ỉpaši augstas METR vērtības mazturīgiem iedzīvotājiem. Tā 2013. gadā $94 \%$ indivìdu, kam METR vērtība bija augsstāka par 50\%, atradās ekvivalento rīcībā esošo ienākumu sadalījuma zemākajās decilēs. Tas padara Latviju atšḳiiīgu no daudzām Eiropas valstīm, kurās augsto METR vērtỉbu sadalijjums pa ienākumu decilēm ir vai nu daudz vienmērīgāks, vai pieaug augstākajās decilēs (H.K. Haras un A. Tumino (2013) dati par 2007.gadu). Galvenais iemesls, kāpēc Latvijā tieši mazturīgākiem indivìdiem raksturīgas augstas METR vērtības, ir no ienākumiem atkarīgo (means tested) pabalstu (garantētā minimālā ienākuma pabalsta-GMI, mājokḷa pabalsta) noteikumi, kuru rezultātā pabalstu sanēēējiem METR vērtìba ir $100 \%$. Proti, no katra papildus nopelnìtā eiro pabalsta apmērs tiek samazināts par vienu eiro, un rezultātā neto ienākumi nemainās. Tas negatīvi ietekmē nabadzịgāko indivīdu stimulus strādāt un palielina nabadzibas risku.

Taisnīguma un efektivitātes bilances analīzes rezultāti liecina, ka Latvijas nodokḷu un pabalstu sistēmai ir raksturīga gan salīdzinoši zema ienākumu pārdales pakāpe, gan salīdzinoši vāji stimuli strādāt. No ienākumiem atkarīgo pabalstu (GMI un mājokḷa pabalsta) sanēmēju METR vērtības ir $100 \%$, jo pabalsti tiek samazināti par to pašu lielumu, par kuru palielinās ienākumi no darba. Tas vāji stimulē zemu ienākumu saṇēmējus un mazkvalificētos strādniekus iesaistīties darba tirgū, un tas savukārt rada nabadzības riskus. Iepriekšējo pētỉjumu rezultāti liecina, ka zemu ienākumu saņēmēji ir īpaši jutīgi pret stimuliem, ko rada nodokḷu un pabalstu sistēma, tādējādi reformas, kas vērstas uz METR vērtību samazināšanu zemākajās ienākumu sadalījuma decilēs, varētu dot pozitīvus rezultātus, ja tiktu palielināta zemu ienākumu saṇēmēju un mazkvalificēto strādnieku nodarbinātỉba.

NODOKLU UN PABALSTU SISTĒMAS IETEKME UZ darbaspḗKA PIEDĀVĀJUMA IZMAIN̦ĀM Izstrādājot nodokḷ un pabalstu politiku, ir ḷoti svarīgi izprast darbaspēka piedāvājuma priekšnoteikumus, jo ipaši nodokḷu un pabalstu sistēmas izmainu ietekmi uz individa lēmumu piedalīties darba tirgū. Pastāv plašs pētijumu klāsts (piemēram, Benczur et al., 2012; Bicakova, Slacalek, \& Slavik, 2011; Siebertová et al., 2013), kas parāda, ka līdzdalības varbūtība ir atkarīga no sagaidāmā tirgus neto ienākumu līmena un no sagaidāmām neto izmaināam pabalstos, kas ir saistīti ar sākšanu strādāt. Projekta ietvaros
(Pluta, 2016; Pluta, 2017b) tika novērtēta nodoklu un pabalstu sistēmas ietekme uz darbaspēka piedāvājuma izmaiṇām. Tika izstrādāts strukturālais darbaspēka piedāvājuma modelis, kas ḷauj novērtēt nodokḷu un pabalstu reformu ietekmi uz darbaspēka piedāvājuma izmainām. Ieguvumi no darba tiek definēti kā starpỉba starp neto darba ienākumiem un zaudēto pabalstu summu, kas rodas, uzsākot darbu. Empīriskajā analīzē tiek izmantoti apsekojuma «ES statistika par ienākumiem un dzīves apstākḷiem» (EU-SILC) dati 2011.-2015. gadā (atbilst ienākumu gūššnai 2010.-2014. gadā).

Pētijuma rezultāti ḷauj noteikt nodokḷu un pabalstu reformu veidus, kas spēj visvairāk ietekmēt dažādu grupu līdzdalỉbu. Nodokḷu un pabalstu sistēmas instrumenti visefektīvāk darbojas tajās iedzìvotāju grupās, kurām ir visaugstākā lïdzdalības varbūtības atbildes reakcija uz nodokḷu un pabalstu sistēmas izmaiṇām.

Pētījumā secināts, ka darba tirgus politikai, kuras mērkis ir veicināt nodarbinātību, izmantojot nodoklu un pabalstu sistēmu, galvenokārt ir jābūt mērkēētai uz šìm iedzivotāju grupām:

1) vïrieši līdz 25 gadu vecumam; vīrieši vecuma grupā no 25 līdz 54 gadiem ar nepabeigtu pamatizglitīibu vai pamatizglitīibu; vïrieši, kuri dzīvo mazapdzīvotās vietās; zemu ienākumu guvēji;

2) sievietes, kuras ir jaunākas par 25 gadiem, un gados vecākas sievietes virs 55 gadiem; sievietes vecuma grupā no 25 lídz 54 gadiem ar nepabeigtu pamatizglitïbu vai pamatizglitibu; precējušās sievietes vecuma grupā no 25 līdz 54 gadiem; neprecējušās sievietes vecuma grupā no 25 līdz 54 gadiem, kurām ir vismaz viens bērns jaunāks par 3 gadiem; sievietes, kuras dzìvo mazapdzīvotās vietās; zemu ienākumu guvējas.

NODOKLU SISTĒMAS PROGRESIVITĀTE Iepriekšějos gados Latvijas valdība, îstenojot divas nodokḷ reformu paketes, pievērsās zemo ienākumu pārdales problēmai. Vispirms 2016. gadā tika ieviests solidaritātes nodoklis. Tas tiek piemērots augstiem ienākumiem (virs 48600 eiro gadā), un tā likme ir vienāda ar sociālās apdrošināšanas iemaksu (SAI) likmi. Šis nodoklis faktiski aizvietoja SAI, kas netika piemērotas ienākumiem virs 48600 eiro, un tādējādi solidaritātes nodoklis novērsa nodokḷ regresivitāti, kas veidojas SAI griestu dēl. Turklāt 2016. gadā tika ieviests diferencēts IIN neapliekamais minimums: pirms 2016. gada neapliekamais minimums bija vienāds visiem, bet, sākot ar 2016. gada janvāri, tika ieviests progresīvs neapliekamais minimums, kas samazinājās, ja samazinājās ienākumi. Šis divas izmainas - solidaritātes nodokḷa un diferencētā neapliekamā minimuma ieviešana - bija vērstas uz nodokḷu sistēmas progresivitātes palielināšanu, paaugstinot ienākumu pārdales pakāpi un samazinot nodokḷu slogu zemu algu sanēmējiem. 
2017. gada augustā Saeima pienēma vēl vienu reformu paketi, kas stājās spēkā 2018. gada janvārî. Šì reformu pakete arī iekḷauj pasākumus, kas vērsti uz nodokḷu sistēmas progresivitātes palielināšanu. Reforma paredz virkni izmainuu, bet nozīmīgākās nodokḷu progresivitātes kontekstā ir šādas: 1) vienota IIN likme $23 \%$ apmērā tiek aizvietota ar progresīvo likmi ar trim vērtībām: $20 \%$ (piemērota gada ienākumiem zem 20000 eiro), $23 \%$ (piemērota ienākumiem no 20000 eiro līdz 55000 eiro) un 31,4\% (piemērota ienākumiem virs 55000 eiro gadā); 2) diferencētā neapliekamā minimuma progresivitāte tiek palielināta.

Simulāciju rezultāti liecina, ka lielākie ieguvēji gan no 2016. gada, gan no 2018. gada reformu paketes lēmumiem būs mājsaimniecības, kas ierindojas ienākumu sadalījuma vidū. 2018. gada reformu paketes ietekmi ir vērts îpaši uzsvērt. Tiek prognozēts, ka reforma samazinās nodokḷu slogu darbaspēka ienākumiem, taču nodokḷu slogs zemām algām joprojām saglabāsies augsts pēc starptautiskiem standartiem. Lielākās ar IIN apliekamo ienākumu sanēmēju daḷas (93,5\%) ienākumi tiks aplikti ar zemāko nodokḷu likmi, tādējādi nodokḷu reforma faktiski samazinās nodokḷu slogu, bet ietekme uz nodokḷu sistēmas progresivitāti būs maza. Turklāt neliels nodoklu sistēmas progresivitātes palielinājums tiks nodrošināts ar diferencēto neapliekamo minimumu, savukārt nodokḷu progresīvās likmes ieviešanas ietekme būs niecīga (Zasova \& Zdanovica (Pluta), 2014; Vanags \& Zasova, 2015; Pluta \& Zasova, 2017).

NODOKḶU SLOGA PĀRNEŠANA Nodokḷu sloga pārnešana no darbaspēka uz nekustamo ỉpašumu var palïdzēt samazināt nodoklu slogu zemām algām, palīdzot risināt problēmu, uz kuru vairākkārt bija norādījuši gan Latvijas politikas veidotāji, gan Eiropas Komisija, Pasaules Banka un OECD. Nodokḷi zemo algu saṇēmējiem Latvijā ir vieni no augstākajiem ES un OECD valstīs, un tas rada vājus stimulus strādāt un ierobežo Latvijas uznēmumu konkurētspēju. Kā minēts iepriekš, nodokḷu slogs zemām algām saglabāsies augsts salīdzinājumā ar citām valstīm arì pēc 2018. gada nodokḷu reformas.

Šajā projektā (Zasova \& Pluta, 2016) tika novērtētas iespējas reformēt IIN, padarot to progresīvāku, un daḷēji kompensēt zaudētos nodokḷu ieṇēmumus no IIN, palielinot nodokli uz nekustamo īpašumu. Visas simulètās reformas ir vērstas uz trīs mērḳu sasniegšanu: 1) samazināt nodokḷ slogu uz darbaspēku, īpaši -zemo algu sanēmējiem, 2) kompensēt (vismaz dalēji) zaudētos nodokḷu ienēēmumus, palielinot nekustamā îpašuma nodokli (NīN); 3) nodrošināt labākus stimulus strādāt.

Kā tika minēts iepriekš, pašreizējā nodokḷu un pabalstu sistēma Latvijā rada īpaši sliktus stimulus strādāt zemākajās ienākumu sadalījuma decilēs, un to galvenokārt nosaka no ienākumiem atkarīgo pabalstu saṇemšanas noteikumi. Turklāt tiek parādīts, ka pašreizējie NîN noteikumi palielina MET R vērtỉbu zemākajās ienākuma sadalījuma decilēs, jo mājsaimniecỉbas

3. attēls. Simulētās piedāvāto reformu rezultātā panāktās izmainas a) reformu rezultātā panāktās izmaiṇas rīcībā esošajos ienākumos (\% salīdzinājumā ar bāzes scenāriju)

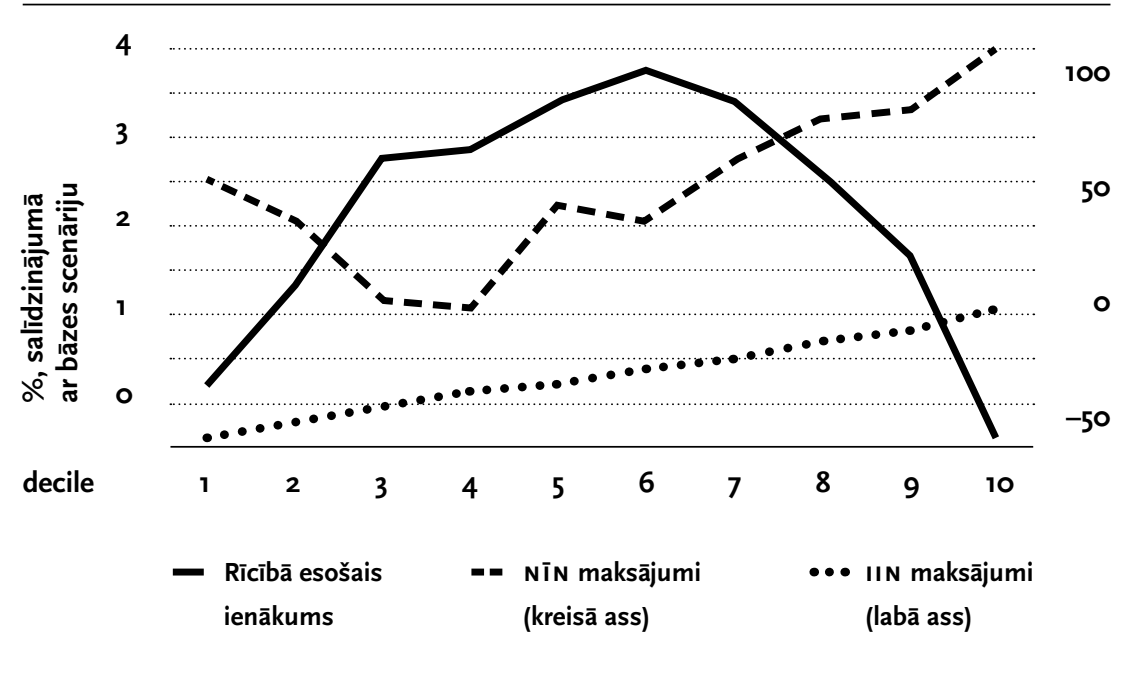

(Autoru aprēḳini)

b) METR vērtības pirms un pēc reformām (\%)

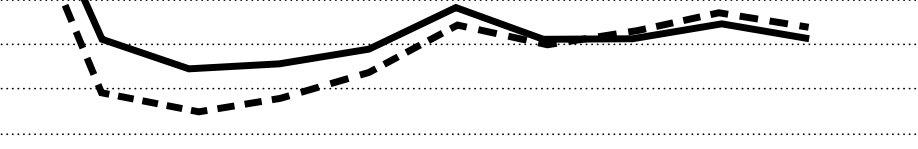

decile

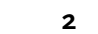

7

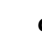

10 scenārijs 
ar ienākumiem zem noteikta sliekšna ir tiesīgas sanemt NīN atlaidi. Tiklïdz mājsaimniecības ienākumi pieaug virs šì sliekšņa, mājsaimniecība zaudē tiesības uz NİN atlaidi, un tas palielina METR vērtìbu. Tāpēc šajā projektā tiek piedāvāts izvairīties no jebkādām atlaidēm, kas ir atkarīgas no ienākumiem.

3. attēlā parādītas simulētās piedāvāto reformu rezultātā panāktās izmaiṇas rīcībā esošajos ienākumos pa ienākumu decilēm un izmaiņas METR. Piedāvātās NīN reformas rada progresīvas izmaiņas, t.i., nodokḷu maksājumi visvairāk pieauğs mājsaimniecībām augstākajās decilēs. Turklāt piedāvātās reformas samazinās MET R vērtības zemākajās decilēs, tādējādi uzlabojot stimulus strādāt. Tai pašā laikā ir parādìts - lai vēl vairāk samazinātu MET R vērtību mājsaimniecībām ar zemiem ienākumiem, ir nepieciešams reformēt pabalstus, kas atkarīgi no ienākumiem.

IZVAIRİŠANĀS NO NODOKL̦U MAKSĀŠANAS UN NODOKLLU UN PABALSTU SISTĒMA Šajā projektā (Jascisens \& Zasova, 2017) tiek analizēti stimuli godīgi maksāt nodokḷus, kurus rada Latvijas nodokḷu un pabalstu sistēma. Jautājums par to, kā stimulēt cilvēkus maksāt nodokḷus, ir aktuāls politikas veidotājiem daudzās valstīs visā pasaulē, jo ir pierādīts, ka izvairīšanās no nodokḷu maksāšanas samazina ekonomikas ilgtermiņa izaugsmi.

Lai radītu labākus stimulus maksāt nodokḷus, bieži tiek piedāvāts saistīt pabalstu apmēru ar deklarētajiem ienākumiem. Piemēram, vairāki pētnieki parādīja (Kumler, Verhoogen, \& Frías, 2013), ka reforma, kuras rezultātā pensijas bija piesaistitas deklarētajiem ienākumiem, palielināja iedzīvotāju deklarētos ienākumus. Lìdzīgi tam citi pētnieki (Cruces \& Bergolo, 2013; Bergolo \& Cruces, 2014) parādīja, ka bērnu veselības apdrošināšanas piesaiste vecāku deklarētajiem ienākumiem ir palielinājusi oficiālo nodarbinātību Urugvajā. Tajā pašā laikā K. Kreiners ar kolēǵiem (Kreiner, Leth-Pedersen, \& Skov, 2016) parāda, ka Dānijas iedzìvotāji manipulē ar ienākumu sanemšanas laiku, lai ienākumi tiktu aplikti ar zemāku nodokli. Šie rezultāti liecina, ka darbinieki un darba devēji var vienoties, lai palielinātu deklarētos ienākumus un lìdz ar to - arī sagaidāmo pabalstu lielumu, ja pabalsti ir atkarīgi no deklarētajiem ienākumiem. Turklāt, ja šì ienākumu «legalizācija» ir îslaicīga un notiek tikai periodā, kas tiek ṇemts vērā, aprēḳinot pabalstu lielumu, tad pabalstu piesaiste pie deklarētajiem ienākumiem noved pie budžeta zaudējumiem. Tādējādi jautājums par to, vai pabalstu piesaiste deklarētajiem ienākumiem ir labs risinājums ēnu ekonomikas kontekstā, paliek atklāts.

Šajā projektā tiek pierādīts, ka sociālo pabalstu piesaistei pie deklarētajiem ienākumiem var būt negatīvas sekas: šis princips palielina budžeta izdevumus pabalstiem, tajā pašā laikā praktiski neietekmējot izvairišanos no nodokḷu maksāšanas. Proti, tiek pierādīts - ja ienākumu saṇemšanas periods, kas tiek ṇemts vērā, aprēḳinot pabalstu apmēru, ir salīdzinoši ìss, bet pabalsti ir augsti, tad darbinieki un darba devēji savā starpā vienojas un īslaicīgi «legalizē» ienākumus, lai vēlāk sanemtu augstākus pabalstus. Šì atzina ir svarīga sociālās apdrošināšanas sistēmas uzbūves kontekstā daudzās valstīs, kurās īss sociālo iemaksu periods nodrošina dāsnus pabalstus ilgākā laika posmā.

Šis fenomens tiek ilustrēts, analizējot bērna kopšanas pabalstu Latvijā, kas periodā no 2005. līdz 2008. gadam bija atkarīgs no vecāku ienākumiem. Sistēma, kura tika ieviesta 2005. gadā, aizvietoja universālu (un loti nelielu) bērna kopšanas pabalstu. Jaunie noteikumi paredzēja, ka viens no vecākiem varēja saṇemt pabalstu, kas bija vienāds ar viṇa neto ienākumiem. Pabalsts tika izmaksāts lỉdz brīdim, kad bērnam paliek viens gads. Vidējā alga, kura tika nemta vērā, nosakot pabalsta lielumu, bija aprēkināta par 12 mēnešu periodu, kurš beidzās trīs mēnešus pirms bērna piedzimšanas (turpmāk tekstā-pabalsta kvalifikācijas periods), un tādējādi šis periods iekḷāva piecus grūtniecības mēnešus. Sākotnēji bērna kopšanas pabalstu nevarēja apvienot ar darbu, bet, sākot ar 2007. gada martu, pilnu laiku strādājošie vecāki kluva tiesīgi saņemt pabalstu.

Iespējams, ka 2005.gada reforma radijja stimulus deklarēt augstākus ienākumus pirms bērna piedzimšanas, jo pabalsts bija liels, bet pabalsta kvalifikācijas periods pārklājās ar grūtniecību - periodu, kad topošā māmiṇa precizi zina laiku, kad vinai vai bērna tēvam būs tiesības saṇemt pabalstu. Lai identificētu šos stimulus deklarēt augstākus ienākumus, tika izmantot administratīvie dati par deklarētajām mēnešalgām, trīs identificējošie pienēmumi un starpibu starpibas (difference in differences) metode.

Pirmkārt, algas pieaugums grūtniecības laikā tika salīdzināts ar alğas pieaugumu sievietēm, kuras nav stāvoklī. Identificējošais pienēmums ir šāds: ja grūtniecība tomēr nebūtu iestājusies, algas pieaugums sievietēm, kuras palika stāvoklī, saglabātos tādā pašā līmenī, kā sievietēm, kuras nav stāvoklì. Ja ir spēkā šis pienēmums, jebkura algas pieauguma starpiba ir interpretējama kā iepriekš nedeklarēto ienākumu legalizācija. Tomēr šis pieṇēmums var arī nebūt korekts, jo grūtniecība nav nejaušs notikums: sievietes var sagaidìt algas pieaugumu (piemēram, sagaidot paaugstinājumu amatā) un tad, ṇemot to vērā, pienemt lēmumu dzemdēt bērnu.

Tādēl tika izmantots otrs identificējošās variācijas avots - tika salīdzināts algas pieaugums grūtniecības laikā sievietēm, kuras strādā privātajā sektorā, ar alğas pieaugumu sievietēm, kuras strādā publiskajā sektorā, kur izvairišanās no nodokḷu maksāšanas neeksistē. Pieṇemot, ka algas pieauguma gaidu efekts publiskajā un privātajā sektorā ir vienāds, starpība, kas novērojama starp algas pieaugumu publiskajā un privātajā sektorā, ir interpretējama kā iepriekš nedeklarēto ienākumu legalizācija.

Bet arī šis pieṇēmums varētu nebūt korekts, jo paaugstinājumu amatā publiskajā sektorā ir vieglāk paredzēt, nekā paaugstinājumu amatā privātajā sektorā (tas nozìmē, ka algas pieauguma gaidu efekts privātajā un 
4. attēls. 3. pakāpes starpību starpības novērtējums

grūtniecības mēnešu griezumā (\%)

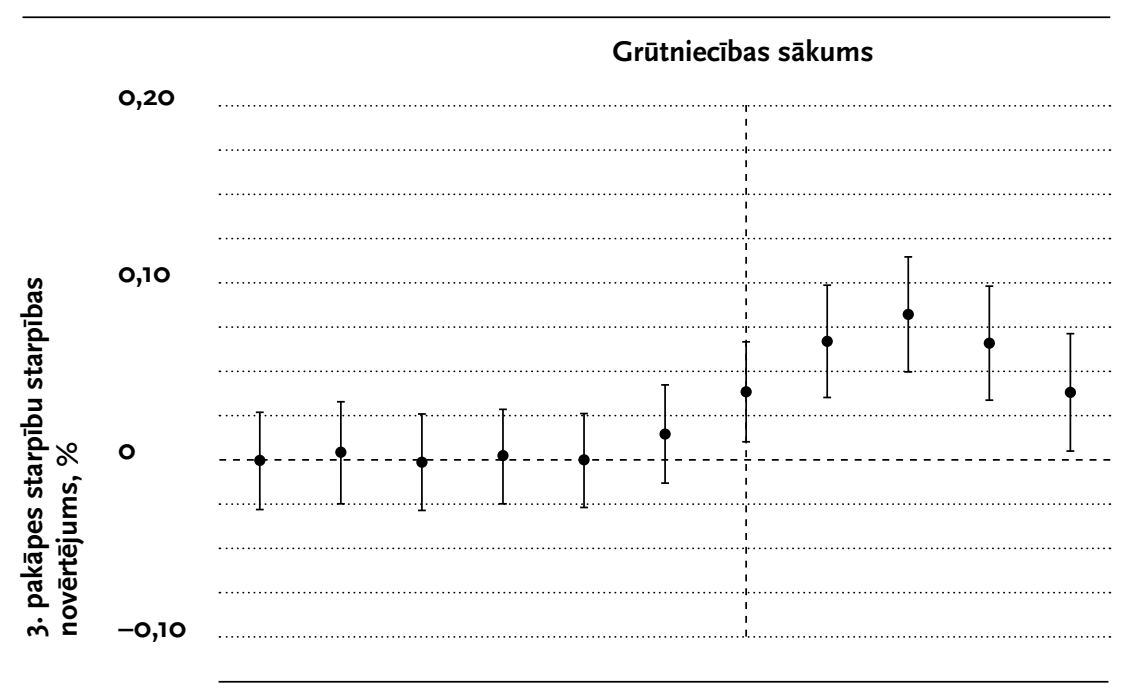

$\begin{array}{llll}-6 & -5 & -4 & -3\end{array}$

\section{Grūtniecïbas mēnesis}

Piezīme: 3.pakāpes starpïbu starpibas (difference in difference in difference in differences estimate) novērtējums noteiktam mēnesim ir iegüts, pirmkärt, salidzinot grūtnieču algas a algăm sievietem, kuras nav stavolki noteiktaja mênesi, un salidzinot ar mênesi, pirms iestäjās grūtnieciba. Tad sis novêrtejums privătajam sektoram tiek salidzinăts ar novêrtêjumu publiskajam sektoram, un visbeidzot tiek salidzinātas šis starpibas pirms un pēc 2005.gada reformas. (Autoru aprēḳini)

publiskajā sektorā var atšķirties). Lai novērstu šo problēmu, tiek izmantots trešais identificējošās variācijas avots - 2005. gada reforma, kuras rezultātā bērna kopšanas pabalsts tika piesaistîts vecāku deklarētajiem ienākumiem; ṇemot vērā, ka šĩ reforma palielināja stimulus deklarēt augstākus ienākumus, algas pieauguma starpība privātajā un publiskajā sektorā nevar būt novērota pirms reformas.

Aprēḳinos tika izmantoti anonimizēti administratīvie dati par darba ṇēmējiem un darba devējiem, un šie dati satur informāciju par deklarētajām algām mēnešu griezumā par visiem Latvijā nodarbinātajiem individiem periodā no 1996. līdz 2010. gadam.

Trīs galvenie pētījuma rezultāti ir šādi. Pirmkārt, algas pieaugums grūtniecības pirmajos piecos mēnešos privātajā sektorā ir vienmēr augistāks nekā publiskajā sektorā. Izmantojot šo rezultātu, lai novērtētu, kāds ir algas

pieaugums ienākumu legalizēšanas dēl, atkarībā no regresijas specifikācijas tika iegūts novērtējums $5-7 \%$.

Otrkārt, šis efekts ir novērojams tikai pēc 2005. gada, kad bērna kopšanas pabalsts tika piesaistîts deklarētajai algai.

Treškārt, pētījumā pierādīts, ka straujš algas palielinājums privātajā sektorā salīdzinājumā ar publisko sektoru ir novērojams, tieši sākot ar pirmo grūtniecỉbas mēnesi (4. attēls).

Apkopojot iepriekš aprakstītos rezultātus, ir pierādìts, ka deklarētās algas strauji pieaug periodā, kas tiek ṇemts vērā, nosakot bērna kopšanas pabalsta lielumu (pabalsta kvalifikācijas periodā). Šis pieaugums ir ìslaicīgs un nav novērojams pēc pabalsta kvalifikācijas perioda beigām. Ši parādība tiek interpretēta kā iepriekš nedeklarēto ienākumu legalizācija: tā ir iespējama, jo pabalsta kvalifikācijas periods ir salīdzinoši ìss (12 mēneši) un iekḷauj grūtniecỉbas piecus mēnešus, kā rezultātā vidêjo algu šajā periodā ir viegli ietekmēt. Šāda sistēma rada sliktus stimulus: darba nēmējs un darba devējs var savā starpā vienoties, lai palielinātu vidējo algu, kura ietekmē pabalsta lielumu. Tas var radīt zaudējumus valsts budžetam un nesamazina izvairīšanos no nodokḷ maksāšanas ilgtermiṇā. 


\section{Inovativi risinājumi ilgtspējīgai lauku attīstibai}

Eiropas Vides birojs (European Environmental Bureau-EEB) uzsver, ka mūsdienu industrializètais lauksaimniecības modelis ir padarīijis lauksaimniekus atkarīgus no liela mēroga agrouzṇēmumiem, kur piegādā: a) insekticīdus, kas kaitē apputeksnētājiem; b) lauksaimniecības dzīvniekiem paredzētas antibiotikas, kas veicina pret antibiotikām rezistentu baktēriju izplatību; c) kultūraugu sēklas, un šai jomā dominē nedaudzi uzṇēmumi, un tāpēc lauksaimnieki saskaras ar ievērojami augstākām cenām un mazākām izvēles iespējām. Tādējādi palielinās monokultūru izplatība, samazinās kultūru un bioloğiskā daudzveidỉba, kultūraugi kḷūst jutīgāki pret klimata pārmaiṇām, un tas kopā rada sistēmiskus riskus. Turklāt lielākās lauksaimniecības zemes platîbas pieder nelielam skaitam lauksaimnieku, un šì tendence pieaug (EEB, 2017). Pēdējo desmit gadu laikā daudzās Eiropas valstīs gan lauksaimnieku skaits, gan lauksaimnieku un citu laukos strādājošo cilvēku ienākumi ir būtiski samazinājušies (European Parliament, 2016). Laika posmā no 2007. lỉdz 2013. gadam lauksaimniecības nozarē ir zaudēti apmēram $20 \%$ darbvietu un arvien vairāk mazo saimniecību no uzṇēmējdarbības tiek izstumtas (EEB \& BirdLife Europe, 2016).

Kaut gan mazās lauku saimniecības līdztekus lauksaimnieciskajai darbībai îsteno citas svarīgas funkcijas (sniedz ekosistēmu pakalpojumus, nodrošinot sabiedrisko labumu; veic sociālas un kultūras darbības, saglabājot materiālās un nemateriālās kultūrvēsturiskās vērtības, kā arì ražojo reǵionālos un tradicionālos produktus), to intereses nav pietiekami nemtas vērā ES kopējā lauksaimniecības politikā (European Parliament, 2014). Eiropas Parlaments norāda, ka mazās un vidèjās saimniecības, atbalstot lauku ekonomiku, ir diversificētākas, inovatīvākas un elastīgākas, un, veidojot ražotāju grupas un kooperatīvus, sniedz labumu kopienām un sabiedrība (European Parliament, 2016).

Pašreizējās kopējās lauksaimniecības politikas īstenošana un lauksaimnieku atkarība no subsīijīām ierobežo inovāciju attīstību un kavē ilgtspējigas pārtikas sistēmas izveidei un alternatīvu augkopības sistēmu atbalstǐ̌ša nepieciešamo saimniekošanas darbibu diversifikāciju un dažādošanu ( $\mathrm{EE} B$, 2017; Melece \& Lakovskis, 2017). A. Bakvels ar lídzautoriem (Buckwell et al, 2017) norāda, ka ir nepieciešamas izmaiņas veidā, kādā lauksaimnieki iesaistās lauku politikas îstenošanā, un šis izmainas saistītas arī ar skaidrāku mērku un rezultātu noteikšanu, ar stimuliem inovācijām, daudzpusīgāku pieeju ainavām un integrāciju pārtikas kẹedes iniciatīvās, tostarp kopējās lauksaimniecības politikas strukturālos ieguldījumus novirzot inovācijām, produktivitātei, cilvēkkapitālam, tirgvedības uzlabošanai, kvalitativai ražošanai un plašākai lauku diversifikācijai. Lai gan saimnieciskās darbības diversifikācija ir lauku attīstības galvenais virzìtājspēks, kas fokusēts uz modernizāciju un inovācijām, tomēr kopējās lauksaimniecības politikas investīciju piesaistes iespējas atbilstīgi ES regulu nosacījumiem pārsvarā ir saistītas ar zemes 
izmantošanas problēmām (Dax \& Oedl-Wieser, 2016), un tas ierobežo lauku ekonomikas dažādošanu.

Viedā specializācija radikāli maina valsts politiku attiecībā uz lauku inovācijām (da Rosa Pires et al., 2014). Pētnieki (Dargan \& Shucksmith, 2008, p. 281) norāda, ka «inovācija tradicionāli valsts politikas limmenī tiek saprasta kā tehnoloğiskā inovācija, kas pārsvarā rodas pilsētvidē zinātnisko izstrāžu rezultātā universitātēs un pētniecības iestādēs un tiek tālāk nodota uznēmējiem». Viṇi uzsver, ka šādas inovācijas lauku videi ir svešas, un tāpēc inovatīva ekonomikas attīstība laukos ir jāsaista ar sociālo inovāciju (veicinot vietējās saiknes un kolektīvo mācišanās kultūru) un kultūras inovāciju (uzlabojot lauku vidi). Agrākā specializācijas politika, kas bija saistìta ar jaunu tehnoloǵiju ieviešanu lauksaimniecībā, nespēja atrisināt lauku attīstības izaicinājumus. Pētijumi un pieredze liecina, ka visbiežāk lauku inovācijas saistītas ar diversifikāciju, kuras rezultātā tiek apvienotas dažādas tehnoloǵijas, organizatoriskās un mārketinga stratēǵijas (da Rosa Pires et al., 2014).

Lauku attīstībai nozīmīga ir plašāka inovāciju koncepcija un inovāciju darbibas jomas paplašināšana, kas ietver dažādus inovācijas narativvuszinātnes un tehnolog̣iju, ekoloğijas, sociālo un pārmainu (da Rosa Pires et al., 2014). Būtisku demogrāfisko izmaiņu, akūtu vides problēmu un risku novēršanai laukos ir nepieciešama inovācijās balstīta attīstības politika, kur sociālās un kultūras inovācijas ir galvenais resurss plašāka spektra inovāciju veidošanā (da Rosa Pires et al., 2014).

Sasaistot vides un sabiedrības pārmainas, sociālekoloğiskā koncepcija piedāvā inovatīvus un piemērotus instrumentus vides, ekonomisko (lauksaimnieku un lauku iedzivotāju ienākumu pieauguma) un sociālo jautājumu risināšanai, tādējādi veicinot lauku turpmāku ilgtspējigu attīstību (Daniel et al., 2012; Tancoigne et al., 2014; Bennett et al., 2015; Scholte, Teeffelen, \& Verburg, 2016; Andersen, 2017). Lai apmierinātu sabiedrïbas vajadzības, veiksmīgos inovatīvos projektos un risinājumos tiek integrēti dabas resursi un kultūrvēsturiskais mantojums tiek apvienots ar jaunām tehnoloğijām (da Rosa Pires et al., 2014). Turpmāk tekstā aplūkotas dažas sociālās inovācijas (precīzāk, jauktās - sociālās, vides jeb ekoloğiskās un organizatoriskās inovācijas) un to ieviešana Latvijā. Šìs inovācijas ir: 1) ekosistēmu pakalpojumi agrovides pasākumu ietvaros; 2) bioenergóijas un biomasas ražošana; 3) lokālās pārtikas sistēmas jeb isās pārtikas kēdes.

\section{Sociālo inovāciju potenciāls} ilgtspējīgai lauku attīstībai

Ir atzīts, ka mūsdienu ekonomiskā sistēma, kurā ekonomiskā izaugsme nenodrošina sociālo labklājỉbu, ir radijjusi vairākas sarežğìtas un neatliekamas sociālās problēmas (OECD, 2011; Benneworth et al., 2013). Sociālo inovāciju izpētes aktualitāte izriet no vairākiem faktoriem: 1) arvien pieaugošā interese par sociālajām inovācijām, un tā ir saistìta ar sabiedrības un atsevišḳu tās locekḷu (indivìdu) labklājības apdraudētību (Harayama \& Nitta, 2011), it īpaši ilgtspējigigas attīstỉbas kontekstā (OECD, 2011); 2) neatliekamās sociālās problēmas, kas saistītas ar vides (tostarp dabas) piesārnojuma un degradācijas tendencēm un no tām izrietošajām klimata izmaiņām (Benneworth et al., 2013; Milner-Gulland et al., 2014; Kotiaho \& Moilanen, 2015); 3) lauku teritoriju iedzivotāju labklājības samazināšanās (Bertolini, Montanari, \& Peragine, 2008), it ippaši Centrāleiropā un Austrumeiropā (Copus \& de Lima, 2014) u. tml. Turklāt tiek uzsvērts, ka pētỉjumiem par sociālajām inovācijām lauku teritorijās un kopienās jeb lauku sabiedrībās Eiropā nav pievērsta pietiekami liela vērība un tos ir nepieciešams aktivizēt (Jenson \& Harrisson, 2013).

Lai gan daudzi pētnieki norāda, ka, ṇemot vērā sociālo inovāciju daudzdimensiālo raksturu, vēl joprojām nav vienošanās par sociālo inovāciju definīciju ne akadēmiskajā vidē, ne arī starptautiskajās institūcijās (Bock, 2012; Science Communication Unit, 2014; TEPSIE, 2014). Eiropā sociālās inovācijas tiek raksturotas šādi: sociālās inovācijas ietver jaunas idejas un risinājumus, kuru mērkis ir atrisināt sociālās vajadzības un problēmas (Science Communication Unit, 2014; TEPSIE, 2014). Turklāt jaunās idejas, institūcijas vai darba metodes risina sociālās vajadzības, t. sk. vides vajadzības, efektīvāk un ilgtspējighāk nekā pašreizējās pieejas (Phills, Deiglmeier, \& Miller, 2008, p. 39; Reeder et al., 2012, p. 7). Tās tiek ieviestas ar programmu, projektu un uzṇēmumu, kā arì ar investīciju palīizību (Reeder et al., 2012), un radītā vērtỉba jeb ieguvumi galvenokārt ir sabiedrỉbai kopumā, nevis tikai atsevišķām personām (Phills, Deiglmeier, \& Miller, 2008; OECD, 2011).

Sociālās inovācijas var izpausties dažādās formās un veidos: produkts, ražošanas process, tehnoloğija, pakalpojums, uznēmējdarbības modelis, ideja, princips, likumdošanas akts, sociālā kustība, intervence vai to kombinācija (Phills, Deiglmeier, \& Miller, 2008; Caulier-Grice et al., 2012). Kopumā sociālo inovāciju sociālie rezultāti ir cilvēka vai vides labklājības (well-being) uzlabošana (Choi \& Majumdar, 2015). Viena no sociālo inovāciju risināmām problēmām ir vides problēmas (Science Communication Unit, 2014), piemēram, vides saglabāšana un ilgtspēja (Phills, Deiglmeier, \& Miller, 2008). Vides problēmām jeb risināmiem jautājumiem ir tendence pastāvīgi mainìties un attīstīties, un ir nepieciešamas adaptīvas un dinamiskas pieejas, kas palīdzētu nodrošināt sociālās inovācijas, ja darbojas relatīvi mazas sociālās grupas un uzkrātā pieredze vides un ilgtspējigga dzīvesveida jomā jānodod citām sabiedribas grupām un kopienām (Science Communication Unit, 2014).

Lielākā dą̣a vides ieguvumu, piemēram, bioloğiskās daudzveidỉbas saglabāšana un ekosistēmu pakalpojumi, ir sabiedriskie labumi, kam nav noteiktas monetārās vērtïbas jeb cenas (TEEB, 2008). Šie sabiedriskie labumi tiek apmaksāti jeb kompensēti ražotājiem ar sabiedriskā finansējuma 
palīdzību. Ekosistēmu pakalpojumi ir daudzveidīgi, un tos var iedalìt četrās kategorijās: 1) apgādes pakalpojumi vai ekosistēmas, kas nodrošina pārtiku, koksni, medikamentus un citus noderīgus produktus; 2) regulējošie pakalpojumi, piemēram, klimata regulēšana, augsnes erozijas un plūdu ierobežošana; 3) atbalsta pakalpojumi, piemēram, apputeksnēšana, augsnes veidošanās un ūdens attīrišana; 4) kultūras pakalpojumi, kas ir estētiski, garīgi vai rekreativi un nodrošina gan nemateriālus, gan materiālus labumus, piemēram, ekotūrisma objektus (Scherr \& McNeely, 2009).

Visbeidzot, varbūt vairāk nekā citās nozarēs lauksaimniecība un lauksaimniecības pārtikas sistēma saskaras ar tādu problēmu atdzimšanu, kas ilgterminā pievērš uzmanību lauksaimniecības inovācijām, un tās ir: pielāgošanās klimata pārmain̄ām (lauksaimniecība ir ekonomikas nozare, kuru šis pārmaiṇas skar visvairāk); ilgtermiṇa saistību pieaugums sakarā ar bioloğiskās daudzveidības un dabas resursu apsaimniekošanu; valsts lomas strukturāla pārskatiššna (reớionalizācija) un publisko/privāto attiecību pārveidošana (Touzard et al., 2015). Šie sarežğîtie jautājumi pastiprina nepieciešamību turpmāk lauksaimniecības inovācijas sasaistīt ar vides un sabiedrības prasībām, tādējādi veicinot starpnozaru inovācijas, kas risinātu aktuālos jautājumus, piemēram, lauksaimniecība un vide, lauksaimniecība un nodarbinātỉba, lauksaimniecỉba un veselïba (Coudel et al., 2012).

Novērtējot sociālo inovāciju potenciālu lauku teritorijās, redzams, ka to nozīme ir plašāka nekā vienkāršu cilvēku sociālo vajadzību apmierināšana. Tajā ir ietverti daudzi izaicinājumi, piemēram, energoefektivitāte un drošỉba, nodrošinātîba ar pārtiku, nevienlīdzības palielināšanās, nabadzības līmena pieaugums, nestabila ekonomika, ilgtermiṇa bezdarbs, darbvietu pārvietošana, klimata pārmaiṇas, vides degradācija u. tml. Šo izaicinājumu risinājums sniegs labumu sabiedrỉbai kopumā.

Lauksaimniecības ainavas, kuras daudzi zinātnieki ir nosaukuši par kultūras ainavām (Daniel et al., 2012; Andersen, 2017), ir pamats dažādu sociālo inovāciju radīšanai (Melece, 2015; Garcia-Llorente et al., 2016; Maes et al., 2016). Šo inovāciju attīstỉba ir saistita ar dažādiem uz sabiedrību orientētiem pakalpojumiem un ar uzṇēmējdarbību, kas var uzlabot gan cilvēku labklājību, gan lauku iedzīvotāju, tostarp lauksaimnieku, ienākumus. Piemēram, ainavu saglabāšana rada iespējas uznēēmējdarbības attīstībai laukos, bet arī sniedz ieguldījumu sabiedrības veselībai, piemēram, nodrošinot fizisko un garìgo labklājibu (Coutts \& Hahn, 2015).

Populārākās lauku saimniecību daudzfunkcionālās un diversifikācijas darbības, kas vienlaikus ir gan sociālās, gan ekoloğiskās inovācijas, jo piedāvā ekosistēmu pakalpojumus (Melece, 2015; Melece, Šēna, 2016), ir šādas: ilgtspējigiga vai videi draudzịga lauksaimniecība (biolog̣iskā vai integrētā lauksaimniecība); lokālās pārtikas sistēmas jeb îsās pārtikas piegādes k̦ēdes; tūrisms, viesmilīiba; rekreācija un veselības veicināšana; fiziskās aktivitātes un izklaide; sociālā vai aprūpes lauksaimniecība; izglìīiba, rehabilitācija; vairākas tūrisma formas (lauku saimniecību, kultūras, kulinārijas tūrisms); kooperācija un sadarbỉba.

\section{Agrovides pasākum \\ ekosistēmu pakalpojumu \\ nodrošināšanai}

Kaut gan zinātnieku un ekspertu vidū na vienprātības par ekosistēmu pakalpojumu definīciju, tomēr viedoklis un pārliecība, ka ekosistēmu funkcijas nodrošina ekosistēmu pakalpojumus, kas sniedz cilvēkiem un sabiedrībai tiešu un netiešu sabiedrisko labumu, ir akceptēts globālajā un Eiropas līmenì (Bennett et al., 2015; Maes et al., 2016; Scholte, Teeffelen, \& Verburg, 2016; Andersen, 2017). Dabas, ekosistēmu un cilvēku attiecỉbas un savstarpējā mijiedarbība ir sarežǵìita un daudzdimensionāla, sociālekoloğiskās attiecibas (Tancoigne et al 2014; Bennett et al., 2015; Maes et al., 2016) ietver sociālos, kultūras, ekonomiskos un vides aspektus (Daniel et al., 2012; Duru et al., 2015).

Ar ekosistēmu pakalpojumiem ir saistīta bioloğiskās daudzveidības saglabāšana, kas nodrošina cilvēku labklājību, tostarp iztiku. Pēdējā laikā arvien vairāk tiek uzsvērta ainavu nozīmība un ainavas saistība ar cilvēku vajadzību apmierināšanu (Daniel et al., 2012). Bioloğiski daudzveidīga ainava veidojas vidi saudzējošas un daudzfunkcionālas lauksaimnieciskās darbības rezultātā, un tā sniedz iespēju diversificēt lauku saimniecību darbību (Sepp, 2012; Tancoigne et al., 2014; Bennett et al., 2015). Lauksaimniecības un mežsaimniecības ainavas nodrošina ekosistēmu pakalpojumu (pārtikas ieguve, bioloğiskās daudzveidỉbas saglabāšana, pielāgošanās klimata pārmaiṇām u.tml.), kā arī piedāvā iespējas to daudzveidīgai izmantošanai, lai gūtu ienākumus un nodrošinātu darbvietas (Maes et al., 2016; Andersen, 2017).

Gan pētnieki, gan eksperti un politikas veidotāji atzīst, ka ainavas, tostarp kultūrainavas, Eiropā ir apdraudētas. Pieaugot pārtikas pieprasījumam un tehnoloğiskajam progresam, intensīvi pieaugusi liela mēroga lauksaimnieciskā ražošana produktīvās lauksaimniecības zemēs. Savukārt zemes pamešana novērojama platībās, kas ir mazāk piemērotas intensīva lauksaimniecībai (Tieskens et al., 2017). Gan lauksaimniecības intensifikācija, kas palielina lauksaimniecibas produkcijas ražošanu, gan zemes pamešana negatīvi ietekmē ekosistēmu pakalpojumu klāstu, tostarp kultūras pakalpojumus. Tas savukārt samazina laukos iespēju piedāvāt preces un pakalpojumus, kas balstiti kultūras ekosistēmu pakalpojumos, - kultūrvēsturiskās ainavas, kultūras mantojumu (Tieskens et al., 2017).

Lauku attīstības kontekstā sociālās inovācijas ir instruments, ar kura palīdzību dažādos sociālos, ekonomiskos un vides izaicinājumus ir iespējams pārvērst jaunos risinājumos (produktos, pakalpojumos, modeḷos, 
tirgus, procesos utt.), kas būtu efektīvāki nekā pašreizējie un atbilstu cilvēku un sabiedrības sociālajām un ekonomiskajām vajadzībām. Tiek uzsvērts, ka šādas sociālās inovācijas var veidoties arì kā jauns princips, ideja, tiesibu akts, sociāla kustỉba vai to kombinācija (Pisano, Lange, \& Berger, 2015), radot jaunas vai uzlabotas dabas un vides resursu izmantošanas iespējas (Garcia-Llorente et al., 2016). Lauku attīstībai un sabiedrỉbai nepieciešamo sociālo inovāciju pamatā ir ekonomisko, sociālo un vides aspektu mijiedarbỉba. Sociālās inovācijas, kas saistītas ar vides problēmu risināšanu, piemēram, ekosistēmu pakalpojumu nodrošināšana, ir orientētas uz cilvēka labklājỉbas uzlabošanu (Melece, 2015).

Par sociālajām inovācijām uzskata dažādus sociālekonomisko un kultūras vajadzību risinājumus, kas saistīti ar ilgtspējīgas attīstỉbas ekonomiskajiem un vides aspektiem, piemēram, videi draudzīgas lauksaimniecības prakses (bioloğiskā lauksaimnieciba) ievērošanu un ğimennu vai mazo lauku saimniecību saglabāšanu (Patias et al., 2016; Melece \& Lakovskis, 2017).

Bioloğiskās daudzveidības saglabāšanai lauksaimniecībā Eiropā tika izstrādāts bioloğiskās daudzveidības rīcības plāns, kur lauku attīstỉbas programmā tika integrētas galvenās prioritātes: atbalsts tādas videi draudzịgas lauksaimniecības prakses veicināšanai, kas tieši vai netieši dod labumu bioloğiskajai daudzveidībai; atbalsts ekoloğisko infrastruktūru uzturēšanai un uzlabošanai. Lai lauksaimnieki savā lauksaimniecības zemē aizsargātu un uzlabotu vidi, lauku attīstības programmas 2. asī ir paredzēts pasākumu kopums, to skaitā - agrovides pasākumi. Tie līdztekus labas lauksaimniecības prakses ievērošanai paredz maksājumus lauksaimniekiem par papildu pakalpojumiem - par agrovides saistību ievērošanu un papildu pasākumu istenošanu.

Tā kā Latvijā nosacijumi pasākumiem netika konkretizēti pa jomām vai darbībām, Latvijas Lauku attīstības programmas 2007.-2013. gadam (LAP 2007-2013) rezultāti liecina, ka agrovides pasākumi netika isstenoti «Natura 2000» teritorijās, kurās ainavu noturībai ir vislielākā nozīme, kāa arī nitrātu jutīgās zonās (1. attēls)

ES regula (European Commission, 2013a) paredz, ka no 2015. gada pastāvīgo zālāju platība attiecībā pret kopējo lauksaimniecībā izmantojamās zemes (turpmāk - LIZ) platību nedrikkst samazināties par vairāk nekā pieciem procentiem. Tomēr Latvija nav pienēmusi stingrus noteikumus un nav veikusi darbības, lai palielinātu pastāvīgo zālaugu platību, īpaši teritorijās, kurās notiek intensīva lauksaimniecības kultūru audzēšana. Latvijā «Natura 2000» teritorijās 40-80\% no ES svarīgākajām plavu platībām nebija pienācīgi pārvaldìtas (Melece \& Lakovskis, 2014). Turklāt LIZ izmainu telpiskā analizze par 2007--2012. gadu liecina arī par ievērojamu pagaidu pḷavu samazinājumu. Pagaidu plavu īpatsvars laika posmā no 2007. lỉdz 2012. gadam ir pieaudzis tikai piecās pašvaldỉbās un mazāk nekā par 5\%; sešās pašvaldībās nav

1. attēls. Agrovides pasākumu ieviešanas platību îpatsvars Latvijas novados un nozīmīgākās vides mērḳa teritorijas 2013.gadā

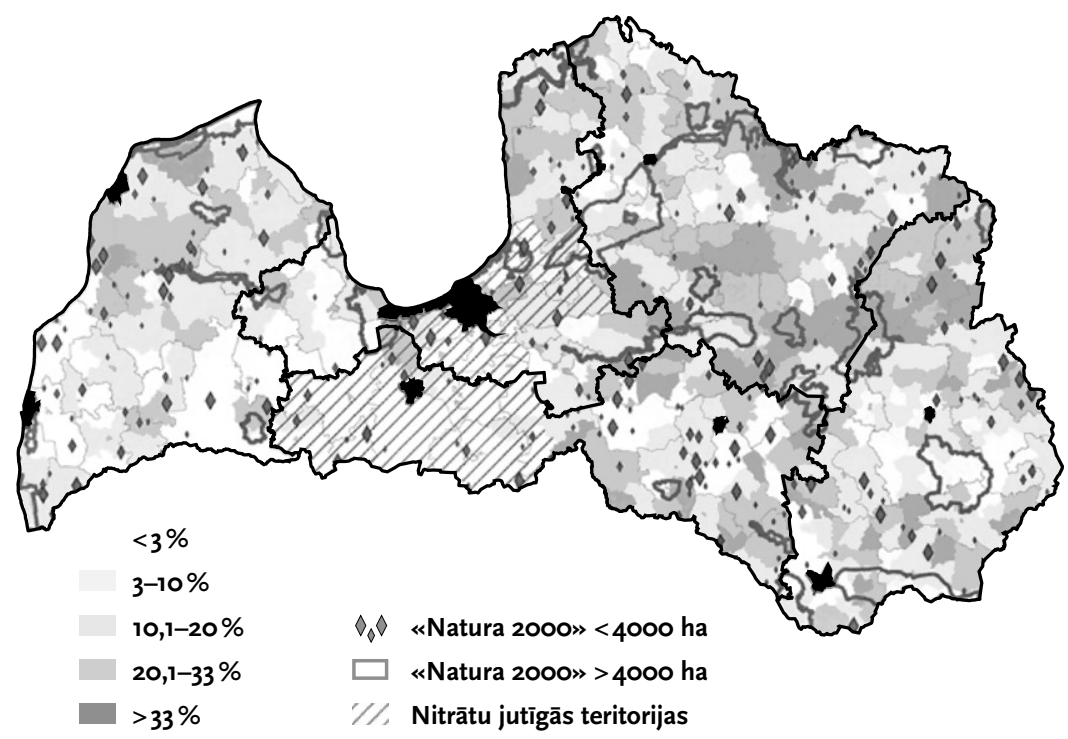

(Melece \& Lakovskis, 2017)

2. attēls. Graudaugu platību īpatsvars vidēji Latvijas aizsargājamo ainavu platībās 2013.-2016. gadā

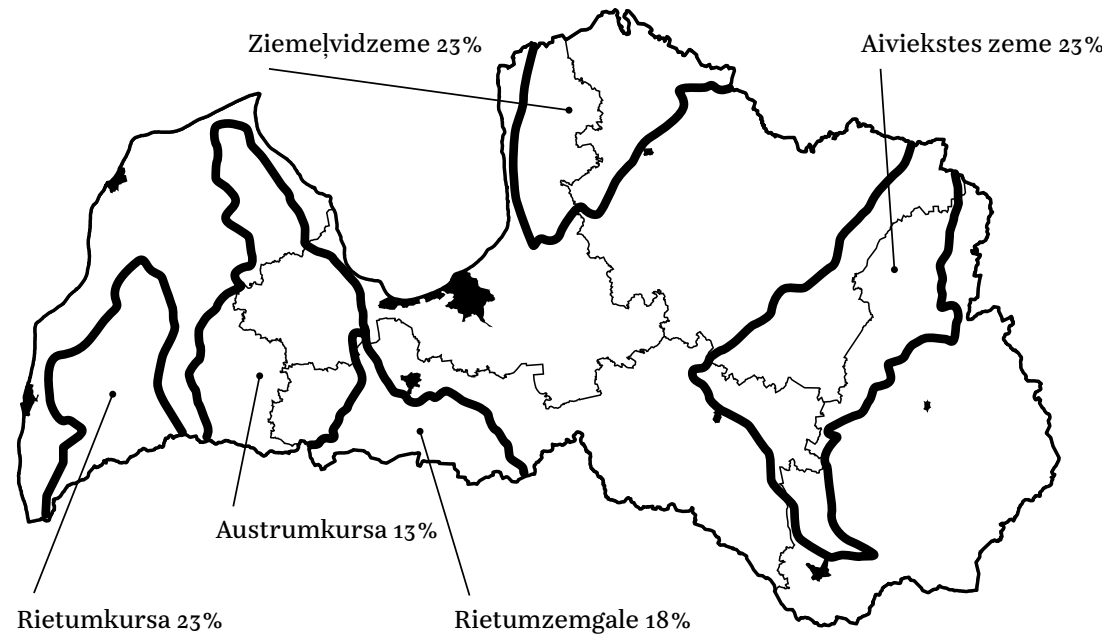

(Melece \& Lakovskis, 2017) 
reǵistrētas izmaiņas, bet citās pašvaldībās pagaidu pḷavu îpatsvars ir samazinājies, îpaši Pierīgas reğionā.

Novērtējot graudaugu îpatsvaru augsekā, tika izvēlēts četru gadu periods un analizēts labỉbas klātbūtnes vidējais rādìtājs šajā laikā. Rezultāti liecina, ka kultūraugu struktūrā novērojama relativi augsta graudaugu dạ̧a augstvērtigoo vai aizsargājamo lauksaimniecības ainavu teritorijās, kurās ir augsts ainavu noturības risks (2. attēls). Jāatzīmē, ka graudaugu proporcija trīs aizsargājamās ainavās ir augstāka (23\%) nekā visā Latvijas teritorijā vidēji (19\%).

Laika posmā no 2007. līdz 2013. gadam vērojama negativa tendence attiecībā uz lauksaimniecības ainavu ilgtspējību vai noturību - samazinājās atbalsta sanēmēju (lauksaimnieku) skaits un palielinājās LIZ platība uz vienu saimniecỉbu. Ši tendence liecina, ka ievērojams skaits mazo saimniecību pārtraukušas nodarboties ar lauksaimniecibu vai lauksaimniecisko ražošanu. Šãds process nav labvēlīgs ainavu saglabāšanai, jo mazajām saimniecībām raksturīga ekstensīva ražošana, un tāpēc tās var nodrošināt bioloğisko un lauksaimniecības ekosistēmu daudzveidību, kā arī uzturēt ḷoti vērtīgu un pievilcīgu ainavu.

Augu sugu un škirnu skaita samazināšana izraisa biolog̣iskās daudzveidības samazināšanos, jo daudzveidīgāka zemsedze (t. sk. kultūru dažādība) rada lielāku dzìvotņu skaitu dažādu sugu taksoniem. Pētnieki (Goulson et al., 2006; Fahrig et al., 2011) uzsver biolog̣iskās daudzveidības, tai skaitā kultūraugu daudzveidības, saglabāšanas nepieciešamību lauksaimniecỉbas ainavās.

Kopumā var secināt, ka mūsdienās lauksaimniecība saskaras ar vairāku veidu pretrunīgām prasībām, kuras būtu jāpilda, lai sniegtu lielāku skaitu ekosistēmu pakalpojumu. Pirmajā grupā ietilpst tā dēvētie nodrošināšanas pakalpojumi, kuru mērḳis ir piegādāt plašu lauksaimniecības produktu (preču) klāstu. Šìs preces ir, piemēram, pārtika, dažādi biomasas materiāli, genētiskie resursi, koksne u.c. Lai to nodrošinātu, ir nepieciešams efektīivi intensificēt ražošanu, piemēram, palielināt neorganiskā mēslojumu izmantošanu, aizstāt mazāk produktīvas tradicionālās šḳirnes ar produktīvākām, paplašināt aramzemes platības utt. Otrā grupa ietver daudzfunkcionālus ekosistēmu pakalpojumus, kuri nodrošina ilgtspējigu attīstỉbu un kuru esamībā ir ieinteresēti arī lauksaimnieki (vismaz tālredzīgi domājošie saimnieki). Tie ir pakalpojumi, kas samazina augsnes eroziju un emisijas, novērš gaisa un ūdens piesārnojumu, saudzē apputeksnētājus, kā arī ietver dažādas darbības, kas paredzētas, lai saglabātu dabas un vides resursus, ekosistēmu funkcionālās spējas, jo ịpaši bioloğisko daudzveidību. Turklāt, lai nodrošinātu lauku teritorijas galveno ekosistēmas pakalpojumu - ainavu, būtiski svarīga ir abu biolog̣iskās daudzveidỉbas veidu - savvaḷas un agrobiolog̣iskās daudzveidības - saglabāšana.

Pašreizējā ES agrovides politika galvenokārt ir vērsta uz vides un ainavu mērḳu sasniegšanu, mazāk domājot par sociālo un cilvēkkapitāla pavairošanu (Mills, 2012). Lielāka izpratne par agrovides pakalpojumu sociālajiem ieguvumiem ḷautu līdztekus vides mērḳiem veiksmịgāk panākt arī sociālos ieguvumus (Mills, 2012; Prager, 2015). Savukārt sociālie instrumenti, piemēram, sadarbība (kooperācija) un koordinācija, kas vairo sociālo un cilvēkkapitālu, agrovides pasākumu pārvaldībā lautu sasniegt labākus rezultātus, it īpaši, ja tiktu ieviesta vairāku līmeṇu pārvaldība (Prager, 2015). Vietējās sabiedrības ietekmi uz dabas resursu saglabāšanu (Holmes, 2013), tai skaitā lauksaimnieku sadarbību, kolektīvo iniciatīvu un pārvaldību, loti ierobežo pašreizējais ES regulējums, kas nosaka ekosistēmu (agrovides) pakalpojumu mērķus augstākā līmenī, tie pieḷauj tikai nelielu elastỉgumu vietējo īpatnību ievērošanā (Prager, 2015).

\section{Bioenergijias ražošana}

ES politikas nostāja ir, ka atjaunojamie energoresursi, tostarp bioenerǵija, palīdz mazināt klimata pārmaiṇas, sekmēt ilğtspējīgu attīstību, aizsargāt vidi un uzlabot iedzìvotāju veselību, kā arī mazināt enerğijas atkarību. Turklāt atjaunojamo energoresursu enerǵija klūst arī par iekḷaujošas ekonomikas izaugsmes virzītāju, radot darbvietas. Turklāt tiek atzìts, ka inovācijas piesārṇojuma mazināšanai, t. sk. siltumnīcefekta gāzu emisiju samazināšanai, ir sociālās inovācijas (Bergman et al., 2010), un tās ietver atjaunojamās enerğijas, t. sk. bioenergijas, ražošanu (Knickel, Tisenkopfs, \& Peter, 2009; Levidow, 2011).

Bioenerğijas ražošana saistīta gan ar pozitivo, gan arī ar negativo ietekmi. Pozitīvo ietekmi raksturo potenciālie ieguvumi: lauksaimniecības diversifikācija; lauku ekonomikas stimulēšana un nabadzības samazināšana; pārtikas cenu paaugstināšanās un lauksaimnieku ienākumu palielināšanās; infrastruktūras attīstība un nodarbinātības paaugstināšanās lauku teritorijās; mazākas siltumnìcefekta gāzu emisijas; palielinātas investīcijas lauksaimniecības zemju uzlabošanai; ieṇēmumi no meža un lauksaimnieciskas izcelsmes atliekām; enerǵijas atkarības samazināšana un vietējās enerǵijas ražošanas diversifikācija, it ippaši lauku teritorijās; piekḷuve tīrai enerğijai, kas iegūta mazos un vidējos uznēmumos (FAO, 2008).

Ja enerğijas kultūras tiek audzētas degradētās augsnēs, tad to audzēšana potenciāli var pozitivi ietekmēt bioloğisko daudzveidību ekosistēmās tās atjaunošanas vai dabas vides funkciju saglabāšanas ceḷā.

Bioenerg̛ijas ražošanas negatîvo ietekmi apliecina vietējās pārtikas pieejamības samazināšanās, jo enerğētisko augu plantācijas aizvieto zemnieku saimniecības, tāpat to apliecina paaugstinātas pārtikas cenas, paaugstināts pieprasijjums pēc lauksaimniecības zemēm, samazināta bioloğiskā daudzveidība, paaugstinātas siltumnīcefekta gāzu emisijas, palielināts piesārṇotāju skaits, augstākas enerğijas izmaksas, palielināta koksnes ieguve (tā veicina meža ekosistēmu degradāciju), mazo lauku saimniecību aizvietošana 
ar lauksaimniecības zemes īpašumu un ienākumu koncentrēšanos, augsnes kvalitātes un auglības samazināšanās enerǧêtisko augu intensivvas audzēšanas rezultātā (FAO, 2008; Fargione et al., 2009). Būtiski ir vēl šādi potenciāli negatīvie aspekti: 1) bioloğiskās daudzveidības samazināšanās (augsnes faunas sastāva izmaiņas; draudi bezmugurkaulniekiem - bitēm un citiem apputeksnētājiem; mugurkaulnieku, it îpaši putnu, bioloğiskās daudzveidības samazināšanās), kultūraugu daudzveidības samazināšanās (lauku platību palielināšanās), introducēto svešzemju vai hibrīdo augu (hibrīdo apšu, ātraudzīgo kārklu šḳirṇu, miskanšu u.c.) neprognozējamā ietekme; 2) mazo saimniecību skaita samazināšanās un lauku «iztukšošanās»; 3) lauksaimniecības zemes cenas paaugstināšanās un pieejamỉbas samazināšanās; 4) pārtikas pašnodrošinājuma (drošǐbas) un kvalitātes samazināšanās; 5) ètiskie apsvērumi (pārtikas iznīcināšana). Pētnieki pauž viedokli, ka vides un ekosistēmu degradācija raisa lielas bažas par pašreizējo biomasas un enerğijas programmu ilgtspējibu (Abbasi, T. \& Abbasi, S., 2010).

Eiropas Komisija (European Commission, 2009) katrai dalībvalstij ir noteikusi obligâto mērḳi-noteiktu kopējo enerǵijas patēriņu no atjaunojamās enerĝ́ijas avotiem -, kurš jāsasniedz līdz 2020. gadam, Latvijai šis rādītājs ir $40 \%$. Lai gan starpposmā noteiktais ietaupījuma rādìtājs 34,1\% Latvijā tika pārsniegts par 1,7\% (mūsu valstī tas sasniedza 35,8\%), ES ilgtspējīga mērka sasniegšana ir apdraudēta.

Pamatojoties uz politikas pamatnostādnēm, Latvijā tika īstenots plašs un daudzveidīgs pasākumu kopums atjaunojamo energoresursu, tostarp bioenerğijas, atbalstam. Lai novērtētu enerǵijas jeb enerğētisko kultūru audzēšanas ietekmi, tika izvēlēti šādi kultūraugi: rapsis (biodīzelim), kukurūza zaḷmasai (biogāzei) un kvieši, kurus pārsvarā eksportē, jo tos izmanto bioetanola ražošanai un to cena ir augsta. Viens no Eiropas Savienïbas, tai skaitā Latvijas, bioenerğijas tiesiskā regulējuma mērkiem ir nodrošināt biomasas ilgtspējigu ražošanu, neatstājot negatīvu ietekmi uz zemes izmantošanu. Galvenās bažas, kas saistītas ar enerớijas augu audzēěanu, ir bioloğiskās daudzveidības samazināšanās (Pang, Mortberg, \& Brown, 2014). Par to zinātnieki brīdināja jau kopš bioenerğijas nozares pirmsākumiem (Dauber et al., 2012). Jāuzsver, ka arī kultūraugu ğenētiskajai daudzveidībai ir būtiska nozīme, lai uzturētu un paaugstinātu lauksaimnieciskās ražošanas līmeni, kā arì, veicinot augsnes bioloğisko daudzveidỉbu, uzlabotu augsnes struktūru un auglỉbu (Tilman, Reich, \& Isbell, 2012). Šajā kontekstā būtiska ir augsekas, kultūraugu maisījumu un pastāvigo augseku (piemēram, ilggadīgo zālāju) izmantošana (Werling et al., 2014, p.1655). Nemot vērā lauksaimniecības dinamisko raksturu, vienam no politikas galvenajiem uzdevumiem ir jābūt tādas lauksaimnieciskās prakses veicināšanai, kas nevis samazina, bet paaugstina bioloğisko daudzveidību, kā arī nodrošina dabiskāku, tai skaitā mozaīkveida, lauksaimniecības dzìvotnu atjaunošanos (Fahrig et al., 2011).

1. tabula. Atbalsta indikatori energijas kultūrām Latvijā 2007.-2009.gadā

\begin{tabular}{lccc}
\hline Indikators & 2007 & 2008 & 2009 \\
\hline Atbalsta likme, EUR/ha & 32,0 & 45,0 & 45,0 \\
\hline Deklarētās platības, tūkst. ha & 35,6 & 19,1 & 17,1 \\
\hline LIZ ìpatsvars, \% & 3,0 & 1,6 & 1,5 \\
\hline
\end{tabular}

(Melece, Krievina, \& Spoge, 2016)

Pēdējos gados bioenerğija ir visstraujāk augošais atjaunojamās energoijas avots Eiropā (European Biomass Association, 2010). Pētnieki (Bentsen \& Felby, 2012; Qin, Zhuang, \& Chen, 2012) uzsver, ka pašlaik bioeneróija pārsvarā tiek ražota no tām lauksaimniecības kultūrām, kuras izmanto pārtikai, piemēram, no rapša. Tas rada ētiskas problēmas, jo ražošanā izmantotie zemes, ūdens un enerğijas resursi varētu tikt izmantoti pārtikas ieguvei (Pimentel et al., 2009; Tilman et al., 2009).

Agroekosistēmu bioloợiskā daudzveidība paaugstina lauksaimniecības kultūru produktivitāti (Tilman, Reich, \& Isbell, 2012), turklāt šai daudzveidība ir būtiska nozīme agroekoloǵiskajos procesos, jo tiek nodrošinātas dažādās lauksaimnieku un sabiedrības vajadzỉbas, sniedzot ekosistēmu pakalpojumus, piemēram, pievilcīgas lauku ainavas rekreācijai un tūrismam (Bergmann, Colombo \& Hanley, 2008; Power, 2010).

Lai novērtētu enerǵijas kultūru audzēšanas ietekmi uz ekosistēmām un sociālekonomiskiem rādītājiem, tika veikta atbalsta pasākumu analīze, ietekmes izvērtēšana uz sējumu un LIZ struktūru, augsnes kvalitāti, kā arî tika pētìta potenciālā ietekme uz apputeksnētājiem.

Laika posmā no 2007. līdz 2009. gadam saskanāā ar ES tiešo atbalsta maksājumu sistēmu lauksaimnieki bija tiesigi pieteikties uz atbalstu enerǵijas kultūru audzēšanai. Atbalsta maksājumi tika ieviesti, lai palīdzētu attīstīt bioenerǵijas nozari (1.tabula). Tomēr, nnemot vērā nozares attīstību, jo ippaši lielo pieprasijumu starptautiskajos tirgos, kā arī saistošu ES mērku noteikšanu attiecībā uz biodegvielas īpatsvaru kopējā transporta enerǵijas patēriṇā, valsts atbalsts kopš 2010. gada tika pārtraukts (Melece, Krievina, \& Spoge, 2016).

Saskanā ar Direktīvu 2009/28/EK valsts atbalsta biodegvielas ilgtspējïgu ražošanu. Tas nozīmē, ka jānodrošina vismaz 35\% (no 2017. gada 1. janvāra $-50 \%$ ) siltumnīcefekta gāzu emisiju ietaupijumi; nedrikst veicināt zemes platību ar augstu bioloğisko daudzveidỉbu samazināšanos; kā arī zemes 
3. attēls. Ziemas kviešu, rapša un kukurūzas platību dinamika Latvijā 2007.-2013.gadā

\section{$\mathrm{y}=23,693 \mathrm{x}+206,99^{* * *} \quad \mathrm{y}=6,6 \mathrm{x}+81,129^{* *} \quad \mathrm{y}=2,7429 \mathrm{x}+0,4857^{* * *}$ $R^{2}$ kvieši $=0,9772 \quad R^{2}$ rapsis $=0,7533 \quad R^{2}$ kukurūza $=0,8209$}

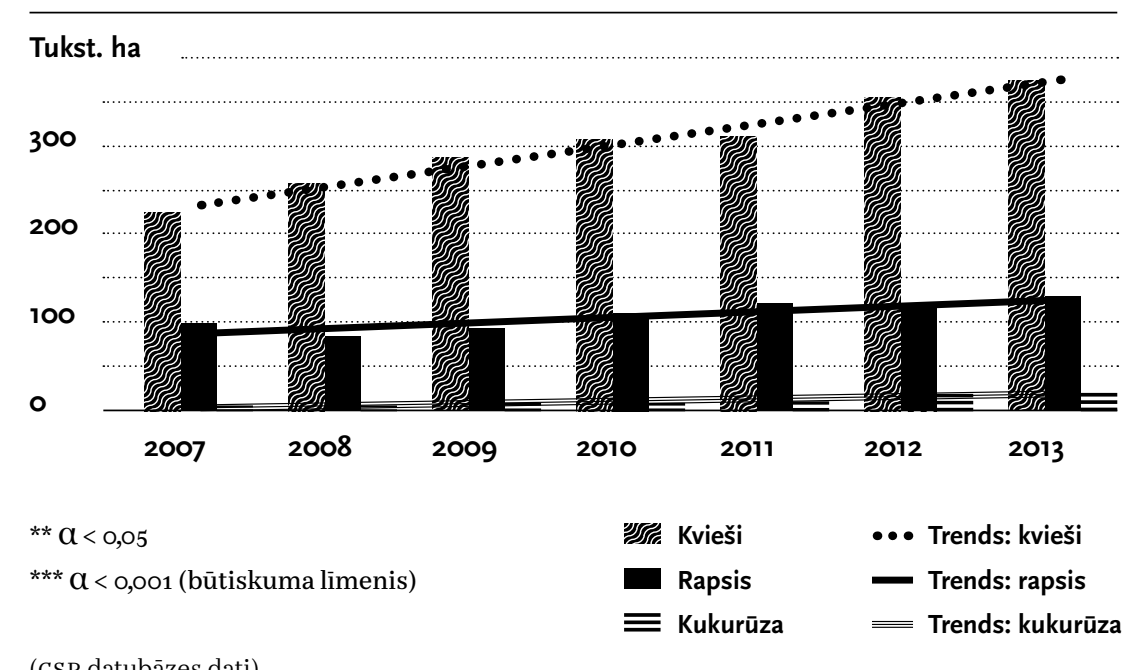

2. tabula. Kviešu, rapšu un citu kultūru platību izmainas

Latvijā 2007.-2013. gadā (tūkst. ha)

\begin{tabular}{lcccccccr} 
Kultūra & 2007 & 2008 & 2009 & 2010 & 2011 & 2012 & 2013 & $13 /$ 'o7 \\
\hline Kvieši & 224,6 & 256,6 & 285,7 & 307,6 & 311,3 & 354,7 & 371,8 & 1,7 \\
\hline Rapsis & 99,2 & 82,6 & 93,3 & 110,6 & 121,3 & 117,5 & 128,2 & 1,3 \\
\hline Ilgggadīgie zālāji & 427,1 & 413,1 & 413,7 & 387,3 & 370,8 & 351,4 & 356,7 & 0,8 \\
\hline Pārējās & 375,3 & 359,2 & 319,3 & 297,2 & 283,3 & 298,5 & 289,8 & 0,8 \\
\hline Kopā & 1126,2 & 1111,5 & 1112 & 1102,7 & 1086,7 & 1122,1 & 1146,5 & 1,0 \\
\hline
\end{tabular}

(CSP datubāzes dati)
4. attēls. Ilggadīgo zālāju, pārējo kultūru (citas, iznemot ziemas kviešus, rapsi, kukurūzu un ilggadīgos zālājus) un LIZ platību dinamika Latvijā 2007.-2013.gadā

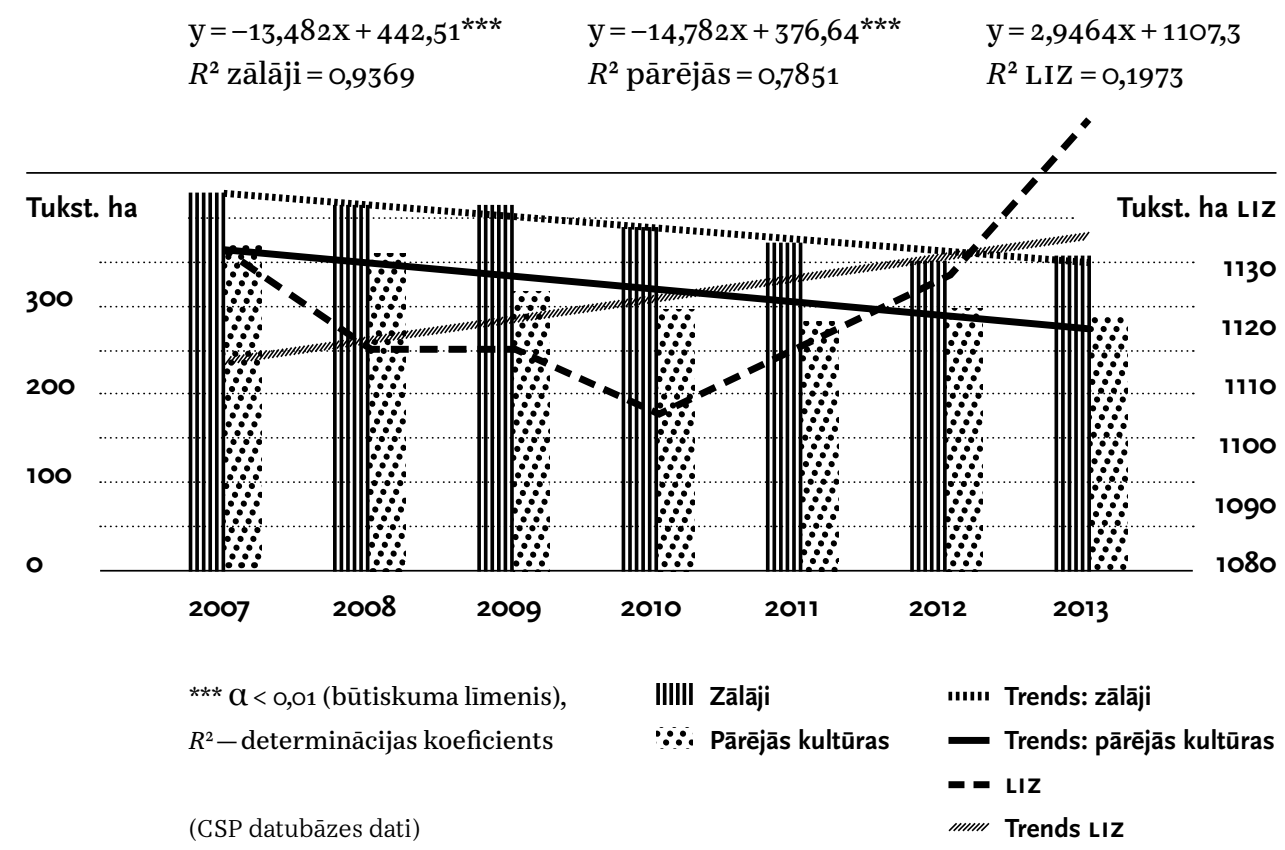

platības, kuru augsnes ir ar augstu oglekḷa uzkrājumu (soil carbon storage), nedrïkst izmantot kultūrām, kas paredzētas biodegvielas biomasas ražošanai (European Commission, 2009). Tāpēc kopš 2011. gada Latvijā ir ieviesti ilgtspējības kritēriji un valsts sertificēšanas shēma, kas paredz lauksaimniekiem uzrādīt apstiprinājumu, ka vinu izaudzētās biodegvielas izejvielas ir iegūtas kritērijiem atbilstošās platībās. 2011. gadā sertificēti 29,5 tūkst. ha, kas aiznemem $2,4 \%$ no kopējās aramzemes platības.

Laika periodā no 2007. lìdz 2013. gadam būtiski un statistiski ticami pieaugušas kviešu, rapša un kukurūzas platības (3. attēls), kaut gan kopējo apstrādātās aramzemes platību pieaugums ir niecīgs un nebūtisks (4. attēls). Kviešu platības Latvijā periodā no 2007. līdz 2013. gadam pieaugušas 1,7 reizes (2. tabula), turklāt statistiski būtiski $(\alpha<0,001)$ (3. attēls). Rapša platỉbas šajā periodā ir pieaugušas 1,3 reizes, un pieauguma tendence ir statistiski ticama $(\alpha<0,05)$. Šo divu kultūru platību pieaugums ir noticis uz pārējo kultūru rēḳina (2.tabula), jo kopējais izmantotās LIZ apjoms ir palicis praktiski nemainīgs. Tajā pašā periodā (2007.-2013. g.) novērojama lot negatīva tendence, jo būtiski (statistiski ticami) ir samazinājušās ilggadīgo 
3. tabula. Papuves platību îpatsvara izmainas

Latvijas regionos 2007.-2012. gadā (\%)

\begin{tabular}{lcccccccc}
\hline Regions & $\mathbf{2 0 0 7}$ & $\mathbf{2 0 0 8}$ & $\mathbf{2 0 0 9}$ & $\mathbf{2 0 1 0}$ & $\mathbf{2 0 1 1}$ & $\mathbf{2 0 1 2}$ & $\boldsymbol{R}^{\mathbf{2}}$ & Bütisk. \\
\hline Kurzeme & 0,8 & 0,6 & 0,7 & 0,7 & 0,6 & 0,4 & $-0,86$ & $\alpha<0,05$ \\
\hline Latgale & 0,9 & 0,7 & 0,7 & 0,7 & 0,6 & 0,4 & $-0,95$ & $\alpha<0,01$ \\
\hline Pieriga & 0,8 & 0,5 & 0,6 & 0,6 & 0,5 & 0,3 & $-0,82$ & $\alpha<0,05$ \\
\hline Vidzeme & 1,0 & 0,7 & 0,7 & 0,7 & 0,6 & 0,4 & $-0,91$ & $\alpha<0,01$ \\
\hline Zemgale & 0,5 & 0,4 & 0,4 & 0,4 & 0,4 & 0,3 & $-0,92$ & $\alpha<0,01$ \\
\hline
\end{tabular}

(CSP datubāzes dati)

zālāju un pārējo kultūraugu platības (4. attēls). Tas liecina par gan par agrobioloğiskās, gan dabas bioloğiskās daudzveidības samazināšanos un ainavu kvalitātes (pievilcīguma) pazemināšanos.

Ilggadīgie zālāji veicina bioloğisko daudzveidību, ierobežo kaitēkḷu izplatību un nodrošina apputeksnētājiem labvēlīgu dzìvotni, tādējādi sniedzot vērtīgu ieguldijjumu lauksaimnieciskajā ražošanā (Gaujour et al., 2012; Werling et al., 2014). Vienlaikus arī papuve ir vērtīgs biotops bioloğiskās daudzveidības uzlabošanai (Sircely \& Naeem, 2012), un tā ir nozìmīga augsnes struktūras un auglỉbas saglabāšanā (Aguilera et al., 2013). Papuves platîbu īpatsvara izmaiņas un izmaiṇu tendenču novērtējuma apkopojums redzams 3.tabulā.

N̦emot vērā, ka Latvijā, it īpaši Zemgalē un Kurzemē, kā arī Pierỉgā, ir samazinājies ne tikai ilggadịgo zālāju un p̣̣avu, bet arī papuvju platỉbu ỉpatsvars, un ši tendence ir statistiski ticama, ir apdraudēta biolog̣iskās daudzveidỉbas un lauku ainavu saglabāšanās.

Arī kviešu platību îpatsvara paaugstināšanās rada draudus gan bioloğiskajai daudzveidībai un ainavu saglabāšanai, gan videi kopumā, jo optimālas augu sekas nenodrošināšana rada augsnes auglības samazināšanās un ūdens piesārṇošanās draudus. Augu sekas neievērošana palielina nepieciešamību paaugstināt minerālmēslojuma devas, kā arī kaitēklu savairošanas rezultātā palielināt pesticīdu lietošanas intensitāti (Melece, Šēna, 2016).

Neizmantotās LIZ ipatsvars Latvijas reǵionos samazinājies pavisam nedaudz (par 1-3\%) visos reǵionos, izṇemot Latgali, bet tieši tur LIZ ipatsvaram ir vislielākā nozīme, nemot vērā, ka Latgalē ir augstākais bezdarba
4. tabula. Kukurūzas zalmasas īpatsvara tendences Latvijas reǵionos 2004.-2012. gadā (\%)

\begin{tabular}{lcccccccc}
\hline Reǵions & 2007 & 2008 & 2009 & 2010 & 2011 & 2012 & $\boldsymbol{R}^{\mathbf{2}}$ & Būtisk. \\
\hline Kurzeme & 0,2 & 0,2 & 0,2 & 0,2 & 0,3 & 0,8 & 0,80 & $\alpha>0,05$ \\
\hline Latgale & 0,1 & 0,1 & 0,1 & 0,1 & 0,1 & 0,3 & 0,75 & $\alpha>0,05$ \\
\hline Pierīga & 0,3 & 0,3 & 0,4 & 0,5 & 0,9 & 1,8 & 0,85 & $\alpha<0,05$ \\
\hline Vidzeme & 0,1 & 0,2 & 0,1 & 0,1 & 0,2 & 0,5 & 0,69 & $\alpha>0,05$ \\
\hline Zemgale & 0,5 & 0,5 & 0,6 & 0,6 & 1,3 & 1,8 & 0,88 & $\alpha<0,05$ \\
\hline
\end{tabular}

(Melece et al., 2015)

līmenis - 10,6 \% (Melece, Šēna, 2016) - un zemākie ienākumi no lauksaimniecìbas - 477 eiro/mēnesī, kas ir $82 \%$ salīdzinājumā ar vidējo rādītāju valstī un tikai $69 \%$ no ienākumiem Zemgalē (Melece, Šēna, 2016).

Par to, ka enerğijas kultūras (rapsis un kukurūza zaḷmasai) pārsvarā tiek audzētas teritorijās, kurās ir augstākā augsnes auglība, liecina telpiskās analīzes rezultāti (5. attēls).

Latvijā kukurūzas zalımasas sējumu platība 2013. gadā bija 20,4 tūkst. ha, salīdzinājumā ar 2007. gadu (5,1 tūkst. ha) tā ir pieaugusi 4 reizes. Tomēr reğionu griezumā ir ievērojamas atšḳirības. Vislielākais kukurūzas zaḷmasas ipatsvars ir Zemgalē un Pierīgā -1,8\%, bet pārējos reǵionos tas ir ievērojami zemāks. Tāpat Zemgalē un Pierīgā novērota statistiski ticama kukurūzas zaḷmasas ippatsvara pieauguma tendence salīdzinājumā ar periodu no 2007. līdz 2012. gadam (4.tabula). Jāatzīmē, ka Zemgalē, kur ir novērojams visaugstākais ipatsvara pieaugums, ir visauglīgākās augsnes, un tur notiek intensiva lauksaimniecibas produkcijas ražošana (Melece et al., 2015).

Tas, ka kukurūzas platību ipatsvara pieaugums ir saistìts ar bioenerớijas (biogāzes) ražošanu, ir redzams 6. attēlā-platību pieauguma tendences ir saistītas ar biogāzes iekārtu izvietojumu.

LIZ struktūras izmainas ietekmē gan mājas bišu, gan savvaḷas apputeksnētāju (kameṇu, ziedmušu u.c.) skaita izmainnas. Apputeksnētāji ir ipaši nozīmīgi lauksaimniecības produkcijas ieguvē, un to skaita samazināšanās apdraud pārtikas nodrošinājumu (Aizen et al., 2009). Visbūtiskākā ietekme apputeksnētāju skaita samazināšanā ir lauksaimnieciskās ražošanas intensifikācijai, kas ir saistīta: 1) ar pieaugošu pesticīdu daudzumu izmantošanu, 
5. attēls. Rapša, kviešu un sēto zālāju platības (ha) Latvijas novados 2015.gadā

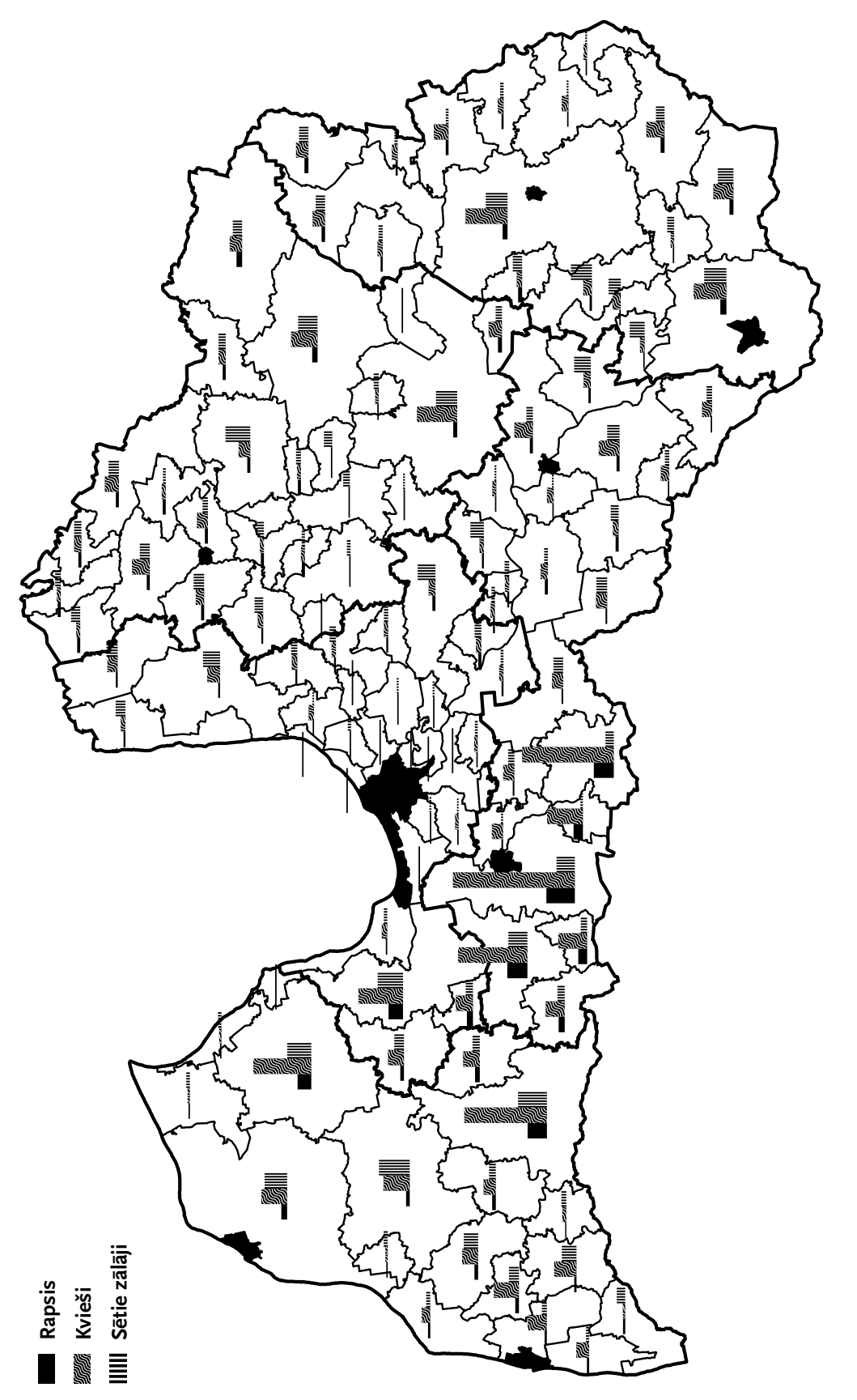

6. attēls. Biogāzes iekārtu izvietojums 2015. gadā un zalmasai paredzēto kukurūzas platību izmaiṇas Latvijas novados 2009.-2015. gadā

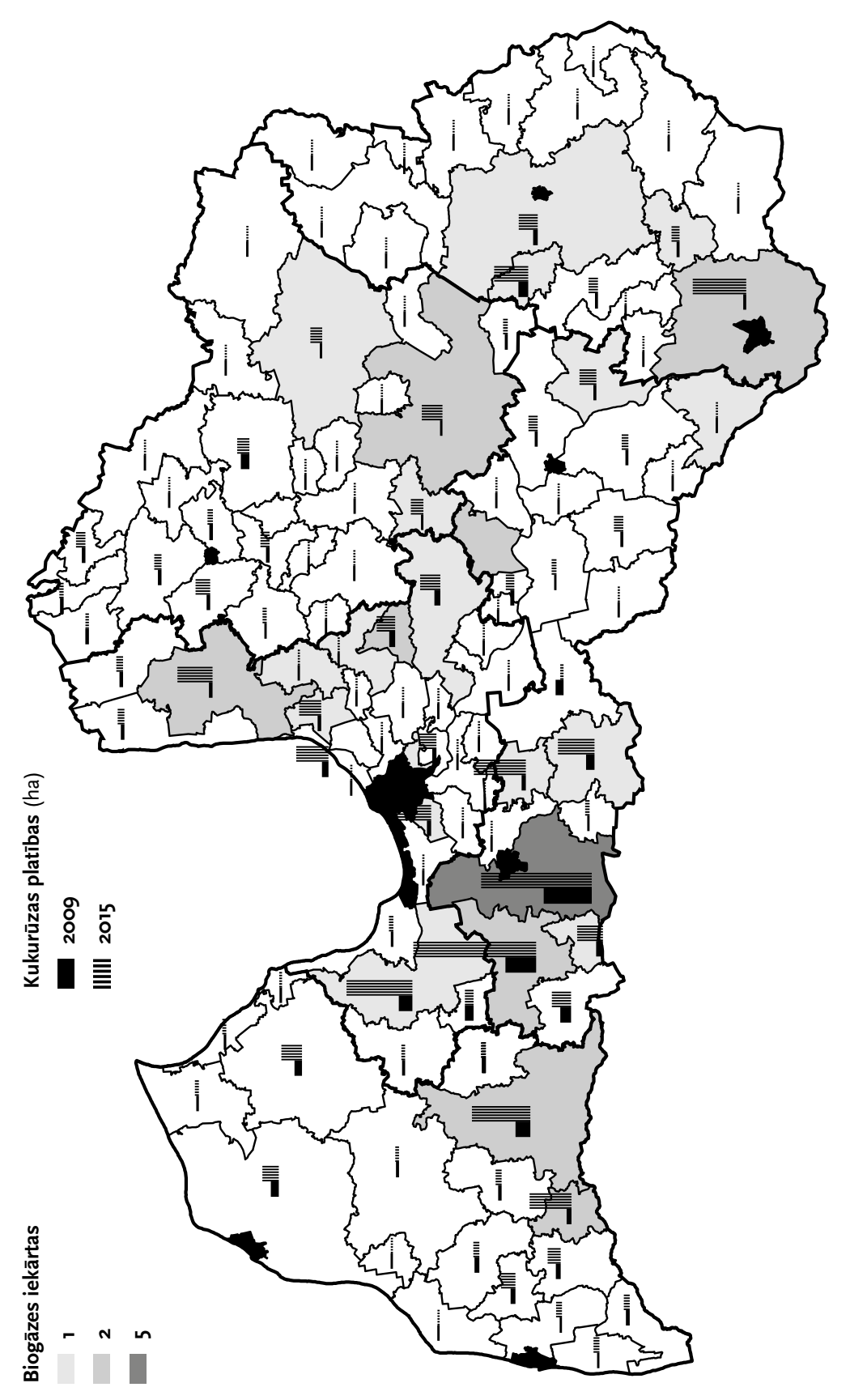


it ippaši rapša un kukurūzas sējumos (Henry et al., 2012; Krupke et al., 2012); 2) ar kultūraugu daudzveidības samazināšanos jeb monokultūru īpatsvara palielināšanos (Aizen et al., 2009).

Latvijā 2012.gadā graudaugu sējumos izmantotas 598 tonnas pesticīdu jeb 1,04 kg/ha. Rapša platībām izmantotas 181,3 tonnas pesticīdu jeb vidēji $1,54 \mathrm{~kg} / \mathrm{ha}$ (Centrālā statistikas pārvalde, 2013). Centrālās statistikas pārvaldes 2013. gada apsekojuma rezultāti liecina, ka visintensīvāk augu aizsardzības lỉdzekḷus graudaugiem lauksaimnieki lietoja ziemas kviešu audzēšanai$1,51 \mathrm{~kg}$ pesticīdu vienam sējumu hektāram; ziemas miežu sējumos-1,41 kg/ ha, bet vasaras kviešu laukos $-0,89 \mathrm{~kg} / \mathrm{ha}$. Savukārt ziemas un vasaras rapša sējumos šis rādìtājs sasniedza $1,75 \mathrm{~kg}$ un 1,29 kg vienam hektāram, bet auzu, griḳu un graudaugu mistru sējumos pesticīdu izlietojums vienam sējumu hektāram bija ievērojami mazāks. Turklāt jāatzīmē, ka augstākas pesticìdu devas tiek izmantotas tajās saimniecībās, kurās ir lielākas platības, piemēram, līdz 20 ha lielās saimniecībās ziemas kviešiem izlieto 2,5 reizes mazāk pesticìdu uz vienu ha nekā saimniecībās ar platību virs 500 ha, ziemas rapsim šì starpiba ir 1,8 reizes.

Parasti kviešu un rapša audzēšanā tiek izmantotas lielākas slāpekḷa devas, un dạ̣a slāpekḷa tiek zaudēta izskalošanās rezultātā (Palmieri et al., 2014), tas kḷūst par ūdens piesārṇojuma avotu. Arī Latvijā novērots paaugstināts slāpekla mēslojuma lietojums (Rekis, 2011), it īpaši Zemgalē, kur salīdzinājumā ar Vidzemi un Latgali slāpeklis tiek izmantots attiecīgi 4,4 un 6,5 reizes vairāk.

Slāpekḷa minerālmēslu lietošanas rezultātā rodas gandrīz trešdala no visām amonjaka emisijām - 2014. gadā tie bija 26,9\% no visām lauksaimniecības sektora amonjaka emisijām. Apkopojot CSP datus par slāpekḷa minerālmēslu izmantošanu graudaugiem un rapsim (pārrēḳinot 100\% augu barības vielās) laikā no 2007. līdz 2015. gadam (5.tabula), redzams, ka 2015. gadā vislielākais slāpekḷa minerālmēslu izmantošanas īpatsvars ir graudaugiem $-79 \%$ gadā un rapsim $-13 \%$. Turklāt pēdējos divus gadus graudaugiem tas ir pieaudzis - kopš 2012. gada pieaugums ir 7 procentpunkti.

Vērtējot, kurā saimniecību grupā koncentrējusies lielākā dą̣a (īpatsvars) no graudaugu platībām, redzams, ka $69 \%$ no visām graudaugu platībām apsaimnieko saimniecības, kurās ir vairāk par 100 ha. Turklāt $45 \%$ no graudaugu platībām apsaimnieko saimniecības, kurās graudaugu sējumu ir vairāk par 300 ha. Tas liecina par to, ka lielākās uz tirgu orientētās augkopības saimniecības rada lielāko dabas resursu un vides apdraudējumu.

Biedribas «Zemnieku saeima» vadỉba ir paudusi bažas par straujo biogāzes staciju skaita pieaugumu Latvijā, jo zemniekiem samazinās pārtikas produktu audzēšanai un ražošanai paredzētās platības, kā arī strauji paaugstinās zemes nomas maksa (Kalns, 2012). Patlaban vidēji 70\% lauksaimnieku nomā papildu zemes platības, bet biogāzes staciju projektu istenotāju
5. tabula. Slāpekla minerālmēslu izmantošana 2007.-2015. gadā graudaugu un rapša sējumos, pārrēḳinot $100 \%$ augu barības vielās (\%)

\begin{tabular}{lccccccccr}
\hline Kultūra & 2007 & 2008 & 2009 & 2010 & 2011 & 2012 & 2013 & 2014 & 2015 \\
\hline Graudaugi & 72 & 73 & 73 & 70 & 70 & 72 & 70 & 79 & 79 \\
\hline Rapsis & 20 & 19 & 15 & 20 & 20 & 20 & 21 & 15 & 13 \\
\hline Kopā & 92 & 92 & 88 & 90 & 90 & 92 & 91 & 94 & 92 \\
\hline
\end{tabular}

(CSP datubāzes dati)

piedāvātās summas pārsniedz reālo tirgus cenu. Līdz ar to zemnieki zaudē iespēju audzēt pārtikas izejvielas, piemēram, graudus. Tāpēc «Zemnieku saeima» uzskata, ka biogāzes rūpnīcām ir jānosaka stingrāka kontrole, tostarp attiecībā uz izejvielu ilgtspējas kritēriju ievērošanu.

Gan biogāzes, gan biodegvielas ieguvē tiek izmantotas pārtikas (graudi un rapsis) un lopbarības (kukurūza) kultūras. Tas izraisa arī ētiskas dabas problēmu. Nemot vērā, ka pasaulē arvien vairāk pieaug pārtikas cenas, un tas savukārt rada pārtikas nodrošinājuma problēmas daudzos pasaules reǵiionos, pārtikā izmantojamo graudu sadedzināšana biogāzes ražošanai vai izmantošana satiksmes līdzekḷu motoru eḷlas iegūšanai nešḳiet ētiska no vispārcilvēcisko vērtību viedokla (Thompson, 2012).

Kopumā var secināt, ka enerǵijas kultūraugu audzēšana Latvijā ir radījusi monokultūru platību pieaugumu, agrobioloğiskās daudzveidības samazināšanos, kā arī papuvju un ilggadīgo zālāju platību ippatsvara samazināšanos, un tas viss apdraud ekosistēmu pakalpojumu pieejamību, bioloğiskās daudzveidības un ainavu saglabāšanos. Turklāt palielināta slāpekḷa minerālmēslu un pesticīdu lietošana rapša un graudaugu, it īpaši kviešu, sējumos negatīvi ietekmē apputeksnētājus un rada vides piesārnojumu (slāpekla noplūžu radītu ūdens piesārṇojumu, siltumnīcefekta gāzu un amonjaka emisiju).

Latvijā būtu nepieciešams atbalstìt tādas biomasas izmantošanu, kas ir videi draudzīga, piemēram, notekūdenu, kūtsmēslu, organisko rūpniecības un komunālo (sadzives) atkritumu, tostarp pārtikas atkritumu, izmantošanu. Pašreizējā situācija bioloğisko kultūru audzēšanā un arī zemes izmantošanā ir pretrunā ar ES bioenerǵijas politiku, kas ir orientēta uz neizmantotās LIZ vai «lieko» zemju izmantošanu bioenerǵijas izejvielu ražošanā, kā arī ar dabas resursu saglabāšanas un vides kvalitātes uzlabošanas politiku (bioloğiskā daudzveidība, lauku ainavas, augsnes auglība, ūdens piesārṇojums u.tml.) un lauku attīstības veicināšanu, it īpaši reớionos ar zemāku attīstības līmeni. 
Kaut arī atbalsta pasākumi enerğijas kultūrām kopš 2010. gada ir atcelti, lauku attīstỉbas politikas tiešmaksājumu un agrovides maksājumu saṇemšanas nosacijumi nav ierobežojuši lielo graudkopỉbas saimniecību izvēli audzēt enerğijas kultūras. Enerğijas kultūru audzēšana lielajiem lauksaimniekiem ir sniegusi peḷnu no kviešu un rapša eksporta, vienlaikus radot ekosistēmu pakalpojumu kvantitātes un kvalitātes pazemināšanos lauku teritorijās.

\section{Lokālās pārtikas sistēmas jeb īsās pārtikas kēedes}

Eiropas Savienībā joprojām ir saglabājies Eiropas lauksaimniecības daudzfunkcionālais modelis, kas ievēro pārtikas nodro-

šināšanas neatkarību, ilgtspēju un lauksaimnieku un patērētāju vajadzības. Eiropas Komisija (European Commission, 2013b) norāda, ka pašreizējā kopējā lauksaimniecības politika apdraud šāda modeḷa turpmāku pastāvēšanu. Turklāt vēlme paaugstināt konkurētspēju, tostarp veicināt eksportu, nodrošinot zemākās cenas, efektivizējot saimniecisko darbỉbu un atbalstot specializētu un reğionāli koncentrētu ražošanu, nedrīkst būt kopējās lauksaimniecības politikas vienigais mērḳis. Lai uzṇēmumi paaugstinātu konkurētspēju un spētu pretoties lielo tirdzniecības k̦ēžu diktātam (netaisnīgiem lïguma nosacijumiem), ir jāveicina un jāatbalsta daudzveidīga un lauku reǵioniem raksturīga kvalitativvu preču ražošana.

Nelielu uznēmumu konkurētspēja jāsekmē, veicinot ìsās pārtikas ķēes un lauksaimnieku vai ražotāju apvienību piekḷuvi patēriṇa tirgiem. Jāatzīmē, ka Latvijas stratēogiskajos un programmatiskajos dokumentos konkurētspējas paaugstināšana un eksporta veicināšana ir noteiktas kā galvenais mērḳis.

Lokālo pārtikas sistēmu jeb īso pārtikas k̦ēžu ekonomiskos, vides un sociālos ieguvumus raksturo dažādi aspekti: 1) sociālie - nodarbinātỉba, vietējo kopienu un sabiedrību stiprināšana, inovatīvas pārvaldības formas u.tml.; 2) kultūras - kultūras un nacionālais mantojums, amatniecība, kultūras un lauku ainava u. tml.; 3) vides - bioloğiskās daudzveidības saglabāšana, vides piesārnojuma un siltumnīcefekta gāzu emisiju samazināšana (īsākas pārtikas k̦ēdes, vides un dabas resursu saudzēěana, bioloǵiskā lauksaimniecība); 4) pārtikas pašnodrošinājums u.c. (Melece, 2014). Mazāka mēroga sistēmas var uzlabot lauksaimniecības un ekosistēmu daudzveidību ainavā, bet ar liela mēroga lauksaimniecību saistītai monokultūru audzēšanas praksei ir negativa ietekme uz vidi un dabas resursiem (Jensen, 2010). Mazākas saimniecības, kas veido lielāko daḷu ražotāju vietējās pārtikas sistēmās, ražo dažādākus produktus, izmantojot lielāku kultūru, sugu un šķirn,u dažādību, t.i., nodrošina lielāku lauksaimniecības augu un dzivnieku bioloğisko daudzveidību (Jensen, 2010; Donkers, 2014). Jaunākās iniciatīvas vietējo pārtikas sistēmu attīstỉbā ir tādas, kurās liela nozīme ir patērētāju-ražotāju attiecībām
(Lagane, 2015), piemēram, patērētāju iegādes grupas, kas pārtikas produktus iegādājas tieši no primārajiem ražotājiem/lauksaimniekiem, it îpaši bioloğiskajiem lauksaimniekiem. Šādas patēēētāju grupas - tiešās pirkšanas pulciṇi-darbojas arī Latvijā (Tiešā pirkšana, b.g.).

Eiropas Komisijas (European Commission, 2013b) zinojumā Padomei un Eiropas Parlamentam par vietējās lauksaimniecības un tiešās tirdzniecības marḳeššanas shēmu sniegtas šādas aktuālo jēdzienu definīijas:

— isās pārtikas piegādes kēèdes - pārdošanas veids, kad lauksaimnieks savus produktus pārdod patērētājam, izmantojot samazinātu starpnieku skaitu;

- lokālās pārtikas sistēmas - pārtikas ražošana, pārstrāde, tirdzniecība un patērinšs notiek salīdzinoši nelielā geogrāiskajā teritorijā.

Jāatzīmē, ka vēl joprojām šìs definīcijas nav oficiāli akceptētas, un līdz ar to vienotas definīcijas nav. Turklāt daudzi pētnieki un eksperti vienkāršỉbas labad abus nosaukumus apvieno, izvēloties vienu vai otru (Melece \& Krievina, 2015). Jāatzīmē, ka nav arī vienotas termina «vietējā teritorija» definīcijas. Lai gan dažādos avotos norādīts, ka šis termins nozīmē salīdzinoš nelielu ǵeogrāfisko apgabalu, nav vienprātības par attālumu no ražošanas vietas, tas variē 20-100 km robežās (European Commission, 2013b).

Lokālās pārtikas sistēmas ir jāveicina, piešķirot prioritāti kvalitātei, videi, ètikai, kultūrai, sociālajām saiknēm un kopībai (European Commission, 2013b). Vietējā pārtika piedod jaunu nozīmi pārtikas kvalitātei, kur papildus pārtikas drošībai un uzturvērtībai tiek uzsvērtas arī tādas ịpašỉbas kā kultūras mantojums, vietējās vērtības un uzticības veicināšana starp ražotāju un patērētāju (Rytkonen, 2016). Lokāliem produktiem ir raksturīgi vietējie resursi un saistība ar vietējo kultūru, vēsturi, tradīcijām, kā arī būtiskas ir ainavu un cilvēku materiālās un nemateriālās saites. Šo produktu inovācijas procesā svarīga ir kolektīiās rīcības mobilizēšana un vietējo zināšanu apguve (Rytkonen, 2016).

EP Reğionu komiteja (Committee of the Regions, 2011) norāda, ka, istenojot kopējo lauksaimniecības politiku pēc 2013. gada, vairāk līdzekḷu jāpieškir nodarbinātībai, lauksaimniecības un pārtikas ražošanas ilgtspējigai attīstỉbai, vietējo pārtikas sistēmu atbalstam. Vietējām pārtikas sistēmām piemìt vairākas priekšrocības.

Ekonomiskās priekšrocības - vietējā lauksaimniecība un pārtikas ražošana nodrošina darbvietas, sekmē vietējā potenciāla attīstību un uzlabo teritorijas tēlu; vietējās pārtikas iegāde trīs reizes palielina kopienas ieṇēmumus un vietējo ražotāju ienākumus, kā arī palielina nodarbinātību.

Sociālās priekšrocības - vietējās pārtikas sistēmas veido ciešas patērētāju un ražotāju attiecības un izpratni, nodrošina produkta izsekojamību 
un veicina sociālo kohēziju. Vietējo produktu tirdzniecības vietas veicina sabiedrības integrāciju.

Ekoloǵiskās priekšrocības - vietējās pārtikas sistēmas izmanto ilgtspējigākas ražošanas metodes, nepieciešama salīdzinoši mazāka transportēšana (mazāka «pārtikas jūdze»-ar produktu saistītā oglekḷa dioksīda emisija) un tiek izmantotas videi draudzīgākas metodes.

EP Reǵionu komiteja uzskata, ka vajadzētu ieviest jaunu logotipu un kopīgu simboliku, ar ko apzīmēt vietējos pārtikas produktus, kā arì izveidot vietējo produktu identitātes zīmi (Committee of the Regions, 2011). EK (European Commission, 2013b) atzīmē, ka brīvprātīga kvalitātes apzīmējuma izmantošana ir efektivss līdzeklis, kas lautu lauksaimniekiem sniegt informāciju par viṇu radīto produkta pievienoto vērtību un nodrošinātu šo papildu centienu atlīizzināšanu, norādot, ka juridisku apsvērumu dēl brīvprātīgs kvalitātes apzīmējums neietvertu logotipu/simbolu, bet gan tikai tekstu.

Latvijā ir istenotas dažas iniciatīvas un aktivitātes, kas atbalsta vietējo pārtikas sistēmu attīstību (Melece, 2014; Melece \& Krievina, 2015). Tās ir saistìtas ar dažāda lieluma un teritoriālās piederības pārtikas ražotāju - vietējo lauksaimnieku un amatnieku - apvienošanos, piemēram, biedrībā «Pārtikas amatnieki». Projekts «Vietējais identitātes produkts (VIP) Ilgtspējigas atbalsta sistēmas Eiropas kopienām» (Local Identity Product - LIP) ar zīmolu «Vietējais identitātes produkts (VIP)» ir izveidots, lai pārstāvētu visu veidu lauku saimniecības un uzṇēmumus. Asociācija «Lauku ceḷotājs» izveidojusi zīmolu «Lauku labumi», kas vieno visdažāāāko veidu un nozaru saimniecības un uzṇēmumus laukos, kuri uznem apmeklētājus un piedāvā savus ražojumus. Tāpat vietējo pārtikas sistēmu ir iespējams atbalstitt, izveidojot vietējās pārtikas mārketinga un pārdošanas kooperatīvus, kuros piedalās mazie pārtikas ražotāji un zemnieki. Piemēram, lauksaimniecības pakalpojumu kooperativāà sabiedrība «Saime» ir uzsākusi mazumtirdzniecibas tīkla «Maxima» projektu.

Lielākā nepilnība ir tā, ka Latvijā uz mazajiem pārtikas ražotājiem un mājražotājiem attiecas tādas pašas higiēnas prasības kā uz industriālajiem ražotājiem. Pretēji EP un EK rekomendācijām nav piemēroti ES regulā paredzētie atvieglojumi, nav elastīgas pieejas. Trūkst nacionālo noteikumu, kas regulētu higiēnas prasības pārtikas mājražotājiem. Eksistē tikai vadlīnijas, kas nosaka prasības un regulē pašmāju produkciju, un uz šiem produktiem attiecas gandrīz tādi paši ES regulu nosacỉjumi kā uz lielo ražotāju produktiem. Turklāt Pārtikas un veterinārā dienesta (PVD) amatpersonas interpretê labas higiēnas prakses vadlīniju ieteikumus atšķirīgi. Arī EK (European Commission, 2013b) norāda, ka ES tiesibu aktos ir ietverts elastigums attiecibā uz higiēnas prasībām mazajiem pārtikas ražotājiem, tomēr tas dalībvalstīs, tostarp Latvijā, netiek pilnībā izmantots.

Citās ES valstīs ir pienemti mazo pārtikas ražotāju darbību reglamentējoši akti, piemēram, Ungārijā 2006. gadā tika pieṇemti noteikumi

7. attēls. Reǵistrēto mājražotāju īpatsvars Latvijas reǵionos (\%)

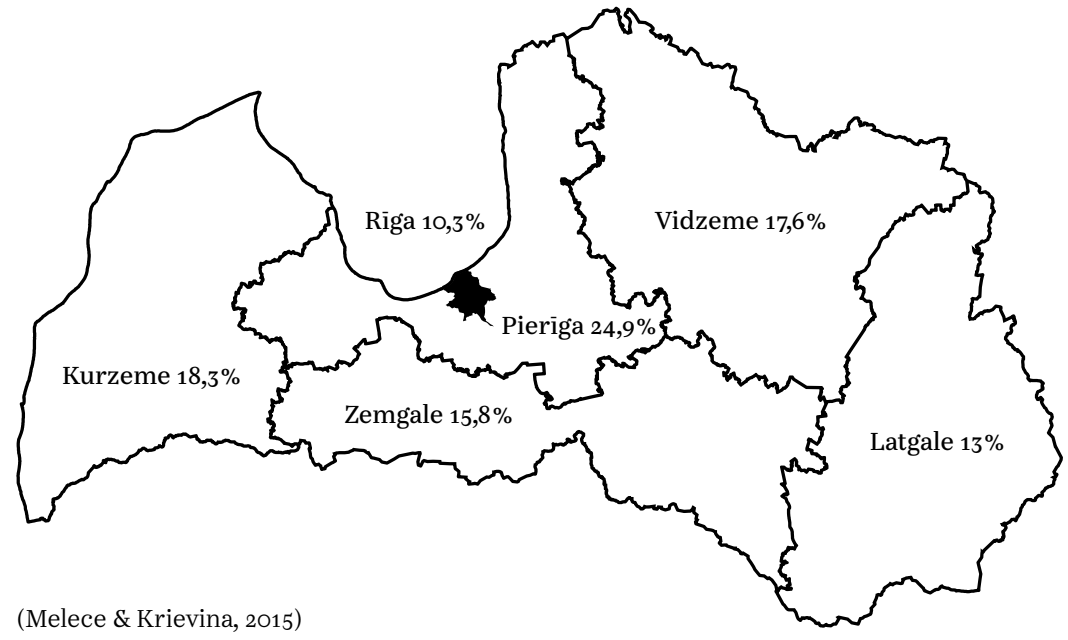

mazajiem ražotājiem, lai atvieglotu pārtikas higiēnas nosacijumus fiziskām personām, kas ražo un pārdod produktus mazos daudzumos; un 2010. gada regulas grozịjumi palielināja pārdošanas apjomu un lāva mazajiem ražotājiem, kas dzìvo jebkurā valsts daḷā, pārdot savus produktus galvaspilsētā (Balazs, 2012). N̦emot to vērā, ES noteikumi kavē ìsu pārtikas piegādes k̦ēžu attīstību, un daudzos gadijumos ir pierādīts, ka ES dalībvalstu līmenī ir iespējams pielāgot regulas vienā un tajā pašā Eiropas regulativijā sistēmā (Galli \& Brunori, 2013).

Eiropas Komisija (European Commission, 2013b) norāda, ka pārtikas un ēdināšanas nozare ir viena no prioritārajām nozarēm saistībā ar videi draudzīgu tā saukto zaḷo publisko iepirkumu. Tāpēc, lai publiskās sabiedriskās ēdināšanas iestādes nodrošinātu ar vietējo pārtiku, valsts institūcijām būtu jāizmanto inovativas pieejas, kas lautu lauksaimniekiem piedalīties iepirkumos. Tomēr ir nepieciešama arī pašu lauksaimnieku aktīva iesaistī̌sanās viniiem būtu jāorganizējas un jāizmanto dažādi sadarbības modeḷi, lai varētu kopigi piedalïties publiskā iepirkuma konkursos.

Latvijā 2015. gada sākumā PVD reǵistrēto mājražotāju skaits sasniedza 1287, un to lielākā daḷa darbojās netālu no Rỉgas (Pierīgas rajonā-24,9 \%) un Rìgā (10,3\%) (7. attēls).

Mājražotāju iesaistī̌anās dažādu produktu ražošanā Latvijas reğionos atšḳiras, tāpat atšķiras arī to saražoto produktu veidi (6.tabula).

Proporcionāli lielākā daḷa mājražotāju (57\%) ir iesaistīti augu izcelsmes produktu, maizes un miltu produktu ražošanā (attiecīgi $41 \%$ un $16 \%$ ), bet mazākā dala ražo dzivnieku izcelsmes produktus - 38\% (8. attēls). 
6. tabula. Mājražotāju skaits"* Latvijas reǵionos

pa darbības veidiem 2015. gadā

\begin{tabular}{|c|c|c|c|c|c|c|c|}
\hline Darbības veids & $\begin{array}{l}\stackrel{0}{\tilde{E}} \\
\stackrel{\underline{N}}{\underline{\underline{\Sigma}}}\end{array}$ & $\begin{array}{l}\frac{0}{\pi} \\
\stackrel{\varpi}{J}\end{array}$ & & 棁 & 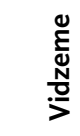 & 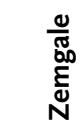 & $\begin{array}{l}\text { "Ig } \\
\text { ô }\end{array}$ \\
\hline Gaḷas produkti & 29 & 37 & 56 & 13 & 60 & 29 & 224 \\
\hline Piena produkti & 25 & 28 & 43 & 1 & 27 & 27 & 151 \\
\hline Zvejas produkti & 31 & 13 & 36 & 1 & 18 & 7 & 106 \\
\hline Augu izcelsmes produkti & 85 & 63 & 118 & 73 & 89 & 102 & 530 \\
\hline $\begin{array}{l}\text { Maize un miltu } \\
\text { izstrādājumi }\end{array}$ & 49 & 20 & 43 & 39 & 37 & 23 & 211 \\
\hline Olas un to produkti & & & & 1 & 1 & & 2 \\
\hline Dzīvnieku produkti & 2 & 1 & & & & & 3 \\
\hline Bezalkoholiskie dzērieni & & 2 & & 2 & & 1 & 5 \\
\hline Ēdiena gatavošana & 7 & 7 & 18 & 7 & 13 & 3 & 55 \\
\hline Кора̄ & 228 & 171 & 314 & 137 & 245 & 192 & 1287 \\
\hline
\end{tabular}

* Mājražotājs var būt iesaistitts vairākās darbībās. (Melece \& Krievina, 2015)

Iespējams, tā iemesls ir, ka augu izcelsmes produktu ražošana ir mazāk regulēta, un tāpēc vieglāk ir reğistrēties PVD un saṇemt aț̣auju pārdot produktus mazumtirdzniecības tīklā, tostarp sabiedriskās ēdināšanas uznēmumos.

Pašreizējā situācija nav labvēlīga mazo lauksaimnieku darbības diversifikācijai un ienākumu avotu dažādošanai, tostarp iesaistei vietējās pārtikas ražošanā un izplatîšanā iso pārtikas piegāžu k̦ēžu ietvaros, it îpaši marginālajos reǵionos un teritorijās, piemēram, Latgalē. Tā neveicina ražotāju un patērētāju sadarbību, kā arī kopienu veidošanos. Turklāt higiēnas likumdošanas dalēji nesakārtoto prasību dēl liela dala vietējo ražotāju ir nereǵistrēti (Latvijas Lauku ..., 2009; Melece \& Krievina, 2015).
8. attēls. Mājražotāju skaita sadalījums pa pārtikas produktu grupām 2015.gadā

Ēdiena

gatavošana $4 \%$

Maize un miltu izstrādājumi $\quad 16 \%$

Augu izcelsmes produkti $41 \%$

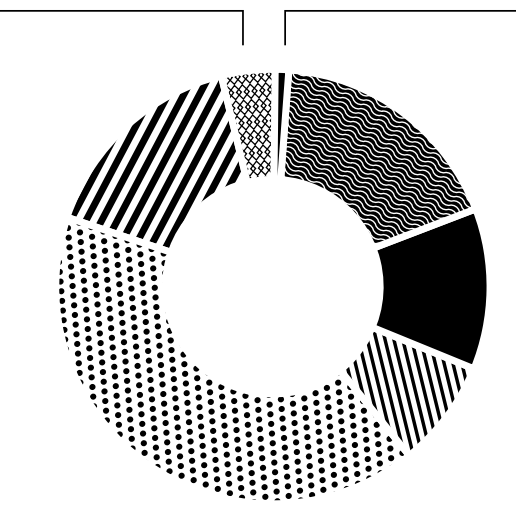

Citi $1 \%$

Galas produkti $\quad 18 \%$

Piena produkti $12 \%$ Zvejas produkti $\quad 8 \%$ 


\section{Sabiedrības vērtības-rīcības- \\ slodzes un municipālā \\ vides pārvaldìba}

Viens no lielākajiem izaicinājumiem sabiedrības videi draudzīgas rīcības pārvaldībā, t. sk. tieši praktiski vietējā pārvaldes līmenī un mājsaimniecībās, ir atrast optimālāko veidu, kā veicināt pozitīvas pārmainnas indivìdu un mājsaimniecību ikdienas rīcībā, laujot cilvēkiem pārvarēt videi draudzịgas rīcības barjeras un padarot cilvēku ikdienu videi draudzịgāku un ilgtspējigāku. Lai gan starptautiskās un arī nacionālās aptaujās daudzi respondenti apgalvo, ka nākotnē būtu gatavi samazināt savu patērinu, mazāk izmantot privāto autotransportu vai vairāk uzzināt par ilgtspējigu dzīvesveidu un to uzsākt, pētniekiem un plānotājiem nav pārliecības par to, ka cilvēki bez sistēmiska atbalsta visos pārvaldes līmeṇos un procesos, bez mērķgrupu sadarbības spēs izkḷunt no ierastās rutīnas un savas labās vēlmes pārvērst rīcībā.

Tāpēc ir būtiski izzināt, novērtēt un saistỉbā ar videi draudzīgu rīcību tālāk attīstìt sabiedrības vērtību izpratni un orientāciju, ikdienas praktisko rīcību, uzvedību un dzivesveidu, kā arī novērtēt sabiedrības, atsevišku indivìdu un mājsaimniecību ietekmi uz vidi un kopējo antropogēeno slodzi. Tātad nepieciešama virzība uz sabiedrïbas vērtïbu-rīiibu-slodžu mijsakarību cikla attīstību videi draudzīgā veidā, proti, nepieciešama virzỉba uz sabiedrības vides pārvaldības attīstību un galvenokārt tieši municipālās vides pārvaldības izzināšanu un attīstī̌šnu. Atbilstoši valsts pētijjumu programmas SUSTINNO projektam «Vides daudzveidỉba un ilgtspējiga izmantošana» pētijumos un rīcībpolitiku priekšlikumu izstrādnēs pamatakcents saskaņā ar subsidiaritātes principu tiek likts uz vietējo pārvaldes līmeni, kas atrodas iedzìvotājiem un citām interešu grupām vistuvāk, - uz vietējo pašvaldỉbu videi draudzigas attīstības pārvaldību. Tāpēc sabiedrības vērtību-rīcību-slodžu mijsakarību cikla videi draudzīgas attīstības iespējas un nosacijumi tika izzināti un vērtēti sabiedrïbas pārvaldības procesa cikla pamata komponenšu kontekstā: 1) vērtību attīstỉbas plānošanas process, saturs un dokumenti; 2) to ieviešanas process un instrumenti, praktiskās videi draudzīgās rīcības; 3) plānošanas dokumentu darbïbas un sabiedrïbas attīstïbas monitorings un uzraudzìba.

Valsts un pašvaldību teritoriju un sabiedrības attīstības pārvaldỉbas (Latvijas pārvaldes praksē vēsturiski nostiprinājies lietot terminu «attīstības plānošana», kaut tas ir tikai viens no attīstības pārvaldỉbas procesa posmiem un instrumentiem) pamatprincipus un ikdienas praksi Latvi-

jā nosaka normatīvā bāze, kas pamatos izstrādāta saskanā ar ilgtspējigas attīstības un tās plānošanas teorētiskajām nostādnēm un labo starptautisko praksi. Vadošais likums šeit ir Attīstības plānošanas sistēmas likums (Saeima, 2008). Tajā tiek noteikti plānošanas dokumentu veidi un to hierarhija un, kas ir svarīgi no pētijuma viedokḷa, vairāki principi, saskaṇā ar kuriem realizējama attīstības plānošana.

Sabiedribas attīstibas pārvaldỉbai, saprotams, nepietiek nedz tikai ar likumdošanas, nedz plānošanas instrumentiem, tomēr noteikti ir jāpiemin, 
ka galvenie no tiem nacionālajā pārvaldes līmenī ir ilgtermina attīstības plānošanas dokuments «Latvijas ilgtspējigas attīstỉbas stratēǵija» (LIAS 2030) un vidēja termiṇa attīstības plānošanas dokuments «Nacionālais attīstības plāns» (NAP 202O), jo to kontekstā notiek ne tikai reǵionālā un vietējā plānošana, izstrādājot analoğiska nosaukuma un termiṇu plānošanas dokumentus, bet arī visu atsevišḳo tautsaimniecības nozaru tematiskā plānošana. Būtiska un komplementāra nozīme ir arī citām pārvaldỉbas instrumentu grupām, proti, institucionāli administratīvajiem, finanšu ekonomiskajiem, infrastruktūras un tehnoloğiskajiem, kā arī noteikti komunikācijas instrumentiem (Ernšteins, 1999). Minēto sešu galveno instrumentu attīstība un prasmīga un integratìva piemērošana pamatos arī nosaka sabiedrības videi draudzīgas rīcības šḳēršḷ mazināšanu un iespēju attīstỉbu visām galvenajām interešu grupām un pārvaldỉbas segmentiem.

Kvantitatīvas uzraudzības îstenošana plānošanas dokumentu ieviešanas prakses novērtēšanā un arī iespējamās teritorijas daudzveidīgās attīstības parametru regulārā noteikšanā ir viens no labas pārvaldỉbas pamatelementiem. Tas ir principiāli būtisks process, lai nodrošinātu ilgtspējigu attīstību arī tālākā perspektīvā, t. sk. vides pārvaldības un citu aktualitāšu integrēšanā attīstības pārvaldībā (plānošanā). Visefektīvākais veids, lai uzraudzītu pašvaldības progresu virzībā uz plānotajiem attīstības mērḳiem, ir pārvaldības indikatoru sistēmas izveidošana. Latvijā indikatoru sistēmas attīstība vietējā līmenī ir tikai sākusies, un arī vienotas nacionālas vertikālās un horizontālās indikatoru sistēmas izveide pagaidām ir nākotnes jautājums, tomēr municipālās attīstības monitorings un noteikti arī sabiedriskais monitorinğs ir aktuāla prioritāte, un tāpēc šie jautājumi ir jāpēta, kā arī ir jāizstrādā un jāaprobē rīcībpolitikas priekšlikumi.

\section{Integratīiās plānošanas principi sabiedrïbas attīstības plānošanā}

Ilgtspējigas attīstības plānošana ir konsekventi iestrādāta Latvijas Republikas normatīvo aktu sistēmā un attiecas uz visiem valsts pārvaldes līmeṇiem. Ilgtspējība ir pirmais plānošanas princips vispārējo principu uzskaitijumā kā Attīstības plānošanas sistēmas likumā, tā Teritorijas attīstības plānošanas likumā (Saeima, 2011). Vairums pārējo principu faktiski ir papildinoši, lai ilgtspējības princips tiktu ievērots. No tiem būtiskākais savukārt ir integrācijas princips. Integrācija un ilgtspējība ir nesaraujami saistìti jautājumi; tas nozīmē, ka plānošanas dokumentam, kurš pretendē uz ilǵtspējīgas attīstības plānošanas dokumenta statusu, ir jābūt pilnvērtīgi integrētam - gan iekšejēās tā komponentēs (stratēĝiskajos formulējumos, uzraudzỉbas un novērtēšanas sistēmā, rīcibu plānojumā utt.), gan ārēji ar citiem plānošanas dokumentiem kā horizontālā (saturiskajā), tā vertikālā (pārvaldes līmenu) griezumā. Diemžēel šìs prasības metodiskā bāze nav pilnībā izstrādāta, savukārt normatīvajā bāzē ar integrativitāti vairāk apzīmē dažādu viedokḷu un rīcību saskaṇošanu, arī prioritāšu saskaņošanu ar augstāka līmeṇa plānojumiem. Tā rezultātā vispārējiem kopējās attīstības plānošanas dokumentiem nereti ir nozariskās plānošanas raksturs (plānošanas objekts ir dominējoši «sadalīts» nozaru komponentēs) un to savstarpējās mijsakarības nav pietiekami apzinātas vai sliktākajā gadỉjumā vispār nav konstatējamas.

Kaut gan pastāvošais normatīvais regulējums ir radijis priekšnoteikumus integrētai ilgtspējiggas attīstības plānošanai, praksē tā nereti ir deklaratìva, nav tāda pēc būtības. Attīstības mērišana oficiālajā pašvaldību plānošanas modelī aprobežojas tikai ar uzraudzỉbas funkciju (salīdzināšanas un prognozēšanas elementi metodiskā līmenī ir sastopami), bet neietver ne integrācijas, ne ilgtspējības aspektus. Jāpiebilst, ka ḷoti maz vērības ir veltìts ilgtermina jeb stratēĝiskajai plānošanai; normatīvajos aktos tā apskatīta loti vispārīgi. Metodiskie materiāli ir veltīti galvenokārt vidēja un ìsa termina plānošanas dokumentiem. Tāpēc tiek piedāvāts praksē aprobēts ilgtspējigas attīstỉbas stratēǵiskās plānošanas modelis (Ernšteins et al., 2015), kas ir principiāli balstīts integrācijas konceptā, ieskaitot mērijumu sistēmu, kurai ir funkcionāla un informatīva nozīme visos plānošanas posmos un aspektos, ieskaitot arī integrāciju starp dažādiem pārvaldības līmeniem.

Ar integrācijas konceptu tiek saprasta īpaša pieeja attīstības plānošanai (Ernšteins et al., 2016; Lontone-Ievina et al., 2016), kad plānošanas procesā komplementāri tiek skatīta teritorija kā sociāli ekoloğiska sistēma, kad tiek izmantotas dažādas un komplementāras informācijas ieguves metodes, piemēram, integratīvo situāciju analīzes pētỉjums, un arī plānošanas objekta atsevišķās daḷas tiek skatītas, ievērojot to savstarpējās saistības un mijsakarības, bet attiecībā uz plānošanas rezultātu atseviš̌saās komponentes ir saistìtas savā starpā, tās ietekmē un papildina cita citu, turklāt tiek ṇemti vērā arì citi aspekti.

Vides nozares jeb vides pārvaldỉbas attīstība Latvijas pašvaldībās aizvien jāskata lejupvērstās un augšupvērstās plānošanas pieejas pretstatu un iespēju kontekstā. Starptautiskajos un arī nacionālajos rīcībpolitikas ietvara dokumentos vispāratzìtajai un izpildei būtiski noteiktajai vides pārvaldỉbai (kā vienai no ilğtspējīgas attīstības pamata dimensijām) vietējās pārvaldes plānošanas procesā un saturā ir raksturīga vides (nozares) izpratnes, plānošanas un prakses nepietiekamība, arī tā attīstības potenciāla nenovērtēšana un neizmantošana vietējai sabiedrības un teritorijas attīstībai. Atjaunotajā 2006. gada Vides aizsardzības likumā (Saeima, 2006) pašvaldībām vairs netiek pieprasīta vides nozares disciplinārā plānošana (proti, vides rīcības programmu izstrāde), un tāpēc municipālajā vides pārvaldỉbā visos daudzveidīgajos vides nozares sektoros var konstatēt tā saukto minimālās nepieciešamības pieeju (lai gan 2009. gadā Attīstības 
plānošanas sistēmas likumā teritoriju attīstỉbas plānošanā tiek prasīti ilgtspējības un tās dimensiju integrācijas principi). Tā sekas ir pētijumā konstatētā vides un ilgtspējības pārvaldības komponentu vāja klātesamība un savstarpēja integrācija pašvaldību ilgtermiṇa plānošanas dokumentos, to ieviešanas un uzraudzibas instrumentos.

Šādos apstākḷıos vides nozares atsevišķu plānošanu jeb t. s. disciplināro pieeju brīvprātigi izvēlas tikai atsevišḳas pašvaldības ar argumentētu ilgtermiṇa perspektivvu vai pašvaldības, kas darbojas, orientējoties uz konkrētiem projektiem. Savukārt pārējās pašvaldības, izstrādājot savus obligātos attīstības plānošanas dokumentus (ilgtspējigas attīstības stratēóiju, attīstības programmu, teritorijas plānojumu), palaujas uz lielākā vai mazākā mērā kvalitatīvi, bet daudzviet formāli realizējamu normatīvi noteikto vides integrācijas pieeju. Teorētiski prasība pēc adekvātas integrācijas pieejas vides pārvaldībā pašvaldībās saskaras ar integratīvās plānošanas kapacitātes nepietiekamỉbu, t. sk. atbilstošu tradīciju neesamỉbu (ilgstoši dominējušās plānošanas nozariskās pieejas kontekstā), ar nepietiekami attīstītu integrācijas metodoloğiju un apmācības sistēmu no valsts pārvaldes puses, kā arī ar iepriekšminēto minimālās nepieciešamības pieeju no vietējās pārvaldes puses. Apkopojot veiktos pētijjumus, izvērtējot pašvaldību plānošanas dokumentus (Ernšteins et al., 2015; 2016; Kauliṇ̌š, 2015) un Latvijas zinātnisko un praktisko literatūru, intervējot un diskutējot ar pašvaldỉbu, kā arì to teritoriju, privātpersonu un uzṇēmēju darbỉbu uzraugošo reǵ̛ionālo vides pārvalžu speciālistiem, jāpieñem vispārināta situācijas problēmnostādne, ka municipālā vides pārvaldība (īpaši mazajās/lauku pašvaldỉbās) netiek sistēmiski un sistemātiski nedz plānota, nedz praktiski realizēta - netiek pietiekami nodrošināta starptautiski un nacionāli plānotā vides pārvaldỉbas attīstỉba, ietverot gan nozariskās (disciplinārās), gan integratīiās vides pārvaldības komplementāru plānošanu un ieviešanu (Lontone et al., 2016).

Nozariskā plānošana ir tradicionāla attīstības plānošanas pieeja, skatoties attīstības procesus atsevišķo nozaru griezumā un parasti nesaistot procesus ekonomiskajā, dabas vai sociālajā vidē. Katras nozares speciālisti atsevišḳi izstrādāja savas jomas attīstības plānus, bet saistības ar citām jomām bieži vien netika ṇemtas vērā - nereti pat plašākas jomas apakšnozaru ietvaros. Latvijas Universitātē izstrādātajai ${ }_{5} \mathrm{P}$ integratīvās plānošanas metodikai (Ernšteins, 1999), kas balstās uz starptautiski atzìtās pieejās izveidotu $5 \mathrm{P}$ pārvaldỉbas procesa cikla strukturējumu (problēmanalize - politika - plānošana - pārvalde - pārbaude (uzraudzība)), ir izstrādāts detalizēts praktiskās realizācijas ietvars, kas praksē tika aprobēts un precizēts iepriekšējos pētijumos (Ernšteins, Kauliņ̌š, Zïlniece, 2014) sešās ḷoti atšķiriiga rakstura pašvaldībās: Alojas, Aglonas, Beverīnas, Cesvaines (pirms valsts pētijumu programmas projekta uzsākšanas) un Salacgrīvas un Saulkrastu novadā (valsts pētijumu programmas ietvaros). Metodikas praktiskās realizācijas pamatā ir visu plānošanas komponenšu savstarpēja saistība un realizācijas loğika; to savstarpējā mijsakarība veido attīstības plānojuma integrativitāti un ir arī karkass, kas valsts pētijumu programmā izmantots ne tikai integrativās pieejas izmantošanai attīstỉbas plānošanā, bet arī vides pārvaldỉbas nozares plānošanas koncepta attisstišanai. $5 \mathrm{P}$ integrativā plānošanas metodika sastāv no attiecīgo cikla posmu plānošanas soḷu detalizācijas to pēctecīgā mijsakarībā, un pašvaldību stratēǵiju izstrādē šie soḷi ir šādi:

1. Problēmanalīze, sākot ar visu sektoru un to mijiedarbïbas auditu, ir galvenais analīiskais instruments problēmjomu identificēšanai (P1). Integratîvo problēmjomu audits tiek veikts, katrā problēmjomā atrodot vērtības, plānošanas nodomus, izmantojamos politikas principus un iespējamos instrumentus, galvenos rīcības virzienus, indikatorus vai rezultatīvos rādītājus, kā arì aprakstot paredzamā pārvaldỉbas cikla nodrošinājumu un izvērtējot problēmjomu savstarpējās saistības $(\mathrm{P} 1)$.

2. Politika. Stratēǵijas galveno elementu definēšana. Vizija, attīstības virsmērkis un mērki, prioritātes $\left(\mathrm{P}_{2}\right)$. Prioritāšu izvēlēm iespējamas divas pieejas: nozariskā, kas noteiktas nozares definē kā prioritāras ( $\left.\mathrm{P}_{2}\right)$, un ar uzvedības modeli saistitā, kas dod priekšroku noteiktiem darbïbas veidiem izvēlētajā rīcibas virzienā, tos nozariski neierobežojot ( $\left.\mathrm{P}_{3}, \mathrm{P}_{4}\right)$ Telpiskās attīstības pamatnostādnes ir viens no stratēǵijas pamatelementiem (prasits normativi), kas attīstibas aspektus izskata telpiskā griezumā $\left(\mathrm{P}_{2}\right)$.

3. Plānošana. Ilgtermiṇa rīcības virzieni izriet no mērḳiem, kuri ir jārealizē un kuri veido «jumtu» vidēja termiṇa plānošanas dokumentam - attistības programmai (teritorijām) vai politikas pamatnostādnēm (nozaru plānošanā) (P3).

4. Pārvalde. Rīcības un investīciju plāna priekšlikumu izstrāde, sākotnēji nekritiski definējot priekšlikumus ar prāta vētras metodi. Pēc tam ieteiktās rīcības sadala pa integratìvajān problēmjomām, atmetot acimredzami neatbilstošās vai nerealizējamās un atkārtoti sijājot, vērtējot finanšu avotu iespējas un veidojot attīstības scenārijus $\left(\mathrm{P}_{4}\right)$.

5. Pārbaude. Plānošanas dokumenta ieviešanas uzraudzības sistēmas izstrāde, un tās pamatā ir rezultatīvo rādītāju vai indikatoru sistēma. Tālākā attīstỉbas posmā šeit var runāt par ilgtspējigas attīstības municipālo monitoringu (P5).

Valsts pētijumu programmas ietvaros $5 \mathrm{P}$ integrētās plānošanas metodika ir izvērtēta un pilnveidota, ievērojot plānošanas integrativitātes un 
ilgtspējigas attīstības pārvaldības indikatoru nozīmi un vietu visos 5P plānošanas cikla posmos, un tika iegūti vairāki papildinājumi. Tie ir:

— savstarpējo saistību noteikšana mērķiem, prioritātēm, rīcības virzieniem;

— indikatoriem raksturīgās informācijas izmantošana visos plānošanas etapos un pašu indikatoru sasaiste ne vien ar plānošanas rezultātiem, bet arì ar pašu plānošanas procesu tajā iegūtās informācijas novērtēšanai;

— uzraudzỉbas un novērtēšanas mehānisma informatīva balstī̌šana uz ilgtspējigas attīstības pārvaldības indikatoru sistēmas sniegtās informācijas bāzes;

— indikatoru komunikācijas funkcijas izmantošana plānošanas procesā.

Minētie pilnveidojumi būtu uzskatāmi par pamatu integrētās plānošanas metodoloğijas tālākai attīstỉbai municipālā, reg̛ionālā un nacionālā lìmeni.

\section{Vides pārvaldība kopējā attīstïbas plānošanas} kontekstā Latvijā

Vides nozares attīstības kontekstā noteikti pozitīvi vērtējama Attīistības plānošanas sistēmas likuma pieeja, kas paredz pašvaldības attīstības plānošanas procesā ieviest sākotnējo situācijas novērtējumu, kurā tad parasti vides situācijas novērtējums arī tiek iekḷauts. Diemžēl arī šāda ilgtermiṇam paredzēta dokumenta (un/vai datu materiālu) uzturēšana un atjaunošana tiek apdraudēta abos - valsts un pašvaldības - pārvaldes līmeṇos. Uz šo brīdi normatīvi tiek prasīts vienīgi stratēǵiskās ietekmes uz vidi novērtēšanas procedūras ietvaros izstrādājamais vides pārskats - formāls un sistēmiski nepietiekami aptverošs dokuments, kas piesaistîts noteiktam plānošanas dokumentam (praksē-arī vienlaikus izstrādājamu dokumentu grupai). Tas ir apjomīgs un darbietilpīgs, bet vides pārvaldības integrācijai visos plānošanas sektoros un jomās principiāli svarīgs dokuments, taču îslaiciggi lietojams - faktiski tikai līdz auditējamā plānošanas dokumenta oficiālai pieṇemšanai. Situācijas analizes pētījumā tika konstatēts:

— vides pārvaldības plānošanai nav skaidras vietas plānošanas dokumentu sistēmā; t. s. tematiskie plānojumi konceptuāli ir vairāk piemēroti nozaru un jomu (t. sk. vides), bet ne pārvaldības plānošanai; vides pārvaldības integrativvais raksturs neḷauj sniegt pietiekami vispusīgu problēmas analizzi un ieteikumus citos plānošanas dokumentos;

— vispārīgā gadījumā vides jautājumi nopietni tiek skarti vienīgi stratēóiskajā ietekmes uz vidi novērtēšanā, kas nesatur vides pārvaldības elementus, bet tikai izvērtē citos dokumentos atspoguḷoto ietekmi uz vidi ārpus attīstības kopējā konteksta; — stratēǵiskās ietekmes uz vidi novērtēšanas laikā ir paredzēta sabiedrības iesaistī̌sana, bet tikai paša dokumenta apspriešanā, savukārt sabiedrības un tās mērḳgrupu vieta un nozīme vides pārvaldỉbā netiek apskatīta.

No šis analīzes izrietēja secinājumi par iespējām nelabvēlīgās situācijas izmainišanai, proti, ir nepieciešams

— ietekmi uz vidi izvērtēt nevis noteikta plānošanas dokumenta aspektā, bet kā plānošanas dokumentu un ārpusplānošanas faktoru - sabiedrības mērkgrupu - rīcību summu;

— ilgtermiṇa pamatnostādnes saistībā ar vides pārvaldību un tās novērtēšanu definèt kā pārvaldes uzdevumu;

- izstrādāt dokumentu, kas skatītu vidi gan vides stāvokḷa, gan tās pārvaldības un sabiedrỉbas iesaistes aspektos, kā vienu no ilgtspējigas attīstības koncepta pamatelementiem.

Kā šāda dokumenta koncepts tiek piedāvāts vides pārvaldỉbas pārskats. Konceptuāli pārejot no plānotājiem labi pazistamā vides pārskata uz vides pārvaldības pārskatu, ar relatīvi nelielu papildu darba apjomu ir iegūstams ilgterminā lietojams dokuments, kas būtu periodiski atjaunojams un daudzveidīgi izmantojams dažādu plānošanas procesu un satura dokumentu vajadzībām, proti, tas pildītu vides sākotnējā novērtējuma funkciju (Attīstības plānošanas sistēmas likuma kontekstā) un būtu nepieciešamais pamat vides integrēěšanai visos plānošanas dokumentu izstrādes procesos un saturā (Ernšteins at al., 2016). Savstarpēji salīdzinot šos dokumentus, iespējams akcentēt būtiskās atškiriìbas. Vides pārskats

— sniedz informāciju par vides stāvokli un dạ̣ēji arì par problemātiku teritorijā;

— izvērtē konkrētu plānošanas dokumentu paredzamās ietekmes uz vides stāvokli un prasa novērot to plānošanas dokumentu darbības laikā;

— novada šo informāciju līdz plašākai sabiedrībai;

— sniedz informāciju, lai apsvērtu iespējamās plānošanas dokumentu korekcijas.

Savukārt vides pārvaldības pārskats

— izvērtē likumdošanas un plānošanas dokumentus saistībā ar teritorijas vides problemātiku;

- sniedz informāciju par slodžu avotiem, vides stāvokli un problemātiku teritorijā; 
— izvērtē esošo plānošanas dokumentu paredzamās ietekmes uz vides stāvokli;

— izvērtē dažādus vides pārvaldības aspektus, vides slodžu vadības iespējas un sabiedrības iesaisti vides problēmu risināšanā;

— nosaka vides politikas ilgtermina nostādnes;

— prasa novērot vides slodzes un stāvokli ilgtermiṇā ilgtspējīgas attīstības un tās pārvaldības kontekstā;

— sniedz informāciju par vidi citiem plānošanas dokumentiem.

Tuvākajā nākotnē paredzot turpināt valsts pētijumu programmas SUSTINNO ietvarā realizētos pētijjumus, vides pārvaldības pārskata koncepta funkcionalitāti paredzēts izvērtēêt, aprobējot pirmā šāda veida pirmsplānošanas dokumenta izstrādi vienā no SUSTINNO programmas modeḷteritorijām. Sekmīgas aprobācijas gadỉjumā ir sagatavojami attiecīgi rīcībpolitikas iniciatīvas priekšlikumi vietējam un, iespējams, arī nacionālam pārvaldes līmenim par iespējamu vides pārvaldības pārskata principa vai pieejas ieviešanu praksē, lai atbilstoši Attīstības plānošanas sistēmas likumā pieprasìtajam ilgtspējigas attīstïbas principam (paradigmatiskajam principam) varētu nodrošināt vides pārvaldības integrēšanu gan obligātajos, valsts noteiktajos kopējos/vispārējos un pašvaldības attīstības plānošanas, gan pašvaldībai brivprātīgajos nozaru un sektoru plānošanas dokumentos.

Turpmāko pētījumu virsuzdevums sabiedrỉbas vērtību-rīcỉbu-slodžu mijsakarību kopuma novērtēěanai ir attīstības pārvaldỉbas un vides pārvaldības savstarpējās plānošanas un prakses kontekstā detalizētāk izzināt abu 5P pārvaldības ciklu procesuālo mijiedarbību un koppārvaldi. Savukārt atbilstoši tam rīcībpolitiku attīstības virsuzdevums ir katrā ${ }_{5} \mathrm{P}$ pārvaldības cikla posmā izstrādāt inovatīvu risinājumu vides pārvaldības un attīstības pārvaldības savstarpējās integrētības nodrošināšanai, t. sk. šajā rakstā izskatìto valsts pētījumu programmu izmantot kā līdzekli perspektīvo ieguldỉjumu sabiedrības vērtību - vides rīcību - vides slodžu mijsakarỉbu atsegšanai jau pirmsplānošanas stadijā. Vides pārvaldības pārskats būtu vērtējams arì kā būtisks, regulārs un visaptverošs vides un attīstības komunikācijas instruments. Vides komunikācijas komplementārie instrumenti (informācija, izglītìba, lïdzdalība un videi draudzīga rīcība) joprojām ir nepietiekami izprasti, novērtēti un izmantoti pašvaldību pārvaldībā.

\section{Vides pārvaldības process} Valmieras pašvaldībā

pilsētas vadības ieinteresētība uzturēt ietverot to kodolīgos, mārketingam raksturīgos formulējumos (popularizējot pilsētas tēlu), gan pēc būtỉbas. Valmiera ir vienīgā no Latvijas pašvaldībām, kurā par vides komunikāciju atbild speciāls darbinieks. Savstarpēji pretrunīgu pamatprincipu noteikšana pilsētas stratēógiskajā attīstībā (vienlaikus gan zaḷa, gan industriāla teritorija) pilsētas pašvaldỉbai izvirza konkrētus uzdevumus, kuri tiek risināti atbildīgi. Pilsētas domē ir aktīva interese par pētijumu veikšanu un Latvijas Universitātes speciālistu iesaistīšanos.

N̦emot vērā vides pārvaldības multisektoriālo, komplekso raksturu un visu teritorijas attīstības plānošanas aspektu saistību, pētījuma pamatmetode ir integratīvās situācijas analīzes pētišsana, kas paredz dažādu metožu izmantošanu apstrādājamās informācijas ieguvei. Valmieras vides pārvaldības pētijumā (Kauliňš, 2017a) šìs metodes bija:

— intervijas ar sabiedrības mērkgrupām, to skaitā arī ar mājsaimniecībām par videi draudzīgas rīcības izplatību pārvaldỉbas praksē un īpatnībām;

— mājsaimniecību aptauja par videi draudzīgu rīcību (tika aptverts plašs iedzīvotāju loks);

— patstāvigss pētijums par ilgtspējigu mobilitāti Valmierā;

— dokumentu studijas: pašvaldỉbas un augstāka līmena plānošanas dokumentu analīze, valsts un vietējo normatīvo aktu analizze;

- statistikas un tai pielīdzināmu datu analīze;

— institūciju sniegtās informācijas analīze.

Intervijas par videi draudzịgu rīcību notika visās galvenajās pārvaldības mērkgrupās arī saskanāa ar vides pārvaldības komunikācijas pamatmodeli-sadarbỉbas komunikācijas modeli-, komplementāri aptverot ne tikai videi draudzīgu rīcību, bet arī vides informāciju un izglìtību, vides līdzdalību (Ernšteins, 1999). Intervijas notika valsts un municipālajā pārvaldē, komunālo pakalpojumu un ražošanas uznēmumos, ar minētās komunikācijas pārvaldi vistiešāk saistîtās grupās (mediji, izglītotāji, zinātne, nevalstiskās organizācijas) un mājsaimniecībās. Mājsaimniecību aptauja (373 respondenti) bija orientēta ne tikai uz videi draudzịgas rīcības izpēti, bet uz plašu mājsaimniecību vides pārvaldỉbas jautājumu loku: radītajām slodzēm uz vidi (būvniecība, elektroenerǵêtika, siltumenerǵētika, ūdenssaimniecība, atkritumu saimnieciba), patēriṇu un pakalpojumiem, vides vērtībām un kvalitāti, vides pārvaldību mājsaimniecībā.

Pētījums par ilgtspējīgu mobilitāti Valmierā bija patstāvīgs darbs (Krukle, Ernsteins, Brizga, 2017), bet tas komplementāri papildināja konkrētās pētijumu programmas kontekstu, jo visi trīs ilgtspējīga patērina klasteri, kuri visvairāk ietekmē vidi (mobilitāte, pārtika un, protams, mājsaimniecība), gan anketās, gan kopējo mērḳgrupu intervijās jau tika skatìti paralēli tradicionālajiem vides sektoriem. Dokumentu un statistika avotu studiju laikā informācija tika iegūta no brivvpieejas datu avotiem, kā 
arī tā tika pieprasīta no institūcijām - datu turētājām. Šĩ informācija veidoja informatīvo fonu, kas ḷauj pašreizējā pētijuma stadijā noskaidrot, kādi situācijas raksturošanai nepieciešamie dati ir pieejami vai atrodas Valmieras pašvaldības rīcībā, ar kādiem nosacījumiem tos var izmantot un vai tie ir noderīgi vides pārvaldības raksturojuma tālākai izvēršanai un detalizācijai.

Problēmanalīzes $(P 1)$ stadijā ir svarīgi saprast, kādi uz vides pārvaldību attiecināmi dati ir pārvaldes rīcībā, vai tie ir potenciāli pieejami, kaut arī neizmantoti. Šeit nozīmigi avoti ir Valmieras 2017. gada teritorijas plānojuma (Valmieras pilsētas ... 2017) vides pārskats, attīstības stratēǵijas un programmas apskata dalas. Kopumā ir pieejama loti detalizēta un labi ilustrēta informācija par Valmieras pilsētu, taču nepietiekami raksturotas slodzes uz vidi, kā arī būtiski trūkst informācijas par vides pārvaldỉbas organizāciju pašvaldībā. Šai kontekstā nav apskatītas sabiedrības mērkgrupas.

Politikas formulēšanas $\left(\mathrm{P}_{2}\right)$ stadijā pilsētas dome ir rīkojusies proaktīvi. Valmierā 2015. gada 29. janvārī tika pieṇemta Vides deklarācija, kas ir pašvaldỉbas politisko gribu apliecinošs «jumta» dokuments attiecībā uz rīcībām, kas skar vai var skart vidi Valmieras pilsētā. Deklarācijas ievadā minētajiem nodomiem un misijai seko 14 rīcību punkti, un tos var iedalìt četros galvenajos ilgtspējības dimensijām nosacìti atbilstošos blokos. Lìdz 2017. gada rudenim deklarāciju bija parakstijjuši 366 iedzivotāji un visu nozīmīgāko uzṇēmumu pārstāvji. Valmieras pilsētas ilgtspējigas attīstības stratẹĝija 2015.-2030. gadam ir veidota, ievērojot savstarpēju vienotỉbu, interešu saskanotību un pēctecību ar augstāka līmena plānošanas dokumentiem. Vismaz trīs vīzijas punkti runā par vidi - sociālo, dabas vidi un pilsētvidi. Savukārt viens no četriem stratēǵiskajiem mērḳiem - cilvēkvides attīstība - ir veltîts vides un tās pārvaldỉbas jautājumiem un noteikts kā mērḳa izpildes pamatnosacijums. Stratēǵiskajiem mērkiem atbilst attiecīga satura stratēǵiskās prioritātes. Valmieras pilsētas teritorijas plānojums tiek attiecīgi veidots saskaṇā ar hierarhiski augstākiem plānošanas dokumentiem -

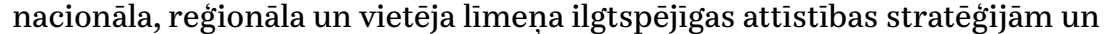
attīstības programmām. Viens no teritorijas plānojuma noteiktajiem stratēǵiskajiem principiem, kas aktuāls arī videi draudzīgas rīcības kontekstā, ir radìt priekšnoteikumus vides kvalitātes un teritorijas racionālas izmantošanas nodrošināšanai, rūpniecisko un vides risku novēršanai.

Politikas plānošanas $\left(P_{3}\right)$ jomā Valmieras pilsētas attīstības programmā 2015.-202O. gadam ir vērojamas konsekvences attiecībā uz tajā iestrādāto vides pārvaldības elementu attiecībām pret stratēǵijā minēto. Plānošanas dokumentu kopanalīze pārliecina, ka vides un tās pārvaldības jautājumi veido būtisku pilsētas attīstības komponenti. Tomēr nav konstatējams sistēmiskums. Rodas iespaids, ka attīstības programmā ir apkopoti nozaru speciālistu priekšlikumi. Konkrētajā plānošanas situācijā šie priekšlikumi raksturo labu vides apzinu, taču būtu vēlams vairāk sabalansētības un koncepta vienotības, integrācijas. Uzmanība nav pietiekami pievērsta vides pārvaldības un tās komunikācijas attīstībai. Šai sakarā nākotnē Valmierai būtu ieteicams izstrādāt jaunu plānošanas instrumentu - vides pārvaldības pārskatu (tā koncepts ir pamatots iepriekš), un pašvaldības vadītāji jau ir izrādijjuši interesi, kad šie jautājumi vides pārvaldības apậā galda diskusijā tika skatīti. Pilsētā darbojas liels skaits pašvaldības domes izdoto saistošo noteikumu, kas atbilstoši pašvaldỉbas kompetencei un funkcijām regulē dažādus domes pārvaldības pārziṇā esošus pilsētas dzīves aspektus. Vairāki no tiem tieši vai netieši ir attiecināmi arī uz vides pārvaldības konkrētiem aspektiem, vai arì tajos ir atsevišķi ar vides pārvaldību saistīti aspekti.

Pārvaldes ìstenošanā (P4) vispārināti ir iespējams runāt par videi draudzịgu rīcỉbu pašvaldības kopējā rīcību plānā. Attīstības îstermina rīcību plāns saskaṇā ar normatīvo aktu prasībām ir veidots kā vidēja termina attīstỉbas pārvaldības dinamiska sastāvdaḷa. Atbilstoši četriem stratēĝiskajiem mērḳiem rīcības plāns sadalīts četrās daḷās. Stratēĝiskais mērkiis «Iedzīvotāju sociālā un fiziskā drošỉba» satur trīs videi draudzịgas rīcības virzienā «Pārvalde», un kā nozīmīgāko var minēt vides pārvaldības ieviešanu, līdz 2020. gadam izstrādājot vides pārvaldības stratēǵiju. Virkne rīcību vērtējamas kā netieši saistītas ar videi draudzīgu rīcību, jo paredz resursu taupišanu. Stratēĝiskais mērkis «Estētiska, funkcionāla un dabas vērtības iekḷaujoša pilsētvide» gandrīz visos tā punktos satur videi draudzīgas rīcības elementus. Stratēếiskais mērkis «Uznēmējdarbības attīstība» iekḷauj vismaz trīs videi draudzīgas rīcības, kas tieši saistītas ar ekonomikas un vides rīcību mijsakarībām.

Šobrīd Valmierā nav institucionāla rakstura vides pārvaldības instrumentu; nemot vērā teritorijas mērogu, iespējams, ka tādu izveidošana arī nav mērḳtiecīga. Kā administratīvais pārvaldes instruments jau vairākus gadus Valmierā darbojas vides komunikācijas speciālists, un tā darbību sabiedrība augsti vērtē. Pārējie vides pārvaldības jautājumi ir sadalīti jomu speciālistiem, un šajās jomās vides pārvaldỉbas jautājumi tiek risināti visumā sekmīgi (par to liecina arī sabiedrības reakcija), taču daḷa jautājumu paliek ārpus šīm jomām, un tāpēc pastāvošā shēma nespēj pilnībā nodrošināt vides pārvaldībai tālāku izaugssmi un attīstību. Intervijās tika atzīts, ka situāciju atrisinātu tāda amatpersona, kas atbildētu par vides informācijas apriti (tai skaitā sagatavojot informāciju vides komunikācijas speciālistam) un par vides pārvaldības pasākumu koordināciju pilsētā (Kaulinš̌, 2017a).

Pārvaldes pārraudzība un kontrole (P5). Valmieras ilgtspējigas attīstības stratēǵija nesatur uzraudzības un novērtēšanas elementus, jo normatīvais regulējums to neprasa. Tomēr pārraudzība un novērtēšana ir saistīta ar attīstības pārvaldību, kuras uzraudzības un novērtēšanas sistēmā ir 
9 stratēếiskie attīstības rādītāii un 23 rādītāji, kas saistīti ar attīstības prioritātēm un sasniedzamiem rezultātiem atbilstošajos rīcības virzienos. Kopš 2015. gada tiek sagatavoti regulāri pārskati par šiem rādītājiem. Pārskati ir vairāk aprakstoša rakstura, trūkst analīzes, it îpaši teritorijas kopējā ilgtspējigas attīstības kontekstā. Teritorijas plānojuma vides pārskata obligātā monitoringa sistēma ir deklaratīva, jo satur daudzus neskaidri definētus parametrus, kas par indikatoriem ir nosaukti nepamatoti, jo neatbilst indikatora definīcijai un nepieciešamajai funkcionalitātei. Atseviškos gadijumos minēti datu avoti, kas nav reāli izmantojami. Nav paredzēta kārtỉba monitoringa ziņojumu sagatavošanai, un nav izstrādātas prasības tā saturam.

Valmieras pilsētas pārvalde ir izteikusi skaidru politisku gribu vides pārvaldības instrumentu tālākai attīstišanai, pien̦emot vides deklarāciju par ilgtermiṇa pamatnostādni, par rīcības modeli pilsētas tālākai sociālajai, ekonomiskajai un pārvaldības attīstībai, sabalansēti ievērojot dabas dimensijas nozìmi ilgtspējigas attīstỉbas procesos (Valmieras pilsētas dome, 2015). Vides pārvaldỉbas instrumentu izmantošana Valmieras ilgtermiṇa un vidēja termiṇa plānošanas dokumentos ir pamatota teritorijas vispārējā raksturojumā un par sektoriem atbildīgo amatpersonu apzināti/neapzināti attīstitajā vides apziṇā. Plānošanas dokumenti satur vairākas būtiskas nostādnes vides pārvaldības instrumentu tālākā izmantošanā; isstermiṇa plānošanas dokumentos šìs nostādnes ir detalizētas līdz specializētu rīcību grupu līmenim, skaidri novērtējot potenciālos ieguvumus. Vienlaikus rīcības plānā vairākās jomās tomēr nav minēti konkrēti objekti (galvenokārt attiecināmi uz infrastruktūru), uz kuriem šīs rīcības būs attiecināmas; iespējams, ka tas saistīts ar neskaidrajām finansēšanas iespējām. Plānošanas un komunikācijas jomā ir definēti precīzi uzdevumi vides pārvaldības un attiecīgo tās instrumentu tālākai attīstī̌sanai.

Plānošanas instrumentu izmantošanas tālāka attīstība vides pārvaldībā Valmierā ir cieši saistīta ar institucionālajiem, administratīvajiem un komunikācijas instrumentiem. Institucionālā attīstỉba ir atslēgas faktors pārējo instrumentu attīstišanai, jo ir nepieciešams izveidot attiecīgi sagatavota speciālista posteni kā koordinējošo posmu vides pārvaldības plānošanā un rīcībās, kā arī vides disciplinārās informācijas apritē. Šāds koordinators atbildētu par dabaszinātniskās informācijas apriti, kā arī saskanotu vides pārvaldības pasākumus starp pašvaldības struktūrvienībām un sagatavotu informāciju vides komunikācijas speciālistam, lai tas varētu informēt plašāku sabiedrību. Savukārt komunikācijas speciālists nodrošinātu atgriezenisko saiti ar sabiedrību, izprotot tās vajadzības un pieprasijumu pēc trūkstošās informācijas.

Valmieras pilsētas ilgtspējīgas attīstības nodrošināšanai no vides pārvaldības disciplinārā viedokḷa, kā arī lai pilnībā noslēgtu P5 pārvaldỉbas ciklu, ir nepieciešami šādi plānošanas instrumenti (Kaulinš, 2017a):

— vides pārvaldības pārskats (P1);

— vides deklarācija ( $\mathrm{P} 2$, jau istenota);

— vides pārvaldības un vides komunikācijas programmas (P3);

— vides pārvaldības un vides komunikācijas rīcību plāni $\left(\mathrm{P}_{4}\right)$;

- ilgtspējīgas attīstības un tās pārvaldỉbas monitoringa sistēma (P5).

Vides pārvaldības pārskatā ir jāiekḷauj maksimāli izvērsts pārskats par vides un tās pārvaldības situāciju, izmantojot visus pieejamos datu avotus un dokumentus iespējami augstā detalizācijas pakāpē. Materiāls ir pēc iespējas bagātīgi jāilustrē ar diagrammām, kartēm un fotofiksācijas materiāliem. Iespējami detalizēti jāaplūko arī videi draudzīgas rīcības un vides pārvaldības elementi dažādās sabiedrības mērkgrupās. Šĩ dokumenta sastāvdala ir arī priekšlikumi monitoringa un indikatoru sistēmu veidošanai.

Municipālā monitoringa sistēmu veido

— horizontāli un vertikāli integrēts ilǵtspējigas attīstības un tās pārvaldības indikatoru bloks;

— plānošanas dokumentu rezultativo rādītāju bloks;

— plānošanas dokumentu rīcību izpildes rādītāju bloks;

— sabiedriskā monitoringa parametru apakšsistēma.

Monitoringa sistēmas pamatdokuments ir rokasgrāmata, kas satur detalizētus metodiskos norādijjumus sistēmas lietošanai.

Sekmīga vides pārvaldības cikla instrumentu aprobācija Valmierā var kḷut par pamatu uzlabojumiem normativajos aktos, kas šos jautājumus regulē valsts mērogā. Tas attiecas galvenokārt uz 1) vides pārvaldības pārskata un vides politikas plānošanas principu ieviešanu teritorijas attīstỉbas plānošanas dokumentu sistēmā un 2) uz nacionāla mēroga ilğtspējiggas attīstības un tās pārvaldības indikatoru sistēmas tīkla darbïbu. Pārvaldības indikatoru sistēmas tikkls darbojas kā komplekss, laujot pilnvērtỉgi salīdzināt kā dažādus pārvaldỉbas līmeṇus, tā teritorijas viena pārvaldības limmeṇa ietvaros. Indikatoru sistēmai ir jāraksturo pēc iespējas visu sabiedrïbas mērkgrupu darbỉba - ietekme uz vidi un videi draudzịgas rīcības: pārvaldes, komunālā sektora, uzṇēmumu, mājsaimniecību darbība u.c.

Mājsaimniecību videi draudzīgas rīcību prakses novērtējums Latvijā
Lai novērtētu mājsaimniecību vides pārvaldību un videi draudzịu rīcību, pētijumā tika izmantotas kvantitatīvās un kvalitatīvās socioloğiskās pētniecības metodes. Anketēšanu, izmantojot stratificēto nejaušo daudzpakāpju izlasi un klātienes intervijas respondentu dzìvesvietās, 2016. gada martā veica socioloğisko pētījumu firma TNS (respondentu skaits $N=1009$; ticamïbas intervāls $-3 \%$ ). 
Aptaujas mērkis bija identificēt sabiedrības vērtību - vides rīcību vides slodžu atšḳirības un novērtēt to rašanās cēloṇus. Izvirzìtā hipotēze paredz-lai gan cilvēkiem ir zināšanas un motivācija (vēlme) rīkoties videi draudzīgi, sabiedrībā pastāv daudz škēeršlu, kas to liedz pilnvērtīgi darìt. Šie šķērṣ̌ıi var būt, piemēram, informācijas vai finanšu trūkums, mazattīstīta infrastruktūra, sociālais spiediens. Anketas struktūra sastāv no piecām galvenajām dạ̦ām. Tās ir:

1) mājsaimniecības vispārīgs raksturojums,

2) mājsaimniecības slodze uz vidi,

3) patēriņš un pakalpojumi,

4) vides vērtỉbas,

5) videi draudzīga rīcība un tās motivācija.

Lai testētu un pielāgotu izstrādāto nacionālo mājsaimniecības interviju anketu un perspektīvā izstrādātu un adaptētu vietējo pašvaldību anketu, 2016. gada februārī tika veiktas 14 padziḷinātas intervijas Liepājas pilsētas mājsaimniecībās. Savukārt, lai izvērtētu nacionālajā anketā iegūtos datus un iegūtu vietējā līmena skatîjumu, tika veiktas padzilinātas, dalẹji strukturētas mājsaimniecību intervijas Valmieras pilsētā (2016. gada jūnijs, 10 intervijas). Interviju laiks bija vidēji no 20 līdz 45 minūtēm, un tās tika strukturētas, nemot vērā galvenos videi draudzịgas rīcības aspektus, kas saistīti ar mājokli un enerğijas patērinu, transportu, pārtiku un sadzives preču un pakalpojumu patērinuu. Nacionālās anketas un padziḷināto interviju rezultāti tika prezentēti un apspriesti fokusgrupu intervijās Liepājā un Valmierā, projekta pilotteritorijās, kā arī prezentēti pašvaldību pārstāvjiem Liepājas domes Vides komisijā 2016. gada maijā, bet Valmieras pilsētas ekspertu apaḷā galda diskusija notika 2016. gada oktobrì.

Lai padzilināti novērtētu mājsaimniecību vides pārvaldību un videi draudzīgu rīcỉbu, 2016. gada septembrī un oktobrī tika veikta vietējā mājsaimniecību anketēšana (Valmiera: $N=373$; Liepāja: $N=361$; ticamības intervāls $-5 \%$ ). Šīs anketas bija veidotas pēc līdzigas struktūras, kā nacionālā anketa, taču jautājumi par sabiedrības vērtīborientācijām tika aizstāti ar jautājumiem par iedzīvotāju apmierinātību ar pašvaldības sniegtajiem vides pakalpojumiem. Anketēšanu Valmierā un Liepājā veica pilsētas skolu skolēni (pamatā vidusskolēni) ciešā sadarbībā ar pašvaldību un tās izglitīibas pārvaldi. Pirms tam tika veikta skolēnu un skolotāju koordinatoru apmācība par vietējo mājsaimniecību teritoriālo anketēšanu. Anketu datu apstrādi finansiāli atbalstijja abas pašvaldības.

Pētỉjuma būtiska saturiskā dala bija tieši vērtỉbu - rīcību - slodžu neatbilstības novērtējums Latvijas sabiedrībā, un tas īsumā aplūkots nākamajās nodạạās. Lai noskaidrotu cilvēku vides apziņas līmeni, t. sk. gatavību rìkoties videi draudzigi, pētỉjumā, pamatojoties uz 15 jautājumiem par vides vērtỉbām, tika izstrādāts videi draudzīgas rīcības indekss. Indekss parāda, ka kopumā Latvijas sabiedrība sevi uzskata par zali domājošu un gatavu iesaistīties vides slodžu mazināšanā. Taču ne vienmēr cilvēku gataviba rỉkoties videi draudzīgi tiek īstenota praksē. Piemēram, lielākā dạ̣a respondentu ikdienā uzturā lieto dzivnieku izcelsmes produktus, jo tā ir ierasta prakse, un bieži pārvietojas ar privāto autotransportu, jo tā ir ērtāk noklūt vajadzīgajā vietā, bet sabiedrisko transportu izmanto tie, kas nevar aț̣auties privāto. Cilvēk apgalvo, ka ir gatavi škirot atkritumus, bet tikai daḷa respondentu atzīst, ka to dara ikdienā. Tāpat ne visas videi draudzịgas rīcības ir sabiedrībā vienlīdz populāras. Respondenti ir vairāk gatavi īstenot tādas rīcības kā atkritumu šķirošana, èku siltināšana vai zināšanu palielināšana, taču nav gatavi samazināt patērinu un komforta līmeni, kā arī sadarboties ar citiem.

Pētijums parāda, ka sabiedrībā pastāv dažādas psiholoğiskas, sociālas un fiziskas barjeras, kas ierobežo videi draudzigas rīcibas attīstību un izplatību, bet izplatîtākās videi draudzịgās rīcības ne vienmēr nodrošina pietiekamu vides slodžu samazinājumu. Cilvēku rīcības ir «ieslēgtas» sociālajās normās, piegādes sistēmās un infrastruktūrā (piemēram, rīcỉbu ietekmē satiksmes, pārtikas un siltumapgādes normas) (Stern et al., 1999; Stern, 2000). Lai saprastu sabiedrības motivāciju un šḳēršlıs, tika veikta sabiedrības vērtīborientāciju un klasteru analīze.

Analizējot sabiedrības vērtīborientācijas, tika izmantots Švarca universālais vērtỉbu modelis (Schwartz, 1992; Schwartz, 2012). Var secināt, ka dažām vērtībām, piemēram, paštranscendences vērtībām, ir statistiski nozīmīga pozitīva korelācija ar videi draudzīgas rīcības indeksu un oglekḷa dioksīda pēdu. Pētījums arī atklāj drošības vērtību būtiskumu Latvijas sabiedrībā. Taču kopumā jāsecina (un regresijas analizze to parāda), ka sabiedrības vērtỉborientācijas un sociāli ekonomiskie faktori skaidro tikai nelielu daḷu cilvēku motivāciju rïkoties videi draudzigi.

Lai pārbaudītu, vai pastāv būtiskas atškirības starp respondentiem atkarībā no vinu vides apziṇas, videi draudzīgas rīcības, apmierinātỉbas ar

1. tabula. Ilgtspējīga patērina mērkauditorijas

\begin{tabular}{|c|c|c|}
\hline Rīcība/apziṇa & $\begin{array}{l}\text { Apziṇa-rūpes par } \\
\text { vides problēmām }\end{array}$ & $\begin{array}{l}\text { Apziṇa-nevērīga izturēšanās } \\
\text { pret vides jautājumiem }\end{array}$ \\
\hline $\begin{array}{l}\text { Videi draudzīga } \\
\text { rīīiba }\end{array}$ & $\begin{array}{l}\text { Ceturtais klasteris - vide rūp un } \\
\text { praktizē videi draudzīgu rīcību }\end{array}$ & $\begin{array}{l}\text { Otrais klasteris - vide nerūp, tomēr } \\
\text { praktizē videi draudzīgu rīcíbu }\end{array}$ \\
\hline $\begin{array}{l}\text { Neilgtspējīga } \\
\text { rīiciba }\end{array}$ & $\begin{array}{l}\text { Trešais klasteris - vide rūp, bet } \\
\text { nepraktizē videi draudzīgu rīcību }\end{array}$ & $\begin{array}{l}\text { Pirmais klasteris - vide nerūp un } \\
\text { nepraktizē videi draudzīgu rīcību }\end{array}$ \\
\hline
\end{tabular}


dzivi un ienākumu līmena, ar SPSS 23 programmatūras palīdzību, izmantojot divsoḷu K-vidējo (TwoStep K-means) metodi, tika veikta klasteru analīze. Tā atklāj četras atšḳirīgas patērētāju grupas (1. tabula), kurām raksturīgas atškiriīgas vajadzỉbas, iespējas un prasme ìstenot ilgtspējigu patērinu, kā arī raksturiggas atškiririgas vides slodzes un to struktūra.

Pētijjums arì atklāj, ka vēlme aizsargāt vai uzlabot vidi reti ir primārā motivācija, istenojot videi draudzịgu rīcibu, bet var to pastiprināt. Vairāku videi draudzịgu rīcību pamatā ir vēlme ietaupìt naudu (energoefektīvu ieriču izmantošana), rūpes par veselību (veselīgāka pārtika, videi draudzīgi tīī̌šanas līdzekḷi), vēlme dzīvot sakoptā vidē un celt ịpašuma vērtỉbu (ēku renovācija) vai iegūt apkārtējo atzinību (zaḷā mode, auduma iepirkuma maisinii). Būtisks motivējošs faktors var būt arì kopienas piederība un cilvēka personiggie ieguvumi no videi draudzigas rīcības un vēlme labi justies. Lìdz ar to arī cilvēka labklājiba un gandarỉjuma sajūta var būt būtiski videi draudzịgas rīcības priekšnosacijumi.

Taču Latvijas sabiedrībā aktuālas ir arī videi draudzīgas rīcíbas izmaksas, jo lielākās daḷas iedzīvotāju ienākumi ir ḷoti ierobežoti. Tāpēc aktuāls ir jautājums par dažādu videi draudzīgu rīcību (kā ēku siltināšana vai energoefektivva automobiḷa izmantošana) izmaksām, jo pietiekamu resursu trūkums var cilvēkus novest pie bezspēcības sajūtas vai «bezbiḷetnieku» problēmas - tādas sabiedrības locekḷ uzvedības, kad tie gūst labumu no citu rīcības vides aizsardzībā, bet paši nav gatavi par to maksāt. Tas var novest pie nepatîkamu vides apsvērumu ignorēšanas. Gadỉjumos, kad cilvēka rīcību nosaka bažas par vides jautājumiem un vides problēmu apzināšanās, tiem, kas īsteno videi draudzīgu rīcību, tik loti nerūp sociālais spiediens vai infrastruktūras pieejamība. Līdz ar to, kaut gan sociālās normas joprojām ir būtiskas, ietekmējot vēlmi piedalìties, sociālais spiediens var arī nebūt noteicošais videi draudzīgas rīcības faktors. Ievērojot, ka patērina un rīcības paradumus lielā mērā nosaka ieradumi un rutīna, dzīvesveida izmaiņas ir vairāk iespējamas brī̌̌os, kad notiek būtiskas izmaiņas cilvēka dzivēe: ejot pensijā, veidojot ǵimeni u.tml. To respondenti arī apliecina padzilinātajās intervijās.

Šajā pētījumā mājsaimniecību slodžu novērtēšanai tika izmantota oglekḷa dioksīda pēdas aprēḳina metodika (Druckman \& Jackson, 2009; Hertwich \& Peters, 2009; Peters, 2010; Brizga, Feng, \& Hubacek, 2017). Oglekḷa dioksīda pēda ir rādìtājs, ko var izmantot, lai noteiktu mājsaimniecības, procesa, produkta vai kādas teritorijas patēriṇa radīto siltumnīcefekta gāzu emisijas apjomu, kas rodas preču un pakalpojumu pilnā dzīves ciklā - no resursu ieguves un ražošanas lïdz lietošanai un utilizācijai. Aptaujas 18 jautājumi tika izmantoti, lai aprēķinātu respondentu oglekḷa dioksīda pēdas nospiedumu. Tie aptvēra būtiskās patēriṇa kategorijas - mājokli (ieskaitot enerḡètiku, ūdeni un atkritumus), mobilitāti un pārtikas patērinu -, kas rada līdz $80 \%$ no kopējām mājsaimniecību vides slodzēm (1.attēls).

1. attēls. Oglekḷa dioksīda pēda Latvijā ( $\mathrm{kg} \mathrm{CO}_{2 \mathrm{e}}$ uz cilvēku gadā)

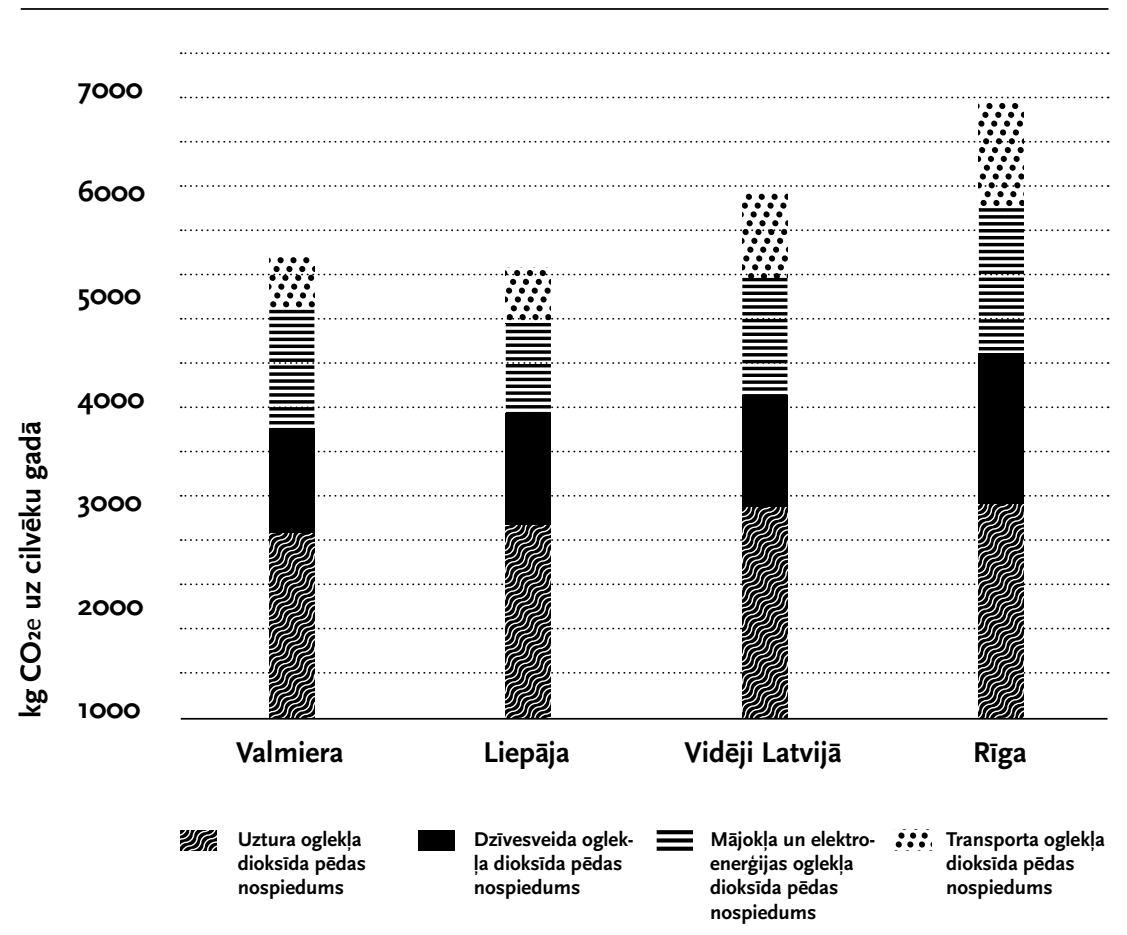

Lielākās atšḳirības oglekḷ dioksīda pēdā ir vērojamas tieši mājokḷa un transporta sektoros, jo dažādās teritorijās var būtiski atškiirties pieejamā transporta infrastruktūra un izmantojamie enerợijas resursi. Pētījums parāda, ka būtiskais faktors, kas nosaka mājsaimniecību slodzi vidē, ir ienākumijo augstāki ienākumi, jo lielāka oglekḷa dioksīda pēda. Savukārt ienākumi ir cieši saistiti ar cilvēku izglitīibas līmeni. Tāpēc cilvēkiem ar augstāku izglitî̉bu arī oglekla dioksīda pēda ir lielāka. Tas apliecina, ka mēs kā sabiedrība neesam spējuši ekonomisko attīstỉbu un materiālo labklājibu atsaistīt no resursu patēriṇa un vides piesārṇojuma. Šìs atsaistes nodrošināšana arī būs viens no galvenajiem 21. gadsimta vides politikas izaicinājumiem (Schandl et al., 2016), ja vēlamies nodrošināt ilgtspējigu attīstību gan Latvijā, gan globāli.

Respondentu atbildes par populārākajām videi draudzīgām rīcībām parāda arī rīcību un slodžu neatbilstību (sk. arī Csutora, 2012), kad cilvēku izvēlētās videi draudzīgās rīcības nespēj nodrošināt būtisku vides slodžu samazinājumu. Piemēram, cilvēki šḳiro atkritumus, izmanto auduma iepirkumu maisinus, bet dzìvo neefektivos mājokḷos un daudz pārvietoja ar privāto transportu, un tas vinu radìto slodzi uz vidi būtiski palielina. Lai 
izstrādātu detalizētus ieteikumus, kā monitorēt visus vides pārvaldības parametrus pašvaldībās (un arī mājsaimniecībās) vidējā termiṇā un ìstermiṇā, nepieciešami papildu dziḷāki pētijumi, lai gan līdzšinējos pētijumos jau ir izstrādāti municipālā monitoringa pamata principi un ir aprobētas un novērtētas ilgtermina indikatoru sistēmas, tāpat ir arī izvirzìts priekšlikums izstrādāt ilgtspējīgas pārvaldības pārskatu.

\section{Attīstības pārvaldības}

\section{uzraudzība: indikatori un}

to sistēmu attīstība Latvijā

Starptautiskajā praksē ilgtspējigas attīstības pārvaldības indikatoru sistēmas attīstijjās uz jau agrāk zināmo vides un ekonomisko indikatoru sistēmu bāzes un parādījās faktiski tūdal pēc «Agenda 21» (United Nations, 1992) koncepta pienemšanas Riodežaneiro konferencē 1992. gadā. Praksē lietojamu indikatoru sistēmu izstrādē lielu ieguldijumu ir devusi ANo Pārtikas un lauksaimniecības organizācija (FAO, 1999), ne tikai pakāpeniski attīstot indikatoru sistēmu pasaules pārtikas sektora dažādu aspektu novērtēšanai, bet veicot arī teorētiskas izstrādnes un apkopojot to atzinas. Latvijā 2009. gadā ar Ministru kabineta noteikumiem Nr. 175 (Ministru kabinets, 2009) tika nostiprināta nacionālā vides indikatoru sistēma, taču attiecīgie ziṇojumi par vides stāvokli valstĩ tika sagatavoti neregulāri; informācija pēdējo reizi tika atjaunota tikai 2011. gadā. No 2006. līdz 2014. gadam regulārus indikatoru sistēmas pārskatus sniedza Rīgas pilsētas pašvaldība, taču pilsētas attīstības plānošanas dokumentos šì detalizētā indikatoru sistēma netika integrēta, un kopš 2014. gada tā ir aizvietota ar vidēja termina rīcību rezultatīvo rādītāju kopu (Rỉgas domes .., 2014). Municipālā līmenī ilğtspējiggas attīstỉbas pārvaldības indikatoru sistēma tieši kā attīstības plānošanas dokumentos integrēta uzraudzỉbas sistēmas sastāvdala Latvijā pirmo reizi ir ieviesta Saulkrastu novadā 2013. gadā (Saulkrastu novada ..., 2013), bet vēl četrām pašvaldībām tā ir iestrādāta uzraudzības sistēmā kā ieteikums.

Pilnveidojot izpratni par sistēmas veidošanas principiem un veidojot nacionālam un lokālam līmenim adaptētu indikatoru sistēmu, varēja konstatēt, ka ilghtspējigas attīstỉbas pārvaldības indikatoru sistēmas veidošanas metožu teorētiskie pamati līdz šim ir nepietiekami izstrādāti (Kauliṇš, 2015). To skaitā:

— indikatoru sistēmas veidošana nav pietiekami integrēta attīstības plānošanas procesā;

— nav norādīta indikatoru un indikatoru sistēmas vieta attīstības plānošanas dokumentācijā;

— plānošanas dokumentu ìstenošanas uzraudzìbas un novērtēšanas sistēma Latvijā patlaban ir vairāk piemērota rīcibu izpildes kontrolēšanai, nevis stratēóiskās virzības un ilgtspējigas attīstỉbas novērtēšanai un nepilda agrã brīdinājuma funkciju par problēmām, kas saistītas ar lēmumu pieṇemšanas mehānismiem.

Kvantitatīvas uzraudzības plānošanas dokumentu istenošana ir viens no labas pārvaldības pamatelementiem, un tas ir būtisks, lai nodrošinātu ilgtspējìgu attīstỉbu arī tālākā perspektīvā. Attīstības plānošanas dokumentos teritorijas ilgtspējību var definēt kā ilgtermiṇa mērḳi vai arì tas netieši izriet no teritoriālajā redzējumā definētajiem izmērāmiem mērkiem. Visefektīvākais veids, lai uzraudzītu progresu virzībā uz plānotajiem mērḳiem, ir ilgtspējigas attīstỉbas un tās pārvaldỉbas indikatoru sistēma.

LU Geogrāfijas un Zemes zinātnu fakultātes Vides pārvaldības grupa projekta SUSTINNO ietvaros ir noslēgusi pirmo mērijjumu ciklu ar 64 rādītājiem, kuri ir iekḷauti jau minētajā Saulkrastu novada indikatoru sistēmā. Galvenie rezultāti ir šādi: 1) ir izstrādāts pašvaldības ilgtspējības novērtējums - ilgtspējības pārskats (Saulkrastu novada ..., 2017), kas balstīts četrās ilgtspējības dimensijās; inovatīva rakstura ilgtspējīgas pārvaldības pārskats sniedz ieteikumus lēmumu pieņēmējiem un informāciju sabiedrībai; 2) ir novērtēta indikatoru sistēmas darbība un noteiktas tās uzlabošanas iespējas (Kaulinšš, 2017b); attiecīgi sistēmā un atsevišḳos tās indikatoros ir iestrādātas izmainas.

Ilg̣tspējības pārskats ir izstrādāts, ievērojot ilǵtspējības dimensiju principus, un tas satur atsevišḳu pielikumu ar pašvaldības ilgtermiṇa attīstỉbas mērḳu vērtējumu. Pēc piecu punktu skalas Saulkrastu novada ilgtspēju SUSTINNO projekta pētnieki vērtē ar 3,3 dabas vidē, 2,8 sociālajā vidē un 2,7 ekonomiskajā un pārvaldības vidē. Paši rādītāji tika vērtēti pēc septinu kritēriju sistēmas. Piecus kritērijus piemēroja datu ieguvei un kvalitātei, savukārt pārējie divi raksturoja indikatoru saderỉbu ar mērījuma mērkì. Atseviški rādītāji izrādījās neefektīvi vai neaprēkināmi, jo trūka adekvātu datu; tie no sistēmas tika izslēgti vai tos aizstāja ar citiem. Sistēma kopumā tika uzlabota, nedaudz pārstrukturējot to, nosakot galvenos rādītājus dimensijām un atseviškāām nozarēm, kā arì papildinot stratēóiskos rādītājus.

Redzams, ka Saulkrastos pašvaldības indikatoru sistēma darbojas veiksmigi, taču problēma ir resursu trūkums - nepietiekamais pašvaldỉbas finansējums indikatoru sistēmas uzturēšanai. Turklāt sistēma nav integrēta ar citām, ieskaitot augstākā līmena attīstības plānošanas dokumentus. Tas tiek ṇemts vērā, izstrādājot ilgtspējības pārraudzības sistēmas citām pašvaldībām un provizoriski veidojot ilgtspējigas attīstības pārvaldības novērtējuma nacionālo indikatoru sistēmas tīklu. Detāla informācija par Saulkrastu indikatoru sistēmas struktūru ir sniegta nākamajā nodalāā.

Indikatoru sistēmas teorētiskais pamats ilgtspējigas attīstības pārvaldỉbas izstrādei ir pakāpeniski attîstijies, taču tas joprojām ir nepietiekami saistīts ar pašvaldỉbu vadības sistēmu un procesu teoriju un praksi. Šobrīd 
ir pabeigts pētỉjums par ilgtspējīgas attīstỉbas pārvaldỉbas indikatoru sistēmas izstrādi, ieviešanu un izmantošanu pašvaldību teritorijas attīstības pārvaldības procesā (Kauliņš, 2018). Tika izstrādāti priekšnosacỉjumi indikatoru sistēmas veidošanai, tostarp iezīmēti arī virzieni ilgtspējīgas attīstības pārvaldības rādītāju integrativitātes pamata konceptu turpmākai izstrādei un saistībai starp ilgtspējības aspektiem (jo īpaši pārvaldības un saziņas aspektu), kā arì tika izstrādātas horizontālās un vertikālās integrācijas pieejas. Indikatoru sistēmas izmantošanas galvenā praktiskā problēma ir: sistēmas izstrādei un uzturēšanai nepieciešami ievērojami resursi-labi apmaksāti augstas kvalifikācijas speciālisti, to trūkst. Vienlaikus jāatzīmē, ka indikatoru pieejā līdz šim izmantotajā praksē nepilnỉba ir arī vidēja termina un îstermiṇa plānošanas dokumentu nostādṇu nesaiste, kaut gan, piemēram, indikatoriem un rezultatīvajiem rādītājiem ir daudz kopìga.

\section{Indikatoru sistēmu} attīistišana un tās prakse

Lai nodrošinātu ilgtspējigas attīstìbas pārvaldības procesu (plānošanu, uzraudzỉbu, novērtēěšnu), ir jāievēero vairāki principi, kas raksturo indikatoru sistēmas attīstību. Pētot eksistējošu indikatoru sistēmu un indikatoru saistỉbu ar plānošanas procesu, tika konstatēti priekšnosacijumi ilgtspējigas attīstības pārvaldỉbas indikatoru sistēmas attīstīšanai. Indikatoru sistēmas horizontālo integrāciju nodrošina ilgtspējibas dimensiju un integratīvo problēmjomu savstarpējo saistību ievērošana, kas ḷauj izveidot tādu ilğtspējiğas attīstibas pārvaldības indikatoru sistēmu, kura adekvāti un komplementāri atspogulo kā ilgtspējības dimensiju, tā nozaru integrativitāti un atsevišķo un kopigo faktoru sadalījumu. Indikatoru sistēmas vertikālā integrācija ḷauj veidot dažādu līmeṇu indikatoru harmonisku metasistēmu un izprast tās atseviško dalu ilgtspèjigas attīstības pārvaldības stāvokli, sekmes un ieguldỉjumu kopiggà ilgtspējigas attīstības kontekstā visos pārvaldỉbas līmeṇos.

Vertikālās integrācijas princips nozīmē konkrētas indikatoru sistēmas saistỉbu ar citu pārvaldības līmeņu indikatoru sistēmām. Tas ir ịpaši nozīmìgi valsts vienotas plānošanas sistēmas ietvaros; praksē saistība ar augstāku līmeṇu sistēmām var būt loti ierobežota pārvaldības sistēmu atškirïgo uzdevumu un funkcionēšanas mehānismu dēl. Latvijā lokālās indikatoru sistēmas var iedalīt reǵionālajās (pēc plānošanas reǵioniem) indikatoru sistēmās un novadu/pilsētu indikatoru sistēmās. Vertikālā integrācija nacionālā līmeṇa ilgtspējigas attīstības pārvaldības indikatoru sistēmā ir nepieciešama starpnacionālo salīdzinājumu izdarīšanai un valsts attīstības sekmju novērtēšanai uz ES un tuvāko konkurējošo valstu fona. Šāa integrācija reāli izpaužas saistībā ar stratēǵijas «Eiropa 2O2O» loti kompakto indikatoru sistēmu, kas gandrīz pilnīgi ir ieklauta arì Latvijas ilgtspējīgas attīstības stratēóijāā līdz 2030. gadam (Saeima, 2010). Šādu integrāciju izdodas realizēt tādēl, ka Eurostat sniedz loti viendabīgu informatīvo bāzi kā šiem indikatoriem, tā arì citiem, kas raksturo ilgtspējigas attīstības pārvaldỉbu Latvijā.

Ilgtspējigas attīstības pārvaldības indikatoru sistēmas praktiskai attīstǐ̌̌anai ir izveidots indikatoru atlases algoritms, kas sastāv no divām dalāām. Vispirms notiek tā saukto indikatora kandidātu atlase no parametriem, kuri raksturo iespējamos stratēógiskos mērḳus (un virsmērḳi, ja tāds ir), prioritārās integrativās problēmjomas un ilgtermina rīcības virzienus integrētās plānošanas procesā. Šìs atlases laikā notiek pārbaude, vai indikators atbilst prasībām, kas izvirzītas ilgtspējigas attīstības pārvaldības indikatoram, t.i., vai pastāv saistība ar ilgtspējības, attīstības un pārvaldỉbas galvenajiem aspektiem, kā arī vai tiek novērtēta indikatora integrativitāte. Pēc tam piedāvātie indikatori tiek ranžēti, izdalot vadošos un stratēǵiskos (integrālos) indikatorus. Tālāk notiek atlasìto indikatoru kandidātu pārbaude, vai tie atbilst indikatora informatīvā nodrošinājuma un pārvaldības indikatora definīcijas apgabala priekšnosacijumiem. Šajā atlases procesā tiek novērtēta arī to parametru nozìme, kuri formāli neiekḷaujas ilgtspējiggas attīstības pārvaldības indikatora definīcijas apgabalā, taču konkrētu iemeslu dēl var būt nozīmīgi pārvaldības lēmumu pieṇemšanā. Atlases gala rezultātā tiek izveidota ilgtspējigas attīstības pārvaldỉbas indikatoru sistēma, kas pēc attiecīga pārvaldỉbas lēmuma (apstiprināšanas) kḷūst par pamatu tālākai praktiskai darbỉbai indikatoru sistēmas dokumentācijas detālā izstrādāšanā.

Indikatoru sistēma Saulkrastu novadam ilgtspējīgas attīstības stratēĝijas istenošanas uzraudzībai un novērtēšanai izstrādāta, balstoties uz pētỉjuma gaitā iegūtajām teorētiskajām atzinām par integrēto attīstības plānošanu un ilgtspējigas attīstỉbas pārvaldības indikatoru nozīmi un vietu. Ilgtspējīgas attīstības pārvaldības indikatoru sistēma ir iekḷauta ilgtermina attīstības stratēégijā kā uzraudzības un novērtēšanas mehānisma informatīvā bāze. Tajā ietilpst strukturēts indikatoru saraksts, kurā indikatori grupēti pa ilgtspējības dimensijām un integratīvajām problēmjomām, un «Attīstības un ilgtspējības monitoringa indikatoru sistēmas lietošanas rokasgrāmata», kurā ir sniegtas metodiskas rekomendācijas indikatoru sistēmai kopumā un katra atsevišķa indikatora lietošanai. Pēc vienota sistēmas ir detalizēti aprakstīta konkrēto indikatoru mērïjumu veikšanas metodika un sniegti norādỉjumi par rezultātu sagatavošanu un atspogulošanu lēmumu pieṇēmēju un citu sabiedrības mērḳgrupu vajadzībām. Sistēmas ieviešanas gaitā notika pašvaldības personāla apmācība indikatoru sistēmas praktiskā lietošanā (izpratne par sistēmu un tās dokumentāciju, datu avoti un ieguve, praktiskie aprēķini un rezultātu atspogul,ošana). Indikatoru sistēma ir apstiprināta lietošanai ar pārvaldības lēmumu kā novada ilgtspējigas attīstības stratēǵijas sastāvdaḷa. 2014. un 2015. gadā notika pirmais pilna apjoma ilgtspējigas attīstības pārvaldības novērtējums. 
Saulkrastu pašvaldības ilgtspējiggas attīstības pārvaldības indikatoru sistēma atspoguḷo pašvaldības teritorijas ilgtspējigu attīstỉbu un tās pārvaldību gan attiecībā uz visām ilgtspējịgajām dimensijām, gan arī saistībā ar pašvaldības ilgtermina attīstības mērkiem un prioritātēm. Šobrīd šì sistēma ir vienīgais šāda veida ilgtspējības un attīstības novērtēšanas instruments Latvijas pašvaldībās, tādēl iespējas novērtēt ilgtspējību salīdzinājumā ar citām pašvaldỉbām ir ierobežotas.

ES Interreg III programmas projekta DEDUCE (Marti et al., 2007) ietvaros tika veikts vispārējs Latvijas piekrastes ilgtspējības novērtējums. Salīdzinot ar šo novērtējumu, Saulkrastu pašvaldības attīstības situācija ir labāk lïdzsvarota. Rādìtāju zinojuma apkopotajai formai-ilgtspējības pārskatam ir ievērojams potenciāls iesaistìt mērḳgrupas, plānojot kā nozaru, tā teritorijas vispārējo attīstību, uzlabojot rādītāju sistēmu un tās darbību. Saulkrastu pašvaldības pieredze un labā prakse ir nozīmīgs ieguldỉjums rādītāju sistēmu turpmākā attīstîbā saskanaa ar to horizontālās un vertikālās integrācijas principiem, t.i., ṇemot vērā savstarpēju saistību starp indikatoru sistēmu vienā līmenī un tām sistēmām, kas noteiktas augstāka līmeņa plānošanā. Šì pieredze ir arī nozīmīga, izstrādājot rādītājus nacionālo interešu teritorijām, Latvijas gadỉjumā-tās piekrastes zonā.

Vietējās pašvaldības pārvaldības praksē izmantojams horizontālās integrācijas princips tika ievērots, izstrādājot indikatoru sistēmu Salacgrīvas novadam, un šo darbu veica LU pētnieki novada ilgtspējigas attīstỉbas stratēǵijas plānošanas gaitā. Sistēmu raksturo padzị̣ināta horizontālā integrācija, jo tā tika novērtēta kā starp problēmjomām, tā starp ilgtermina rīcības virzieniem, attiecīgi šo saistỉbu pārnesot uz indikatoriem, kas raksturo attiecīgās jomas. Izmantojot indikatoru sistēmu, tika aprobēta pieeja specializētu ilgtspējības aspektu atspoguḷošanai un novērtēšanai tematiskā un teritoriālā griezumā. Tematiskā griezumā tā ir rezultējusies, izstrādājot indikatoru sistēmu adaptācijai saistībā ar klimata pārmaiņām Salacgrīvas novadā, kā arī raksturojot noteiktu ekonomikas sektoru vides un veselības aspektā: novērtējot videi un veselībai draudzīgas pārtikas aprites ciklu Salacgrìvas novadā. Teritoriālā griezumā ir izstrādāti priekšlikumi indikatoru sistēmām Latvijas piekrastes ilgtspējības novērtēšanai, adaptējot DEDUCE indikatoru sistēmu Latvijas apstākḷiem, un piekrastes risku un komunikācijas novērtēšanai Saulkrastu novadā.

Ilgtspējigas attīstības pārvaldỉbas indikatoru sistēma stratēǵiskās plānošanas dokumentu uzraudzībai un novērtēšanai ir labāk piemērota nekā rezultatīvo rādītāju sistēma (Kaulinš, 2015). Ilgtspējīgas attīstības pārvaldības indikatoru sistēma salīdzinājumā ar rezultatīvo rādìtāju sistēmu atspoguḷo virzību uz stratēǵiskajiem mērḳiem šo mērḳu un prioritāšu līmenì (rezultatīvie rādìtāji to arī var atspoguḷt, bet šāda prasība nav obligāta), tā parāda ilgtspējibas un pārvaldỉbas elementus, plānošanas elementu savstarpējo

saistību un vismaz dalai sistēmas komponenšu spēj nodrošināt salīdzinājumus ar radniecīgām vai konkurējošām teritorijām. Atškiriībā no rezultatīvajiem rādītājiem, kas ir domāti tikai plānošanas rezultātu uzraudzībai un novērtēěanai, ilgtspējigas attīstības pārvaldỉbas indikatoru lietošana ir nozimigga visos attīstības plānošanas posmos. Jāpiebilst, ka labas pārvaldības praksei neatbilst valsts pārvaldē iedibinājusies kārtìba, ka rezultatīvo rādītāju mērķa vērtỉbas nereti tiek koriǵētas, ja kādā attīstības posmā ir redzams, ka šìs vērtības reāli netiks sasniegtas.

Inovatīi instrumenti ilgtspējīgas attīstības pārraudzības uzraudzībā un plānošanā
SUSTINNO projektā izstrādāta vietējās pārvaldības inovācija - municipālais ilgtspējības monitorings. Tas ir vērtējams kā sadarbỉbas pārvaldības (attīstības plānošanas procesa) instruments, kas sistēmiski un integratīvi apvieno Latvijā tradicionāli nesaistītas, pārsvarā maz zināmas vai maz izprastas un nepietiekami attīstitas uzraudzības un novērtēšanas sistēmas - ilgtspējīgas attīstỉbas pārvaldības indikatoru sistēmu, plānošanas dokumentu rezultatīvo rādītāju sistēmu un eventuālo sabiedriskā monitoringa sistēmu. No šìm trim minētajām sistēmām plašāk tiek lietota tikai rezultatīvo rādītāju sistēma, kuru izmanto Latvijas attīstības plānošanas dokumentu uzraudzībā un novērtēšanā, jo to prasa normatīvie akti. Municipālā monitoringa koncepts (2. attēls) ietver un integrē visas atsevišḳo sistēmu priekšrocības, vienlaikus laujot gan izvērtēt plānošanas dokumentu istenošanas sekmes, gan analizēt vispārēju, ar konkrētiem plānošanas procesiem nesaistìtu teritorijas ilgtspējibu.

Veidojot municipālo monitoringu, ir jāveic teritorijas analīze saskanā ar teorētiskajiem pārvaldības uzraudzības un novērtēšanas modeliem, kā arī jāievēro indikatoru sistēmas vertikālās integrācijas principi. Rezultātā izraudzìto ilgtspējīgas attīstības pārvaldības indikatoru kopa dạ̣ejii pārsedzas ar plānošanas dokumentu rezultativo rādìtāju kopu, un tas lauj ievērojam samazināt mērāmo parametru kopējo skaitu, vienlaikus veidojot kvalitatīvu metodisko nodrošinājumu. Monitoringa sistēmas obligāta komponente ir sabiedriskais monitorings, kas nodrošina iespēju gan mērīt parametrus, par kuriem dati citādā celā nav iegūstami, gan sekmēt sabiedrības iesaisti vides pārvaldības praksēē (mērišana, novērtēšana, komunikācija, plānošanas ieteikumi), kā arī veicina uzticību monitoringa mērỉjumiem.

Vertikālā integrācija ir nepieciešama, lai labāk varētu izprast reǵionālo līdzību un atškiriỉbu raksturu, tās cēloṇus un ietekmi uz ilgtspèjību nacionālā, reǵionālā un vietējā līmenī. Lìdz ar to vertikālās integrācijas sniegtā informācija var palīdzēt uzlabot patlaban daudz kritizēto attīstības centru «9+21» modeli, kas definēts Nacionālajā attīstības plānā, palīdz mērḳtiecīgi 
2. attēls. Municipālais monitorings teritorijas

attīstības plānošanas sistēmā

\begin{tabular}{|c|c|c|}
\hline $\begin{array}{l}\text { Ilgtspējibas } \\
\text { novērtēšana }\end{array}$ & $\begin{array}{l}\text { Ilgterminaa } \\
\text { plänošana }\end{array}$ & $\begin{array}{l}\text { Vidēja terminaa } \\
\text { plānošana }\end{array}$ \\
\hline
\end{tabular}

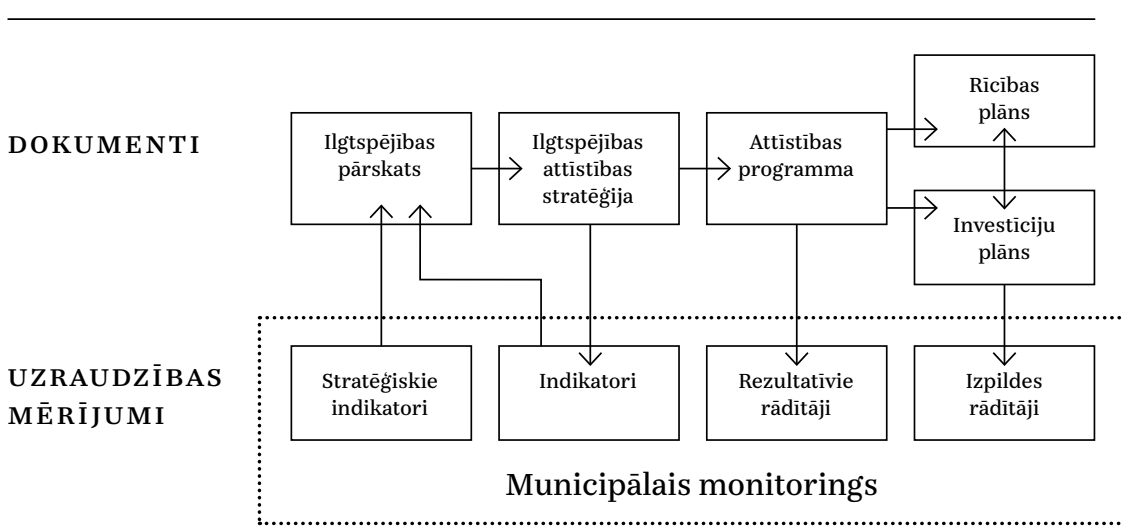

iedarboties uz faktoriem, kas nosaka investīciju plūsmas, migrāciju u.tml. attīstības faktorus. Latvijas Nacionālā attīstỉbas plāna 2014.-202O. gadam (Pārresoru koordinācijas centrs, 2012) indikatoru sistēma ir samērā vāji saistìta ar Latvijas ilgtspējigas attīstības stratēǵijā «Latvija 2030» iekḷauto indikatoru sistēmu (gandrīz tikai stratēǵisko indikatoru līmenī); Nacionālais attīstības plāns satur daudzus specifisku jomu indikatorus (it ịpaši sociālās labklājības atspoguḷojumā), kas nav tieši iegūstami no publiskās statistikas avotiem. N̦emot vērā to, ka vertikālās integrācijas modelī liela dạıa indikatoru ir kopịgi gan visām viena līmena teritorijām, gan arī dažādos pārvaldỉbas līmenos, var paredzēt, ka vertikāli un horizontāli integrēta nacionālā indikatoru sistēmu tỉkla ieviešana ilğtspējīgas attīstības novērtēšanas praksē ḷautu arì ievērojami samazināt izdevumus salīdzinājumā ar situāciju, kad katrs plānošanas subjekts to darītu patstāvīgi. 
1 ILGTSPĒJITGAS ATTİSTĪBAS

IZAICINĀJUMI PĒCKRĪZES LATVIJĀ:

SABIEDRĪBA, EKONOMIKA, VIDE

1.1 ANOMIJAS TÉMA UN TEORIJAS SOCIĀLAJĀS ZINĀTNËS

Ajzen, I. (1985). From intentions to actions; a theory of planned behavior. In J. Kuhl, J.Beckman (Eds.). Action control:from cognition to behavior (pp.11-39). Heidelberg, Germany: Springer.

Bak, C. K., \& Larsen, J.L. (2015). Social exclusion or poverty individualisation? An empirical test of two recent and competing poverty theories. European Journal of Social Work, 18(1), 17-35. doi:10.1080/13691457.2013.878316

Bandura, A. (1977). Social Learning Theory. Englewood Cliffs, NJ: Prentice Hall. Bandura, A. (1986). Social Foundations of Thought and Action: A Social Cognitive Theory. Englwood Cliffs, NJ: Prentice-Hall.

Bandura, A. (2004). Health promotion by social cignitive means. Health education and Behavior, 31(2), 143-164.

Branson, C., Duffy, B., Perry, C., \& Wellings, D. (2012). Acceptable Behaviour? Public opinion on behaviour change policy. London: Ipsos MORI, Social Research Institute.

Bueren, E. M., Klijn, E.-H., \& Koppenjan, J.F. M. (2003). Dealing with Wicked Problems in Networks: Analyzing an Environmental Debate from a Network Perspective. Journal of Public Administration Research and Theory, 13(2), 193-212.

Carter, T., \& Polevychok, C. (2004). Housing Is Good Social Policy. (Research report). Canadian Policy Research Networks Inc. Retrieved from http://www. urbancenter.utoronto.ca/pdfs/elibrary/CPRN_Housing-Good-Soc-Polic.pdf Conner, M. (2002). Health behaviors. University of Leeds UK.

Council of the European Union. (2004, 5 March). Joint report by the Commission and the Council on social inclusion, 7101/04 C. F. R. Brussels. Retrieved from http://ec.europa.eu/employment_social/soc-prot/soc-incl/final_joint inclusion report 2003 en.pdf

Dahlgren, G., \& Whitehead, M. (1991). Policies and strategies to promote social equity in health. Stockholm: Institute for Future Studies.

Darnton, A. (2008). Practical Guide: An overview of behaviour change models and their uses. Government Social Research Unit.

Davis, R., Campbell, R., Hildon, Z., Hobbs, L., \& Michie, S. (2015). Theories of behaviour and behaviour change across the social and behavioural sciences: a scoping review. Health Psychology Review, 9(3), 323-344.

Eiropas Savienibas Padome. (2006). Atjaunota ES Ilgtspējiğas attīistïbas stratēǵija. Brisele. Izgūts no www.varam.gov.lv/lat/darbibas.../ilgtspejiga...//ST10917REo3[1].LVo6.DOC.doc 
Emerson, K., Nabatchi, T., \& Balogh, S. (2012). An Integrative Framework for Collaborative Governance. Journal of Public Administration Research and Theory, 22(1), 1-29.

Eppard, L. M., Chomsky, N., Rank, R. M., \& Brady, D. (2017). On Culture, Politics, and Poverty. Contexts, 16(4), 8-11. Retrieved from http://journals.sagepub.com/ doi/pdf/10.1177/1536504217742382

European Commission. (2001). European Governance:A White Paper. Brussels, $\mathrm{COM}(2001)$ 428. Retrieved from http://europa.eu/rapid/press-release DOC01-10_en.htm

European Commission. (2010). EUROPE 2020. A strategy for smart, sustainable and inclusive growth. Brussels. Retrieved from http://eur-lex.europa.eu/ LexUriServ/LexUriServ.do?uri=COM:2010:2020:FIN:EN:PDF

European Commission. (2013). Health inequalities in the EU. Retrieved from http://ec.europa.eu/health/social_determinants/docs/ healthinequalitiesineu 2013 en.pdf

Eurostat. (2015). Life expectancy at birth, by sex. Retrieved from http://ec.europa.eu/ eurostat $/$ tgm/table.do?tab=table\&plugin $=1$ \&language $=$ en\&pcode $=$ tpsooo25

Eyal, N., Hurst, S. A., Norheim, O. F., \& Wikler, D. (Eds.). (2013). Inequalities in Health Concepts, Measures, and Ethics. New York: Oxford University Press, p. 6.

Fahey, T., \& Norris, M. (2010). Housing. In F. G. Castles, S. Leibfried, J.Lewis, H. Obinger \& C.Pierson (Eds.), The Oxford Handbook of the Welfare State (pp. 479-494). Oxford: Oxford University Press.

Franz, H.W., Hochgerner, J., \& Howaldt, J. (2012) Challange Social Innovation. Potentials for Business, Social Entrepreneurship, Welfare and Civil Society. Springer, p. 4

Galbraith, J.K. (2011, 1 March). Inequality and economic and political change: a comparative perspective. Cambridge Journal of Regions, Economy and Society, 4(1), 13-27. https://doi.org/10.1093/cjres/rsqo14. Retrieved from https:// academic.oup.com/cjres/article/4/1/13/425177

Galbraith, J.K. (2016). Ethics and Inequality: A Strategic and Practical View. [Book review] Ethics \& International Affairs, 30(3), 379-390. Retrieved from https:// datubazes.lanet.lv:4876/10.1017/So892679416000150

Graham, H. (2009). Understanding Health Inequalities (2nd ed.). Berkshire: Open University Press.

Hansen, P. G. (2014). Nudge and libertarian paternalism: Does the hand fit the glove? Copenhagen: Roskilde University, p. 23.

Haugh, H., \& Kitson, M. (2007) The third way and the third sector: New Labour's economic policy and the social economy. Cambridge Journal of Economics, 31(6).

Holma, B. (red.) (2017). Latvija. Pārskats par tautas attīstību 2015/2016. Dzīves meistarība un informācijpratība. Riga: Latvijas Universitāte, Sociālo un politisko pētijumu institūts.
Jochumsen, H., Rasmussen, C., \& Skot-Hansen, D. (2012). The four spaces - a new model for the public library. New Library World, 113(11/12), 586-597. http:// dx.doi.org/10.1108/0307480121128294

Killoran, A., \& Kelly, M.P. (2010). Evidence-based Public Health:Effectiveness and Efficiency. Oxford: Oxford University Press, pp. 63, 64, 148

Klepfers, M. (2003) Vides aizsardzība konstitucionālajās tiesībās. Vācijas Pamatlikuma 2o.a pants. Likums un Tiesïbas, 11.

Kollmuss, A., \& Agyeman, J. (2002). Mind the Gap: Why do people act environmentally and what are the barriers to pro-environmental behavior? Environmental Education Research, 8, 239-260.

Latvijas Republikas Saeima. (2016) Saeima konceptuāli atbalsta tiesisko regulējumu sociālajai uznēmējdarbïbai Latvijā. Izgūts no http://www.saeima.lv/lv/ aktualitates/saeimas-zinas/25438-saeima-konceptuali-atbalsta-tiesiskoregulejumu-socialajai-uznemejdarbibai-latvija

Lāce, T. (2012). Sociālā atstumtība Latvijāa. Rīga: Zinātne.

Maunz, T., \& Dürig, G. (Begr.) (2014, Dec.). Grundgesetz-Kommentar (Loseblatt, Art. 20, VIII. Die Sozialstaatlichkeit), Bd. III. München: Verlag C.H. Beck

Mont, O., Lehner, M., \& Heiskanen, E. (2014). Nudging. A tool for sustainable behaviour?(Report 6643). The Swedish Environmental Protection Agency.

Muckel, S. (2009). Sozialrecht (3. Auflage). München: Verlag C. H. Beck.

Mulgan, G., Tucker, S., Ali, R., \& Sanders, B. (2007). Social Innovation: What is it, why it matters, and how it can be accelerated? London, UK: The Young Foundation.

OECD. (2008). Inequalities in Health Care Use in OECD countries. Retrieved from http://www.oecd.org/health/inequalities

Pol, E., \& Ville, S. (2009) Social Innovation: Buzz Word or Enduring Term? The Journal of Socio-Economics, 38(6), 878-885.

Prager, K. (2012). Understanding behaviour change. How to apply theories of behaviour change to SEWeb and related public engagement activities. Report for SEWeb LIFE10 ENV-UK-0oo182

Prochaska, J.O., \& DiClemente, C. C. (1982). Transtheoretical therapy: Toward a more integrative model of change. Psychotherapy: Theory, Research and Practice, 19(3), 276-288.

Reinholde, I. (2013). Pārvaldība: laba vai vieda? Latvijas intereses Eiropas Savienībā, $2013 / 4,22-27$.

Roca, J. G. (2012-2013). Taking Social Rights Seriously: Principle of Financial Sustainability. Annuaire International des droits de l'homme, viI.

Saaremäel-Stoilov, K. (2007). How to Handle a Double-edges Sword Safely: Protection of the Elements of the Principle of the Social State in the Constitutional Jurisprudence of the Supreme Court of Estonia. Juridica International, 2.

Scholl, H.J., \& Scholl, M.C. (2014). Smart Governance: A Roadmap for Research and Practice. In iConference 2014 Proceedings (p.163-176). doi:10.9776/14060 
Sen, A. (1999). Development as Freedom. New York: Anchor Books.

Stiglitz, E.J. (2012). The Price of Inequality. New York, London: W.W. Norton \& Company.

Stiglitz, E.J. (2015). The Origins of Inequality, and Policies to Contain It. National TaxJournal, 68(2). 425-448. dx.doi.org/10.17310/ntj.2015.2.09. Retrieved from http://www.ntanet.org/NTJ/68/2/ntj-v68no2p425-448-origins-inequalitypolicies-contain.html

United Nations Conference on Environment \& Development. (1992). AGENDA 21. Rio de Janerio, Brazil, 3 to 14 June 1992. Retrieved from https:// sustainabledevelopment.un.org/content/documents/Agenda21.pdf

United Nations General Assembly (2015). Transforming our world: the 2030 Agenda for Sustainable Development. Resolution adopted by the General Assembly on 25 Sept. 2015. Retrieved from http://www.un.org/sustainabledevelopment/ sustainable-development-goals/

United Nations. (1995). Report of the World Summit for Social Development. A/CONF.166/9. Copenhagen, Denmark, 6 to 12 March 1995. Retrieved from http://www.un.org/documents/ga/conf166/aconf166-9.htm

Walker, R. (2014). The Shame of Poverty. Oxford: Oxford University Press.

WCED. (1987). Report of the World Commission on Environment and Development Our Common Future. Oxford, UK: Oxford University Press. Rerieved from www.un-documents.net/our-common-future.pdf

World Health Organization Regional Office for Europe. (2011). Governance for health in 21st century: a study conducted for the WHO Regional Office for Europe. Retrieved from http://www.euro.who.int/ data/assets/pdf

file/0010/148951/RC61_InfDoc6.pdf

\subsection{KOLEKTİVĀ RİCİBA INTERNETA POLITISKĀS KOMUNIKĀCIJAS UN SABIEDRĪBAS} VERTİBORIENTĀCIJAS IZMAIN̦U KONTEKSTĀ

van Aelst, P., \& Walgrave, S. (2011). Minimal or Massive? The Political Agenda Setting Power of the Mass Media According to Different Methods. The International Journal of Press/Politics, 16(3), 295-313.

Bartlett, J., Froio, C., Littler, M., \& Mcdonnell, D. (2013). New political actors in Europe: Beppe Grillo and the M5s. London: Demos Country briefing papers. Benford, R.D., \& Snow, D. A. (2000). Framing processes and social movements: an overview and an assessment. Annual Review of Sociology, 26, 611-639.

Bennett, W. L., \& Segerberg, A. (2012). The logic of connective action. Digital media and the personalization of contentious politics. Information, Communication \& Society, 15(5), 739-768.

Bennett, W.L. (2003). Communicating global activism: strengths and vulnerabilities of networked politics. Information, Communication \& Society, 6(2), 143-168. Bocsh, T. (2017). Twitter activism and youth in South Africa: The case of \#RhodesMustFall, information. Communication \& Society, 2O(2), 221-232.

Boutyline, A., \& Willer, R. (2016). The Structure of Political Echo Chambers: Variation in Ideological Homophily in Online Networks. Political Psychology, $38(3)$.

Brannelly, K. (2016, Nov. 4). Trump Campaign Pays Millions to Overseas Big Data Firm. NBC News.

Broersma, M., \& Graham, T. (2012). Social media as beat: Tweets as a news source during the 2010 British and Dutch elections. Journalism Practice, 6(3), 403-419.

Brooks, C., \& Manza, J. (1994). Do Changing Values Explain the New Politics? A Critica Assessment of the Postmaterialist Thesis [online], pp. 542. Retrieved 22.04.2016 from http://sociology.as.nyu.edu/docs/IO/3858/Do_Changing_Values_ Explain_the_New_Politics.pd

Bruns, A., \& Burgess, J. (2012). Researching news discussion on Twitter: New methodologies. Journalism Studies, 13(5-6), 801-814.

Bruns, A., Moon, B., Paul, A., \& Münch, F. (2016). Towards a typology of hashtag publics: A large-scale comparative study of user engagement across trending topics. Communication Research and Practice, 2(1), 20-46.

Carlson, T., \& Strandberg, K. (2011). The rise of web campaigning in Finland. In R. L. Fox, J.M. Ramos (Eds.), iPolitics: Citizens, Elections, and Governing in the New Media Era (pp.125-150).

Chadwick, A. (2013). The hybrid media system: Politics and power. Oxford: Oxford University Press.

Clift, S. (2002) The future of e-democracy: The 50 year plan. Retrieved 01.01.2018 from http://www.publicus.net/articles/future.html 
Dang-Xuan, L., Stieglitz, S., Wladarsch, J., \& Neuberger, C (2013). An investigation of influentials and the role of sentiments in political communication on twitter during election periods. Information, Communication \& Society, 5, 795-825.

van Dijck, J., \& Poell, T. (2013). Understanding social media logic. Media and Communication, 1(1), 2-14.

Engesser, S., Ernst, N., Esser, F., \& Büchel, F. (2016). Populism and social media: How politicians spread a fragmented ideology. Information, Communication \& Society, $20(8), 1109-1126$

Enli, G. (2017). Twitter as arena for the authentic outsider: Exploring the social media campaigns of Trump and Clinton in the 2016 Us presidential election. European Journal of Communication, 32(1), 50-61.

Enli, G. S., \& Skogerbo, E. (2013). Personalized campaigns in party-centred politics. Twitter and Facebook as arenas for political communication. Information, Communication and Society, 16(5), 757-774.

EPRS. (2014, Mar. 21) Social media in election campaigning. Briefing.

Eurobarometer. (2013, Autumn). Media use in the European Union. Standard Eurobarometer 80. Fieldwork November 2013.

Eurobarometer. (2016, Autumn). Media use in the European Union. Standard Eurobarometer 86. Fieldwork November 2016.

Eurobarometer. (2017). Media use in the European Union. Standard Eurobarometer 88. Fieldwork November 2017.

European Commission. (2017, Oct. 16). Digital Single Market: Fake News. Retrieved 06.03.2018 from https://ec.europa.eu/digital-single-market/en/fake-news

European Commission. (2017, Sept. 28). Communication from the Commission to the European Parliament, the Council, the Economic and Social Committee and the Committee of the Regions. Tackling Illegal Content Online. Towards an enhanced responsibility of online platforms. $\operatorname{COM(2017)~555.~Brussels.~}$

Eurostat. (2017). Internet use. Individuals using the internet for participating in social networks (tino0127). Retrieved from http://ec.europa.eu/eurostat/ data/database

Fox, R.L., \& Ramos, J.M. (Eds.). (2012). iPolitics: Citizens, Elections, and Governing in the New Media Era. Cambridge: Cambridge University Press.

Gasser, U., \& Gerlach, J. (2011). E-campaigns in Old Europe: Observations from Germany, Austria, and Switzerland. In R.Fox \& J.M. Ramos (Eds.). iPolitics. Citizens, Elections, and Governing in the New Media Era. Cambridge University Press.

Gerbaudo, P. (2017). Social media teams as digital vanguards: The question of leadership in the management of key Facebook and Twitter accounts of occupy Wall Street, Indignados and UK Uncut. Information, Communication \& Society, 2O(2), 185-202.

Graham, T., Broersma, M., Hazelhoff, K., \& van 't Haar, G. (2013). Between broadcasting political messages and interacting with voters. The use of Twitter during the 2010 UK general election campaign. Information, Communication and Society, 16(5), 692-716.

Gustafsson, N. (2012, Apr. 2). The subtle nature of Facebook politics: Swedish socia network site users and political participation. New Media and Society, 14(7).

Halupka, M. (2014). Clicktivism: A systematic heuristic. Policy \& Internet, 6(2), 115-132.

Holma, B. (red.). (2017). Latvija. Pārskats par tautas attīstību 2015/2016. Dzīves meistarība un informācijpratība. Rīga: LU Sociālo un politisko pētijumu institūts.

Hunt, S., Benford, R., \& Snow, D. (1994). Identity fields: framing processes and the social construction of movement identities. In E. Larana, H.Johnston \& J.R.Gusfield (Eds.). New Social Movements: From Ideology to Identity (pp. 185208). Philadelphia: Temple University Press.

Issenberg, S. (2016, Feb. 2). How Ted Cruz Engineered His Iowa Triumph. Bloomberg.

Kalsnes, B., Larsson, A. O., \& Enli, G. S. (2017, Feb. 6). The social media logic of political interaction: Exploring citizens' and politicians' relationship on Facebook and Twitter. First Monday, 22(2).

Karpf, D. (2012). The moveon effect: The unexpected transformation of American political advocacy. Oxford: Oxford University Press.

Kosinski, M., Matz, S. C., Gosling, S. D., Popov, V., \& Stillwell, D. (2015, Sept.). Facebook as a Research Tool for the Social Sciences. American Psychologist, 70(6), $543-556$.

Kreiss, D. (2014). Seizing the moment: The presidential campaigns' use of Twitter during the 2012 electoral cycle. New Media \& Society, 18(8), 1473-1490.

van Laer, J., \& van Aelst, P. (2010). Internet and social movement action repertoires. Opportunities and limitations. Information, Communication \& Society, 13(8), 1146-1171.

Lodge, J. (2010) Irrelevant and obsolete? The European Parliament and voters in perspective. In J.Lodge (Ed.), The 2009 Elections to the European Parliament (pp.13-29). London: Palgrave Macmillan.

ManaBalss.lv. (b. g.). Par paveikto. Izgūts 12.01.2018. no https://manabalss.lv/page/ progress.

Marvin, C. (1988). When old technologies were new: Thinking about communications in the late 19th century. New York, NY: Oxford University Press.

McAdam, D., McCarthy, J.D., \& Zald, M. N. (Eds.). (1996). Introduction: opportunities, mobilizing structures, and framing processes - toward a synthetic, comparative perspective on social movements. In Comparative Perspectives on Social Movements: Political Opportunities, Mobilizing Structures, and Cultural Framings. New York: Cambridge University Press.

McAdam, D., Tarrow, S., \& Tilly C. (2001). Dynamics of Contention. New York: Cambridge University Press.

McCarthy, J.D., \& Zald, M. N. (1977). Resource mobilization and social movements: a partial theory. American Journal of Sociology, 28(6), 1212-1241. 
Moe, H., \& Larsson, A. (2012). Studying political microblogging: Twitter users in the 2010 Swedish election campaign. New Media \& Society, 14(5), 729-747.

Morozov, E. (2011). The net delusion: How not to liberate the world. London: Penguin. National Telemedia Council (1992). Telemedium:The Journal of Media Literacy, 38(3/4). Oates, S., \& Moe, W.W. (2016, Aug. 25). Donald Trump and the "oxygen of publicity": Branding, social media, and mass media in the 2016 presidential primary elections. Paper prepared for the American Political Science Association Annual Meeting 2016. Retrieved from SSRN: https://ssrn.com/ abstract $=2830195$ or http://dx.doi.org/10.2139/ssrn.2830195

Ott, B.L. (2017). The age of Twitter: Donald J. Trump and the politics of debasement. Critical Studies in Media Communication, 34(1), 59-68.

Penney, J., \& Dadas, C. (2013). (Re)Tweeting in the service of protest: Digital composition and circulation in the Occupy Wall Street movement. New Media \& Society, 16(1), 74-90.

Pilkington, E., \& Michel, A. (2012, Feb. 17) Obama Facebook and the power of friendship: the 2012 data election. The Guardian.

Populares Latvija, SKDS. (2012, marts.). Pasaules uzskats: pašvērtējums un realitāte. Latvijas iedzivotäjju ideoloğiskais portrets. Izgūts 02.02.2018. no https://docs. wixstatic.com/ugd/5e1eac_2c98293446174f268945ao7ba86fo685.pdf

Puķe, I. (2017). Latvieši uzkarst. Ir, 400/401, 48-53.

Rasmussen, T. (2007, Oct. 5-6) Two Faces of the Public Sphere. The Significance of Internet Communication in Public Deliberation. Conference paper presented at Symposium "Changing politics through digital networks: The role of ICTs in the formation of new social and political actors and actions".

Rheingold, H. (2002). Smart Mobs: The Next Social Revolution. Cambridge, MA: Perseus Pub.

Römmele, A. (2012). Electronic political campaigning. In N. Kersting (Ed.), Electronic Democracy. Barbara Budrich Publishers.

Rotman, D., Vieweg, S., Yardi, S., Chi, E. D., Preece, J., Shneiderman, B., ... Glaisyer, T. (2011, May). From slacktivism to activism: Participatory culture in the age of social media. In CHI'11 Extended Abstracts on Human Factors in Computing Systems (pp. 819-822). Vancouver, BC: ACM.

Skovsgaard, A., van Dalen, M. (2013). Dodging the gatekeepers? Social medi in the campaign mix during the 2011 Danish elections. Information, Communication and Society, 16(5), 737-756.

Small, T. (2011). What the hashtag? A content analysis of Canadian politics on Twitter. Information, Communication \& Society, 14(6), 872-895.

Snow, D.A., \& Benford, R.D. (1988). Ideology, frame resonance, and participan mobilization. International Social Movement Research, 1, 197-217.

Snow, D. A., Rochford, B. Jr., Worden, S. K., \& Benford, R.D. (1986). Frame alignment processes, micromobilization, and movement participation. American Sociological Review, $51,464-481$.
Spruds, A., Rožukalne, A., Sedlenieks, K., Daugulis, M., Potjomkina, D., Tölgyesi, B., Bruge, I. (2016). Internet Trolling as a Tool of Hybrid Warfare: the Case of Latvia. Results of the Study. NATO StratComCoe.

Stieglitz, S., \& Dang-Xuan, L. (2012). Social media and political communication: a social media analytics framework. Social Network Analysis Minin.

Strandberg, K. (2013). A social media revolution or jus a case of history repeating itself? The use of social media in the 2011 Finnish parliamentary elections. New Media \& Society, 15(8), 1329-1347.

Stromer-Galley, J. (2014). Presidential campaigning in the Internet age. Oxford: Oxford University Press.

SUSTINNO. (2015). Valsts pētijumu programma «Inovācija un ilgtspējiga attīstïba: Latvijas pēckrïzes procesi globālā kontekstā» (SUSTINNO), 2015. 3. projekts. «Sabiedrības vērtīborientācijas un sabiedrības atjaunošanās». Aptauja.

SUSTINNO. (2017). Valsts pētijumu programma «Inovācija un ilgtspējiga attīstiba: Latvijas pēckrīzes procesi globālā kontekstā» (SUSTINNO), 2017. 3. projekts. «Sabiedrības vērtīborientācijas un sabiedrības atjaunošanās». Aptauja.

TNS. (2018). Google ir nemainīgi visapmeklētākā vietne Latvijā. TNS Kantar Latvija. Izgūts o2.02.2018. no http://tns.lv/?lang=lv\&fullarticle=true\&category=show uid\&id $=5163$.

Trent, J. (2011). Political Campaign Communication: Principles and Practices. Rowman and Littlefield Publishers.

Valtenbergôs, V. (2010). Interneta politiskās komunikācijas nozīme atklātības un elektroniskās demokrātijas attīstība (promocijas darbs). Rīga: Latvijas Universitātes Sociālo zinātnu fakultātes Politikas zinātnes nodala.

Wallis, C. (2011). New media practices in China: Youth patterns, processes, and politics. International Journal of Communication, 5, 406-436.

Wallsten, K. (2015). Non-elite Twitter sources rarely cited in coverage. Newspaper Research Journal, 36(1), 24-41.

Wells, C., Shah, D. V., Pevehouse, J.C., Yang, J., Pelled, A., Boehm, F., ... Schmidt, J.L. (2016). How Trump drove coverage to the nomination: Hybrid media campaigning. Political Communication, 33(4), 669-676.

Yang, G. (2014, Spring). Internet activism \& the Party-State in China. Daedalus, 143(2), 110-123. 


\subsection{UZN ĖMĒJDARBĪBA, EKSPORTS, NODOKLI, ENU EKONOMIKA UN KONKURETSPËJA: TURPMĀKAS ANALİZES IETVARS}

Acs, Z.J., \& Varga, A. (2005). Entrepreneurship, agglomeration and technological change. Small Business Economics, 24(3), 323-334.

Acs, Z.J., \& Audretsch, D. B. (1988). Innovation in large and small firms: an empirical analysis. American Economic Review, 78(4), 678-69o.

Acs, Z.J., \& Storey, D. (2004). Introduction: Entrepreneurship and Economic Development. Regional Studies, Taylor \& Francis Journals, 38(8), 871-877.

Arnold, J. M., Brys, B., Heady, C., Johansson, A., Schwellnus, C., Vartia, L. (2011). Tax Policy for Economic Recovery and Growth. The Economic Journal, 121(550), F59-F80.

Baumol, W.J. (2002). Entrepreneurship, Innovation and Growth: The DavidSymbiosis. Journal of Entrepreneurial Finance and Business Ventures, 7(2), 1-10.

Bellone, F., Musso, P., Nesta, L., \& Schiavo, S. (2009). Financial Constraints and Firm Export Behavior. http://dx.doi.org/10.2139/ssrn.1342342.

Benczur, P., Katay, G., Kiss, A., \& Racz, O. (2012). Income Taxation, Transfers and Labour Supply at the Extensive Margin. Banque de France Working Paper, 487.

Benkkovskis, K. (2012). Competitiveness of Latvia's exporters. Bank of Latvia Working Paper, 3/2012.

Bicakova, A., Slacalek, J., \& Slavik, M. (2011). Labor Supply after Transition: Evidence from the Czech Republic. Czech Journal of Economics and Finance (Finance a úverr), 61(4), 327-347.

Central Statistical Bureau of Latvia. (2017). NBGo2. Activity rate, employment rate and unemployment rate (\%) Population and Social Processes Annual Statistics Data. Retrieved 23.05.2017 from http://data.csb gov.lv/pxweb/en/Sociala/Sociala_ikgad_nodarb/NBoo2o.px/table/ tableViewLayout1/?rxid=cdcb978c-22bo-416a-aacc-aa65odze2ceo

Das, S., Roberts, M., \& Tybout, J. (2007). Market entry costs, producer heterogeneity, and export dynamics. Econometrica, 75(3), 837-873. de Soto, H. (1989). The Other Path. New York, NY: Basic Books.

de Soto, H. (2000). The Mystery of Capital: Why Capitalism Triumphs in the West and Fails Everywhere Else. New York, NY: Basic Books.

Eurostat (2015). Statistics comparing enterprises which trade internationally with those who do not. Retrieved 04.01.2017 from http://ec.europa.eu/eurostat/ statistics-explained/index.php/Statistics_comparing_enterprises_which trade_internationally_with_those_who_do_not\#Characteristics_of exporters

Farrell, D. (2004). The Hidden Dangers of the Informal Economy. McKinsey Quarterly, 3, 27-37.
Gilbert, B.A., Audretsch, D. B., \& McDougall, P.P. (2004). The emergence of entrepreneurship policy. Small Business Economics, 22(3/4), 313-323.

Gomory, R. (1994). A Ricardo Model with Economies of Scale. Journal of Economic Theory, 62, 394-419.

Greenaway, D., Guariglia, A., \& Kneller, R. (2007). Financial factors and exporting decisions. Journal of International Economics, 73(2), 377-395

Hsieh, C., \& Olken, B. (2014). The missing “missing middle”. The Journal of Economic Perspectives, 28(3), 89-108

La Porta, R., \& Shleifer, A. (2008). The Unofficial Economy and Economic Development. Brookings Papers on Economic Activity, 39(2), 275-352.

La Porta, R., \& Shleifer, A. (2014). Informality and Development. Journal of Economic Perspectives, 28(3), 109-126.

Llopis, J.A. S., Millán, J. M., Baptista, R., Burke, A., Parker, S. C., \& Thurik, R. (2015). Good times, bad times: entrepreneurship and the business cycle. International Entrepreneurship and Management Journal, 11(2), 243-251.

Love, J.H., \& Roper, S. (2015). SME innovation, exporting and growth: a review of existing evidence. International Small Business Journal, 33(1), 28-48.

Masso, J., \& Vahter, P. (2015). Exporting and productivity: The effects of multiproduct and multi-market export entry. Scottish Journal of Political Economy, 64(4), 325-350.

McMillan, J. \& Woodruff, C. (2002). The Central Role of Entrepreneurs in Transition Economies. Journal of Economic Perspectives, 16(3), 153-170.

Melitz, M.J. (2003). The Impact of Trade on Intra-Industry Reallocations and Aggregate Industry Productivity. Econometrica, 71(6), 1695-1725.

Muller, P., Conlon, G., Lewis, M., \& Mantovani, I. (2013). From Shadow to Formal Economy: Levelling the Playing Field in the Single Market. Policy Department Economic and Scientific Policy.

OECD. (2010). Tax Policy Reform and Economic Growth. OECD Publishing. http:// dx.doi.org/10.1787/9789264091085-en.

Prammer, D. (2011). Quality of Taxation and the Crisis: Tax Shifts from a Growth Perspective. Taxation papers. European Commission Working Paper No. 29.

Putninš, T. (2013). Exporting by Latvian companies: vitality, drivers of success, and challenges. Baltic Journal of Economics, 13(2), pp. 3-33.

Putniņš, T., \& Sauka, A. (2016). Shadow economy index for the Baltic countries 2009-2015. Report. Riga: Stockholm School of Economics in Riga.

Rauch, J. (1991). Productivity Gains from Geographic Concentration of human Capital: Evidence from the Cities. NBER Working Papers, 3905.

Sauka, A., \& Putninšs, T. (2011). Shadow economy index for the Baltic countries 2009 and 2010. Report. Riga: Stockholm School of Economics in Riga.

Schank, T., Schnabel, C., \& Wagner, J. (2010). Higher wages in exporting firms: self-selection, export effect, or both? First evidence from linked employeremployee data. Review of World Economics, Springer Verlag, 146(2), 303-322. 
Schneider, F. (1998). Further Empirical Results of the Size of the Shadow Economy of 17 OECD-Countries over Time. Congress of the IIPF Cordowa, Argentina and discussion paper. Department of Economics, University of Linz, Linz, Austria.

Schumpeter, J.A. (1934). The Theory of Economic Development. Cambridge, MA: Harvard University Press. (First edition in German: 1911.)

Siebertová, Z., Senaj, M., Švarda, N., \& Valachyová, J. (2013). To Work or Not to Work? Estimates of Labour Supply Elasticities. National Bank of Slovakia, Working Paper, 5/2013. Bratislava.

Suddle, K., \& Hessels, J. (2007). Ambitious Nascent Entrepreneurs and National Innovativeness [Summary]. Frontiers of Entrepreneurship Research, 27(4), Art. 9. Retrieved from https://digitalknowledge.babson.edu/fer/vol27/iss4/9

Tanzi, V. (1982). Underground Economy and Tax Evasion in the United States: Estimates and Implications. The Underground Economy in the United States and Abroad, Lexington Books.

Vanags, A. (2013). Latvia's exports: the real 'success story. In Baltic Development Forum: State of the Region Report.

Wagner, J. (2007). Exports and productivity: a survey of the evidence from firm level data. The World Economy, 30, 60-82.

Wennekers, S., \& Thurik, R. (1999). Linking entrepreneurship and economic growth. Small Business Economics, 13, 27-55.

\subsection{ILGTSPẼ JÍGAS LAUKU ATTİSTİBAS EKONOMISKIE, VIDES UN SOCIĀLIE ASPEKTI}

Aguglia, L., Henke, K., Poppe, K. J., Roest, A., \& Salvioni, C. (2009). Diversification and multifunctionality in Italy and the Netherlands: a comparative analysis. Retrieved from http://library.wur.nl

Allen, K.E., \& Moore, R. (2016). Moving beyond the exchange value in the nonmarket valuation of ecosystem services. Ecosystem Services, 18, 78-86.

Boggia, A., Rocchi, L., Paolotti, L., Musotti, F., \& Greco, S. (2014). Assessing rura sustainable development potentialities using a dominance-based rough set approach. Journal of Environmental Management, 144, 160-167.

Brickhill, D. (2015). Ecosystem services and the environment. In-depth report 11. Bristol: Science Communication Unit, UWE.

Brown, D. L., \& Schucksmith, M. (2016). A new lens for examining rural change. European Countryside, 8(2), 183-188.

Davidson, M.D. (2013). On the relation between ecosystem services, intrinsic value existence value and economic valuation. Ecological Economics, 95, 171-177.

European Commission. (2017b). Report on the distribution of direct payments to agricultural producers (financial year 2016). Retrieved from https:// ec.europa.eu/agriculture/cap-funding/beneficiaries/direct-aid_lv

European Commission. (2008). Other gainful activities: pluriactivity and farm diversification in EU-27. Retrieved from https://ec.europa.eu/agriculture/ sites/agriculture/files/rural-area-economics/more-reports/pdf/othergainful-activities-text_en.pdf

European Commission. (2010). EUROPE 202O:A strategy for smart, sustainable and in clusive growth. COM/2010/2020 final. Retrieved from https://eur-lex.europa.e

European Commission. (2011). Our life insurance, our natural capital: an EU biodiversity strategy to 2020. COM/2011/0244. Retrieved from http://eur-lex. europa.eu/

European Commission. (2013a). Agricultural Genetic Resources - from conservation to sustainable use COM(2013) 838 final. Brussels, 28.11.2013. Retrieved from https://ec.europa.eu/

European Commission. (2013b). Regulation (EU) No 1305/2013 of the European Parliament and of the Council of 17 December 2013 on support for rura development by the European Agricultural Fund for Rural Development (EAFRD) and repealing Council Regulation (EC) No 1698/2005. Official Journal of the European Union, L 347, 487-548.

European Commission. (2015). The Mid-Term Review of the $\mathrm{EU}$ Biodiversity Strategy to 2020 \{SWD(2015) 187 final\}. Retrieved from http://eur-lex.europa.eu/

European Commission. (2016). Next steps for a sustainable European future: European action for sustainability. $\operatorname{COM(2016)} 739$ final. Retrieved from http://eur-lex.europa.eu/ 
European Commission. (2017a). Report from the Commission to the European Parliament and the Council on the implementation of the ecological focus area obligation under the green direct payment scheme. $\mathrm{COM} / 2017 / 0152$ final. Retrieved from http://eur-lex.europa.eu/

EEB. (2017). The future of the CAP:An urgent need for a truly sustainable agriculture, land and food policy. Brussels: European Environmental Bureau (EEB).

EESC. (2010). Opinion of the European Economic and Social Committee on the "Reform of the common agricultural policy in 2013". Official Journal of the European Union, C 354, 35-42.

EESC. (2015). Opinion of the European Economic and Social Committee on "Land grabbing - a warning for Europe and a threat to family farming". Official Journal of the European Union, C 242, 15-23.

EESC. (2016). Opinion of the European Economic and Social Committee on "The biodiversity policy of the EU". Official Journal of the European Union, C487, 14-23.

European Parliament. (2014). European Parliament resolution of 4 February 2014 on the future of small agricultural holdings (2013/2096(INI)). Retrieved from http://www.europarl.europa.eu

European Parliament. (2016). European Parliament resolution of 2 February 2016 on "The Mid-term Review of the EU's Biodiversity Strategy". (2015/2137(INI)). Retrieved from http://www.europarl.europa.eu

Eurostat. (2018). Europe 2020 indicators - poverty and social exclusion. Retrieved from http://ec.europa.eu/eurostat/statistics-explained

Fagioli, F.F., Rocchi, L., Paolotti, L., Slowinski, R., \& Boggia, A. (2017). From the farm to the agri-food system: A multiple criteria framework to evaluate extended multi-functional value. Ecological Indicators, 79, 91-102.

Galler, C., von Haaren, C., \& Albert, C. (2015). Optimizing environmental measures for landscape multifunctionality: Effectiveness, efficiency and recommendations for agri-environmental programs. Journal of Environmental Management, 151, 243-257.

Gliessman, S.R. (2005). Agroecology and agroecosystems. In J.Pretty (Eds). The earthscan reader in sustainable agriculture (pp.104-114). London: Earthscan

Gomez-Baggethun, E., \& Ruiz-Perez, M. (2011). Economic valuation and the commodification of ecosystem services. Progress in Physical Geography, 35(5), 613-628.

Haines-Young, R., \& Potschin, M. (2017). Common International Classification of Ecosystem Services (CICES) V5.1 and Guidance on the Application of the Revised Structure. Nottingham, UK: Fabis Consulting.

Henke, R., \& Vanni, F. (2017). Drivers of on-farm diversification in the Italian periurban agriculture. Rivista di Economia Agraria, 72(1), 79-100.

van Huylenbroeck, G., Vandermeulen, V., Mettepenningen, E., \& Verspecht, A. (2007). Multifunctionality of agriculture: a review of definitions, evidence and instruments. Living reviews in landscape research, 1(3), 1-43.
Knickel, K., Renting, H., \& van der Ploeg, J.D. (2004). Multifunctionality in European agriculture. Sustaining Agriculture and the Rural Environment. Cheltenham, UK: Edward Elgar, 81-104.

Latvijas Republikas Saeima (2010). Latvijas ilstspējiğas attīistỉbas stratếgija līd 203o. gadam. Izgūts no https://www.pkc.gov.lv/sites/default/files/inlinefiles/Latvija_2030_7.pdf

Maes, J., Hauck, J., Paracchini, M. L., Ratamaki, O., Hutchins, M., Termansen, M., \& Bidoglio, G. (2013). Mainstreaming ecosystem services into EU policy. Current Opinion in Environmental Sustainability, 5(1), 128-134.

Maes, J., Teller, A., Erhard, M., Murphy, P., Paracchini, M. L., Barredo, J. I., et al. (2014). Mapping and Assessment of Ecosystems and their Services. Indicator for ecosystem assessments under Action 5 of the $\mathrm{EU}$ Biodiversity Strategy to 2020. Luxembourg: Publications Office of the European Union.

Melece, L., \& Krievina, A. (2015). Development of local food systems in Latvia. Research for Rural Development, 2, 104-111.

Meraner, M., Heijman, W., Kuhlman, T., \& Finger, R. (2015). Determinants of farm diversification in the Netherlands. Land Use Policy, 42, 767-780.

Millenium Ecosystem Assessment (MEA). (2005). Ecosystems and Human Wellbeing: Synthesis. Washington, DC: Island Press.

Nieto, A., Roberts, S. P., Kemp, J., Rasmont, P., Kuhlmann, M., Garcia Criado, M., et al. (2014). European red list of bees. Luxembourg: Publication Office of the European Union.

Papadopoulos, A. G. (2015). The impact of the CAP on agriculture and rural areas of EU Member States. Agrarian South:Journal of Political Economy, 4(1), 22-53.

Papageorgiou, F. (2007). Culture and Sustainable Rural Development. Athens: European Academy for Sustainable Rural Development.

Pe'er, G., Lakner, S., Müller, R., Passoni, G., Bontzorlos, V., Clough, D., et al. (2017). Is the CAP Fit for purpose? An evidence based fitness-check assessment. Leipzig: German Centre for Integrative Biodiversity Research (iDiv) Halle-JenaLeipzig.

van der Ploeg, J.D., \& Roep, D., 2003. Multifunctionality and rural development: the actual situation in Europe. In G. van Huylenbroeck, G. Durand (Eds.), Multifunctional Agriculture. A New Paradigm for European Agriculture and Rural Development (pp. 37-54). Aldershot, Hampshire: Ashgate.

Pretty, J. (2008). Agricultural sustainability: concepts, principles and evidence. Philosophical Transactions of the Royal Society B: Biological Sciences, 363(1491), 447-465.

Pretty, J., \& Bharucha, Z.P. (2014). Sustainable intensification in agricultural systems. Annals of Botany, 114(8), 1571-1596.

Renting, H., Rossing, W.A. H., Groot, J.C.J., van der Ploeg, J.D., Laurent, C., Perraud, D., van Ittersum, M.K. (2009). Exploring multifunctional agriculture. 
A review of conceptual approaches and prospects for an integrative transitional framework. Journal of Environmental Management, 90, 112-123. Scholte, S. S., van Teeffelen, A. J., \& Verburg, P. H. (2015). Integrating socio-cultural perspectives into ecosystem service valuation: a review of concepts and methods. Ecological Economics, 114, 67-78.

van der Sluis, T., Pedroli, B., Kristensen, S. B., Cosor, G. L., \& Pavlis, E. (2016). Changing land use intensity in Europe-Recent processes in selected case studies. Land Use Policy, 57, 777-785.

Spangenberg, J.H., \& Settele, J. (2010). Precisely incorrect? Monetising the value of ecosystem services. Ecological Complexity, 7(3), 327-337.

Sutherland, L.A., Toma, L., Barnes, A. P., Matthews, K. B., \& Hopkins, J. (2016). Agri-environmental diversification: Linking environmental, forestry and renewable energy engagement on Scottish farms. Journal of Rural Studies, $47,10-20$.

(2010). Mainstreaming the Economics of Nature: A Synthesis of the Approach, Conclusions and Recommendations of TEEB. London and Washington: Earthscan.

United Nations. (2015). Transforming our World: The 2030 Agenda for Sustainable Development. Retrieved from https://sustainabledevelopment.un.org

Underwood, E., Tucker, G. (2016) Ecological Focus Area choices and their potential impacts on biodiversity. Report for BirdLife Europe and the European Environmental Bureau, Institute for European Environmental Policy, London.

Weltin, M., Zasada, I., Franke, C., Piorr, A., Raggi, M., Viaggi, D. (2017). Analysing behavioural differences of farm households: An example of income diversification strategies based on European farm survey data. Land Use Policy, 62, 172-184.

\subsection{ILGTSPĒJITGS PATĒRIN Š UN VIDES PĀRVALDĪBA}

Ajzen, I. (1991). The theory of planned behavior. Organizational Behavior and Human Decision Processes, 50, 179-211.

Ajzen, I., Fishbein, M. (1980). Understanding attitudes and predicting social behaviour.

Allport, G. (1985). The historical background of social psychology. In G. Lindzey, E. Aronson (Eds.), The handbook of social psychology (Vol.1, pp.1-46). New York: Random House.

Almeida, C. M., Giannetti, B. F., Agostinho, F., Huisingh, D. (2015). Cleaner production towards a sustainable transition. Journal of Cleaner Production, 30, 1

ASCEE Team. (2008). Policy Instruments to Promote Sustainable Consumption. EU FP 6.

Ayres, R. U. (2000). Commentary on the utility of the ecological footprint concept. Ecological Economics, 32, 347-349.

Bähr, H., Treib, O. (2007). Governing modes in social and environmental policies. Deliverable 1: D50.

Bergh van den Bergh, J.C., Ferrer-i-Carbonell, A. (1999). Economic theories of sustainable consumption. In Serie Research Memoranda. Amsterdam: Vrije Universiteit.

Bonds, E., Downey, L. (2015). Green Technology and Ecologically Unequal Exchange: The Environmental and Social Consequences of Ecological Modernization in the World-System. Journal of World-Systems Research, 18, 167-186.

Boulanger, P.-M. (2010). Three strategies for sustainable consumption. SAPI EN. S. Surveys and Perspectives Integrating Environment and Society.

Brizga, J. (2012). Ilgtspējīga patēriṇa pārvaldïbas ietvars: instrumenti, sadarbïbas tīkli un indikatori [doktora disertācija vides zinātnes nozarē vides pārvaldỉbas apakšnozarē]. Rīga: Latvijas Universitāte, Gẹegrāfijas un Zemes zinātṇu fakultāte.

Brizga, J., Ernšteins, R. (2016). Sustainable consumption governance development in Latvia: framework, collaboration, integration. In $3 r d$ International Multidisciplinary Scientific Conference on Social Sciences \& Arts : Conference Proceedings Book 2. Vol.1, Political Sciences, Law, Finance, Economics and Tourism Conference Proceedings (p. 543-554).

Buttel, F. H. (2000). Ecological modernization as social theory. Geoforum, 31, 57-65.

Church, C., Lorek, S. (2007). Linking policy and practice in sustainable production and consumption: an assessment of the role of NGOs. International Journal of Innovation and Sustainable Development, 2, 230-240.

Clark, G. (2007). Evolution of the global sustainable consumption and production policy and the United Nations Environment Programme's (UNEP) supporting activities. Journal of Cleaner Production, 15, 492-498. 
Daly, H.E. (1973). Toward Steady-state Economics. WH Freeman.

Deaton, A. (1992). Understanding consumption. Oxford University Press.

Diekmann, A., Preisendörfer, P. (2003). Green and greenback the behavioral effects of environmental attitudes in low-cost and high-cost situations. Rationality and Society, 15, 441-472.

Ernšteins, R. (2016b). Vides pārvaldības rīcibpolitikas prakses attīstibas ietvars: vides sistēmiski integratīvās pārvaldības struktūrshēmas. No Latvijas Universitätes 74. zinātniskā konference. Geogräfija. Geoloğija. Vides zinātne [referātu tēzes] (448.-454.lpp.). Rỉga: Latvijas Universitāte.

Ernšteins, R., (1999). Videszinātniskās izgglitīibas attīstība. Riga: Vide. 342 lpp.

Ernšteins, R., Graudina-Bombiza, S., Lontone-Ievinna, A., Kauliṇ̌̌, J., Rusmanis, U., Ošniece, K., Antons, V. (2016c). Videi draudzīgas rīcības attīstība pašvaldībās: ietvars, novērtējums un rīcībpolitika [rakstu krājums] (309.-324.lpp.). Liepājas Universitātes 18. starptautiskā zinātniskā konference, Liepāja.

Ernšteins, R., Jūrmalietis, R. (red.). (2008). Piekrastes ilgtspējiga attīstiba: sadarbỉbas pārvaldība [rakstu krājums]. Rīga: Eiropas Parlamenta Nāciju Eiropas grupa un Latvijas Universitāte, LU Akadēmiskais apgāds.

Ernšteins, R., Kaulins, J., Zilniece, I., Lontone, A. (2015). Coastal Governance Solutions Development in Latvia: Collaboration Communication and Indicator Systems (Chapter 6). In J.Baztan, J.P.Vanderlinden at al. (Eds.), Coastal Zones: Solutions for the 21st Century (pp. 85-96). Elsevier.

Ernšteins, R., Krišlauka, M., Lice, E., Graudina-Bombiza, S., Lontone-Ievina, A., Antons, V. (2016a). Mājsaimniecibu vides pārvaldïbas pieejas attistïba: mājokḷa, pārtikas un mobilitātes klāsteru integrācija. No Latvijas Universitātes 74. zinātniskā konference. Geogrăfija. Geoloğija. Vides zinātne [referātu tēzes] (454.-460. lpp.). Rīga: Latvijas Universitāte.

European Commission. (2014). Special Eurobarometer 409: Climate Change. Wave EB80.2. Brussles TNS Opinion \& Social.

Fishbein, M., Ajzen, I. (1975). Belief, attitudes, intention, and behavior. An introduction to theory and research. Massachussets: Addison-Wesley.

Fuchs, D.A. \& Lorek, S. (2005). Sustainable consumption governance: A history of promises and failures. Journal of Consumer Policy, 28(3), 261-288.

Graham, S., Marvin, S. (2001). Splintering urbanism: networked infrastructures, technological mobilities and the urban condition. Psychology Press.

Greening, L.A., Greene, D. L. \& Difiglio, C. (2000). Energy efficiency and consumption-the rebound effect-a survey. Energy Policy, 28(6), 389-401.

Hargreaves, T., Longhurst, N., Seyfang, G. (2013). Up, down, round and round: connecting regimes and practices in innovation for sustainability. Environment and Planning A, 45, 402-42O.

Harvey, M., McMeekin, A., Randles, S., Southerton, D., Tether, B., Warde, A. (2001). Between demand and consumption: a framework for research. Centre for Research on Innovation and Competition Discussion Paper, 40.
Herring, H. (1998). Does energy efficiency save energy: the implications of accepting the Khazzoom-Brookes Postulate. EERU, the Open University.

Hertwich, E. G. (2005). Consumption and the rebound effect: An industrial ecology perspective. Journal of Industrial Ecology, 9(1-2), 85-98.

Holm, S.-O. \& Englund, G. (2009). Increased ecoefficiency and gross rebound effect: Evidence from USA and six European countries 1960-2002. Ecological Economics, 68(3), 879-887.

Hopwood, B., Mellor, M., O’Brien, G. (2005). Sustainable development: mapping different approaches. Sustainable Development, 13, 38-52.

Huber, J. (1995). Nachhaltige Entwicklung. Strategien für eine ökologische und soziale Erdpolitik. Berlin.

Huber, J. (2000). Towards industrial ecology: sustainable development as a concept of ecological modernization. Journal of Environmental Policy and Planning, 2, 269-285.

IUCN, UNEP, WWF. (1980). World Conservation Strategy. Living Resource Conservation for Sustainable Development. IUCN, UNEP, WWF, Gland, Switzerland.

Jackson, T. (1993). Clean Production Strategies Developing Preventive Environmental Management in the Industrial Economy. CRC Press.

Jaeger-Erben, M., Rückert-John, J., Schäfer, M. (2015). Sustainable consumption through social innovation: a typology of innovations for sustainable consumption practices. Journal of Cleaner Production, 108, 784-798.

Jevons, W. S. (2001). Of the economy of fuel. Organization \& Environment, 14, 99.

Kauliņ̌s, J., Ernsteins, R., Kudrenickis, I. (2017). Indicator Systems for Municipal Sustainable Development Governance: Prerequisites for Design and Implementation. WIT Transactions on Ecology and the Environment (Ecosystems and Sustainable Development $\mathrm{XI}$ ), 214, 35-45.

Kemp, R., Soete, L. (1992). The greening of technological progress: an evolutionary perspective. Futures, 24, 437-457

Khazzoom, J.D. (1980). Economic implications of mandated efficiency in standards for household appliances. The Energy Journal, 1(4), 21-40.

Latvijas Republikas Saeima. (2010). Latvijas ilgtspējiğas attīstības stratēǵija lìdz 2030. gadam. Riga: Latvijas Republikas Saeima.

Litvin, D. (1998). Dirt poor: A survey of development and the environment. The Economist, 346(8060), 3-16.

Lontone-Ievina, A., Ernšteins, R., Zïlniece, I. (2016). Vides pārvaldības attīstìba pašvaldībās: vides sektora, attīstības pārvaldības sektoru un dimensiju pieejas un to integrācija. No Latvijas Universitātes 74. zinātniskā konference. Geogrä̆fija. Ģeoloğija. Vides zinātne [referātu tēzes] (470.-474.lpp.). Rìga: Latvijas Universitāte.

Lorek, S. (2005). Linking praxis to policy making and policy back to praxis. In Sustainable Production and Consumption:Policies, Action and Communication. Kiev, Sept. 7, 2006. 
Lorek, S., Fuchs, D. (2013). Strong Sustainable Consumption Governanceprecondition for a degrowth path? Journal of Cleaner Production, 38, 36-43.

Lorek, S., Giljum, S., Bruckner, M. (2008). Sustainable Consumption Policies Effectiveness Evaluation (SCOPE2)-Inventory and assessment of policy instruments (final draft). FP7 Research Project, Sustainable Europe Research Institute, Overath, Vienna.

Malthus, T. (1798). An essay on the principle of population, as it affects the future improvement of society. St. Paul's Church-yard, London.

Maniates, M. (2010). Editing out unsustainable behavior. State of the World, 119-126. Maslow, A. H., Frager, R., Fadiman, J., McReynolds, C., Cox, R. (1970). Motivation and personality. New York: Harper \& Row.

Mauch, U., North, N., Pulli, R. (2001). Between efficiency and sufficiency. The optimal combination of policy instruments in the mobility sector towards sustainable development. In Changing Things-Moving People (pp.133-150). Springer.

McEachern, M., Seaman, C., Padel, S., Foster, C. (2005). Exploring the gap between attitudes and behaviour: Understanding why consumers buy or do not buy organic food. British Food Journal, 107, 606-625.

Meadows, D. H., Meadows, D. L., Randers, J., Behrens, W.W. (1972). The limits to growth. New York.

Ministru kabinets (2015). Zaḷa iepirkuma un zalā publiskā iepirkuma veicināšanas pläns 2015-2017. gadam. Ministru kabineta rikojums Nr. 83.

Mont, O., Plepys, A. (2003). Customer satisfaction: review of literature and application to the product-service systems. International Institute for Industrial Environmental Economics at Lund University.

Mylan, J. (2015). Understanding the diffusion of sustainable product-service systems: insights from the sociology of consumption and practice theory. Journal of Cleaner Production, 97, 13-20.

Newell, J.P., Cousins, J.J. (2014). The boundaries of urban metabolism Towards a political-industrial ecology. Progress in Human Geography.

Ofsted, S. (1994). Symposium: Sustainable Consumption. Ministry of Environment, Oslo.

Paavola, J. (2001). Towards sustainable consumption: economics and ethical concerns for the environment in consumer choices. Review of Social Economy, 59, 227-248.

Paredis, E., Crivits, M., Bauler, T., Mutombo, E., Zaccai, E., Boulanger, P., Lefin, A., (2009). Construction of Scenarios and Exploration of Transition Pathways for Sustainable Consumption Patterns "Consentsus". Final Report Phase 1.

van Raaij, W.F. (1991). The formation and use of expectations in consumer decision making. In Handbook of consumer behavior (pp.401-418).

Rehfeld, K.-M., Rennings, K., Ziegler, A. (2007). Integrated product policy and environmental product innovations: An empirical analysis. Ecological Economics, 61, 91-100.
Rennings, K., Brohmann, B., Nentwich, J., Schleich, J., Traber, T., Wüstenhagen, R. (2012). Sustainable energy consumption in residential buildings. Springer Science \& Business Media.

Rice, G. (2006). Pro-environmental behavior in Egypt: is there a role for Islamic environmental ethics? Journal of Business Ethics, 65(4), 373-390.

Rogers, E. M. (1995). Diffusion of Innovations: modifications of a model for telecommunications. In Die Diffusion von Innovationen in der Telekommunikation (pp. 25-38). Springer.

Røpke, I. (1999). The dynamics of willingness to consume. Ecological Economics, 28 , 399-420.

Rubik, F, Scholl, G., Biedenkopf, K., Kalimo, H., Mohaupt, F, Söebech, Ó, Stø, E., Strandbakken, P., \& Turnheim, B. (2009). Innovative approaches in European sustainable consumption policies, 192.

Sachs, W. (2000). Planet dialectics: explorations in environment and development. Zed Books.

Schmidheiny, S. (1992). Changing course: A global business perspective on development and the environment. MIT press.

Schot, J., Geels, F.W. (2008). Strategic niche management and sustainable innovation journeys: theory, findings, research agenda, and policy. Technology Analysis \& Strategic Management, 20, 537-554.

Scitovsky, T. (1976). The joyless economy: An inquiry into human satisfaction and consumer dissatisfaction. Oxford University Press.

Seyfang, G. (2004). Consuming values and contested cultures: a critical analysis of the UK strategy for sustainable consumption and production. Review of Social Economy, 62, 323-338.

Seyfang, G., Haxeltine, A. (2012). Growing grassroots innovations: exploring the role of community-based initiatives in governing sustainable energy transitions. Environment and Planning C: Government and Policy, 30, 381-400.

Seyfang, G., Paavola, J. (2007). Sustainable consumption and environmental inequalities. In Working Paper-Centrefor Social and Economic Research on the Global Environment (pp.1-29).

Shove, E. (2003a). Changing human behaviour and lifestyle: a challenge for sustainable consumption. Lancaster, UK: Department of Sociology, University of Lancaster.

Shove, E. (2003b). Converging conventions of comfort, cleanliness and convenience. Journal of Consumer Policy, 26, 395-418.

Shove, E. (2010). Beyond the ABC: climate change policy and theories of social change. Environment and Planning A, 42, 1273-1285.

Shove, E., Pantzar, M., Watson, M. (2012). The dynamics of social practice: everyday life and how it changes. Sage Publications.

Shove, E., Trentmann, F., Wilk, R. (2009). Time, consumption and everyday life: Practice, materiality and culture. Berg. 
Shove, E., Walker, G. (2010). Governing transitions in the sustainability of everyday life. Research Policy, 39, 471-476.

Simon, H.A. (1972). Theories of bounded rationality. Decision and Organization, 1 , $161-176$.

Socolow, R. (1997). Industrial ecology and global change. Cambridge University Press.

Soper, K. (2008). Alternative Hedonism' and the Citizen Consumer. Citizenship and consumption, 191-205.

Southerton, D., Chappells, H., van Vliet, B. (2004). Sustainable consumption: The implications of changing infrastructures of provision. Edward Elgar Publishing.

Spaargaren, G. (2003). Sustainable consumption: a theoretical and environmental policy perspective. Society \& Natural Resources, 16, 687-701.

Spaargaren, G. (2011). Theories of practices: Agency, technology, and culture: Exploring the relevance of practice theories for the governance of sustainable consumption practices in the new world-order. Global Environmental Change, 21, 813-822.

Spaargaren, G., Martens, S., Beckers, T.A. (2006). Sustainable technologies and everyday life. In User Behavior and Technology Development (pp.107-118). Springer.

Spaargaren, G., Mol, A.P. (1992). Sociology, environment, and modernity: Ecological modernization as a theory of social change. Society \& Natural Resources, 5, 323-344.

Spaargaren, G., van Vliet, B. (2000). Lifestyles, consumption and the environment: The ecological modernization of domestic consumption. Environmental Politics, 9, 50-76.

Stahel, W. (1999). Geteiltes Notebook-doppelte Freude? Nutzenorientierung als Strategie für eine ressourcenschonende Gesellschaft. Politische Ökologie, $17(62), 63-66$.

Stern, P.C. (2000). New environmental theories: toward a coherent theory of environmentally significant behavior. Journal of Social Issues, 56(3), 407-424.

Stern, P.C., Dietz, T., Abel, T.D., Guagnano, G.A., \& Kalof, L. (1999). A valuebelief-norm theory of support for social movements: The case of environmentalism. Human Ecology Review, 6(2), 81-97.

Thaler, R. (1980). Toward a positive theory of consumer choice. Journal of Economic Behavior \& Organization, 1, 39-60.

Tukker, A., Huppes, G., Guinée, J., Heijungs, R., Koning, A. d., Oers, L. v., Suh, S., Geerken, T., Holderbeke, v. M., \& Jansen, B. (2006). Environmental Impact of Products (EIPRO). Analysis of the life cycle environmental impacts related to the final consumption of the EU-25. IPTS/ESTO project. European Commission, Joint Research Centre, Institute for Prospective Technological Studies.
United Nations. (1992). Agenda 21. The United Nations programme for action from Rio United Nations.

United Nations. (2016). United Nations Environment Assembly of the United Nations Environment Programme. Second session Nairobi, 23-27 May 2016. Retrived from http://wedocs.unep.org/bitstream/handle/20.500.11822/11184/ K1607179_UNEPEA2_RES8E.pdf?sequence $=1$ \&isAllowed $=\mathrm{y}$

Vergragt, P.J. (2017). 13 Sustainable Consumption: An Important but Ambiguous Concept. In Conceptual Innovation in Environmental Policy (p. 307).

van Vliet, B. (2002). Greening the Grid. The Ecological Modernisation of Networkbound Systems. [s. n.].

Warde, A. (2005). Consumption and theories of practice. Journal of Consumer Culture, 5, 131-153.

von Weizsacker, E. U., Hargroves, C., Smith, M. H., Desha, C., Stasinopoulos, P. (2009). Factor Five: Transforming the global economy through $80 \%$ improvements in resource productivity. Routledge.

York, R., Rosa, E.A., \& Dietz, T. (2003). STIRPAT, IPAT and ImPACT: analytic tools for unpacking the driving forces of environmental impacts. Ecological Economics, 46(3), 351-365. 


\section{INOVATİVI RISINĀJUMI CELĀ UZ ILGTSPĒJU}

\subsection{ILGTSPẼJíGAS ATTİSTİBAS SOCIĀLĀ}

\section{DIMENSIJA — KĀ VIRZĀMIES PRETİ CIEN PILNAI}

\section{DZĪVEI SOCIĀLI ATBILDĪGĀ VALSTI}

Augstākā Padome. (1993, 29. apr.). Likums «Par dzīvojamo telpu îri». Latvijas Vêstnesis, 19. Izgüts no https://likumi.lv/doc.php?id=56863

Bela, B., N̦ikišins, J. (2018). Ilgtstspējas sociālā dimensija: vai virzāmies pretī labklājībai un cieṇpilnai dzīvei? No B. Bela (red.), Ilgtspējiğga attīstība un sociālās inovācijas (106.-137.lpp.). Rīga: LU Akadēmiskais apgāds.

Brigsa, S., Broka, A., Rajevska, F., Ročāns, K., Romanovska, L., Zivverte, L. (2014). Krīze: izaicinājumi un iespējas sociālajai cilvēkdrošībai Latvijā. No J. Rozenvalds, A. Zobena (red.), Daudzveidīgāàs un mainīgās Latvijas identitātes (149.-172.lpp.). Rīga: LU Akadēmiskais apgāds.

Brikse, I., \& Spurava, G. (2014). Kids online - safety and risks: full findings from children survey of 9- to 16-year-olds in Latvia. Retrieved from http://eprints. lse.ac.uk/60574/

Celminina, E. (2017). Plāns minimālo ienākumu sistēmas pilnveidošanai. No Sociālās iekḷaušanas politikas koordinācijas komitejas materiāli 2017. gada 21. aprìla sēdē. Riga: Labklājības ministrija. Izgūts no http://www.lm.gov.lv/text/3645

Centrālā statistikas pārvalde. (2013, 5. febr.). 2011. gadā pieauga nabadzības riskam paklıauto iedzìvotäju skaits. Izgūts no http://www.csb.gov.lv/notikumi/2011gada-pieauga-nabadzibas-riskam-paklauto-iedzivotaju-skaits-36965.html

Centrālā statistikas pārvalde. (2015, 9. apr.). Ekonomiskā spriedze. [Terminu skaidrojumi]. Izgūts no http://www.csb.gov.lv/statistikas-temas/termini/ ekonomiska-spriedze-3607o.html

Centrālā statistikas pārvalde. (2016, 30. maijs). Nabadzības riska slieksnis. [Terminu skaidrojumi]. Izgūts no http://www.csb.gov.lv/statistikas-temas/termini/ nabadzibas-riska-slieksnis-36066.html

Centrālā statistikas pārvalde. (2016a). Ienākumi un dzīves apstākli Latvijāa 2015. gadā. [Statistisko datu krājums]. Rỉga: Centrālā statistikas pārvalde. Izgūts no http:// www.csb.gov.lv/dati/e-publikacijas/ienakumi-un-dzives-apstakli-latvija-2015gada-44193.html

Centrālā statistikas pārvalde. (2016b). Mājokla apstākli. Izgūts no http://www. csb.gov.lv/statistikas-temas/metodologija/majokla-apstakli-eu-silcapsekojums-38993.html

Centrālā statistikas pārvalde. (2017). IIGo5. Mājsaimniecību rīcībā esošo ienākumu sastāvs un struktūra pilsētās un laukos vidēji uz vienu mãjssaimniecības locekli mēnesī. Izgūts no http://data.csb.gov.lv/pxweb/lv/Sociala/Sociala_ikgad ienemumi/IIoo5o_euro.px/table/tableViewLayout2/?rxid=cdcb978c-22bo416a-aacc-aa65odzerceo
Centrālā statistikas pārvalde. (2017, 22. maijs). 2017. gada 1. ceturksnī bezdarba lìmenis Latvijā bija 9,4\%. Izgūts no http://www.csb.gov.lv/notikumi/2017gada-1-ceturksni-bezdarba-limenis-latvija-bija-94-46617.html

Centrālā statistiskas pārvalde. (2017, 15. dec.). Materiālā nenodrošinātība (EU SILC apsekojums). Definīcijas. Izgūts no http://www.csb.gov.lv/ statistikas-temas/metodologija/materiala-nenodrosinatiba-37053 html\#Definicijas

Centrālā statistikas pārvalde. (2017a). DSO2. Strādājošo mēneša vidējā darba samaksa pa ceturkšņiem. [Datubāze]. Izgūts no http://www.csb.gov.lv/ statistikas-temas/darba-samaksa-datubaze-30046.htm

Centrālā statistikas pārvalde. (2017b). SDG05. Strā dājošo mēneša vidējā darba samaksa Latvijas reǵionos. [Datubāze]. Izgūts no http://www.csb.gov.lv/ statistikas-temas/darba-samaksa-datubaze-30046.html

Centrālā statistikas pārvalde. (2017c). NIG15. Nabadzības riska indekss Latvijas reǵionos pēc vecuma un dzimuma. [Datubāze]. Izơūts no http://www.csb. gov.lv/statistikas-temas/monetara-nabadziba-un-ienakumu-nevienlidzibadatubaze-30062.html

Centrālā statistikas pārvalde. (2017d). MNG O3. Ekonomiskā spriedze mājsaimniecībās. Materiālā nenodrošinātība. [Datubāze]. Izgūts no http:// www.csb.gov.lv/statistikas-temas/monetara-nabadziba-un-ienakumunevienlidziba-datubaze-30062.html

Centrālā statistikas pārvalde. (2017e). Ienākumi un dzìves apstāklị Latvijä 2016. gadā. [Statistisko datu krājums]. Rīga: Centrālā statistika pārvalde. Izgūts no http://www.csb.gov.lv/sites/default/files/ $\mathrm{nr}$ 14_ienakumi_un_dzives_apstakli_latvija_2016_17_oo_lv_en.pdf

Centrālā statistikas pārvalde. (2018, 18. janv.). Nabadzības riskam Latvijā pakḷaut 22,1\% iedzivotäju. Izgūts no http://www.csb.gov.lv/notikumi/nabadzibasriskam-latvija-paklauti-221-iedzivotaju-47205.htm

Council of the European Union. (2004). Joint report by the Commission and the Council on social inclusion, 7101/04 C. F. R. Brussels, 5 March 2004 Retrieved from http://ec.europa.eu/employment_social/soc-prot/soc-incl/ final joint inclusion report 2003 en.pdf

Deaton, A. (2013). The Great Escape Health, Wealth, and the Origins of Inequality. Princeton, New Jersy: Princeton University Press.

Ekonomikas ministrija. (2017). Pārskats par pieškirto pašvaldības palīdzību dzīvokḷa jautājumu risināăšnā 2010, 2011, 2012, 2013, 2014, 2015, 2016. Izgūts no https://www.em.gov.lv/lv/nozares_politika/majokli/petijumi_statistika/

EuroHealthNet. (n.d.). Latvia. Retrieved from http://www.health-inequalities.eu/ HEALTHEQUITY/EN/about_hi/health_inequalities/latvia/

European Commission. (2010). EUROPE 2020. A strategy for smart, sustainable and inclusive growth. Brussels. Retrieved from http://eur-lex.europa.eu/ LexUriServ/LexUriServ.do?uri=COM:2010:2020:FIN:EN:PDF 
European Commission. (2012). Smart regulation-Questions and Answers. Retrieved from http://europa.eu/rapid/press-release_MEMO-12-974_en.htm

European Commission. (2013). Health inequalities in the EU. Retrieved from http://ec.europa.eu/health/social_determinants/docs/ healthinequalitiesineu_2013_en.pdf

European Parliament. (2010). The interrelationship between the structural funds and the provision of services of general (economic) interests and the potential for cross-border service delivery, p.14.

Eurostat. (2014). Glossary: Severe housing deprivation rate. Retrieved from http://ec.europa.eu/eurostat/statistics-explained/index.php/ Glossary:Severe_housing_deprivation_rate

Eurostat. (2016a). People at risk of poverty or social exclusion. Retrieved from http:// ec.europa.eu/eurostat/statistics-explained/index.php/People_at_risk_of poverty_or_social_exclusion

Eurostat. (2016b). In-work at-risk-of-poverty rate. Retrieved from http://ec.europa.eu/ eurostat/web/products-datasets/-/tsdsc320

Eurostat. (2017a). Gini coefficient of equivalised disposable income-EU-SILC survey, Code ilc di12. Last update: 19.12.2017. Retrieved from http://appsso.eurostat. ec.europa.eu/nui/show.do?dataset=ilc_di12

Eurostat. (2017b). Minimum wage statistics. Retrieved from http://ec.europa.eu/ eurostat/statistics-explained/index.php/Minimum wage statistics

Eurostat. (2017c). Material deprivation rate for the "Economic strain" and "Durables" dimensions, by number of item of deprivation-EU-SILC survey [ilc_sip8]. Retrieved from http://ec.europa.eu/eurostat

Eurostat. (2017d). Annual net earnings [earn nt net]. Single person without children, $100 \%$ of $A W$. Retrieved from http://ec.europa.eu/eurostat

Eurostat. (2017e). Statistika par mäjokliem. Izgūts no http://ec.europa.eu/eurostat/ statistics-explained/index.php/Housing_statistics/lv

Finanšu ministrija. (2009, 27.jūl.). Latvija: Nodomu protokols Starptautiskajam Valūtas fondam. 5.lpp. Izgūts no http://www.fm.gov.lv/files/files/Nodomu_vestule SVF_2 julijs_2009.pdf

Finanšu ministrija. (2010). Latvija: Nodomu vēstule. Rīgā, 05.07.2010., 4.lpp. Izgūts no http://www.fm.gov.lv/files/files/Nodomu_vestule_SVF_2010-07-05.pdf

Finanšu ministrija. (2017). Saeima apstiprina nodokḷ reformas likumu paketi. Rỉgá, 31.07.2017. Izgūts no https://www.mk.gov.lv/lv/aktualitates/saeima-apstiprinanodoklu-reformas-likumu-paketi

Galbraith, J.K. (2011, 1 March). Inequality and economic and political change: a comparative perspective. Cambridge Journal of Regions, Economy and Society, 4(1), 13-27. https://doi.org/10.1093/cjres/rsqo14. Retrieved from https:// academic.oup.com/cjres/article/4/1/13/425177

Hazans, M. (2012). Latvijas darba tirgus krïes laikā. No A. Oslunds, V.Dombrovskis. Kā Latvija pārvarēja finanšu krīzi (254.-264.lpp.). Rīga: Ekonomistu apvienïba 2010.
Holma, B., Spurava, G. (2018). Bibliotekāra kā mediatora loma bērnu un jauniešu digitālās pratības veicināšanā: bibliotekāru priekšstatu un pašvērtējuma analīze. No B. Bela (red). Ilgtspējiğa attīstība un sociālās inovācijas (204.223. Ipp.). Rīga: LU Akadēmiskais apgāds.

House of Commons. Health Committee. (2009). Health Inequalities. Third Report of Session 2008-09 (Vol. I. Report, together with formal minutes). London: The Stationery Office Limited. Retrieved from https://publications.parliament. uk/pa/cm200809/cmselect/cmhealth/286/286.pdf

Koval̨evska, A. (2008). Sociāli atbildīgas valsts princips. Jurista Vārds, 32(537). Izgūts no http://www.juristavards.lv/doc/180049-sociali-atbildigas-valsts-princips/

Kovalevska, A. (2018). Sociāli atbildīgas valsts princips kā Latvijas Republikas valst iekārtu raksturojošs princips. No B. Bela (red). Ilgtspējiğa attīstība un sociālās inovācijas (32.-67.lpp.). Rīga: LU Akadēmiskais apgāds.

Labklājības ministrija. (2014a). Koncepcija par minimälā ienākuma līmeņa noteikšanu. Ministru kabineta 30.10.2014. rikojums Nr.619. Izgūts no http:// www.lm.gov.lv/upload/sociala_ieklausana/koncepcija_fin.pd

Labklājibas ministrija. (2014b). Nacionālais sociālais zinnojums. Izgūts no www. Im.gov.lv/upload/sociala aizsardziba/.../nsr 2014 latvia fin2.pdf

Labklājỉbas ministrija. (2017). Sociālā uznêēmējdarbība. Izgūts no http://www.lm.gov. $\operatorname{lv} /$ text/3091

Labklāijibas ministrija. (2017, 9. marts). LM uzsāk diskusiju par minimālo ienākumu atbalsta sistēmas pilnveidi. Izgūts no http://www.lm.gov.lv/news/id/7542

Labklājibas ministrija. (B. g.). Galvenie [darba tirgus] politikas rezultatìvie rādìtājij. Izgūts no http://www.lm.gov.lv/text/332

Latvijas Republikas Saeima. (2005). Zinātniskās darbïbas likums. Pienemts 14.04.2005. Latvijas Vēstnesis, 70. Izgūts no http://likumi.lv/doc. php?id=107337

Latvijas Republikas Saeima. (2010). Latvijas ilgtspējigasas attīstības stratéğija lìdz 2030. gadam. Apstiprināts ar 10.06.2010. Latvijas Republikas Saeimas lēmumu. Izgūts no http://www.latvija203o.lv/upload/latvija2030_saeima. pdfLR Saeima.

Latvijas Republikas Saeima. (2017). Saeima galīgajā lasijumā lems par sociālās uznēmējdarbïbas likuma projektu. Izgūts no http://www.saeima.lv/lv/ aktualitates/saeimas-zinas/26230-saeima-galigaja-lasijuma-lems-parsocialas-uznemejdarbibas-likuma-projektu

Mierina, I., Koroḷeva, I. (2015). Metodoloğiskie risinājumi emigrantu viedokḷu izzināšanai pētijumā «Latvijas emigrantu kopienas». No I. Mieriṇa (red.). Latvijas emigrantu kopienas. Cerïbu diaspora (26.-10.lpp). Rīga: Latvijas Universitātes Filozofijas un socioloğijas institūts.

Ministru kabinets (2009, 16. apr.). Ministru kabineta noteikumi Nr. 300 «Ministru kabineta kārtïbas rullis». Pieṇemts 07.04.2009. Latvijas Vēstnesis, 28. 3. pielikums, 2.1. punkts. 
Niklass, M., Rasnača, L. (2018). Sociālā nedrošǐba Latvijā. Rịga: LU Akadēmiskais apgāds.

OECD. (2018). About the Organisation for Economic Co-operation and Development $(O E C D)$. Retrieved from http://www.oecd.org/about/

Oslunds, A., Dombrovskis, V. (2012). Kā Latvija pārvarēja finanšu krīzi. Rīga: Ekonomistu apvienïba 2010.

Pārresoru koordinācijas centrs. (2012). Latvijas Nacionālais attīstības plāns 2014.-2020. gadam. Apstiprināts ar 20.12.2012. Latvijas Republikas Saeimas lēmumu. Izgūts no http://www.varam.gov.lv/lat/pol/ppd/ ilgtsp_att/?doc $=13858$

Reinholde, I. (2018). Sociālās rīcībpolitikas pārvaldības izaicinājumi un krīzes mācības. No B. Bela (red). Ilgtspējiğa attīstība un sociālās inovācijas (68.-83.lpp.). Rīga: LU Akadēmiskais apgāds.

Satversmes tiesa. (2006). Par likuma «Grozijjumi Valsts sociālo pabalstu likumā» 1. panta dalas, ar kuru Valsts sociālo pabalstu likumā ieviests jauns 7. panta pirmäs dalas 3. punkts, un 2. panta atbilstïbu Latvijas Republikas Satversmes 110. pantam. 02.11.2006. spriedums lietā Nr. 2006-07-01. Izgыts no www.satv. tiesa.gov.lv.

Satversmes tiesa. (2009). Par likuma «Par valsts pensiju un valsts pabalstu izmaksu laika periodā no 2009. gada lïdz 2012. gadam» 2. panta pirmās daḷas atbilstïbu Latvijas Republikas Satversmes 1. un 109. pantam un 3. panta pirmās daḷas atbilstību Latvijas Republikas Satversmes 1., 91., 105. un 109. pantam. 21.12.2009. spriedums lietā Nr. 2009-43-01. Izgūts no www.satv. tiesa.gov.lv.

Silkāne, V. (2018). Pavirzīšanas iespējas dalïbas veicināšanai vēža savlaicīgas atklāšanas programmā. No B. Bela (red). Ilgtspējiğga attīstība un sociālās inovācijas (188.-203.lpp.). Rīga: LU Akadēmiskais apgāds.

Stiglitz, J.E. (2012). The Price of Inequality. New York, London: W.W. Norton \& Company. pp. 425-448. http://dx.doi.org/10.17310/ntj.2015.2.09

Tripāne, M. (2018). Veselības stāvokḷa nevienlīdzỉba un veselïbas rīcībpolitika Latvijā. No B. Bela (red). Ilğtspējīga attīstība un sociālās inovācijas (84.104.lpp.). Rīga: LU Akadēmiskais apgāds.

Vācijas Federālā Konstitucionālā tiesa. (2010.gada 9. febr.). Spriedums lietā $N r .1$ BvL 1/o9, 1 BvL 3/o9, 1 BvL 4/o9 (BVerfGE 125, 175), 143.-144.punkts. Izgūts no http://www.bundesverfassungsgericht.de/SharedDocs/Entscheidungen/ DE/2010/02/ls20100209_1bvlooo109.html

Vingre, A. (2018). Sociālās inovācijas: valsts loma to sekmēšanā pasaulē un Latvijā. No B. Bela, (red). Ilgtspējiğa attīstība un sociālās inovācijas (166.-187.lpp.). Rịga: LU Akadēmiskais apgāds.

Walker, R. (2014). The Shame of Poverty. Oxford: Oxford University Press.

Walsh, M., Stephens, M., \& Moore, S. (2000). Social Policy and Welfare. Nelson Thornes.
Wilkinson, R., \& Pickett, K. (2010). The Spirit Level: Why Greater Equality Makes Societies Stronger. Bloomsbury Publishing.

The World Bank. (2013). Latvia: Who is Unemployed, Inactive or Needy? An Assessment of Post-Crisis Policy Options. Retrieved from http://www.lm.gov. lv/text $/ 2562$

The World Bank. (2017). Health Nutrition and Population Statistics. World Dat Bank. Retrieved from http://databank.worldbank.org/data/reports. aspx?source=health-nutrition-and-population-statistics

United Nations. (2016). Report of the World Summit for Social Development. A/CONF.166/9. Copenhagen, Denmark.

World Economic Forum. (2013). Breaking the Binary: Policy Guide to Scaling Social Innovation. Retrieved from http://www.weforum.org/pdf/schwabfound/ PolicyGuide_to_ScalingSocial\%2oInnovation.pdf

World Health Organization. (2011, 18 Aug.). Governance for health in the 21st century: a study conducted for the wHO Regional Office for Europe (EUR/ RC61/Inf.Doc./6). Retrieved from http://www.euro.who.int/_data/assets/ pdf_file/oo10/148951/RC61_InfDoc6.pdf

Zorgenfreija, L. (2016, 24. aug.). Ekonomiskās attīstības tendences un monetārā politika eirozonā. Prezentācija Latvijas Bankas seminārā ekonomikas skolotājiem «Aktualitātes ekonomikā 2016». Rīga: Latvijas Banka. Izgūts no https://www.slideshare.net/LatvijasBanka/ekonomisks-attstbas-tendencesun-monetr-politika-eirozon 


\subsection{CELĀ NO ANOMIJAS UZ PAŠORGANIZĀCIJU} UN KOLEKTĨVU RİCĪBU

Bakker, K., \& Bridge, G. (2006). Material worlds? Resource geographies and the "matter of nature". Progress in Human Geography, 30(1), 5-27.

Bowen, S. (2011). The Importance of Place: Re-territorialising Embeddedness. Sociologia Ruralis, 51(4), 325-348.

Castells, M. (2010). The Rise of the Network Society, With a New Preface (2nd ed.). Vol. 1 of The Information Age: Economy, Society and Culture. Malden, MA: Blackwell.

Edmondson, R. (1997). Introduction: The context of collective political action. In R. Edmondson (Ed.), The political context of collective action: Power, argumentation and democracy (pp.1-11). London and New York: Routledge. Granovetter, M. (1992). Economic Institutions as Social Constructions: A Framework for Analysis. Acta Sociologica, 35, 3-11.

Hannigan, J. (2006). Environmental Sociology (2nd ed.). London and New-York: Routledge.

Jänicke, M. (2005). Governing Environmental Flows: The Need to Reinvent the Nation State. Environmental Policy Research Centre, FFU-report 03-2005. [The paper originally presented at the International conference "Governing Environmental Flows - Reinventing the State in Global Modernity",

Wageningen, The Netherlands, June 13-14.] Retrieved from http://userpage. fu-berlin.de/ffu/download/rep_2005_03.pdf

Mierina, I. (2016). Political Alientation in Post-Communist Countries - a Sign of Social Anomie? [Paper to be presented at the 3rd ISA Forum of Sociology

"The Future We Want: Global Sociology and the Struggle for a Better World." Vienna, Austria, 10.-14.07. 2016].

Misāne, A. (2016a). Anomie, Anomia and Anomy - Distinct Concepts or Distinct Research Approaches? A View from Latvia. [Paper presented at The Future We Want: Global Sociology and the Struggle for a Better World. 3rd ISA Forum of Sociology. Vienna, 27.05.2015]

Misāne, A. (2016b). Anomija kā laikmeta un sabiedrïbas diagnoze. No M. Kūle (zin.red.). Vêrtïbas: Latvija un Eiropa, 1. sēj. Vērtību pētijumi-filosofiskie aspekti (297.-308.lpp.). Riga: LU FSI.

Misāne, A. (2016c). Conversion to Islam in Latvia: The Value Aspects. In Rendre compte des conversions à lislam: Vers quelle approche en sciences sociales ? Résumés. (Investigating Conversions to Islam. Which Approaches in Social Sciences? Abstracts). Observatoire Sociologique du Changement et CEvIPOF (Centre de recherches politiques), Laboratoires de Sciences Po. Paris, Febr. 15-16, 2016.

Moschitz, H., Roep, D., Brunori, G., \& Tisenkopfs, T. (2015). Learning and Innovation Networks for Sustainable Agriculture: Processes of Co-evolution, Joint
Reflection and Facilitation, The Journal of Agricultural Education and Extension, 21(1), 1-11. doi: 10.1080/1389224X.2014.991111.

O'Neill, K. (2009). The environment and International Relations. Cambridge, UK, New York: Cambridge University Press.

Ostrom, E. (1990). Governing the Commons. Cambridge; New York: Cambridge University Press.

Ostrom, E. (1998). A Behavioral Approach to the Rational Choice Theory of Collective Action. The American Political Science Review, 92(1), pp.1-22.

Ostrom, E. (2007). A diagnostic approach for going beyond panaceas. Proceedings of the National Academy of Sciences, 104(39), 15181-15187.

Polanyi, K. (1977). The Livelihood of Man. New York, San Francisco, London: Academic Press.

Polanyi, K. (2001). The Great Transformation: The Political and Economic Origins of Our Time. Foreword by Joseph E. Stiglitz; with a new introd. by Fred Block. 2nd Beacon Paperbacked. Boston: Beacon Press.

Rozentāls, G., Daugaviete, M., Konstantinova, I., Lazdāns, V., Liepiņš, K., Šmits, A., Zaluma, A., Zarina, I. (2017). Kas jāzina meža ìpašniekam [rokasgrāmata]. Salaspils, Alsunga: Latvijas Valsts mežzinātnes institūts «Silava»; biedrïba «Meža ippašnieku kooperācijas atbalsta centrs».

Schnaiberg, A., \& Gould, K. A. (2000). Environment and Society: The Enduring Conflict. The Blackburn Press.

Schnaiberg, A. (1980). The Environment. From Surplus to Scarcity. New York, Oxford: Oxford University Press.

Valtenbergs, V., Irbite, I., Ebele, I. (2016). Global education for next generation of business decision makers. What do the teachers say? In Proceedings of the Conference New Challenges of Economic and Business Development-2016: Society, Innovations and Collaborative economy (pp. 882-89o). Riga, University of Latvia. 


\subsection{UZNE ÉNU EKONOMIKA UN KONKURĒTSPËJA: ANALİZES REZULTĀTI}

Amit, R., Muller, E., \& Cockburn, I. (1995). Opportunity costs and entrepreneurial activity. Journal of Business Venturing, 10, 95-106.

Arnold, J. M., Brys, B., Heady, C., Johansson, A., Schwellnus, C., \& Vartia, L. (2011). Tax Policy for Economic Recovery and Growth. The Economic Journal, 121(550), F59-F80.

Barbakadze, I., Kapanadze, K., \& Kokashvili, N. (2017). How Participating in the Shadow Economy Affects the Growth of Latvian Firms. Working Paper Series, University of Tartu, Faculty of Economics and Business Administration. ISSN 1736-8995. Retrieved from http://www.mtk.ut.ee/sites/default/files/mtk/ dokumendid/febawb101.pdf

Benczur, P., Katay, G., Kiss, A., \& Racz, O. (2012). Income Taxation, Transfers and Labour Supply at the Extensive Margin. Banque de France Working Paper, 487, 1-27. Bergolo, M., \& Cruces, G. (2014). Work and tax evasion incentive effects of social insurance programs. Journal of Public Economics, 117(C), 211-228.

Bicakova, A., Slacalek, J., \& Slavik, M. (2011). Labor Supply after Transition: Evidence from the Czech Republic. Czech Journal of Economics and Finance (Finance a úvěr), 61(4), 327-347.

Cruces, G., \& Bergolo, M. (2013). Informality and Contributory and NonContributory Programmes. Recent Reforms of the Social-Protection System in Uruguay. Development Policy Review, 31(5), 531-551.

Dombrovsky, V., Paalzow, A., \& Rastrigina, O. (2011). Latvia: Panel Study of Entrepreneurial Dynamics Overview. In P.D. Reynolds, R.T.Curtis (Eds.), New Business Creation, International Studies of Entrepreneurship. Springer.

EUROMOD statistics on Distribution and Decomposition of Disposable Income. (N. d.). Retrieved 14.10.2014 from http://www.iser.essex.ac.uk/euromod/ statistics/. Version G2.0.

Jara, H.X., \& Tumino, A. (2013). Tax-benefit systems, income distribution and work incentives in the European Union. International Journal of Microsimulation, 1(6), 27-62.

Jascisens, V., \& Zasova, A. (2017). Gaming the System: Side Effects of Earnings Dependent Benefits, FREE policy brief. Retrieved from https://

freepolicybriefs.org/wp-content/uploads/2017/o1/FREEPolicyBriefs_Jan3o pdf [working paper coming soon].

Kreiner, C. T., Leth-Pedersen, S., \& Skov, P.E. (2016, Aug.). Tax Reforms and Intertemporal Shifting of Wage Income: Evidence from Danish Monthly Payroll Records. American Economic Journal: Economic Policy, 8(3), 233-257.

Krumina, M., \& Paalzow, A. (2017). The Business Cycle and Early-Stage Entrepreneurship in Latvia. In A. Sauka, A. Chepurenko (Eds.),
Entrepreneurship in Transition Economies. Diversity, Trends, and Perspectives (pp.135-152). doi:10.1007/978-3-319-57342-7.

Kumler, T., Verhoogen, E., \& Frías, J.A. (2013, Aug.). Enlisting Employees in Improving Payroll-Tax Compliance: Evidence from Mexico. NBER Working Paper, 19385. National Bureau of Economic Research, Inc.

Love, J.H., \& Roper, S. (2015). SME innovation, exporting and growth: a review of existing evidence. International Small Business Journal, 33(1), 28-48.

Mirrlees, J., Adam, S., Besley, T., Blundell, R., Bond, S., Chote, R., Gammie, M., Johnson, P., Myles, G., \& Poterba, J. (2012). The Mirrlees Review: a proposal for systematic tax reform. National Tax Journal, 65(3).

OECD. (2010). Tax Policy Reform and Economic Growth. OECD Publishing. http:// dx.doi.org/10.1787/9789264091085-en

Pluta, A. (2017a, May 18-20). The comparison of exporting and non-exporting enterprises in Latvia. In New Challenges of Economic and Business Development 2017: Digital Economy (pp. 425-439). Riga: University of Latvia. Retrieved from https://www.bvef.lu.lv/fileadmin/user_upload/lu_portal/projekti/ evf_conf2017/Proceedings.pdf

Pluta, A. (2017b, May 18-20). The impact of the tax and benefit system on the labour supply in Latvia. In New Challenges of Economic and Business Development2017: Digital Economy (pp.440-450). Riga: University of Latvia.. Retrieved from https://www.bvef.lu.lv/fileadmin/user_upload/lu portal/projekti/ evf_conf2017/Proceedings.pdf

Pluta, A., \& Zasova, A. (2017). Latvia Stumbling Towards Progressive Income Taxation: Episode II. Retrieved from https://freepolicybriefs.org/wp-content/ uploads/2017/10/FREEPolicyBriefs_Oct16-1.pdf

Pluta, A. (2016, May 12-14). Incentives to enter the labour market in Latvia. In New Challenges of Economic and Business Development-2016: Society, Innovations and Collaborative Economy (pp. 541-549). Riga: University of Latvia. ISBN 978-9934-18-140-5; Web of Science. Retrieved from http:// www.evf.lu.lv/fileadmin/user_upload/lu_portal/projekti/evf/konferences/ konference_2016/Proceedings.pdf

Prammer, D. (2011). Quality of Taxation and the Crisis: Tax Shifts from a Growth Perspective. Taxation papers. European Commission Working Paper No. 29. do i:10,1080/1406099X.2013.10840531

Siebertová, Z., Senaj, M., Švarda, N., \& Valachyová, J. (2013). To Work or Not to Work? Estimates of Labour Supply Elasticities. National Bank of Slovakia, Working Paper 5/2013. Bratislava.

Sutherland, H., \& Figari, F. (2013). EUROMOD: the European Union tax-benefit microsimulation model. International Journal of Microsimulation, 1(6), 4-26.

Vanags, A., \& Zasova, A. (2015). Latvia Stumbling Towards Progressive Income Taxation. FREE policy brief. Retrieved from http://freepolicybriefs.org/ wp-content/uploads/2015/11/freepolicybriefs_nov161.pdf 
Viksna, V., \& Bekeris, R. (2017, May 18-20). European funding: Does it induce exports? In New Challenges of Economic and Business Development-2017: Digital Economy (pp. 724-735). Riga: University of Latvia. ISBN 978-9934-18286-o; Web of Science. Retrieved from https://www.bvef.lu.lv/fileadmin/ user_upload/lu_portal/projekti/evf_conf2017/Proceedings.pdf

Wennekers, S., van Stel, A., Carree, M., \& Thurik, R. (2010). The relation between entrepreneurship and economic development: is it U-shaped? Foundation and Trends(R) in Entrepreneurship, 6(3), 167-237.

Zasova, A., \& Pluta, A. (2016, Sept. 5-6). Shifting Tax Burden from Labour to Property: the case of Latvia [conference report]. In EUROMOD 2Oth Anniversary Conference. ISER, University of Essex, UK.

Zasova, A., \& Zdanovica (Pluta), A. (2014). Equity and Efficiency in the Latvian TaxBenefit System. FREE policy brief. Retrieved from http://freepolicybriefs. org/wp-content/uploads/2014/11/freepolicybrief nov31.pdf

\subsection{INOVATİVI RISINĀJUMI ILGTSPĒJITGAI} LAUKU ATTİSTİBAI

Abbasi, T., \& Abbasi, S.A. (2010). Biomass energy and the environmental impacts associated with its production and utilization. Renewable and Sustainable Energy Reviews, 14(3), 919-937.

Aizen, M. A., Garibaldi, L. A., Cunningham, S. A., \& Klein, A. M. (2009). How much does agriculture depend on pollinators? Lessons from long-term trends in crop production. Annals of Botany, 103(9), 1579-1588.

Andersen, E. (2017). The farming system component of European agricultural landscapes. European Journal of Agronomy, 82(B), 282-291.

Balazs, B. (2012). Local Food System Development in Hungary. International Journal of sociology of Agriculture \& Food, 19(3), 403-421.

Bennett, E. M., Cramer, W., Begossi, A., Cundill, G., Diaz, S., et al. (2015). Linking biodiversity, ecosystem services, and human well-being: three challenges for designing research for sustainability. Current Opinion in Environmental Sustainability, 14, 76-85.

Benneworth, P., Amanatidou, E., Edwards-Schachter, M., \& Gulbrandsen, M. (2013). Social innovation futures: beyond policy panacea and conceptual ambiguity. Working Paper for the TIK Group Series. Oslo: University of Oslo.

Bentsen, N. S., \& Felby, C. (2012). Biomass for energy in the European Union-a review of bioenergy resource assessments. Biotechnology for Biofuels, 5(1), 25.

Bergmann, A., Colombo, S., \& Hanley, N. (2008). Rural versus urban preferences for renewable energy developments. Ecological Economics, 65, 616-625.

Bertolini, P., Montanari, M., \& Peragine, V. (2008). Poverty and Social Exclusion in Rural Areas. Brussels: European Communities.

Bock, B. B. (2012). Social innovation and sustainability; how to disentangle the buzzword and its application in the field of agriculture and rural development. Studies in Agricultural Economics, 114(2), 57-63.

Buckwell, A., Matthews, A., Baldock, D., \& Mathijs, E. (2017). CAP: Thinking Out of the Box. Further modernisation of the CAP - why, what and how? Brussels: The RISE Foundation.

Caulier-Grice, J.Davies, A. Patrick, R., \& Norman, W. (2012). Defining Social Innovation. A deliverable of the project: "The theoretical, empirical and policy foundations for building social innovation in Europe" (TEPSIE). European Commission -7th Framework Programme, Brussels: European Commission, DG Research.

Choi, N., \& Majumdar, S. (2015). Social Innovation: Towards a Conceptualisation. In S. Majumdar, Majumdar, S. Guha and N. Marakkath (Eds.) Technology and Innovation for Social Change (pp. 7-34). New Dheli: Springer.

Committee of the Regions (2011). Opinion on "Local food systems" (outlook opinion). 2011/C 104/01. Official Journal of the European Union, C, 104, 1-6. 
Copus, A. K., \& de Lima, P. (2014). Territorial Cohesion in Rural Europe:The Relational Turn in Rural Development. New York: Routledge.

Coudel, E., Devautour, H., Soulard, C. T., Faure, G., \& Hubert, B. (Eds.). (2013). Renewing innovation systems in agriculture and food: How to go towards more sustainability? Springer.

Coutts, C., \& Hahn, M. (2015). Green infrastructure, ecosystem services, and human health. International Journal of Environmental Research and Public Health, 12(8), 9768-9798.

Centrālā statistikas pārvalde. (2013). Graudaugu kultūrām lietoti 1,04 kg, rapsim1,54 kg pesticìdu vienam sējumu hektāram. Izgūts no http://www.csb.gov. lv/notikumi/graudaugu-kulturam-lietoti-104-kg-rapsim-154-kg-pesticiduvienam-sejumu-hektaram-36633

Daniel, T. C., Muhar, A., Arnberger, A., Aznar, O., Boyd, J.W., et al. (2012). Contributions of cultural services to the ecosystem services agenda. Proceedings of the National Academy of Sciences, 109(23), 812-8819.

Dargan, L., \& Shucksmith, M. (2008). LEADER and Innovation. Sociologia Ruralis, 48, 274-291.

Dauber, J., Brown, C., Fernando, A. L., Finnan, J., Krasuska, E., et al. (2012). Bioenergy from "surplus" land: environmental and socio-economic implications. BioRisk: Biodiversity \& Ecosystem Risk Assessment, 7, 5-50.

Dax, T., \& Oedl-Wieser, T. (2016). Rural innovation activities as a means for changing development perspectives - an assessment of more than two decades of promoting LEADER initiatives across the European Union. Studies in Agricultural Economics, 118(1), 30-37.

Donkers, H. (2014). Sustainable Food Security, A Paradigm for Local and Regional Food Systems. International Journal of Humanities and Social Science, 4(12), 89-102.

Duru, M., Therond, O., Martin, G., Martin-Clouaire, R., Magne, M.A., et al. (2015). How to implement biodiversity-based agriculture to enhance ecosystem services: a review. Agronomy for Sustainable Development, 35(4), 1259-1281.

EEB, \& BirdLife Europe. (2016). UNCAP the Truth: Spotlight on EU Farm Policy. Retrieved from https://www.living-land.org/studies/

European Commission. (2009). Directive 2009/28/EC of the European Parliament and of the Council of 23 April 2009 on the promotion of the use of energy from renewable sources and amending and subsequently repealing Directives 2001/77/EC and 2003/30/EC. Official Journal of the European Union, L, 140, 16-62.

European Commission. (2013a). Regulation (EU) No 1305/2013 of the European Parliament and of the Council of 17 December 2013 on support for rural development by the European Agricultural Fund for Rural Development (EAFRD) and repealing Council Regulation (EC) No 1698/2005. Official Journal of the European Union, L, 347, 487-548.

European Commission. (2013b). Report from the Commission to the European Parliament and the Council on the case for a local farming and direct sales labelling scheme. \{COM(2013) 866 final\}. Retrieved from https://ec.europa.eu/ agriculture/sites/agriculture

EEB. (2017). The future of the CAP:An urgent need for a truly sustainable agriculture, land and food policy. Brussels: European Environmental Bureau (EEB).

European Parliament. (2014). European Parliament resolution of 4 February 2014 on the future of small agricultural holdings (2013/2096(INI)). Retrieved from http://www.europarl.europa.eu

European Parliament. (2016). European Parliament resolution of 27 October 2016 on how the CAP can improve job creation in rural areas (2015/2226(INI)). Retrieved from http://www.europarl.europa.eu

European Biomass Association. (2010). Bioenergy 2030: European Energy Issues and the Development of Bioenergy Towards 2030. Brussels: European Biomass Association.

Fahrig, L., Baudry, J., Brotons, L., Burel, F. G., Crist, T. O., et al. (2011). Functional landscape heterogeneity and animal biodiversity in agricultural landscapes. Ecology Letters, 14, 101-112.

FAO. (2008). The state of food and agriculture. Biofuels: prospects, risks and opportunities. Rome: FAO.

Fargione J.E., Cooper T.R., Flaspohler D.J., Hill J., Lehman C., McCoy T., et al. (2009) Bioenergy and Wildlife: Threats and Opportunities for Grassland Conservation. BioScience, 59(9), 767-777.

Galli, F., \& Brunori, G. (2013). Short food supply chains as drivers of sustainable development. Evidence document. Pisa, Italy: Laboratorio di studi rurali Sismondi.

Garcia-Llorente, M., Rossignoli, C. M., Di Iacovo, F., \& Moruzzo, R. (2016). Social Farming in the Promotion of Social-Ecological Sustainability in Rural and Periurban Areas. Sustainability, 8(12), 1238.

Gaujour, E., Amiaud, B., Mignolet, C., \& Plantureux, S. (2012). Factors and processes affecting plant biodiversity in permanent grasslands. A review. Agronomy for Sustainable Development, 32, 133-160.

Goulson, D., Hanley, M.E. Darvill, B., \& Ellis, J. S. (2006). Biotope associations and the decline of bumblebees (Bombus spp.). Journal of Insect Conservation, 10, 95-103.

Harayama, Y., \& Nitta, Y. (2011). Introduction: Transforming Innovation to Address Social Challenges. In: Fostering Innovation to Address Social Challenges (pp.13-19). OECD Publishing.

Henry, M., Beguin, M., Requier, F., Rollin, O., Odoux, J.F., Aupinel, P., et al. (2012). A common pesticide decreases foraging success and survival in honey bees. Science, 336(6079), 348-350.

Holmes, G. (2013). Exploring the relationship between local support and the success of protected areas. Conservation and Society, 11(1), 72-82.

Jensen, J. (2010). Local and regional food systems for rural futures. RUPRI Rural Futures Lab Foundation Paper No.1. 
Jenson, J., \& Harrisson, D. (2013). Social innovation research in the European Union: Approaches, findings and future directions. Policy Review. Luxembourg: Publications Office of the European Union.

Kalns, J. (2012). Biogāāzes ražošana: pagaidām problēmu vairāk nekā ieguvumu. Izgūts no http://www.lvportals.lv/likumi-prakse.php?id=251397

Knickel, K., Tisenkopfs, T., \& Peter, S. (2009). Innovation processes in agriculture and rural development. Retrieved from http://www.insightproject.net/files IN-SIGHT_final_report.pdf

Kotiaho, J. S., \& Moilanen, A. (2015). Conceptual and operational perspectives on ecosystem restoration options in the European Union and elsewhere. Journal of Applied Ecology, 52(4), 816-819.

Krupke, C.H., Hunt, G.J., Eitzer, B.D., Andino, G., \& Given, K. (2012). Multiple routes of pesticide exposure for honey bees living near agricultural fields. PLOS ONE, $7(1), 1-8$

Lagane, J. (2015). When students run AMAPs: Towards French model of CSA. Agriculture and Human Values, 32(1), 133-141.

Latvijas Lauku sieviešu apvienība (2009). Lauku mājražotāju uznēmējjdarbību kavējošo un veicinošo faktoru izpēte un veicinošo aktivitāšu apzināšana un ierosināšana. Rīga: LLS.

Levidow, L. (2011). Agricultural Innovation: Sustaining What Agriculture? For What European Bio-Economy? Co-operative Research on Environmental Problems in Europe (CREPE).

Maes, J., Liquete, C., Teller, A., Erhard, M., Paracchini, M. L., Barredo, J.I., et al. (2016). An indicator framework for assessing ecosystem services in support of the EU Biodiversity Strategy to 2020. Ecosystem Services, 17, 14-23.

Melece, L. (2014). Local Food Systems and their Development in Latvia. Management Theory and Studies for Rural Business and Infrastructure Development, 36(2-3), $588-598$.

Melece, L. (2015). Social Innovation and Its Types in Rural Areas. Economic Science for Rural Development: Integrated and Sustainable Regional Development, 38 , $142-153$.

Melece, L., \& Krievina, A. (2015). Development of local food systems in Latvia. Research for Rural Development, 2, 104-111.

Melece, L., Krievina, A., Spoge, I. (2016). Sustainability aspects of bioenergy production: Case of Latvia. IInternational Multidisciplinary Scientific GeoConference Surveying Geology and Mining Ecology Management, 5(3), 569-576.

Melece, L., \& Lakovskis, P. (2017). Eco-system services and social innovations in rural areas. International Multidisciplinary Scientific GeoConference Surveying Geology and Mining Ecology Management, 17(51), 305-312.

Melece, L., Popluga, D., Lakovskis, P., Šēna, I. (2015). Bioenerğijas ietekme uz lauksaimniecības zemju izmantošanu. No Sadarbība un kultūra, XVII (332.-339.lpp.).
Melece, L., Šēna, I. (2016). Sociālās inovācijas lauku teritorijās. No A. Medvedckis (red.), Sabiedrïba un kultūra, XVIII (366.-373.lpp.). Liepāja: LiePA.

Mills, J. (2012). Exploring the social benefits of agri-environment schemes in England. Journal of Rural Studies, 28(4), 612-621.

Milner-Gulland, E.J., Mcgregor, J.A., Agarwala, M., Atkinson, G., Bevan, P., Clements, T., et al. (2014) Accounting for the impact of conservation on human wellbeing. Conservation Biology, 28(5), 1160-1166.

OECD (2011). Fostering Innovation to Address Social Challenges. OECD Publishing.

Palmieri, N., Forleo, M. B., Suardi, A., Coaloa, D., \& Pari, L. (2014). Rapeseed for energy production: Environmental impacts and cultivation methods. Biomass and Bioenergy, 69, 1-11.

Pang, X., Mortberg, U., \& Brown, N. (2014). Energy models from a strategic environmental assessment perspective in an EU context - What is missing concerning renewables? Renewable and Sustainable Energy Reviews, 33, 353-362.

Patias, T. Z., Bobsin, D., Gomes, C., Liszbinski, B. B., \& Damke, L.I. (2016). Family agro-industry clusters from the social innovation perspective. Revista de Administração Mackenzie, 17(6), 191-215.

Phills, J.A., Deiglmeier, K., \& Miller, D. T. (2008). Rediscovering social innovation. Stanford Social Innovation Review, 6(4), 34-43.

Pimentel, D., Marklein, A., Toth, M.A., Karpoff, M. N., Paul, G. S., McCormack, R., et al. (2009). Food versus biofuels: environmental and economic costs. Human Ecology, 37(1), 1.

Pisano, U., Lange, L., \& Berger, G. (2015). Social Innovation in Europe: An overview of the concept of social innovation in the context of European initiatives and practices. ESDN Quarterly Report, 36, 1-26.

Power, A. G. (2010). Ecosystem services and agriculture: tradeoffs and synergies. Philosophical Transactions of the Royal Society, B, 365, 2959-2971.

Prager, K. (2015). Agri-environmental collaboratives for landscape management in Europe. Current Opinion in Environmental Sustainability, 12, 59-66.

Qin, Z., Zhuang, Q., \& Chen, M. (2012). Impacts of land use change due to biofuel crops on carbon balance, bioenergy production, and agricultural yield, in the conterminous United States. GCB Bioenergy, 4(3), 277-288.

Reeder, N., O’Sullivan, C., Tucker, S., Ramsden, P., \& Mulgan, G. (2012). Strengthening social innovation in Europe:Journey to effective assessment and metrics. Brussels: Publications Office of the European Union.

Reķis, J. (2011). Pētijums par biodegvielas izejvielu audzēšanas emisijām Latvijā direktîvas 2009/28/EK ietvaros pēc Eiropas Komisijas pieprasïjuma. Rïga: Ekonomikas ministrija.

da Rosa Pires, A., Pertoldi, M., Edwards, J., \& Hegyi, F. B. (2014). Smart Specialisation and Innovation in Rural Areas. Luxembourg: Publications Office of the European Union. 
Rytkonen, P. (2016). Local resources, foreign influences, value creation, tradition and modernity. The case of a Local Agro-food System in Jämtland, Sweden. Culture \& History Digital Journal, 5(1), o०9.

Scherr, S.J., \& McNeely, J.A. (2008). Biodiversity conservation and agricultura sustainability: towards a new paradigm of "ecoagriculture" landscapes. Philosophical Transactions Royal Society B, 363, 477-494.

Scholte, S. S., van Teeffelen, A.J., \& Verburg, P.H. (2016). Integrating socio-cultural perspectives into ecosystem service valuation: a review of concepts and methods. Ecological Economics, 114, 67-78.

Science Communication Unit (2014). Social Innovation and the Environment. Bristol: Science Communication Unit, University of the West of England.

Sepp, K., (2012). Landscape Functions and Ecosystem Services. Rural Development and Land Use, 3, 39-51.

Sircely, J., \& Naeem, S. (2012). Biodiversity and Ecosystem Multi-Functionality: Observed Relationships in Smallholder Fallows in Western Kenya. PLOS ONE, 7(11), e50152.

Tancoigne, E., Barbier, M., Cointet, J.P., \& Richard, G. (2014). The place of agricultural sciences in the literature on ecosystem services. Ecosystem Services, 10, 35-48.

TEEB. (2008). The economics of ecosystems \& biodiversity. An Interim Report. Brussels: European Communities.

TEPSIE. (2014). Social Innovation Theory and Research: A Guide for Researchers. Brussels: European Commission, DG Research.

Thompson, P. B. (2012). The Agricultural Ethics of Biofuels: The Food vs. Fuel Debate. Agriculture, 2, 339-358.

Tiešā pirkšana. (B.g.). Kas ir tiešăs pirkšanas pulcinini. Izgūts no http://tiesapirksana. lv/kas.html

Tieskens, K.F., Schulp, C. J., Levers, C., Lieskovsky, J., Kuemmerle, T., Plieninger, T., \& Verburg, P. H. (2017). Characterizing European cultural landscapes: Accounting for structure, management intensity and value of agricultural and forest landscapes. Land Use Policy, 62, 29-39.

Tilman, D., Reich, P. B., \& Isbell, F. (2012). Biodiversity impacts ecosystem productivity as much as resources, disturbance, or herbivory. PNAS, 109(26), 10394-10397.

Tilman, D., Socolow, R., Foley, J.A., Hill, J., Larson, E., et al. (2009). Beneficial biofuelsthe food, energy, and environment trilemma. Science, 325(5938), 270-271.

Touzard, J. M., Temple, L., Faure, G., \& Triomphe, B. (2015). Innovation systems and knowledge communities in the agriculture and agrifood sector: a literature review. Journal of Innovation Economics \& Management, (2), 117-142.

Werling, B.P., Dickson, T. L., Isaacs, R., Gaines, H., Gratton, C., et al. (2014). Perennial grasslands enhance biodiversity and multiple ecosystem services in bioenergy landscapes. Proceedings of the National Academy of Sciences, 111(4), $1652-1657$.

\subsection{SABIEDRĪBAS VĒRTİBAS-RĪCĪBAS-SLODZES} UN MUNICIPĀLĀ VIDES PĀRVALDİBA

Brizga, J., Feng, K. and Hubacek, K. (2017). Household carbon footprints in the Baltic States: A global multi-regional input-output analysis from 1995 to 2011 Applied Energy, 189, 780-788.

Csutora, M. (2012). One More Awareness Gap? The Behaviour-Impact Gap Problem. Journal of Consumer Policy, 35(1), 145-163.

Druckman, A. and Jackson, T. (2009). The carbon footprint of UK households 1990-2004: a socio-economically disaggregated, quasi-multi-regional input-output model. Ecological Economics, 68(7), 2066-2077.

Ernšteins, R. (1999). Vides zinātniskās izglìtības attīstība. Rìga: Vide. 342 lpp.

Ernšteins, R., Kauliṇš, J., Zïlniece, I. (2014). Municipālā attīstības plānošana un vides pārvaldība Latvijā: integrētās pieejas metodoloğija un instrumentu komplementāra attīstỉba. No Liepājas Universitātes 16. starptautiskā zinātniskā konference [rakstu krājums] (321.-338.lpp.). Liepāja: Liepājas Universitāte.

Ernšteins, R., Kaulinš, J., Zilniece, I., Lontone-Ievina, A., Kepals, A. (2015). Piekrastes integrētā pārvaldỉba: integrācijas principa nodrošināšana piekrastes pašvaldību ilgtspējigas attistiibas stratēgisiskajā plānošanā. No Liepājas Universitātes 17. starptautiskā zinātniskā konference [rakstu kräjums] (308.-319.lpp.). Liepāja: Liepājas Universitāte sadarbībā ar Malardālenas Universitāti.

Ernšteins, R., Kauliňš, J., Lontone-Ievina, A., Zvirbule, L., Zilniece, I. (2016). Vides pārvaldỉba pašvaldībās: vides integrācijas pieejas nodrošināšana attistỉba plānošanā mijiedarbībā ar vides pārvaldības pārskata disciplināro pieeju. No Liepājas Universitātes 18. starptautiskā zinātniskā konference [rakstu krājums] (325.-337.lpp.). Liepāja.

FAO. (1999). Indicators for sustainable development of marine capture fisheries. Technical Guidelines for Responsible Fisheries no 8. Rome. 68 p.

Hertwich, E. G., Peters, G.P. (2009). Carbon footprint of nations: A global, tradelinked analysis. Environmental Science \& Technology, 43(16), 6414-6420.

Kauliňš, J. (2008). Iespējas Latvijas piekrastes ilgtspējības novērtēšanai ar indikatoru metodi. No R.Ernšteins un R.Jūrmalietis (red.), Piekrastes ilgtspējiğga attīstība: sadarbības pārvaldība (127.-137.lpp.). Rīga: LU Akadēmiskais apgāds.

Kauliņ̌̌, J. (2015). Ilgtspējīgas attīstības pārvaldïbas indikatoru sistēmas [promocijas darbs]. Rīga: Latvijas Universitāte. 16o lpp.

Kauliņ̌̌, J. (2017a). Valmieras vides pārvaldỉbas nozares plānošanas instrumentu novērtējums, priekšlikumi un integrācijas nosacijumi attīstības plānošan [analïtisks pārskats]. No Valsts pētijumu programmas SUSTINNO projekts Nr. 4 «Vides daudzveidība un ilgstspējīga pārvaldība». Rīga, 34 lpp. 
Kaulinš, J. (2017b). Saulkrastu novada ilgtspējigas attīstïbas indikatoru un to sistēmas tehniskais novērtējums. No LU 75. zinātniskā konference. Geogrāfija. Ģeoloğija. Vides zinātne [referātu tēzes] (336.-340.lpp.). Rīga: Latvijas Universitāte.

Krukle, Z., Ernsteins, R., Brizga, J. Sustainable mobility governance for urban municipalities in Latvia: social-ecological systems approach requirement and practice. In 17 International Multidisciplinary Scientific GeoConference SGEM 2017 conference proceedings. Vol. 17. "Ecology, Economics, Educations and Legistation", Issue 52, pp. 923-934.

Lontone-Ieviṇa, A., Ernšteins, R., Zïlniece, I. Vides pārvaldības attīstỉba pašvaldībās: vides sektora, attistibas pārvaldibas sektoru un dimensiju pieejas un to integrācija. No Latvijas Universitātes 74. zinātniskā konference. Geogrāfija. Geoloğija. Vides zinātne [referātu tēzes] (470.-474.lpp.). Rīga: Latvijas Universitāte, 2016.

Marti, X., Lescrauvaet, A.-K., Borg, M., Valls, M. (ed.). (2007). Indicators Guidelines: To adopt an indicators-based approach to evaluate coastal sustainable development. In DEDUCE Consortium, Interreg IIIc, Barcelona. 98 p.

Ministru kabinets. (2009). Ministru kabineta noteikumi Nr. 175. «Noteikumi par nacionālajiem vides indikatoriem». Pieṇemti 24.02.2009. Latvijas Vēstnesis, 34(4020).

Pārresoru koordinācijas centrs. (2012). Latvijas Nacionālais attīstības plāns 2014.-2020. gadam. Apstiprināts ar 20.12.2012. Latvijas Republikas Saeimas lēmumu. Izgūts no http://www.varam.gov.lv/lat/pol/ppd/ ilgtsp_att/?doc $=13858$

Peters, G.P. (2010). Carbon footprints and embodied carbon at multiple scales. Current Opinion in Environmental Sustainability, 2(4), 245-250.

Rỉgas domes Pilsētas attīstības departaments. (2014) Rìgas ilgtspējigasas attīstïbas stratếgija lìdz 2030. gadam. Apstiprināta ar Rīgas domes 27.05.2014. lēmumu Nr.1173.

Latvijas Republikas Saeima. (2006). Vides aizsardzības likums. Pieñemts 02.11.2006. Latvijas Vēstnesis, 183(3551). Izgūts no https://likumi.lv/doc.php?id=147917

Latvijas Republikas Saeima. (2008). Attīstības plānošanas sistēmas likums.

Pienemts 08.05.2008. Latvijas Vēstnesis, 80(3864). Izgūts no https://likumi.lv/ doc.php?id $=175748$

Latvijas Republikas Saeima. (2010). Latvijas ilgtspējigas attīstïbas stratēǵija lìdz 2030. gadam. Apstiprināts ar 10.06.2010. Latvijas Republikas Saeimas lēmumu. Izgūts no https://www.pkc.gov.lv/sites/default/files/inline-files/ Latvija_2030_7.pdf.

Latvijas Republikas Saeima. (2011). Teritorijas attīstības plānošanas likums. Pieṇemts 13.10.2011. Latvijas Vēstnesis, 173(4571). Izgūts no https://likumi.lv/ doc.php?id=238807

Saulkrastu novada ilgtspējīgas attīstības stratêǵija 25 gadu perspektīvā. (2013). КвLC. 25 lpp.
Saulkrastu novada ilgtspējība 2014. gadà. (2017). Zinojums izstrādāts ar Valsts pētijumu programmas atbalstu apakšprogrammas SUSTINNo ietvaros. Rỉga: LU ĢZZF. 43 lpp.

Schandl, H., Hatfield-Dodds, S., Wiedmann, T., Geschke, A., Cai, Y., West, J., Newth, D., Baynes, T., Lenzen, M. and Owen, A. (2016). Decoupling global environmental pressure and economic growth: scenarios for energy use, materials use and carbon emissions. Journal of Cleaner Production, 132, $45-56$.

Schwartz, S.H. (1992). Universals in the content and structure of values: Theoretical advances and empirical tests in 20 countries. Advances in Experimental Social Psychology, 25, 1-65.

Schwartz, S.H. (2012). An overview of the Schwartz theory of basic values. Online readings in Psychology and Culture, 2(1), 11

Stern, P.C. (2000). New environmental theories: toward a coherent theory of environmentally significant behavior. Journal of Social Issues, 56(3), 407-424.

Stern, P.C., Dietz, T., Abel, T. D., Guagnano, G.A. and Kalof, L. (1999). A valuebelief-norm theory of support for social movements: The case of environmentalism. Human Ecology Review, 6(2), 81-97.

United Nations. (1992). Agenda 21 [The United Nations programme for action from Rio]. United Nations.

Valmieras pilsētas teritorijas plānojums (no 2017. gada). (2017). Izgūts no http://www. valmiera.lv/lv/attistiba/teritorijas_planosan/

Valmieras pilsētas dome. (2015). Valmieras pilsētas vides deklarācija. Izgūts no http://valmiera.lv/sites/default/files/vides_deklaracija_1_o.pdf 


\section{BAIBA BELA, DR. SC. SOC.}

Latvijas Universitātes Sociālo zinātṇu fakultātes Socioloğijas nodaḷas asociētā profesore, Sociālo un politisko pētijumu institūta vadošā pētniece. Pētnieciskās intereses: ilgtspējiga attīstība, sociālā politika, nabadzība un sociālā atstumtība, migrācija, identitāte.

\section{JĀNIS BRIZGA, DR. GEOGR.}

Latvijas Universitātes Geogrāfijas un Zemes zinātṇu fakultātes Vides zinātnes nodaḷas pētnieks. Pētnieciskās intereses: ilgtspējiga patēriṇa pārvaldība, vides ilgtspēja un videi draudzigss dzīvesveids, vērtībasrīcibas-slodzes mijsakarïbas.

\section{RAIMONDS ERNŠTEINS, DR. HABIL. PAED.}

Latvijas Universitātes G̣eogrāfijas un Zemes zinātṇu fakultātes profesors un Vides zinātnes nodaḷas vadošais pētnieks. Pētnieciskās intereses: integratīvās pārvaldības metodolog̣ijas attīstība, ilgtspējigas attīstības un vides pārvaldỉba, vides komunikācija un videi draudzīga rīcība, piekrastes integrēta pārvaldība.

\section{BAIBA HOLMA, DR. PHILOL.}

Latvijas Universitātes Sociālo zinātnu fakultātes Informācijas un bibliotēku studiju nodaḷas asociētā profesore, Sociālo un politisko pētijumu institūta vadošā pētniece. Pētnieciskās intereses: informācijpratība, medijpratība, digitālā pratība.

\section{JĀNIS KAULIN̦š, DR. GEOGR.}

Latvijas Universitātes G̣eogrāfijas un Zemes zinātṇu fakultātes Vides zinātnes nodalas pētnieks. Pētnieciskās intereses: ilgtspējigas attīstības un vides pārvaldība - plānošanas sistēmas un indikatoru sistēmu attīstība un darbỉbas analīze.

ANITA KOVALEVSKA, MG. IUR.

Latvijas Universitātes Juridiskās fakultātes Valststiesību zinātṇu katedras lektore, tiesnese. Pētnieciskās intereses: sociāli atbildīgas valsts princips, tiesības uz sociālo nodrošinājumu.

\section{MARIJA KRŪMIN̦A, MG. OEC.}

Baltijas Starptautiskā ekonomikas politikas studiju centra pētniece. Pētnieciskās intereses: uznēemējdarbības ekonomika, labklājỉbas ekonomika, darbaspēka ekonomika.

\section{LIGITA MELECE, DR. OEC.}

Agroresursu un ekonomikas institūta Kvalitātes un vides aizsardzības daḷas vadītāja un vadošā pētniece. Pētnieciskās intereses: ilgtspējīgas attīstības vides un sociālekonomiskie aspekti, lauku attīstỉbas un pārtikas nodrošinājuma inovatīvie risinājumi.

MAREKS NIKLASS, DR. SC. SOC.

Latvijas Universitātes Sociālo zinātṇu fakultātes Socioloğijas nodạalas docents, Sociālo un politisko pētỉjumu institūta pētnieks. Pētnieciskās intereses: nodarbinātības politika, darba tirgus apsteidzošie pārkārtojumi, sociālā nevienlīdzība, strādājošo nabadziba.

JURIJS N̦IKIŠINS, DR. SC. SOC.

Latvijas Universitātes Sociālo zinātnu fakultātes Sociologíijas nodaḷas docents, Sociālo un politisko pētījumu institūta pētnieks. Pētnieciskās intereses: ilgtspējīga attīstība, nabadzība un sociālā atstumtība, politiskās vērtības un attieksmes, pilsoniskā līdzdalība.

\section{JĀNIS PLEPS, DR. IUR.}

Latvijas Universitātes Juridiskās fakultātes docents, Tiesību teorijas un vēstures katedras vadītājs, Valsts prezidenta konstitucionālo tiesību padomnieks. Pētnieciskās intereses: tiesību teorija un vēsture, konstitucionālās tiesības.

\section{LīGA RASNAČA, DR. SC. SOC.}

Latvijas Universitātes Sociālo zinātṇu fakultātes Socioloğijas nodaḷas asociētā profesore, Sociālo un politisko pētỉjumu institūta vadošā pētniece. Pētnieciskās intereses: sociālā politika, sociālā atstumtība, mājokḷa politika, sociālā darba organizācija.

IVETA REINHOLDE, DR. SC. POL.

Latvijas Universitātes Sociālo zinātnu fakultātes Politikas zinātnes nodalıas asociētā profesore, Sociālo un politisko pētijumu institūta vadošā pētniece. Pētnieciskās intereses: pārvaldība, administratīvās reformas, pārvaldes līmeṇu attiecības.

VINETA SILKĀNE, MG. PSYCH, MG. MATH.

Latvijas Universitātes Sociālo zinātṇu fakultātes Sociālo un politisko pētijumu institūta zinātniskā asistente, Vidzemes Augstskolas lektore. Pētnieciskās intereses: sociālā izziṇa, ekonomikas psiholoğija, veselības uzvedỉba. 


\section{GUNA SPURAVA, MG. SC. SOC.}

Latvijas Universitātes Sociālo zinātṇu fakultātes Sociālo un politisko pētijumu institūta zinātniskā asistente, Latvijas Universitātes Sociālo zinātṇu fakultātes Komunikācijas studiju nodaḷas lektore.

Pētnieciskās intereses: jaunās paaudzes mediju lietojums,

medijpratība, mediju industrijas un mediju ekonomika.

\section{MARTA TRIPĀNE, DR. SC, POL.}

Pētnieka pienākumu izpildītāja Latvijas Universitātes Sociālo zinātṇu fakultātes Sociālo un politisko pētījumu institūtā. Pētnieciskās intereses: publiskā pārvalde, laba un vieda pārvaldība, evidencēs balstīta rīcībpolitika, veselības rīcībpolitika.

\section{VISVALDIS VALTENBERGS, DR. SC. POL.}

Vadošais pētnieks Latvijas Universitātes Sociālo zinātnu fakultātes Sociālo un politisko pētijumu institūtā. Pētnieciskās intereses: interneta politiskā komunikācija, sabiedrības vērtības globālajā

kontekstā, vietējā un reğionālā attīstība.

\section{ANETE VINGRE, DR. SC. POL.}

Zinātniskā asistente Latvijas Universitātes Sociālo zinātṇu fakultātes Sociālo un politisko pētỉjumu institūtā. Pētnieciskās intereses:

zinātnes, tehnoloğiju un inovācijas rīcībpolitika, socialās inovācijas, rīcībpolitikas izvērtēšana.

\section{AIJA ZOBENA, DR.SC. SOC.}

Latvijas Universitātes Sociālo zinātṇu fakultātes Socioloğijas nodaḷas profesore, Sociālo un politisko pētijumu institūta direktore un

vadošā pētniece. Pētnieciskās intereses: lauku un reǵionālā attīstība. 


\section{Innovative Solutions for Sustainability: Society, Economy, Environment}


competence in innovation, sustainable development, environmental and policy research. The LU program executors were represented by the Advanced Social and Political Studies Institute at the Faculty of Social Sciences, University of Latvia, and its group of researchers lead by professor Jānis Ikstens, Dr. sc. pol., (2014-2017), professor Aija Zobena, Dr. sc. soc., (2017-2018) and associate professor Baiba Bela, Dr. sc. soc.; and researchers from Department of Environmental Science at the Faculty of Geography and Earth Sciences, lead by Professor Raimonds Ernšteins, Dr. habil. paed. An important contribution to the implementation of SUSTINNO was made by the DPP "Institute of Agricultural Resources and Economics" (AREI), researchers team led by lead researcher Ligita Melece, Dr. oec. AREI is the leading research institution in the economic development of rural areas. The field of Latvia's economic sustainability and innovation research, under direction of Professor Alf Vanags, MSc. (Econ.), (1942-2016) (2014-2016) and Marija Krūmina, Mg. oec., (2016-2018) was conducted by Baltic International Center for Economic Policy Studies (BICEPS), which has accumulated substantial experience in conducting economic research.

Collective monograph Innovative Solutions for Sustainability: Society, Economy, Environment (scientific editor Aija Zobena) summarizes the most significant theoretical knowledge, practical recommendations and recommendations of further research, obtained during the implementation of SUSTINNO.

The first part of the collective monograph "Challenges of Sustainable Development in the Post-crisis Latvia: Society, Economics, Environment" addresses the conceptualisation of the problems identified in the projects of SUSTINNO and their national, regional and global contextual characteristics. Authors of the first chapter "Social Challenges For Sustainable Development” (Baiba Bela, Baiba Holma, Anita Kovalevska, Jānis Pleps, líga Rasnača, Iveta Reinholde, Vineta Silkāne, Marta TriPĀNe, ANETE Vingre) mark scope of the State Research Program SUSTINNO project No. 2 "Social dimension of sustainable development and social innovation" covering the analysis of Latvia's post-crisis social problems in relation to sustainable social and regional development, legislative framework for ensuring sustainable development and the ability of the governance system to deal effectively with social problems, as well as analysis of social innovations in relation to their contribution to the securitability of communities.

In Chapter Two, "Collective ACTiON IN THE Context of ChANGES in Internet Political Communication and Society VAlue OrientATION" Visvaldis VALTENBERGS researches the effect of interactivity and the availability of new information access channels, Internet and social media impact on the involvement of citizens in public activities and policy research. The experience of the US presidential election, Brexit and Russia's strategic information campaign has diminished the initial optimism about the positive impact of the Internet on political communication and democratic processes in society. Will the collective organizations confidence crisis and growing anomie, combined with manipulative communicative effects, turn into a time bomb for liberal democracies?

In the third chapter "ENTREPRENEURSHIP, EXPORTS, TAXES, SHADOW ECONOMY AND COMPETITIVENESS: THE CONCEPTUAL Framework for Analysing Post-Crisis Processes", Marija Krūmiña outlines the conceptual framework for analysing economic processes in the post-crisis Latvia, focusing in particular on the competitiveness of Latvian exports. Summarizing the results of empirical studies on exporting and non-exporting companies in European and US companies, it can be concluded that the exporting companies on average are more productive than non-exporting companies. The chapter also summarizes theoretical conclusions about the impact of the shadow economy and tax structure on long-term economic growth of the country.

In the next chapter "ECONOMIC, ENVIRONMENTAL AND Social Aspects of Sustainable Rural Development" Ligita Melece gives an overview of the programmatic challenges of EU strategy and policy in the field of sustainable (economic, environmental and social) rural development. The author explains the multifunctionality of farming and environmental interactions, their impact on conservation of biodiversity and supply of ecosystem services, emphasizing the importance of small farms. Looking at the role of diversification of farms in further development of rural areas, potential benefits are highlighted - supply of diverse goods and services and additional income.

The first part of the collective monograph concludes by the chapter "Sustainable Consumption AND ENVIRONMENTAL GovernANCE", in which JĀNIS BRIZGA and RAIMONDS ERNŠTEINS summarize the lessons learned from the implementation of the project "Environmental diversity and sustainable resource usage". The aim of this project was to study management of complex socio-ecological systems, environment and sustainable development in Latvia by assessing parameters and factors of change of society's value-action-pressues in the context of environmental protection and sustainable use, multidimensional thematic and general development management, starting at the level of local governance.

The second part of the collective monograph "Innovative Solution for Sustainability" features the main practical conclusions learned from the implementation of SUSTINNO.

In the first chapter "The Social Dimension of Sustainable DeveLOPMENT: A Way to a Decent Life in Socially Responsible State” 
authors Baiba Bela, Anita Koval,evska, Mareks Niklass, Jurijs N̦ikišıns, Lïga RASNaČa, IVETA REINHolde, MARTA TripĀne, ANETE VINGRE, Vineta SiLkĀNe AND GUNA SpURAVA express the view that social innovation analysis is important, but so far relatively seldom used (and little studied) resource for solving social problems, developing an inclusive economy and promoting common good of the society. The limited resources of the project conducted within the framework of the SUSTINNO made it possible to carry out only in-depth assessment of the role of the state in promoting social innovations and in-depth analysis of individual cases. The authors note that the public administration has little understanding of the role and importance of social innovation, that is evidenced by the lack of social innovation as a resource and instrument in the National Development Plan 2020 (NAP 2020) Priority Area "Human Securitability", as well as the long and difficult path to the social entrepreneurship law. The analysis of the case studies suggests a wider scope of social innovations than just social entrepreneurship, and emphasizes the essential need for social innovation to make full use of all the benefits of life in the 21st century.

In the following chapter, "ON THE WAY FROM ANOMY TO SELForganisation AND Collective ACTiON” authors Aija Zobena and RENĀRS FELCIS, summing up the conclusions on the diverse manifestations of anomy and its impact on the value orientations of the population in the post-crisis Latvian society, acknowledge that, in spite of the varied and extensive manifestations of anomy, there are processes that allow looking into the future with certain of optimism. Cautious conclusions about this can be made based on the survey of 18-74-year-old Latvian residents $(N=1003)$ conducted by the market and social research center "Latvijas Fakti" between December 2 and 20, 2017 (SUSTINNO 2017). Survey data show that, although the level of mutual trust is quite low, almost a tenth of the population of Latvia is already involved, and almost a quarter is ready to engage in collective action for decision-making initiatives. The data obtained in SUSTINNO 2017 poll encourages further study of the attitudes and values of Latvian people from an anomy perspective in search of possible conditions for overcoming it.

In the third chapter, "ENTREPRENEURSHIP, EXPORTS, TAXES, SHADOW ECONOMY ANd COMPETITIVENESS in THE Post-CRisis LatVia”, MARIJA KRUMMIN̦A summarizes the main conclusions of the SRP SUSTINNO project "Economic Competitiveness and Innovation". The aim of this project was to empirically analyse the competitiveness of Latvian companies in foreign markets, paying particular attention to company-level factors. Using the latest research methodologies, a number of scientific studies were carried out on the factors affecting the competitiveness of companies: early stage entrepreneurship, exports and the impact of EU Structural Funds on the export capacity of companies, impact of shadow economy and taxation system on the competitiveness of Latvian enterprises.

In the next chapter "InNovative Solutions for Sustainable Rural Development", Ligita Melece summarizes the findings of the research projects "Economic competitiveness and innovation" and "Social dimension of sustainable development and social innovation" and assesses potential of social innovation for sustainable agriculture and rural development. The author describes relationship and interaction of social and environmental innovations and provides assessment of some innovative solutions implemented in Latvia (agri-environmental measures, bioenergy production and local food systems).

The monograph is concluded by the chapter "Public VALUES-ACTIons-Pressures and Municipal Environmental Governance”, in which RAIMONDS ERNŠTEINS, JĀNIS KAULIN̦Š and JĀNIS BRIZGA addresS the challenges posed by the practice of environmental management at local government level and in households in order to find the most optimal way to promote positive changes to daily routines of individuals and households, allowing people to overcome the barriers to eco-friendliness and making people's everyday routines more environmentally friendly and sustainable. In order to analyse environmental management and eco-friendly behaviour in households, SRP SUSTINNO in March 2016 commissioned a representative survey of Latvian residents $(N=1009)$, conducted by sociological research company TNS, the data of the survey are discussed in this chapter.

\section{Acknowledgements}

The authors of the collective monograph thank everyone who contributed to the creation of this work. We especially thank Professor Jānis Ikstens leader of State Research Programme Innovation and sustainable development: Latvia's post-crisis experience in a global" (SUSTINNO) and project "Value orientations and reproduction of society" from 2014 to 2017, and Professor Alf Vanags $\dagger$ (1942-2016), leader of the project "Economic competitivenes and innovation" from 2014 to 2016 about the idea of the program and significant contribution to its implementation. For English translations of texts our thanks to Zane Vārpina.

Scientific editor

Dr. sc. soc. Aija Zobena 


\section{BAIBA BELA, DR. SC. SOC.}

Associate professor at the Department of Sociology, Senior

researcher at the Advanced Social and Political Research Institute, Faculty of Social Sciences, University of Latvia. Research interests: sustainable development, socialpolicy, poverty and social exclusion, migration, identity.

\section{JĀNIS BRIZGA, DR. GEOGR.}

Researcher at the Department of Environmental Science, Faculty of Geography and Earth Sciences, University of Latvia. Research interests: sustainable consumption governance, environmental sustainability and pro-environmental lifestyle, values-actions-loads correlations.

\section{RAIMONDS ERNŠTEINS, DR. HABIL. PAED.}

Professor and Senior researcher at the Department of Environmental Science, Faculty of Geography and Earth Sciences, University of Latvia. Research interests: development of integrative governance methodology, sustainable development and environmental governance, environmental communication and pro-environmental behavior, coastal integrated governance.

\section{BAIBA HOLMA, DR. PHILOL.}

Associate professor at the Department of Information and Library Studies, Senior researcher at the Advanced Social and Political Research Institute, Faculty of Social Sciences, University of Latvia. Research interests: informationliteracy, medialiteracy, digitalliteracy.

\section{JĀNIS KAULIN Š, DR. GEOGR.}

Researcher at the Department of Environmental Science, Faculty of Geography and Earth Sciences, University of Latvia. Research interests: sustainable development and environmental governancedevelopment and performance analysis of planning system and indicators systems.

\section{ANITA KOVALEVSKA, MG. IUR., PHD CANDIDATE}

Lecturer at the Department of Constitutional and Administrative Law, Faculty of Law, University of Latvia, judge. Research interests: welfare state as a principle of law, right to social security.

\section{MARIJA KRŪMINA, MG. OEC., PHD CANDIDATE}

Senior researcher at the Baltic International Centre for Economic Policy Studies. Research interests: economics of entrepreneurship, economics of well-being, labour economics.

\section{LIGITA MELECE, DR. OEC.}

Head of Division and Senior Researcher of Quality and Environment Protection Division at the Institute of Agricultural Resources and Economics. Research interests: environmental and socio-economic aspects of sustainable development, innovative solutions of rural development and food security.

\section{MAREKS NIKLASS, DR. SC. SOC.}

Docent at the Faculty of Social Sciences, University of Latvia, Researcher at the Advanced Social and Political Research Institute. Research interests: employment policies, labour market anticipation measures, social inequality, in-work poverty.

JURIJS N̦IKIŠINS, DR. SC. SOC.

Assistant professor at the Department of Sociology, Researcher at the Advanced Social and Political Research Institute, Faculty of Social Sciences, University of Latvia. Research interests: sustainable development, poverty and social exclusion, political values and attitudes, civic participation.

\section{JĀNIS PLEPS, DR. IUR.}

Assistant Professor at the Faculty of Law of the University of Latvia, Head of the Department of Legal Theory and History, Adviser for Constitutional Affairs to the President. Research interests: legal theory and history, constitutional law.

LİGA RASNAČA, DR. SC. SOC.

Associate professor at the Department of Sociology, Senior researcher at the Advanced Social and Political Research Institute, Faculty of Social Sciences, University of Latvia. Research interests: social policy, social work organization, social welfare, social justice and regional inequality. 


\section{IVETA REINHOLDE, DR. SC. POL.}

Associate professor at the Department of Political Science, Senior researcher at the Advanced Social and Political Research Institute, Faculty of Social Sciences, University of Latvia. Research interests:

governance, administrative reforms, relations in governance levels.

\section{VINETA SILKĀNE, MG. PSYCH, MG. MATH, PHD CANDIDATE}

Scientific assistant at the Advanced Social and Political Research Institute, Faculty of Social Sciences, University of Latvia, lecturer at the Vidzeme University of Applied Sciences. Research interests: social judgment, behavioral economics, health behavior.

\section{GUNA SPURAVA, MG. SC. SOC., PHD CANDIDATE}

Scientific assistant at the Advanced Social and Political Research Institute, Faculty of Social Sciences, University of Latvia, Lecturer at the Department of Communication sciences, Faculty of Social Sciences, University of Latvia. Research interests: media use of young generation, media literacy, media industries and media economy.

\section{MARTA TRIPĀNE, DR. SC. POL.}

Researcher at the Advanced Social and Political Research Institute, Faculty of Social Sciences, University of Latvia. Research interests: public administration, good and smart governance, evidence based policy, health policy.

\section{VISVALDIS VALTENBERGS, DR. SC. POL.}

Senior Researcher at the Advanced Social and Political Research Institute, Faculty of Social Sciences, University of Latvia. Research interests: internet political communication, society values in global context, local and regional development.

ANETE VINGRE, DR. SC. POL.

Research assistant at the Advanced Social and Political Research Institute, Faculty of Social Sciences, University of Latvia. Research interests: science, technology and innovation policy, social innovation, policy evaluation.

\section{AIJA ZOBENA, DR. SC. SOC.}

Professor at the Department of Sociology, director and senior researcher at the Advanced Social and Political Research Institute, Faculty of Social Sciences, University of Latvia. Research interests: rural and regional development. 
Grāmatas dizainu un maketu izveidojis Aleksejs

Muraško. Teksta salikumā izmantoti burtveidol

FF Casus Pro (Jevgeniijs Jukečevs, Berline) un

FF Scala Sans Pro (Martins Majors, Arnema).

Grāmata iespiesta un iesieta Jelgavas tipograāfijā. Papirs iekšlapām: Munken Print Cream $1590 \mathrm{~g} / \mathrm{m}^{2}$

(Arctic Paper, Zviedrija); papirs vãkam: Materica

Acqua $250 \mathrm{~g} / \mathrm{m}^{2}$ (Fedrigoni, Itālija).
Inovatīvi risinājumi cẹ̣ā uz ilgtspēju:

sabiedrïba, ekonomika, vide

LU Akadēmiskais apgād

Aspazijas bulvāris 5-132, Rīga, LV-1050

apgads@lu.lv·Mājaslapa:www.lu.lv/apgads/

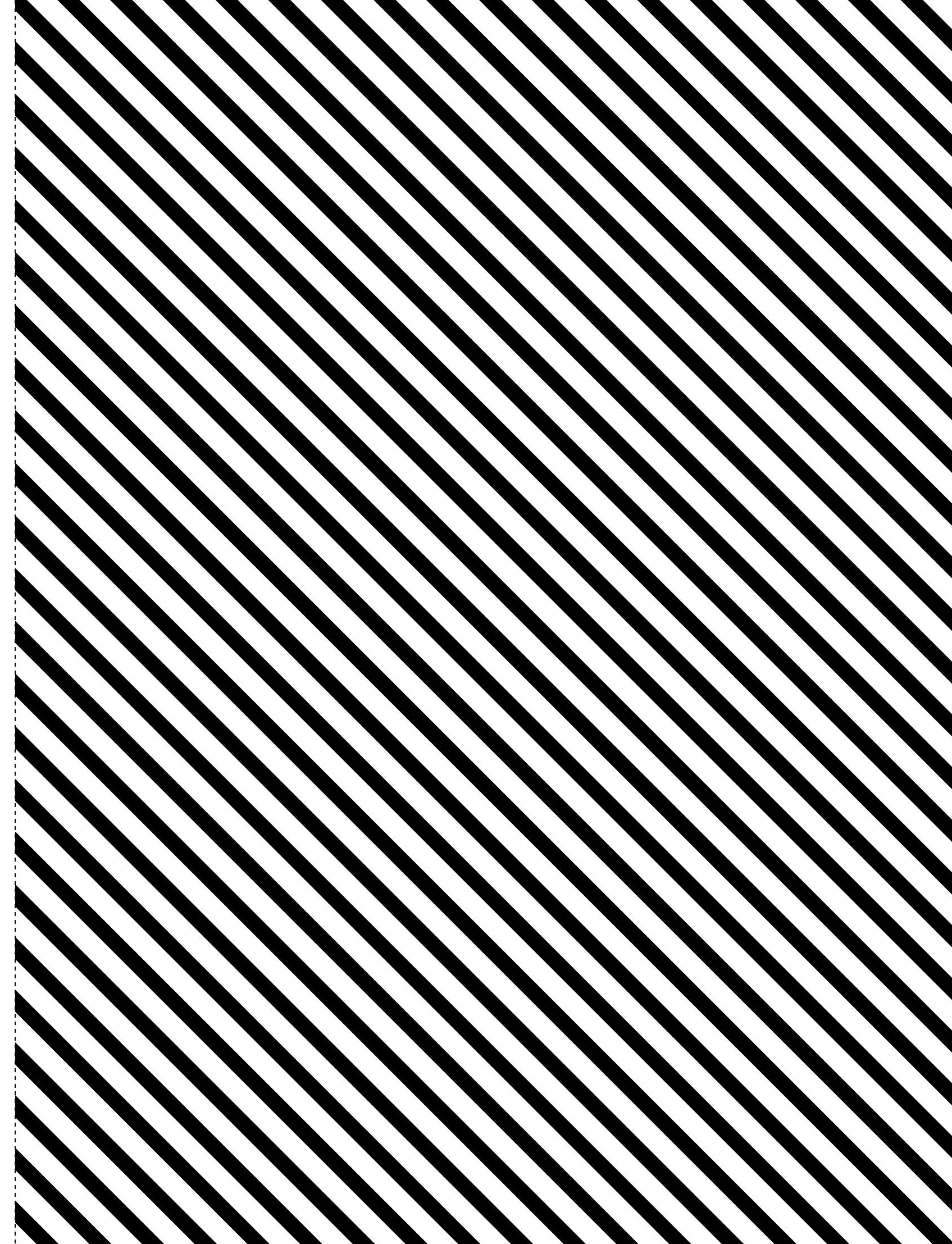


Zinātniskā monogrāfija «Inovatīvi risinājumi ceḷā uz ilgtspēju: sabiedrïba, ekonomika, vide» ir sagatavota valsts pētijumu programmas «Inovācija un ilgtspējīga attīstība: Latvijas pēckrīzes procesi globālā kontekstā» (SUSTINNO) ietvaros Latvijas Universitātes Sociālo zinātṇu fakultātes Sociālo un politisko pētījumu institūta vadībā.

Šĩ kolektīvā monogrāfija, kas iznāk sērijā «Inovācijas un ilgtspējiga attīstỉba Latvijā», apkopo SUSTINNo izpildes gaitā iegūtas nozīmīgākās teorētiskās atziṇas, praktiskos ieteikumus un iezīmē turpmākās izpētes virzienus. Monogrāfijas pirmā dą̣a «Ilgtspējigas attīstỉbas izaicinājumi pēckrīzes Latvijā: sabiedrība, ekonomika, vide» pievēršas SUSTINNO projektos identificēto problēmu konceptualizācijai un to nacionālā, reǵionālā un globālā konteksta raksturojumam. Otrajā dạ̣ā «Inovatîvi risinājumi ceḷā uz ilgtspēju» ir apkopotas nozīmīgākās praktiskās atziņas, kas gūtas SUSTINNO realizācijas gaitā.

Valsts pētijumu programmas SUSTINNO ìstenošanas laikā no 2014. līdz 2018. gadam tika îstenoti četri pētnieciskie projekti: «Ekonomiskā konkurētspēja un inovācija tautsaimniecībā», «Ilgtspējas sociālā dimensija un sociālā inovācija», «Sabiedrības vērtīborientācijas un sabiedrības atjaunošanās» un «Vides daudzveidība un ilgtspējiga izmantošana». Multidisciplināro sociālo zinātnieku komandu veidoja LU Sociālo zinātṇu fakultātes Sociālo un politisko pētijumu institūta, LU G̣eogrāfijas un Zemes zinātṇu fakultātes Vides zinātnes nodą̣as, Agroresursu un ekonomikas institūta un Baltijas Starptautiskā ekonomikas politikas studiju centra pētnieki.

ISBN 978-9934-18-309-6

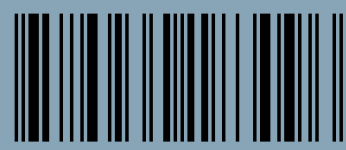

